\title{
Jurisdiction in cross-border copyright infringement cases
}

Citation for published version (APA):

Rebero - van Houtert, B. (2020). Jurisdiction in cross-border copyright infringement cases: rethinking the approach of the Court of Justice of the European Union. [Doctoral Thesis, Maastricht University]. ProefschriftMaken Maastricht. https://doi.org/10.26481/dis.20201027br

Document status and date:

Published: 01/01/2020

DOI:

10.26481/dis.20201027br

Document Version:

Publisher's PDF, also known as Version of record

\section{Please check the document version of this publication:}

- A submitted manuscript is the version of the article upon submission and before peer-review. There can be important differences between the submitted version and the official published version of record.

People interested in the research are advised to contact the author for the final version of the publication, or visit the DOI to the publisher's website.

- The final author version and the galley proof are versions of the publication after peer review.

- The final published version features the final layout of the paper including the volume, issue and page numbers.

Link to publication

\footnotetext{
General rights rights.

- You may freely distribute the URL identifying the publication in the public portal. please follow below link for the End User Agreement:

www.umlib.nl/taverne-license

Take down policy

If you believe that this document breaches copyright please contact us at:

repository@maastrichtuniversity.nl

providing details and we will investigate your claim.
}

Copyright and moral rights for the publications made accessible in the public portal are retained by the authors and/or other copyright owners and it is a condition of accessing publications that users recognise and abide by the legal requirements associated with these

- Users may download and print one copy of any publication from the public portal for the purpose of private study or research.

- You may not further distribute the material or use it for any profit-making activity or commercial gain

If the publication is distributed under the terms of Article $25 \mathrm{fa}$ of the Dutch Copyright Act, indicated by the "Taverne" license above, 


\section{Jurisdiction in Cross-border Copyright Infringement Cases}

Rethinking the Approach of the Court of Justice of the European Union

Birgit Marianne Willy van Houtert-Rebero 
(C) copyright Birgit van Houtert-Rebero, Maastricht 2020

Printing: ProefschriftMaken || www.proefschriftmaken.nl

Layout cover: Stefanie van den Herik

ISBN 978-94-6380-936-8

All rights reserved. No part of this publication may be reproduced, stored in a retrieval system or transmitted, in any form or by any means, electronic, mechanical, photocopying, recording or otherwise, without prior permission of the author or the copyright-owing journals for previous published chapters. 


\title{
Jurisdiction in Cross-border Copyright Infringement Cases
}

\section{Rethinking the Approach of the Court of Justice of the European Union}

\author{
DISSERTATION
}

\author{
to obtain the degree of Doctor \\ at the Maastricht University, \\ on the authority of the Rector Magnificus, Prof. Dr. Rianne M. Letschert \\ in accordance with the decision of the Board of Deans, \\ to be defended in public on Tuesday 27 October 2020 at 16:00 hours
}

by

Birgit Marianne Willy van Houtert-Rebero 


\title{
Supervisor
}

Prof. Dr. G. R. de Groot

\section{Co-Supervisor}

Dr. S. F. G. Rammeloo

\author{
Assessment Committee \\ Prof. Dr. M. Pertegás Sender (chair) \\ Prof. Dr. M. M. M. van Eechoud (University of Amsterdam) \\ Dr. J.-J. Kuipers (Court of Appeal of The Hague) \\ Dr. A. Moerland
}




\section{Table of Contents}

Acknowledgements

List of abbreviations

Abbreviations of case law

Glossary of Latin terms

1.1 Introductory remarks $\quad 33$

1.1.1 Diverging interests regarding which court should be competent in 33 a cross-border copyright infringement dispute

1.1.2 Rules governing jurisdiction in cross-border copyright 33 infringement cases

1.1.3 The broad possibilities to sue an alleged copyright infringer 35 domiciled in the European Union before a Member State court

1.1.4 Jurisdiction limited to local damage 37

1.2 The aim and the methodologies of the research 37

1.3 The structure of this dissertation $\quad 40$

Part I: Private international law and copyright law 43

Chapter 2: Divergence and convergence between private international law 45 and copyright law

2.1 The field of private international law $\quad 47$

$\begin{array}{lll}2.1 .1 & \text { General features } & 47\end{array}$

2.1.2 Developments 51

2.1.2.1 Demise of neutrality of private international law 51

2.1.2.1.1 United States of America 51

2.1.2.1.2 Europe 54

2.1.2.1.3 Protecting or favouring certain persons or concepts 56

2.1.2.1.4 Public policies $\quad 58$

2.1.2.1.5 Private international law used as tool for global governance 59

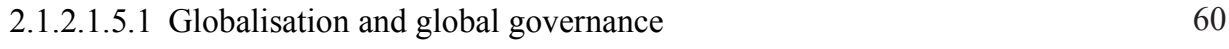

2.1.2.1.5.2 The role of private international law in global society 61

2.1.2.1.6 Concluding remarks on the demise of neutrality 63

2.1.2.2 Flexible approach to territoriality as basis for jurisdiction 64

2.1.2.2.1 Demise of territoriality as basis for jurisdiction in public $\quad 64$ international law and its relation to jurisdiction in private international law 
2.1.2.2.2 Effects-based approach to jurisdiction in tort cases 67

2.2 The field of copyright law $\quad 72$

$\begin{array}{lll}2.2 .1 & \text { General features } & 72\end{array}$

2.2.1.1 The rationales behind copyright protection 76

$\begin{array}{ll}\text { 2.2.1.2 Copyrights as private rights or human rights } & 78\end{array}$

2.2.2 Developments related to copyrights 79

2.2.2.1 The increased interaction between interests of copyright holders $\quad 79$

$\begin{array}{ll} & \text { and stakeholders } \\ \text { 2.2.2.1.1 The overprotection of copyrights } & 79\end{array}$

2.2.2.1.2 The principle of balancing the interests related to copyrights 80

2.2.2.2 The rising criticism on the territoriality principle related to 81 copyrights

2.3 The interaction between private international law and copyright law regarding $\quad 84$ copyright infringement disputes

2.3.1 Private international law related to jurisdiction in cross-border $\quad 84$ copyright infringement cases

2.3.2 The influence of the territorial nature of copyrights on the court's 85 jurisdiction
The lex loci protectionis as applicable law $\quad 88$

2.3.3 The lex loci protectionis as applicable law 88

2.3.4 Towards a flexible approach to territoriality in cross-border 90 copyright infringement cases

2.3.4.1 On jurisdictional level 90

2.3.4.2 On the level of the conflict of laws: deviating from the 92

2.3.5 Table on the influence of the territoriality principle related to 94 copyrights with respect to private international law involving cross-border copyright infringement cases

2.4 Concluding remarks

Chapter 3: The CJEU's approach to jurisdiction in cross-border copyright 97 infringement cases

3.1 Preliminary rulings 99

$\begin{array}{ll}3.2 \text { Pinckney v. Mediatech } & 100\end{array}$

$\begin{array}{lll}3.2 .1 & \text { The facts } & 100\end{array}$

3.2.2 The Opinion of Advocate General Jääskinen 101

$\begin{array}{ll}\text { 3.2.3 The preliminary ruling } & 102\end{array}$

3.3 Hi Hotel v. Spoering 106

$\begin{array}{lll}3.3 .1 & \text { The facts } & 106\end{array}$

$\begin{array}{ll}\text { 3.3.2 The preliminary ruling } & 106\end{array}$

3.4 Pez Hejduk v. EnergieAgentur $\quad 107$

$\begin{array}{lll}3.4 .1 & \text { The facts } & 107\end{array}$

3.4.2 The Opinion of Advocate General Cruz Villalón 108 
$\begin{array}{lll}3.4 .3 & \text { The preliminary ruling } & 108\end{array}$

3.5 The so-called Pinckney doctrine 109

3.5.1 The influence of the territorial principle related to copyrights 111

3.5.2 Table on the jurisdictional framework referred to as the 112

Pinckney doctrine

3.6 European Union jurisdictional rules related to infringements of intellectual 112 property rights

3.6.1 The place of infringement as connecting factor in case of 114

$\begin{array}{ll}\text { 3.6.2 The Wintersteiger ruling } & 116\end{array}$

Part II: Rethinking the CJEU's approach to jurisdiction in cross-border 119 copyright infringement cases

Chapter 4: The assessment framework 121

4.1 The CJEU as interpreter of European Union law 124

4.1.1 The CJEU as "the motor of European integration" 124

$\begin{array}{lll}\text { 4.1.1.1 Judicial activism } & 126\end{array}$

4.1.2 The CJEU as "objective interpreter" 128

4.1.3 The CJEU as "law-finder" 129

4.2 Interpretation methods regarding the special jurisdiction rule of Article 7(2) 131

Brussels Ibis

4.2.1 The textual method 133

4.2.2 The historical method 134

4.2.3 The contextual method 136

$\begin{array}{lll}\text { 4.2.4 The teleological method } & 138\end{array}$

4.2.4.1 Pro-integrationist interpretation 138

4.2.4.2 Principles underlying the special jurisdiction rule of Article 7(2) 140

4.2.5 The comparative law method 143

4.3 The precedent-based method of interpretation $\quad 144$

4.3.1 Relevant rulings regarding 'the place where the damage occurred' 145

4.3.2 Table on seminal rulings involving the interpretation of the 147

4.4 The principle of balancing the interests related to copyrights 151

4.4.1 The interests of copyright holders, users of information and 151 traders

4.4.2 Arguments in favour of balancing the interests involved 153

4.4.2.1 Balancing as common "interpretative technique" 153

4.4.2.1.1 "Interessenjurisprudenz" 154

4.4.2.2 Indirect horizontal effect of fundamental rights 156 
4.4.2.3 Consequentialist reasoning 157

4.4.2.4 Fundamental rights as primary source of European Union law 159

4.4.2.4.1 Balancing competing fundamental rights and public interests such $\quad 161$ the interests of traders

4.4.2.5 The principle of interest balancing in substantive copyright law $\quad 164$

4.5 The possible impact of the Geo-blocking Regulation on the approach to 165

jurisdiction in cross-border copyright infringement cases as part of the assessment framework

4.5.1 The aim and the scope of the Geo-blocking Regulation 166

4.5.2 The prohibitions under the Geo-blocking Regulation 167

4.5.2.1 The prohibitions under Article 3 of the Geo-blocking Regulation 168

to use technologies that block or limit a customer's access to the trader's online interface

4.5.2.2 The prohibitions under Article 4 and 5 of the Geo-blocking Regulation to use "other forms of discrimination" such as the application of different general conditions of access to goods and services

4.5.2.3 Services that are excluded from the prohibitions in the 170 Geo-blocking Regulation

4.5.2.4 Diagram on the four main provisions related to prohibitions to unjustified geo-blocking and other forms of discrimination under the Geo-blocking Regulation based on the customers' nationality or place of residence or establishment

4.5.3 The interaction between the Geo-blocking Regulation and special jurisdiction rule related to consumers disputes under Article 17(1) Brussels Ibis

4.5.4 The Geo-blocking Regulation as part of the assessment framework

4.6 The assessment framework and the interpretation methods to rethink the CJEU's approach to jurisdiction in cross-border copyright infringement cases

4.6.1 Diagram on the principles of the assessment framework to 179 provide jurisdiction under Article 7(2) Brussels Ibis in crossborder copyright infringement cases

4.6.2 Table on the methods of interpretation that will be employed in this dissertation to rethink the CJEU's approach to jurisdiction under Article 7(2) Brussels Ibis in cross-border copyright infringement cases 
Chapter 5: Examining the CJEU's approach to jurisdiction in cross-border

copyright infringement cases

5.1 The concept of locus protectionis as connecting factor

5.1.1 The CJEU's rulings involving the concept of locus protectionis under Article 7(2) Brussels Ibis

5.1.2 Diverging concepts of locus protectionis

5.1.3 The role of the locus protectionis regarding the attribution of

5.1.4 Assessing the locus protectionis criterion from a legitimate perspective

5.2 The 'likelihood of damage' and 'mere accessibility' criterion as connecting factor

5.2.1 The Handlungs and the Erfolgsort in the context of cross-border copyright infringements

5.2.2 Diverging concepts of the damage

5.2.3 Jurisdiction based on damage caused by a third party

5.2.3.1 Other rulings on the interpretation of Article 7(2) Brussels Ibis

5.2.3.1.1 The ruling of Dumez France and Tracoba v. Hessische

Landesbank and Others involving successive victims

5.2.3.1.1.1 The Dumez ruling versus the rulings Pinckney and Hi Hotel

5.2.3.1.2 The ruling of Melzer v. MF Global UK Ltd involving coperpetrators

5.2.3.1.2.1 The Melzer ruling versus the rulings Pinkney and Hi Hotel

5.2.3.1.3 The ruling of Coty Germany GmbH v. First Note Perfumes NV involving successive perpetrators

5.2.3.1.3.1 The Coty ruling versus the rulings Pinkney and Hi Hotel

5.2.3.1.3.2 Advocate General Jääskinen's rejection of a third party-based approach to jurisdiction in the cases Coty and Pinckney

5.2.3.1.4 Table on the rulings involving the third party-based approach to jurisdiction under Article 7(2) Brussels Ibis

5.2.4 Assessing the 'likelihood of damage' and 'mere accessibility' criterion from a legitimate perspective

5.2.4.1 The principle of predictability

5.2.4.2 A close connection between dispute and court/ sound administration of justice

5.2.4.3 The principle of balancing the interests and the influence of the Geo-blocking Regulation

5.3 Assessing the territorially limited approach to jurisdiction under the Pinckney doctrine

5.3.1 Arguments against the mosaic approach under the Pinckney doctrine 
5.3.2 The declining role of the territorial protection of copyrights regarding the scope of the court's jurisdiction

5.3.3 The territorial scope of the jurisdiction of the court of the

Erfolgsort with respect to damage and an injunction to cease or prevent copyright infringing activities

5.3.3.1 The influence of the principle of international comity on the actual scope of full jurisdiction

5.3.4 Certain basic conditions to consider when providing full jurisdiction under Article 7(2) Brussels Ibis

5.3.4.1 A strong (territorial) connection between the dispute and the court 234

5.3.4.2 The application of a single copyright law 238

5.3.5 European Union copyright courts or a Unified Copyright Court? 239

5.4 Concluding remarks

Chapter 6: Alternative approaches to jurisdiction in cross-border copyright

infringement cases established by scholars and courts of European Union Member States

6.1 The 'directed activities' approach

6.1.1 The 'directed activities' approach in case law of courts of

6.1.2 The 'directed activities' approach in the Pammer and Alpenhof

6.1.2.1 The Pammer and Alpenhof ruling versus the rulings Pinckney, Hi Hotel and Pez Hejduk

6.1.3 The 'directed activities' approach as escape clause in Article 2:202 CLIP Principles of 2011

6.1.3.1 The general objectives of the CLIP Principles

6.1.3.2 The 'directed activities' approach in the escape clause of Article 2:202 CLIP

$\begin{array}{lll}\text { 6.1.4 Assessing the 'directed activities' approach } & 257\end{array}$

6.1.4.1 The principle of predictability 258

6.1.4.2 A close connection between dispute and court/sound 259 administration of justice

6.1.4.3 The principle of balancing the interests 260

6.1.4.4 The Geo-blocking Regulation and the 'directed activities' 261 approach

6.2 The 'victim's centre of interests' approach

6.2.1 The 'victim's centre of interests' approach established by the 264

CJEU regarding online infringement of personality rights

6.2.1.1 The joined cases of eDate and Martinez 264

$\begin{array}{lll}\text { 6.2.1.1.1 The facts } & 264\end{array}$

$\begin{array}{lll}\text { 6.2.1.1.2 The preliminary ruling } & 265\end{array}$ 
6.2.1.2 The case of Bolagsupplysningen OÜ and Ingrid Ilsjan v. Svensk

\section{Handel $A B$}

6.2.1.2.1 The Opinion of the Advocate General Bobek

6.2.2 The 'victim's centre of interests' approach applied to infringements of moral rights

6.2.2.1 Moral rights

6.2.2.2 The 'copyright holder's centre of interests' approach related to

6.2.3 The 'case-specific copyright holder's centre of interest' approach

6.2.4 Assessing the various 'victim's centre of interests' approaches

6.2.4.1 Pro and contra arguments of the 'victim's centre of interests'

6.2.4.2 The principle of predictability

6.2.4.3 A close connection between dispute and court/ sound

6.2.4.4 The principle of balancing the interests

6.2.4.5 The Geo-blocking Regulation and the 'victim's centre of interests' approach

6.3 Table 1: The assessment of various approaches to jurisdiction in cross-border copyright infringement cases

6.4 Combined approaches to jurisdiction

6.4.1 Assessing the 'centre of gravity of the dispute' approach

6.4.2 Article 10 of the Draft Hague Convention of 1999

6.4.2.1 The combined approach to jurisdiction in infringement cases

6.4.2.2 Assessing the combined approach to jurisdiction under Article 10 Hague Draft Convention of 1999

6.4.2.2.1 The principle of predictability

6.4.2.2.2 A close connection between dispute and court/ sound administration of justice

6.4.2.2.3 The principle of balancing the interests

6.4.2.2.4 The Geo-blocking Regulation and Article 10 Draft Hague Convention of 1999

6.4.3 Article 6 of the Dreyfuss and Ginsburg-Convention of 2002

6.4.3.1 The two combined approaches to jurisdiction in infringement cases under Article 6 Dreyfuss and Ginsburg-Convention of 2002

6.4.3.2 Assessing the two combined approaches under Article 6 Dreyfuss and Ginsburg-Convention of 2002

6.4.3.2.1 The principle of predictability 
6.4.3.2.3 The principle of balancing the interests 309

6.4.3.2.4 The Geo-location Regulation and Article 6 of the Dreyfuss and 310 Ginsburg-Convention of 2002

6.4.4 Article 12a MPI Proposal of $2001 \quad 312$

6.4.4.1 The combined approaches to jurisdiction in infringement cases 313 under Article 12a MPI Proposal of 2001

6.4.4.2 Assessing Article 12a MPI Proposal of $2001 \quad 314$

6.4.4.2.1 The principle of predictability 316

6.4.4.2.2 A close connection between dispute and court/ sound 317 administration of justice

6.4.4.2.3 The principle of balancing the interests 317

6.4.4.2.4 The Geo-blocking Regulation and Article 12a MPI Proposal of 319 2001

6.4.5 Article 2:202 and 2:203(2) CLIP Principles of 2011320

6.4.5.1 The combined approach to jurisdiction in infringement cases 322 under Article 2:202 CLIP and Article 2:203(2) CLIP

6.4.5.2 Assessing the combined approach to jurisdiction under Article 322 2:202 CLIP and Article 2:203(2)(b) CLIP

6.4.5.2.1 The principle of predictability 323

6.4.5.2.2 A close connection between dispute and court/sound 324 administration of justice

6.4.5.2.3 The principle of balancing the interests 324

6.4.5.2.4 The Geo-blocking Regulation and the combined approach to 325 jurisdiction under Article 2:202 CLIP and Article 2:203(2)(b) CLIP

6.4.6 Article 5 of the Draft Guidelines ILA 'Intellectual Property and 326 Private International Law' of 2018

6.4.6.1 Approach to jurisdiction in infringement cases under Article 5 of $\quad 328$ the Draft Guidelines ILA 'Intellectual Property and Private International Law' of 2018

6.4.6.2 Assessing the effects-based approach in Article 5(b) Draft Guidelines of 2018

6.4.6.2.1 The principle of predictability

6.4.6.2.2 A close connection between dispute and court/ sound 330 administration of justice

6.4.6.2.3 The principle of balancing the interests 331

6.4.6.2.4 The Geo-blocking Regulation and Article 5(b) Draft Guidelines 332 ILA of 2018

6.5 Table 2: The assessment of various combined approaches to jurisdiction in infringement cases

6.6 Concluding remarks 

States of America

7.1 Applying the method of comparative law under Article 7(2) Brussels Ibis 351

7.2 Subject-matter jurisdiction related to cross-border copyright infringement 352 disputes

7.3 Personal jurisdiction related to cross-border copyright infringement disputes 353

$\begin{array}{lll}\text { 7.3.1 General personal jurisdiction } & 354\end{array}$

7.3.2 Specific personal jurisdiction $\quad 355$

7.3.2.1 The case of Penguin Group (USA) Inc. v. American Buddha 356

7.3.2.1.1 Assessing the Penguin ruling 358

7.4 The constitutional analysis arising from the International Shoe ruling 359

7.4.1 The rationale behind the 'minimum contacts' requirement and the 361 resemblance with the principles underlying Article 7(2) Brussels Ibis

7.5 The various interpretations of the 'minimum contacts' requirement in copyright infringement disputes

$\begin{array}{lll}\text { 7.5.1 The Calder effects approach } & 362\end{array}$

7.5.1.1 The mere effects-based approach 363

$\begin{array}{lll}\text { 7.5.1.2 The 'focal point' approach } & 364\end{array}$

7.5.1.2.1 Assessing the 'focal point' approach 365

7.5.1.2.1.1 The principle of predictability 366

7.5.1.2.1.2 A close connection between dispute and court/ sound 367 administration of justice

7.5.1.2.1.3 The principle of balancing the interests 368

7.5.1.2.1.4 The Geo-blocking Regulation and the 'focal point' approach 368

7.5.1.3 The 'individualized targeting' approach 369

7.5.1.3.1 Assessing the 'individualized targeting' approach 371

$\begin{array}{ll}\text { 7.5.1.3.1.1 The principle of predictability } & 371\end{array}$

7.5.1.3.1.2 A close connection between dispute and court/ sound 372 administration of justice

7.5.1.3.1.3 The principle of balancing the interests 373

7.5.1.3.1.4 The Geo-blocking Regulation and the 'individualized targeting' 373 approach

$\begin{array}{lll}\text { 7.5.2 The Zippo approach } & 373\end{array}$

7.5.2.1 Assessing the Zippo approach 376

7.5.2.1.1 The principle of predictability 376

7.5.2.1.2 A close connection between dispute and court/ sound 376 administration of justice

7.5.2.1.3 The principle of balancing the interests 377

7.5.2.1.4 The Geo-blocking Regulation and the Zippo approach 377

$\begin{array}{lll}\text { 7.5.3 The targeting approach } & 378\end{array}$ 
7.5.3.1 Assessing the targeting approach

$\begin{array}{lll}\text { 7.5.3.1.1 The principle of predictability } & 380\end{array}$

7.5.3.1.2 A close connection between dispute and court/ sound 380

7.5.3.1.3 The principle of balancing the interests 380

7.5.3.1.4 The Geo-blocking Regulation and the targeting approach 381

7.6 Table on the assessment of various approaches to jurisdiction in the United 382 States of Amerika

7.7 The United States Supreme Court rejects a third party-based approach to 387 specific personal jurisdiction

$\begin{array}{ll}7.8 \text { Concluding remarks } & 388\end{array}$

Chapter 8: Conclusion 391

8.1 The necessity to rethink the CJEU's approach to jurisdiction in cross-border 393 copyright infringement cases
8.1.1 Legitimate interpretation of Article 7(2) Brussels Ibis in cross- border copyright infringement cases
8.1.2 The CJEU's approach to jurisdiction in cross-border copyright infringement cases undermines the principles underlying the special jurisdiction rule of Article 7(2) Brussels Ibis

8.1.2.1 The principle of predictability

8.1.2.2 A close connection between dispute and court/ sound 396

8.1.2.3 The principle of balancing the interests involved 396

8.2 The 'directed activities' approach to jurisdiction under Article 7(2) Brussels 398 Ibis in cross-border copyright infringement cases

8.2.1 The principle of predictability 398

8.2.2 A close connection between dispute and court/ sound 400

8.2.3 The principle of balancing the interests 401

8.3 'Full' jurisdiction of the court of the Erfolgsort in ubiquitous copyright 402 infringement cases

8.3.1 The concept of 'full' jurisdiction 404

8.3.2 Approaches that confer 'full' jurisdiction in cross-border 404

8.3.2.1 The 'copyright holder's centre of interests', or forum actoris, 405 approach

8.3.2.2 The substantial effects-based approach 407

8.3.2.2.1 The combination of the 'directed activities' criterion and the 409 'flagrant substantial damages in relation to the entire damage' criterion 
8.4 Table on the desirable approach to effects-based jurisdiction under Article

7(2) Brussels Ibis in cross-border copyright infringement cases

8.4.1 Applying the desirable approach to jurisdiction to cases Pinckney, Hi Hotel and Pez Hejduk

8.4.1.1 The Pinckney case 412

8.4.1.2 The Hi Hotel case 413

8.4.1.3 The Pez Hejduk case 413

8.5 A codified uniform approach to jurisdiction in cross-border copyright 414 infringement cases?

$\begin{array}{lll}\text { 8.5.1 At European Union level } & 414\end{array}$

$\begin{array}{lll}\text { 8.5.2 At international level } & 415\end{array}$

$\begin{array}{lr}\text { Bibliography } & 417\end{array}$

Literature $\quad 419$

$\begin{array}{ll}\text { Case law } & 467\end{array}$

Treaties/Agreements $\quad 480$

European Union Directives and Regulations $\quad 484$

$\begin{array}{ll}\text { Soft law } & 488\end{array}$

$\begin{array}{ll}\text { Reports and miscellaneous } & 490\end{array}$

$\begin{array}{ll}\text { Samenvatting } & 493\end{array}$

$\begin{array}{ll}\text { Valorisation Addendum } & 501\end{array}$

$\begin{array}{ll}\text { Curriculum Vitae } & 509\end{array}$ 



\section{Acknowledgements}

In 2005, I obtained my master's degree at the Faculty of Law at Maastricht University. It has been a pleasure to return to this university for my $\mathrm{PhD}$ research in 2017. After three years, my extensive $\mathrm{PhD}$ research has come to an end. I really enjoyed this special journey.

Professor Dr. René de Groot and Dr. Stephan Rammeloo, my promotor and co-promotor respectively, guided me on this special journey. I would like to express my sincere gratitude and thanks for their supervision by giving valuable advice and interesting comments on my research. My appreciation for their enthusiastic and kind support; I always enjoyed our meetings. I am very grateful that Professor Dr. René de Groot provided me the opportunity to do my PhD research at Maastricht University.

A very special thanks to the members of the Assessment Committee, Professor Dr. Marta Pertegás Sender, Professor Dr. Mireille van Eechoud, Dr. Jan-Jaap Kuipers and Dr. Anke Moerland, for assessing my dissertation and providing valuable comments on my research.

My sincere appreciation and thanks go to Professor Dr. Agustin Parise for hosting the interesting Maastricht European Private Law Institute (M-EPLI) meetings and providing the opportunity to present my research at the M-EPLI meeting. It is an honor to have you as my paranymph. I am also very grateful to Fabiola Jiménez, my dear sister-in-law, for being my paranymph.

Special thanks go to Joerie Minses, my college friend, who accompanied and supported me during my law study at Maastricht University. I am very grateful to Elout Korevaar, my former colleague at Hoeberechts Weert, who introduced me to the field of private international law and inspired me to develop my academic writing skills. Especially thanks for providing access to the legal 'walhalla'. Many thanks to Lianca de Vos, my friend, for helping me to set up an archive of a vast amount of literature for my research.

Finally, I would like to express my gratitude to my family and friends for their support. Special thanks to Professor Dr. Boris Brummans, my dear cousin, for giving valuable advice on writing my dissertation. I am especially grateful for the faithful assistance and encouragement given by my aunt Annie Cootjans. Many thanks to my dear husband Babu Rebero for being by my side. My heartfelt thanks go to my parents and two brothers, Rutger and Roderik, for always supporting me.

Birgit van Houtert-Rebero

24 July 2020

Maaseik, Belgium 



\title{
List of Abbreviations
}

AG

The Advocate General who provides a so-called Opinion regarding a question that has been referred to the CJEU (See paragraph 3.1).

\begin{abstract}
ALI Principles
Principles on Intellectual Property: Principles Governing Jurisdiction, Choice of Law and Judgments in Transnational Disputes have been published in 2008 under the auspices of the American Law Institute.
\end{abstract}

\section{Berne Convention 1979}

Berne Convention for the Protection of Literary and Artistic Works signed at Berne on 9 September 1886, entered into force 5 December 1887, lastly amended on 28 September 1979, 828 UNTS 221.

\section{Brussels I}

Council Regulation (EC) No. 44/2001 of 22 December 2000 on jurisdiction and the recognition and enforcement of judgments in civil and commercial matters (OJ L 12, 16.01.2001, pp. 123), also referred to as the Brussels I Regulation.

\section{Brussels Ibis}

Regulation (EU) No. 1215/2012 of the European Parliament and the Council of 12 December 2012 on jurisdiction and the recognition and enforcement of judgements in civil and commercial matters (OJ L 351, 20.12.2012, pp. 1-32), also referred to as the Brussels Ibis Regulation.

\section{Brussels Convention of 1968}

Brussels Convention on jurisdiction and the enforcement of judgments in civil and commercial matters (OJ L 299, 31.12.1972, pp. 32-42).

\section{Brussels system}

For the purpose of this dissertation, the term 'the Brussels system' includes the Brussels Convention of 1968, the Brussels I Regulation, and the Brussels Ibis Regulation.

\section{Charter of Fundamental Rights of the European Union of 2000}

Charter of Fundamental Rights of the European Union proclaimed on 7 December 2000 by the European Parliament, the Council of Ministers and the European Commission, entered into force on 1 December 2009 (OJ C 364, 18.12. 2000, pp. 1-22). 


\section{CJEU}

Court of Justice of the European Union

\section{CLIP}

Principles on Conflict of Laws in Intellectual Property established by the European Max Planck Group on Conflict of Laws in Intellectual Property between 2004 and 2011. For the final text of the Principles on Conflict of Laws in Intellectual Property of 1 December 2011, see https://www.ip.mpg.de/en/research/research-news/principles-on-conflict-of-laws-inintellectual-property-clip.html

\section{CLIP group}

European Max Planck Group on Conflict of Laws in Intellectual Property

\section{Commercial Agents Directive}

Council Directive 86/653/EEC of 18 December 1986 on the coordination of the laws of the Member States relating to self-employed commercial agents (OJ L 382, 31.12.1986, pp. 1721).

\section{Community trade mark Regulation}

Council Regulation No. 40/94 of 20 December 1993 on the Community trade mark (OJ L 11, 14.01.1994, pp. 1-66).

\section{Directive on Copyright in the Digital Single Market}

Directive (EU) 2019/790 of the European Parliament and of the Council of 17 April 2019 on copyright and related rights in the Digital Single Market and amending Directives 96/9/EC and 2001/29/EC (OJ L 130, 17.05.2019, pp. 92-125).

\section{Directive on the Enforcement of Intellectual Property Rights}

Directive 2004/48/EC of the European Parliament and of the Council of 29 April 2004 on the enforcement of intellectual property rights (OJ 2004 L195 pp. 16-25).

\section{Draft Guidelines ILA of 2016}

Under the auspices of the International Law Association (ILA), the Committee on Intellectual Property and Private International Law drafted the Draft Guidelines 'Intellectual Property and Private International Law'. For the Draft Guidelines ILA as of 25 May 2016, see the Report International Law Association Johannesburg Conference Intellectual Property and Private International Law (2016), T. Kono, P. A. de Miguel Asensio \& A. Metzger (eds.), pp. 1-18. See documents at http://www.ila-hq.org/index.php/committees.

\section{Draft Guidelines ILA of 2018}

Under the auspices of the International Law Association (ILA), the Committee on Intellectual Property and Private International Law drafted the Draft Guidelines 'Intellectual Property and 
Private International Law'. For the Draft Guidelines ILA as of 22 May 2018, see the Report International Law Association Sydney Conference (2018) Intellectual Property and Private International Law, T. Kono, P. A. de Miguel Asensio and A. Metzger (eds.), pp. 1-18. See documents at http://www.ila-hq.org/index.php/committees.

\section{Draft Hague Convention of 1999}

Draft Convention on Jurisdiction and Foreign Judgments in Civil and Commercial Matters adopted by the Special Commission under the auspices of the Hague Conference on Private International Law on 30 October 1999(See Nygh \& Pocar 2000).

\section{Dreyfuss and Ginsburg-Convention of 2002}

Draft Convention on Jurisdiction and Recognition of Judgments in Intellectual Property Matters by R. C. Dreyfuss and J. Ginsburg. See R. C. Dreyfuss and J. Ginsburg, "Draft Convention on Jurisdiction and Recognition of Judgments in Intellectual Property Matters", Chicago-Kent Law Review 2002, 77(3), pp. 1065-1153.

\section{EC Treaty}

Treaty establishing the European Community (OJ 1997 C340, 10.11.1997, pp. 173-306).

\section{ECtHR}

European Court of Human Rights

EU

European Union

\section{European Convention on Human Rights of 1950}

European Convention for the Protection of Human Rights and Fundamental Freedoms adopted in Rome on 4 November 1950, entered into force 3 September 1953, ETS No. 005.

\section{EU trade mark Regulation}

Council Regulation (EC) No. 207/2009 of 26 February 2009 on the European Union trade mark (OJ L 78, 24.3.2009, p. 1) replaced by Regulation (EU) No 2017/1001 of the European Parliament and of the Council of 14 June 2017 on the European Union trade mark (OJ L 154, 16.6.2017, pp. 1-99).

\section{First Restatement of Conflict of Laws}

Restatement of Conflict of Laws enacted by the American Law Institute in 1934.

\section{Geo-blocking Regulation}

Regulation (EU) 2018/302 of the European Parliament and of the Council of 28 February 2018 on addressing unjustified geo-blocking and other forms of discrimination based on customers' nationality, place of residence or place of establishment within the internal market and 
amending Regulations (EC) No 2006/2004 and (EU) 2017/2394 and Directive 2009/22/EC (OJ L 60I, 2.3.2018, pp. 1-15).

\section{Hague Judgments Convention of 2019}

Hague Convention of 2 July 2019 on the Recognition and Enforcement of Foreign Judgments in Civil or Commercial Matters. See https://www.hcch.net/en/instruments/conventions/fulltext/?cid=137.

\section{HCCH-WIPO Guide}

In 2019, the Hague Conference on Private International Law and the World Intellectual Property Organisation jointly drafted a guide titled "When Private International Law meets Intellectual Property Law. A Guide for Judges” (See Bennett \& Granata 2019, pp. 1-88).

Available at https://www.wipo.int/edocs/pubdocs/en/wipo pub 1053.pdf

\section{ILA Committee}

Committee on Intellectual Property and Private International Law created under the auspices of the International Law Association in November 2010. (See paragraph 6.4.6)

See http://www.ila-hq.org/index.php/committees

\section{Information Society Directive}

Directive 2001/29/EU of the European Parliament and of the Council of 22 May 2001 on the harmonisation of certain aspects of copyrights and related rights in the information society (OJ L167, 22.06.2001, pp. 10-19).

\section{Jenard Report on the Brussels Convention of 1968}

Jenard Report on the Convention on Jurisdiction and the Enforcement of Judgments in Civil and Commercial Matters signed at Brussels, 27 September 1968, by Mr. P. Jenard. See Official Journal of the European Communities 5. 03. 1979, No C 59/1-59/65.

\section{Joint Recommendation WIPO}

Joint Recommendation Concerning Provisions on the Protection of Marks, and Other Industrial Property Rights in Signs, on the Internet adopted by the Assembly of the Paris Union for the Protection of Industrial Property and the General Assembly of the World Intellectual Property Organization (WIPO) at the Thirty Sixth Series of Meetings of the Assemblies of the Member States of WIPO 24 September to 3 October 2001. See https://www.wipo.int/publications/en/details.jsp?id=345\&plang=RU.

\section{Member States}

The 27 countries that are a member of the European Union. For a list of the countries, see https://europa.eu/european-union/about-eu/countries_en - tab-0-0). 


\section{MPI Proposal of 2001}

In 2001, the Max Planck Institute for Intellectual Property, Competition and Tax Law drafted the so-called Max Planck Institute Proposal, hereinafter MPI Proposal of 2001, that contains private international law provisions related to intellectual property rights. (See Drexl \& Kur 2005, pp. 309-347; Kur 2005, pp. 21-34).

N.Y. C.P.L.R.

New York Civil Practice Law and Rules

\section{Protocol No. 1 to the European Convention on Human Rights of 1952}

Protocol No. 1 to the European Convention for the Protection of Human Rights and Fundamental Freedoms adopted in Paris on 20 March 1952, entered into force on 18 May 1954, ETS No. 009.

\section{Restatement (Second) of Conflict of Laws}

Restatement (Second) of Conflict of Laws enacted by the American Law Institute in 1969.

\section{Rome I}

Regulation (EC) No. 593/2008 of the European Parliament and of the Council of 17 June 2008 on the Law Applicable to Contractual Obligations (OJ L177, 4.7.2008, pp. 6-16).

\section{Rome II}

Regulation (EC) No 864/2006 of the European Parliament and the Council of 11 July 2007 on the applicable law to non-contractual obligations (OJ L199, 31.07.2007, pp. 40-49).

\section{Special Commission}

Under the auspices of the Hague Conference on Private International Law, the Special Commission drafted the Hague Convention on Jurisdiction and Foreign Judgments in Civil and Commercial Matters adopted by the Special Commission on 30 October 1999.

\section{TEU}

Treaty on European Union established by the Treaty of Maastricht, signed on 7 February 1992, entered into force 1 November 1993, and alternated by the Treaty of Lisbon signed on 13 December 2007, entered into force 1 December 2009 (OJ C 326, 26.10.2012, pp. 13-46).

\section{TFEU}

Treaty on the Functioning of the European Union (OJ C 326, 26.10.2012, pp. 47-390).

\section{Treaty of Lisbon of 2007}

The Treaty of Lisbon, signed on 13 December 2007, entered into force 1 December 2009, is divided into two parts: Treaty on European Union and Treaty on the Functioning of the European Union (OJ C 326, 26.10.2012, pp. 13-390). 


\section{Treaty of Paris of 1952}

The Treaty establishing the European Coal and Steel Community signed on 18 April 1951, also known as the Treaty of Paris, entered into force on 23 July 1952 and expired on 23 July 2002.

\section{Treaty of Rome of 1957}

Treaty establishing the European Economic Community (EEC Treaty), also referred to as Treaty of Rome, signed on 25 March 1957 came into force 1 January 1958 (not published in an official journal).

\section{TRIPS-Agreement 1994}

Agreement on Trade Related Aspects of Intellectual Property Rights, Annex 1C of the Marrakesh Agreement Establishing the World Trade Organisation, signed in Marrakesh, Morocco on 15 April 1994, entered into force 1 January 1995, 1869 UNTS 299.

United Nations International Covenant on Economic, Social and Cultural Rights of 1966 United Nations International Covenant on Economic, Social and Cultural Rights adopted in New York on 16 December 1966, entered into force 3 January 1976, 993 UNTS 3.

\section{United States Code}

Code of Laws of the United States of America comprises codifications of federal laws of the states of the United States of America.

\section{WIPO}

World Intellectual Property Organization has been established in 1967. "WIPO is the global forum for intellectual property services, policy, information and cooperation." It is "a selffunding agency of the United Nations, with 193 member states."

See https: https://www.wipo.int/about-wipo/en/.

\section{WIPO Copyright Treaty of 1996}

World Intellectual Property Organization Copyright Treaty signed at Geneva on 20 December 1996, entered into force 6 March 2002, 2186 UNTS 152.

\section{WTO}

World Trade Organisation 


\section{Abbreviations of case law}

AMS Neve

C-172/18 AMS Neve Ltd and Others v. Heritage Audio SL, Pedro Rodriguez Arribas

Bier

C-21/76 Handelskwekerij G.J. Bier v. Mines de Potasse d'Alsace SA

Bolagsupplysningen Ö̈

C-194/16 Bolagsupplysningen Ö̈ and Ingrid Ilsjan v. Svensk Handel AB

Calder

Calder v. Jones, 465 U.S. 783 (1984)

Concurrence

C-618/15 Concurrence SARL v. Samsung Electronics France SAS and Amazon Services

Europe Sarl

Coty

C-360/12 Coty Germany GmbH v. First Note Perfumes NV

Dumez

C-220/88 Dumez France and Tracoba v. Hessische Landesbank and Others

eDate and Martinez

C-509/09 and C-161/10 eDate Advertising GmbH v. X and Olivier Martinez and Robert Martinez v. MGN Limited

Eva Glawischnig

Case C-18/18 Eva Glawischnig-Piesczek v. Facebook Ireland Limited

Folien Fischer

C-133/11 Folien Fischer AG and Foltitec AG v. Ritrama SpA

Hi Hotel

C-387/12 Hi Hotel HCF SARL v. Uwe Spoering

Hotel Maritime

Bundesgerichtshof (BGH), 13 October 2004, I ZR 163/02 [2005] GRUR 431 
Infopaq

C-5/08 Infopaq International A/S v. Danske Dagblades Forening

Ingmar

C-381/98 Ingmar GB Ltd. v. Eaton Leonard Technologies Inc.

International Shoe

International Shoe Co. v. Washington, 326 U.S. 310 (1945)

Keeton

Keeton v. Hustler Magazine, 465 U.S. 770 (1984)

Kolassa

C-375/13 Harald Kolassa v. Barclays Bank plc

Kronhofer

C-168/02 Rudolf Kronhofer v. Marianne Maier and Others

L'Oréal and Others

C-324/09 L'Oréal and Others v. eBay

Marinari

C-364/93 Antonio Marinari v. Loyds Bank plc and Zubaidi Trading Company

Melzer

C-228/11 Melzer v. MF Global UK Ltd.

Pammer and Alpenhof

C-585/08 and C-144/09 Peter Pammer v. Reederei Karl Schlüter GmbH \& Co. KG and Hotel Alpenhof GesmbH v. Olivier Heller

Pez Hejduk

C-441/13 Pez Hejduk v. EnergieAgentur NWR GmbH

Pinckney

C-170/12 Peter Pinckney v. KGD Mediatech AG

Roche

C-539/03 Roche Nederland BV and Others v. Frederick Primus and Milton Goldenberg,

Shevill

C-68/93 Shevill and Others v. Presse Alliance 


\section{Wintersteiger}

C-523/10 Wintersteiger AG v. Products $4 U$ Sondermaschinenbau GmbH

\section{Zippo}

Zippo Manufacturing Co. v. Zippo Dot Com Inc., 952 F. Supp. 1119 (W.D. Pa. 1997) 


\section{Glossary of Latin terms}

actor sequitur forum rei

contra legem

de minimis

erga omnes

ex ante

ex officio

favor auctoris

favor divortii

forum

forum actoris

forum loci protectionis

forum rei

forum specialis

forum state

forum non conveniens

ius

lex

lex fori

lex loci contractus

lex loci delicti

lex loci damni

lex loci protectionis the plaintiff should follow the forum of the

defendant's domicile. In civil law-based states, this has been referred to as the general jurisdiction rule (see paragraph 2.1.2.2.2)

against the law

litigation concerning minor issues

towards everyone

in advance

officially

favour the copyright holder

favour the possibility to obtain a divorce

competent court

the competent court of the place where the plaintiff resides or has his domicile

the court of a state that protects the intellectual property right involved (see Polak 2012, sub 4-5)

the competent court of the place where the defendant is domiciled

a court that is competent on the basis of a so-called special jurisdiction rule (see the actor sequitur forum rei rule above as socalled general jurisdiction rule)

the state of the court seised

"the doctrine that applies in situations where it would be appropriate -to promote justice and the convenience of parties- for a case to be heard in a different forum" (See Goldstein \& Hugenholtz 2013, p. 122) the law in a broad sense contrary to the law enacted by legislators

the law enacted by legislators

the law of the country where protection is sought the law of the place where the contract has been concluded

the law of the place where the delict or tort was committed

the law of the place where the damage occurred the law of the state for which protection is sought 
lex mercatoria

lex originis

lex specialis

lis pendens

locus contractus

locus delicti

locus protectionis

praeter legem

stare decisis

statuta personalia

statuta realia

statuta mixta the transnational law of economic transactions

the law of the state from which the right originates

a special law that takes precedence over the general law

concerns the procedural rule that where proceedings involving the same cause of action and between the same parties are brought in the courts of different states, any court other than the court first seised shall of its own motion stay proceedings until such time as the jurisdiction of the court first seised is established. (See also Article 29(1) Brussels Ibis)

the place where the contract was concluded

the place where the tort or delict was committed

place in which a right is legally protected

the court has interpreted beyond the law

according to this principle courts have to follow previous decisions

rules related to the status of persons

rules related to immovable property

rules related to the form of legal acts 



\section{Chapter 1}

\section{Introduction}





\subsection{Introductory remarks}

\subsubsection{Diverging interests regarding which court should be competent in a cross-border copyright infringement dispute}

In this era of globalisation and the Internet, copyright infringement disputes will often have a cross-border character. Imagine you are the author of an academic article and you discover that parts of your article have been uploaded on the Internet by an infringer domiciled in another state. You will likely want to sue the alleged infringer in the state of your domicile for the entire damage. Litigation in your home state will keep the travel costs low and prevents language problems. For the same reasons, the alleged infringer will generally prefer to appear before the court of the state where he is domiciled. From the perspective of the sound administration of justice, it is desirable to attribute jurisdiction to the court of the state where the relevant facts of the case took place. ${ }^{1}$

The different national procedural laws may also be considered when choosing in which state to sue an alleged copyright infringer. ${ }^{2}$ Although the law of the forum state, the lex fori, usually governs the procedural issues regarding copyright cases, ${ }^{3}$ it is noteworthy that there are certain exceptions with respect to copyright infringement disputes. ${ }^{4}$ Furthermore, everyone would like to evade long procedures as in Italian courts. Thus, from various perspectives, many factors may play a role regarding which court should be competent with respect to a crossborder copyright infringement dispute.

\subsubsection{Rules governing jurisdiction in cross-border copyright infringement cases}

The answer to the question whether the court seised has jurisdiction to determine a crossborder copyright infringement claim lies in the jurisdiction rules related to private international law. In principle, every state has its own national rules regulating jurisdiction in international

\footnotetext{
${ }^{1}$ Strikwerda 2015, pp. 222-223; Strikwerda \& Schaafsma 2019, pp. 40-41. With respect to the attribution of jurisdiction related to private international law, Strikwerda and Schaafsma also point out the interests of states to maintain order in their territory and to keep the financial burden on the judicial system low.

${ }^{2}$ With respect to the adjudication of intellectual property infringements, Van Engelen (2007, p. 30) mentioned that the national procedural laws of the Member States are not harmonized. Yet, the Directive 2004/48/EC of the European Parliament and of the Council of 29 April 2004 on the enforcement of intellectual property rights (OJ 2004 L195 pp. 16-25) does force the Member States of the European Union to harmonize certain procedural rules necessary to enforce intellectual property rights (Article 3) such as rules related to evidence (Article 6 and 7); provisional and precautionary measures (Article 9); damages (Article 13) and legal costs (Article 14). See also Maas, Shannon, De Boer 2013, preface.

${ }^{3}$ Basedow 2010, p. 17; Van Engelen 2007, p. 204.

${ }^{4}$ Basedow 2010, pp. 17-18. Basedow notes that the classification into substantive or procedural issues varies between common law and civil law systems. Furthermore, the European Union Regulations regarding private international law contain specific rules. With respect to cross-border copyright infringement cases, the lex loci protectionis will be the applicable law to assess the damage, the issue of prescription and burden of proof according to Article 15(c) and (h), Article 22(1) of the Regulation (EC) No 864/2006 of the European Parliament and the Council of 11 July 2007 on the applicable law to non-contractual obligations (OJ L199, 31.07.2007, pp. 40-49) referred to as Rome II. Article 8(1) Rome II has laid down the lex loci protectionis rule that "the law applicable to a non-contractual obligation arising from an infringement of an intellectual property right shall be the law of the country for which protection is claimed".
} 
cases related to civil matters. ${ }^{5}$ At international level, between 1992 and 2001, the Hague Conference on Private International Law purported to unify the private international law rules on jurisdiction in civil and commercial matters. ${ }^{6}$ But this attempt failed due to irreconcilable differences between the Contracting States, particularly between the European Union Member States and the states of the United States of America. ${ }^{7}$ In the context of intellectual property rights, Kur pointed out various reasons for this failure such as the disagreement "whether exclusive jurisdiction of the courts in the country of registration/protection should also encompass infringement litigation over industrial property rights" 8 and "the fear that an international convention on jurisdiction and enforcement might be used as a vehicle to impose national doctrines concerning initial copyright ownership on countries applying a different view"9.

Although there exist several treaties related to copyrights, ${ }^{10}$ they do not contain jurisdiction rules on cross-border copyright infringements. ${ }^{11}$ Yet, specialised academic working groups drafted principles of private international law with respect to intellectual property rights. Examples of these principles of soft law are the American Law Institute's Principles on Intellectual Property; the Principles on Conflict of Laws in Intellectual Property; the Joint Japanese-Korean Proposal; the Transparency Proposal on Jurisdiction, Choice of Law, Recognition and Enforcement of Foreign Judgments in Intellectual Property; the Principles on International Intellectual Property Litigation. ${ }^{12}$

\footnotetext{
${ }^{5}$ Grusic, Heinze, Merrett, Mills, Garcia-Castrillón, Tang, Trimmings, Walker 2017, p. 8. For instance, the Dutch jurisdiction rules related to private international law can be found in Articles 1-14 of the Dutch Code of Civil Procedure. In Belgium, rules regarding jurisdiction in cross-border civil cases are laid down in the Code of Private International Law.

6 See https://www.hcch.net/en/projects/legislative-projects/judgments/preparation-of-a-preliminary-draftconvention-1997-1999- on the various preliminary documents related to the work of the Special Commission on International Jurisdiction and the Effects of Foreign Judgments in Civil and Commercial Matters drawn up between 1997 and 2000. Paragraph 6.4.2 will elaborate on the jurisdiction rules applicable to cross-border copyright infringements as stipulated in the Draft Convention on Jurisdiction and Foreign Judgments in Civil and Commercial Matters adopted by the Special Commission on 30 October 1999.

${ }^{7}$ Kono \& Jurcys 2012, p. 11. See https://www.hcch.net/en/states/hcch-members for a list of the current Contracting States of the Hague Conference on Private International Law.

${ }^{8}$ Kur 2002, pp. 175-176.

${ }^{9}$ Kur 2002, p. 182.

${ }^{10}$ For example, the Berne Convention for the Protection of Literary and Artistic Works signed at Berne on 9 September 1886, entered into force 5 December 1887, lastly amended on 28 September 1979, 828 UNTS 221; the Universal Copyright Convention adopted at Geneva on 6 September 1952, entered into force 16 September 1955 , 216 UNTS 132; The Agreement on Trade Related Aspects of Intellectual Property Rights (known as the TRIPSAgreement), Annex 1C of the Marrakesh Agreement Establishing the World Trade Organisation, signed in Marrakesh, Morocco on 15 April 1994, entered into force 1 January 1995, 1869 UNTS 299; the World Intellectual Property Organization Copyright Treaty (known as the WIPO Copyright Treaty of 1996) signed at Geneva on 20 December 1996, entered into force 6 March 2002, 2186 UNTS 152.

${ }^{11}$ Von Lewinski 2008, p. 4.

12 The American Law Institute's Principles on Intellectual Property: Principles Governing Jurisdiction, Choice of Law and Judgments in Transnational Disputes (known as the ALI-Principles) have been published in 2008 under the auspices of the American Law Institute. Between 2004 and 2011, the European Max Planck Group on Conflict of Laws in Intellectual Property established the Principles on Conflict of Laws in Intellectual Property, the socalled CLIP Principles. Paragraph 6.1.3.1 will provide more information on these principles. With respect to the Joint Japanese-Korean Proposal of October 2010 (also referred to as Waseda Principles) see "Commentary on Principles of Private International Law on Intellectual Property Rights (Joint Proposal Drafted by Members of the Private International Law Association of Korea and Japan)", Waseda University Global COE Project, 14 October 2010. Available at http://www.win-cls.sakura.ne.jp/pdf/28/08.pdf. For more information on principles drafted in
} 
In Europe, the Member States of the European Union (hereinafter Member States) have successfully enacted jurisdiction rules regarding cross-border civil and commercial cases. These rules have to be applied by the Member States' courts in cross-border copyright infringement cases whenever the defendant is domiciled in a Member State. ${ }^{13}$ Currently, these rules can be found in the Regulation (EU) No. 1215/2012 on jurisdiction and the recognition and enforcement of judgments in civil and commercial matters, also referred to as the Brussels Ibis Regulation (hereinafter Brussels Ibis). ${ }^{14}$ The Brussels Ibis Regulation prevails above the national rules on private international law of the Member States based on the principle of supremacy of the European Union law $^{15}$ and the direct effect inherent to European Union Regulations. ${ }^{16}$

\subsubsection{The broad possibilities to sue an alleged copyright infringer domiciled in the European Union before a Member State court}

When you bring your cross-border copyright infringement claim before a Member State court against an alleged infringer, who has been domiciled in a Member State, the following two provisions may serve as basis for the court's jurisdiction. First, according to the general jurisdiction rule of Article 4 Brussels Ibis, the alleged infringer may always be sued in the courts of the Member State of his domicile. ${ }^{17}$ Second, regarding "matters relating to cross-border tort,

\footnotetext{
Asia, such as the Transparency Proposal on Jurisdiction, Choice of Law, Recognition and Enforcement of Foreign Judgments in Intellectual Property; the Principles on International Intellectual Property Litigation of October 2009, see Kono \& Jurcys 2012, p. 12. The Principles on International Intellectual Property Litigation (KOPLIA Principles) have been drafted by the Korean Private International Law Association on 26 March 2010, see GarcíaCastrillón 2014, p. 423. Chapter six will examine several scholarly proposals related to the intersection of private international law and intellectual property law. See, for instance, paragraph 6.4.6 on the Guidelines on Intellectual Property on Private International Law drafted by the International Law Association.

${ }^{13}$ See Article 4 and 7(2) of the Council Regulation (EU) No. 1215/2012 of the European Parliament and the Council of 12 December 2012 on jurisdiction and the recognition and enforcement of judgements in civil and commercial matters (OJ L 351, 20.12.2012, pp. 1-32) referred to as Brussels Ibis. See also recital 14 in the preamble to this Regulation.

${ }^{14}$ In Europe, the first set of unified jurisdiction rules regarding private international law can be found in the Brussels Convention on Jurisdiction and the Enforcement of Judgments in Civil and Commercial Matters, concluded in 1968 by the six Member States of the European Economic Community (OJ L 299, 31.12.1972, pp. 34-42). In addition, the Lugano Convention on Jurisdiction and the Enforcement of Judgments in Civil and Commercial Matters of 1988, revised in 2007, extended the Brussels Convention, with some alternations, to the European states that belong to the European Free Trade Association (OJ L 319, 25.11.1988, pp. 9-48), revised in 2007 (OJ L 339, 21.12.2007, pp. 3-41). In 2002, the legislators of the European Union replaced the Brussels Convention of 1968 by the Council Regulation (EC) No. 44/2001 of 22 December 2000 on jurisdiction and the recognition and enforcement of judgments in civil and commercial matters (OJ L 351, 20.12.2012, pp. 1-32). Subsequently, the latter so-called Brussels I Regulation has been replaced by the Council Regulation (EU) No. 1215/2012 of the European Parliament and the Council of 12 December 2012 on jurisdiction and the recognition and enforcement of judgments in civil and commercial matters (OJ L 351, 20.12.2012, pp. 1-32), known as the Brussels Ibis Regulation.

${ }^{15}$ Case C-6/64 Flaminio Costa v. E.N.E.L..

${ }^{16}$ Case C-26/62 Van Gend \& Loos v. Nederlandse Administratie der Belastingen. According to Article 288 Treaty on the Functioning of the European Union (hereinafter TFEU), "a regulation shall have general application, it shall be binding in its entirety and directly applicable in all Member States." Treaty on the Functioning of the European Union (OJ C 326, 26.10.2012, pp. 47-390).

${ }^{17}$ Pursuant to Article 62 Brussels Ibis Regulation, the place of domicile has to be determined according to the national law of the court seised. According to Article 63, "a company or other legal person or association of natural
} 
delict or quasi-delict" Article 7(2) Brussels Ibis confers jurisdiction on the court of "the place where the harmful event occurred or may occur". ${ }^{18}$ With respect to cross-border copyright infringement disputes, the Court of Justice of the European Union (hereinafter CJEU) ${ }^{19}$ interpreted the latter special jurisdiction rule in a trilogy of cases, referred to as Pinckney, Hi Hotel and Pez Hejduk. ${ }^{20}$

The CJEU's broad interpretation in these rulings seems to enable copyright holders domiciled anywhere in the world- to initiate proceedings in each Member State where the alleged copyrighted infringing work has been for sale, or the infringing content has been accessible via the Internet. ${ }^{21}$ The CJEU based this so-called Pinckney doctrine on the policy aim that "copyrights must be automatically protected, in particular by virtue of Directive 2001/29" (hereinafter Information Society Directive). ${ }^{22}$ It suits the active role of the CJEU with respect to the harmonisation of copyright laws in the European Union. ${ }^{23}$

As courts of each Member State where the copyright infringing content has been available for sale or online accessible may obtain jurisdiction, it will, however, be difficult for potential copyright infringers to anticipate in which Member State(s) they may be sued. ${ }^{24}$ To provide predictability is the main objective of jurisdiction rules under the Brussels system. ${ }^{25}$ The risk of unexpectedly being sued in several Member States may even prevent internet users to exchange information or impede traders to freely sell products in all Member States. ${ }^{26}$

\footnotetext{
or legal persons is domiciled where it has its: a) statutory seat, or b) central administration, or c) principal place of business."

18 The CJEU ruled that the concept of "in matters relating to tort, delict or quasi-delict" must be autonomously interpreted as covering "all actions which seek to establish the liability of a defendant and which are not related to a 'contract' within the meaning of Article 5(1) of the Brussels Convention." See case C-189/87 Kalfelis v. Schröder, para. 16-18.

${ }^{19}$ The Court of Justice of the European Union (hereinafter CJEU), formerly known as the Court of Justice of the European Coal and Steel Communities established by the Treaty of Paris in 1952, as of 1958 the Court of Justice of the European Communities. The CJEU is the highest judicial authority in the European Union and consists of two courts: the Court of Justice and the General Court. For more information see https://europa.eu/europeanunion/about-eu/institutions-bodies/court-justice en.

${ }^{20}$ Case C-170/12 Peter Pinckney v. KGD Mediatech AG; Case C-387/12 Hi Hotel HCF SARL v. Uwe Spoering; Case C-441/13 Pez Hejduk v. EnergieAgentur NWR GmbH.

${ }^{21}$ See chapter 3 on the three rulings referred to as Pinckney, Hi Hotel and Pez Hejduk.

${ }^{22}$ Case C-170/12 Peter Pinckney v. KGD Mediatech AG, para. 39. See also Case C-387/12 Hi Hotel HCF SARL v. Uwe Spoering, para. 34; Case C-441/13 Pez Hejduk v. EnergieAgentur NWR GmbH, para. 22. Directive 2001/29/EU of the European Parliament and of the Council of 22 May 2001 on the harmonisation of certain aspects of copyrights and related rights in the information society (OJ L167, 22.06.2001, pp. 10-19), referred to as the Information Society Directive.

${ }^{23}$ See Bengtsson 2016, p. 492; Van Eechoud 2012, p. 76. Leistner demonstrates the active role the CJEU has been playing regarding the interpretation of the European Union Directives related to copyrights, in particular the Information Society Directive. See Leistner 2014, pp. 559-600. Rosati denotes the CJEU's proactive approach to copyright by means of the judicial interpretation of the originality requirement. See Rosati 2013, pp. 97-127. Griffiths criticises the broad interpretations by the CJEU of copyright concepts, such as "work" and "creativity". See Griffiths 2013(a), pp. 767-790. Geiger discusses the role of the CJEU regarding "harmonizing creating and sometimes disrupting copyright law in the EU'. See Geiger 2016, pp. 435-446.

${ }^{24}$ Husovec 2014, p. 372; Matulionyte 2015, p. 133.

${ }^{25}$ See recital 15 of the preamble to the Brussels Ibis Regulation. See also Magnus \& Mankowski 2016, p. 12; Pontier \& Burg 2004, pp. 69-111. For the purpose of this dissertation, the term 'the Brussels system' includes the Brussels Convention of 1968, the Brussels I Regulation, and the Brussels Ibis Regulation.

${ }^{26}$ See also Matulionyte 2015, p. 134.
} 


\subsubsection{Jurisdiction limited to local damage}

In the final part of the Pinckney, Hi Hotel and Pez Hejduk rulings, the CJEU held that the territorial protection of copyrights entails the territorially limited jurisdiction of the court of the place where the damage occurred. ${ }^{27}$ The competent court can therefore only ascertain the damage caused within the forum state. This so-called mosaic approach increases the chance that the alleged infringer gets sued before the courts of many Member States. ${ }^{28}$ Particularly in case of alleged online copyright infringements, multiple Member State courts will be competent. If the defendant gets sued in many Member States, it will be quite expensive to defend himself in all the cases. ${ }^{29}$ This approach to jurisdiction likely causes unpredictability, increases litigation costs and the risk of irreconcilable decisions. ${ }^{30}$

From a perspective of the copyright holder, it may seem unfair that a copyright holder can only receive full redress in the Member State where a malicious infringer is located or acted. Considering the pressing problem of online piracy, ${ }^{31}$ it is particularly desirable to establish an adequate approach to jurisdiction. Several scholars argued that under certain conditions the court of the place where the damage occurred should obtain jurisdiction regarding the entire damage caused by online copyright infringements. ${ }^{32}$

\subsection{The aim and the methodologies of the research}

This dissertation aims to rethink the CJEU's approach to jurisdiction under Article 7(2) Brussels Ibis in cross-border copyright infringements disputes. First of all, the leeway of the CJEU to interpret the special jurisdiction rule in Article 7(2) Brussels Ibis will be examined on the basis of general accepted interpretation methods. On the basis of these methods an assessment framework will be set up. The necessity to rethink will be demonstrated by analysing the connecting factors and the territorially limited jurisdiction as adopted by the CJEU in the cases Pinckney, Hi Hotel, Pez Hejduk. On the one hand, this dissertation points out that the CJEU's policy-based interpretation of the special jurisdiction rule suits the development of employing private international law as a policy instrument, referred to as the

\footnotetext{
${ }^{27}$ Case C-170/12 Peter Pinckney v. KGD Mediatech AG, para. 44-46; Case C-387/12 Hi Hotel HCF SARL v. Uwe Spoering, para. 38-39; Case C-441/13 Pez Hejdukv. EnergieAgentur NWR GmbH, para. 36-37.

${ }_{28}$ According to Magnus and Mankowski, the CJEU developed in the case C-68/93 Shevill v. Press Alliance SA (para. 28-33) the so-called mosaic principle under Article 7(2) Brussels Ibis: "at the place where the damage was sustained, a claim can only be brought for damage sustained in the forum state, not for the world-wide damage." See Magnus and Mankowski 2016, p. 278. See also joined cases C-509/09 and C-161/10 eDate Advertising GmbH v. X and Olivier Martinez and Robert Martinez v. MGN Limited, para. 51.

${ }^{29}$ Torremans 2016, p. 384.

${ }^{30}$ See Matulionyte 2015, pp. 133-134; Neumann 2014, p. 509; Opinion of Advocate General Jääskinen delivered on 21 November 2013 in the case C-360/12 Coty Germany GmbH v. First Note Perfumes NV, para. 61; Opinion of Advocate General Bobek delivered on 13 July 2017 in the case C-194/16 BolagsupplysningenOü Ingrid Ilsjan v. Svensk Handel $A B$, para. 79-90.

${ }^{31}$ Solley 2008, p. 813. "Unauthorised online content distribution" has been referred to as "online piracy". See Global Online Piracy Study of the Institute for Information Law of University of Amsterdam 2018, p. 9

32 See Kono \& Jurcys 2015, pp. 24-28; Maunsbach 2012, pp. 56-58; Torremans 2014, pp. 387-389. See also Article 2:203(2) of the CLIP Principles, see paragraph 6.4.5. See chapter 6 for more scholarly proposals.
} 
"instrumentalisation of private international law". ${ }^{33}$ On the other hand, arguments will be provided that the CJEU's approach to jurisdiction in copyright infringement disputes does not meet the principles underlying the special jurisdiction rule of Article 7(2) Brussels Ibis.

Scholars have made some critical notes on the instrumentalisation of private international law in the European Union. Meeusen argued that "private international law mustn't be degraded into an auxiliary instrument of EC law". ${ }^{34}$ Van Den Eeckhout even raised questions related to legitimacy: supposing that 'the dogma 'neutral PIL' is abandoned...what interest can or may PIL serve at the end of the day?". ${ }^{35}$ While scholars have already started to discuss the instrumentalisation of private international law with respect to various policy areas of the European Union, ${ }^{36}$ the area of copyright law has not been scrutinised in this setting yet.

This dissertation aims to find connecting factors that satisfy the principles underlying the special jurisdiction rule of Article 7(2) Brussels Ibis. Hence, the connecting factors will be viewed on the basis of teleological reasoning of this special jurisdiction rule. ${ }^{37}$ That means the connecting factors should provide predictability; entail a close connection between the dispute and the forum state; enhance sound administration of justice; and strike a fair procedural balance between the copyright holder and the alleged infringer. ${ }^{38}$

From a broad perspective, it is desirable that the connecting factors balance the interests between copyright holders, on the one hand, and traders and users of information, on the other hand. ${ }^{39}$ In this dissertation, it will be argued that the aim to establish 'balanced' connecting factors fits the principle of balancing the interests related to copyright law. ${ }^{40}$ From a perspective of private international law, it has also been argued that fundamental rights -like copyrights and the right to information- should be balanced "in the process of allocation of jurisdiction". ${ }^{4}$ Taking into consideration the global interests of traders and users of information also suits the contemporary way of policy-making referred to as global governance. Various academics advocate that private international law should play an important role in addressing global

\footnotetext{
33 De Boer 1980, pp. 785-796; Meeusen 2007, pp. 287-305; Strikwerda 1978, p. 6; Van Den Eeckhout 2002; 2010(b), 2013(b), 2014.

${ }^{34}$ Meeusen 2007, p. 287.

${ }^{35}$ Van Den Eeckhout 2013(a), p. 11. See also Van Den Eeckhout 2002, p. 145; Van Den Eeckhout 2013(b), p. 2.

${ }^{36}$ Van Den Eeckhout refers to the instrumentalisation of private international law with respect to, inter alia, migration law, labour law, social security law, nationality law, human rights and environmental law. See Van Den Eeckhout 2002, pp. 144-158; Van Den Eeckhout 2010; Van Den Eeckhout 2013(a). See Meeusen (2007, p. 288) on the instrumental function of private international law for the achievement of the internal market of the European Union. To illustrate this instrumentalisation, Meeusen refers to the case C-381/98 Ingmar GB Ltd. v. Eaton Leonard Technologies Inc that will be briefly demonstrated in paragraph 4.1.1.

37 The word teleological has been derived from the Greek word "telos" that means "end". In the Oxford English Dictionary 'teleological' is defined as 'the doctrine or study of ends or final causes'. See Woodfield 2010, p. 2. The teleological method has also been referred to as the purposive method, see Fennelly 1996, p. 666.

${ }^{38}$ Magnus \& Mankowski 2016, p. 143.

${ }^{39}$ See also the Preamble No 6 to the Principles on Conflict of Laws related to Intellectual Property, the so-called CLIP Principles. In this dissertation CLIP refers to the final text of the Principles on Conflict of Laws in Intellectual Property of 1 December 2011, available at https://www.ip.mpg.de/en/research/research-news/principles-onconflict-of-laws-in-intellectual-property-clip.html. See also paragraph 4.4.1.

${ }^{40}$ Hugenholtz (2016, p. 429) argues that the principle of balancing the interests between copyright holders and users of protected subject-matter, as enshrined in the preamble of the Information Society Directive, "has increasingly become the cornerstone of the European's Court's jurisprudence in the area of copyright and related rights".

${ }^{41}$ Muir-Watt 2016, p. 881.
} 
issues. ${ }^{42}$ While searching an approach to jurisdiction in copyright infringement disputes, it will be desirable to address the global issues of copyright piracy and copyright havens. ${ }^{43}$

In view of the contextual method of interpretation, this dissertation will also examine the (desirable) effects of the territorial principle related to copyrights on the approach to jurisdiction under Article 7(2) Brussels Ibis in cross-border copyright infringement cases. In addition, this dissertation will consider the possible impact of the Regulation (EU) 2018/302 of the European Parliament and of the Council of 28 February 2018 on addressing unjustified geo-blocking and other forms of discrimination based on customers' nationality, place of residence or place of establishment within the internal market (hereinafter Geo-blocking Regulation) on the approach to jurisdiction in cross-border copyright infringement cases. ${ }^{44}$

After analysing the CJEU's approach to jurisdiction under Article 7(2) Brussels Ibis in cross-border copyright infringement disputes, this dissertation will assess various alternative approaches. These alternative approaches will be examined in light of the principles under Article 7(2) Brussels Ibis; the principle of balancing the relevant interests involved; and the Geo-blocking Regulation. Several of these approaches are established by scholars or courts of Member States such as the 'directed activities' approach ${ }^{45}$ and the 'victim's centre of interests' approach $^{46}$. In addition, proposals of scholarly groups such as the soft law provisions of the Principles on Conflict of Laws in Intellectual Property (hereinafter CLIP Principles) related to copyright infringement disputes will be explored. ${ }^{47}$

Whereas the so-called CLIP Principles are mainly oriented towards European law, ${ }^{48}$ it is also interesting to research the connecting factors adopted by courts in states of the United States of America in cross-border copyright infringement disputes. Watson argued that transplanting legal rules from another legal system "plays a powerful role in law reform" and can be considered as "the most fertile source of legal development" ${ }^{49}$ In particular the Internet

${ }^{42}$ Carballo Pineiro \& Kramer 2014, pp. 109-112; Muir-Watt 2011, pp. 347-428; Muir-Watt 2016, pp. 862-881; Wai 2002, pp. 209-274; Van Den Eeckhout 2017; Van Loon 2008, pp. 197-208.

${ }^{43}$ See paragraph 2.2.2.2 on the concept of copyright havens.

${ }^{44}$ Regulation (EU) 2018/302 of the European Parliament and of the Council of 28 February 2018 on addressing unjustified geo-blocking and other forms of discrimination based on customers' nationality, place of residence or place of establishment within the internal market and amending Regulations (EC) No 2006/2004 and (EU) 2017/2394 and Directive 2009/22/EC (OJ L 60I, 2.3.2018, pp. 1-15), referred to as the Geo-blocking Regulation. The Geo-blocking has been applicable from 3 December 2018. See Article 11(1) Geo-blocking Regulation.

${ }^{45}$ See paragraph 6.1.1 on the 'directed activities' approach in case law of courts of European Union Member States. See also Nuyts 2008, pp. 121-127; Pavelka 2011.

${ }^{46}$ Kono \& Jurcys, 2015; Maunsbach, 2012, pp. 56-57. See also the judgment of the Swedish Supreme Court in the case Michael Engström v. Tylden \& Co AS (Norway) NJA 2012 s 483 decided 4 July 2012. See paragraph 6.2.2.

${ }^{47}$ See the final text of the Principles on Conflict of Laws in Intellectual Property of 1 December 2011, available at https://www.ip.mpg.de/fileadmin/ipmpg/content/clip/the_draft-clip-principles-25-03-20117.pdf. See also paragraph 6.1.3.1. See chapter 6 on proposals drafted by other scholarly groups.

${ }_{48}$ Jurcys 2012, p. 177. See also Peukert 2013, pp. 27-28, PRE:C05-PRE:C07, p. 35, PRE:C25; Van Eechoud \& Kur 2012, p. 187.

${ }^{49}$ Watson 1993, pp. 95, 118. Watson coined the methodology of "legal transplants" that allows legal rules to be transferred from one legal system to another. Watson referred to Roscoe Pound's statement that: "History of a system of law is largely a history of borrowings of legal materials from other legal systems and of assimilation of materials from outside of the law." See Watson 1993, p. 22. The drafters of several national codifications on private international law have looked at private international law rules of other states or international conventions. For instance, the drafters of the Swiss Federal Act on Private International law of 1987 or the Louisiana codification of choice-of-law rules of 1992. See Reimann 2019, p. 1354. The well-known scholar Joseph Story “drew heavily on foreign learning" in Commentaries on the Conflict of Laws (see paragraph 2.1.1). See Reimann 2019, p. 1346. 
and globalisation have compelled both European and United States courts to find legal solutions concerning the attribution of jurisdiction in cross-border copyright infringement disputes. It is therefore useful to focus on connecting factors in United States case law that confer jurisdiction over non-resident defendants in cross-border copyright infringement disputes. ${ }^{50}$ Moreover, it is considered to be desirable to unify the jurisdiction rules in cross-border copyright infringement cases. ${ }^{51}$ However, as argued by Poiares Maduro, when applying the method of comparative law for the interpretation of European Union Law, the "best solution" is "the solution that best fits the underlying goals and requirements of the EU legal order and its particular context of application". ${ }^{52}$ The connecting factors therefore need to be assessed in light of the principles underlying the special jurisdiction rule of Article 7(2) Brussels Ibis.

In sum, this dissertation will rethink the CJEU's approach to jurisdiction under Article 7(2) Brussels Ibis in cross-border copyright infringements by applying general accepted methods of interpretation namely the teleological, contextual and comparative method of interpretation.

\subsection{The structure of this dissertation}

This dissertation consists of two main parts and is divided into eight chapters. In part I, chapter two will start with an introduction to the field of copyright law and the area of private international law. It will map out the general features regarding both fields. In addition, developments will be described that these fields are undergoing in this era of globalisation such as the instrumentalisation of private international law and the demise of territoriality. In the context of cross-border copyright infringement disputes, the interaction between private international law and copyright law will be discussed. Chapter three will outline the CJEU's approach to jurisdiction in cross-border copyright infringement cases by describing the rulings Pinckney, Hi Hotel and Pez Hejduk. ${ }^{53}$ In addition, chapter three will briefly demonstrate several European Union jurisdictional rules that are applicable in case of infringements of other intellectual property rights.

Part II will concern the rethinking of the CJEU's approach to jurisdiction in cross-border copyright infringement cases referred to as the Pinckney doctrine. Chapter four will therefore set up an assessment framework. The main focus will be on the leeway that the CJEU generally has to interpret Article 7(2) Brussels Ibis from a legitimate perspective. Common methods of interpretation will therefore be explored. It will also be argued that the precedent-based method of interpretation should play a role regarding the rethinking of the Pinckney doctrine. The

\footnotetext{
${ }^{50}$ The term non-resident defendant refers to both a defendant domiciled in a state outside the United States of America as well as a defendant domiciled within a state of the United States of America but in another state than the forum state. The principles related to personal jurisdiction as established by United States courts have to be applied to both interstate and international cases. See Hestermeyer 2006, p. 275. See also paragraph 2.1.1.

${ }^{51}$ Chapter six will demonstrate various academic proposals and the aim of the Hague Conference on Private International Law to unify the private international law rules on jurisdiction in civil and commercial matters.

52 Poiares Maduro 2007, p. 141. With respect to the 'best solution' approach, Maduro referred to the Opinion of Advocate General Lagrange in Case C-14/61 Koninklijke Nederlandsche Hoogovens en Staalfabrieken NV v. High Authority of the European Coal and Steel Community.

${ }^{53}$ Case C-170/12 Peter Pinckney v. KGD Mediatech AG; Case C-387/12 Hi Hotel HCF SARL v. Uwe Spoering; Case C-441/13 Pez Hejduk v. EnergieAgentur NWR GmbH.
} 
assessment framework of this dissertation will involve principles derived from private international law and copyright law. The possible impact of the Geo-blocking Regulation on the approach to jurisdiction in cross-border copyright infringement disputes will also be included in the assessment framework.

In chapter five, the Pinckney doctrine will be assessed on the basis of the assessment framework as set up in chapter four. Chapter five will also analyse the (desirable) effects of the territorial principle related to copyrights on the approach to jurisdiction under Article $7(2)$ Brussels Ibis in cross-border copyright infringement disputes. In the chapters two and five, the possible influence of the field of public international law will be addressed. From a perspective of the principle of international comity, special attention will be devoted to the concept of 'full' jurisdiction under Article 7(2) Brussels Ibis in cross-border copyright infringement cases.

In light of the assessment framework set up in chapter four, chapter six will examine alternative approaches to jurisdiction in cross-border copyright infringement cases adopted by scholars and courts of European Union Member States. In chapter seven, various approaches to jurisdiction in cross-border copyright infringement cases established by courts in several states of the United States of America will be discussed and examined on the basis of the assessment framework.

The final chapter of the dissertation will conclude which connecting factors should be employed under Article 7(2) Brussels Ibis to decide whether the court of the place where the damage occurred, or may occur, has jurisdiction in cross-border copyright infringement cases. The suggested approach to jurisdiction will also be applied to the cases Pinckney, Hi Hotel and Pez Hejduk. 



\section{Part I}

\section{Private international law and copyright law}





\section{Chapter 2}

Divergence and convergence between private international law and copyright law 

The rethinking of the CJEU's approach to jurisdiction in cross-border copyright infringement cases will generally involve two areas of law: private international law and copyright law. ${ }^{54}$ This chapter will first describe these two fields of law separately by highlighting their general features. In addition, certain main developments of these fields will be described that are relevant for the rethinking of the CJEU's approach such as the instrumentalisation of private international law and the demise of territoriality in both fields of law. While the two fields seem entirely different, similarities can be indicated as a result of developments.

Finally, this chapter will focus on the interaction between private international law and copyright law with respect to cross-border copyright infrinffgement disputes. In view of rethinking the CJEU's approach to jurisdiction and the related examination of case law in the United States of America in chapter seven, this dissertation will mainly focus on the general features and developments of the two fields in the European Union and the United States of America.

\subsection{The field of private international law}

\subsubsection{General features}

The field of private international law deals with cases between private parties concerning a cross-border element. ${ }^{55}$ These cases may relate to civil, commercial or family matters. ${ }^{56}$ The cross-border element may, for example, lie in the fact that the parties involved are domiciled in different states, or the harmful event took place in another state than where the parties are domiciled. Alleged copyright infringements disseminated via the Internet also constitute a cross-border element. Due to cross-border activities and the existence of different legal systems, private international law will be required to coordinate cross-border legal issues. ${ }^{57}$ Providing predictability, certainty, international harmony of decisions, and conflicts justice are traditional key elements of private international law. ${ }^{58}$

The rules of private international law can be divided into three branches corresponding with three chronological questions that will arise in cross-border cases, as mentioned above. ${ }^{59}$ The first question concerns the issue whether the court seised is competent to ascertain the crossborder case. The court therefore has to consult the rules related to jurisdiction. Second, the

\footnotetext{
${ }^{54}$ Paragraph 2.1.2.2.1 will demonstrate the interaction between public international law and private international law in the context of the conferral of jurisdiction. See also paragraphs 5.3.3.1 and 5.3.4.1 on the possible influence of the field of public international law on the approach to jurisdiction in cross-border copyright infringement cases. ${ }^{55}$ See Hay 2018, p. 1. The term 'private parties' denotes both individuals and legal entities, such as corporations. Hay, Borchers and Symeonides refer in this context to "persons or entities other than countries or states as such". See Hay, Borchers \& Symeonides 2010, p. 1.

${ }^{56}$ Hill 2001, p. 439.

${ }^{57}$ Strikwerda 2015, pp. 1-2. See also Strikwerda \& Schaafsma 2019, pp. 1-2.

58 Kiestra 2014, p. 16 As noted by Kiestra, Von Savigny introduced the aim of decisional harmony (Entscheidungseinklang), see Von Savigny 1849, pp. 114-115. De Boer (1990, p. 3) pointed out that the term 'conflicts justice' (Internationalprivatrechtliche Gerechtigkeit) may be attributed to Kegel, see Kegel 1987, pp. $80-82$.

${ }^{59}$ See Strikwerda 2015, p. 2; Strikwerda \& Schaafsma 2019, p. 2.
} 
competent court has to assess which law has to be applied to the facts of the cross-border case. The so-called conflict-of-laws rules indicate the law of which state should be applied. The third question relates to the issue whether a foreign judgment has effect in a state. The rules on recognition and enforcement govern this last issue. This dissertation concerns the rethinking of the CJEU's interpretation of the special jurisdiction rule of Article 7(2) Brussels Ibis in crossborder copyright infringement cases. The focus will therefore be on the first branch of private international law; in particular the question regarding the competence of Member States' courts in cross-border copyright infringement disputes on the basis of Article 7(2) Brussels Ibis.

The term 'international' may mislead since each state enacted national rules regulating private international law. ${ }^{60}$ Yet, at international level, states have been aiming to unify rules of private international law. Some of these attempts succeeded. For example, under the auspices of the Organization of American States, several states of North and South America unified certain rules on private international law in conventions. ${ }^{61}$ Under the auspices of the organisation of the Hague Conference on Private International Law, various states around the world concluded treaties related to different areas of private international law. ${ }^{62}$ As mentioned in the introduction, the Hague Draft Convention on Jurisdiction and Recognition of Judgments in Civil and Commercial Matters of October 1999 nonetheless failed to come into force. ${ }^{63}$ The legislators of the European Economic Community and its successor the European Union succeeded to enact several regulations concerning various areas of private international law. ${ }^{64}$

From perspective of the states of the United States of America, the expression of private international law may also be misleading. The fifty states of the United States of America generally follow their own statutory rules and "common law principles" 65 with respect to issues related to private international law. ${ }^{66}$ Nevertheless, courts in each state have to follow the

\footnotetext{
${ }^{60}$ See Hay, Borchers \& Symeonides 2010, pp. 1-2. The term 'private international law' is commonly used in continental European countries, while the term 'conflict of laws' is generally employed in the United States of America, Canada, and England.

${ }^{61}$ The Organization of American States (OAS) is a regional organization, currently consisting of thirty-five states of North and South America. The OAS has been established by the Charter of the Organization of American States concluded in 1948, entered into force in December 1951. For a list of Member States, see http://www.oas.org/en/. To date, the OAS held seven Inter-American Specialized Conferences of Private International Law. For more information on these Conferences and the ensuing Conventions, see http://www.oas.org/en/sla/dil/private international law.asp.

62 For a list of the Member States of the Hague Conference on Private International Law, see https://www.hcch.net/en/states/hcch-members For more information on the treaties concluded by the Hague Conference on Private International Law, see https://www.hcch.net/en/instruments/conventions.

${ }^{63}$ See paragraph 1.1.2.

${ }^{64}$ See the Brussels Convention of 1968 and subsequent European Regulations enumerated in paragraph 1.1.2 of this dissertation. In 1980, the European Economic Community, for instance, enacted the Convention 80/934/EEC on the law applicable to contractual obligations (OJ L266, 9.10.1980, pp. 1-19), referred to as the Rome Convention. Subsequently, the European Union enacted its successor the Regulation (EC) No. 593/2008 of the European Parliament and of the Council of 17 June 2008 on the Law Applicable to Contractual Obligations (OJ L177, 4.7.2008, pp. 6-16), referred to as the Rome I. Another example is the Regulation (EC) No. 864/2007 of the European Parliament and of the Council of 11 July 2007 on the Law applicable to Non-Contractual Obligations, referred to Rome II (OJ L199, 31.07.2007, pp. 40-49).

${ }^{65}$ Silberman 2017, p. 2641. Based on the so-called doctrine of stare decisis, courts in the United States of America should generally follow legal principles established in preceding decisions involving similar cases. See Clark 2002, p. 38. Silberman even argues that "case-law at both the state and federal levels is the primary source of private international law in the USA". See Silberman 2017, p. 2639.

${ }^{66}$ Silberman 2017, pp. 2639-2641; Symeonides 2008, pp. 16-19.
} 
rulings related to private international law provided by the Supreme Court of the United States. ${ }^{67}$

When the court of the state of the United States of America is dealing with an issue related to private international law, the following four types of cases involving conflict of laws can be discerned. ${ }^{68}$ First, cases involving conflicts between federal law and state law, referred to as "vertical conflicts". ${ }^{69}$ Second, cases consisting of so-called "international (federal) conflicts" referring to conflicts between the federal law of the United States of America and foreign law, that means law outside the states of the United States of America. ${ }^{70}$ Third, cases known as "international (state) conflicts" that are conflicts between the law of a state in the United States of America and foreign law. ${ }^{71}$ Fourth, cases involving so-called "interstate conflicts" that means conflicts between the laws of different states of the United States of America. ${ }^{72}$ The first category of conflicts will be solved by "delineating the scope of federal law". ${ }^{73}$ The other three categories, involving interstate and international conflicts, will mainly have to be solved by applying rules and principles of private international law. ${ }^{74}$

Although the first rules of private international law originated in the Middle Ages in Northern Italy under the so-called statutist theory, ${ }^{75}$ it was only in 1834 that an influential judge of the Supreme Court of the United States named Story coined the term 'private international law'. ${ }^{76}$ According to Story's writing the Commentaries on the Conflict of Laws, Foreign and Domestic, in regard to Contracts, Rights and Remedies and especially in regard to Marriages, Divorces, Wills, Successions and Judgments, ${ }^{77}$ he advocated a largely apolitical approach to private international law. ${ }^{78}$ Story established territorial-based connecting factors such as the place of the tort and the place of the contract. ${ }^{79}$ This territorial-based approach deviated from the statutist theory that adopted a unilateral approach by resolving "conflict of laws via the spatial scope of the substantive rules in conflict" ${ }^{80}$ As will be indicated in paragraph 2.1.2.2.1, the rules on jurisdiction have traditionally been mainly territorial-based as a result of the sovereignty of states. ${ }^{81}$ With respect to cross-border tort cases, the jurisdiction rules in Europe

\footnotetext{
${ }^{67}$ Silberman 2017, pp. 2639, 2641; Symeonides 2006, p. 4.

${ }^{68}$ Symeonides 2006, p. 3.

${ }^{69}$ Symeonides 2006, p. 3.

${ }^{70}$ Symeonides 2006, p. 3.

${ }^{71}$ Symeonides 2006, p. 3.

72 Symeonides 2006, p. 3.

${ }^{73}$ Symeonides 2008, p. 17.

${ }^{74}$ Symeonides 2008, p. 17.

${ }^{75}$ See Kegel 1987, p. 103; Strikwerda 2015, p. 16; Strikwerda \& Schaafsma 2019, p. 20. In the $12^{\text {th }}$ and $13^{\text {th }}$ century, glossators in Northern Italy established the first rules of private international law, known as the statutist theory. Subsequently, Bartolus de Saxoferrato (1314-1357) developed rules of private international law. See Strikwerda 2015, p. 16.

${ }^{76}$ See Kegel 1987, p. 17; Kosters \& Dubbink 1962, pp. 6-7; Michaels 2005, p. 5; Symeonides 2017(a), pp. 290292. Whereas Story $(1834$, p. 9 §9) coined the term private international law, Foelix $(1843$, p. 1$)$ and Schaeffner (1841, p. 3) imported this term to Europe. See Kegel 1987, p. 17; Kosters \& Dubbink 1962, pp. 6-7; Michaels 2005 , p. 5.

${ }^{77}$ Story 1834.

${ }^{78}$ Michaels 2005, p. 5.

${ }^{79}$ See Franq 2017, p. 1779; Michaels 2017(a), p. 1663. See also Pontier 2005, p. 6.

${ }^{80}$ See Michaels 2017(a), p. 1663. See also Van Eechoud 2003, p. 24.

${ }^{81}$ Michaels 2004, pp. 106-108; Wautelet 2004, p. 63.
} 
have remained territorial based; however, paragraph 2.1.2.2.2 will describe a more flexible approach to territoriality. ${ }^{82}$

In Europe, the well-known scholar Von Savigny laid down the foundations of classical private international law in the $8^{\text {th }}$ volume of his treatise on Roman law named the System des heutigen Römischen Rechts. ${ }^{83}$ Von Savignys' method can be characterised as apolitic. ${ }^{84}$ Von Savigny based the conflict-of-laws rules on the seat (Sitz) of the legal relationship. ${ }^{85}$ The socalled Sitz-formula refers to the law of the state most connected to the legal relationship. ${ }^{86}$ Von Savigny's rules can be denoted as abstract: they compel the competent court to apply a predetermined connecting factor regardless of a closer connection to another legal system based on the actual circumstances of the case. ${ }^{87}$ An example of such an abstract Sitz rule related to tort cases is the lex loci delicti rule that refers to the law of the place where the delict or tort was committed. ${ }^{88}$

Von Savigny's rules of private international law can also be denoted as blindfolded rules since the substantive content of the potential applicable laws is deemed irrelevant. ${ }^{89}$ Von Savigny's rules can therefore be referred to as neutral rules because they consider all legal systems applicable on an equal basis. ${ }^{90}$ According to Von Savigny, conflict-of-laws rules should focus on conflicts justice instead of material (substantive) justice. ${ }^{91}$

Von Savigny's approach has a multilateral character since the connecting factors don't give preference to the own legal system or foreign legal systems. ${ }^{92}$ Pursuant to Von Savigny, states were only allowed to deviate from the aforementioned rules on the basis of rules "of a strictly positive and imperative nature and that carried vital policies for the state which could never be displayed by a foreign law". ${ }^{93}$ Similar to conflict-of-laws rules, European jurisdiction rules have traditionally been characterised as multilateral and apolitic; "matters of private litigation are considered apolitical" and jurisdiction rules should reflect common principles such as consent and the closest connection. ${ }^{94}$ Paragraph 2.1.2.1.2 will demonstrate that most European states do not strictly follow the abovementioned method of Von Savigny anymore. ${ }^{95}$ Paragraph 2.1.2.1.1

\footnotetext{
${ }^{82}$ Michaels 2004, pp. 105-110; Wautelet 2004, p. 64.

${ }^{83}$ Michaels 2005, p. 7. See Von Savigny 1849. Von Savigny extensively referred to Story's Commentaries of the Conflict of Laws of 1834. See Kegel 1989, pp. 39-40. With respect to other scholars referred to by Von Savigny, see Kegel 1989, pp. 39-66.

${ }^{84}$ Michaels 2005, p. 21. See also Neuhaus 1949, p. 372; Van Den Eeckhout 2013(b), p. 3.

${ }^{85}$ Von Savigny 1849, pp. 28, 108. See also Van Eechoud 2003, p. 28.

${ }^{86}$ Strikwerda 2015, pp. 36-37; Strikwerda \& Schaafsma 2019, p. 24; Vonken 2018, no. 201, 202.

${ }^{87}$ De Boer 2012, pp. 35-36. See also Strikwerda 2015, pp. 30-31; Van Eechoud 2003, p. 29.

${ }^{88}$ See Van Eechoud 2003, p. 29.

${ }^{89}$ De Boer 2012, pp. 35-36; Deelen 1966; Martinek 2001, para. 4.2; Strikwerda \& Schaafsma 2019, p. 24.

${ }^{90}$ De Boer 2012, p. 36; Jessurun D’Oliveira 1976, p. 5; Strikwerda 1978, p. 129; Van Eechoud 2003, p. 29.

${ }^{91}$ Symeonides 2001, pp. 126-128.

92 Strikwerda 2015, pp. 30-31; Strikwerda \& Schaafsma 2019, p. 24.

93 Kuipers 2011, p. 56. Von Savigny referred to "Gezetzen von streng positiver, zwingender Natur" and "Rechtsinstitute eines fremdes Staates, deren Daseyn in dem unsrigen unerhaupt nicht anerkannt ist" See Von Savigny 1849, pp. 32-33 para. 346, 349. See also Vonken 2018, no. 357. The current concepts of public policy exception and priority rules are reminiscent of Von Savigny's exceptions to the Sitz method, see Pontier 1997, p. 343; Vonken 2018, no. 357. See paragraph 2.1.2.1.4 on public policies.

${ }^{94}$ Michaels 2017(b), p. 1048.

95 See also Jessurun D’Oliveira 2002, pp. 113-118; Michaels 2005, p. 9 Strikwerda 2015, p. 38; Strikwerda \& Schaafsma 2019, p. 169.
} 
will describe the demise of the neutrality regarding the field of private international law in the United States of America.

\subsubsection{Developments}

The following two developments in the field of private international law that will be discussed in this chapter will be relevant for the rethinking of the CJEU's approach to jurisdiction in cross-border copyright infringement disputes. First, the development of the demise of neutrality of private international law will be set out. ${ }^{96}$ This will include the development of instrumentalisation of private international law for policy aims and so-called common goods. ${ }^{97}$ Second, the development of a flexible approach to territoriality as basis for jurisdiction in particular an effects-based approach to jurisdiction in tort cases will be demonstrated. ${ }^{98}$

\subsubsection{Demise of neutrality of private international law}

After the Second World War, the structuring of the welfare state in European states yielded new legislation to improve the society, such as social security, public health, and consumer protection..$^{99}$ As will be demonstrated in this section, private international law also got drawn into this process of "social engineering". ${ }^{100}$ In the United States of America, the advent of the social-interventionist state in the twentieth century spurred the so-called American conflicts revolution ${ }^{101}$ that will be described in the following paragraph.

\subsection{United States of America}

In 1934, the American Law Institute enacted the Restatement of the Law of Conflict of Laws drafted by Beale. ${ }^{102}$ With respect to various legal fields, the American Law Institute has enacted Restatements that aim to simplify and unify laws among states of the United States of America. ${ }^{103}$ The rules of Restatements are mainly based on case law of the courts of the United States of America and statutes of the states of the United States of America. ${ }^{104}$ While

\footnotetext{
${ }^{96}$ See paragraph 2.1.2.1.

${ }^{97}$ Van Den Eeckhout 2017. Van Loon (2015, pp. 45, 108) employs the term “common goods". Muir-Watt (2011, p. 356) refers in this context to "collective goods of planetary concern". See paragraph 2.1.2.1.5.2 of this dissertation on the role of private international law in global society.

${ }^{98}$ See paragraph 2.1.2.2.

${ }^{99}$ Jessurun D'Oliveira 2002, p. 113.

${ }^{100}$ Jessurun D'Oliveira 2002, p. 116. See also Strikwerda 1978, p. 1.

${ }^{101}$ Michaels 2008, p. 1617.

102 Parra-Aranguren 1988, p. 159; Symeonides 2006, p. 10.

103 American Law Institute 2015, pp. 13, 21. The Council of the American Law Institute consists of lawyers, judges, and academics. See American Law Institute 2015, p. 18. See also www.ali.org.

${ }^{104}$ See American Law Institute 2015, pp. 7-8. Secondary sources of Restatements are, inter alia, foreign law, treatises, legal encyclopedias and studies. See American Law Institute 2015, pp. 10-11.
} 
Restatements are not legally binding, they "enable courts to render their judgments in a consistent, reasonably predictable manner". ${ }^{105}$

The Restatement of the Law of Conflict of Laws of 1934 has been referred to as the First Restatement of Conflict of Laws. The rules in the First Restatement of Conflict of Laws relied on the territorial principle and the so-called vested rights theory. ${ }^{106}$ Pursuant to the vested rights theory, foreign law could "constitute a fact to be considered in the determination of the case". ${ }^{107}$ Under the vested rights theory, it was important "when and where a particular right was vested, because the law in place where the right vested would control the content of the right". ${ }^{108}$ Connecting factors therefore identified "a particular contact as the trigger for the vesting of a right". ${ }^{109}$ Similar to the method of Von Savigny, these connecting factors can be characterised as neutral, abstract, blindfolded and multilateral; they aimed to provide conflicts justice. ${ }^{110} \mathrm{With}$ respect to tort cases, for instance, the First Restatement of Conflict of Laws enacted the lex loci delicti rule, the law of the place of the injury governs the tort. ${ }^{111}$

However, in the 1920s and 1930s, scholars already started to criticise the formalistic and rigid methods to conflict of laws adopted by courts in the United States of America. ${ }^{112}$ Several critics proposed new approaches of conflict-of-laws that focused on the content and policies of the conflicting laws and included the interests of states. ${ }^{113}$ In 1950 s and early 1960s, the influential scholar Currie proposed the governmental interest analysis in his articles. ${ }^{114}$ It has been argued that Currie induced "the decisive blow" of the scholastic conflicts-of-law revolution. ${ }^{15}$ As a result of this "scholastic revolution", ${ }^{116}$ courts also started to deviate from the traditional territorial-based rules by adopting flexible approaches to conflict of laws; this development has been referred to as the "judicial revolution"117.

\footnotetext{
105 American Law Institute 2015, p. 4.

106 See Symeonides 2008, pp. 65-66. U. Huber proclaimed the vested rights theory in his chapter "De Conflictu Legum Diversarum in Diversis Imperiis" in: Praelectiones iuris Romani et hodierni, Vol. II, Book 1, Title iii, 1689. See Michaels 2006, p. 26. The vested rights theory has been further developed in the United States of America by J.H. Beale in A Treatise on the Conflict of Laws (1935) and in England by A.V. Dicey in A Digest of the Law of England with Reference to the Conflict of Laws (1896). See Mills 2013, pp. 450-451.

${ }^{107}$ Beale 1935, p. 53.

${ }^{108}$ Richman \& Riley 1997, p. 1197.

${ }^{109}$ Richman \& Riley 1997, p. 1197.

${ }^{110}$ Symeonides 2006, pp. 10-11. See also Weinberg (2005, p. 1645) who described the traditional territorial-based methods as "at least superficially 'neutral', striking with even-handed ferocity now at plaintiffs, now at defendants".

${ }^{111}$ First Restatement of Conflict of Laws of 1934 § 384. According to the First Restatement of Conflict of Laws of $1934 \S 377$, the locus delicti is the place where "the last event necessary to make an actor liable for an alleged tort takes place".

112 Weinberg 2005, p. 1633. See also Juenger 1993, p. 92; Richman and Riley 1997, p. 1198. The critics mainly belonged to the strand of American legal realism. Well-known critics were Lorenzen (1924, pp. 736-751) and Cook (1924, pp. 457-488). See Mills 2013, pp. 447, 454; Weinberg 2005, p. 1633. For more information on the realist movement in American jurisprudence, see Wardhaugh 1989, pp. 337-352.

${ }^{113}$ For example, the local law theory by Cook. See Cook 1924. See Symeonides argued that David F. Cavers, Walter W. Cook, and Brainerd Currie were the three influential leaders of the so-called scholastic choice-of-law revolution. See Symeonides 2015, p. 1850.

${ }^{114}$ See, inter alia, Currie 1958; Currie 1959.

115 See Symeonides 2006, p. 13. See also Weinberg 2005, pp. 1637-1643.

116 See Symeonides 2006, pp. 9-36.

${ }^{117}$ See Symeonides 2006, pp. 37-62. See also Reimann 2017, p. 180; Weinberg 2005, pp. 1637-1643.
} 
In 1963, the first clear deviation of the traditional lex loci delicti rule appeared in the landmark case Babcock v. Jackson. ${ }^{118}$ In this case, Miss Babcock and Mr. and Mrs. Jackson, all residents of the state New York, went on a trip to Canada by car. In a province of Canada named Ontario, the passenger Miss Babcock got seriously injured because the driver Mr. Jackson accidently lost control of the car and hit a stone wall. Miss Babcock sued Mr. Jackson for negligence before the Court of Appeals of New York. According to the traditional lex loci delicti rule, the law of Ontario would be applicable. ${ }^{119}$ The Highway Traffic Act of Province of Ontario stipulated "the owner or driver of a motor vehicle, other than a vehicle operated in the business of carrying passengers for compensation, is not liable for any loss or damage resulting from bodily injury to, or death of any persons being carried in, or upon, or entering or getting onto, or alighting from such motor vehicle". ${ }^{120}$

The Court of Appeals of New York pointed out that the vested rights theory has been criticised in literature and case law ${ }^{121}$ for being inflexible with respect to the circumstances and policy interests involved. ${ }^{122}$ In addition, the Court referred to the draft of the Restatement (Second) of Conflict of Laws that employed the "law of the state which has the most significant relationship with the occurrence and with the parties determines their rights and liabilities in tort" and gave importance to "the issues, the character of the tort and the relevant purposes of the tort rules involved". ${ }^{123}$ The New York Court of Appeals concluded that the interests of the state New York in this litigation are greater and more direct than the state Ontario and therefore the law of New York should be applied instead of the law of Ontario that would be applicable based on the traditional rule of lex loci delicti. ${ }^{124}$

Many courts in the United States of America started to integrate substantive law and policybased values into the choice of law process; the focus shifted from conflict justice to "material justice". ${ }^{125}$ Most of these courts adopted 'flexible' methods to the choice-of-law process such as "the governmental interest analysis" 126 or "the better law" approach" ${ }^{127}$. In 1969, the American Law Institute enacted the so-called Restatement (Second) of Conflict of Laws that enshrined a flexible approach to conflict-of-laws by enumerating seven factors to find the law

\footnotetext{
${ }^{118}$ Babcock v. Jackson, 12 N.Y.2d 473 (1963). See Symeonides 2006, p. 38. Two previous seminal cases involving contracts in which courts deviated from the lex loci contractus rule are "W. H. Barber Co. v. Hughes, 63 N.E.2d 417 (Ind. 1945) (adopting a significant-contacts approach) and Auten v. Auten, 124 N.E.2d 99 (N.Y. 1954) (adopting a center-of-gravity approach, but also examining the interests of the competing jurisdictions)". See Symeonides 2006, p. 38 footnote 7.

${ }_{119}$ Babcock v. Jackson, 12 N.Y.2d 473 at 477 (1963).

${ }^{120}$ Highway Traffic Act of Province of Ontario $\$ 105(2)$, Ontario Revised Statute of 1960, chapter 172, $\S 105(2)$.

${ }^{121}$ Swift \& Co. v. Bankers Trust Co., 280 N. Y. 135 at 141 (N. Y. 1939); Auten v. Auten, 308 N. Y. 155 at 160

(N.Y. 1954); Kilberg of Northeas Airlines, 9 N. Y. 2d 34 (N. Y. 1961).

${ }^{122}$ Babcock v. Jackson, 12 N.Y.2d 473 at 478-481 (1963).

${ }^{123}$ Babcock v. Jackson, 12 N.Y.2d 473 at 482 (1963). The Court of Appeals referred to the Restatement, Second, Conflict of Laws, §379[1], [2], [3]; Introductory Note to Topic 1 of Chapter 9, p. 3 [Tentative Draft No. 8, 1963].

${ }^{124}$ Babcock v. Jackson, 12 N.Y.2d 473 at 482 (1963). See also Symeonides 2017(a), pp. 42-43.

125 Symeonides 2017(a), p. 43. See also De Boer 1990, pp. 3-5.

${ }^{126}$ See Symeonides 2017(a), p. 43. Currie established the "governmental interest analysis", see Currie 1959, pp. 171-181. See also Symeonides 2008, pp. 92-117. Strikwerda 2015, pp. 21-22. See also Strikwerda \& Schaafsma 2019 , p. 27.

${ }^{127}$ Leflar established the "better law" approach, see Leflar 1966, pp. 267-327. See also Symeonides 2008, pp. 102103; Strikwerda 2015, pp. 23-24; Strikwerda \& Schaafsma 2019, pp. 28-29.
} 
of the state that has the "most significant relationship" to the case. ${ }^{128}$ In 2016, the American Law Institute has started to work on the Third Restatement of Conflicts of Laws. ${ }^{129}$

Paragraph 2.1.2.2.2 will demonstrate that the traditionally territorial based approach to jurisdiction in civil cases has evolved into a more flexible approach to jurisdiction that considers "traditional notions of fair play and substantial justice" ${ }^{130}$. Due to globalization, Michaels claims that territoriality shifted its meaning in the context of jurisdiction; "it is concerned less with considerations of power and fairness, and more with the need for formal and easily administrable criteria for jurisdiction allocation"131.

\subsection{Europe}

Although several European scholars endorsed the abovementioned American approach based on substantive justice, European states did not adopt the 'flexible' American methods. ${ }^{132}$ It has generally been argued that civil law states prefer clear abstract rules that provide certainty instead of 'flexible' American methods that aim to enhance litigational fairness by taking into account the particular circumstances of the case. ${ }^{133}$

Considering the rules of private international law laid down in national codifications, treaties and European Union law, European states did nonetheless adopt provisions that deviate from the strict method of Von Savigny. ${ }^{134}$ Instead of relying on connecting factors based on the Sitz-methode (such as the locus contractus and the locus delicti), provisions of private international law started to include so-called alternative connecting factors and exception clauses. ${ }^{135}$ For instance, Article 4 of the Hague Convention on the Law Applicable to Traffic Accidents of 1971 provides the opportunity to deviate from the lex loci delicti rule by enumerating various conditions under which the law of the State of registration of the vehicle is applicable. ${ }^{136}$

In addition, states enacted so-called "semi-open conflicts rules" 137 that will lead to the socalled "spatially best solution" 138 . An excellent example of this type of rules is the "closer

\footnotetext{
${ }^{128}$ Borchers 2005, p. 50. See $\S 6$ of the Restatement (Second) of Conflict of Laws. See also paragraph 2.3.3.

129 See Roosevelt \& Jones 2016, pp. 139-143. Symeonides (2017(b), pp. 1-52) discusses the Third Conflicts Restatement's First Draft on Tort Conflicts.

${ }^{130}$ International Shoe Co. v. Washington, 326 U.S. 310 at 316. See Von Mehren (2007, pp. 95-97) on "the passage from a power to a litigational justice theory". "The dominant theory saw adjudicatory authority as an expression of territoriality based power". See Von Mehren 2007, p. 272.

${ }^{131}$ Michaels 2017(b), p. 1049. See paragraph 2.1.2.1.5.1 on globalisation and global governance regarding the changing meaning of territoriality related to states and the role of the state.

132 De Boer (1990, pp. 4-5) enumerates European scholars who opposed the traditional method of Von Savigny. Notably, Strikwerda (1978) advocated the interest analysis as a suitable choice-of-law method in his dissertation.

133 See Von Mehren 2007, pp. 51-55.

${ }^{134}$ Carballo Pineiro \& Kramer 2014, p. 111; De Boer 2012, pp. 39-40; Symeonides 2017(a), pp. 52-91, $171-217$.

135 De Boer 2012, pp. 39-40. See Kokkini-Iatridou and Frohn (1989, pp. 215-264) on the distinction between special and general exception clauses. See also Symeonides 2017(a), p. 175.

${ }^{136}$ See Articles 3 and 4 of the Hague Convention on the Law Applicable to Traffic Accidents concluded 4 May 1971 , entered into force 3 June 1975.

${ }^{137}$ De Boer 1987, pp. 25-41.

${ }^{138}$ De Boer (1993, p. 17) referred to Kegel's well-known view that substantive law and conflict of laws are "entirely distinct things: substantive law aims at the materially best solution, PIL [private international law] aims
} 
connection' exception. ${ }^{139}$ In case of tort conflicts, this "flexible" connecting factor allows courts to apply the law of the state that is actually most connected to the tort instead of the lex fori delicti. $^{140}$

The pre-existing relationship between parties can also be identified as a frequent connecting factor in national codifications, treaties, and European Regulations. ${ }^{141}$ The common domicile of parties has also regularly been enacted as a connecting factor that can set aside the lex loci delicti. ${ }^{142}$ As noted by Symeonides, these geographical 'flexible' factors are a "step forward from the traditional choice-of-law rules, which assigned a priori seat to each relationship". ${ }^{143}$

The aforementioned semi-open connecting factors reflect the change of the objectives of tort law. While the main objectives of substantive tort law in the 1950s were deterrence and punishment, the focus shifted to compensation of losses. ${ }^{144}$ Due to the introduction of insurance systems and rules of strict liability, the objective of compensation of losses has become more important while the objective of conduct regulation moved into the background. ${ }^{145}$ In this connection Symeonides distinguishes "conduct-regulating rules" and "loss-allocating" or "lossdistributing rules". ${ }^{146}$ Symeonides points out that "conduct-regulating rules are territorially oriented" such as "the place of conduct and injury", "whereas loss-distribution rules are not "necessarily territorially oriented" such as "the parties' domicile". ${ }^{147}$

Due to the abovementioned shift to compensation of losses and the ensuing rise of strict liability rules, the territorial approach to jurisdiction has been affected. ${ }^{148}$ Since the focus has been moved from the tortious activities to the settlement of damages, thus the consequences, it is not self-evident anymore that the connecting factor related to torts has to concern the tortious activities and not the consequences. ${ }^{149}$ From the perspective of compensation of losses, De Boer argued that the victim's place of domicile is a suitable connecting factor. ${ }^{150}$ In the context of rethinking the CJEU's approach to jurisdiction in cross-border copyright infringement cases,

at the spatially best solution”. See Kegel 1979, p. 616. However, De Boer (1993, p. 17) noted that semi-open conflict rules provide courts nevertheless broad discretion to choose the applicable law.

${ }^{139}$ Symeonides 2017(a), pp. 68-72, 176-189. Symeonides refers to national codifications and treaties that adopted the 'closer' or 'closest' connection exception in contract conflicts and miscellaneous cases, see Symeonides 2017(a), pp. 176-184. The 'closest connection' exception has also been laid down in the Articles 4(3), 5(3), 7(2), and 8(4) of the Regulation (EC) No 593/2008 of the European Parliament and of the Council of 17 June 2008 on the Law Applicable to Contractual Obligations (OJ L177, 4.7.2008, pp. 6-16), hereinafter Rome I.

${ }^{140}$ Symeonides (2017(a), pp. 68-81) enumerates states that adopted the 'closer connection' exception regarding torts. With respect to various torts, this exception has also been laid down in the Articles 4(3), 5(2), 10(4), 11(4), and 12(2)(c) of the Regulation (EC) No 864/2007 of the European Parliament and of the Council of 27 July 2007 on the Law Applicable to Non-Contractual Obligations (OJ L 199, 31.07.2007, pp. 40-49), hereinafter Rome II.

${ }^{141}$ Symeonides (2017(a), pp. 81-83) demonstrates which national codifications comprise the parties' pre-existing relationship exception to the lex loci delicti rule. This exception has also been enshrined in the Articles 4(3) and 5(2) Rome II.

${ }^{142}$ Symeonides (2017(a), pp. 72-88) demonstrates which national codifications comprise the 'common domicile' exception to the lex loci delicti rule. This exception is also laid down in Article 4(2) Rome II.

${ }^{143}$ Symeonides 2017(a), p. 188.

144 Strikwerda 2015, pp. 189-190; Strikwerda \& Schaafsma 2019, pp. 345-346; Symeonides 2017(a), p. 44.

145 Strikwerda 2015, pp. 189-190; Strikwerda \& Schaafsma 2019, pp. 345-346.

146 Symeonides 2017(a), p. 44.

${ }^{147}$ Symeonides 2017(a), p. 45.

${ }^{148}$ Strikwerda 2015, p. 189. Strikwerda \& Schaafsma 2019, p. 346.

149 Strikwerda 2015, pp. 189-190; Strikwerda \& Schaafsma 2019, p. 346.

${ }^{150}$ De Boer 1987, p. 497. 
the possibility to provide jurisdiction to the court of the place where the copyright holder is domiciled, the so-called forum actoris, will be examined in chapter six. ${ }^{151}$

\subsection{Protecting or favouring certain persons or concepts}

Most states adopted rules of private international law that aim to protect specific persons "whose social condition is structurally weak" such as children, maintenance creditors, consumers. ${ }^{152}$ De Boer refers in this context to "conflict rules based on functional allocation;" "functional allocation translates the protective function of substantive law into a connecting factor that points to the law of the jurisdiction that is presumed to be most concerned with the party in need of protection, as a rule the country of his domicile." ${ }^{153}$ Many treaties concluded under the auspices of the Hague Conference on Private International Law comprise multiple connecting factors that aim to protect certain 'weaker' persons. ${ }^{154}$ European Union Regulations related to private international law also comprise provisions that aim to protect particular 'weaker' parties such as consumers ${ }^{155}$, policyholders ${ }^{156}$, and employees ${ }^{157}$.

The Brussels Ibis Regulation does not consider the copyright holder as a 'weaker party' who needs special jurisdictional protection. This Regulation stipulates that only "in relation to insurance, consumer and employment contracts, the weaker party should be protected by rules of jurisdiction more favorable to his interests than the general interests". ${ }^{158}$ The CJEU has also emphasised that the special jurisdiction rule of Article 7(2) Brussels Ibis does not pursue the same objective as the special jurisdiction rules related to insurance, consumer and employment contracts "which are designed to offer the weaker party stronger protection". ${ }^{159}$

Several rules of private international law aim to favour certain persons or concepts. ${ }^{160}$ Since these rules reflect policies and values underlying substantive law, they have been denoted as "result-selective, or result-oriented, rules". ${ }^{161}$ These rules are often favourable to victims who suffer from damage caused by particular cross-border torts, for example, unfair competition, violation of privacy and defamation, product liability, environmental damage. ${ }^{162}$ The favour

\footnotetext{
${ }^{151}$ See paragraph 6.2.4.1 on the pro and contra arguments of the 'victim's centre of interests' approach in crossborder copyright infringement disputes.

${ }^{152}$ De Boer 1987, p. 44; De Boer 2012, p. 39.

${ }^{153}$ De Boer 1987, p. 44; De Boer 2012, p. 39.

${ }^{154}$ For example, see Articles 4 and 5 of the Hague Convention on the Law Applicable to Maintenance Obligations concluded 2 October 1973, entered into force 1 October 1977. See, for instance, Articles 5-21 of the Hague Convention on Jurisdiction, Applicable Law, Recognition, Enforcement and Co-operation in Respect of Parental Responsibility and Measures for the Protection of Children concluded 19 October 1996, entered into force 1 January 2002.

${ }^{155}$ Article 17-19 Brussels Ibis; Article 6 Rome I.

${ }^{156}$ Article 10-16 Brussels Ibis; Article 7 Rome I.

${ }^{157}$ Article 20-23 Brussels Ibis; Article 8 Rome I.

${ }^{158}$ Recital 18 in the preamble to the Brussels Ibis Regulation.

${ }^{159}$ See Case C-133/11 Folien Fischer AG and Fofitec AG v. Ritrama SpA, para. 46.

${ }^{160}$ De Boer 1987, pp. 53-75. See also Van Eechoud 2003, pp. 38-40.

${ }^{161}$ Symeonides 2017(a), p. 251. For more examples of "result-selective, or result-oriented, rules", see Symeonides 2017(a), pp. 252-282. See also De Boer 1987, pp. 53-75.

${ }^{162}$ See, inter alia, Articles 5-7 Rome II, Article 9 of the Hague Convention on the Law Applicable to Traffic Accidents concluded 4 May 1971, entered into force 3 June 1975; Articles 4-6 of the Hague Convention on the Law Applicable to Products Liability concluded 2 October 1973, entered into force 1 October 1977. Symeonides
} 
principle can also regularly be identified in provisions of private international law related to the field of family law. ${ }^{163}$ For instance, Article 3 and 4 of the Hague Protocol on the Law Applicable to Maintenance Obligations of 2007 aim to achieve the 'best' result for the maintenance creditor. ${ }^{164}$ Result-selective rules seem reminiscent of the American so-called "better law approach"165 established by Leflar. ${ }^{166}$ Yet, while result-selective rules determine ex ante the law which will likely entail the best result in a certain case, the 'better law' approach provides courts broad discretion to determine the 'best' substantive law "regardless of the result in the concrete case". 167

Result-selective rules may also favour "the formal or substantive validity of a juridical act such as a testament, a marriage, or an ordinary contract" or "a certain status such as legitimacy or filiation, the status of a spouse, or even the dissolution of a status (divorce)". ${ }^{168}$ Many national codifications, for instance, stipulate rules of private international law that reflect their policy "to favour the possibility to obtain a divorce in international cases", referred to as favor divortii. ${ }^{169}$

This dissertation will demonstrate that when interpreting the special jurisdiction rule of Article 7(2) Brussels Ibis in cross-border copyright infringement cases, the CJEU's appears to favour copyright protection by ruling that copyrights should be protected in all Member States by virtue of the Information Society Directive. ${ }^{170}$ Instead of "the principle of favor auctoris", ${ }^{171}$ chapter four will argue to adopt the principle of balancing the procedural interests between the copyright holder and the alleged infringer ${ }^{172}$ and the broader interests related to copyrights ${ }^{173}$.

(2017(a), pp. 60-64) enumerates national codifications that comprise choice-of-law rules based on the favor laesi (that means in favour of the victim) principle.

${ }^{163}$ See Strikwerda 2015, pp. 39-40 for examples. See also Strikwerda \& Schaafsma 2019, pp. 170-171.

${ }^{164}$ The Hague Protocol on the Law Applicable to Maintenance Obligations concluded 23 November 2007, entered into force 1 August 2013. See also, for instance, Article 15 of the Hague Convention on the Recognition and Enforcement of Decisions Relating to Maintenance Obligations concluded 2 October 1973, entered into force 1 August 1976.

${ }^{165}$ Leflar 1966, pp. 267-327. Pursuant to Leflar, the 'better law' criterion is only one of the five "choice-influencing considerations" to determine the applicable law.

${ }^{166}$ De Boer 1987, p. 70; Strikwerda 2015, pp. 23-24; Strikwerda en Schaafsma 2019, pp. 28-29.

${ }^{167}$ Reimann 2017, p. 184. See also De Boer 1987, p. 70; Strikwerda 1986, p. 17.

168 Symeonides 2017(a), p. 251. Symeonides (2017(a), pp. 260-271) refers to provisions in several national codifications and conventions favouring a certain status.

${ }^{169}$ Baarsma 2011, p. 18. Symeonides (2017(a), pp. 269-271) refers to provisions of national codifications that enshrine the principle of favor divortii.

${ }^{170}$ The Directive 2001/29/EU of the European Parliament and of the Council of 22 May 2001 on the harmonisation of certain aspects of copyrights and related rights in the information society (OJ L167, 22.06.2001, pp.10-19), referred to as the Information Society Directive. See chapter 3 on the cases C-170/12 Peter Pinckney v. KGD Mediatech AG, para. 39; Case C-387/12 Hi Hotel HCF SARL v. Uwe Spoering, para. 36; Case C-441/13 Pez Hejduk v. EnergieAgentur NWR GmbH, para. 36-37. See paragraphs 5.1.2 up to and including 5.1.4 on the broad concept of the CJEU's locus protectionis.

${ }^{171}$ Ohly 2009, pp. 238-239.

172 See paragraph 4.2.4.2.

${ }^{173}$ See paragraph 4.4 . 


\subsection{Public policies}

Most national codifications and several treaties adopted so-called public policy exceptions that allow the competent court to set aside the applicable foreign rule when the content of this rule, or its application, is incompatible with fundamental legal principles of the forum state. ${ }^{174}$ For example, a Dutch court will not apply foreign rules allowing polygamy. ${ }^{175}$ Several public policy exceptions provide the competent court the possibility to refuse the recognition and enforcement of a decision rendered in another state. ${ }^{176}$

Public interests of states also influence rules of private international law by means of socalled priority rules, also referred to as overriding mandatory provisions. ${ }^{177}$ Article 9 of the Regulation (EC) No 593/2008 of the European Parliament and of the Council of 17 June 2008 on the Law Applicable to Contractual Obligations (hereinafter Rome I) provides a description of rules that may be indicated as priority rules namely "provisions the respect for which is regarded as crucial by a country for safeguarding its public interests, such as its political, social or economic organisation". ${ }^{178}$ The latter provisions are often laid down in (semi) public laws of the forum or other states, and will thus have priority over the rules that are applicable according to choice-of-law rules. ${ }^{179}$ Some scholars draw a parallel between priority rules and the earlier mentioned American 'flexible' method of the "governmental interest analysis". ${ }^{180}$

For the establishment of the internal market, the European Community, and subsequently the European Union, enacted uniform rules of private international law regarding various areas to improve legal protection and certainty. ${ }^{181}$ The influence of European Union policy values in the field of private international law is also clearly visible in the case law of the CJEU. ${ }^{182}$ The

\footnotetext{
${ }^{174}$ Strikwerda 2015, pp. 53-59; Strikwerda \& Schaafsma 2019, pp. 187-194; Van Bochove \& Kramer 2010, p. 12; Vonken 2018, no. 487, 492. Pursuant to Vonken (2018, no. 57, 493), the public policy-exception can also be invoked in case of infringements of fundamental European legal principles if there is a close connection to the legal order of a Member State of the European Union or a Contracting State of the European Convention on Human Rights and Fundamental Freedoms of 1950. Pontier (1977, pp. 340-359) sets out the negative and positive function of the public policy exception. See also Strikwerda 1978, pp. 18-29; Van Eechoud 2003, pp. 40-41. Both Article 21 Rome I and Article 26 Rome II stipulate: "The application of a provision of the law of any country specified by this Regulation may be refused only if such application is manifestly incompatible with the public policy (ordre public) of the forum". See also, for instance, Article 10 of the Hague Convention on the Law Applicable to Products Liability concluded 2 October 1973, entered into force 1 October 1977.

${ }^{175}$ Vlas (2011, pp. 15-16) illustrates the public policy exception in Article 10:6 of the Dutch Civil Code.

${ }^{176}$ Pursuant to Article 45(1)(a) Brussels Ibis Regulation, the recognition of a judgment can be refused "if such recognition is manifestly contrary to public policy (ordre public) in the Member State addressed". See also, inter alia, Article 5(1) of the Hague Convention on the Recognition and Enforcement of Decisions Relating to Maintenance Obligations concluded 2 October 1973, entered into force 1 August 1976.

${ }^{177}$ De Boer 1987, pp. 75-91; Strikwerda 2015, pp. 68-72; Symeonides 2017(a), pp. 299-302; Vonken 2018, no. 245.

${ }^{178}$ Regulation (EC) No 593/2008 of the European Parliament and of the Council of 17 June 2008 on the Law Applicable to Contractual Obligations (OJ L177, 4.7.2008, pp. 6-16) (hereinafter Rome I). See also Article 16 Rome II.

${ }_{179}$ Pursuant to Pontier (1997, p. 359) mandatory rules may include private law and (semi) public law.

${ }^{180}$ De Boer 2012, pp. 38-39; Van Bochove \& Kramer 2010, p. 11. See paragraph 2.1.2.1.1.

${ }^{181}$ Jessurun D'Oliveira 2002, pp. 111-136; Meeusen 2004, pp. 80-84. See also Babayev 2012, pp. 63-82. Currently, Article 81 TFEU (former Article 65 EC Treaty) provides the legal basis for the adoption of rules of private international law by the European Union legislator that are "necessary for the proper functioning of the internal market".

${ }^{182}$ Meeusen 2004, p. 83.
} 
CJEU started to characterise the Brussels Convention of 1968 on jurisdiction and enforcement of judgments in civil and commercial matters as "an attempt to facilitate the achievement of the common market". ${ }^{183}$ While interpreting rules of European private international law, the CJEU frequently employed principles of European Union law, such as the freedom of establishment of companies $^{184}$, free movements of persons, and non-discrimination ${ }^{185}$. The instrumentalisation of private international law in the European Union has been profound and even denoted as a new ${ }^{186}$ "European Conflicts Revolution"187. Martinek has argued that substantive laws increasingly consist of " "mixed' private-public law with 'social' or 'economic' norms which serve both public and private interests". ${ }^{188}$ According to his view, "the growing importance of this public-private law" requests a new pillar of private international law. ${ }^{189}$

This dissertation will demonstrate that the CJEU employed the Information Society Directive to provide a pro-integrationist interpretation of the special jurisdiction rule of Article 7(2) Brussels Ibis Regulation in cross-border copyright infringement cases. ${ }^{190}$ This approach appears to fit the abovementioned "new pillar" of private international law. As mentioned in the introduction, several scholars nevertheless warned that instrumentalisation of private international law should not erode the traditional objectives of private international law such as predictability and certainty. ${ }^{191}$ From a legitimate perspective, chapter four will set out an assessment framework to rethink the CJEU's approach to jurisdiction under Article 7(2) Brussels Ibis in cross-border copyright infringement cases. This framework will include the principles underlying the special jurisdiction rule of Article 7(2) Brussels Ibis.

\subsection{Private international law used as tool for global governance}

The foregoing indicates that private international law in Europe and the United States of America lost its strict neutral and apolitical character, it has increasingly become a tool to achieve public objectives at national, regional and international level. ${ }^{192}$ In view of globalisation, several scholars argue that private international law should fulfil a regulatory function in the setting of global governance. ${ }^{193}$

\footnotetext{
${ }^{183}$ Case C-12/76 Industrie Tessili Italiana Como v. Dunlop AG, para. 9.

184 Case C-208/00 Überseering BV v. Nordic Construction Company Baumanagment GmbH (NNC); Case C167/01 Kamer van Koophandel en Fabrieken voor Amsterdam v. Inspire Art Ltd.

${ }^{185}$ Case C-353/06 Grunkin and Paul; Case C-148/02 Garcia Avello v. Belgium. See also Michaels 2005, p. 5.

${ }^{186}$ Michaels (2008, pp. 1612) argued that there has already been a European choice of law revolution before the American conflict of laws revolution (see paragraph 2.1.2.1.1) caused by the so-called "Copernican turn" of the method of Von Savigny. With respect to this "Copernican turn", see Neuhaus 1949, p. 366. In the Netherlands, the 1960s and 1970s could also be denoted as a revolutionary conflicts period due to criticism of several Dutch legal scholars regarding the traditional method of Von Savigny (See Boele-Woelki, Joustra \& Steenhoff 1998, p. 215; De Boer 1998, p. 35; Dubbink 1998, pp. 10-12). Examples of critical Dutch scholars are Jessurun D' Oliveira (Jessurun D’Oliveira 1976), Dubbink (Dubbink 1947; Dubbink 1973) and Strikwerda (Strikwerda 1978). See also the case Alnati (1966) by the Dutch Supreme Court that introduced the concept of foreign mandatory rules.

${ }^{187}$ Meeusen 2007, pp. 287-305. See also Michaels 2008, pp. 1607-1644; Mills 2013, pp. 461-464.

${ }_{188}$ Martinek 2001, para 7.3.

${ }^{189}$ Martinek 2001, para. 8.

${ }^{190}$ See paragraph 4.1 .1 on the concept of pro-integrationist interpretation by the CJEU.

${ }^{191}$ Martinek 2001, para. 6.1. See paragraph 1.2.

192 See also Symeonides 2016, pp. 100-130.

${ }^{193}$ See, inter alia, Muir-Watt 2011, pp. 347-428; Muir-Watt 2016, pp. 862-881; Wai 2002, pp. 209-274.
} 


\subsection{Globalisation and global governance}

At the heart of the concept of globalisation lies "worldwide interconnectedness" caused by cross-border activities and relationships. ${ }^{194}$ In contemporary society, relationships and activities often contain a cross-border element: people, information, business, capital easily cross the national borders. "These increased 'flows' create new areas or spaces which are no longer tied to nation states alone." ${ }^{\prime 195}$ Cyberspace is an example of such a new area. The foregoing indicates that "territoriality has lost much of its meaning". 196

Consequently, the position of the state has changed. Cross-border issues regarding human rights, migration, environmental pollution, financial crises demand cooperation at international level. There is an increasing global and regional involvement and influence of non-state actors like human rights organisations, ${ }^{197}$ multinationals, and international trade organisations ${ }^{198}$. States have to deal with the emerging legal pluralism, ${ }^{199}$ non-state law $^{200}$ and non-state norms ${ }^{201}$ that have been coming into force and influence or even overrule state law. ${ }^{202}$ "Lex mercatoria, the transnational law of economic transitions, is the most successful example of global law without a state." 203

Since the increasing use of arbitration in international business sector, it has been argued that states lost their absolute adjudicatory power. ${ }^{204}$ McGrew refers to the "denationalization of power"; "sovereignty today is increasingly understood as the shared exercise of public power and authority by national, regional, and global authorities." 205 In short, the position and power of the initial absolute sovereign states have changed in the new world order. ${ }^{206}$ Considering this new world order, global governance by state and non-state actors has been advocated as a way to promote, regulate or intervene in the common affairs of humanity". ${ }^{207}$ The next paragraph will point out the role of private international law in global governance.

\footnotetext{
194 McGrew 2017, p. 20.

195 Johnston \& Powles 2004, p. 14.

${ }^{196}$ Michaels 2005, p. 23. See also Michaels 2004, pp. 105-130.

${ }^{197}$ Bianchi 1997, pp. 179-204.

${ }^{198}$ Examples are the European Union, GATT, IMF, the World Bank, NAFTA See Schmidt 1995, p. 2.

199 Teubner 1997(a), pp. xiii-xvii; Berman 2015, pp. 15-40.

${ }^{200}$ Hefland points out that there are various forms of non-state law "from transnational law to international law and from religious law to indigenous law". See Hefland 2015, p.1.

${ }^{201}$ Non-state norms are, for example, established by trade associations or neighbourhood-dispute resolutions. See Hefland 2015, pp. 5-6.

${ }^{202}$ Berman 2015, pp. 15-40.

${ }^{203}$ Teubner 1997(b), p. 3. See also De Ly 1989; Shapiro 1993, pp. 36-64.

${ }^{204}$ Wai 2002 , pp. $215-218$. However, an arbitral award is generally annullable if it is contrary to the public policy of the state where the recognition and enforcement of this award is sought. See Article V sub 2 (b) of the United Nations Convention on the Recognition and Enforcement of Foreign Arbitral Awards adopted in New York by the United Nations on 10 June 1958 entered into force 7 June 1957 UNTS 330. See also Grenig (2014, pp. 96-98) regarding the case law of courts in the states of the United States of America. In view of this public policy exception, the CJEU held that an arbitral award is void when it is contrary to Article 101 TFEU concerning unfair competition. See Case C-126/97 Eco Swiss China Time Ltd v. Benetton International NV, para. 36-39.

${ }^{205}$ McGrew 2017, pp. 20, 29. See also Michaels 2005, p. 22; Dinwoodie 2009(a), p. 769.

${ }^{206}$ Schmidt 1995, pp. 1-46. See also Ruggie 1993, pp. 139-174; Sassen 2015, pp. 23-32; Strange 1996.

${ }^{207}$ Held \& McGrew 2002, p. 1. See Annan 2000, p. 6.
} 
Globalisation and the Internet have increased the risk of "overlapping claims of jurisdiction and overregulation", ${ }^{208}$ "jurisdictional hyperregulation"; "there is a clear meta-trend of states making overly broad... claims of jurisdiction" ${ }^{209}$. With respect to the assessment to confer full jurisdiction to the court under Article 7(2) Brussels Ibis based on effects in cross-border copyright infringement cases, this dissertation will therefore include the possible influence of the so-called principle of international comity on the exercise of adjudicatory and prescriptive jurisdiction. ${ }^{210}$ Paragraph 2.1.2.2.1 will explain the latter two types of jurisdiction. ${ }^{211}$

\subsection{The role of private international law in global society}

In the setting of global governance, scholars have pointed out that private international law can be employed as a valuable tool. ${ }^{212}$ In the current global society, private international law "should enable market deficiencies to be corrected, and weaker parties, important societal values and common goods to be protected". ${ }^{213}$ It has been advocated to use private international law to balance "the informal power in the global economy". ${ }^{214}$ Globalisation entails an increasing private economic power of corporations, like multinational companies, while there is a lack of rules to regulate this power. ${ }^{215}$ In the context of Internet, it has been argued to employ jurisdiction rules to fight abuses, protect human rights, and promote the digital economy. ${ }^{216}$

Rules of private international law can be used to protect economical weaker parties, such as small companies or customers, against this increasing power. ${ }^{217}$ As mentioned earlier, the Hague Conference on Private International Law and the European Union legislators did enact special rules of private international law to protect certain weak parties, such as consumers, policyholders, employees, and children. ${ }^{218}$ The scholars Kono and Jurcys argue that whenever a copyright holder can be considered as economically weak, this copyright holder should receive special protection at jurisdictional level. ${ }^{219}$ In cases involving an economical weak copyright holder and a powerful multinational corporation, they suggest that the court of the copyright holder's place of domicile may obtain jurisdiction regarding the entire damage. ${ }^{20}$

\footnotetext{
${ }^{208}$ Ryngaert \& Vagias 2019.

${ }^{209}$ Svantesson 2019(a), p. 51.

${ }^{210}$ See paragraphs 5.3.3.1 and 5.3.4.1 that will also explain the concept of the principle of international comity.

${ }^{211}$ See paragraph 2.1.2.2.1 on the distinction between adjudicative, prescriptive, and enforcement jurisdiction. The rethinking of the CJEU's approach to jurisdiction in cross-border copyright infringement cases will mainly concern adjudicative jurisdiction. Yet, paragraph 5.3.3.1 will involve prescriptive jurisdiction. Although this dissertation will occasionally point out the risk of enforcement problems, the concept of enforcement jurisdiction will not be addressed in this dissertation.

${ }^{212}$ Carballo Pineiro \& Kramer 2014, pp. 109-112; Muir-Watt 2011, pp. 347-428; Wai 2002, pp. 209-274; Van Den Eeckhout 2017.

${ }^{213}$ Van Loon 2015, pp. 45, 108. Instead of “common goods", Muir-Watt refers in this context to "collective goods of planetary concern". See Muir-Watt 2011, p. 356.

${ }^{214}$ Muir-Watt 2011, p. 347. See also Wai 2002, pp. 239-274.

${ }^{215}$ Cutler 2003; Sassen 2015, pp. 25-28.

${ }^{216}$ Svantesson 2019(a), p. 25.

${ }^{217}$ Muir-Watt 2011, pp. 358, 363-370; Van Loon 2015, pp. 45, 108.

${ }^{218}$ See paragraph 2.1.2.1.3.

${ }^{219}$ Kono \& Jurcys 2015, pp. 28-31.

${ }^{220}$ Kono \& Jurcys 2015, pp. 28-31.
} 
This so-called case-specific copyright holder's centre of interest approach will be further assessed in chapter six.

From a broader perspective, several scholars assert that private international law should be used to facilitate human rights, environmental law and labour law. ${ }^{221}$ States enacted rules of private international law to protect the rights of certain parties. ${ }^{222}$ For instance, the Hague Convention on the Civil Aspects of International Child Abduction of 1980 protects the interest of children by means of rules of private international law. ${ }^{223}$ With respect to environmental damage, the European Union legislature enacted a special conflict-of-laws rule laid down in Article 7 of the Regulation (EC) No 864/2006 of the European Parliament and the Council of 11 July 2007 on the applicable law to non-contractual obligations (hereinafter Rome II). ${ }^{224}$ Article 7 Rome II stipulates that the victim of environmental law can choose between the law of the place where the damage occurred, ${ }^{225}$ or the law of the state in which the event giving rise to the damage occurred. This discrimination in favour of the victim of environmental damage has been justified by "the principle of priority for corrective action at source and the principle that the polluter pays". ${ }^{226}$ In the case Apkan et al. $v$. Shell, the latter principles even seem to lead to the broad attribution of jurisdiction in case of environmental damage. ${ }^{227}$ In this case, and in two parallel cases, ${ }^{228}$ the Dutch courts obtained jurisdiction over the parent company of Shell located in the Netherlands regarding activities committed by its subsidiary company located in Nigeria that caused environmental damage in Nigeria. ${ }^{229}$

The leading principle of international labour law namely "the protection of the employee" has also been adopted by the European Union legislature regarding the rules of private international law. ${ }^{230}$ In view of the United Nations Guiding Principles on Business and Human

\footnotetext{
${ }^{221}$ Carballo Pineiro \& Kramer 2014, p. 110; Jayme 1990, p. 22; Muir-Watt 2011, pp. 347-428; Van Den Eeckhout 2010; Van Loon 2015, pp. 63-108.

${ }^{222}$ See also paragraph 2.1.2.1.3.

${ }^{223}$ Hague Convention on the Civil Aspects of International Child Abduction concluded 25 October 1980, entered into force 1 December 1983.

${ }^{224}$ Regulation (EC) No 864/2006 of the European Parliament and the Council of 11 July 2007 on the applicable law to non-contractual obligations (OJ L199, 31.07.2007, pp. 40-49), hereinafter Rome II.

${ }^{225}$ According to the general rule of Article 4 Rome II, the law of the place where the damage occurred, lex loci damni, will be applicable to a regular tort case.

${ }^{226}$ See recitals $24-25$ in the preamble to the Rome II Regulation.

${ }^{227}$ Gerechtshof Den Haag 18 December 2015 Apkan and Vereniging Mileudefensie v. Royal Dutch Shell PLC and Shell Petroleum Development Company of Nigeria LTD. Appeal from Rechtbank Den Haag 30 January 2013 Apkan and Vereniging Mileudefensie v. Royal Dutch Shell PLC and Shell Petroleum Development Company of Nigeria LTD.

${ }^{228}$ Gerechtshof Den Haag 18 December 2015 Dooh and Vereniging Mileudefensie v. Royal Dutch Shell PLC and Shell Petroleum NV. Gerechtshof Den Haag 18 December 2015 Orugu and Efanga and Vereniging Mileudefensie v. Shell Petroleum NV. Appeals from Rechtbank Den Haag 30 January 2013 Dooh and Vereniging Mileudefensie v. Royal Dutch Shell PLC and Shell Petroleum NV; Rechtbank Den Haag 30 January 2013 Orugu and Efanga and Vereniging Mileudefensie v. Shell Petroleum NV.

${ }^{229}$ See Van Den Eeckhout 2010 on the topic of international environment pollution and some other private international law issues related to transnational corporate social responsibility.

${ }^{230}$ Grusic 2015, pp. 17-55; Van Den Eeckhout 2015. See Articles 20-23 Brussels Ibis; Article 8 Rome I.
} 
Rights of 2011, ${ }^{231}$ Van Calster illustrates the role that private international law should play with respect to corporate social responsibility. ${ }^{232}$

The case law of the European Court of Human Rights (hereinafter ECtHR) demonstrates that human rights and the field of private international law interact. ${ }^{233}$ For instance, in the case Wagner and J.M.W.L. v. Luxembourg, ${ }^{234}$ the ECtHR set aside a conflict-of-laws rule involving adoption as the result of applying this rule encroached on the right of family life laid down in Article 8 of the European Convention for the Protection of Human Rights and Fundamental Freedoms of 1950 (hereinafter the European Convention on Human Rights of 1950). ${ }^{235}$ Yet, in a similar case of Harroudj v. France involving adoption, the ECtHR did not agree to set aside the conflict-of-laws rule on the basis of the right of family life in Article 8 of the European Convention on Human Rights of $1950 .{ }^{236}$ When rethinking the CJEU's interpretation of the special jurisdiction rule of Article 7(2) Brussels Ibis in cross-border copyright infringement cases, chapter four will advocate to balance certain competing fundamental rights related to copyrights.

\subsection{Concluding remarks on the demise of neutrality}

The foregoing paragraphs demonstrated that states adopted many deviations from the traditional method of Von Savigny. Instead of relying on the Sitz-methode, rules and approaches became more open-ended and flexible. ${ }^{237}$ Moreover, substantive values, policies, and results have been starting to play a role in contemporary private international law. ${ }^{238}$

Two developments concerning the demise of neutrality of private international law can be indicated. ${ }^{239}$ First, the demise of substantive neutrality within the field of private international law. Current rules of private international law are often interconnected with objectives underlying substantive laws. ${ }^{240}$ In Europe, the "classic view of conflicts justice" has increasingly "accepted the corrective function of material justice". ${ }^{241}$ Several jurisdiction rules contain connecting factors that aim to protect certain weaker persons or concepts. ${ }^{242}$ The CJEU's approach to jurisdiction in cross-border copyright infringement cases reflects the aim to enhance copyright protection in the European Union. ${ }^{243}$

\footnotetext{
${ }^{231}$ The United Nations Guiding Principles on Business and Human Rights endorsed by the United Nations Human Rights Council in June 2011, also referred to as the Ruggie Principles, are implementing the United Nations 'Project, Respect and Remedy' Framework 2011.

${ }^{232}$ Van Calster 2016, p. 357. See also Van Loon 2015, pp. 87-98, 108.

${ }^{233}$ Kiestra 2014; Van Loon 2015, pp. 63-65.

${ }^{234}$ ECtHR 28 June 2007, Wagner and J.M.W.L. v. Luxembourg, App. No. 76240/01.

${ }^{235}$ European Convention for the Protection of Human Rights and Fundamental Freedoms adopted in Rome on 4 November 1950, entered into force 3 September 1953, ETS No. 005.

${ }^{236}$ ECtHR 4 October 2012, Harroudj v. France, App. No. 43631/09.

${ }^{237}$ Symeonides 2017(a), pp. 174-189.

${ }^{238}$ De Boer 1990, p. 3; Martinek 2001, para. 6.

${ }^{239}$ See also Van Den Eeckhout 2017.

${ }^{240}$ De Boer 1993, pp. 13-22; Strikwerda 2015, pp. 38-39.

${ }^{241}$ See Symeonides 2017(a), pp. 246-288.

${ }^{242}$ See paragraphs 2.1.2.1.3 and 2.1.2.1.5.2.

${ }^{243}$ See chapter 3 on the rulings Pinckney, Hi Hotel and Pez Hejduk.
} 
Second, the demise of neutrality related to the entire field of private international law. ${ }^{244}$ While private international law used to be denoted as an island, it nowadays need to interact with other areas of law, and is even used as an instrument to achieve aims underlying other areas. ${ }^{245}$ The proper functioning of the globalising society demands private international law to interact with other fields of law and serve global interests. ${ }^{246}$ Chapter four will advocate that an approach to jurisdiction in cross-border copyright infringement disputes should seek to balance the broader interest of copyright holders, on the one hand, and users of information and traders, on the other hand.

From a perspective of legitimacy, it is important that the instrumentalisation of private international law does not undermine the principles of this field of law. ${ }^{247}$ As mentioned in paragraph 1.2, "private international law mustn't be degraded into an auxiliary instrument of EC law". ${ }^{248}$ Chapter four will therefore argue to include the main principles underlying the special jurisdiction rule of Article 7(2) Brussels Ibis into the assessment framework to rethink the CJEU's approach to jurisdiction in cross-border copyright infringement cases.

\subsubsection{Flexible approach to territoriality as basis for jurisdiction}

\subsection{Demise of territoriality as basis for jurisdiction in public international law and its relation to jurisdiction in private international law}

In public international law, jurisdiction has been defined as "the regulatory competence or power of a State vis-à-vis other States: the right to regulate". ${ }^{249}$ The latter right "tends to be divided into three types: the right to prescribe laws, the right to adjudicate disputes and the right to enforce rules or judgment." ${ }^{250}$ Hence, jurisdiction in public international law has been distinguished into adjudicative (or adjudicatory) jurisdiction, prescriptive jurisdiction, and enforcement jurisdiction. ${ }^{251}$ Private international law employs a narrower concept of jurisdiction that concerns the issue whether a court has the right to hear a cross-border dispute. ${ }^{252}$ From a perspective of public international law, adjudicative jurisdiction refers to

\footnotetext{
244 Van Den Eeckhout 2017.

${ }^{245}$ Van Den Eeckhout 2013(b), pp. 3-4; Van Den Eeckhout 2017.

${ }^{246}$ Muir-Watt 2011, pp. 358-359; Wai 2002, pp. 209-274.

${ }^{247}$ Van Den Eeckhout 2013(a), p. 11. See also Van Den Eeckhout 2002, p. 145; Van Den Eeckhout 2013(b), p. 2.

${ }^{248}$ Meeusen 2007, p. 287.

${ }^{249}$ Kohl 2010, p. 14.

${ }^{250} \mathrm{Kohl} 2010$, p. 16. With respect to the right to prescribe laws, Kohl noted that "this applies to both judge-made law and legislation".

${ }^{251}$ Kohl 2010, p. 18; Mills 2014, p. 195; Wautelet 2004, p. 55. Wautelet refers to the following common distinction regarding the concept of jurisdiction in international law: "jurisdiction to prescribe (i.e. to make its law applicable to activities and relations, whether by legislation, regulation or determination of a court), jurisdiction to adjudicate (i.e. to subject persons or things to process of courts), and, finally jurisdiction to enforce (i.e. to induce or compel compliance, through courts or by use of executive, administrative, etc.)". Wautelet refers in this context to $\S 401$, $3^{\text {rd }}$ Restatement Foreign Relations Law of the United States. See also Mann 1984, p. 67. The rethinking of the CJEU's approach to jurisdiction in cross-border copyright infringement cases will mainly concern adjudicative jurisdiction. Yet, paragraph 5.3.3.1 will involve prescriptive jurisdiction. Although this dissertation will occasionally point out the risk of enforcement problems, the concept of enforcement jurisdiction will not be addressed in this dissertation.

${ }^{252}$ Kohl 2010, p. 14.
} 
the state's competence "to subject persons or things to process of courts". ${ }^{253}$ Brownlie argued that "two generally recognized bases for jurisdiction of all types are the territorial and nationality principles". 254 On the basis of the principle of territoriality, a state "has jurisdiction over persons, and things, and over events occurring, within its territory". ${ }^{255}$ With respect to jurisdiction rules related to private international law, the principles of territoriality and personality, that means nationality, domicile, and residence, reflect the bases for jurisdiction in public international law. ${ }^{256}$

In view of public international law, "jurisdiction is an aspect of a State's sovereignty". ${ }^{257}$ Based on the principle of state sovereignty, states "have full and exclusive sovereign power over their own territory". ${ }^{258}$ As indicated in paragraph 2.1.2.1.5.1, the traditional concept of the state's sovereignty has been affected due to globalisation and the Internet. It is argued that intersection of territoriality and sovereignty has been "reconfigured". ${ }^{259}$ Berman asserts that territory-based jurisdiction became obsolete since the focus shifted from territorial-bounded states to the existence of communities of individuals. ${ }^{260}$ Ryngaert argues that "states may even be obliged to exercise jurisdiction (rather than just being allowed to, let alone being precluded from doing do) especially in respect of values dear to the international community" such as human rights obligations. ${ }^{261}$ "It is generally accepted now that core crimes against international law are amenable to universal jurisdiction, that is jurisdiction exercised by a State without any nexus to the violation whatsoever."262

The topic of this dissertation involves the first branch of private international law, ${ }^{263}$ in particular the jurisdiction of Member State courts in cross-border copyright infringement disputes. When a court exercises jurisdiction based on the special jurisdiction rule of Article 7(2) Brussels Ibis, this concerns adjudicative jurisdiction. ${ }^{264}$ Paragraph 5.3.3.1 will nonetheless involve prescriptive jurisdiction when demonstrating the possible influence of the principle of international comity on the exercise of full jurisdiction under Article 7(2) Brussels Ibis in crossborder copyright infringement cases.

According to Svantesson, "as far as jurisdiction is concerned, there is no strong reason to strictly separate between public and private international law". ${ }^{265}$ As argued by Wautelet, the

\footnotetext{
${ }^{253}$ Wautelet $\left(2004\right.$, p. 55) refers in this context to $\S 401,3^{\text {rd }}$ Restatement Foreign Relations Law of the United States. See also Ryngaert 2015(b), p. 58.

${ }^{254}$ See Brownlie 2008, p. 311. Jurisdiction in may also be based on the protective principle or the principle of universality. See Hudson 1998, pp. 95-96. See also Kohl 2010, p. 20; Mann 1964, p. 40; Mills 2014, pp. $196-197$.

${ }^{255}$ Greig 1976, p. 210. See also Michaels 2004, pp. 106-108; Ryngaert 2015(b), p. 51.

256 Mills 2018, p. 24.

${ }^{257}$ Ryngaert 2015(b), p. 50. See also Mann 1964, p. 30; Mann 1984, p. 20; Michaels 2004, p. 106.

${ }^{258}$ Ryngaert 2015(b), p. 51.

${ }^{259}$ Sassen 2015, p. 31.

${ }^{260}$ Berman 2007, p. 1155. See also Boer \& Werner 2019, pp. 15-58; Ryngaert \& Zoetekouw 2017, pp. 185-201.

${ }^{261}$ Ryngaert 2015(b), p. 54.

${ }^{262}$ Ryngaert 2015(a), p. 192. See also Hill 2003, p. 53; Kohl 2010, p. 16.

${ }^{263}$ See paragraph 2.1.1.

${ }^{264}$ See Ryngaert (2015(b), p. 59) on adjudicative jurisdiction of courts.

${ }^{265}$ Svantesson 2017, p. 7. Svantesson (2017, p. 84) even argues that there seems to be a natural and desirable development of uniting the field of private international law and the field of public international law into one discipline; "a discipline covering both what traditionally falls within private international law, and the jurisdictional issues that arise within public international law".
} 
link between jurisdiction in international law and rules of jurisdiction in private international law is obvious because "the latter determine the sphere of influence of national courts". 266 "The sovereign cannot confer jurisdiction on his courts or his legislature when he has no such jurisdiction according to principles of international law". ${ }^{267}$ Mann argues that jurisdiction of courts in civil matters "is determined and circumscribed by international rules of jurisdiction". 268

Michaels points out that constrains from public international law can "determine the outer boundaries of jurisdiction" in two ways. ${ }^{269}$ First, human rights law can limit the exercise of jurisdiction; this should, for instance, not encroach fundamental rights such as the right to a fair trial. ${ }^{270}$ In the context of rethinking the CJEU's approach to jurisdiction in cross-border copyright infringement cases, this dissertation will examine the possible influence of human rights. ${ }^{271}$ Second, considering jurisdiction as exercise of sovereign power, as indicated above, "public international law limits the exercise of sovereign power vis-à-vis the sovereign interests of other states". ${ }^{272}$ In view of this second way, paragraph 5.3.4.1 will advocate a "strong territorial connection' requirement to justify full jurisdiction of the court under Article 7(2) Brussels Ibis based on effects in cross-border copyright infringement cases. The principle of international comity that reflects the principle of sovereignty of states related to public international law will therefore be employed. ${ }^{273}$ Paragraph 5.3.3.1 will discuss the possible influence of this principle on the scope of the court's jurisdiction under Article 7(2) Brussels Ibis in cross-border copyright infringement cases.

It has been argued that "the public international law governing civil jurisdiction has remained more firmly rooted in territoriality than most other branches of the law."274 The branch of civil law seems to require more legal certainty and foreseeability than other branches of law. ${ }^{275}$ Yet, in the context of private international law, it has been asserted that "the territoriality principle and the nationality principle have lost ground to other focal points such as 'domicile' and 'habitual residence'." 276 With respect to "conduct-connected bases of jurisdiction" under the Brussels Ibis Regulation such as Article 7(2) Brussels Ibis, Michaels nonetheless claims that territoriality still plays a great role. ${ }^{277}$ The following paragraph will demonstrate that the basis of jurisdiction in private international law has developed into a more flexible approach to territoriality regarding cross-border tort cases through case law in the United States of America and the European Union.

\footnotetext{
${ }^{266}$ Wautelet 2004, p. 56.

${ }^{267}$ Mann 1964, p. 11. Mann refers to Jospeh Beale 36 (1922-1923) Harvard Law Review, pp. 241, 243.

${ }^{268}$ Mann 1964, p. 73. See also Mills 2018, p. 24; Wautelet 2004, p. 59.

${ }^{269}$ Michaels 2017(b), p. 1043. See Hill (2003, pp. 42-43) on different views on the influence of principles of public international law on the exercise of jurisdiction in private law matters.

${ }_{270}$ Michaels 2017(b), p. 1043; Wautelet 2004, pp. 59-60. See also Reimann 2019, pp. 1365-1367.

${ }^{271}$ See paragraphs 4.4.2.2 and 4.4.2.4.

${ }^{272}$ Michaels 2017(b), p. 1043.

${ }^{273}$ See paragraph 5.3.3.1 on the principle of international comity.

${ }^{274}$ Mann 1984, p. 67.

275 See Mann 1984, p. 67.

${ }^{276}$ Svantesson 2017, p. 38. See also Mills 2014, p. 207.

${ }^{277}$ Michaels 2004, p. 108. With respect to conduct-connected bases of jurisdiction, Michaels refers to the place of contract performance (Article 7(1) Brussels Ibis) and the place where the tort was committed (Article 7(2) Brussels Ibis).
} 


\subsection{Effects-based approach to jurisdiction in tort cases}

In public international law, the concept of extraterritorial jurisdiction "ought to imply that a State exercises its jurisdiction without any territorial link". ${ }^{278}$ Jurisdiction based on alleged harmful effects that occurred within the forum state but are caused by activities that took place outside this state, can therefore not be denoted as extraterritorial. To avoid confusion, scholars either provide a clear definition of extraterritorial, or do not use the term. ${ }^{279}$ This dissertation will employ the term 'effects-based jurisdiction' or 'effects-based approach to jurisdiction' to denote the court's jurisdiction based on alleged harmful effects in the forum state caused by tortious activities that took place in another state. ${ }^{280}$ The term extraterritorial will return with respect to the topic whether the court under Article 7(2) Brussels Ibis can issue an injunction with extraterritorial effects in cross-border copyright infringement cases. ${ }^{281}$ This paragraph will briefly demonstrate the development towards an effects-based approach to jurisdiction in crossborder tort cases in the states of the United States of America and the European Union Member States.

The case of Pennoyer $v$. Neff, decided in 1878, reflects the traditional strict territorial approach to jurisdiction in the states of the United States of America. ${ }^{282}$ In this case, the Supreme Court of the United States endorsed the concept of so-called tag jurisdiction ${ }^{283}$ that the court may exercise jurisdiction over a defendant who was present within the forum state at the time of service of process. ${ }^{284}$ The United States Supreme Court referred to the public international law principle that "no State can exercise direct jurisdiction and authority over persons or property without its territory". ${ }^{285}$ At that time, courts could thus not obtain jurisdiction based on alleged harmfull effects that occurred in the forum state.

\footnotetext{
${ }^{278}$ Ryngaert 2015(a), p. 7.

${ }^{279}$ Ryngaert 2015(a), p. 8; Svantesson 2017, pp. 41-43.

${ }^{280}$ The concept of effects-based jurisdiction has already been employed in the Lotus case in 1927. This case concerned the public international law issue whether a state may exercise jurisdiction with respect to harmful effects caused by alleged criminal activities committed outside its territory. The Permanent Court of International Justice gave an affirmative response provided that "one of the constituent elements of the offence, and more especially its effects" took place in that particular state. See the case of the S. S. Lotus, France v. Turkey, Permanent Court of International Justice 7 September 1927, No. 10, at 23. Subsequently, the seminal case Alcoa confirmed that it has been settled case law that states in the United States of America exercise effects-based jurisdiction in antitrust cases. See United States v. Aluminium Co of America, 148 F. 2 d 416 ( $2^{\text {nd }}$ Cir. 1945). See Gerber 1984, pp. 194-202; Ryngaert 2015(a), pp 82-83; Staker 2014, pp. 317-318. According to Svantesson (2016(a), p. 125, note 138-139), the roots of the concept of effects-based jurisdiction are traceable to the era of Edward III (13121377), or at least to the decision Strassheim v. Daily, 221 U.S. 280 (1911) by the Supreme Court of the United States of America in 1911. In this dissertation the term effects-based jurisdiction will denote the private international law issue whether the court seised may obtain jurisdiction based on alleged tortious effects caused by cross-border torts.

${ }^{281}$ See paragraph 5.3.3.

${ }^{282}$ Pennoyer v. Neff, 95 U.S. 714 (1878). See Grossi 2016, p. 27; Symeonides 2008, p. 29.

${ }^{283}$ See Grossi 2016, p. 37; Hartley 2014 p. 161. "Tag jurisdiction” (Juenger 1984, p. 1197) has traditionally been referred to as "transient jurisdiction". See Restatement (First) Conflict of Laws §77-78 (1934); Ehrenzweig 1956, pp. 289-314. Juenger (1996, p. 37) claimed that the term tag jurisdiction was coined by Silberman. See Silberman 1978 , p. 75.

${ }^{284}$ Pennoyer v. Neff, 95 U.S. 714 at 724. See also Burnham v. Superior Court of California, 495 U.S. 604 (1990).

${ }^{285}$ Pennoyer v. Neff, 95 U.S. 714 at 722.
} 
In the landmark case of International Shoe Co. v. State of Washington in $1945,{ }^{286}$ the Supreme Court of the United States introduced a more flexible approach to territoriality as basis for jurisdiction according to private international law. ${ }^{287}$ Based on the Due Process Clauses of the United States Constitution, ${ }^{288}$ the Supreme Court of the United States ruled that the court may exercise so-called personal jurisdiction over a non-resident defendant, who is not present within the territory of the forum state, if this defendant has "certain minimum contacts" with the forum state, from which the complaint arises, such that the exercise of jurisdiction does not offend "traditional notions of fair play and substantial justice". ${ }^{289}$ Thus, a defendant who engaged in tortious activities that occurr, or have effects, in the forum state can be subjected to jurisdiction. ${ }^{290}$ Paragraph 37 of the Restatement (Second) of Conflict of Laws also reflects an effect-based approach to jurisdiction by stipulating that "a state has power to exercise judicial jurisdiction over an individual who causes effects in the state by an act done elsewhere with respect to any cause of action arising from these effects unless the nature of the effects and of the individual's relationship to the state make the exercise of such jurisdiction unreasonable". Chapter seven will elaborate on the 'minimum contacts' approach established in the case of International Shoe Co. v. State of Washington and interpreted by the lower courts in the United States of America in cross-border copyright infringement disputes. ${ }^{291}$

In European Union Member States, the traditional principle of actor sequitur forum rei, that provides jurisdiction to the court of the place of the defendant's domicile, ${ }^{292}$ reflects the importance of "a direct link between the dispute and the territory". ${ }^{293}$ While this general rule is still in force, Member States also adopted special jurisdiction rules. With respect to cross-border torts, Member States generally adopted the connecting factor "the place of the harmful event". ${ }^{294}$ Hence, the European Union legislators also enacted "the place of the harmful event" as special jurisdiction rule in cross-border tort cases, currently enshrined in Article 7(2) Brussels Ibis. ${ }^{295}$ Through interpretation of this special jurisdiction rule, the CJEU established an effect-based approach to jurisdiction in tort cases. ${ }^{296}$

\footnotetext{
${ }^{286}$ International Shoe Co. v. Washington, 326 U.S. 310.

${ }^{287}$ Wautelet 2004, p. 64. See chapter 7 on the case of International Shoe Co. v. Washington.

${ }^{288}$ The Due Process clause of the Fifth Amendment binds the federal government and therefore the federal courts. "No person shall be...... deprived of life, liberty, or property, without due process law..." The Due Process clause of the Fourteenth Amendment binds the states and therefore the state courts. “...or shall any State...deprive any person of life, liberty, or property without due process of law...” See Schack 1983, pp. 1-3.

${ }^{289}$ International Shoe Co. v. Washington, 326 U.S. 310 at 316.

${ }^{290}$ Von Mehren 2007, p. 136. See also paragraph 7.3.2 on specific personal jurisdiction.

${ }^{291}$ Hartley 2015, pp. 153-160. The minimum contacts approach keeps developing on the basis of case law by the Supreme Court of the United States. See, inter alia, World-Wide Volkswagen Corp v. Woodson, 444 U.S. 286 (1980); Helicopteros Nationales de Columbia S.S. v Hall, 466 U.S. 408 (1984); Walden v. Fiore, 571 U.S. 277, 134 S. Ct. 1115 (2014). For more case law, see Dorsaneo 2015; Grossi 2016, pp. 27-70.

292 The general principle of actor sequitur forum rei has been laid down in the general jurisdiction rule of Article 4 Brussels Ibis Regulation and its predecessors (see paragraph 1.1.2). See Case C-412/98 Group Josi Reinsurance Company SA v. Universal General Insurance Company (UGIC), para. 35; C-256/00 Besix SA v. Wasserreinigungsbau Alfred GmbH \& Co. KG and Planungs-und Forschungsgesellschaft Dipl. Ing. W. Kretzschmar GmbH \& KG, para. 52. See also Jenard Report on the Brussels Convention of 1968, No C 59/18. See also Von Mehren (2007, p. 153) on the universally approved principle of actor sequitur forum rei.

${ }^{293}$ Wautelet 2004, p. 66. See also Mann 1964, p. 76; Mann 1984, p. 67.

294 Jenard Report on the Brussels Convention of 1968, No C 59/26.

295 Jenard Report on the Brussels Convention of 1968, No C 59/26.

${ }^{296}$ Michaels 2004, p. 110.
} 
In the seminal case of Handelskwekerij G.J. Bier v. Mines de Potasse d'Alsace SA in 1976 involving cross-border environmental damage, the CJEU interpreted that "the place of the harmful event" covers both the place of the event given rise to the damage, the Handlungsort, as well as the place where the damage occurred, the Erfolgsort. ${ }^{297}$ The CJEU reasoned that these two connecting factors entail a close connection between the court seised and the dispute that will be "particularly helpful from the point of view of the evidence and of the conduct of the proceedings". ${ }^{298}$ Therefore, these connecting factors enhance the sound administration of justice. ${ }^{299}$ The CJEU's interpretation in the Bier ruling deemed to guarantee the effectiveness of the special jurisdiction rule of Article 7(2) Brussels Ibis. ${ }^{300}$ Furthermore, most national provisions and courts of the Member States employ the Handlungs- and Erfolgsort. ${ }^{301}$

Settled case law of the CJEU demonstrates that the Erfolgsort concerns the place where the initial damage occurred, ${ }^{302}$ not the place(s) of the consequential damage. ${ }^{303}$ Pursuant to the CJEU, the Erfolgsort does not include the place(s) where the victim suffered consequential financial loss. ${ }^{304}$ It has been also argued that the Erfolgsort does not include the place where the victim allegedly suffered physical or psychic damage caused by an injury in another place. $^{305}$ The requirement that only the initial damage is sufficient to establish jurisdiction restricts the effects-based approach to jurisdiction and expresses the importance of the territorial link between the dispute and forum.

In the defamation case of Shevill and Others $v$. Presse Alliance, the CJEU ruled that the Erfolgsort concerns each Member State "in which the defamatory publication was distributed and in which the victim claims to have suffered injury to his reputation". ${ }^{306}$ However, the court's jurisdiction based on this Erfolgsort will be limited to the damage caused within the forum state. ${ }^{307}$ This limitation of jurisdiction, the so-called "mosaic principle" 308 reflects the territoriality principle. ${ }^{309}$

\footnotetext{
${ }^{297}$ Case C-21/76 Handelskwekerij G.J. Bier v. Mines de Potasse d'Alsace SA, para. 24-25.

${ }^{298}$ Case C-21/76 Handelskwekerij G.J. Bier v. Mines de Potasse d'Alsace SA, para. 17.

${ }^{299}$ Case C-21/76 Handelskwekerij G.J. Bier v. Mines de Potasse d'Alsace SA, para. 11. See also Case C-189/08 Zuid-Chemie $B V$ v. Philippo's Mineralenfabriek NV/SA, para. 24; Case C-167/00 Verein für Konsumenteninformation v. Karl Hein, para. 46.

${ }^{300}$ Case C-21/76 Handelskwekerij G.J. Bier v. Mines de Potasse d'Alsace SA, para. 20-21. See also Von Hein 2014-2015, p. 245.

${ }^{301}$ Case C-21/76 Handelskwekerij G.J. Bier v. Mines de Potasse d'Alsace SA, para. 22-23.

${ }^{302}$ See, inter alia, Case C-220/88 Dumez France SA and Traboca SARL v Hessische Landesbank and Others, para. 20-21; Case C-364/93 Marinari v. Lloyd's Bank and Zubaidi Trading Company, para. 14-21; Case C-168/02 Rudolf Kronhofer v. Marianne Maier and Others, para. 18-21.

${ }^{303}$ Hertz 1998, p. 264; Stone 2014, pp. 99-101. See also paragraph 5.2.2.

${ }^{304}$ See, inter alia, Case C-220/88 Dumez France SA and Traboca SARL v. Hessische Landesbank and Others, para. 20-21; Case C-364/93 Marinari v. Lloyd's Bank and Zubaidi Trading Company, para. 14-21; Case C-168/02 Rudolf Kronhofer v. Marianne Maier and Others, para. 18-21.

${ }^{305}$ See the Dutch Supreme Court (Hoge Raad) 7 December 2001, para. 3.3. See Schaafsma 2018, p. 14. See also the Conclusion of Advocate General L. Strikwerda, 21 September 2001, para. 10; the Conclusion of Advocate General L. Strikwerda, 1 February 2008, Zuid-Chemie B.V. v. Philippo's Mineralenfabriek N.V./S.A., para. 15. See also paragraph 5.2.2.

${ }^{306}$ Case C-68/93 Shevill and Others v. Presse Alliance, para. 29.

${ }^{307}$ Case C-68/93 Shevill and Others v. Presse Alliance, para. 30-31.

${ }^{308}$ See paragraph 1.1.4.

${ }^{309}$ Michaels 2004, p. 111.
} 
The foregoing indicates that the CJEU seemed to have remained close to the territorial based approach to jurisdiction when interpreting the effects-based connecting factor the Erfolgsort under Article 7(2) Brussels Ibis. Yet, in recent years, the CJEU has broadly interpreted the Erfolgsort in online infringement cases. In the two joined cases eDate Advertising GmbH v. X and Olivier Martinez and Robert Martinez v. MGN Limited involving the infringements of personality rights via the Internet, the CJEU broadly construed the Erfolgsort as being each place where the infringing content is or has been online accessible. ${ }^{310}$ Nonetheless, in line with the Shevill ruling, the CJEU limited the jurisdiction of these courts to the damage caused in the territory of the forum state. ${ }^{311}$ In addition, the CJEU added one connection factor namely the victim's centre of interests. ${ }^{312}$ The court of the place where victim's centre of interests is located will have jurisdiction regarding the entire damage. ${ }^{313}$ The CJEU argued that the Internet makes it difficult to confine the damage caused by the defamation to the territory of the forum state, and emphasised the serious nature of the harm suffered by the victim. ${ }^{314}$

In view of "the global accessibility of online publications", scholars have pointed out that "territoriality-focused" connecting factors, such as "the place where the information has been published", ${ }^{315}$ are "almost valueless". ${ }^{316}$ As mentioned in paragraph 2.1.2.2.1, it has been asserted that "the territoriality principle and the nationality principle have lost ground to other focal points such as 'domicile' and 'habitual residence'." 317

"Jurisdictional rules lay down what nexus is needed between the State and the activity or person to be regulated to found an entitlement to regulate." 318 It has been argued that these rules should point to the state that is "most closely connected to the facts of the case". ${ }^{319}$ The issue whether the mere occurrence of alleged tortious effects is sufficient to establish jurisdiction is a vexed one in the field of private international law. ${ }^{320}$ Particularly with respect to alleged tortious activities via the Internet, the mere effects-based approach will enable courts to obtain jurisdiction in each state where the website involved is or has been available. ${ }^{321}$ This approach

\footnotetext{
310 Joined Cases C-509/09 and C-161/10 eDate Advertising GmbH v. Olivier Martinez and Robert Martinez v. MGN Limited, para. 51. See also paragraph 6.2.1.1.

311 Joined Cases C-509/09 and C-161/10 eDate and Martinez, para. 51.

312 Joined Cases C-509/09 and C-161/10 eDate and Martinez, para. 48.

313 Joined Cases C-509/09 and C-161/10 eDate and Martinez, para. 48. The place of the victim's centre of interests will generally be the place of his habitual residence but other factors may also constitute the existence of a particularly close link with the forum state, such as the pursuit of a professional activity (para. 49). See paragraph 5.3.3.1 on the concept of 'full' jurisdiction.

${ }^{314}$ Joined Cases C-509/09 and C-161/10 eDate and Martinez, para 46-47. See also paragraph 6.2.1.1.

315 Svantesson 2016(b), p. 64.

316 Oster 2012, p. 122.

${ }^{317}$ Svantesson 2017, p. 38. See also Mills 2014, p. 207.

${ }^{318}$ Kohl 2010, p. 15.

${ }^{319}$ Kohl 2010, p. 20. See also Mills 2014, p. 208.

${ }^{320}$ See Mann 1964, p. 78; Michaels 2004, pp. 115-130.

${ }^{321}$ See Kohl 2010, pp. 23, 25.
} 
will entail forum shopping. ${ }^{322}$ Plaintiffs will opt the most favourable court(s) ${ }^{323}$ based on, for example, geographical reasons, inconveniencing defendants, ${ }^{324}$ or the application of the most favourable law, referred to as law shopping. ${ }^{325}$ It may also lead to irreconcilable decisions of various courts. ${ }^{326}$ Moreover, this approach will yield unpredictability for the defendant as regards in which state he may be sued. ${ }^{327}$ Chapter five of this dissertation will assess the mere accessibility approach adopted by the CJEU in cross-border copyright infringement cases. Chapter six will demonstrate that in internet-related copyright infringement disputes, several scholars have advocated to confer jurisdiction to a certain court regarding the entire dispute instead of only the damage that occurred within the forum state. ${ }^{328}$

According to Michaels, a theory of jurisdiction should yield "legitimate results". ${ }^{329}$ As argued by Michaels, "there seems to be little concern with the legitimacy of territory as such as a basis for jurisdiction". ${ }^{330}$ As long as a state is territorial defined, he claims that "jurisdiction must be territorial defined". 331 Hence, Michaels asserts that connecting factors "must necessarily have a more or less strong territorial component". ${ }^{332}$ This requirement of territorial connection is also visible in the preamble to the Brussels Ibis Regulation which explicitly stipulates that, besides the defendant's domicile, "there should be alternative grounds of jurisdiction based on a close connection between court and the action". ${ }^{333}$ This close connection requirement "should ensure legal certainty and avoid the possibility of the defendant being sued in a court of a Member State which he could not reasonably have foreseen." 334

In sum, in view of globalisation and the Internet, a more flexible approach to territoriality as basis for jurisdiction is generally warranted. ${ }^{335}$ While there seems to be a common consensus on the requirement of a "substantial connection" between the dispute and the forum state, the question remains what constitutes a substantial connection in tort cases. ${ }^{336}$ This dissertation will in particular focus on this question with respect to cross-border copyright infringement disputes. As will be demonstrated in this dissertation, instead of adopting a mere effects-based approach, most courts, as well as scholars, demand additional connecting factors to establish jurisdiction

\footnotetext{
322 Pursuant to Juenger, Leflar already employed the term 'forum shopping' in his conflict of laws class in 1927. Leflar told Juenger that he even might have heard this term when he took Beale's conflict of laws class. See Juenger 1989, p. 553. The doctrine against forum shopping seems to originate in the case of Erie Railroad Co v. Tompkins, 304 US 64 (1938) involving an interstate conflict of laws of states in the United States of America. See Ferrari 2017, p. 789. This doctrine has also been adopted in European private international law and case law by the CJEU. See, inter alia, recital 6 in the preamble to the Rome I Regulation and Case C-33/07 Seagon v. Deko Marty Belgium, para. 23. For more examples, see Ferrari 2017, pp. 789-790.

${ }^{323}$ Ferrari 2017, p. 792.

324 Juenger 1989, p. 555.

${ }^{325}$ Ferrari 2017, p. 797.

${ }^{326}$ Matulionyte 2015, p. 134.

${ }^{327}$ Matulionyte 2015, pp. 133-134.

${ }^{328}$ See also Torremans 2014, p. 388.

${ }^{329}$ Michaels 2004, p. 116. See also Hill 2003, pp. 43-44.

${ }^{330}$ Michaels 2004, p. 112.

${ }^{331}$ Michaels 2004, p. 113.

${ }^{332}$ Michaels 2004, p. 113.

${ }^{333}$ Recital 16 in the preamble to the Brussels Ibis Regulation.

${ }^{334}$ Recital 16 in the preamble to the Brussels Ibis Regulation.

${ }^{335}$ See Svantesson 2016(b), p. 62. Svantesson, inter alia, refers to Mills 2014; Ryngaert 2015(a).

${ }^{336}$ Hill 2003, pp. 48-49, 54-55. See also Neumann 2011, pp. 591-600; Svantesson 2017, pp. 62-63; Wautelet 2004, p. 66 .
} 
in cross-border copyright infringement cases. ${ }^{337}$ As will be set out in chapter six, the CLIP principles adopted the 'directed activities'-based escape clause. ${ }^{338}$

In this dissertation, the rethinking of the CJEU's approach to jurisdiction in the rulings Pinckney, Hi Hotel, Pez Hejduk will involve the issue which connecting factors may establish effects-based jurisdiction in cross-border copyright infringement disputes. From a legitimate perspective, chapter four will therefore set up an assessment framework to rethink the CJEU's interpretation of the special jurisdictional rule of Article 7(2) Brussels Ibis in cross-border copyright infringement cases. Based on common methods of interpretation, chapter four will demonstrate the principles underlying the special jurisdiction rule of Article 7(2) Brussels Ibis. Furtherm ore, chapter four will elaborate on the principle of balancing the interests related to copyright law. ${ }^{339}$ These principles will also be employed to assess alternative approaches to effects-based jurisdiction established by scholars, courts of Member States and the United States of America.

With respect to the scope of the court's jurisdiction in cross-border copyright infringement cases, chapter five will address the issue whether the jurisdiction of the court of the place where the damage occurred should be territorially limited to the damage caused within the forum state. $^{340}$ This dissertation will also discuss the importance of the abovementioned 'close connection' requirement with respect to the conferral of so-called full jurisdiction. ${ }^{341}$ Furthermore, the scope of the court's jurisdiction to issue an injunction to cease or prevent copyright infringing activities will be discussed. ${ }^{342}$ The chapters six and seven will examine various approaches that confer jurisdiction to a certain court regarding the entire copyright infringement dispute.

\subsection{The field of copyright law}

\subsubsection{General features}

Copyright law is a branch of the broader field of intellectual property law that regulates the rights granted to creators of intellectual property. Intellectual property rights can be divided into two main branches namely copyrights and rights related to copyrights, on the one hand, and industrial property, on the other hand. ${ }^{343}$ The latter branch comprises, inter alia, trademarks, patents for inventions, and industrial design rights. Intellectual property rights share common features such as the intangible character. ${ }^{344}$

\footnotetext{
${ }^{337}$ Kur \& Dreier 2013, p. 529; Michaels 2004, p. 110-111. Kur and Dreier refer to the American Law Institute Principles on Intellectual Property: Principles Governing Jurisdiction, Choice of Law and Judgments in Transnational Disputes (ALI Principles); the European Max-Planck Group Principles on Conflict of Laws related to Intellectual Property (the CLIP Principles); the Joint-Japanese Korean Principles (Waseda Principles); and the Japanese Transparency Principles.

${ }^{338}$ See Article 2:202 CLIP Principles which will be set out in paragraph 6.1.3.

${ }^{339}$ See also paragraph 2.2.2.1.2 on the principle of balancing the interests related to copyrights.

${ }^{340}$ See paragraph 5.3.1.

${ }^{341}$ See paragraph 5.3.4.1. See paragraph 5.3.3.1 on the concept of 'full' jurisdiction in this dissertation.

${ }^{342}$ See paragraph 5.3.3.

${ }^{343}$ Gielen 2017, pp. 1-2. See also https://www.wto.org/english/tratop_e/trips_e/intel1_e.htm.

${ }^{344}$ Davis 2012(a), p. 2; Koumantos 1998, p. 40; Kur \& Dreier 2013, p. 2.
} 
Another important common feature is the limitation of protection to the territory of the state that granted the right. ${ }^{345}$ This so-called territorial principle related to intellectual property rights has been generally accepted by states. ${ }^{346}$ In the European Union, the CJEU confirmed the territorial protection of copyrights in the case Lagardère Active Broadcast v. SPRE and Others. ${ }^{347}$ It has been argued that the rationale behind the territorial protection lies in sovereignty considerations: "each country as a sovereign power legislates its own copyright and related rights". ${ }^{348}$ States consider copyright law as an important instrument to achieve public economic, social and cultural aims. ${ }^{349}$

The "subjective" concept of copyrights denotes the exclusive rights of authors with respect to the works that they created. ${ }^{350}$ The "objective" concept of copyrights includes all rules related to copyrights enshrined in national codifications and treaties. ${ }^{351}$ Similar to the national character of private international law, each state has its own copyright law. ${ }^{352}$ Yet, as mentioned in paragraph 1.1.2, various treaties have been concluded to regulate certain issues of copyright protection at international level. ${ }^{353}$ For example, the Agreement on Trade Related Aspects of Intellectual Property Rights of 1995 (hereinafter TRIPS-Agreement 1995) contains provisions to enhance the enforcement of copyright protection. ${ }^{354}$

The Berne Convention for the Protection of Literary and Artistic Works of 1979 (hereinafter Berne Convention 1979) is a very important treaty as it stipulates that the existence of copyrights should not be subjected to any formalities. ${ }^{355}$ Since the majority of states in the world are a Member of the Berne Convention 1979, ${ }^{356}$ copyrights generally "possess a greater universality" than most other intellectual property rights that require registration in a particular state. ${ }^{357}$ Furthermore, Article 5(1) of the Berne Convention 1979 comprises the principle of national treatment that provides foreign authors protected by the Convention ${ }^{358}$ the same

\footnotetext{
${ }^{345}$ Barbosa 2008, p. 51; Kur \& Dreier 2013, p. 12; Neumann 2014, p. 498.

${ }^{346}$ Peukert 2012, pp. 190-192.

${ }^{347}$ Case C-192/04 Lagardère Active Broadcast v. SPRE and Others, para. 46. See Goldstein \& Hugenholtz 2013, p. 99.

${ }^{348}$ Van Eechoud 2003, p. 97. See also Dinwoodie 2009(b), p. 123; Goldstein \& Hugenholtz 2013, p. 97; Schaafsma 2009 , p. 416. In the context of territoriality related to copyrights and legislative sovereignty, Van Eechoud (2003, p. 97) nonetheless refers to Troller's statement that the territorial boundaries of intellectual property rights are not their special characteristics, "they share it with all other laws". See Troller 1983, p. 137.

${ }^{349}$ Neumann 2011, p. 584. See also Dinwoodie 2009(a), pp. 766-768; Kur \& Dreier 2013, p. 13.

${ }^{350}$ Ras 2011, p. 1; Spoor, Verkade \& Spoor 2019, pp. 1-2. See paragraph 2.2.1.1 on the division between economic and moral rights.

${ }^{351}$ Ras 2011, p. 1; Spoor, Verkade \& Visser 2019, p. 2.

352 Van Engelen 2007, p. 30.

${ }^{353}$ Von Lewinski 2008 provides an extensive view of international copyright law and policy.

354 The Agreement on Trade Related Aspects of Intellectual Property Rights (known as the TRIPS-Agreement), Annex 1C of the Marrakesh Agreement Establishing the World Trade Organisation, signed in Marrakesh, Morocco on 15 April 1994, entered into force 1 January 1995, 1869 UNTS 299.

${ }^{355}$ The Berne Convention for the Protection of Literary and Artistic Works signed at Berne on 9 September 1886, entered into force 5 December 1887, lastly amended on 28 September 1979, 828 UNTS 221. See Article 5(2) of the Berne Convention 1979. See also Spoor, Verkade \& Visser 2019, p. 893.

356 To date, 179 states are a member of the Berne Convention 1979. See http://www.wipo.int/treaties/en/ShowResults.jsp?treaty_id=15.

${ }_{357}$ Dinwoodie 2005, p. 198 .

${ }^{358}$ Articles 3 and 4 of the Berne Convention 1979 stipulate whether an author is eligible to claim the rights under the Berne Convention 1979. See also paragraph 5.2.1.
} 
copyright protection that the law of the Member State grants to its own national authors. ${ }^{359}$ Article 2(1) of the Berne Convention 1979 enumerates various categories of works that could be protected by copyrights such as books, other writing, architecture and paintings.

Not all works are eligible to be protected, works generally require a certain degree of creativity from the author. ${ }^{360}$ This requirement of originality has been either stipulated in copyright laws or developed in case law. ${ }^{361}$ In the case of Infopaq International A/S v. Danske Dagblades Forening, ${ }^{362}$ the CJEU established an originality criterion that applies to all Member States of the European Union. Paragraph 5.1.2 will elaborate on the adoption of this originality criterion by the CJEU.

Although each state of the United States of America has its own copyright law, the federal government enacted so-called United States copyright law that pre-empts most state laws. ${ }^{363}$ In the United States of America, copyright law has a constitutional basis in Article One of the United States Constitution, section 8(8) that stipulates "The Congress shall have the Power...To promote the Progress of Science and useful Arts, by securing for limited Times to Authors and Inventors the exclusive Right to their respective Writings and Discoveries". ${ }^{364}$ In 1790, the first federal copyright act was enacted, referred to as the First Copyright Act of $1790 .{ }^{365}$ In 1947, the Congress enacted Title 17 of the Code of Laws of the United States of America (hereinafter the United States Code) that codified the federal copyright laws of the United States of America. ${ }^{366}$ While there have been several amendments to the United States Copyright law as laid down in Title 17, the last main amendment has been the United States Copyright Act of 1976 enacted on 19 October $1976 .{ }^{367}$

The academic proposal named the European Copyright Code failed to come into force. ${ }^{368}$ The legislators of the European Economic Community, European Community, and the European Union did enact various Directives related to copyright. ${ }^{369}$ Although these Directives

\footnotetext{
359 Grosheide 1998, p. 38. Schaafsma argued that the principle of national treatment in Article 5(1) Berne Convention consist of both a choice-of-law rule and a non-discrimination principle. See Schaafsma 2009, p. 39. For more on this topic, see paragraph 2.3.2 of this dissertation.

${ }^{360}$ Ras 2011, pp. 1-2; Cases Vallés 2009, pp. 102-132. With respect to the requirement of originality, Cases Vallés points out the difference between the droit d'auteur states and utilitarian copyright states; the latter states usually adopt a lesser strict approach to originality: it is important that the work is not copied. See Cases Vallés 2009, p. 110. See paragraph 2.2.1.1 of this dissertation on the difference between the droit d'auteur tradition and the utilitarian copyright tradition.

${ }^{361}$ Cases Vallés 2009, pp. 106-108; Ras 2011, pp. 1-2, 5-25. Ras refers to the requirement of originality adopted in the Netherlands, England and Germany.

${ }^{362}$ Case C-5/08 Infopaq International A/S v. Danske Dagblades Forening.

${ }^{363}$ See Halpern, Port \& Seymore 2015, pp. 1; Patry 1994, p. 1.

364 The Constitution of the United States of America came into force in 1789.

365 The First Copyright Act has been revised by subsequent federal copyright acts in 1831, 1870, 1909 and 1976. See Patry 1994, pp. 25-36.

${ }^{366}$ Title 17 of the Code of Laws of the United States of America (hereinafter the United States Code) was codified on 30 July 1947. For the text of title 17 of the United States Code, including all amendments enacted through December 9, 2010, in the second session of the $111^{\text {th }}$ Congress, see United States Copyright Office, Copyright Law of the United States and Related Laws Contained in Title 17 of the United States Code: Circular 92, December 2011, Washington D.C. Library of Congress 2011. See also https://www.copyright.gov/title17/.

${ }^{367}$ United States Copyright Act of 1976 enacted on 19 October 1976, Pub. L. No. 94-553, 90 Stat. 2541.

${ }^{368}$ The proposal of the European Copyright Code in 2010 established by the Wittem Group has been explained by Hugenholtz 2012(a), pp. 339-354.

369 Council Directive 91/250/EEC of 14 May 1991 on the legal protection of computer programs (OJ 1991 L122 pp. 9-13) replaced by Directive 2009/24/EC of the European Parliament and of the Council of 23 April 2009 on
} 
aim to harmonise the different copyright laws of the Member States, significant divergences remain between the Member States' copyright laws. ${ }^{370}$ For instance, each Member State has its own rules on moral rights. ${ }^{371}$ A copyright holder will thus be the owner of "a bundle" of 28 national copyrights instead of a unitary European Union copyright. ${ }^{372}$ The protection of copyrights is nonetheless an important policy area within the European Union, particularly for the functioning of a Digital Single Market. ${ }^{373}$ Combating copyright piracy and enhancing enforcement of copyright infringements are therefore high priority. ${ }^{374}$

the legal protection of computer programs (OJ 2009 L111 pp.16-22); Council Directive 92/100/EEC of 19 November 1992 on rental right and lending right and on certain rights related to copyright in the field of intellectual property (OJ 1992 L 346, pp. 61-66) replaced by Directive 2006/115/EC of the European Parliament and of the Council of 12 December 2006 on rental right and lending rights and on certain rights related to copyright in the field of intellectual property (OJ 2006 L 376, pp. 28-35); Council Directive 93/83/EEC of 27 September 1993 on the coordination of certain rules concerning copyright and related rights to copyright applicable to satellite broadcasting and cable transmission (OJ 1993 L 248, pp. 15-21) amended by Directive (EU) 2019/789 of the European Parliament and of the Council of 17 April 2019 laying down rules on the exercise of copyright and related rights applicable to online transmissions of broadcasting organisations and retransmissions of television and radio programmes (OJ L 130, 17.5.2019, pp. 82-91); Council Directive 93/98/EEC of 29 October 1993 harmonizing the term of protection and certain related rights (OJ 1993 L 290, pp. 9-13) replaced by Directive 2006/116/EC of the European Parliament and of the Council of 12 December 2006 on the term of protection of copyright and certain related rights (OJ 2006 L 372, pp. 12-18) replaced by Directive 2011/77/EU of the European Parliament and of the Council of 27 September 2011 (OJ 2011 L 265, pp. 1-5); Directive 96/6/EC of the European Parliament and of the Council of 11 March 1996 on the legal protection of databases (OJ 1996 L 77, pp. 20-28); Directive 2001/29/EU of the European Parliament and of the Council of 22 May 2001 on the harmonisation of certain aspects of copyrights and related rights in the information society (OJ 2001 L167, pp.10-19); Directive 2001/84/EC 27 of the European Parliament and of the Council of 27 September 2001 on the resale right for the benefit of the author of an original work of art (OJ 2001 L 272, pp. 32-36); Directive 2004/48/EC of the European Parliament and of the Council of 29 April 2004 on the enforcement of intellectual property rights (OJ 2004 L195 pp. 16-25); Directive 2012/28/EU of the European Parliament and of the Council of 25 October 2012 on certain permitted uses of orphan works (OJ 2012 L 299 pp. 5-12); Directive 2014/26/EU of the European Parliament and of the Council of 26 February 2014 on collective management of copyright and related rights and multi-territorial licensing of rights in musical works for online use in the internal market (OJ 2014 L 84, pp. 72-98); Directive (EU) 2017/1564 of the European Parliament and of the Council of 13 September 2017 on certain permitted uses of certain works and other subject matter protected by copyright and related rights for the benefit of persons who are blind, visually impaired or otherwise print-disabled and amending Directive 2001/29/EC on the harmonization of certain aspects of copyright and related rights in the information society (OJ L 242, 20.9.2017, pp. 6-13); Directive (EU) 2019/790 of the European Parliament and of the Council of 17 April 2019 on copyright and related rights in the Digital Single Market and amending Directives 96/9/EC and 2001/29/EC (OJ L 130, 17.05.2019, pp. 92-125).

${ }^{370}$ Kur and Dreier argued that "the piecemeal approach adopted by the Commission and the Member States in the harmonisation process has not led to complete harmonisation." See Kur \& Dreier, 2013 pp. 244, 245, $271,315$. See also García-Castrillón 2014, p. 422; Hugenholtz 2013, p. 278. Matulionyte particularly argued that "a number of issues remain non-harmonised (most importantly, copyright exceptions), which means that the scope of protection in different Member States still differs". See Matulionyte 2015, p. 139.

${ }^{371}$ See paragraph 6.2.2.1. See also Sirvinskaite (2010, pp. 263-288) on the lack of harmonisation of the protection of moral rights related copyrights.

${ }^{372}$ Kur \& Dreier 2013, p. 316. See also Hugenholtz 2013, p. 278. After the implementation of the Brexit, the 'bundle' referred to may be reduced to twenty-seven national copyrights.

373 See the Communication from the Commission to the European Parliament, the Council, the European Economic, and Social Committee and the Committee of the Regions, Promoting a fair, efficient and competitive European copyright-based economy in the Digital Single Market, COM (2016) 592 final. See Directive (EU) 2019/790 of the European Parliament and of the Council of 17 April 2019 on copyright and related rights in the Digital Single Market and amending Directives 96/9/EC and 2001/29/EC (OJ L 130, 17.05.2019, pp. 92-125). See also Jütte 2017(a); Stamatoudi 2016, preface.

${ }^{374}$ Green Paper of 15 October 1998 Combating Counterfeiting and Piracy in the Single Digital Market, COM (98) 569 final; Anti-Counterfeiting Trade Agreement signed on 1 October 2011, not in force yet.; Council Resolution of 16 March 2009 on the EU customs Action combat IPR infringements for the years 2009 to 2012 [2009] OJ 


\subsubsection{The rationales behind copyright protection}

The reasons of states to protect copyrights concern individual authors as well as the public since copyright protection enhances, inter alia, creativity, innovation, cultural heritage, legal certainty and economic growth. ${ }^{375}$ Common law states, like the United States of America, emphasise that copyright law benefits the society; this so-called "copyright tradition" is based on instrumental and utilitarian thoughts. ${ }^{376}$ Besides the achievement of public aims, ${ }^{377}$ civil law states underscore the need to protect the "private' rights of copyright holders: the so-called "author's rights tradition". ${ }^{378}$ The latter approach stems from the "droit d'auteur philosophy" that considers copyright as a natural right "reflecting the 'sacred' bond between the author and his personal creation". 379

Several scholars have used Locke's theory of natural rights, as laid down in Second Treatise of Government of 1689 , to justify intellectual property. ${ }^{380}$ The lack of formality as requirement to create copyrights suits this natural law-based approach. ${ }^{381}$ Other scholars argue that intellectual property has "its source in the statute or utilitarian justification" 382 .

There exist various views on the legal nature of copyrights. ${ }^{383}$ Considering the legal nature as property rights, the work of the author is viewed as legal property and the copyright has been identified with the work. ${ }^{384}$ The states of the United States of America mainly adhere to the latter view. ${ }^{385}$ While European civil law-based states consider copyrights as "quasiproperty", ${ }^{386}$ they generally also acknowledge the "personality-rights dimension". ${ }^{387}$ In France, the latter dimension is referred to as droit moral. ${ }^{388}$ Pursuant to the personality rights approach, the work is viewed as an "extension" of the creator of the work. ${ }^{389}$ Finally, there also exist the

C71/1. See also recital 29-30 in the preamble to the Directive 2004/48/EC of the European Parliament and of the Council of 29 April 2004 on the enforcement of intellectual property rights (OJ 2004 L195 pp. 16-25).

${ }^{375}$ Hua 2014(a), xiii.

${ }^{376}$ Barbosa 2008, pp. 20-33; Ginsburg 1990, pp. 991-992; Goldstein \& Hugenholtz 2013, pp. 6, 14-19; Van Eechoud 2003, pp. 141-142.

377 Ginsburg demonstrates that the demarcation between the rationale underlying copyright protection in the common law-based United States of America, on the one hand, and continental civil law states, such as France, on the other hand, is not so strict; both copyright regimes comprise society- and author-oriented aims. See Ginsburg 1990, pp. 995.

${ }^{378}$ Goldstein \& Hugenholtz 2013, p. 6. See also Van Eechoud 2003, p. 141.

${ }^{379}$ Hugenholtz 2001, p. 344. See also Goldstein \& Hugenholtz 2013, pp. 14, 20. Article I. 111-1 of the French Intellectual Property Code (Act No. 92-597 of 1 July 1992) illustrates the droit d'auteur approach as it stipulates "The author of a work of the mind shall enjoy in that work, by the mere fact of its creation, an exclusive incorporeal property right which shall be enforceable against all persons".

380 See Barbosa 2008, pp. 36-37. See also Gervais 2015, pp. 3-4; Grosheide 1986, p. 166. See also Locke 1689.

${ }^{381}$ Grosheide 1986, p. 167.

${ }^{382}$ Barbosa 2008, p. 37. See also Geiger 2015, p. 123.

${ }^{383}$ Grosheide 1986, p. 151.

${ }^{384}$ Grosheide 1986, p. 151.

${ }^{385}$ Barbosa 2008, p. 42.

${ }^{386}$ For instance, "unlike other forms of property, copyrights are limited in time". See Van Eechoud 2003, p. 139.

${ }^{387}$ Van Eechoud 2003, p. 139. See also Barbosa 2008, pp. 42-43; Grosheide 1986, pp. 152-158.

${ }^{388}$ Van Eechoud 2003, p. 139. See also Grosheide 1986, p. 156. See paragraph 6.2.2 on the concept of moral rights with respect to the establishment of jurisdiction in cross-border copyright infringement cases.

${ }^{389}$ Grosheide 1986, p. 151. See also Barbosa 2008, pp. 42-43. 
so-called sui generis theories that consider copyrights as a legal concept that contains elements from both property rights and personality rights. ${ }^{390}$

With respect to copyrights, two opposite approaches can be denoted: dualism and monism. ${ }^{391}$ According to the so-called dualist conception of copyrights, copyrights can be distinguished into economic rights, on the one hand, and moral rights, on the other hand. ${ }^{392}$ "Classical economic rights" are the reproduction right, the distribution right, and "the right of communication to the public". ${ }^{393}$ Moral rights "derive from the relationship of the author with the work"; ${ }^{394}$ they have also been regarded as personality rights of the author. ${ }^{395}$ Paragraph 6.2.2.1 will demonstrate several moral rights such as the right to oppose alternations or impairment of the work, also referred to as the right of integrity. ${ }^{396}$ While economic rights can be transferred, moral rights will remain at the copyright holder. ${ }^{397}$ Moral rights relate to the aforementioned 'author's rights' tradition. ${ }^{398}$ In the context of rethinking the CJEU's approach to jurisdiction in cross-border copyright infringement cases, paragraph 6.2 .2 will assess the 'victim's centre of interests' approach to jurisdiction with respect to infringements of moral rights.

Pursuant to the monistic or unitary approach to copyrights, copyrights cannot be divided into economic and moral rights. ${ }^{399}$ Van Eechoud notes that common law states and some civil law states adhere to this monistic approach. ${ }^{400}$ Yet, the Berne Convention of 1979 seems to have adopted a dualistic approach to copyrights. Article 6bis Berne Convention 1979 appears to acknowledge moral rights by stipulating that "independently of the author's economic rights, and even after the transfer of the said rights, the author shall have the right to claim authorship of the work and to object to any distortion, mutilation or other modification of, or other derogatory action in relation to, the said work, which would be prejudicial to his honor or reputation". 401

\footnotetext{
${ }^{390}$ Grosheide 1986, pp. 160-163. See also Van Eechoud 2003, p. 139.

${ }^{391}$ Grosheide 1986, p. 161.

392 Goldstein \& Hugenholtz 2013, pp. 6-7, 20; Van Eechoud 2003, p. 139. Pursuant to De Beer, the German scholar Joseph Kohler established the so-called dualist conception of copyrights. See De Beer 1989, p. 388.

${ }^{393}$ See Ohly 2009, pp. 212-229. These "classical economic rights" are enshrined in most codifications, treaties, and European Union Directives related to copyrights, see Ohly 2009, pp. 213. Ohly (2009, pp. 223-224, 229-232) refers to other economic rights such as the rental and lending right and the resale right. See also Goldstein \& Hugenholtz (2013, pp. 303-356) on economic rights.

394 Barbosa 2008, p. 42. See also Goldstein \& Hugenholtz 2013, p. 358.

${ }^{395}$ Barbosa 2008, pp. 42-49. See also Sterling \& Cook 2015, p. 402.

${ }^{396}$ See also Goldstein \& Hugenholtz 2013, pp. 357-369 on moral rights.

${ }^{397}$ Barbosa 2008, p. 45.

${ }^{398}$ Barbosa 2008, p. 45. For example, the French Copyright Act of 1957 that reflects a dualist approach to copyrights, see Barbosa 2008, p. 48; Mendis 2011, p. 18.

${ }^{399}$ Barbosa 2008, pp. 47-48. For example, the German Copyright Act adopted a monistic view to copyright, see Barbosa 2008, p. 48; Mendis 2011, p. 18.

${ }^{400}$ Van Eechoud 2003, p. 139. Civil law states that adhere to the monistic approach to copyrights are, for instance, Germany and Austria.

${ }^{401}$ Article 6bis(1) Berne Convention 1979. See Grosheide 2009, p. 251. See also Sterling and Cook who pointed out that "the WIPO Copyright Treaty 1966 obliges Contracting Parties to comply with the substantive provisions of the Berne Convention”. See Sterling \& Cook 2015, p. 403.
} 


\subsubsection{Copyrights as private rights or human rights}

It is a debated issue whether intellectual property rights can be considered as private rights or human rights. ${ }^{402}$ The abovementioned personality rights approach to copyrights gave an impetus to the view of considering copyrights as human rights. ${ }^{403}$ It has been argued that copyrights are human rights when focusing on the right to property. ${ }^{404}$ In the case law of the ECtHR, copyrights have been indicated as property rights that require protection under Article 1 of the Protocol No. 1 to the European Convention for the Protection of Human Rights and Fundamental Freedoms of 1952 (hereinafter Protocol No. 1 to the European Convention on Human Rights of 1952). ${ }^{405}$ The right to privacy protected in Article 8 of the European Convention on Human Rights of $1950^{406}$ may also serve as a basis for copyright protection. ${ }^{407}$ The European Union enacted Article 17(2) of the Charter of Fundamental Rights of the European Union in 2000 that stipulates "intellectual property shall be protected" ${ }^{408}$

Article 27(2) of the United Nations Universal Declaration of Human Rights of 1948 stipulates that "everyone has the right to the protection of the moral and material interests resulting from any scientific, literary or artistic production". ${ }^{409}$ Similarly, Article 15(1)(c) of the United Nations International Covenant on Economic, Social and Cultural Rights of 1966 laid down that Member States should recognize the right of everyone "to benefit from the protection of the moral and material interests resulting from any scientific, literary, or artistic production of which he is the author. ${ }^{410}$ The foregoing seems to indicate that author's rights can be considered as a human right. ${ }^{411}$

${ }^{402}$ Grosheide elaborates on the debated issue whether intellectual property rights can be considered as private rights or human rights by referring to the views of various scholars. See Grosheide 2010, pp. 13-33. See also Goldstein \& Hugenholtz 2013, pp. 23-26.

403 Grosheide 1986, p. 151.

${ }^{404}$ Chapman 2001, pp. 13-15; Geiger 2009, pp. 27-48; Geiger 2015, pp. 132-137; Helfer 2015, p. 32; Hugenholtz 2001, p. 345.

${ }^{405}$ Geiger 2015, pp. 132-137; Helfer 2015, pp. 41-46. Protocol No. 1 to the European Convention for the Protection of Human Rights and Fundamental Freedoms adopted in Paris on 20 March 1952, entered into force on 18 May 1954, ETS No. 009. In the case of Dima v. Romania, the ECtHR explicitly ruled that Article 1 of the Protocol No. 1 to the European Convention for the Protection of Human Rights and Fundamental Freedoms protects copyrighted works. See ECtHR 26 May 2005, Dima v. Romania, App. No. 58472/00, para. 38. See also ECtHR 29 January 2008, Balan v. Moldova, App. No. 19247/03 (2008).

406 The European Convention for the Protection of Human Rights and Fundamental Freedoms adopted in Rome on 4 November 1950, entered into force 3 September 1953, ETS No. 005.

407 See Drexl (2007, p. 171) on "the privacy - or 'personality right'- approach of German law and the Universal Declaration of Human Rights". See also Hugenholtz 2001, p. 345.

408 Charter of Fundamental Rights of the European Union proclaimed on 7 December 2000 by the European Parliament, the Council of Ministers and the European Commission, entered into force on 1 December 2009 (OJ C 364, 18.12. 2000, pp. 1-22).

409 United Nations Universal Declaration of Human Rights adopted in Paris on 10 December 1948. See http://www.un.org/en/universal-declaration-human-rights/. Although the United Nations Universal Declaration of Human Rights it not legally binding itself, it is argued that it became binding on the basis of customary international law. See Steiner, Alston \& Goodman 2008, pp. 146-147.

${ }^{410}$ United Nations International Covenant on Economic, Social and Cultural Rights adopted in New York on 16 December 1966, entered into force 3 January 1976, 993 UNTS 3. See http://www.ohchr.org/EN/ProfessionalInterest/Pages/CESCR.aspx.

${ }^{411}$ See Haugen 2007, pp. 53-54. See also Geiger 2015, pp. 128-129. According to Haugen, the General Comment No. 17 on Authors' Rights adopted by the Committee on Economic, Social and Cultural rights on 21 November 2005 "does not provide the full answer for distinguishing between scientific, literary and artistic production that 


\subsubsection{Developments related to copyrights}

The following paragraphs will demonstrate two developments related to copyrights that influence the rethinking of the CJEU's approach to jurisdiction in cross-border copyright infringement cases. First, the increased interaction between interests of copyright holders and stakeholders that lead to the principle of balancing the interests involved. Second, the rising criticism on the territoriality principle related to copyrights.

\subsubsection{The increased interaction between interests of copyright holders and stakeholders}

Copyright holders will like to receive effective worldwide protection of their rights. In the context of global trade and online communication, these interests of copyright holders will frequently collide with public interests. The next paragraphs will demonstrate that a balance has generally been sought between the interests of copyright holders, on the one hand, and stakeholders such as users of information and traders, on the other hand.

\subsection{The overprotection of copyrights}

Globalisation and the Internet have increased the need to provide adequate protection to copyright holders. Online piracy has become a serious threat to copyright holders. ${ }^{412}$ However, as argued by scholars, contemporary copyright regulations tend to overprotect copyright holders. ${ }^{413}$ Consequently, "access to works, and thus to knowledge contained in them, becomes endangered". ${ }^{414}$ This development may also "impede future creations that are based on the originals". 415 "Technology intermediaries may hesitate to develop new technologies that facilitate information dissemination and adaptation" due to the risk to get sued for copyright infringements. ${ }^{416}$

The Directive (EU) 2019/790 of the European Parliament and of the Council of 17 April 2019 on copyright and related rights in the Digital Single Market (hereinafter Directive on Copyright in the Digital Single Market) holds online content-sharing services responsible for the prevention of the dissemination of copyright infringing content via the Internet. ${ }^{417}$ It has been argued that the latter type of overprotection of copyrights will be detrimental to the freedom of expression, right to information and privacy. ${ }^{418}$

might qualify for human rights protection in accordance with article 15, paragraph 1(c) of the Covenant, and intellectual efforts that qualify for intellectual property protection but are outside of the human rights realm". See Haugen 2007, pp. 65-66.

412 Solley 2008, p. 813.

${ }^{413}$ De Cock Buning 2010, pp. 47-48, 66-67; Geiger 2006, pp. 368-369; Hua 2014(a), pp. xiii-xxiii.

${ }^{414}$ Geiger 2006, p. 369. See also De Cock Buning 2010, pp. 47-48, 66-67.

${ }^{415}$ Hua 2014(b), p. 57.

${ }^{416}$ Hua 2014(a), p. xv.

${ }^{417}$ See Article 17 of the Directive (EU) 2019/790 of the European Parliament and of the Council of 17 April 2019 on copyright and related rights in the Digital Single Market and amending Directives 96/9/EC and 2001/29/EC (OJ L 130, 17.05.2019, pp. 92-125).

${ }^{418}$ See Article 13 Open letter-Monitoring and Filtering of Internet Content is Unacceptable, 16 October 2017, by the Civil Liberties Union for Europe (Liberties). 
Overprotection also seems to increase the economic disparity. Geiger points out that "the balance between the different interests within the system is threatening to tip in favour of the investors". ${ }^{419}$ Developing countries are likely to be most affected by overprotection of copyrights since they are highly dependent on access to knowledge and education. ${ }^{420}$ It has been argued that "overprotection will increase the digital divide which already exists between the developed and the developing countries, as well as between economically developed and rural areas." 421

In sum, it is important to seek for a balance between the rights of copyright holders and stakeholders in the contemporary (digital) society. ${ }^{422}$ The next paragraph will demonstrate the principle of balancing the interests related to copyrights.

\subsection{The principle of balancing the interests related to copyrights}

As a consequence of globalisation and the Internet, the rights of copyright holders increasingly meet human rights such as the right to information, freedom of expression, right to privacy, freedom of science, right to health, right to education. ${ }^{423}$ With respect to the interaction of copyrights and human rights, two main approaches can be discerned. ${ }^{424}$ Pursuant to the first approach, these rights are "in fundamental conflict", this conflict can only be resolved by giving human rights preference to the rights of copyright holders. ${ }^{425}$ According to the second approach, both the rights of copyright holders and the public rights involved pursue similar interests and should be balanced. ${ }^{426}$ The latter prevailing approach ${ }^{427}$ seeks to reunite the earlier mentioned utilitarian so-called copyright approach and the 'author's rights' approach. $^{428}$

The copyright law of most European states aims to balance the interests of copyright holders and public interests by stipulating copyright limitations and exemptions. ${ }^{429}$ This approach also suits the aforementioned view that considers copyrights as human rights. ${ }^{430}$ As explained earlier, the ECtHR indicates copyrights as property rights that require protection under Article 1 of Protocol No. 1 to the European Convention on Human Rights of 1952.431 Consequently, the ECtHR ruled "the government should strike a "fair balance between the

\footnotetext{
${ }^{419}$ Geiger 2015, p. 126.

${ }^{420}$ Patry 2011, pp. 248-250; Shi 2008, p. 43.

${ }^{421}$ Hua 2014(a), p. xv. See also Chapman 2001, p. 22.

422 See also Geiger 2015, pp. 127-161.

${ }^{423}$ Helfer 2015, p. 31. See also Mendis 2011, p. 15.

${ }^{424}$ Helfer 2003, pp. 47-61.

${ }^{425}$ Helfer 2003, p. 48.

${ }^{426}$ Chapman 2001, pp. 4-36; Geiger 2006, pp. 366-370; Geiger 2015, pp. 115-161; Helfer 2003, p 48; Torremans 2015, pp. 236-245.

${ }^{427}$ Hua 2014(b), p. 40; Mendis 2011, p. 15. See also the Preamble to the World Intellectual Property Organization Copyright Treaty signed at Geneva on 20 December 1996, entered into force 6 March 2002, 2186 UNTS 152.

${ }^{428}$ Grosheide 2009, p. 244. See paragraph 2.2.1.1.

${ }^{429}$ Hugenholtz 2001, p. 350; Mendis 2011, p. 34; Van Eechoud 2003, p. 160. See also recital 31 in the preamble to the Information Society Directive.

${ }^{430}$ See paragraph 2.2.1.2.

${ }^{431}$ See paragraph 2.2.1.2.
} 
general interests of the community and the protection of the right of property". ${ }^{432}$ Many European national courts have started to balance copyrights with other human rights. ${ }^{433}$

Provisions of international conventions emphasise the need to balance both the author's rights and the rights to access to knowledge and culture. ${ }^{434}$ For instance, Article 27 of the Universal Declaration of Human Rights of 1948 and Article 15(1) of the United Nations International Covenant on Economic, Social and Cultural Rights of 1966 stipulates that the rights of copyright holders should be protected ${ }^{435}$ as well as the rights of everyone "to freely participate in the cultural life of the community, to enjoy the arts and to share in scientific advancement and its benefits" 436 .

When rethinking the approach to jurisdiction in cross-border copyright infringement cases, this dissertation will adopt the abovementioned prevailing approach that a balance should be aimed between the interests of copyright holders and stakeholders. Paragraph 4.4 will argue to adopt the principle of balancing the interests between copyright holders, on the one hand, and users of information and traders, on the other hand, into the assessment framework of this dissertation to rethink the CJEU's approach to jurisdiction in cross-border copyright infringement cases.

\subsubsection{The rising criticism on the territoriality principle related to copyrights}

Due to the territorial protection of copyrights, "a country's copyright law has no effect outside its territory". ${ }^{437}$ Hence, "the effects of a subjective intellectual property right and the prerogatives accorded to the rightholder are limited to the territory of the state granting the right". 438 Since the globalisation and the Internet entail the worldwide dissemination of copyright infringing content and products, a strict application of this territoriality principle makes it difficult to protect copyrights worldwide. ${ }^{439}$ With respect to multistate copyright infringements, many copyright laws have to be assessed in order to receive full compensation for the copyright holder. The adjudication of these disputes will be costly and time-consuming for courts and the litigants. ${ }^{440}$

Online copyright infringements will frequently involve infringers who distribute unauthorised content via the Internet that is simultaneously accessible in many states. ${ }^{441}$ These infringers may deliberately be settled and act in states that provide less or no copyright

\footnotetext{
432 ECtHR 19 June 2006, Hutten-Czapska v. Poland, App. No. 35014/97. According to literature and European case law, the provisions of the European Convention on Human Rights have horizontal effect, the balancing test is therefore applicable to conflicts between human rights of individuals. See Geiger 2009, pp. 29-30, 34. See also Alkema 1988, pp. 33-45. See paragraph 4.4.2.2 on the indirect horizontal effect of fundamental rights.

${ }^{433}$ Hugenholtz 2001, pp. 343-364. See also Geiger 2009, pp. 27-48.

${ }^{434}$ See Article 27 of the Universal Declaration of Human Rights of 1948 and Article 15 of the United Nations International Covenant on Economic, Social and Cultural Rights of 1966, see paragraph 2.2.1.2.

435 See paragraph 2.2.1.2.

${ }^{436}$ See Article 27(1) of the Universal Declaration of Human Rights of 1948. Article 15(1)(a) and (b) United Nations International Covenant on Economic, Social and Cultural Rights of 1966 employs similar terms.

${ }^{437}$ Goldstein \& Hugenholtz 2013, p. 95.

${ }^{438}$ Neumann 2011, p. 587.

${ }^{439}$ Basedow 2010, pp. 10-11; Neumann 2014, p. 50; Van Engelen 2007, p. 203.

${ }^{440}$ Dinwoodie 2009(a), p. 770; Van Engelen 2007, p. 203.

${ }^{441}$ See paragraph 1.1.4 on the definition of online piracy.
} 
protection. ${ }^{442}$ The latter states can be denoted as copyright havens ${ }^{443}$. The concept of copyright haven has been employed for the first time by the European Commision. ${ }^{444}$ While the concept of copyright haven may seem unusual or merely a "hypothetical concept", a "copyright haven can be defined to mean countries or jurisdiction in which certain copyright protections are not respected or are enforce in a lax fashion". ${ }^{445}$ The risk of copyright havens in the European Union could be rejected since states generally have to maintain a standard of minimum protection of copyrights due to the Berne Convention of $1979^{446}$. Furthermore, the European Union aims to harmonize the copyright laws of the Member States. ${ }^{447}$ Member States will generally also provide an adequate enforcement of judgments involving cross-border copyright infringements. ${ }^{448}$

However, the scope of protection still differs in Member States because not all aspects related to copyrights have been harmonized (yet). ${ }^{449}$ For instance, moral rights have not been harmonised by European Union law ${ }^{450}$ and the Berne Convention of 1969 acknowledges only certain moral rights ${ }^{451}$. Only "if the world were governed by one system of copyright law, which provides the same level of copyright protection for the same types of copyright infringement, copyright haven would not exist". 452

The territorial protection of copyrights is also not favourable to the international business community that requires certainty in order to freely trade and move capital. ${ }^{453}$ The "territorial dimension of copyright" often "prevents consumers from using content services (e.g. video services) when they travel from one Member State to another, or deny them the possibility of purchasing content online". ${ }^{454}$ In 2004, the European Union legislators have enacted the Directive on the Enforcement of Intellectual Property Rights since "the disparities between the

${ }^{442}$ See Heinze 2010, p. 64. Matulionyte (2015, p. 139) points out that service providers may also establish themselves in (or provide their services from) a country with the lowest copyright protection standard.

${ }^{443}$ Ginsburg 1995, p. 1498; Kang 2003, pp. 95-151. See also the term “infringement haven” (Peukert 2012, p.

225) or "infringers haven" (Kur 2013(b), p. 88, 2:203.C09).

${ }^{444}$ Kang 2003, p. 96. "The term was employed, if not coined, by the European Commission in its explanatory memorandum accompanying its Proposal for a Council Directive on the coordination of certain rules concerning copyright and neighboring rights applicable to satellite broadcasting and cable transmission, COM(91) 276 final at 4 ; it is the copyright equivalent of tax havens. The proposal itself is reprinted at 1991 O.J. (C 255) 3. Ginsburg (1995, p. 1498) pointed out that the according to the European Commisssion "harmonization is necessary in order to avoid creation of 'copyright havens'.

445 Kang 2003, p. 100.

${ }^{446}$ Eechoud 2003, p. 219.

${ }^{447}$ See paragraph 2.2 .1 .

${ }^{448}$ Van Eechoud 2003, p. 219. Paragraph 1.1.1 noted that the Directive 2004/48/EC of the European Parliament and of the Council of 29 April 2004 on the enforcement of intellectual property rights (OJ 2004 L195 pp. 16-25) does force the Member States of the European Union to harmonize certain procedural rules necessary to enforce intellectual property rights. The Hague Judgments Convention of 2019 nonetheless excludes matters related to intellectual property from its scope. See paragraph 6.4.2.

${ }^{449}$ See Kur \& Dreier, 2013 pp. 244, 245, 271, 315. According to Matulionyte, it is true that national copyright laws of Member States are harmonised to a certain extent". "However, a number of issues remain non-harmonised (most importantly, copyright exceptions), which means that the scope of protection in different Member States still differs". See Matulionyte 2015, p. 139. See also paragraph 2.2.1.

${ }^{450}$ Hugenholtz 2013, p. 278; Sirvinskaite 2010, pp. 263-288. See paragraphs 2.2.1.1 and 6.2.2.1 on moral rights.

${ }^{451}$ See paragraph 2.2.1.1 on Article 6bis Berne Convention 1979 that only refers to the right of integrity and the right of paternity.

${ }_{452}$ Kang 2003, p. 102.

${ }^{453}$ Leaffer 2014, pp. 7-8. See also Monti 2010, p. 45.

${ }^{454}$ Madiega 2015, p. 5. 
systems of the Member States as regards the means of enforcing intellectual property rights are prejudicial to the proper functioning of the Internal Market and make it impossible to ensure that intellectual property rights enjoy an equivalent level of protection throughout the Community". 455

The European Union claimed that "approximation of the legislation of the Member States in this field is therefore an essential prerequisite for the proper functioning of the internal market". ${ }^{456}$ Yet, as Hugenholtz notes, the harmonisation of copyrights by European Union Directives did not abolish the territorial nature of copyrights within the European Union. ${ }^{457}$ To enhance the proper functioning of the internal market within the European Union, Hugenholtz suggests a uniform European Copyright Law. ${ }^{458}$ Other proposals are "a unitary copyright title which would co-exists with national copyrights"; "the enactment of a Community Copyright Regulation" that requires abolishment of national titles; or "the creation of a registration system that would run in parallel to national copyright systems". ${ }^{459}$

From the perspective of the concept of sovereignty of states, it has been argued that the abolition of the territoriality principle related to intellectual property rights will be difficult. ${ }^{460}$ Yet, the territoriality principle related to copyrights may not "be justified by the sovereignty concept anymore". ${ }^{461}$ Unlike other intellectual property rights, copyrights are granted without any formalities in the Member States of the Berne Convention 1979. ${ }^{462}$ Hence, Schack argued that a state does not grant copyrights but merely "recognises them as soon as the prerequisites of the substantive law are fulfilled". ${ }^{463}$

Whereas a uniform copyright law at worldwide level has not been achieved yet, states started to cooperate regarding the field of enforcement of copyrights. For instance, the Agreement on Trade Related Aspects of Intellectual Property Rights of 1994 (hereinafter TRIPS-Agreement 1994) ${ }^{464}$ contains special provisions regarding international enforcement. ${ }^{465}$

\footnotetext{
${ }^{455}$ Recital 8 in the preamble to the Directive 2004/48/EC of the European Parliament and of the Council of 29 April 2004 on the enforcement of intellectual property rights (OJ 2004 L195 pp. 16-25), also referred to as the Directive on the Enforcement of Intellectual Property Rights. See also Hugenholtz 2009, p. 18; Madiega 2015 , p. 4.

${ }^{456}$ Recital 9 in the preamble to the Directive on the Enforcement of Intellectual Property Rights.

${ }^{457}$ Hugenholtz 2009, p. 12. See also Kur \& Dreier 2013, p. 316.

${ }^{458}$ Hugenholtz 2009, p. 12. According to Hugenholtz, Article 118 TFEU provides a specific competence for Union-wide intellectual property rights. See Hugenholtz 2013, p. 290. See also European Commission, “A Single Market for Intellectual Property Rights. Boosting creativity and innovation to provide economic growth, high quality jobs and first class products and services in Europe”, COM (2011) 287 final, Brussels, 24 May 2011, p. 11. Kur and Dreier set out the pros and cons of a unitary Community Copyright, see Kur \& Dreier 2013, p. 319321. The proposal of the European Copyright Code in 2010 established by the Wittem Group has been explained by Hugenholtz 2012(a), pp. 339-354.

${ }^{459}$ Madiega 2015, pp. 10-11. See also Monti 2010, p. 46; Strowel 2014, pp. 1135-1136.

${ }^{460}$ See Dinwoodie 2009(a), p. 767.

${ }^{461}$ Schack 2009, p. 90. See also Peukert 2012, p. 197. See paragraph 2.1.2.1.5.1 on the change of the traditional concept of the state's sovereignty due to globalisation and the Internet.

${ }^{462}$ See Article 5(2) of the Berne Convention 1979. See also Eechoud (2003, pp. 101-103) on the debate of universal versus territorial copyrights.

${ }^{463}$ Schack 2009, p. 90. See also Peukert 2012, p. 197.

464 The Agreement on Trade Related Aspects of Intellectual Property Rights (known as the TRIPS-Agreement), Annex 1C of the Marrakesh Agreement Establishing the World Trade Organisation, signed in Marrakesh, Morocco on 15 April 1994, entered into force 1 January 1995, 1869 UNTS 299.

${ }^{465}$ See Barbosa 2008, pp. 96-107; Goldstein \& Hugenholtz 2013, pp. 410-421.
} 
On regional level, the European Union legislators enacted the Directive on the Enforcement of Intellectual Property Rights (hereinafter Directive on the Enforcement of Intellectual Property Rights). ${ }^{466}$

To enhance the protection of copyrights, it is first and foremost important that the copyright holder has the possibility to bring a copyright infringement claim before a suitable court to receive an adequate title to obtain redress. As mentioned above, the strict application of the territoriality principle will impede efficient litigation in multistate copyright infringement cases since it leads to the application of many national copyright laws in order to receive full redress. This dissertation will demonstrate that several courts and scholars have come up with exceptions to the territorial approach in favour of efficient adjudication of multistate copyright infringement disputes. ${ }^{467}$ Paragraph 2.3.4.2 will briefly demonstrate that some scholars have proposed a conflict-of-laws rule with respect copyright infringements that points to a single copyright law. Paragraph 2.3.2 will demonstrate three ways in which the traditional territorial protection of copyrights may influence the approach to jurisdiction in cross-border copyright infringement cases. Thereafter, paragraph 2.3.4 will discuss developments that indicate the decreasing influence of the territorial principle related to copyrights in private international law.

\subsection{The interaction between private international law and copyright law regarding copyright infringement disputes}

In case of cross-border copyright infringements, the court seised first has to determine whether it has jurisdiction to hear the infringement claim. When the court is competent, the second question is which national copyright law is applicable to the case. Therefore, the conflict-of-laws rule concerning copyright infringement cases has to be consulted. The final stage of the private international law procedure concerns the recognition and enforcement of the judgment. The rules regarding this latter stage will not be discussed in this dissertation. The rethinking of the CJEU's approach to jurisdiction in cross-border copyright infringement cases concerns the abovementioned first question regarding the competence of the court. This chapter will nevertheless also discuss the conflict-of-laws rule generally applicable to copyright infringement disputes to demonstrate the influence of the territorial nature of copyrights on the field of private international law.

\subsubsection{Private international law related to jurisdiction in cross-border copyright infringement cases}

As mentioned in paragraph 1.1.2, there exists no international 'hard' law to determine whether a court has jurisdiction in copyright infringement cases. ${ }^{468}$ The court seised generally

\footnotetext{
${ }^{466}$ Directive 2004/48/EC of the European Parliament and of the Council of 29 April 2004 on the enforcement of intellectual property rights (OJ 2004 L195 pp. 16-25).

${ }^{467}$ See chapters six and seven.

${ }^{468}$ Yet, as mentioned in paragraph 1.1.2, different academic projects drafted rules of 'soft' law related to private international law and intellectual property law.
} 
has to assess the private international law of the forum state. Civil law-based states adopted the actor sequitur forum rei principle that provides jurisdiction to the court of the state where the defendant is domiciled, referred to as the forum rei. ${ }^{469}$ In tort cases, such as copyright infringement disputes, states generally adopted an additional rule that provides jurisdiction to other courts. The "place where the harmful event occurred" has been a common additional connecting factor to jurisdiction in tort cases. ${ }^{470}$ In the United States of America, the Supreme Court of the United States established the so-called 'minimum contacts' approach to determine jurisdiction regarding cross-border infringing activities that will be demonstrated in chapter seven. ${ }^{471}$

If the alleged infringer is domiciled in the European Union, the Member State court has to apply the Regulation (EU) No. 1215/2012 on jurisdiction and the recognition and enforcement of judgments in civil and commercial matters (hereinafter Brussels Ibis). ${ }^{472}$ To determine whether a Member State court has jurisdiction in a copyright infringement case, the Brussels Ibis does not contain a forum specialis rule. Therefore, both the general rule actor sequitur forum rei of Article 4 Brussels Ibis and the special jurisdiction rule related to torts in Article 7(2) Brussels Ibis are applicable to copyright infringements cases. The latter rule confers jurisdiction to the court of "the place where the harmful event occurred or may occur". In the cases Pinckney, Hi Hotel and Pez Hejduk, the CJEU interpreted this special jurisdiction rule with respect to cross-border copyright infringement disputes as will be demonstrated in chapter three. ${ }^{473}$

\subsubsection{The influence of the territorial nature of copyrights on the court's jurisdiction}

This paragraph will demonstrate three ways in which the traditional territorial protection of copyrights may influence jurisdiction rules regarding cross-border copyright infringements. First, territorial protection can be seen as an indispensable condition to obtain jurisdiction since a copyright can only be infringed within the country of protection. ${ }^{474}$ That means a court may only obtain jurisdiction if the alleged copyright is protected in the forum state: the forum state has to be the locus protectionis. ${ }^{475}$

\footnotetext{
${ }^{469}$ According to general rule in Article 4 Brussels Ibis Regulation, the alleged infringer can always be sued before the court of the Member States where he is domiciled. See also paragraph 2.1.2.2.2.

${ }^{470}$ The Jenard Report on the Brussels Convention of 1968 states that the fact that the "place where the harmful event occurred" has been "recognized under most of the legal systems, and incorporated in the majority of the bilateral conventions, was a ground for including it in the Convention". See Jenard Report on the Brussels Convention of 1968, p. C 59/26.

${ }^{471}$ The Supreme Court of the United States established the 'minimum contacts' approach in the case of International Shoe Co. v. Washington, 326 U.S. 310.

${ }^{472}$ Regulation (EU) No. 1215/2012 of the European Parliament and the Council of 12 December 2012 on jurisdiction and the recognition and enforcement of judgments in civil and commercial matters (OJ 2012 L 351, pp. 1-32).

${ }^{473}$ Case C-170/12 Peter Pinckney v. KGD Mediatech AG; Case C-387/12 Hi Hotel HCF SARL v. Uwe Spoering; Case C-441/13 Pez Hejduk v. EnergieAgentur NWR GmbH.

${ }^{474}$ Jooris 1996, pp. 127, 139-140; Neumann 2014, pp. 592-594.

475 As noted by Schaafsma, the term territorium protectionis would be more accurate because the protection involves a territory and not just a place. See Schaafsma 2009, pp. 267, 270.
} 
In the United States of America, this strict application of the territoriality principle seems to be reflected in Title 28 United States Code $\S 1338$ (a) that stipulates "district courts have original jurisdiction of any civil action arising under Act of Congress relating to ... copyrights". ${ }^{476}$ Therefore, a district court appears to only obtain so-called subject matter jurisdiction ${ }^{477}$ in a cross-border copyright infringement case provided that the case involves an infringing activity that occurred in the United States of America. ${ }^{478}$ Paragraph 2.3.4.1 will demonstrate the development towards a more flexible approach with respect to territorial protection of copyrights in the context of jurisdiction.

States adhering to the common law system traditionally adopted "the rule of nonjusticiability of foreign copyright claims" ${ }^{479}$ If the locus protectionis of the alleged copyright was not situated in the forum state, the court seised could not obtain so-called subject matter jurisdiction with respect to an alleged infringement. ${ }^{480}$ These courts were therefore deemed to reject jurisdiction over cases involving infringements of foreign copyrights. ${ }^{481}$ Since the Brussels Convention of 1968, the courts in the United Kingdom have to establish jurisdiction in cases involving infringements of foreign copyrights when the defendant is domiciled in the United Kingdom. ${ }^{482}$ In 2011, the Supreme Court of the United Kingdom explicitly ruled that an English court had jurisdiction over a defendant domiciled in the United Kingdom who allegedly infringed a United States copyright. ${ }^{483}$

476 Title 28 United States Code $\S 1338$. Patents, plant variety protection, copyrights, mask works, designs, trademarks, and unfair competition June 25, 1948, ch. 646, 62 Stat. 931; Pub. L. 91-577, title III, §143(b), Dec. 24, 1970, 84 Stat. 1559; Pub. L. 100-702, title X, §1020(a)(4), Nov. 19, 1988, 102 Stat. 4671; Pub. L. 105-304, title V, §503(b)(1), (2)(A), Oct. 28, 1998, 112 Stat. 2917; Pub. L. 106-113, div. B, §1000(a)(9) [title III, §3009(1)], Nov. 29, 1999, 113 Stat. 1536, 1501A-551; Pub. L. 112-29, §19(a), Sept. 16, 2011, 125 Stat. 331. District courts are part of the United States federal court system. The United States federal court system consists of the United States Supreme Court, United States Courts of Appeals, and Unites States District Courts. Cohen (1993, pp. 360398) focuses on the issue when a claim arises under the copyright laws of the United States of America.

${ }^{477}$ Paragraph 7.2 of this dissertation will explain the concept of subject matter jurisdiction.

${ }^{478}$ See Leaffer 2014, p. 16; Goldstein \& Hugenholtz 2013, pp. 119-120. See also Dinwoodie 2009(a), pp. 733734. See also the following case law: Peter Starr Production Co. v. Twin Continental Films, Inc., 783 F.2d 1440 ( $9^{\text {th }}$ Cir. 1986); Subafilms, Ltd v. MGM-Pathe Communications Co., 24 F.3d 1088 ( $9^{\text {th }}$ Cir. 1994). Leaffer (2014, p. 16) notes that when the infringing activities have been taking place in the United States of America as well as abroad, the courts in the United States of America can obtain subject matter jurisdiction even if the extent of the infringement that occurred in the United States of America has been minimal. Leaffer refers to the case Update Art v. Modiin Publishing, Ltd., 843 F.2d 67 (2d Cir. 1988).

${ }^{479}$ Ricketson \& Ginsburg 2006, p. 1293. See also Kono \& Jurcys 2015, pp. 9-12; Nuyts 2008, pp. 154-161; Peukert 2012, p. 193; Wadlow 1998, p. 326.

${ }^{480}$ Ricketson \& Ginsburg 2006, p. 1294. See also Goldstein \& Hugenholtz 2013, p. 118; Nuyts 2008, pp. 154-161.

${ }^{481}$ Ricketson \& Ginsburg 2006, p. 1294. See also Goldstein \& Hugenholtz 2013, p. 118; Nuyts 2008, pp. 154-161.

To reject jurisdiction over cases involving infringements of foreign intellectual property rights, courts in the United Kingdom used the 'double actionability' rule or the Moçambique rule established on 8 September 1983 by the House of Lords of the United Kingdom in the case of British South Africa Co. v. Companhia de Moçambique [1893] A. C. 602. See Austin 1997, p. 321; Nuyts 2008, p. 160; Schaafsma 2009, p. 220.

${ }^{482}$ Schaafsma 2009, p. 221. See also Court of Appeal (Civil Division) of England and Wales 21 January 1999 , Pearce v. Ove Arup Partnership Ltd. and Others [2000] 3 W.L.R. 332 [2000] Ch. 403. After the implementation of the Brexit, the United Kingdom may not be bound anymore by the European Union jurisdiction rules related to private international law.

${ }^{483}$ United Kingdom Supreme Court 27 July 2011, Lucasfilm Ltd. and Others v. Andrew Ainsworth and Another [2011] UKSC 39 [2012] 1 AC 208. See also Goldstein \& Hugenholtz 2013, pp. 118-119; Kono \& Jurcys 2015, pp 12 . 
Nowadays, civil law-based states generally accept that the court of the place where the defendant is domiciled does not need to be the locus protectionis. ${ }^{484}$ Even if a dispute involves infringements of foreign copyrights, the alleged infringer may thus be sued before the court of the Member State of his domicile. ${ }^{485}$ As will be explained in the next chapter, the CJEU did employ the requirement of locus protectionis as jurisdiction criterion to interpret the Erfolgsort under Article 7(2) Brussels Ibis in cross-border copyright infringement cases. ${ }^{486}$ The debated issue of the locus protectionis as jurisdiction criterion will be further examined in chapter five of this dissertation.

Second, the territorial protection of copyrights may limit the scope of the court's jurisdiction to the infringing activities and the damage sustained within the forum state. ${ }^{487}$ The territoriality principle inherent to copyrights does, however, not affect the scope of the jurisdiction of the court of the state where the infringer is domicile. ${ }^{488}$ The latter court will obtain jurisdiction with respect to the entire damage caused by the copyright infringement dispute. Paragraph 2.3.4.1 will demonstrate that some courts in the United States of America adopted a flexible approach to the territorially limited jurisdiction in cross-border copyright infringement cases. As will be explained in the next chapter involving the cases Pinckney, Hi Hotel and Pez Hejduk, the CJEU territorially limited the jurisdiction of the court of the Erfolgsort based on the territorial protection of copyrights. This dissertation will address the vexed topic whether the territorial protection of copyrights should limit the court's jurisdiction to the damage caused by the copyright infringement within the forum state. ${ }^{489}$

Third, in view of the territorial principle related to copyrights, scholars generally advocate to employ "the place of infringement" as connecting factor to establish jurisdiction besides the forum rei. ${ }^{490}$ Based on the territoriality principle, most scholars argue that the dichotomy of Handlungsort and Erfolgsort established in the Bier ruling under Article 7(2) Brussels Ibis is not suitable to copyright infringements; these two places cannot be separated since they coincide in the country of protection. ${ }^{491}$ According to these scholars, "the event giving rise to the damage is the infringement itself" and the damage to a copyright "occurs in the place where the right is infringed" ${ }^{492}$ The CJEU nonetheless applied the dichotomy Handlungsort and Erfolgsort under Article 7(2) Brussels Ibis in the rulings Pinckney, Hi Hotel, Pez Hejduk involving cross-border copyright infringement cases as will be demonstrated in the next chapter.

\footnotetext{
${ }^{484}$ Lundstedt 2001, pp. 127-128; Metzger 2009, p. 253; Neumann 2011, p. 592; Vicente 2016, p. 726. See also Peukert 2012, p. 193.

${ }^{485}$ See Neumann 2014, p. 508; Pansch 2000, p. 355.

${ }^{486}$ See the rulings Pinckney, Hi Hotel, Pez Hejduk in chapter 3.

${ }^{487}$ Fawcett \& Torremans 2011, pp. 161-162; Metzger 2009, p. 261; Neumann 2011, p. 594.

${ }^{488}$ Fawcett \& Torremans 2011, pp. 161-162; Metzger 2009, p. 261; Neumann 2011, p. 594.

${ }^{489}$ See paragraphs 5.3.2 and 5.3.3.1.

${ }^{490}$ Chapter six will elaborate on this connecting factor as stipulated in Article 2:202 CLIP Principles. See also paragraph 5.2.1 on the distinction between the Handlungs and the Erfolgsort in the context of cross-border copyright infringements

${ }^{491}$ Jooris 1996, pp. 139-140; Kur 2013, pp. 69-70; Neumann 2011 pp. 592-594; Pontier 2015, p. 116; Schaafsma 2016, pp. 399-401; Schack 2013, p. 3630.

${ }^{492}$ Lundstedt 2001, p. 137. See also Fawcett \& Torremans 2011, p. 163; Schaafsma 2016, p. 399; Schack 2013, p. 3630 .
} 


\subsubsection{The lex loci protectionis as applicable law}

Once the court has obtained jurisdiction in a cross-border copyright infringement case, the question will arise which law is applicable to the case. Many states adopted the lex loci protectionis rule that entails the competent court to apply the copyright law of the state for which protection is sought. ${ }^{493}$ The legislators of the European Union have laid down the lex loci protectionis rule in Article 8(1) Rome II with respect to intellectual property infringement disputes. $^{494}$

While it is generally agreed that the lex loci protectionis rule has been influenced by the territorial nature of copyrights, ${ }^{495}$ the foundation of this conflict-of-laws rule has been disputed. ${ }^{496}$ According to several scholars and European courts, Article 5(2) Berne Convention 1979 comprises the conflict-of-laws rule lex loci protectionis. ${ }^{497}$ Article 5(2) Berne Convention 1979 stipulates that the enjoyment and the exercise of the creator's right "shall be independent of the existence of protection in the country of origin of the work". "Consequently, apart from the provisions of this Convention, the extent of the protection, as well as the means of redress afforded to the author to protect his rights, shall be governed exclusively by the laws of the country where protection is claimed." In the United Kingdom, the Court of Appeal nonetheless held that Article 5(2) Berne Convention 1979 refers to the lex fori including the forum's private international law. ${ }^{498}$

Some scholars and European courts assert that the origin of the lex loci protectionis rule lies in the principle of national treatment enshrined in art 5(1) Berne Convention 1979.499 The latter article stipulates "Authors shall enjoy, in respect of works for which they are protected under this Convention, in countries of the Union other than the country of origin, the rights which their respective laws do now or may thereafter grant to nationals, as well as the rights specially granted by this Convention."

\footnotetext{
${ }^{493}$ Basedow 2010, p. 12; Dinwoodie 2009(a), p. 729; Gottschalk 2007, p. 190; Schaafsma 2009, pp. 170, 174-175, 183; Van Eechoud 2003, pp. 95, 105. Basedow emphasises the words "for which" to distinguish the lex loci protectionis from the lex fori (the law of the country "where" protection is sought). See Basedow 2010, p. 12. Schaafsma concludes that the widespread adoption of the lex loci protectionis as choice-of-law rule in cross-border intellectual property cases has been based on an incomplete interpretation of the principle of national treatment enshrined in art 5(1) Berne Convention 1979. See Schaafsma 2009, pp. 89-126, 161-284.

${ }^{494}$ Pursuant to recital 26 in the preamble to the Rome II Regulation, the principle of lex loci protectionis is universally acknowledged regarding infringement of intellectual property rights. Yet, this paragraph will demonstrate that some states do not adhere to the lex loci protectionis rule.

${ }^{495}$ Fentiman 2005, pp. 140, 148; Neumann 2011, pp. 585, 588. See also Kono \& Jurcys 2012, p. 16.

${ }^{496}$ Schaafsma 2009, p. 183.

497 See Kur \& Dreier 2013, p. 520. See the following authors on the discussion whether Article 5(2) Berne Convention 1979 comprises the conflict-of-laws rule lex loci protectionis: Schaafsma 2009, p. 168; Van Eechoud 2003, p. 107.

${ }^{498}$ Court of Appeal (Civil Division) of England and Wales 21 January 1999, Pearce v. Ove Arup Partnership Ltd. and Others [2000] 3 W.L.R. 332 [2000] Ch. 403. See also Van Eechoud 2003, p. 105.

${ }^{499}$ In the dissertation Intellectual Property and Conflict of Laws; the hidden conflict-of-laws rule in the principle of national treatment, Schaafsma argues that the principle of national treatment in Article 5(1) Berne Convention 1979 comprises both a conflict-of-laws rule and a non-discrimination principle. See Schaafsma 2009, p. 39. Schaafsma also provides an overview of the scholars and courts that acknowledge that the principle of national treatment of Article 5(1) Berne Convention consists of both a choice-of-law rule and the non-discrimination principle. See Schaafsma 2009, pp. 163-165. See also Ginsburg \& Treppoz 2015, p. 652.
} 
Some states adopted the lex loci delicti rule, the law of the place where the delict or tort was committed, as conflict-of-laws rule in cross-border copyright infringement cases. ${ }^{500}$ In a few states, courts have to apply the "law of the country of origin", lex originis, with respect to the right to claim authorship of a work in a cross-border copyright infringement case. ${ }^{501}$ The latter rule may, inter alia, refer to the law of "the country from which the work has been made available to the public", "the country where the work was created", or "the country of which the creator is a national or has its habitual residence at the time of the work's creation". ${ }^{502}$

Many courts in the states of the United States of America ${ }^{503}$ apply the Restatement (Second) of Conflict of Laws of $19699^{504}$ to determine the applicable law in cross-border tort cases. ${ }^{505}$ Section 6 of the Restatement (Second) of Conflict of Laws contains seven factors that may be employed to find the law based on "the most significant relationship" to the issue of a case. ${ }^{506}$ It is possible that different laws are applicable in one particular case. ${ }^{507}$ In the case of Itar-Tass Russian News Agency v. Russian Kurier, the United States Court of Appeals for the Second Circuit applied section 6 of the Restatement (Second) of Conflict of Laws in a cross-border copyright infringement case. Consequently, the Court of Appeals held that the ownership of the infringed copyright had to be determined by the lex originis that meant the Russian copyright law. ${ }^{508}$ In addition, the lex loci delicti, that meant copyright law of the United States of America, had to be applied to determine whether the copyrights were infringed in the United States of America. ${ }^{509}$

\footnotetext{
${ }^{500}$ Van Eechoud 2005, para. 3.1. See also Neumann 2014, p. 508.

${ }^{501}$ See Van Eechoud 2005, para. 3.1; Gottschalk 2007, pp. 187, 190. See, for instance, Article 67(1) of the Greek Law 2121/1993 on Copyright, Related Rights and Cultural Matters that stipulates "Copyright over a published work shall be governed by the legislation of the state in which the work is first made lawfully accessible to the public. Copyright over an unpublished work shall be governed by the legislation of the state in which the author is national". Matulionyte $(2015$, p. 138$)$ states that the lex originis can also be found in copyright statutes in Romania and Portugal.

${ }^{502}$ Gottschalk 2007, pp. 187-188. The lex originis rule "has been applied to determine the law applicable to the initial ownership question in France and the US". See Matulionyte (2015, p. 144). See also the case of Itar-Tass Russian News Agency v. Russian Kurier, Inc., 153 F.3d 82 (2d Cir. 1998) as demonstrated in this paragraph.

${ }^{503}$ See Symeonides 1997, pp. 1248-1283.

${ }^{504}$ See $\S 145$ of the Restatement (Second) of Conflict of Laws of 1969 also paragraph 2.1.2.1.1 of this dissertation.

${ }^{505}$ Dinwoodie 2009(a), pp. 729-731; Symeonides 2008, p. 112.

${ }^{506}$ Peters 2016, p. 114. The list of factors enumerated in $\S 6$ Restatement (Second) of Conflict of Laws is not exhaustive. The factors include "(a) the needs of the interstate and international systems, (b) the relevant policies of the forum, (c) the relevant policies of other interested states and the relative interests of those states in the determination of the particular issue, (d) the protection of justified expectations, (e) the basic policies underlying the particular field of law, (f) certainty, predictability and uniformity of result, and (g) ease in the determination and application of the law to be applied".

${ }^{507}$ Peters 2016, p. 114.

${ }^{508}$ Itar-Tass Russian News Agency v. Russian Kurier, Inc., 153 F.3d 82 (2d Cir. 1998). Based on case law, Dinwoodie notes that "the United States has effectively adopted a lex originis rule on copyright authorship", see Dinwoodie 2009(a), p. 731.

${ }^{509}$ Itar-Tass Russian News Agency v. Russian Kurier, Inc., 153 F.3d 82 (2d Cir. 1998). See also Ginsburg \& Treppoz 2015, p. 657.
} 


\subsubsection{Towards a flexible approach to territoriality in cross-border copyright infringement cases}

\subsubsection{On jurisdictional level}

As demonstrated in this chapter, the issue of jurisdiction in cross-border copyright infringement cases has been influenced by the territorial principle related to both private international law and copyright law. Based on a strict application of the territorial principle related to jurisdiction, the court may only obtain jurisdiction regarding alleged infringing activities that took place within its territory. Yet, as set out in paragraph 2.1.2.2.2, courts have generally adopted an effects-based approach to jurisdiction in tort cases. In view of the territorial principle related to copyrights, courts can only exercise jurisdiction regarding alleged damage that occurred in the forum state and provided that the alleged copyright has been protected by the forum state, the so-called locus protectionis criterion. ${ }^{510}$ The following developments involving jurisdiction in cross-border copyright infringement cases indicate the trend towards a flexible approach to territoriality as basis for jurisdiction as well as a decreasing influence of the territorial principle related to copyrights.

As mentioned in paragraph 2.3.2, based on the territoriality principle reflected in title 28 of the United States Code $\$ 1338(a)$, district courts in the United States of America seem to only obtain subject matter jurisdiction if the copyright relied on has been protected by the United States of America and the alleged copyright infringement has thus occurred within the United States of America. Yet, the 'diversity of citizenship' exception in title 28 United States Code $\$ 1332$ appears to be a deviation from the strict territorial approach in Title 28 United States Code $\S 1338(a) .{ }^{511}$ This exception, inter alia, concerns parties that are citizens of different states in the United States of America, or if one party is a citizen of a state in the United States of America and the other is a citizen or subject of a foreign state. ${ }^{512}$ Furthermore, this exception covers "all civil actions where the matter in controversy exceeds the sum or value of $\$ 75,000$, exclusive of interest and cost". ${ }^{513}$ Based on these latter conditions, district courts can obtain jurisdiction regarding claims related to foreign copyrights, ${ }^{514}$ even if the alleged copyright infringing activities were committed outside the United States of America. ${ }^{515}$

Illustrative is the case of London Film Productions, Ltd. v. Intercontinental Communications, Inc. involving the alleged infringement of a British copyright committed in Chile and other South American states. ${ }^{516}$ In this case a British corporation sued a New York

\footnotetext{
${ }^{510}$ See paragraph 2.3.2.

${ }^{511}$ See paragraph 2.3.2.

512 See Ginsburg \& Treppoz 2015, p. 562. See also paragraph 7.2. With respect to the difference between interstate and international conflict of laws cases in the United States of America, see paragraph 2.1.1.

${ }^{513}$ See Title 28 United States Code $\S 1332$ (a). This exception concerns both interstate and international private international law cases, see paragraph 2.1 .1 of this dissertation.

514 Ginsburg \& Treppoz 2015, pp. 561-562. The case London Film Productions, Ltd. v. Intercontinental Communications, Inc. 580 F. Supp. 47 (S.D.N.Y. 1984) illustrates the application of jurisdiction based on Title 28 United States Code $\$ 1332(a)(2)$.

515 Ginsburg \& Treppoz 2015, pp. 561- 562.

${ }^{516}$ London Film Productions, Ltd. v. Intercontinental Communications, Inc. 580 F. Supp. 47 (S.D.N.Y. 1984). See also Ginsburg \& Treppoz 2015, pp. 563-564.
} 
corporation based in New York City before the United States District Court for the Southern District of New York. The district court established jurisdiction on the basis of diversity of citizenship laid down in title 28 United States Code $\$ 1332(\mathrm{a})(2)$. The district court reasoned that it has an interest to obtain jurisdiction over its citizens regarding infringements of foreign copyright laws that took place outside the United States of America. The interest lies in the principle of reciprocity since a foreign court will in turn likely be more willing to establish jurisdiction over their citizens regarding infringements of the copyright law of the United States of America. ${ }^{517}$

Some courts in the United States of America have also been extending their jurisdiction to foreign infringements by broad interpretation of the concepts laid down in provisions of the United States Copyright Act of $1976^{518}$ and the application of certain legal doctrines. ${ }^{519}$ Dinwoodie pointed out the development of "consolidated litigation" that means that courts in the United States of America established jurisdiction regarding both domestic claims and claims based on foreign copyright law in one single procedure ${ }^{520}$ Illustrative is the case of Boosey \& Hawkes Music Publishers Ltd. v. Walt Disney Company involving multistate copyright infringements. ${ }^{521}$ In this case, the United District Court for the Southern District of New York rejected the plaintiff's foreign copyright claims on the basis of forum non conveniens. ${ }^{522}$ Yet, the United States Court of Appeals for the Second Circuit argued "while reluctance to apply foreign law is a valid factor favoring dismissal... standing alone it does not justify dismissal...Everything before us suggest that trail would be more 'easy, expeditious and inexpensive' in the district court than dispersed to 18 foreign nations". ${ }^{523}$ Finally, the parties in this case reached a global settlement of claims under eighteen different foreign copyright laws. ${ }^{524}$ In the case of Penguin Group (USA) Inc., v. American Buddha involving a cross-border copyright infringement dispute, the New York Court of Appeals broadly interpreted "the place of the injury" as jurisdictional connecting factor in the New York long-arm statute. ${ }^{525}$ Based on an elaborate reasoning, which will be set out in paragraph 7.3.2.1, the New York Court of Appeals ruled that the court of the place where the plaintiff's corporation was located could obtain jurisdiction regarding the entire copyright infringement dispute.

\footnotetext{
${ }^{517}$ London Film Productions, Ltd. v. Intercontinental Communications, Inc. 580 F. Supp. 47 at 49 (S.D.N.Y. 1984). ${ }^{518}$ See Dinwoodie 2009(a), pp. 726, 775. See also Barbosa 2007, pp. 91-95; Leaffer 2014, pp. 8-9; Solley 2008, pp. 825-827. See the United States Copyright Act of 1976 enacted on 19 October 1976, Pub. L. No. 94-553, 90 Stat. 2541.

${ }^{519}$ With respect to the application of doctrine of "root copy" to establish jurisdiction over extraterritorial conduct, see Dinwoodie 2009(a) pp. 726-728; Dinwoodie 2009(b), pp. 133-135. Regarding the concept of the transitory cause of action, see Leaffer 2014, p. 8. See also paragraph 2.3.2.

${ }^{520}$ Dinwoodie 2009(a), pp. 740-742, 791. See also Dinwoodie 2003.

${ }^{521}$ Boosey \& Hawkes Music Publishers Ltd. v. Walt Disney Company, 145 F. 3d 481 (2d Cir. 1998).

${ }^{522}$ Boosey \& Hawkes Music Publishers Ltd. v. Walt Disney Company, 934 F. Supp. 119 (S.D.N.Y. 1996). In common law states, courts may apply the doctrine of forum non conveniens "in situations where it would be appropriate -to promote justice and the convenience of parties- for a case to be heard in a different forum". See Goldstein \& Hugenholtz 2013, p. 122. In the case of Andrew Owusu v. N.B. Jackson, the CJEU ruled that the doctrine of forum non conveniens is not compatible with the Brussels system. See Case C-281/02 Andrew Owusu v. N.B. Jackson.

${ }^{523}$ Boosey \& Hawkes Music Publishers Ltd. v. Walt Disney Company, 145 F. 3d 481 (2d Cir. 1998) at 492.

524 "Boosey \& Hawkes Settle with Disney", The Telegraph, 21 March 2001. Available at http://www.telegraph.co.uk/finance/4478676/Boosey-and-Hawkes-settle-with-Disney.html

${ }_{525}$ Penguin Group (USA) Inc., v. American Buddha, 16 N.Y. 3d 295 (2011).
} 
As mentioned in paragraph 2.3.2, European Member States have adopted the view that the territorial principle related to copyrights does not influence the jurisdiction of the court of the place where the defendant is domiciled. ${ }^{526}$ Since the forum rei has not been subjected to the locus protectionis requirement, this court can even assess alleged copyright infringing activities that took place in other states and infringements of foreign copyrights. ${ }^{527}$ As will be demonstrated in chapter three, the CJEU did employ the requirement of locus protectionis as jurisdiction criterion to interpret the Erfolgsort under Article 7(2) Brussels Ibis in cross-border copyright infringement cases. ${ }^{528}$ The debated issue on the locus protectionis as jurisdiction criterion will be further examined in chapter five.

Due to the territorial protection of copyrights, the CJEU has also limited the jurisdiction of the court of the Erfolgsort under Article 7(2) Brussels Ibis to the damage caused by the alleged copyright infringement within in the forum state. ${ }^{529}$ Yet, with respect to ubiquitous copyright infringements, ${ }^{530}$ scholars $^{531}$ and several courts ${ }^{532}$ have proposed connecting factors that provide jurisdiction to the court regarding the entire copyright infringement dispute. Kur argues that "the principle of efficiency" can constitute a counterweight to territoriality inherent to copyrights; this principle refers to the "efficiency of court proceedings" and "efficiency in the sense of facilitating international transactions". ${ }^{533}$ The paragraphs 5.3.1 and 5.3.2 will set out arguments against territorially limited jurisdiction in copyright infringement disputes. The chapters six and seven will focus on connecting factors that confer jurisdiction to a court regarding the entire copyright infringement dispute.

\subsubsection{On the level of the conflict of laws: deviating from the lex loci protectionis rule}

The influence of the territoriality principle as enshrined in the lex loci protectionis rule has been criticised. Several scholars are opposing the lex loci protectionis rule in multistate copyright infringement cases since this rule will lead to the application of a patchwork of national copyright laws. ${ }^{534}$ Although the Member State court of the place of the infringer's domicile obtains full jurisdiction under Article 4 Brussels Ibis, this court will have to apply a multiple of copyright laws of each Member State in which the right has allegedly been

\footnotetext{
${ }^{526}$ Lundstedt 2001, pp. 127-128; Metzger 2009, p. 253; Neumann 2011, p. 592; Vicente 2016, p. 726.

${ }^{527}$ See Neumann 2014, p. 508; Pansch 2000, p. 355.

${ }^{528}$ See the rulings Pinckney, Hi Hotel, Pez Hejduk in chapter 3.

${ }^{529}$ See the rulings Pinckney, Hi Hotel, Pez Hejduk in chapter 3.

${ }^{530}$ In this dissertation, the term ubiquitous copyright infringements will denote "concurrent multi-territorial infringements evoked by a single act of operation”. See Chaen, Kono \& Yokomizo 2010, p. 98. For instance, copyright infringing content disseminated via the Internet. See Torremans 2014, p. 388; Neumann 2014, p. 497. See also chapter 6 on various approaches to jurisdiction applicable to ubiquitous copyright infringement disputes.

${ }^{531}$ See, inter alia, the proposals as laid down in Article 2:203(2) CLIP; Article 6 of the Dreyfuss-Ginsburg (see Dreyfuss \& Ginsburg 2002, pp. 1077-1078); the so-called 'case-specific copyright holder's centre of interest' approach (see Kono \& Jurcys 2015, pp. 27-31). These proposals will be discussed in chapter six of this dissertation. ${ }^{532}$ See the Swedish Supreme Court in the case of Micael Engström v. Tylden \& Co AS 4 July 2012, NJA $2012 \mathrm{~s}$ 483. This case will be further examined in chapter seven. See also the case law of several courts in states of the United States of America that will be discussed in chapter 7.

${ }^{533}$ See Kur 2009, p. 6.

${ }^{534}$ Van Eechoud 2003, p. 222. See also Matulionyte 2015, p. 138; Van Engelen 2007, p. 202.
} 
infringed. This approach will thus be time and cost consuming for both parties and the competent court.

For reasons of efficient adjudication and enforcement, several scholars have therefore suggested to deviate from the lex loci protectionis rule in multistate copyright infringement cases. ${ }^{535}$ The majority of these scholars advocate that -under certain conditions- the competent court should be able to apply only the law of the state that is most connected to the entire copyright infringement dispute. ${ }^{536}$ For example, the European Max Planck Group on Conflict of Laws in Intellectual Property (hereinafter CLIP group) stipulated that under certain circumstances the competent court may apply the law being most closely connected with the ubiquitous infringement in its entirety. ${ }^{537}$ Van Eechoud advocated that in a "networked world" the competent court should only apply the laws of countries that have an "effective connection" with the case. ${ }^{538}$ Other proposals are, inter alia, "the law of the country of the initiating act" 539 or the law of the author's residence. ${ }^{540}$ Some courts in the United States of America have applied the so-called "root copy approach" that entails the extraterritorial application of United States copyright law "to the distribution of copies abroad, when the foreign copies were further reproductions of an initial infringing reproduction committed in the United States". ${ }^{541}$

Opponents argue to maintain the lex loci protectionis rule. ${ }^{542}$ It has been asserted that this rule guarantees the law of the state most closely connected to the dispute. ${ }^{543}$ Other arguments in favour of the lex loci protectionis rule are that each state maintains its own balance of interests between copyright holders and the public ${ }^{544}$ or that this rule provides the highest level of copyright protection and predictability to the parties concerned. ${ }^{545}$

This dissertation will not elaborate on desirable conflict-of-laws rules with respect to crossborder copyright infringement cases. The focus will be on rethinking the CJEU's approach to jurisdiction in cross-border copyright infringement disputes. Yet, it is relevant to take into account the foregoing trend to reject the influence of the territorial protection of copyrights when finding the applicable law. This trend is also visible on jurisdictional level considering the proposals of scholars and courts to provide full jurisdiction in multistate copyright infringement disputes to a particular court of another state than the state where the defendant is domicile. ${ }^{546}$ The chapters six and seven will address various proposals.

\footnotetext{
${ }^{535}$ See, inter alia, Neumann 2014, pp. 503-520; Van Eechoud 2003, pp. 221-225.

${ }^{536}$ For example, Article 3:603 CLIP Principles; §321 ALI Principles; Article 306 Waseda Principles. See also Basedow 2010, p. 27; Kur 2009, p. 12; Matulionyte 2015, p. 138; 138-142; Neumann 2014, p. 555; Van Eechoud 2003, pp. 221-225.

${ }^{537}$ Article 3:603 CLIP Principles of the final text of 1 December 2011. See paragraph 1.1.2.

${ }_{538}$ Van Eechoud 2003, p. 223. See also Van Eechoud 2003, pp. 221-225; Van Eechoud 2005, pp. 18-19.

${ }^{539}$ Ricketson \& Ginsburg 2006, p. 1303.

${ }^{540}$ Ginsburg 1998, pp. 329-332; Ricketson \& Ginsburg 2006, pp. 1310-1311.

${ }^{541}$ Ginsburg 1998, p. 338. See also Gottschalk 2007, p. 212; Ricketson \& Ginsburg 2006, pp. 1303-1306.

${ }^{542}$ Schaafsma 2009, pp. 415-426.

${ }^{543}$ Schaafsma 2009, pp. 415-419. See also Neumann 2011, pp. 586-589.

544 Schaafsma 2009, pp. 419-426.

545 Schaafsma 2009, pp. 424-425.

${ }^{546}$ See chapters 6 and 7 on proposals of scholars and courts. Kur (2002, pp. 176-177) argues that "the need for consolidated litigation" is "undisputed in the area of copyright".
} 
2.3.5 Table on the influence of the territoriality principle related to copyrights with respect to private international law involving cross-border copyright infringement cases

\begin{tabular}{|c|c|c|}
\hline & $\begin{array}{l}\text { Influence of the territorial } \\
\text { protection of copyrights }\end{array}$ & $\begin{array}{l}\text { More flexible approach to } \\
\text { territoriality }\end{array}$ \\
\hline $\begin{array}{l}\text { On jurisdictional level } \\
\text { regarding the court of the } \\
\text { Erfolgsort }\end{array}$ & $\begin{array}{l}\text {-Locus protectionis as } \\
\text { jurisdiction criterion: } \\
\text { the court seised may only } \\
\text { obtain jurisdiction if the } \\
\text { forum state protects the } \\
\text { copyright relied on by the } \\
\text { plaintiff. } \\
\text {-Limited jurisdiction to } \\
\text { the damage that occurred } \\
\text { within the forum state. }\end{array}$ & $\begin{array}{l}\text {-Some scholars do not } \\
\text { consider the locus } \\
\text { protectionis criterion as } \\
\text { requirement to establish } \\
\text { jurisdiction (see paragraph } \\
5.1 .3 \text { ). } \\
\text { - With respect to } \\
\text { multistate or ubiquitous } \\
\text { copyright infringements, } \\
\text { scholars and courts argued } \\
\text { to provide } \\
\text {-under certain } \\
\text { circumstances- unlimited } \\
\text { jurisdiction (see chapters } 6 \\
\text { and } 7 \text { ). }\end{array}$ \\
\hline $\begin{array}{l}\text { On the level of choice-of- } \\
\text { law }\end{array}$ & $\begin{array}{l}\text { Lex loci protectionis rule: } \\
\text { the court need to apply } \\
\text { the law(s) of the state(s) } \\
\text { for which protection is } \\
\text { claimed. }\end{array}$ & $\begin{array}{l}\text { Some scholars have } \\
\text { proposed to apply only the } \\
\text { law of the state most } \\
\text { connected to the dispute } \\
\text { (see paragraph 2.3.4.2). }\end{array}$ \\
\hline
\end{tabular}

\subsection{Concluding remarks}

This chapter aimed to highlight general traditional principles and developments of the fields of private international law and copyright law that are relevant for the rethinking of the CJEU's approach to jurisdiction in cross-border copyright infringement cases. As described in this chapter, the general features of the two fields mainly diverge regarding their aims and the parties involved. While private international law aims to coordinate cross-border litigation by rules that provide predictability, copyright law seeks to enhance creativity, knowledge, information, cultural, and economic development. Private international law initially focuses on the private parties involved, whereas copyright law includes the interests of copyright holders as well as public parties. Although there are various treaties regulating several issues of these fields, the rules of both fields are mainly laid down in national laws.

This chapter demonstrated two converging developments in the field of private international law and copyright law. The first converging development concerns the so-called 
instrumentalisation of both fields for public aims. Whereas states traditionally have been enacting copyright law to achieve public objectives, rules of private international law also became an instrument to achieve public aims. Yet, as mentioned in this chapter, the instrumentalisation of the two fields may entail negative effects. With respect to the field of copyright law, copyrights currently tend to be overprotected. Therefore, it is important to strike a balance between copyrights and the rights and interests of third parties involved. Chapter four will argue that the principle of balancing the interests related to copyrights should be part of the assessment framework to rethink the CJEU's approach to jurisdiction in cross-border copyright infringement disputes. ${ }^{547}$ From a perspective of legitimacy, it is nonetheless important that the rules of private international law uphold its main function of coordinating cross-border cases in a predictable and efficient way. Paragraph 4.2.4.2 will therefore demonstrate the private international law principles underlying the special jurisdiction rule of Article 7(2) Brussels Ibis that have to be included into the assessment framework of this dissertation.

The second converging development concerns the trend towards a flexible approach to territoriality in both fields. This development has in particular been set out in the context of conferring jurisdiction to courts based on effects in cross-border copyright infringement cases. In view of globalisation and the Internet, the traditional influence of the territorial nature of copyrights on the field of private international law through the requirement of locus protectionis and the territorial limitation of the court's jurisdiction has been criticised for reasons of efficient copyright protection and adjudication. Chapter five of this dissertation will further elaborate on the locus protectionis as jurisdiction criterion and the (desirable) scope of the court's jurisdiction in cross-border copyright infringement cases.

Furthermore, it is commonly agreed that an effects-based approach to jurisdiction regarding cross-border torts seems unavoidable. In addition, it has been generally required that there exists a substantial connection between the dispute and the forum state. ${ }^{548}$ The Brussels Ibis Regulation also stipulates that jurisdiction rules deviating from the actor sequitur forum rei principle have to be based on a close connection between the dispute and the forum state in order to facilitate sound administration of justice and guarantee predictability. ${ }^{549}$ With respect to the rethinking of the CJEU's approach to jurisdiction in cross-border copyright infringement cases, this close connection requirement will be an important feature. As will be demonstrated in chapter four, the assessment framework of this dissertation will therefore include the requirement of a close connection between the dispute and the forum state. ${ }^{550}$ The next chapter will discuss the jurisdictional framework established by the CJEU in the cross-border copyright infringement cases Pinckney, Hi Hotel, and Pez Hejduk.

\footnotetext{
${ }^{547}$ See paragraph 4.4 .

${ }^{548}$ See paragraph 2.1.2.2.2.

549 See recital 16 in the preamble to the Brussels Ibis Regulation.

${ }^{550}$ See paragraph 4.2.4.2 on the principles underlying the special jurisdiction rule of Article 7(2) Brussels Ibis.
} 



\section{Chapter 3}

The CJEU's approach to jurisdiction in cross-border copyright infringement

cases 

This chapter will demonstrate the CJEU's approach to jurisdiction in cross-border copyright infringement cases. Hence, three preliminary rulings referred to as Pinckney, Hi Hotel and Pez Hejduk will be set out. ${ }^{551}$ Paragraph 3.5 will summarise the CJEU's approach to jurisdiction in these three cross-border copyright infringement cases, also referred to as the Pinckney doctrine in this dissertation. In addition, the influence of the territorial principle related to copyrights according to the Pinckney doctrine will be demonstrated.

The European Union jurisdictional rules related to infringement of other intellectual property rights will be briefly mentioned. With respect to effects-based jurisdiction in case of infringements of European Union and national trade marks, two rulings will be described since they may influence the rethinking of the Pinckney doctrine. ${ }^{552}$

\subsection{Preliminary rulings}

Pursuant to Article 267 of the Treaty on the Functioning of the European Union of 2007 (hereinafter TFEU) ${ }^{553}$, the courts of the Member States may, and under certain circumstances have to, request the CJEU to interpret European Union law. The answer to the question should be necessary for the court involved to give a judgment. ${ }^{554}$ Member States' courts are obliged to refer the question to the CJEU if there is no ordinary judicial remedy under national law against their decision. ${ }^{55}$ There are two exceptions to this last rule namely when the answer has already been given in an earlier preliminary ruling by the CJEU (acte éclairé) ${ }^{556}$ or the answer is obvious (acte clair). ${ }^{557}$ The interpretation by the CJEU has to safeguard the uniform interpretation of European Union Law. ${ }^{558}$ Although preliminary rulings concern a particular case, they likely have an erga omnes effect in all Member States because Member State courts generally follow the interpretation provided by the CJEU. ${ }^{559}$

The three cases that will be discussed in this chapter involve the request for a preliminary ruling on the interpretation of the special jurisdiction rule related to torts formerly laid down in Article 5(3) Brussels I, currently in Article 7(2) Brussels Ibis. ${ }^{560}$ Pursuant to this special jurisdiction rule, "a person domiciled in a Member State may be sued in another Member

\footnotetext{
${ }^{551}$ See Case C-170/12 Peter Pinckney v. KGD Mediatech AG; Case C-387/12 Hi Hotel HCF SARL v. Uwe Spoering; C-441/13 Pez Hejduk v. EnergieAgentur. NRW GmbH.

${ }_{552}$ Case C-172/18 AMS Neve Ltd and Others v. Heritage Audio SL, Pedro Rodriguez Arribas and Case C-523/10 Wintersteiger $A G$ v. Products $4 U$ Sondermaschinenbau GmbH. See paragraph 4.3 on the importance of the precedent-based method of interpretation with respect to the rethinking of the CJEU's interpretation of the special jurisdiction rule Article 7(2) Brussels Ibis in cross-border copyright infringement cases.

${ }_{553}$ Treaty on the Functioning of the European Union (OJ C 326, 26.10.2012, pp. 47-390). See also Magnus \& Mankowski 2016, p. 49

554 See Article 267 TFEU. See also Magnus \& Mankowski 2016, p. 50.

555 See Article 267 TFEU. See Magnus \& Mankowski 2016, p. 49. See also Hartley 2014, pp. 295-296.

${ }^{556}$ See Cases C-28/62 to 30/62 Costa en Schaake NV and Others v. Administratie der Belastingen; Case C-283/81 CLIFIT and Lanificio di Gavardo SPA v. Ministry of Health, para. 14.

${ }^{557}$ See Case C-283/81 CLIFIT and Lanificio di Gavardo SPA v. Ministry of Health, para. 6-21. Hartley 2014, p. 305 .

${ }^{558}$ Case C-283/81 CLIFIT and Lanificio di Gavardo SPA v. Ministry of Health, para. 7. See also Article 19 Treaty on European Union (OJ C326, 26.10.2012, pp. 13-390).

${ }_{559}$ Baudenbacher 2005, pp. 396-398. See also Kutscher 1976, p. I-14; Magnus \& Mankowski 2016, p. 52.

${ }^{560}$ See paragraph 1.1 .2 on the jurisdiction rules regarding private international law in the European Union.
} 
State... in matters relating to tort, delict, or quasi-delict, in the courts for the place where the harmful event occurred or may occur". ${ }^{561}$ In view of the need of continuity, the preamble to the Brussels Ibis Regulation explicitly stipulates that the CJEU's interpretation regarding provisions of the Brussels I Regulation, and its predecessor the Brussels Convention of 1968, will apply to equal provisions of the Brussels Ibis Regulation. ${ }^{562}$ The next chapters of this dissertation will generally employ Article 7(2) Brussels Ibis instead of Article 5(3) Brussels I.

In the preliminary reference procedure, the Advocate General will frequently provide a socalled Opinion regarding the question involved. Advocates General have the task to assist the CJEU; they should act "with complete impartiality and independence". ${ }^{563}$ In their Opinions, the Advocates General generally refer to relevant previous rulings by the CJEU, case law of national courts, and legal doctrine. The CJEU is not obliged to follow the Opinion of the Advocate General. ${ }^{564}$ This chapter will include the Opinions of the Advocates General provided in the cases Pinckney v. Mediatech and Pez Hejduk v. EnergieAgentur. ${ }^{565}$

\subsection{Pinckney v. Mediatech ${ }^{566}$}

\subsubsection{The facts}

On 3 October 2013, the CJEU provided in the case of Pinckney v. Mediatech the first interpretation of "the place where the harmful event occurred or may occur" under Article 7(2) Brussels Ibis in a copyright infringement dispute. ${ }^{567}$ Mr. Pinckney, a French resident, sued the company Mediatech, established in Austria, before a French court in order to compensate the damage caused by an alleged copyright infringement. Pinckney asserted to be the author, composer and performer of the songs that Mediatech reproduced by pressing them on compact discs in Austria. The marketing companies Crusoe or Elegy, established in the United Kingdom, put these compact discs for sale via various websites accessible in France. Mediatech claimed that the compact discs had been pressed in Austria at the request of the United Kingdom companies that marketed them through an internet site. ${ }^{568}$

When Mr. Pinckney filed the claim for copyright infringement against Mediatech in a French court, the question arose whether the French court had jurisdiction based on the accessibility of the website that offered the copyright infringing compact discs for sale. Consequently, the Cour de Cassation (the highest court of the French judiciary) requested the

\footnotetext{
${ }^{561}$ Article 7(2) Brussels Ibis.

${ }^{562}$ See recital 34 in the preamble to the Brussels Ibis Regulation.

${ }^{563}$ See Article 252 TFEU. The Council, acting unanimously, may increase the number of Advocates General at the request of the Court.

${ }^{564}$ Hartley 2014, p. 52.

${ }^{565}$ See the Opinion of Advocate General Jääskinen delivered on 13 June 2013 in the case C-170/12 Peter Pinckney v. KGD Mediatech AG; Opinion of Advocate General Cruz Villalón delivered on 11 September 2014 in the case C-441/13 Pez Hejdukv. EnergieAgentur. NRW GmbH.

${ }^{566}$ Case C-170/12 Peter Pinckney v. KGD Mediatech AG.

${ }^{567}$ Several legal commentators provided an annotation to the Pinckney case, for instance, Grünberger 2015, pp. 56-65; Huvosec 2013; Huvosec 2014, pp. 370-374; Rosati 2014(a), pp. 18-19; Schack 2013, pp. 3629-3630; Smith 2013; Strikwerda 2014, 166; Sujecki 2013, pp. 866-867.

${ }^{568}$ Case C-170/12 Pinckney, para. 12, 22.
} 
CJEU to interpret the special jurisdiction rule in Article 7(2) Brussels Ibis that provides jurisdiction to the courts of the place where the harmful event occurred or may occur.

\subsubsection{The Opinion of Advocate General Jääskinen}

Advocate General Jääskinen deemed the request for a preliminary ruling in the so-called Pinckney case inadmissible because the description of the facts was insufficient. ${ }^{569}$ The lack of information involved, inter alia, the nature of the relationship between the Austrian company and the United Kingdom companies, and whether Mr. Pinckney also filed a claim against those latter companies. ${ }^{570}$

Nonetheless, Jääskinen examined the special jurisdiction rule "the place where the harmful event occurred" under Article 7(2) Brussels Ibis in the context of the Pinckney case. With respect to the localisation of the alleged infringements, he made a distinction between the alleged infringement of the reproduction right, on the one hand, and the alleged infringements of the distribution right or communication right, on the other hand. ${ }^{571}$ Jääskinen argued that the act of reproduction generally cannot have a cross-border character, the Handlungsort will therefore coincide with the Erfolgsort. ${ }^{572}$ Consequently, the courts in Austria or the United Kingdom may have obtained jurisdiction regarding the pressing of the CD's or the (hypothetical) placing of the infringing content on the Internet. ${ }^{573}$ On the other hand, an infringement of the distribution and communication right may easily contain cross-border activities; the Handlungsort and the Erfolgsort may therefore not coincide. ${ }^{574}$ Jääskinen argued that "harm resulting from infringements of distribution or communication of rights assumes a potential addressee or public, which may be in a different place from that act". ${ }^{575}$

In line with the ruling by the CJEU in the case of Wintersteiger $A G$ v. Products $4 U$ Sondermaschinenbau $\mathrm{GmbH}$ involving an infringement of a trademark, Jääskinen interpreted "the place of the event giving rise to the damage "as "the place of establishment of the alleged infringers" ${ }^{576}$ In the Pinckney case, the courts in the United Kingdom could therefore obtain jurisdiction. ${ }^{577}$ With respect to "the place where the damage occurred", Jääskinen noted that case law and legal doctrine provide various interpretations. ${ }^{578} \mathrm{He}$ explicitly rejected to confer jurisdiction to the courts of each place where the website containing the copyright infringing content has been accessible. ${ }^{579}$ The latter approach would likely lead to multiple competent

\footnotetext{
${ }^{569}$ Opinion of Advocate General Jääskinen delivered on 13 June 2013 in the case C-170/12 Peter Pinckney v. $K G D$ Mediatech $A G$, para. 19-20.

${ }^{570}$ Opinion of Advocate General Jääskinen in the case C-170/12 Peter Pinckney v. KGD Mediatech AG, para. 19.

${ }^{571}$ Opinion of AG Jääskinen in the case C-170/12 Pinckney, para. 51-56. See also paragraph 6.1 on the 'directed activities' approach to jurisdiction in cross-border copyright infringement cases as suggested by Jääskinen.

572 Opinion of AG Jääskinen in the case C-170/12 Pinckney, para. 53.

${ }^{573}$ Opinion of AG Jääskinen in the case C-170/12 Pinckney, para. 54.

${ }^{574}$ Opinion of AG Jääskinen in the case C-170/12 Pinckney, para. 55.

${ }^{575}$ Opinion of AG Jääskinen in the case C-170/12 Pinckney, para. 55.

576 Opinion of AG Jääskinen in the case C-170/12 Pinckney, para. 57. Jääskinen referred to the case C-523/10 Wintersteiger AG v. Products $4 U$ Sondermaschinenbau GmbH, para. 37.

577 Opinion of AG Jääskinen in the case C-170/12 Pinckney, para. 58.

${ }_{578}$ Opinion of Advocate General Jääskinen in the case C-170/12 Peter Pinckney v. KGD Mediatech AG, para. 59.

${ }^{579}$ Opinion of AG Jääskinen in the case C-170/12 Pinckney, para. 68.
} 
courts which is not in accordance with "the principle of territoriality and the objectives of foreseeability and the sound administration of justice pursued by that regulation". 580

Instead, Jääskinen argued to adopt the CJEU's approach regarding the localisation of infringements of intellectual property rights at the substantive level. ${ }^{581}$ In several rulings involving this localisation, ${ }^{582}$ the CJEU employed the criterion that the infringing activities must reveal the intention to target persons in the Member State of the court seised. ${ }^{583}$ According to Jääskinen, each Member State court may thus obtain jurisdiction if the alleged copyright infringing activities via the Internet have been aimed at the public of the forum state. ${ }^{584}$ In view of the territoriality principle related to copyrights, Jääskinen argued that the jurisdiction of these courts will be limited to the damage that occurred in the territory of the forum state. ${ }^{585}$

Adopting the same approach to jurisdiction would entail consistency in the case law of the CJEU. ${ }^{586}$ In the case of Football Dataco and Others $v$. Sportrader, the CJEU even held that the question of localising the infringing activities at substantive level "is liable to have an influence on the question of the jurisdiction of the referring court". ${ }^{587}$ Moreover, the CJEU "emphasised that the principle of territoriality gives rise to a particular link between the extent of the scope ratione territoriae of the applicable national legislation and that of jurisdiction". ${ }^{58}$ Pursuant to Jääskinen, the non-exhaustive criteria adopted by the CJEU in the Peter Pammer v. Reederei Karl Schlütter GmbH \& Co. KG and Hotel Alpenhof GesmbH v. Oliver Heller ruling may indicate whether the infringing activities are aimed at the public of the forum state. ${ }^{589}$ Chapter six of this dissertation will examine the abovementioned so-called 'directed activities' approach to jurisdiction under Article 7(2) Brussels Ibis in cross-border copyright infringement cases.

\subsubsection{The preliminary ruling}

The CJEU reformulated the questions referred into the following question: "whether Article 5(3) of the Regulation must be interpreted as meaning that where there is an alleged infringement of a copyright which is protected by the Member State of the court seised, that court has jurisdiction to hear an action to establish liability brought by the author of a work against a company established in another Member State, which has in the latter State reproduced that work on a material support which is subsequently marketed by companies established in a

\footnotetext{
${ }^{580}$ Opinion of AG Jääskinen in the case C-170/12 Pinckney, para. 68.

${ }^{581}$ Opinion of AG Jääskinen in the case C-170/12 Pinckney, para. 63-66.

${ }^{582}$ See Case C-324/09 L'Oréal and Others $v$. eBay, para 61-67, regarding alleged infringements of national and Community trademarks; Case C-5/11 Donner, para. 27-30, concerning an alleged infringement of an author's exclusive distribution right of copyrighted works; Case C-173/11 Football Dataco and Others v. Sportrader, para 37-39, involving an infringement of the sui generis right over a database.

583 Opinion of Advocate General Jääskinen in the case C-170/12 Peter Pinckney v. KGD Mediatech AG, para 61.

${ }^{584}$ Opinion of AG Jääskinen in the case C-170/12 Pinckney, para. 64, 67.

${ }^{585}$ Opinion of AG Jääskinen in the case C-170/12 Pinckney, para 46, 64.

${ }^{586}$ Opinion of AG Jääskinen in the case C-170/12 Pinckney, para. 63.

587 Opinion of AG Jääskinen in the case C-170/12 Pinckney, para. 63. See also C-173/11 Football Dataco and Others v. Sportrader, para. 30.

${ }^{588}$ Opinion of AG Jääskinen in the case C-170/12 Pinckney, para. 65.

589 Joined Cases C-585/08 and C-144/09 Peter Pammer v. Reederei Karl Schlütter GmbH \& Co. KG and Hotel Alpenhof GesmbH v. Oliver Heller, para. 83. The non-exhaustive criteria adopted by the CJEU in the ruling Pammer v. Alpenhof will be set out in chapter six of this dissertation.
} 
third Member State through an internet site which is also accessible in the Member State of the court seised". 590

In view of earlier case law, the CJEU first described basic principles underlying the special jurisdiction rule in Article 7(2) Brussels Ibis, which will be further set out in paragraph 4.2.4.2 of this dissertation. ${ }^{591}$ In short, the special jurisdiction rule has to be interpreted restrictively ${ }^{592}$ since it concerns a deviation of principle of actor sequitur forum rei as laid down in Article 4 Brussels Ibis. ${ }^{593}$ The special jurisdiction rule is based "on the existence of a particularly close connecting factor between the dispute and the courts of the place where the harmful event occurred or may occur, which justifies the attribution of jurisdiction to those courts for reasons relating to sound administration of justice and the efficacious conduct of proceedings". 594

The CJEU also referred to the earlier mentioned dichotomy Handlungs- and Erfolgsort, established in the case of Handelskwekerij G.J. Bier v. Mines de Potasse d'Alsace SA ${ }^{595}$ that enables "the court objectively best placed to determine whether the elements establishing the liability of the person sued are present to take jurisdiction". ${ }^{596}$ Applying the latter dichotomy to the Pinckney case, the CJEU held that the place of the event giving rise to the damage, the Handlungsort, was not situated in France. ${ }^{597}$ Hence, the CJEU focused on the interpretation of the place where the damage occurred or may occur, the Erfolgsort, as ground for jurisdiction under the special rule in Article 7(2) Brussels Ibis. ${ }^{598}$

The CJEU noted that this special jurisdiction rule has already been interpreted regarding effects of alleged online infringements in the joined cases of eDate Advertising GmbHv. X and Olivier Martinez and Robert Martinez v. MGN Limited and the case of Wintersteiger AG v. Products $4 U$ Sondermaschinenbau GmbH. ${ }^{599}$ Based on these previous rulings, the CJEU ruled that, first, the nature of the alleged infringed right influences the interpretation of the Erfolgsort. ${ }^{600}$ Second, "the likelihood of damage occurring in a particular Member State is subject to the requirement that the right in respect of which infringement is alleged is protected

\footnotetext{
${ }^{590}$ Case C-170/12 Peter Pinckney v. KGD Mediatech AG, para. 22.

${ }^{591}$ Case C-170/12 Pinckney, para. 23-28.

${ }^{592}$ Case C-170/12 Pinckney, para. 25. The CJEU refers to the case C-228/11 Melzer v. MF Global v. UK Ltd, para. 24.

593 See paragraph 2.3.1.

${ }^{594}$ See Case C-170/12 Pinckney, para. 27. The CJEU refers to the case C-228/11 Melzer v. MF Global v. UK Ltd, para. 25. See also recital 16 in the preamble to the Brussels Ibis Regulation.

${ }^{595}$ See paragraph 2.1.2.2.2 on the dichotomy Handlungs- and Erfolgsort established by the CJEU in the case of C-21/76 Handelskwekerij G.J. Bier v. Mines de Potasse d'Alsace SA.

${ }^{596}$ Case C-170/12 Peter Pinckney v. KGD Mediatech AG, para. 28. The CJEU referred to the case C-133/11 Folien Fischer and Folitec v. Ritrama $S p A$.

${ }_{597}$ Case C-170/12 Peter Pinckney v. KGD Mediatech AG, para. 29.

${ }^{598}$ Case C-170/12 Pinckney, para. 30.

599 Case C-170/12 Pinckney, para. 31. The CJEU referred to the joined cases C-509/09 and C-161/10 eDate Advertising and Martinez v. MGN Limited (see paragraphs 2.1.2.2.2 and 6.2.1.1) and the case C-523/10 Wintersteiger AG v. Products $4 U$ Sondermaschinenbau GmbH.

${ }^{600}$ Case C-170/12 Pinckney, para. 32.
} 
in that Member State." 601 Third, the CJEU held it is important "which court is best placed to determine whether the alleged infringement is well founded". ${ }^{602}$

In the Wintersteiger ruling, the CJEU made a distinction between alleged online infringement of personality rights and alleged online infringements of intellectual property rights. ${ }^{603}$ While the former rights are protected in all Member States, the latter rights are "protected on a territorial basis" 604 . According to the CJEU, the victim of an alleged online infringement of personality rights may bring his action before the courts of each Member State in which the infringing content is or has been accessible via the Internet. ${ }^{605}$ Yet, these courts may only obtain jurisdiction regarding the damage caused within the forum state. ${ }^{606}$ In addition, the CJEU referred full jurisdiction to the court of the place where the victim has his centre of interests since the latter court is best placed to assess all the damage sustained by the victim. ${ }^{607}$ With respect to the alleged online infringement of a trademark, the CJEU interpreted the Erfolgsort as the place where the infringed trademark is protected that means the Member State in which the trademark has been registered. ${ }^{608}$

The CJEU's interpretation of "the place where the damage occurred" in the Pinckney ruling can be divided into three layers that will be set out below. ${ }^{609}$ The first 'foundation' layer of the jurisdictional framework comprises the statement by the CJEU that although copyrights are subjected to the principle of territoriality, "copyrights must be automatically protected, in particular by virtue of Directive 2001/29 [hereinafter the Information Society Directive], ${ }^{610}$ in all Member States, so that they may be infringed in each one in accordance with the applicable substantive law." ${ }^{611}$ Pursuant to this statement, the CJEU seems to consider all places in each Member State as locus protectionis regarding copyrights. Nevertheless, further on in the Pinckney ruling, the CJEU stated that the court seised has only jurisdiction under Article 7(2) Brussels Ibis "if the Member State in which the court is situated protects the copyrights relied

${ }^{601}$ Case C-170/12 Pinckney, para. 33. The CJEU referred to C-523/10 Wintersteiger AG v. Products $4 U$ Sondermaschinenbau GmbH, para. 25.

${ }^{602}$ Case C-170/12 Pinckney, para. 34. The CJEU refers to the joined cases C-509/09 and C-161/10 eDate Advertising and Martinez v. MGN Limited, para. 48 and to the case C-523/10 Wintersteiger AG v. Products $4 U$ Sondermaschinenbau $\mathrm{GmbH}$, para. 27.

${ }^{603}$ Case C-523/10 Wintersteiger AG v. Products 4 U Sondermaschinenbau GmbH, para. 24

${ }^{604}$ See the Opinion of Advocate General Cruz Villalón delivered on 16 February 2012 in the case C523/10 Wintersteiger $A G$ v. Products $4 U$ Sondermaschinenbau $G m b H$, para. 20.

${ }^{605}$ Case C-170/12 Peter Pinckney v. KGD Mediatech AG, para. 36. The CJEU referred to the joined cases C509/09 and C-161/10 eDate and Martinez, para. 52.

${ }^{606}$ Case C-170/12 Pinckney, para. 36

${ }^{607}$ Case C-170/12 Pinckney, para. 36. The CJEU referred to the joined cases C-509/09 and C-161/10 eDate and Martinez, para. 48. See paragraph 6.2.4 on the assessment of the 'victim's centre of interests' approach under Article 7(2) Brussels Ibis in cross-border copyright infringement cases.

${ }^{608}$ Case C-523/10 Wintersteiger AG v. Products $4 U$ Sondermaschinenbau GmbH, para. 25. See paragraph 3.6.2 will discuss the Wintersteiger ruling in more detail.

${ }^{609}$ Advocate General Cruz Villalón noted that the Pinckney doctrine comprises the following three features: "substantive protection, factual protection, and protection which is limited territorially." See the Opinion of Advocate General Cruz Villalón delivered on 11 September 2014 in the case C-441/13 Pez Hejduk v. EnergieAgentur. $N R W G m b H$, para. 38 .

${ }^{610}$ The Directive 2001/29/EU of the European Parliament of the Council of 22 May 2001 on the harmonisation of certain aspects of copyrights and related rights in the information society has also referred to as the Information Society Directive or the Information Society Directive (OJ L167, 22.06.2001, pp. 10-19).

${ }^{611}$ Case C-170/12 Peter Pinckney v. KGD Mediatech AG, para. 39. 
on by the plaintiff'. ${ }^{612}$ Finally, the CJEU noted that the competent court has to decide according to the substantive law of the forum state whether an alleged copyright has actually been infringed. ${ }^{613}$

The second layer of the Pinckney framework concerns the localisation of 'the place where the damage occurred'. Besides the abovementioned requirement of protection of the alleged copyright in the forum state, the CJEU required that the alleged damage may occur within the forum state. ${ }^{614}$ According to the CJEU this so-called 'likelihood of damage' criterion was satisfied due to "the possibility of obtaining a reproduction of the work to which the rights relied on by the defendant pertain from an internet site accessible within the jurisdiction of the court seised." ${ }^{\prime} 15$ The CJEU explicitly rejected the approach that the alleged tortious activities have to be "directed to" the Member State where the court seised is situated, as suggested by Advocate General Jääskinen ${ }^{616}$ and adopted under Article 17(1)(c) Brussels Ibis in the joined cases of Pammer and Hotel Alpenhof. ${ }^{617}$ The CJEU reasoned that the localisation of the place where the damage may occur under Article 7(2) Brussels Ibis "cannot depend on criteria which are specific to the examination of the substance of the action and which do not appear in that provision". 618

In the third layer of the Pinckney ruling, the CJEU limited the jurisdiction of the court of the Erfolgsort to the damage caused within the territory of the forum state. ${ }^{619}$ The CJEU reasoned that, in light of Article 7(2) Brussels Ibis and the territorial protection of copyrights, courts of other Member States "are best placed to ascertain whether the copyrights protected by the Member State concerned have been infringed and, second, to determine the nature of the damage caused". ${ }^{620}$

Based on the foregoing the CJEU provided the following answer to the question referred: "that Article 5(3) of the Regulation must be interpreted as meaning that, in the event of alleged infringement of copyrights protected by the Member State of the court seised, the latter has jurisdiction to hear an action to establish liability brought by the author of a work against a company established in another Member State and which has, in the latter State, reproduced that work on a material support which is subsequently sold by companies established in a third Member State through an internet site also accessible with the jurisdiction of the court seised. That court has jurisdiction only to determine the damage caused in the Member State within which it is situated". ${ }^{621}$

\footnotetext{
${ }^{612}$ Case C-170/12 Pinckney, para. 43.

${ }^{613}$ Case C-170/12 Pinckney, para. 40.

${ }^{614}$ Case C-170/12 Pinckney, para. 43.

${ }^{615}$ Case C-170/12 Pinckney, para. 44.

${ }^{616}$ Opinion of Advocate General Jääskinen delivered on 13 June 2013 in the case C-170/12 Peter Pinckney $v$. KGD Mediatech $A G$, para. 64-68.

617 Joined Cases C-585/08 and C-144/09 Peter Pammer v. Reederei Karl Schlütter GmbH \& Co. KG and Hotel Alpenhof GesmbH v. Oliver Heller. Paragraph 6.1.2 will discuss the 'directed activities' approach in the Pammer and Alpenhof ruling.

${ }^{618}$ Case C-170/12 Peter Pinckney v. KGD Mediatech AG, para. 41.

${ }^{619}$ Case C-170/12 Pinckney, para. 45.

${ }^{620}$ Case C-170/12 Pinckney, para. 46.

${ }^{621}$ Case C-170/12 Pinckney, para. 47.
} 


\subsection{Hi Hotel v. Spoering ${ }^{622}$}

\subsubsection{The facts}

In the case of Hi Hotel v. Spoering, the German photographer Mr. Spoering sold the right to use photographs, which he made of the interior of the Hi Hotel HCF in France, to the Hi Hotel for the purpose of advertising in brochures and on the website of the hotel. When Mr. Spoering found out that these photographs had been published in books that were put for sale in German bookshops, he asserted before a German court that the Hi Hotel infringed the copyrights on these photographs by passing them on to a third party. Therefore, he claimed that Hi Hotel must cease the reproduction and distribution of the copyright infringing activities and pay all the damage sustained. The Hi Hotel argued that the German court did not have jurisdiction because the hotel provided the photographs to a French publisher without being aware of the fact that this publisher would forward these photographs to its subsidiary company in Germany.

The Bundesgerichtshof (the Federal Court of Justice of Germany) asked the CJEU whether "the place where the harmful event occurred or may occur" under Article 7(2) Brussels Ibis should be interpreted as meaning that "where there are several supposed perpetrators of the damage allegedly caused to rights of copyright protected in the Member State of the court seised, that provision allows jurisdiction to be established with respect to one of those perpetrators who did not act within the jurisdiction of that court" ${ }^{623}$ Without a prior Opinion of an Advocate General, ${ }^{624}$ the CJEU delivered on 3 April 2014 the ruling as demonstrated in the next paragraph. ${ }^{625}$

\subsubsection{The preliminary ruling}

In view of its earlier ruling Melzer v. MF Global UK Ltd, ${ }^{626}$ the CJEU held that jurisdiction could not be based on the place of the causal event of the alleged damage, the Handlungsort, because the defendant Hi Hotel did not act in the forum state Germany. ${ }^{627}$ Similar to the Pinckney ruling, the CJEU therefore focused on the interpretation of the place where the alleged

\footnotetext{
${ }^{622}$ Case C-387/12 Hi Hotel HCF SARL v. Uwe Spoering.

${ }^{623}$ This concerns the question of the Bundesgerichtshof reformulated by the CJEU in the case C-387/12 Hi Hotel HCF SARL v. Uwe Spoering, para. 23.

${ }^{624}$ With respect to procedure before the Court of Justice, Article 20 of the Protocol No. 3 on the Statute of the Court of Justice of the European Union stipulates "where it considers that the case raises no new point of law, the Court may decide, after hearing the Advocate General, that the case shall be determined without a submission from the Advocate General" (OJ C 310, 16.12.2004, pp. 210-224). See also Rosati 2014(b), p. 619. Rosati pointed out that several preliminary rulings in the area of copyright have in common that the CJEU "either departed significantly from their Opinions [see, for example, the Pinckney ruling in paragraph 3.2] or ruled without seeking on the first place" [such as in this case of Hi Hotel v. Spoering].

${ }^{625}$ Several legal commentators provided an annotation in the Hi Hotel case, for instance, Müller 2014, pp. 434435; Van Eechoud 2014, pp. 117-120.

${ }^{626}$ Case C-228/11 Melzer v. MF Global UK Ltd, para. 40. Paragraph 5.2.3.1.2 of this dissertation will demonstrate the Melzer ruling and discuss the so-called third party-based approach to jurisdiction under Article 7(2) Brussels Ibis.

${ }^{627}$ Case C-387/12 Hi Hotel HCF SARL v. Uwe Spoering, para. 31-33.
} 
damage occurred or may occur, the Erfolgsort. Although the alleged copyright infringing photographs had not been offered for sale via the Internet but in German bookstores, the CJEU applied the same connecting factors as set out in the Pinckney ruling.

In line with the first 'pillar' of the Pinckney framework, ${ }^{628}$ the CJEU stated that the alleged copyrights were protected in Germany in accordance with the Information Society Directive. ${ }^{629}$ Second, with respect to the 'likelihood of damage' criterion, the CJEU held the mere fact that Hi Hotel provided the photographs to the French publisher "gave rise to the reproduction and distribution of the photographs, and thereby to the possibility that the damage alleged might occur" within the jurisdiction of the court seised. ${ }^{630}$ Finally, regarding the scope of the jurisdiction, the CJEU reiterated that "in the light of Article 7(2) Brussels Ibis and the principle of territoriality the jurisdiction of the court of the place where the damage occurs is limited to the damage caused in the territory of the forum state. ${ }^{631}$

With respect to the preliminary question, ${ }^{632}$ the CJEU ruled that Article 7(2) Brussels Ibis "must be interpreted as meaning that where there are several supposed perpetrators of damage allegedly caused to rights of the copyright protected" in the forum state and the supposed perpetrator who is being sued did not act in that state, that provision does not allow jurisdiction to be established on the basis of the Handlungsort; yet, the court may obtain jurisdiction on the basis of the Erfolgsort "provided that the damage may occur" in the forum state. ${ }^{633}$ The scope of the jurisdiction of the latter court is limited to the damage caused within the forum state. ${ }^{634}$

\subsection{Pez Hejduk v. EnergieAgentur ${ }^{635}$}

\subsubsection{The facts}

The case of Pez Hejduk v. EnergieAgentur NWR GmbH has been the third case in the trilogy of references regarding the interpretation of the special jurisdiction rule of Article 7(2) Brussels Ibis in copyright infringement disputes. ${ }^{636}$ In the latter case, Ms. Hejduk, being a professional photographer domiciled in Austria, noticed that the photographs she took of particular buildings were accessible on the website of the company EnergieAgentur for viewing and downloading. Ms. Hejduk therefore sued EnergieAgentur, located in Germany, before an Austrian court in order to receive compensation and authorisation to publish the judgement at the defendant's expense. EnergieAgentur argued that the Austrian court lacked jurisdiction because the website was not directed at Austria since EnergieAgentur used the country code top-level domain for Germany namely 'de'.

\footnotetext{
${ }^{628}$ See paragraph 3.2.3.

${ }^{629}$ Case C-387/12 Hi Hotel, para. 36.

${ }^{630}$ Case C-387/12 Hi Hotel, para. 37.

${ }^{631}$ Case C-387/12 Hi Hotel, para. 39.

${ }^{632}$ See paragraph 3.3.1.

${ }^{633}$ Case C-387/12 Hi Hotel, para. 40.

${ }^{634}$ Case C-387/12 Hi Hotel, para. 40.

${ }^{635}$ Case C-441/13 Pez Hejduk v. EnergieAgentur NWR GmbH.

${ }^{636}$ Several legal commentators provided an annotation to the Pez Hejduk case, for instance, Huvosec 2015; Smith \& Newton 2015, pp. 459-460; Torremans 2017, pp. 236-240.
} 
Hence, the Handelsgericht Wien (Commercial Court of Vienna) requested the CJEU to provide a preliminary ruling regarding the issue whether the court had jurisdiction under Article 7(2) Brussels Ibis to hear an action for damages caused by a copyright infringement resulting from the placing of protected photographs online on a website accessible in the forum state. ${ }^{637}$

\subsubsection{The Opinion of Advocate General Cruz Villalón}

According to Advocate-General Cruz Villalón, the case Pez Hejduk needed to be distinguished from the Pinckney case since the online dissemination of alleged copyrighted photographs caused "delocalised" damage. ${ }^{638}$ He argued that this type of "diffuse" damage makes it difficult to localise the place where the damage occurred. ${ }^{639}$ Hence, he rejected to adopt the "territorial criteria" of the Pinckney ruling in case of alleged dematerialised copyright infringing content via the Internet. ${ }^{640}$ In view of the objectives pursued by Article 7(2) Brussels Ibis, adopting the approach of the Pinckney ruling would not provide legal certainty, enhance the sound administration of justice, or meet the requirement of a close connection between the relevant facts of the dispute and the forum state. ${ }^{641}$

Cruz Villalón argued that only the courts of the place of the defendant's domicile or the court of the Handlungsort should obtain jurisdiction regarding alleged online copyright infringements such as in the case Pez Hejduk. ${ }^{642}$ Yet, he indicated that another connecting factor might be possible in case the alleged infringements were particularly directed at one or more other Member States. ${ }^{643}$ "In the same way as it could be asked whether the Pinckney case-law is applicable to the cross-border infringement of an author's moral rights". ${ }^{644}$ However, considering the question referred in the case Pez Hejduk, he did not found it necessary to examine these possibilities. ${ }^{645}$

\subsubsection{The preliminary ruling}

In the so-called Pez Hejduk ruling delivered on 22 January 2015, the CJEU localised the Handlungsort in the place in Germany where EnergieAgentur had its seat. ${ }^{646}$ In line with the earlier Wintersteiger ruling, ${ }^{647}$ the CJEU held that the place where the alleged infringer had its seat must be regarded as the Handlungsort under Article 7(2) Brussels Ibis since the place

\footnotetext{
${ }^{637}$ Case C-441/13 Pez Hejduk v. EnergieAgentur NWR GmbH, para. 15.

${ }^{638}$ Opinion of Advocate General Cruz Villalón delivered on 11 September 2014 in case C-441/13 Pez Hejdukv. EnergieAgentur. NRW GmbH, para. 2.

${ }^{639}$ Opinion of AG Cruz Villalón in the case Pez Hejduk, para. 2, 41.

${ }^{640}$ Opinion of AG Cruz Villalón in the case Pez Hejduk, para. 42.

${ }^{641}$ Opinion of AG Cruz Villalón in the case Pez Hejduk, para. 42- 44. The Advocate General referred to recital 12 in the preamble to the Brussels I Regulation, currently recital 16 in the preamble to the Brussels Ibis Regulation.

${ }^{642}$ Opinion of AG Cruz Villalón in the case Pez Hejduk, para. 45.

${ }^{643}$ Opinion of AG Cruz Villalón in the case Pez Hejduk, para. 46.

${ }^{644}$ Opinion of AG Cruz Villalón in the case Pez Hejduk, para. 46 note 26. In this connection, the Advocate General referred to Kur 2013, pp. 69-84. See paragraph 6.2.2.2 on the so-called 'copyright holder's centre of interests' approach to jurisdiction related to infringements of moral rights.

${ }_{645}$ Opinion of AG Cruz Villalón in the case Pez Hejduk, para. 32.

${ }^{646}$ Case C-441/13 Pez Hejduk v. EnergieAgentur. NRW GmbH, para. 26.

${ }^{647}$ See paragraph 3.6.2 on the case C-523/10 Wintersteiger AG v. Products $4 U$ Sondermaschinenbau GmbH.
} 
where the activation of the process for technical display of the photographs on the website could be regarded as the causal event. ${ }^{648}$ Based on the objective of foreseeability, the CJEU rejected the place of the server as connecting factor. ${ }^{649}$

Subsequently, the CJEU focused on the interpretation of the Erfolgsort. The CJEU did not follow the Opinion of the Advocate General but adopted the same approach as in the Pinckney ruling. Again the CJEU employed the premise that "copyrights must automatically be protected, in particular in accordance with the Directive 2001/29, in all Member States". ${ }^{650}$ In this connection, the CJEU held that the copyrights on which Ms Hejduk relied on were protected in Austria. ${ }^{651}$ With respect to the localisation of the place where the damage occurred or may occur, the CJEU ruled that "the occurrence of damage and/or the likelihood of its occurrence arise" from the mere accessibility of the alleged copyrighted photographs via the website in Member State of the court seised. ${ }^{652}$ Hence, it was irrelevant that EnergieAgentur's website had not been directed to the forum state. ${ }^{653}$ Finally, the CJEU reiterated that "in light of Article 5(3) of Regulation No 44/2001 and the principle of territoriality" the jurisdiction of the court is limited to damage caused by the alleged copyright infringement within the forum state. ${ }^{654}$

Returning to the question referred to, the CJEU ruled that in case of an alleged infringement of copyrights protected by the forum state, the court of the Erfolgsort has jurisdiction under to Article 7(2) Brussels Ibis to hear an action for damages caused by a copyright infringement resulting from the placing of protected photographs online on a website accessible in the forum state. ${ }^{655}$ Yet, the jurisdiction of the latter court is limited to the damage caused in the forum state. ${ }^{656}$

\subsection{The so-called Pinckney doctrine}

Considering the abovementioned rulings Pinckney, Hi Hotel, and Pez Hejduk, the CJEU mainly focused on the interpretation of the connecting factor 'the place where the damage occurred', the Erfolgsort under Article 7(2) Brussels Ibis. The CJEU's interpretation in these three rulings provided the two following broad connecting factors. First, the alleged copyright infringement has to involve copyrights that are protected by the forum state, this criterion will be referred to as the locus protectionis criterion. ${ }^{657}$ Second, the possibility should exist that the

\footnotetext{
${ }^{648}$ Case C-441/13 Pez Hejduk v. EnergieAgentur. NRW GmbH, para. 24-26. See Torremans (2017, pp. 236-240) on the possible difference between the CJEU's interpretation of the Handlungsort in the rulings Wintersteiger and Pez Hejduk.

${ }^{649}$ Case C-523/10 Wintersteiger, para. 36.

${ }^{650}$ Case C-441/13 Pez Hejduk, para. 22.

${ }^{651}$ Case C-441/13 Pez Hejduk, para. 30.

${ }^{652}$ Case C-441/13 Pez Hejduk, para. 34.

${ }^{653}$ Case C-441/13 Pez Hejduk, para. 33.

${ }^{654}$ Case C-441/13 Pez Hejduk, para. 36-37.

${ }^{655}$ Case C-441/13 Pez Hejduk, para. 38.

${ }^{656}$ Case C-441/13 Pez Hejduk, para. 38.

${ }^{657}$ In the annotation to the copyright infringement case of $H \& M v$. G-Star decided by the Dutch Supreme Court on 7 December 2012, Strikwerda employed the term "forum van de locus protectionis" to indicate that the forum state protects the intellectual property right involved. See Strikwerda 2013, sub. 6-7. With respect to the interpretation of the Erfolgsort in the trademark infringement case of Wintersteiger v. Products $4 U$ Sondermachinenbau, Polak (2012, sub 4-5) also employed the term "forum loci protectionis". Schaafsma (2016,
} 
alleged damage may occur within the forum state, referred to as the 'likelihood of damage' criterion. With respect to alleged copyright infringements via the Internet, the latter factor can be denoted as the criterion of accessibility ${ }^{658}$ since the CJEU held that the mere accessibility of the website involving the alleged copyright infringement entails the likelihood of damage. ${ }^{659}$ The jurisdiction of the court competent on the basis of these connecting factors will be limited to the damage sustained in the forum state. This territorially limited approach to jurisdiction has been referred to as the mosaic approach. ${ }^{660}$ The next chapter will set out the assessment framework that will be employed in this dissertation to rethink the abovementioned so-called Pinckney doctrine. In the rulings Pinckney and Hi Hotel, the CJEU seemed to have established a so-called third party-based approach to jurisdiction under Article 7(2) Brussels Ibis that will be examined in chapter five. ${ }^{661}$

This dissertation will not focus on the CJEU's interpretation of the "place of the event giving rise to the damage", ${ }^{662}$ the Handlungsort, under Article 7(2) Brussels Ibis in cross-border copyright infringement cases. ${ }^{663}$ In the Pinckney ruling, the CJEU merely held that the Handlungsort was not situated in forum state without any further reasoning. ${ }^{664}$ In the Pez Hejduk ruling, the CJEU provided an interpretation of the Handlungsort that has been equal to the interpretation of the Handlungsort in the Wintersteiger ruling ${ }^{665}$. The CJEU localised the Handlungsort in the place where the alleged infringer had its seat since this was the place of activation of the process for technical display of the infringing content on the website. ${ }^{666}$ The Handlungsort will therefore generally coincide with the place where the alleged infringer is domiciled. ${ }^{667}$ In the Wintersteiger ruling, the CJEU emphasised that the place of the server as

pp. 402-403) also refers to the term locus protectionis in the context of jurisdiction under Article 7(2) Brussels Ibis in intellectual property infringement cases. As mentioned in paragraph 2.3.2, the term territorium protectionis would be more accurate because the protection involves a territory and not just a place. See Schaafsma 2009, pp. 267, 270. Chapter five will elaborate on the concept of locus protectionis as connecting factor in the rulings Pinckney, Hi Hotel and Pez Hejduk.

${ }^{658}$ In the Opinion of the joined cases C-509/09 and C-161/10 eDate Advertising v. X and Martinez v. MGN Limited, Advocate General Cruz Villalón referred to "the criterion of accessibility" as connecting factor regarding the special jurisdiction rule of Article 7(2) Brussels Ibis with respect to infringement of personality rights via the Internet. See the Opinion of Advocate General Cruz Villalón delivered on 29 March 2011 in the joined cases C509/09 and C-161/10 eDate Advertising v. X and Martinez v. MGN Limited, para 56 footnote 39.

659 See Case C-170/12 Peter Pinckney v. KGD Mediatech AG, para. 44; Case C-441/13 Pez Hejduk v. EnergieAgentur. NRW GmbH, para. 34.

${ }^{660}$ See paragraph 1.1.4.

${ }^{661}$ See paragraph 5.2.3.

${ }^{662}$ See Case C-21/76 Handelskwekerij G.J. Bier v. Mines de Potasse d'Alsace SA.

${ }^{663}$ Although most scholars favour the place of infringement as connecting factor (See paragraph 5.2.1), this dissertation will focus on the Erfolgsort as connecting factor in the context of rethinking the CJEU's approach to jurisdiction under Article 7(2) Brussels in cross-border copyright infringement disputes. Nuyts argues that the dichotomy Handlungsort and Erfolgsort is now "firmly enshrined" in the CJEU's case law and "there does not seem to be any determinative reason why it should not be applies also to infringement matters". He also argues that this distinction is relevant in the context of the territorial limitation of jurisdiction of the court of the Erfolgsort. See Nuyts 2008, p. 127.

${ }^{664}$ Case C-170/12 Peter Pinckney v. KGD Mediatech AG, para. 29.

${ }^{665}$ See paragraph 3.4.3.

${ }^{666}$ Case C-441/13 Pez Hejduk v. EnergieAgentur. NRW GmbH, para. 24-26. See also Case C-523/10 Wintersteiger $A G$ v. Products $4 U$ Sondermaschinenbau GmbH, para. 34-36.

${ }^{667}$ However, "in some situations a distinction may be established between the defendant's habitual residence and the place of substantial infringing acts". For instance, if an infringement is caused by a single person who is temporarily "working" in a country where he/she does not reside. Such a "division between defendant's habitual 
connecting factor should be rejected in view of the objective of foreseeability. ${ }^{668}$ Similar to the forum rei, the court of the Handlungsort generally has jurisdiction regarding the entire case. ${ }^{669}$ The table in paragraph 4.3.2 will briefly demonstrate the Handlungsort established by the CJEU in seminal rulings under Article 7(2) Brussels Ibis.

\subsubsection{The influence of the territorial principle related to copyrights according to the Pinckney doctrine}

Pursuant to the rulings Pinckney, Hi Hotel and Pez Hejduk, the territorial principle related to copyrights influenced the CJEU's approach to jurisdiction in cross-border copyright infringement cases in two ways. First, the locus protectionis criterion in the first pillar of the Pinckney doctrine ${ }^{670}$ reflects the territoriality principle that copyright are only protected by the state that granted the right. Paragraph 5.3.1 will focus on the discussion whether this principle of substantive copyright law should be a prerequisite to establish jurisdiction under Article 7(2) Brussels Ibis.

Second, the CJEU limited the jurisdiction of the court due to the territoriality principle related copyrights. ${ }^{671}$ As indicated in paragraph 2.3.4.1, in view of the globalisation and the Internet, scholars have argued that a court can under certain conditions obtain jurisdiction regarding the entire copyright infringement dispute. The chapters six and seven will discuss various of these scholarly proposals and approaches of courts in the European Union and United States of America. Paragraph 5.3.1 will set out arguments against the territorially limited jurisdiction under the Pinckney doctrine. Paragraph 5.3.2 will particularly discuss the (desirable) role of the territorial protection of copyrights regarding the scope of the court's jurisdiction.

\footnotetext{
residence and the place of substantial infringing acts" may occur "due to various circumstances, such as international outsourcing of services or cross-border commuting". See Report International Law Association Sydney Conference (2018) Intellectual Property and Private International Law, Kono, De Miguel Asensio \& Metzger (eds.), p. 5. See also Larsen 2018(a), p. 180.

${ }^{668}$ Case C-523/10 Wintersteiger AG v. Products $4 U$ Sondermaschinenbau GmbH, para. 36.

${ }^{669}$ See the table in paragraph 4.3.2 on seminal rulings involving the interpretation of the special jurisdiction rule under Article 7(2) Brussels Ibis.

${ }^{670}$ See paragraph 3.2.3.

${ }^{671}$ See paragraphs 3.2.3, 3.3.2 and 3.4.3.
} 


\subsubsection{Table on the jurisdictional framework referred to as the Pinckney doctrine}

The table in this paragraph demonstrates the three layers of the Pinckney doctrine. Chapter five of this dissertation will examine these three layers based on the assessment framework that will be set up in the next chapter.

\begin{tabular}{|l|l|l|}
\hline first layer & \multicolumn{2}{|l|}{ locus protectionis } \\
\hline second layer & 'likelihood of damage' & $\begin{array}{l}\text { mere accessibility of } \\
\text { the alleged copyright } \\
\text { infringing content via } \\
\text { the Internet }\end{array}$ \\
\hline third layer & territorially limited jurisdiction \\
\hline
\end{tabular}

\subsection{European Union jurisdictional rules related to infringements of intellectual property rights}

As mentioned in paragraph 2.2.1, copyrights fall under the category of intellectual property rights. With respect to (threatened) infringements of intellectual property rights, ${ }^{672}$ the following jurisdiction rules of the Brussels Ibis will generally be applicable. ${ }^{673}$ Based on the general jurisdiction rule of Article 4 Brussels Ibis, the court of the Member State where the defendant is domiciled will be competent to adjudicate the entire case. In addition, the special jurisdiction rule of Article 7(2) Brussels Ibis confers jurisdiction to the court of "the place where the harmful event occurred or may occur". Paragraph 3.6.2 will discuss the CJEU's interpretation of this special jurisdiction rule regarding an alleged infringement of a national trade mark.

Article 24(4) Brussels Ibis stipulates that if the proceedings involve the "registration or validity of patents, trademarks, designs or other similar rights required to be deposited or registered", the courts of the Member State in which the deposit or registration took place, or has been applied for, will have so-called exclusive jurisdiction, regardless of the domicile of parties. Thus, in case the infringement dispute involves the issue of validity of the aforementioned intellectual property rights, the plaintiff should bring the case before the court of the Member State of registration.

\footnotetext{
${ }^{672}$ See paragraph 2.2 .1 on the concept of intellectual property rights.

${ }^{673}$ See also Pertegás Sender 2002, p. 106.
} 
The abovementioned jurisdiction rules of the Brussels Ibis Regulation will nevertheless not be applicable with respect to infringements of European Union intellectual property rights that are governed by European Union law that contains special jurisdiction rules. ${ }^{674}$ European Union intellectual property rights are European Union trade marks, ${ }^{675}$ Community design rights, ${ }^{676}$ Community plant variety rights, ${ }^{677}$ and European patents ${ }^{678}$. For instance, the Regulation (EU) No 2017/1001 of the European Parliament and of the Council of 14 June 2017 on the European Union trade mark (hereinafter EU trade mark Regulation) ${ }^{679}$ provides special rules on jurisdiction with respect to an alleged infringement of a European Union trademark that prevail above the provisions of the Brussels Ibis Regulation. ${ }^{600}$ The EU trade mark Regulation stipulates that the Brussels Ibis Regulation will be applicable to all actions relating to European Union trade marks except where this Regulation derogates from those rules. ${ }^{681}$ The special jurisdiction rules applicable to torts under the Brussels Ibis Regulation have been excluded by the European Union trade mark Regulation. ${ }^{682}$ As will be demonstrated in the next paragraph, the latter Regulation therefore provides its own jurisdiction rules regarding infringements of European Union trade marks. ${ }^{683}$

The European Union law related to European Union intellectual property rights has required Member States to establish special national courts to assess alleged infringements of European intellectual property rights such as European Union trade mark courts, ${ }^{684}$ Community

\footnotetext{
${ }^{674}$ See Article 122-126 of the Regulation (EU) No. 2017/1001 of the European Parliament and of the Council of 14 June 2017 on the European Union trade mark (OJ L 154, 16.6.2017, pp. 1-99); Article 80-83 of the Council Regulation (EC) No. 6/2002 of 12 December 2001 on Community designs (OJ L 3, 5.1.2002, pp. 1-24); Article 101 of the Council Regulation (EC) No. 2100/94 of 27 July 1994 on Community plant variety rights (OJ L 227, 1.09.1994, pp. 1-30). See also Article 69(2) of the Convention for the European Patent for the common market (Community Patent Convention) (OJ L 71, 26.1.1976, pp. 1-28).

${ }^{675}$ Regulation (EU) No. 2017/1001 of the European Parliament and of the Council of 14 June 2017 on the European Union trade mark (OJ L 154, 16.6.2017, pp. 1-99).

${ }^{676}$ Council Regulation (EC) No. 6/2002 of 12 December 2001 on Community designs (OJ L 3, 5.1.2002, pp. 124).

${ }^{677}$ Council Regulation (EC) No. 2100/94 of 27 July 1994 on Community plant variety rights (OJ L 227, 1.09.1994, pp. 1-30).

${ }^{678}$ Convention for the European Patent for the common market (Community Patent Convention) (OJ L 71, 26.1.1976, pp. 1-28).

${ }^{679}$ Regulation (EU) No. 2017/1001 of the European Parliament and of the Council of 14 June 2017 on the European Union trade mark (OJ L 154, 16.6.2017, pp. 1-99). Previous Regulations are the Council Regulation (EC) No. 40/94 of 20 December 1993 on the Community trade mark (OJ L 11, 14.01.1994, pp. 1-66) and the Council Regulation (EC) No. 207/2009 of 26 February 2009 on the European Union trade mark (OJ L 78, 24.3.2009, p. 1). ${ }^{680}$ See Article 122-126 European Union trade mark Regulation. See Case C-360/12 Coty Germany GmbH v. First Note Perfumes $N V$, para. 25-27. See also the Opinion of the Advocate General Jääskinen delivered on 21 November 2013 in the case C-360/12 Coty Germany GmbH v. First Note Perfumes NV, para. 36. See paragraph 5.2.3.1.3 on the case of Coty Germany GmbH v. First Note Perfumes NV.

${ }^{681}$ Recital 32 in the preamble to the European Union trade mark Regulation. See also Article 122 of the European Union trade mark Regulation.

${ }^{682}$ Article 122(2) of the European Union trade mark Regulation.

${ }^{683}$ See Article 122-126 of the European Union trade mark Regulation. See also paragraph 5.2.3.1.3 on the CJEU's interpretation in the ruling Coty Germany GmbH v. First Note Perfumes NV of the special jurisdiction rule in Article 93(5) of the Community trade mark Regulation, currently Article 125(5) of the European Union trade mark Regulation, that confers jurisdiction to "the courts of the Member State in which the infringement has been committed or threatened".

${ }^{684}$ Article 123-126 of the Regulation (EU) No. 2017/1001 of the European Parliament and of the Council of 14 June 2017 on the European Union trade mark (OJ L 154, 16.6.2017, pp. 1-99).
} 
designs courts, ${ }^{685}$ and Community patent courts ${ }^{686}$. An Agreement has been concluded that aims to confer jurisdiction to a single Unified Patent Court in case an alleged infringement of a European patent with unitary effect that has occurred or may occur in the Contracting Member States. ${ }^{67}$ So far 25 states have signed the Agreement on a Unified Patent Court, the conditions to establish the Unified Patent Court are not yet satisfied. ${ }^{688}$

The European Union legislators did not (yet) establish a (unitary) European Union copyright, nor did they enact rules that force Member States to establish European Union copyright courts or a Unified Copyright Court. As will be demonstrated in paragraph 5.3.5, it is questionable whether specialized copyright courts would be more efficient and whether a Unified Copyright Court could be a valid possibility.

\subsubsection{The place of infringement as connecting factor in case of European Union trade mark infringements}

As mentioned in the previous paragraph, European Union trade mark courts must apply the jurisdiction rules of the EU trade mark Regulation in infringement cases. Based on Article 125(1) EU trade mark Regulation, the alleged infringer can be sued in a court of the Member State in which he is domiciled or established. If the alleged infringer is neither domiciled nor has an establishment in any of the Member States, he can be sued in the court of the Member State in which the plaintiff is domiciled or established. ${ }^{689}$ If neither the alleged infringer nor the plaintiff is domiciled or established in a Member State, the alleged infringer can get sued in the courts of the Member State where the European Union Intellectual Property Office has its seat. ${ }^{690}$ The latter courts have jurisdiction in respect of "acts of infringement committed or threatened within the territory of any of the Member States". 691

As an alternative to the abovementioned jurisdiction rules, Article 125(5) EU trade mark Regulation provides jurisdiction to the courts of the Member State in which the act of infringement has been committed or threatened. The jurisdiction of these courts will be limited to the acts of infringement committed or threatened within the territory of the Member State in which the court is situated. ${ }^{692}$ The CJEU has interpreted the 'place where the act of infringement has been committed or threatened' in two cases. The ruling in the case of Coty Germany GmbH

\footnotetext{
${ }^{685}$ Article 80-83 of the Council Regulation (EC) No 6/2002 of 12 December 2001 on Community designs (OJ L 3, 5.1.2002, pp. 1-24).

${ }^{686}$ Article 17 of the Protocol on the settlement of litigation concerning the infringement and validity of community patents (Protocol on litigation) (OJ L 401, 30.12.89, pp. 34-44) annexed to the Convention for the European Patent for the common market (OJ L 71, 26.1.1976, pp. 1-28).

${ }^{687}$ See Agreement on a Unified Patent Court (OJ L 175, 20.06.2013, pp. 1-40). See also Regulation (EU) No 1257/2012 of the European Parliament and of the Council of 17 December 2012 implementing enhanced cooperation in the area of the creation of unitary patent protection (OJ L 361, 31.12.2012, pp. 1-8); Regulation (EU) No 1260/2012 of 17 December 2012 implementing enhanced cooperation in the area of the creation of unitary patent protection with regard to the applicable translation arrangements (OJ L 361, 31.12.2012, pp. 89-92).

${ }^{688} \mathrm{See}$ https://www.unified-patent-court.org/about for a list on the states that signed the Agreement on a Unified Patent Court (OJ L 175, 20.06.2013, pp. 1-40).

${ }^{689}$ Article 125(2) EU trade mark Regulation.

${ }^{690}$ Article 125(3) EU trade mark Regulation.

${ }^{691}$ Article 126(1)(a) EU trade mark Regulation.

${ }^{692}$ Article 126(2) EU trade mark Regulation.
} 
v. First Note Perfumes $N V$ will be demonstrated in paragraph 5.2.3.1.3. ${ }^{693}$ This paragraph will set out the CJEU's interpretation in the case of AMS Neve Ltd and Others v. Heritage Audio SL, Pedro Rodriguez Arribas. ${ }^{694}$ Unlike the Coty case, the alleged infringement of a European Union trade mark in the AMS Neve case has been internet-related.

In the latter case, a company named AMS Neve, established in the United Kingdom, sued Heritage Audio, a company established in Spain, for copyright infringement before the Intellectual Property and Enterprise Court of the United Kingdom. AMS claimed as proprietor of a European Union trade mark that Heritage Audio has advertised and offered for sale on a website to consumers in the United Kingdom imitations of goods of AMS Neve that bear a sign identical or similar to that trade mark.

The CJEU had to focus on the interpretation of the wording "Member State in which the act of infringement has been committed" as currently laid down in Article 125(5) European Union trade mark Regulation. ${ }^{695}$ By referring to the L'Oréal and Others ruling, ${ }^{696}$ the CJEU held that acts allegedly committed by the defendant that "consist of advertising and offers for sale displayed electronically with respect to products bearing a sign identical or similar to an EU trade mark without the consent of the proprietor of that mark" fall within the scope of Article 9(2)(b) and (e) European Union trade mark Regulation and these acts are deemed to be committed "in the territory where the consumers and traders to whom that advertising and those offers for sale are directed are located". 697

The CJEU also reasoned that if the connecting factor "were to be interpreted as meaning that it refers to the Member State in the territory of which the person carrying out those commercial acts set up his website and activated the display of his advertising and offers for sale", this factor would be ineffective as alternative forum since it would coincide with the forum rei rule in Article 125(1) EU trade mark Regulation. ${ }^{698}$ The "place where the defendant took decision or technical measures to activate a display on a website" would also be difficult or even impossible to identify and prove. ${ }^{699}$ Finally, the CJEU argued that from a perspective of the 'close connection' requirement, also referred to as the "factor of proximity", "the EU trade mark courts of the Member State where the consumers or traders, to whom such advertising and offers for sale are directed are resident, are particularly suited to assessing whether the alleged infringement exists". ${ }^{700}$

Due to the territorially limited jurisdiction, the 'directed activities' criterion may entail multiple competent courts. The CJEU emphasised that the rules on lis pendens will not be

\footnotetext{
${ }^{693}$ Case C-360/12 Coty Germany GmbH v. First Note Perfumes NV.

${ }^{694}$ Case C-172/18 AMS Neve Ltd and Others v. Heritage Audio SL, Pedro Rodriguez Arribas.

${ }^{695}$ Case C-172/18 AMS Neve, para. 43. Article 97(5) of Regulation No 207/2009 the Council Regulation (EC) No. 207/2009 of 26 February 2009 on the European Union trade mark (OJ L 78, 24.3.2009, p. 1) has been replaced by Article 125(5) of the Regulation (EU) No 207/1001 of the European Parliament and of the Council of 14 June 2017 on the European Union trade mark (OJ L 154, 16.6.2017, pp. 1-99).

${ }^{696}$ Case C-324/09 L'Oréal and Others v. eBay, para. 63.

${ }^{697}$ Case C-172/18 AMS Neve, para. 47.

${ }^{698}$ Case C-172/18 AMS Neve, para. 50.

${ }^{699}$ Case C-172/18 AMS Neve, para. 51.

${ }^{700}$ Case C-172/18 AMS Neve, para. 57.
} 
applicable; ${ }^{701}$ although the infringement actions involve the same parties and the use of the same sign, they do not relate to the same territory and therefore do not have the same subject matter. ${ }^{702}$ Hence, the CJEU claimed that there will be no risk of irreconcilable decisions since the infringement actions relate to distinct territories. ${ }^{703}$

In the ASM Neve case, the CJEU held that the 'directed activities' criterion has been satisfied as "it is apparent from the content of the website and the platforms at issue" that the advertising and the offers for sale involving the infringement of the EU trade mark were targeted at consumers and traders situated in the forum state the United Kingdom; particularly, in view of "the details contained on that website and those platforms with respect to the geographical areas were the products at issue were to be delivered". ${ }^{704}$ In chapter six, the application of the 'directed activities' approach to jurisdiction under Article 7(2) Brussels Ibis in cross-border copyright infringement cases will be assessed as an alternative to the Pinckney doctrine.

\subsubsection{The Wintersteiger ruling}

Before the three rulings related to copyright infringements as discussed in this chapter, the CJEU provided a ruling on the interpretation of Article 7(2) Brussels Ibis regarding an infringement of another intellectual property right namely a national trademark. This case of Wintersteiger $A G$ v. Products $4 U$ Sondermaschinenbau $G m b H^{705}$ concerned a plaintiff named Wintersteiger that had been a company established in Austria and the holder of the national trade mark 'Wintersteiger'. The defendant was a company called Products $4 \mathrm{U}$, established in Germany, that allegedly used this national trade mark 'Wintersteiger' as keyword with AdWords on the website google.de which took internet users directly to the website of that company. Wintersteiger had requested an Austrian court to issue an injunction to cease the alleged infringement of the national trademark. Yet, Products $4 U$ argued that the alleged website involved a German top-level domain name and they could therefore not be sued in Austria.

The CJEU had to address the issue whether the Austrian court could obtain jurisdiction under Article 7(2) Brussels Ibis. With respect to the interpretation of 'the place where the damage occurred', the Erfolgsort, the CJEU held that the earlier interpretation regarding infringements of personality rights ${ }^{706}$ cannot be applied to infringements of intellectual property

\footnotetext{
701 The rules on lis pendens have to minimise the possibility of concurrent proceedings and irreconcilable judgments (see recital 21 in the preamble to the Brussels Ibis Regulation). Pursuant to Article 29(1) Brussels Ibis, "where proceedings involving the same cause of action and between the same parties are brought in the courts of different Member States, any court other than the court first seised shall of its own motion stay proceedings until such time as the jurisdiction of the court first seised is established".

${ }^{702}$ Case C-172/18 AMS Neve v. Heritage Audio, para. 47.

${ }^{703}$ Case C-172/18 AMS Neve, para. 47.

${ }^{704}$ Case C-172/18 AMS Neve, para. 56. The CJEU referred to the case of C-324/09 L'Oréal and Others v. eBay, para. 64 and 65. See also paragraph 6.1.2 on the application of the factors of the Pammer and Alpenhof ruling with respect of the 'directed activities' approach to cross-border copyright infringement cases.

${ }^{705}$ Case C-523/10 Wintersteiger AG v. Products $4 U$ Sondermaschinenbau GmbH, para. 37.

${ }^{706}$ See Case C-68/93 Shevill and Others v. Presse Alliance and the joined Cases C-509/09 and C-161/10 eDate Advertising GmbH v. X and Olivier Martinez and Robert Martinez v. MGN Limited.
} 
rights. ${ }^{707}$ The CJEU referred to the Opinion of Advocate General Cruz Villalón who argued that the protection of personality rights differs significantly from intellectual property rights which are protected on a territorial basis. ${ }^{708}$ Subsequently, the CJEU reasoned that "the objective of foreseeability and that of sound administration of justice" militate in favour of conferring jurisdiction to the courts of the Member State in which the trademark is registered..$^{709}$ "Those courts have the power to determine all the damage allegedly caused to the proprietor of the protected right because of an infringement of it and to hear an application seeking cessation of all infringements of that right" ${ }^{710}$

Since the trademark had been registered in Austria, the Austrian court could thus obtain full jurisdiction in the Wintersteiger case regardless of the fact that the website involved had been operated under another country-specific domain name. ${ }^{711}$ As explained in paragraph 3.5, the CJEU also adopted the locus protectionis criterion under the Pinckney doctrine.

With respect to the interpretation of the place of the event giving rise to the damage, the Handlungsort, the CJEU held that the territorial protection of a national trademark does not "exclude the international jurisdiction of courts other than the courts of the Member State in which the trade mark is registered". ${ }^{712}$ The locus protectionis criterion is therefore not a prerequisite to establish jurisdiction based on the Handlungsort. The CJEU emphasised that the Handlungsort as connecting factor is "particularly helpful in relation to the evidence and the conduct of proceedings". ${ }^{713}$ The CJEU considered the place of establishment of the alleged infringer as Handlungsort since this used to be "the place where the activation of the display process is decided". ${ }^{714}$ In view of the objective of foreseeability, the latter place is an "a definite and identifiable place" unlike the place of establishment of the server. ${ }^{715}$ As mentioned in paragraph 3.4.3, the CJEU also adopted the abovementioned interpretation of Handlungsort in the Pez Hejduk ruling.

\footnotetext{
${ }^{707}$ Case C-523/10 Wintersteiger AG v. Products $4 U$ Sondermaschinenbau GmbH, para. 24.

708 Case C-523/10 Wintersteiger, para. 24-25. Opinion of Advocate General Cruz Villalón delivered on 16 February 2012 in the case C-523/10 Wintersteiger AG v. Products $4 U$ Sondermaschinenbau GmbH, para. 20. See paragraph 6.6.2 on the so-called 'necessary means' effects-based approach to jurisdiction under Article 7(2) Brussels Ibis proposed by Advocate General Cruz Villalón in the Wintersteiger case.

${ }^{709}$ Case C-523/10 Wintersteiger, para. 27.

${ }^{710}$ Case C-523/10 Wintersteiger, para. 28.

${ }^{711}$ Case C-523/10 Wintersteiger, para. 29.

${ }^{712}$ Case C-523/10 Wintersteiger, para. 30.

${ }^{713}$ Case C-523/10 Wintersteiger, para. 32-33.

${ }^{714}$ Case C-523/10 Wintersteiger, para. 3.

${ }^{715}$ Case C-523/10 Wintersteiger, para. 34-37.
} 



\section{Part II}

Rethinking the CJEU's approach to jurisdiction in cross-border copyright infringement cases 



\section{Chapter 4}

The assessment framework 

To rethink the CJEU's approach to jurisdiction in cross-border copyright infringement cases, the so-called Pinckney doctrine as set out in paragraph 3.5, this chapter aims to provide an assessment framework. From a legitimate perspective, this framework will contain principles that should be pursued by the CJEU when interpreting the special jurisdictional rule of Article 7(2) Brussels Ibis in cross-border copyright infringement cases. The assessment framework will also be applied with respect to the alternative approaches to jurisdiction that will be demonstrated in the chapters six and seven of this dissertation.

To establish this assessment framework, it is important to consider the leeway that the CJEU generally has regarding the interpretation of the special jurisdiction rule enshrined in Article 7(2) Brussels Ibis, in particular in copyright infringement cases. Therefore, this chapter will first describe the much-discussed issue regarding the role of the CJEU as interpreter of European Union law. ${ }^{716}$ Should the CJEU be an "objective interpreter" of European Union $\mathrm{law}^{717}$ or should the CJEU always opt for the interpretation that enhances an "ever closer union"718? This chapter will concisely outline these opposing views on the role of the CJEU as interpreter of European Union law. In line with the prevailing view on the interpreting role of European courts, this dissertation will advocate to adopt the role of the CJEU as "law-finder" 719 .

Subsequently, this chapter will describe the common methods of interpretation as accepted by the CJEU and doctrine to 'find' the law. In particular the principles and objectives underlying the special jurisdiction rule of Article 7(2) Brussels Ibis will be demonstrated. In the context of the so-called precedent-based method of interpretation, this chapter will also provide a brief description of the CJEU's seminal rulings on the "place where the damage occurred" as basis for jurisdiction under Article 7(2) Brussels Ibis.

Finally, this chapter will adopt four principles for the assessment framework that have to guarantee that the attribution of jurisdiction under Article 7(2) Brussels Ibis in cross-border copyright infringement cases will take place in a legitimate way. While the first three principles are derived from the area of private international law, ${ }^{720}$ the third principle originates from the field of copyright law. ${ }^{721}$

In view of the method of contextual interpretation, ${ }^{722}$ this chapter will demonstrate that the (possible) effect of the Geo-blocking Regulation on the approach to jurisdiction in cross-border copyright cases should also be a part of the assessment framework of this dissertation. Although the territorial principle related to copyright will not be a part of the assessment framework, chapter five will examine the (desirable) influence of this principle on the approach to jurisdiction under Article 7(2) Brussels Ibis in cross-border copyright infringement cases. ${ }^{723}$ In addition, chapter five will demonstrate the influence of the field of public international law. ${ }^{724}$

\footnotetext{
716 See Horsley 2013, pp. 931-964; Tridimas 1996, p. 203.

${ }^{717}$ Hartley 1999, pp. 22-65. See paragraph 4.1.2.

${ }^{718}$ See paragraph 4.1.1.

${ }^{719}$ Pitlo employed the term law-finder with respect to judges in Europe. See Pitlo 1975, p. 12. See also paragraph 4.1.3.

${ }^{720}$ See paragraph 4.2.4.2.

${ }^{721}$ See paragraph 4.4 .

${ }^{722}$ See paragraph 4.2 .3 .

${ }^{723}$ See paragraphs 5.3.2 and 5.3.3.1.

${ }^{724}$ See paragraph 5.3.3.1 and 5.3.4.1.
} 


\subsection{The CJEU as interpreter of European Union law}

Paragraph 3.1 demonstrated that under the conditions of Article 267 TFEU, the CJEU has the task to interpret provisions of European Union law when Member State courts refer a question about the provisions. The leeway that the CJEU has regarding the interpretation of provisions of European Union law relates to the debated issue of what should be the role of the CJEU as interpreter of European Union law. ${ }^{725}$ The next paragraphs will therefore describe the three main strands regarding this vexed issue.

\subsubsection{The CJEU as "the motor of European integration"726}

Many scholars claim that the CJEU should always interpret European Union law in favour of an "ever closer union among the peoples of Europe" to enhance European integration. ${ }^{727}$ According to these scholars the CJEU must fulfil its role as "the motor of integration". ${ }^{28}$ Paragraph 4.2.4.1 will return to the concept of pro-integrationist interpretation ${ }^{729}$ in the context of the teleological method of interpretation. Based on the foregoing view, the CJEU can be regarded as a political actor that "plays a useful role in the European integration process". ${ }^{730}$

Scholars generally acknowledge that the CJEU's interpretations of European Union law have substantially contributed to the process of European integration. ${ }^{731}$ Most scholars have argued that the CJEU's active role has been the inevitable result of the special characteristics of the European Union legal order namely the "deep political and legal pluralism". ${ }^{732}$ At the external level, legal pluralism originates "from the increased communication and interdependence of the European Union legal order with the international and foreign legal orders". ${ }^{733}$ While at the internal level, legal pluralism originates, inter alia, by "the plurality of constitutional sources (both European and national)". ${ }^{734}$ It has been claimed that the CJEU in particular had to play an active role due to the open-ended, and often vague, provisions of the founding Treaties of the European Communities ${ }^{735}$ and the fact that for a long period there has

\footnotetext{
${ }^{725}$ See also Lenaerts and Gutiérrez-Fons on the relationship between the role of the CJEU and judicial legitimacy. See Lenaerts \& Gutiérrez-Fons 2013, p. 28.

${ }^{726}$ Horsley 2013, p. 931. Dehousse (1998) refers to the CJEU as the "engine" of European integration.

${ }^{727}$ Mancini \& Keeling 1994, p. 186; Schepel \& Blankenburg 2001, p. 10. The preambles of the TEU and the TFEU both refer to the objective of 'an ever closer union among the peoples of Europe'. See also Article 1 TEU. Beck refers to rulings in which the CJEU explicitly employed the 'close union' objective. See Beck 2012, pp. 319-322. See, for instance, Case C-105/03 Maria Pupino, para. 36-43.

${ }^{728}$ Horsley 2013, p. 931. Dehousse (1998) refers to the CJEU as the "engine" of European integration.

${ }^{729}$ Beck 2012, p. 323; Conway 2013, p. 37.

${ }^{730}$ Muir, Dawson \& de Witte 2013, p. 1. See also Dehousse 1998, p. 82; Horsley 2013, p. 942.

${ }^{731}$ Bredimas 1978, pp. 177-181; Conway 2013, p. 52; Douglas-Scott 2002, pp. 210, 213; Poiares Maduro 1998, p. 12; Stone-Sweet 2004.

${ }^{732}$ Poiares Maduro 2010, p. 457. See also Beck 2012, pp. 161-186; De Waele 2012, pp. 53-54.

${ }^{733}$ Poiares Maduro 2010, p. 458.

734 Poiares Maduro 2010, p. 458.

${ }^{735}$ Bengoetxea 1993, p. vi; Coutinho 2015, pp. 183-184; Lenaerts 2013, p. 1307. See also Douglas-Scott 2002, pp. 210, 213; Kutscher 1976, p. I-34; Poiares Maduro 1998, p. 12; Stone-Sweet 2004. The founding Treaties of the European Communities are the European Coal and Steel Community Treaty signed on 18 April 1951, also known as the Treaty of Paris, entered into force on 23 July 1952 and expired 23 July 2002; the Treaty establishing the European Economic Community, referred to as the Treaty of Rome signed on 25 March 1957, entered into force
} 
been a "standstill on the part of the political (law and policy-making) institutions of the Community" 736 . Due to conflicting interests of the Member States it has often been difficult to reach "a political consensus", European Union law therefore frequently consists of vague concepts. ${ }^{737}$ In light of the foregoing, it has been argued that the CJEU "has been both forced and left free to develop its own judicial vision of European integration". ${ }^{738}$

The CJEU has provided several rulings that could be characterised as constitutional. ${ }^{739}$ Hence, the CJEU has regularly also been regarded as a constitutional court. ${ }^{740}$ Illustrative is the ruling of Van Gend \& Loos v. Nederlandse Administratie der Belastingen in which the CJEU held that the European "Community constitutes a new legal order of international law". ${ }^{741}$ The CJEU held that a particular provision of the Treaty establishing the European Economic Community of $1957^{742}$ therefore had direct effect in the Member States. ${ }^{743}$ The CJEU emphasised that a provision of European Union law needs to be interpreted not only based on its wording but also the spirit and the general scheme of the provision. ${ }^{744}$ In the well-known case of Costa v. E.N.E.L, the CJEU even established the principle of supremacy of European Union law above the national laws of the Member States. ${ }^{745}$

As illustrated above, the CJEU's active approach to facilitate the internal market has frequently been reflected in its interpretations of European Union law. ${ }^{746}$ Koopmans demonstrated that the CJEU has been employing the law as an instrument to achieve the policy aims of the European Union. ${ }^{747}$ In the case of Ingmar GB Ltd. v. Eaton Leonard Technologies

on 1 January 1958; and the European Atomic Energy Community Treaty on 25 March 1957, entered into force on 1 January 1958. Pursuant to Tridimas, the Treaty establishing the European Community provides no more than a framework traité cadre that need to be moulded by the CJEU, see Tridimas 2006, p. 18.

${ }^{736}$ See Bengoetxea 1993, p. 100. See also Kutscher 1976, p. I-35.

${ }^{737}$ Poiares Maduro 2010, p. 466. See also Nyman-Metcalf \& Papageorgiou 2005, pp. 78-79.

${ }^{738}$ Beck 2012, p. 7. See also Beck 2012, p. 317; Bredimas 1978, p. 144; Dehousse 1998, pp. 72-73, 95-96, 146147; Koopmans 2000, pp. 53, 55, 58; Mancini 1989, pp. 595-614; Nyman-Metcalf \& Papageorgiou 2005, pp. 7879.

${ }^{739}$ See Bengoetxea 1993, pp. v-vi; Conway 2013, pp. 26-40; Dehousse 1998, pp. 36-69; Douglas-Scott 2002, pp. 516-517; Mancini 1989, pp. 595-614; Poiares Maduro 1998, p. 7; Stein 1981, pp. 1-27; Stone-Sweet 2000, pp. 161-163; Weiler 1990, pp. 2405-2431. Examples of 'constitutional' rulings by the CJEU are Case C-26/62 Van Gend \& Loos v. Nederlandse Administratie der Belastingen; Case C-6/64 Flaminio Costa v. E.N.E.L; Case C106/77 Amministrazione delle Finanze dello Stato v. Simmenthal SpA; Case C-294/83 Les Verts v. European Parliament; joined Cases C-6/90 and 9/90 Andrea Francovich and Danila Bonifaci and Others $v$. Italian Republic. ${ }^{740}$ Biering 2010, p. 61; Constantinesco 2000, p. 76; De Búrca 2001, p. 6; Dehousse 1998, p. 34; Everling 1984, p. 1310; Shapiro \& Stone-Sweet 2002, p. 263; Stone-Sweet 2000, p. 1; Schepel \& Blankenburg 2001, p. 28; Tridimas 1996, p. 206.

${ }^{741}$ Case C-26/62 Van Gend \& Loos v. Nederlandse Administratie der Belastingen, p. 12.

${ }^{742}$ Treaty establishing the European Economic Community (EEC Treaty), also referred to as Treaty of Rome, signed on 25 March 1957 (not published in an official journal).

${ }^{743}$ Case C-26/62 Van Gend \& Loos v. Nederlandse Administratie der Belastingen, pp. 12-13.

${ }^{744}$ Case C-26/62 Van Gend \& Loos v. Nederlandse Administratie der Belastingen, p. 12.

${ }^{745}$ Case C-6/64 Flaminio Costa v. E.N.E.L., p. 594. See Beck 2012 p. 197; Lenaerts, Van Nuffel, Bray \& Cambien 2011, pp. 754-755; Stone-Sweet 2000, pp. 161-162.

${ }^{746}$ See Dehousse 1998, pp. 70-96; Koopmans 1986, p. 927. Seminal rulings by the CJEU on the functioning of the internal market are the cases C-8/74 Dassonville and C-120/78 Cassis de Dijon. This dissertation will employ the term European Union law, although the term Community law should actually be employed regarding the law established by the European Communities (the European Coal and Steel Community, the European Atomic Energy Community and the European Economic Community) before the European Union was established by the Treaty on European Union, also referred to as the Treaty of Maastricht, signed on 7 February 1992, entered into force 1 November 1993.

${ }^{747}$ Koopmans 1986, p. 927. 
Inc., the CJEU has interpreted a European Union Directive in favour of the internal market by ruling that the provisions of the Directive involved are mandatory in nature since they aim to "protect, for all commercial agents, freedom of establishment and the operation of undistorted competition in the internal market" ${ }^{748}$ These provisions therefore had to be applied regardless of the choice-of-law agreement of the parties and although the particular party had been established outside the European Union. ${ }^{749}$ In view of the principle of party autonomy, this ruling has nonetheless been criticised. ${ }^{750}$ Considering the aim of mandatory rules to serve "significant public interests", Verhagen argues that commercial agents should not be treated "on the same footing" as "structurally weaker parties" such as consumers and employees. ${ }^{751}$ With respect to the Ingmar ruling, Verhagen claims that "the Court of Justice' decision is an inward-looking approach, which focuses exclusively on the needs of the internal market". ${ }^{752}$

The rulings Pinckney, Hi Hotel, and Pez Hejduk also reflect a pro-integrationist interpretation since the CJEU employed the policy statement that "copyrights must be automatically protected, in particular by virtue of Directive 2001/29 [the Information Society Directive], in all Member States". ${ }^{753}$ This statement suits the policy aim of the Information Society Directive to provide a high level of protection of copyrights for the proper functioning of the internal market. ${ }^{754}$ Chapter five will further elaborate on the CJEU's pro-integrationist interpretation reflected in the concept of locus protectionis under the so-called Pinckney doctrine $^{755}$.

\subsubsection{Judicial activism}

Scholars who criticise the CJEU's active role regarding the interpretation of European Union law often employ the term judicial activism in contrast to "self-restraint". ${ }^{756}$ The term judicial activism generally indicates that the court has interpreted a provision beyond the law and therefore made law or policy. ${ }^{757}$ It has been claimed that this activism may cause "a decline in judicial authority and legitimacy". ${ }^{758}$ With respect to the interpretation of European Union law, several scholars accused the CJEU of judicial activism by broadly or narrowly interpreting provisions in favour of European integration. ${ }^{759}$ Scholars especially argue that the earlier

\footnotetext{
748 Case C-381/98 Ingmar GB Ltd. v. Eaton Leonard Technologies Inc., para. 24. See the Council Directive $86 / 653 /$ EEC of 18 December 1986 on the coordination of the laws of the Member States relating to self-employed commercial agents (OJ L 382, 31.12.1986, pp. 17-21).

${ }^{749}$ Case C-381/98 Ingmar v. GB Ltd. v. Eaton Leonard Technologies Inc., para. 26.

${ }^{750}$ Carruthers 2016, pp. 247-268; Verhagen 2002, pp. 135-154.

${ }^{751}$ Verhagen 2002, p. 145.

${ }^{752}$ Verhagen 2002, p. 153

${ }^{753}$ Case C-170/12 Peter Pinckney v. KGD Mediatech AG, para. 39; Case C-387/12 Hi Hotel HCF SARL v. Uwe Spoering, para. 36; Case C-441/13 Pez Hejdukv. EnergieAgentur. NRW GmbH, para. 22. See chapter 3.

${ }^{754}$ See recitals 1-11 in the preamble to the Information Society Directive.

${ }^{755}$ See the rulings Pinckney, Hi Hotel and Pez Hejduk in chapter 3.

${ }^{756}$ Constantinesco 2000, p. 76; Tridimas 1996, p. 200. See also Conway 2013, pp. 17-18.

${ }^{757}$ See also Allen 2012, p. 744; Bengoetxea 1993, p. 99; Holland 1991(a), p. vii; Rasmussen 1986, pp. 33-34; Urbano 2015, p. 162. The term 'judicial activism' was coined by A. Schlesinger in the article “The Supreme Court: 1947 ”' in Fortune magazine, 1947. See Green 2009, p. 1199.

${ }^{758}$ Rasmussen 1986, pp. 8-9. See also Saurugger \& Terpan 2017, p. 163.

${ }^{759}$ See Nyman-Metcalf \& Papageorgiou 2005, p. 68; Rasmussen 1986; Tridimas 1996, p. 203.
} 
mentioned constitutional rulings by the $\mathrm{CJEU}^{760}$ can be considered as law-making. ${ }^{761}$ It has also been claimed that the CJEU 'made law' regarding various fields of European Union law, such as competition law and the protection of human rights. ${ }^{762}$ As mentioned in paragraph 1.1.3, the CJEU has also played an active role regarding the harmonisation of copyright law.

It is often difficult to determine whether a court merely interpreted the law or 'made law' and to answer the question "when is a 'broad or 'narrow' interpretation legitimate or proper?" ${ }^{763}$ The line between legal and political issues is difficult to draw: "every dispute has political and legal aspects" 764 . Rasmussen argued that "the real problem consists of defining just how much leeway for involvement in judicial law and policymaking society deems to be acceptable". ${ }^{765}$ As noted by Tridimas, it is difficult to objectively determine the concept of judicial activism. ${ }^{766}$ Paragraph 4.2.4.1 of this dissertation will demonstrate that law and policy often meet at the CJEU on the basis of the teleological method of interpretation. ${ }^{767}$

The concept of activism, and whether it is legitimate or not, highly depends on the view of the role of the court as interpreter of the law. ${ }^{768}$ Based on the view of the CJEU as objective interpreter, the CJEU may be 'accused' of illegitimate activism when interpreting Article 7(2) Brussels Ibis in favour of copyright protection. While the same interpretation will be legitimate based on the view of the CJEU as motor of integration that should always interpret the law in favour of integration. Paragraph 4.1.3 will demonstrate the role of the CJEU that will be favoured in this dissertation namely the CJEU as 'law-finder'.

It should be noted that judicial activism has not always been regarded as a negative concept. ${ }^{769}$ For instance, some scholars claim that the CJEU must actively protect fundamental rights. ${ }^{770}$ Even in a democracy, the adherence to the rule of law may not guarantee the protection of minority rights. ${ }^{771}$ Paragraph 4.4.2.4 will elaborate on the role of the CJEU as active protector of fundamental rights in particular copyrights and the rights to access information. ${ }^{772}$

\footnotetext{
${ }^{760}$ See paragraph 4.1.1.

${ }^{761}$ Koopmans 1986, pp. 927-828; Rasmussen 1986, pp. 10-14.

${ }^{762}$ Schermers 1974, pp. 459-464. See also Herzog and Gerken 2008 who argue that the CJEU has acted as legislator in the case C-144/04 Werner Mangold v. Rüdiger Helm.

${ }^{763}$ Conway 2013, p. 49. See also Bengoetxea 1993, p. 102; Rasmussen 1988, p. 31.

${ }^{764}$ Bredimas 1978, p. 149 footnote 2. See also Nonet \& Selznick 2001, p. 83.

${ }^{765}$ Rasmussen 1986, p. 34. Rasmussen's test can be denoted as legal-sociological. See Rasmussen 1986, pp. 3637.

766 Tridimas 1996, p. 200.

${ }^{767}$ See also Poiares Maduro 2010, pp. 461-478.

${ }^{768}$ See also Dehousse 1998, pp. 123-124; Edward 1996, p. 30; Lenaerts \& Gutiérrez-Fons 2013, p. 28 note 195.

${ }^{769}$ See Holland 1991(b), p. 1; La Torre 2015, pp. 3-13; Rasmussen 1992, pp. 146-149.

${ }^{770}$ Mancini \& Keeling 1994, p. 187; Tridimas 2006, p. 302. See Dehousse 1998, p. 121 refers in this context to Rasmussen who criticised the CJEU's timidity on the field of human rights, while "blaming the CJEU for extending the reach of Community law". See also Rasmussen 1986.

${ }^{771}$ Holland 1991(b), p. 1; Nieuwenhuis, Heijer \& Hins 2017, pp. 31-32; Urbano 2015, p. 164. See also Dahl 2006 , p. 10; Palombella 2009, p. 36; Van Hoecke 2002, pp. 121-123.

${ }^{772}$ See also Muir 2013, pp. 76-101.
} 


\subsubsection{The CJEU as "objective interpreter"773}

Some scholars argue that the CJEU should be an objective interpreter of European Union law that means the CJEU must adhere to the text of the provision. ${ }^{774}$ These scholars generally support their view by referring to the democracy, the rule of law and the principle of separation of powers. ${ }^{775}$ Since the legislature has been elected in a democracy, it has been claimed that the courts' interpretation of the text of the law entails democratic legitimacy. ${ }^{776}$ Pursuant to Article 2 of the Treaty on European Union (hereinafter TEU), ${ }^{777}$ the European Union is founded on the values of respect for democracy and the rule of law. Scholars claim that the rule of law has also been reflected in Article 19(1) TEU that stipulates the CJEU "shall ensure that in the interpretation and application of the Treaties the law is observed". 778

The view of the CJEU as objective interpreter is connected with the principle of separation of powers. ${ }^{779}$ According to this principle, the legislative authority has the power to make law; the executive (or administrative) authority should execute and enforce the law; ${ }^{780}$ and the judicial authority needs to interpret the law in a particular case. ${ }^{781}$ This principle reflects the view that in states governed by the rule of law and the democratic principle, law should only be made by legislators "that are elected on the basis of free elections that take place on a regular basis". ${ }^{782}$ The separation of powers is related to the system of checks and balances. ${ }^{783}$ Lenaerts refers in this context to the "external legitimacy of the judiciary": "by drawing the borderline between law and politics, courts are in fact drawing the contours of their own legitimacy". ${ }^{784}$

Based on the foregoing view, the CJEU must provide an 'objective' interpretation of the words of the law involved: the CJEU should be "the mouthpiece of the [written] law" (la bouche de la loi). ${ }^{785}$ This view suits the doctrine of legalism that the courts' interpretation must adhere

\footnotetext{
${ }^{773}$ Hartley employed the term objective interpreter regarding the desired role of the CJEU as interpreter. See Hartley 1999, p. 22.

${ }^{774}$ Hartley 1999, pp. 22-23; La Torre 2015, p. 11; O’Neill 1994, pp. 7-33; Rasmussen 1986, pp. 29-33.

${ }^{775}$ Conway 2013, pp. 86-171; Hartley 1999, p. 23; O’Neill 1994, pp. 7-8, 23-28; Rasmussen 1986, pp. 42-46; Spaak 2009, pp. 487-488.

${ }^{776}$ Conway 2013, p. 20. See also MacCormick \& Summers 1991, pp. 481-482; See also Spaak 2009, pp. 487-488.

777 Treaty on European Union established by the Treaty of Maastricht, signed on 7 February 1992, entered into force 1 November 1993, and alternated by the Treaty of Lisbon signed on 13 December 2007, entered into force 1 December 2009 (OJ C 326, 26.10.2012, pp. 13-46), referred to as Treaty of Lisbon of 2007.

${ }^{778}$ See Lenaerts \& Gutiérrez-Fons 2013, p. 3.

779 The principle of separation of powers, also referred to the doctrine of trias politica, has been set out by Montesquieu in De l'esprit des lois (1748) Livre XI, Chapitre VI. Montesquieu favoured a balance of powers instead of a strict separation of powers. See Jaspers 1980, p. 31; Van Gerven \& Lierman 2010, p. 73. See also Pontier 1998, p. 57.

${ }^{780}$ Van Hoecke 2002, p. 120.

${ }^{781}$ Pontier 1998, p. 57.

782 Van Hoecke 2002, pp. 120-121.

${ }^{783}$ Lenaerts 2013, p. 1305. The system of checks and balances has been introduced by Montesquieu in De l'esprit des lois (1748).

${ }^{784}$ Lenaerts 2013, p. 1305.

${ }^{785}$ Montesquieu 1748, Livre XI, Chapitre VI. See the English translation of la bouche de la loi according to Advocate General Léger in the Opinion delivered on 12 March 1996 in the Case C-84/94 United Kingdom of Great Britain and Northern Ireland v. Council of the European Union, para. 165. See also Pontier 1998, p. 58.
} 
to the exact words of the law, ${ }^{786}$ also referred to as formal reasoning ${ }^{787}$. While this formalistic approach to interpretation seeks to guarantee legal certainty, ${ }^{788}$ the next paragraph will demonstrate that this approach became obsolete.

\subsubsection{The CJEU as "law-finder""}

At the end of the nineteenth century, the abovementioned doctrine of legalism begun to lose its prevailing position in Europe. ${ }^{790}$ Courts started to interpret private law more freely in order to connect the law to the needs of the society. ${ }^{791}$ This suits the earlier mentioned trend in the twentieth century to use private international law as an instrument for changing the society. ${ }^{792}$ Besides interpreting the text of the law, courts started to consider the aim of the law as well as its place in the society, referred to as "sociological or teleological interpretation". ${ }^{793}$ It has been argued that European courts nowadays have to understand the law that means "to find and reconstruct their meaning". ${ }^{794}$ Hence, scholars generally employ the term "lawfinding" (the Dutch term is rechtsvinding). ${ }^{795}$ Bredimas refers to the distinction between "interpretation lato sensu" (in German Rechtsfindung) and interpretation stricto sensu" (in German Auslegung). ${ }^{796}$

Various scholars have made a distinction between 'free' or autonomous law-finding, on the one hand, and heteronomous law-finding, on the other hand. ${ }^{797}$ According to heteronomous law-finding, the court has to interpret the text of the law in an objectively manner. ${ }^{798}$ The doctrine of legalism may therefore be indicated as heteronomous law-finding. Pursuant to autonomous law-finding, the court has the freedom to make a decision based on its own judgment. ${ }^{799}$ Autonomous law-finding therefore enables courts to make law or policy.

\footnotetext{
${ }^{786}$ De Almeida Ribeiro 2015, p. 32; Groenewegen 2006, pp. 62-63; Jaspers 1980, pp. 67-75; Pontier 1998, pp. 53, 57-58.

${ }^{787}$ Douglas-Scott 2002, p. 218.

${ }^{788}$ Wiarda 1999, p. 13.

${ }^{789}$ Pitlo employed the term law-finder with respect to judges in Europe. See Pitlo 1975, p. 12. Pitlo favoured the concept of 'finding' law instead of 'developing' law since "law created by a judgment already existed but was yet unknown and had to be found”. See Pitlo 1975, p. 14. See also Scholten 1974, p. 12.

${ }^{790}$ Groenewegen 2006, pp. 64-65; Hesselink 2002, p. 28; Jaspers 1980, pp. 75-92, 333; Kwak 2003, p. 67; Pontier 1998, pp. 53-54. See also Douglas-Scott 2002, p. 218; Scholten 1974, p. 7.

${ }^{791}$ Fockema Andreae 1904, p. 139; Scholten 1974, pp. 7-12; Vranken 2005, no. 145; Wiarda 1999, pp. 35-36. Based on case law and literature, Fockema Andreae demonstrates the development of more freedom for European courts to interpret the private law in the $19^{\text {th }}$ century, especially in France (pp. 16-21, 28-29), Italy (pp. 64-66) and Austria (pp. 68-75). According to Jaspers, the Supreme Court of the Netherlands confirmed the development of a more freely interpretation of the law by the case of Lindenbaum v. Cohen in 1919. See Japers 1980, p. 3. In the dissertation "Recht der Werkelijkheid" in 1910, Hijmans advocated that courts should interpret private international law more freely. See Jessurun d'Oliveira 1988, pp. 83-106.

792 See paragraph 2.1.2.1.

${ }^{793}$ Scholten 1974, pp. 34-35. See also Koopmans 2000, p. 48; Kwak 2003, p. 67; Pontier 1998, p. 67. Paragraph 4.2.4 of this dissertation will explain these methods of interpretation.

${ }^{794} \mathrm{La}$ Torre 2015, p. 11.

${ }^{795}$ Pitlo 1975, p. 12; Pontier 1998, pp. 9, 66; Scholten 1974, pp. 7-12. See also Everling 2000, pp. 35-36.

${ }^{796}$ Bredimas 1978, p. 2. Pitlo also refers to the evolution in private law from interpretation to law-finding. See Pitlo 1972, chapter VIII.

${ }^{797}$ Pontier 1998, pp. 53-55, 66-69; Wiarda 1999, pp. 13-15.

${ }^{798}$ Pontier 1998, p. 66; Wiarda 1999, p. 13.

${ }^{799}$ Pontier 1998, p. 67; Wiarda 1999, pp. 13-14.
} 
According to the "Free Law School" (In German Freierechtschule) "a judge may disregard a statutory provision if it leads to injustice or is ambiguous or incomplete and lay down the rule which he conceives that the legislator would have formulated had he been aware of the consequences" $" 800$.

The law-finding of European courts generally consists of a combination of heteronomous and autonomous elements. ${ }^{801}$ Based on the prevailing theory of law-finding, European courts are thus allowed to be more creative, also referred to as more autonomous, than under the doctrine of legalism. Nonetheless, in view of legitimacy, ${ }^{802}$ it has commonly been argued that this creativity is not unlimited. ${ }^{803}$ Pontier sets out various scholarly views on legitimate lawfinding that relate to the rule of law, democratic authority, public support, and righteous or rational decisions. ${ }^{804}$

The CJEU has to make decisions in the same legal culture as the abovementioned European national courts that means a legal culture governed by the rule of law, democracy and human rights. The Treaty on European Union emphasises that the European "Union is founded on the values of respect for human dignity, freedom, democracy, equality, the rule of law and respect for human rights". ${ }^{805}$ In line with the aforementioned prevailing role of European courts as 'law-finders', this dissertation will therefore adopt the view of the CJEU as 'law-finder' in order to rethink the CJEU's interpretation of Article 7(2) Brussels Ibis in copyright infringement cases.

Scholars have indicated several common interpretation methods to 'find' the law referred to as methods of interpretation. ${ }^{806}$ Based on these methods, the CJEU should not only interpret the text of Article 7(2) Brussels Ibis but also has to consider the spirit and context of this provision. Paragraph 4.2.1 up to and including paragraph 4.2.5 will describe the common methods of interpretation accepted by doctrine and the CJEU 'to find' the law in particular with respect to Article 7(2) Brussels Ibis. From a legitimate perspective, these interpretation methods will provide an indication regarding the leeway that the CJEU has regarding the interpretation of Article 7(2) Brussels Ibis.

Paragraph 4.2.4 will demonstrate that this leeway has been confined by the principles underlying Article 7(2) Brussels Ibis. These principles will therefore be adopted into the assessment framework of this dissertation to rethink the CJEU's interpretation of Article 7(2)

\footnotetext{
${ }^{800}$ Bredimas 1978, p. 6.

${ }^{801}$ See Pontier 1998, pp. 66-69; Wiarda 1999, pp. 13-14.

${ }^{802}$ As argued by Adams, De Waele, Meeusen, and Straetmans (2015, p. 4), the concept of legitimacy can be "explored from a legal, political, sociological or moral point of view". See also Bobek (2013, p. 199) on various perspectives regarding the issue of legitimacy of the CJEU. This dissertation mainly concerns the legal point of view, although the social legitimacy will also be discussed in para 4.4.2.4. See also the distinction between internal legitimacy (see paragraph 4.2) and external legitimacy (see paragraph 4.1.2).

${ }^{803}$ Pontier 1998, pp. 13-15, 69. See also Wiarda 1999, pp. 77-82.

${ }^{804}$ See Pontier 1998, pp. 13-15. For instance, the court's interpretation should comport with the prevailing view on law according to the society. See De Waele 2009, p. 31. De Waele also argues that the court has to consider the negative consequences of its decision. See De Waele 2009, p. 37. See also paragraph 4.4.2.4 on consequentialist reasoning. Conway (2013) argues that the CJEU's interpretation of European Union law has to be in accordance with the rule of law and democracy.

${ }^{805}$ Article 2 TEU. See also the preamble to the Treaty on European Union.

${ }^{806}$ See, inter alia, Bredimas 1978, p. 2; Kutscher 1976; Llorens 2000, p. 375; Pontier 1998, pp. 30-40; Schermers 1974, pp. 456-459. See also Koopmans in Wiarda 1999, pp. 21-26.
} 
Brussels Ibis in cross-border copyright infringement cases. Furthermore, paragraph 4.4 will provide arguments to adopt the principle of balancing the interests related to copyright into the assessment framework. In view of the contextual method of interpretation, the assessment framework will also include the influence of the Geo-blocking on the approach of jurisdiction in cross-border copyright infringement cases.

With respect to the process of law-finding, it is important to define the sources of law. ${ }^{807}$ Under the doctrine of legalism, the law enacted by national legislators is the only source of law. ${ }^{808}$ Nowadays, the concept of law in Europe has been broad, courts may generally also have recourse to general principles of law, international law, and human rights. ${ }^{809}$ As noted by Koopmans, although the aforementioned trend from heteronomous to more autonomous lawfinding made the courts lesser bound by the text of the law enacted by national legislators, they are still limited by the law in a broad sense, in Latin terminology referred to as ius. ${ }^{810}$

Pursuant to Article 19(1) TEU, the CJEU "shall ensure that in the interpretation and application of the Treaties the law is observed". The concept of the 'law' enshrined in Article 19(1) TEU involves primary ${ }^{811}$ and secondary European Union law, ${ }^{812}$ fundamental rights and general principles ${ }^{813}$ established by the CJEU. ${ }^{814}$ The paragraphs 4.4.2.2 and 4.4.2.4 will demonstrate that certain human rights may also influence the interpretation of Article 7(2) Brussels Ibis in cross-border copyright infringement disputes.

\subsection{Interpretation methods regarding the special jurisdiction rule of Article 7(2) Brussels Ibis}

From a perspective of "internal" legitimacy, it has been argued that the CJEU's rulings should consist of sound legal reasoning. ${ }^{815}$ Scholars have proposed several theories of legal reasoning. ${ }^{816}$ The court's decision will only be justified if the court has employed the accepted 'rational' method of legal reasoning. ${ }^{817}$ The so-called theory of scientific legal reasoning

\footnotetext{
${ }^{807}$ Pontier 1998, p. 18. See also Koopmans in Wiarda 1999, pp. 143-148.

${ }^{808}$ Pontier 1998, p. 55.

${ }^{809}$ Shuibhne 2013, p. 2. See also Koopmans who refers to a pluralism of sources of law. See Koopmans in Wiarda 1999, pp. 143-148.

${ }^{810}$ Koopmans in Wiarda 1999, p. 149. Koopmans refers in this context to the contradiction between lex and ius. See Koopmans in Wiarda 1999, p. 150.

${ }^{811}$ Primary Union law consists of "constitutive norms which come into being as a result of action on the part of the Member States themselves" such as the Treaties. See Lenaerts, Van Nuffel, Bray \& Cambien 2011, p. 753.

${ }^{812}$ Secondary or 'derived' Union law are rules created by Union institutions and bodies, such as Directives and Regulations (See, inter alia Article 288 TFEU). International agreements concluded by the Union are also considered as secondary union law. See Lenaerts, Van Nuffel, Bray \& Cambien 2011, p. 753.

${ }^{813}$ See Beck 2012, p. 195; Kutscher 1976, p. I-36; Lenaerts, Van Nuffel, Bray \& Cambien 2011, p. 825; Ramalho 2016, p. 19.

${ }^{814}$ Lenaerts, Van Nuffel, Bray \& Cambien 2011, pp. 817-818.

${ }^{815}$ Lenaerts 2013, p. 1306. See also Bengoetxea 1993, pp. 17-18; Bobek 2013, p. 203; Everling 1984, pp. 13081309; Poiares Maduro 1998, p. 10.

${ }^{816}$ Beck classifies legal theories into normative versus descriptive, and scientific versus heuristic. See Beck 2012, pp. $15-51$.

${ }^{817}$ Beck 2012, p. 115.
} 
"assumes that there is or can be a specifically legal method or mode of reasoning". 818 This theory postulates interpretative criteria that aim to enhance predictability of judicial decisions. ${ }^{819}$ An example of a scientific model of legal reasoning is the three-stage method of interpretation established by MacCormick and Summers. ${ }^{820}$ According to this method, the court first has to apply the textual method of interpretation. ${ }^{821}$ When the latter method does not provide a solution, the court has to employ the contextual method of interpretation, and subsequently the teleological method of interpretation. ${ }^{822}$

Pursuant to the so-called theory of heuristic legal reasoning, there is no specific legal method to interpret and justify judicial decisions. ${ }^{823}$ According to the latter theory, legal reasoning consists of legal and "extra-legal considerations" such as "psychological, social, economic, institutional and professional considerations". 824 Based on the latter view, the subjective perspective of the court highly influences the process of law-finding. ${ }^{825}$ The latter process of law-finding can therefore be characterised as autonomous.

The textual, ${ }^{826}$ contextual $^{827}$ and teleological ${ }^{828}$ method of interpretation are generally accepted by legal doctrine and the CJEU ${ }^{829}$ These methods are also commonly used by Member State courts. ${ }^{830}$ Most scholars have argued that there is no hierarchical relationship between the methods of interpretation. ${ }^{831}$ The CJEU usually simultaneous applies various methods of interpretation, referred to as a cumulative approach. ${ }^{832}$ In the seminal case of Van Gend \& Loos v. Nederlandse Administratie der Belastingen, the CJEU explicitly held that to interpret

${ }^{818}$ Beck 2012, p. 18. An example of a scientific theory of legal reasoning is MacCormick's theory of legal reasoning that consists of criteria based on consequences, consistency and coherence. See MacCormick 1994. Alexy is another scholar who established a scientific theory of legal reasoning, see Alexy 1983.

${ }^{819}$ Beck 2012, p. 18.

${ }^{820}$ See MacCormick \& Summers 1991, pp. 530-539. See also Beck 2012, pp. 147-150.

${ }^{821}$ MacCormick \& Summers 1991, pp. 530-539. See paragraph 4.2.1 on the textual method of interpretation.

${ }^{822}$ MacCormick \& Summers 1991, pp. 530-539. See paragraph 4.2.3 on the contextual method and paragraph 4.2.4 on the teleological method of interpretation.

${ }^{823}$ Beck 2012, p. 24. The theory of heuristic legal reasoning came into existence due to writings of the scholar Oliver Wendell Holmes and the American Legal Realist movement. See Beck 2012, pp. 24-25. Beck notes that "two of the most influential representatives of the American Realism are Karl Llewellyn and Jerome Frank". See Beck 2012, p. 25 note 24.

${ }^{824}$ Beck 2012, p. 24.

${ }^{825}$ Pontier 1998, p. 71. See also Vranken 1995, no. 114.

${ }^{826}$ See paragraph 4.2.1.

${ }^{827}$ See paragraph 4.2.3.

${ }^{828}$ See paragraph 4.2.4.

${ }^{829}$ Beck 2012, pp. 5, 6, 187, 214, 278; Bengoetxea 1993, pp. 227-262; Bredimas 1978, p. 177; Favale, Kretschmer \& Torremans 2016, p. 7; Koopmans 2000, p. 57, Kutscher 1976; Llorens 2000, pp. 375-375. The CJEU also explicitly ruled that based on Article 19 TEU the CJEU has the task "of ensuring that in the interpretation and application of the Treaty the law is observed, to rule on such a question in accordance with generally accepted methods of interpretation...". See the joined cases C-46/93 and C-48/93 Brasserie du Pêcheur SA and Federal Republic of Germany and The Queen v. Secretary of State for Transport, para. 27.

${ }^{830}$ See also Beck 2012, pp. 220, 278; Koopmans 2000, p. 57; Kutscher 1976, pp. I-5-I-6. Itzovich (2014, p. 538) pointed out that "the interpretative criteria and, more generally, the legal argumentation techniques of the ECJ $[\mathrm{CJEU}]$ are essentially the same ones which are familiar to the national legal" systems.

${ }^{831}$ Beck 2012, pp. 7, 232, 278, 312; Groenewegen 2006, p. 187. Yet, Kutscher argues that the CJEU should start with the textual interpretation of the provision. See Kutscher 1976, pp. I-5, I-15, I-17. MacCormick and Summers's three-stage method of interpretation implies a relative hierarchical relationship between the methods of interpretation. See MacCormick \& Summers 1991, pp. 530-539. See also Beck 2012, pp. 147-150; Groenewegen 2006, pp.190-191.

${ }^{832}$ See Beck 2012, pp. 278-317. See also Kutscher 1976, pp. I-5, I-15. 
provisions of the Treaty establishing the European Economic Community 833 "it is necessary to consider the spirit, the general scheme and the wording of those provisions". ${ }^{834}$ The CJEU also repeatedly ruled that provisions of Brussels Ibis Regulation ${ }^{835}$ should be interpreted "in the light, not only of the wordings of that provision, but also of the system established by the regulation and the objectives it pursues". 836 This formula comprises the textual, contextual, and teleological method of interpretation which will be described in this chapter.

Scholars frequently argue that the CJEU tends to favour the teleological method of interpretation regarding European Union law. ${ }^{837}$ Although some scholars do not consider the historical and comparative method as independent methods of interpretation, ${ }^{838}$ this chapter will describe these methods separately. The CJEU has occasionally employed the latter two methods of interpretation. ${ }^{839}$

\subsubsection{The textual method}

The CJEU generally starts with the interpretation of the wording of a provision. ${ }^{840}$ This socalled textual, linguistic ${ }^{841}$ or literal method of interpretation focuses on "the 'ordinary meaning' of a word, phrase or sentence, and its meaning determined by 'common usage'." Since the wording of European Union provisions are usually vague and ambiguous, the CJEU will regularly turn to other methods of interpretation ${ }^{843}$ that will be described in the next paragraphs. Beck argues "the greater the lack of clarity and imprecision of the provisions ... the greater the interpretative freedom enjoyed by the Court of Justice". ${ }^{844}$ Nonetheless, even when the text of the provision has been clear, the CJEU has usually examined whether the provision is in accordance with the objectives of the Treaties. ${ }^{845}$

\footnotetext{
${ }^{833}$ Treaty establishing the European Economic Community (EEC Treaty), also referred to as Treaty of Rome, signed on 25 March 1957 (not published in an official journal).

${ }^{834}$ Case C-26/62 Van Gend \& Loos v. Nederlandse Administratie der Belastingen, p. 12. See also Case C-283/81 CLIFIT and Lanificio di Gavardo SPA v. Ministry of Health, para. 20.

${ }^{835}$ Whenever this dissertation refers to the Brussels Ibis Regulation, it will also concerns its predecessors namely the Brussels Convention of 1968 and the Brussels I Regulation.

${ }^{836}$ See Case C-619/10 Trade Agency Ltd v. Seramico Investments Ltd., para. 27. See also Case C-189/08 ZuidChemie BV v. Philippo's Mineralenfabriek NV/SA, para. 17; Joined cases C-509/09 and C-161/10 eDate Advertising GmbH v. X and Martinez v. MGN Limited, para. 38; Case C-228/11 Mezler v. MF Global UK Ltd., para. 22; Case C-170/12 Peter Pinckney v. KGD Mediatech AGl, para. 23; Case C-360/12 Coty Germany GmbH v. First Note Perfumes NV para. 33, 43.

${ }^{837}$ See Koopmans 2000, p. 53; Kutscher 1976, pp. I-7, I-16.

838 "Comparative arguments are sometimes subsumed beneath systematic interpretative criteria". See Beck 2012, p. 215. MacCormick and Bankowski consider the historical and comparative arguments as part of the contextual method of interpretation. See MacCormick \& Bankowski 1989, pp. 47-49. Bengoetxea also subsumed comparative arguments under the contextual method of interpretation. See Bengoetxea 1993, p. 245.

${ }^{839}$ See Magnus \& Mankowski 2016, pp. 42-43,46-47.

${ }^{840}$ Beck 2012, pp. 188, 291. Kutscher 1976, p. I-17.

${ }^{841}$ Beck 2012, pp. 188-190; Bengoetxea 1993, p. 234.

${ }^{842}$ Kutscher 1976, p. I-17. Kutscher referred to the cases C-1/54 France Republic v. High Authority of the European Coal and Steel Community and C-30/59 Steenkolenmijnen in Limburg v. High Authority of the European Coal and Steel Community. See also Beck 2012, p. 317; Conway 2013, pp. 144-153; Groenewegen 2006, p. 79.

${ }^{843}$ Beck 2012, pp. 6-7, 189.

${ }^{844}$ Beck 2012, p. 434.

${ }^{845}$ Bredimas 1978, p. 54. See, for instance, Case C-1/54 France Republic v. High Authority of the European Coal and Steel Community, pp. 13-14. The term Treaties refers to the constitutional treaties of the European
} 
Furthermore, European Union law will generally be available in twenty-four different official languages of the European Union. ${ }^{846}$ The CJEU ruled that all different languages are equally authentic; therefore, interpretation of a provision of European Union law will involve a comparison of the different language versions. ${ }^{847}$ Due to discrepancies between various language versions, the CJEU will frequently have to consider other methods of interpretation. ${ }^{848}$

Even when the meaning of different language versions corresponds, the CJEU may interpret legal concepts differently than the meaning in the law of the Member States. ${ }^{849}$ In several rulings, the CJEU has provided so-called autonomous interpretations of legal concepts. ${ }^{850}$ As mentioned in paragraph 1.1.3, the CJEU ruled that the concept of "in matters relating to tort, delict or quasi-delict" in Article 7(2) Brussels Ibis must be autonomously interpreted as covering "all actions which seek to establish the liability of a defendant and which are not related to a 'contract' within the meaning of Article 5(1) of the Brussels Convention". ${ }^{851}$

Based on the textual method of interpretation, the CJEU has thus quite some freedom to interpret "the place where the harmful event occurred or may occur" under Article 7(2) Brussels Ibis in cross-border copyright infringements.

\subsubsection{The historical method}

The "subjective" historical method of interpretation focuses on the "actual intention of the legislature". ${ }^{852}$ This method "looks to the intention of the author or signatories or those who ratified a legal provision". ${ }^{853}$ The "objective" historical method of interpretation ${ }^{854}$ does not consider the intentions of the legislator of a legal provision "but seeks to identify how a constitution or legal provision was understood generally in legal tradition at time of its adoption". 855

\footnotetext{
Communities and the European Union namely the European Coal and Steel Community Treaty, the Treaty Establishing the European Economic Community, the European Atomic Energy Community Treaty, the TEU and the TFEU. See paragraph 4.1.1 on the founding Treaties of the European Communities. See paragraph 4.2.4 on the teleological method of interpretation.

${ }^{846}$ See Hartley 2014, p. 65. The official languages of the European Union are Bulgarian, Croatian, Czech, Danish, Dutch, English, Estonian, Finnish, French, German, Greek, Hungarian, Irish, Italian, Latvian, Lithuanian, Maltese, Polish, Portuguese, Romanian, Slovak, Slovenian, Spanish, Swedish.

${ }^{847}$ See Case C-283/81 CLIFIT and Lanificio di Gavardo SPA v. Ministry of Health, para. 18. See also Kutscher 1976, p. I-17; Pontier \& Burg 2004, p. 83. See, for instance, Case C-305/88 Isabelle Lancray v Peters und Sickert $K G$, para. 16. See also Article 55 TEU.

${ }^{848}$ Beck 2012, p. 189; Kutscher 1976, I-20.

${ }^{849}$ Case C-283/81 CLIFIT and Lanificio di Gavardo SPA v. Ministry of Health, para. 19.

${ }^{850}$ See Gebauer 2000, p. 688; Rösler 2017, pp. 1006-1015; Schaafsma 2018, p. 10. See, inter alia, Case C-189/87 Kalfelis v. Schröder, para. 14-16; C-261/90 Reichert Kockler v. Dresdner Bank, para. 15; C-26/91 Jakob Handte \& Co. GmbH v. Traitment Mécano-chimiques des Surfaces, para. 10.

${ }^{851}$ See Case C-189/87 Kalfelis v. Schröder, para. 16-18.

${ }^{852}$ Kutscher 1976, p. I-21. See also Scholten 1974, p. 78. See also Case C-29/69 Stauder v. City of Ulm-Socialamt, para. 3.

${ }_{853}$ Conway 2013, p. 20.

${ }^{854}$ Kutscher 1976, p. I-21. See also Conway 2012, pp. 20-21; Scholten 1974, p. 78.

${ }^{855}$ Conway 2013, p. 247.
} 
The historical method of interpretation may be applied to the interpretation of European Union law if there are preparatory documents (travaux préparatoires), for example, reports, ${ }^{856}$ opinions of the Parliament, proposals of the Commission, or preambles to European Regulations or Directives. ${ }^{857}$ In view of the dynamic and evolutionary character of European Union law, it has been argued that the historical method of interpretation can only play a complementary role with respect to the interpretation of European Union law. ${ }^{858}$

As mentioned in paragraph 1.1.2, the first unified jurisdiction rules in Europe had been enacted by the European Economic Community. In 1968, the six European states of the European Economic Community concluded the Brussels Convention on jurisdiction and the enforcement of judgments in civil and commercial matters (hereinafter Brussels Convention of 1968) ${ }^{859}$ Pursuant to the corresponding Jenard Report on the Convention on Jurisdiction and the Enforcement of Judgments in Civil and Commercial Matters signed at Brussels in 1968 (hereinafter the Jenard Report on the Brussels Convention of 1968), ${ }^{860}$ the legislators held that legal protection and legal certainty are essential conditions for a true internal market. ${ }^{861}$ In the preambles of the successors of the Brussels Convention of 1968, namely the Brussels I Regulation and the Brussels Ibis Regulation, the legislators emphasised that certain differences between jurisdiction rules of the Member States needed to be unified since "they hamper the sound operation of the internal market". 862

With respect to the special jurisdiction rule related to tort matters, currently laid down in Article 7(2) Brussels Ibis, formerly Article 5(3) Brussels Convention of 1968, the Jenard Report on the Brussels Convention of 1968 states that the legislators of the Brussels Convention did not think it necessary to specify whether "the place where the harmful event occurred" is "the place where the event which resulted in damage or injury occurred, or whether it is the place where the damage or injury was sustained". ${ }^{863}$ Thus, the legislators intentionally left the concept of this special jurisdiction rule open for interpretation by the CJEU. ${ }^{864}$ Based on the method of historical interpretation the CJEU has therefore quite some freedom regarding the interpretation of this special jurisdiction rule.

\footnotetext{
${ }^{856}$ See, for instance, Jenard Report on the Convention on Jurisdiction and the Enforcement of Judgments in Civil and Commercial Matters signed at Brussels, 27 September 1968, by Mr. P. Jenard. See Official Journal of the European Communities 5. 03. 1979, No C 59/1-59/65 (hereinafter the Jenard Report on the Brussels Convention of 1968).

${ }^{857}$ Kutscher 1976, pp. I-21, I-22.

${ }^{858}$ Beck 2012, p. 219. See also Kutscher 1976, p. I-22.

${ }^{859}$ Brussels Convention on jurisdiction and the enforcement of judgments in civil and commercial matters (OJ L 299, 31.12.1972, pp. 32-42).

${ }^{860}$ Jenard Report on the Convention on Jurisdiction and the Enforcement of Judgments in Civil and Commercial Matters signed at Brussels, 27 September 1968, by P. Jenard. See Official Journal of the European Communities 5. 03. 1979, No C 59/1-59/65 (hereinafter the Jenard Report on the Brussels Convention of 1968).

${ }^{861}$ Jenard Report on the Brussels Convention of 1968, p. C 59/3.

${ }^{862}$ See recital 2 of the preamble to the Brussels I Regulation; recital 4 of the preamble to the Brussels Ibis Regulation.

${ }^{863}$ Jenard Report on the Brussels Convention of 1968, p. C 59/26. While Article 5(3) Brussels Convention of 1968 stipulates "the place where the harmful event occurred", Article 5(3) Brussels I and Article 7(2) Brussels Ibis refer to "the place where the harmful event occurred or may occur". Hence, actions to prevent tortious damage are also included. See Magnus \& Mankowski 2016, p. 146.

${ }^{864}$ See Bredimas 1978, p. 64; Hartley 1999, p. 73; Hess, Pfeiffer \& Schlosser 2007, p. 101.
} 


\subsubsection{The contextual method}

The contextual method has also been referred to as the schematic method ${ }^{865}$ or systematic method. ${ }^{866}$ The contextual method of interpretation places the provision that has to be interpreted in its context; ${ }^{867}$ therefore, the provision needs to be interpreted in light of related provisions, the whole system of laws involved, and general principles of law. 868 "The requirements of consistency and coherence can be seen as regulative principles in the justification from systematic-contextual criteria." 869 The contextual interpretation is closely related to teleological interpretation, ${ }^{870}$ which will be set out in the next paragraph. To interpret European Union law, the CJEU regularly combined the contextual and the teleological method of interpretation. ${ }^{871}$

With respect to the contextual interpretation of a provision of European Union law, reference may, inter alia, be made "to international legislation, to the legislative history of the legal text, to other EU legislation (normally EU Directives), to legal philosophy arguments, or to economic arguments (impact on competition or on the internal market)" ${ }^{872}$ Provisions of European Union law have to be interpreted in accordance with the Union Treaties since they are a primary source of law. ${ }^{873}$ Furthermore, all European Union legislation "is to be interpreted in light of the general principles of EU law and, where appropriate, also its more specific principles". ${ }^{874}$ While the CJEU already considered fundamental rights as general principles of the European Union, ${ }^{875}$ the Treaty of Lisbon of 2007 confirmed its status as source of primary law of the European Union. ${ }^{876}$ Paragraph 4.4 will further focus on the fundamental rights that

${ }^{865}$ Fennelly 1996, p. 664; Kutscher 1976, pp. I-15, I-36. In the ruling Van Gend \& Loos v. Nederlandse Administratie der Belastingen, the CJEU employed the term 'scheme' in its seminal phrase that "it is necessary to consider the spirit, the general scheme and the wording of those provisions". See C-26/62 Van Gend \& Loos v. Nederlandse Administratie der Belastingen, p. 12.

${ }^{866}$ Beck 2012, pp. 191-207, 288; Groenewegen 2006, p. 135.

${ }^{867}$ Bengoetxea 1993, p. 240.

${ }^{868}$ MacCormick \& Summers 1999, pp. 513-514. See also Beck 2012, pp. 191-207; Bengoetxea 1993, p. 242; Kutscher 1976, pp. I-36-I-38.

${ }^{869}$ Bengoetxea 1993, p. 241. See also Bredimas 1978, pp. 43-44.

${ }^{870}$ Beck 2012, pp. 214-215; Kutscher 1976, p. I-40; Poiares Maduro 2007, p. 140.

${ }^{871}$ Bengoetxea 1993, p. 250. "Van Gend en Loos also provides a good example of the use of fused teleologicalsystematic criteria." See Beck 2012, p. 213. See also Case C-201/13 Johan Deckmyn, Vrijheidsfonds VZW v. Helena Vandersteen and Others, para. 14; Case C-617/15 Hummel Holding A/S v. Nike Inc., para. 22; Case C172/18 AMS Neve Ltd and Others v. Heritage Audio SL, Pedro Rodriguez Arribas, para. 52.

${ }^{872}$ Favale, Kretschmer \& Torremans 2016, p. 22.

${ }^{873}$ Beck 2012, p. 192; Kutscher 1976, p. I-37; Lenaerts, Van Nuffel, Bray \& Cambien 2011, p. 821; Ramalho 2015, p. 19. Union Treaties are TEU and TFEU. See also Lenaerts, Van Nuffel, Bray \& Cambien 2011 , p. 821.

${ }^{874}$ Beck 2012, p. 195. See also Kutscher 1976, p. I-36. As noted by Beck, general principles of EU law are, inter alia, the principle of proportionality, legal certainty, useful effect, non-discrimination, and respect for fundamental rights. Specific principles of EU law are, for example, the principle of free movement of goods, persons, services, establishment and of capital. See Beck 2012, p. 195. See also Bengoetxea 1993, pp. 76-78. "Many EU legal principles may also be regarded as part of the purposive structure of Union law", and therefore play a role with respect to the teleological method of interpretation. See Beck 2012, p. 205

${ }^{875}$ Lenaerts, Van Nuffel, Bray \& Cambien 2011, p. 825; Ramalho 2016, p. 19. See the case law by the CJEU as mentioned in paragraph 4.4.2.4 of this dissertation.

${ }^{876}$ See Article 6(1) TEU. The Treaty of Lisbon amending the Treaty on European Union and the Treaty establishing the European Community, signed at Lisbon, 13 December 2007, entered into force 1 December 2009 (OJ C 306, 17.12.2007, pp. 1-271). 
may influence the interpretation of Article 7(2) Brussels Ibis in cross-border copyright infringement cases.

In view of contextual interpretation, this chapter will advocate to include the effect of the Geo-blocking Regulation on the approach to jurisdiction in cross-border copyright infringement cases into the assessment framework of this dissertation. ${ }^{877}$ Chapter two demonstrated that the commonly accepted territorial principle related to copyrights generally influences the court's jurisdiction in cross-border copyright infringement cases. ${ }^{878}$ Although the territorial principle related to copyrights will not be part of the assessment framework, the (desirable) influence of this principle on the approach to jurisdiction under Article 7(2) Brussels Ibis in cross-border copyright infringement cases will be particularly discussed in chapter five. ${ }^{879}$ Furthermore, the chapters two and five will demonstrate the possible influence of the field of public international law on the effects-based approach to jurisdiction under Article 7(2) Brussels Ibis in cross-border copyright infringement cases. ${ }^{880}$

In the rulings Pinckney, Hi Hotel and Pez Hejduk, the CJEU employed the Information Society Directive to interpret the special jurisdiction rule of Article 7(2) Brussels Ibis. The CJEU held that copyrights should be protected in all Member States by virtue of the Information Society Directive. ${ }^{81}$ The CJEU's interpretation of Article 7(2) Brussels Ibis in light of the Information Society Directive can be subsumed under the contextual method of interpretation. As mentioned in paragraph 4.1.1, this interpretation can also be characterised as a prointegrationist interpretation since the CJEU employed the aim to harmonize copyright protection in all Member States. The next paragraph will demonstrate the method of teleological interpretation under which the pro-integrationist interpretation can be subsumed.

In the context of the system of jurisdiction rules in the Brussels Ibis Regulation, the special jurisdiction rule of Article 7(2) Brussels Ibis deviates from the general jurisdiction rule laid down in Article 4 Brussels Ibis. The general jurisdiction rule in Article 4 Brussels Ibis provides jurisdiction to the courts of the Member State where the defendant is domiciled. ${ }^{82}$ In this context, the CJEU repeatedly held that the special jurisdiction rule in Article 7(2) Brussels Ibis needs to be interpreted restrictively. ${ }^{883}$ Although this principle of restrictive interpretation will not explicitly be a part of the assessment framework in the dissertation, it definitely remains an important focal point when rethinking the CJEU's interpretation of Article 7(2) Brussels Ibis in cross-border copyright infringement cases.

\footnotetext{
${ }^{877}$ See paragraph 4.5 .

${ }^{878}$ See paragraph 2.3.2 on the influence of the territorial nature of copyrights on the court's jurisdiction. See also paragraph 2.3.4 on the development towards a flexible approach to territoriality in cross-border copyright infringement cases.

${ }^{879}$ See paragraph 5.1.3. See also paragraph 2.3.

${ }^{880}$ See paragraphs $2.1 .2 .2 .1 ; 5.3 .3 .1 ; 5.3 .4 .1$.

${ }^{881}$ See Case C-170/12 Peter Pinckney v. KGD Mediatech AG, para. 39; Case C-387/12 Hi Hotel HCF SARL v. Uwe Spoering, para. 36; Case C-441/13 Pez Hejduk v. EnergieAgentur. NRW GmbH, para. 22.

${ }^{882}$ See also the Jenard Report on the Brussels Convention of 1968, p. C 59/18.

${ }^{883}$ Case C-189/87 Kalfelis v. Schröder, para. 19; Case C-168/02 Rudolf Kronhofer v Marianne Maier and Others, para. 14. Larsen 2018(b), p. 553.
} 


\subsubsection{The teleological method}

The method of teleological interpretation in a narrow sense focuses on the objective of the legal provision involved. ${ }^{884}$ The latter method has therefore also been called the purposive method. ${ }^{885}$ In a broad sense, teleological interpretation also encompasses the objectives and principles of the law(s) related to the legal provision involved. ${ }^{886}$ In the ruling of Van Gend \& Loos v. Nederlandse Administratie der Belastingen, the CJEU held that a provision of European Union law should also be interpreted in light of "the spirit" of the Treaties. ${ }^{877}$ With respect to the interpretation of provisions of private international law in the Brussels Convention of 1968, the CJEU ruled that these provisions need to be interpreted in light of the Convention's "principles and objectives". ${ }^{888}$ Pontier and Burg refer in this context to "principle-based reasoning". ${ }^{889}$ Paragraph 4.2.4.1 will discuss the principles underlying the Brussels Ibis Regulation, in particular the special jurisdiction rule of Article 7(2) Brussels Ibis.

In the broadest sense, teleological interpretation may even include the objective of the particular provision in the society. ${ }^{890}$ Scholten refers in this context to "teleological and sociological interpretation"; when 'finding' the law "requirements of social and economic life" should also play a role. ${ }^{891}$ Scholten argues that the court has to determine the facts but also has to consider the efficiency of a certain practice in society. ${ }^{892}$ Barak claims that it is the task of courts to "bridge the gap between law and society" besides deciding the dispute. ${ }^{893}$ Dehousse also emphasises the relationship between law and society: "Law, although often produced in response to social phenomena and thus shaped by them, also tries to regulate these phenomena". ${ }^{894}$ In the context of interpreting private international law, De Winter argued that courts should consider the particular social interests involved. ${ }^{895}$ This chapter will return to the method of teleological interpretation in the broadest sense when discussing the consequentialist method of reasoning ${ }^{896}$ and the interest-based approach established by Kegel ${ }^{897}$.

\subsubsection{Pro-integrationist interpretation}

As demonstrated in paragraph 4.1.1, scholars have argued that the main objective of European integration 'encourages' the CJEU to interpret European Union law in a dynamic

\footnotetext{
${ }^{884}$ Polak 1953, p. 41. See also Van Hoecke 2002, p. 149.

${ }^{885}$ See Beck 2012, p. 207; Pontier \& Burg 2004, p. 6; Van Hoecke 2002, p. 144.

${ }^{886}$ Polak 1953, p. 41. See also Van Hoecke 2002, p. 149.

${ }^{887}$ Case C-26/62 Van Gend \& Loos v. Nederlandse Administratie der Belastingen, p. 12. See paragraph 4.1.1 of this dissertation. See also Beck 2012, p. 208.

${ }^{888}$ Pontier \& Burg 2004, p. 8. See, for instance, Case C-12/76 Industrie Tessili Italiana Como v. Dunlop AG, para. 9.

${ }^{889}$ Pontier \& Burg 2004, p. 2.

${ }^{890}$ Polak 1953, p. 42; Pontier 1998, p.67; Scholten 1974, p. 119.

${ }^{891}$ Scholten 1974, pp. 116-120. See also Van Hoecke 2002, p. 151.

${ }^{892}$ Scholten 1974, p. 118.

${ }^{893}$ Barak 2006, p. 3.

${ }^{894}$ Dehousse 1998, p. 1.

${ }^{895}$ De Winter 1947, p. 42.

${ }^{896}$ See paragraph 4.4.2.3.

${ }^{897}$ See paragraph 4.4.2.1.1.
} 
way. ${ }^{898}$ Based on the pro-integrationist method of interpretation, the CJEU interprets provisions of European Union law in favour of the European integration. ${ }^{899}$ Case law indicates that the CJEU's interpretation of European Union law generally "tends to favour or enhance further EU integration". 900

Beck demonstrates that the CJEU has nevertheless provided restrictive interpretations with respect to areas of European Union law that are "of constitutional, political and budgetary sensitivity to Member States". 901 Yet, there are "areas of political fashion" that "favour expensive policy and legislation as well as expansive judicial interpretation". ${ }^{902}$ For instance, the CJEU has frequently adopted a more expansive and pro-integrationist interpretation of European Union provisions involving anti-discrimination. ${ }^{903}$ The CJEU also tends to adopt a more expansive and pro-integrationist interpretation with respect to some areas of law involving "policies that have a popular appeal" such as consumer protection ${ }^{904}$, competition law $^{905}$ and copyright protection ${ }^{906}$. These latter areas have been largely regulated by European Union laws. ${ }^{907}$ The next chapter will demonstrate that the CJEU's active role with respect to the harmonization of copyright law ${ }^{908}$ has been reflected in the CJEU's broad interpretation of Article 7(2) Brussels Ibis in cross-border copyright infringement cases. The next chapter will also focus on the issue whether this pro-integrationist interpretation could be considered as legitimate activism.

As mentioned in paragraph 4.1.3, the CJEU has often been accused of illegitimate judicial activism due to pro-integrationist interpretation. Koopmans argues that the CJEU needs a solid legal basis to enhance European integration. ${ }^{909}$ This principle of legality, as reflected in Article 19(1) TEU, ${ }^{910}$ has been considered as "a paramount and overriding principle" of European Union law. ${ }^{911}$ Rodriguez Iglesias, the former President of the CJEU, "reasserted the role of the

\footnotetext{
${ }^{898}$ See also Kutscher 1976, p. I-39; Dehousse 1998, p. 76.

${ }^{899}$ Beck 2012, p. 323. See also Conway 2013, p. 159. See also paragraph 4.1.1.

${ }^{900}$ Beck 2012, p. 322. See also Conway 2013, p. 22. See paragraph 4.1.1 on the Case C-381/98 Ingmar GB Ltd. v. Eaton Leonard Technologies Inc.

${ }^{901}$ Beck 2012, pp. 350-362. Examples of areas 'of constitutional, political and budgetary sensitivity to Member States' are social security, nationality and immigration. For examples of rulings by the CJEU with respect to 'of constitutional, political and budgetary sensitivity to Member States', see Beck 2012, pp. 351-354.

902 Beck 2012, pp. 390-391.

${ }^{903}$ See case law as mentioned by Beck 2012, pp. 391-401.

904 Beck 2012, p. 403.

905 Beck 2012, p. 386.

${ }^{906}$ See paragraph 1.1.3 for scholars on the active role of the CJEU with respect to the harmonisation of copyright laws in the European Union.

${ }^{907}$ Beck 2012, p. 386. See European Union Directives related to copyright enumerated in paragraph 2.2.1 of this dissertation.

${ }^{908}$ See paragraph 1.1.3.

${ }^{909}$ Koopmans 1986, p. 931. According to Koopmans, the CJEU should adopt a minimal role that means only if there is a solid legal basis the CJEU may enhance European integration. This minimal role contrasts with the CJEU as constitutional court and law-maker as mentioned in paragraph 4.1.1 and 4.1.3. See also Schepel \& Blankenburg 2001, p. 37; Rasmussen 1986, pp. 25-33.

${ }^{910}$ See paragraph 4.1.2.

911 Tridimas 2006, p. 20.
} 
Court as a custodian of legality rather than as a 'motor of integration', a perception of the Court which he firmly rejected". 912

Furthermore, it has been claimed that the pro-integrationist approach by the CJEU may undermine other important values in the European Union such as democracy, human rights, the role of subsidiary, the rule of law, and "the extent of enduring Member State sovereignty, and national diversity". ${ }^{913}$ Particularly since the Treaty of Lisbon of 2007, the European Union has to sustain also social, environmental and human rights values ${ }^{914}$ and share a wide range of policies with Member States. ${ }^{915}$ Granger refers in this context to the "multiple teloi of Europe". ${ }^{916}$ The European Union also has obtained a role in the setting of global governance which involves "the use of soft law and non-legislative instruments" that may challenge judicial integration. ${ }^{917}$

As demonstrated in paragraph 1.2, several scholars argued that the instrumentalization of private international law for policy aims should not undermine the principles of private international law. The next paragraph will focus on the principles underlying the special jurisdiction rule of Article 7(2) Brussels Ibis. From a legitimate perspective, it is important that these principles will be satisfied when interpreting Article 7(2) Brussels Ibis in cross-border copyright infringement cases. These principles will therefore be adopted in the assessment framework to rethink the CJEU's approach to jurisdiction in cross-border copyright infringement cases.

\subsubsection{Principles underlying the special jurisdiction rule of Article 7(2) Brussels Ibis}

In order to achieve the internal market, the legislators of the European Community and European Union enacted jurisdiction rules to "strengthen the legal protection of persons". ${ }^{918}$ The latter aim can be denoted as the "overarching principle" of the Brussels Ibis Regulation and its predecessors, the so-called Brussels system. ${ }^{919}$ According to settled case law of the CJEU, the jurisdiction rules of the Brussels system should therefore ensure "the greatest possible degree of legal certainty" by enabling both the plaintiff and the defendant to easily identify and predict which court(s) may have jurisdiction. ${ }^{920}$ The principle of predictability,

\footnotetext{
912 See Fennelly 1996, p. 668. Fennelly notes that G. C. Rodriguez Iglesias referred to the publication of the work of J. V. Louis on the European Union and the future of its institutions (Brussels, Jan. 16, 1997).

913 See Conway 2013, p. 126.

914 See Article 3 TFEU.

915 See Article 4 TFEU.

916 Granger 2013, para. 3.2.

917 Saurugger \& Terpan 2017, p. 208. See paragraph 2.1.2.1.5 on the use of private international law as tool for global governance.

918 Pontier \& Burg 2004, pp. 3, 23. See also Magnus \& Mankowski 2016, p. 144. See paragraph 4.2.2 of this dissertation. See also following case law Case C-26/91 Jakob Handte \& Co. GmbH v. Traitment Mécanochimiques des Surfaces SA, para. 11; Case C-12/76 Industrie Tessili Italiana Como v. Dunlop AG, para. 9; Case C-38/81 Effer SpA v. Hans-Joachim Kantner, para. 6; Case C-256/00 Besix SA v. Wasserreinigungsbau Alfred GmbH \& Co. KG and Planungs-und Forschungsgesellschaft Dipl. Ing. W. Kretzschmar GmbH \& KG, para. 25.

${ }^{919}$ For the purpose of this dissertation, the term 'the Brussels system' includes the Brussels Convention of 1968 , the Brussels I Regulation, and the Brussels Ibis Regulation.

${ }^{920}$ Case C-26/91 Jakob Handte \& Co. GmbHv. Traitements mécano-chimiques des surfaces SA, para. 12. See also Case C-241/83 Erich Rösler v. Horst Rottwinkel, para. 23; Case C-256/00 Besix SA v. Wasserreinigungsbau Alfred
} 
also referred to as legal certainty, with respect to the allocation of jurisdiction contributes thus to the abovementioned overarching principle. ${ }^{921}$ Recital 15 in the preamble to the Brussels Ibis Regulation states that "the rules of jurisdiction should be highly predictable and founded on the principle that jurisdiction is generally based on the defendant's domicile". In view of the latter principle enshrined in Article 4 Brussels Ibis, the CJEU repeatedly held that the special jurisdiction rule of Article 7(2) Brussels Ibis has to be interpreted restrictively. ${ }^{922}$

With respect to special jurisdiction rules, the Jenard Report on the Brussels Convention of 1968 states that these rules are "justified by the fact that there must be a close connection between the dispute and the court with jurisdiction to resolve it". ${ }^{923}$ Similarly, recital 16 in the preamble to the Brussels Ibis Regulation stipulates that the special jurisdiction rule of Article 7(2) Brussels Ibis has been based on a close connection between the court and the action. ${ }^{924}$ The principle of a close connection "ensures the proximity of the court seised to the relevant facts of the dispute". ${ }^{925}$ The foregoing reflects the general principle of private international law to search for proximity. ${ }^{926}$ As argued in paragraph 2.1.2.2, there seems to be a consensus among scholars that the requirement of a close connection between the dispute and the forum state justifies effects-based jurisdiction. Paragraph 2.1.2.2.2 indicated that the principle of a close connection suits the principle of territoriality as basis for jurisdiction according to public international law.

The 'close connection' requirement yields legal certainty and predictability to the defendant regarding in which Member State he could be sued. ${ }^{927}$ It also facilitates the sound administration of justice and the efficacious conduct of proceedings. ${ }^{928}$ The 'close connection' requirement leads to "efficiency of proof" 929 since the competent court will likely have access to the relevant

\footnotetext{
GmbH \& Co. KG and Planungs-und Forschungsgesellscgaht Dipl. Ing. W. Kretzschmar GmbH \& KG, para. 2526; Case C-334/00 Fonderie Officine Meccaniche Taconi Spa v. Heinrich Wagner Sinto Maschinenfabrik, para. 20; Case C-18/02 DFDS Torline v. LO Landesorganisationen, para. 36; Case C-133/11 Folien Fischer and Folitec v. Ritrama SpA, para. 33. See also Jenard Report on the Brussels Convention of 1968, p. C 59/15; Magnus \& Mankowski 2016, p. 144; Pontier \& Burg 2004, pp. 92-94.

${ }^{921}$ See Pontier \& Burg 2004, pp. 21, 93; Ten Wolde 2020, p. 253. See also Case C-38/81 Effer SpA v. HansJoachim Kantner, para. 6; Case C-26/91 Jakob Handte \& Co. GmbH v. Traitment Mécano-chimiques des Surfaces $S A$, para. 11, 12, 18, 19; Case C-269/95 Francesco Benincasa v. Dentalkit, para. 26; Case C-256/00 Besix SA v. Wasserreinigungsbau Alfred GmbH \& Co. KG and Planungs-und Forschungsgesellschaft Dipl. Ing. W. Kretzschmar GmbH \& KG, para. 24.

922 See also paragraph 4.2 .3 .

${ }^{923}$ See Jenard Report on the Brussels Convention of 1968, p. C 59/22. See also Case C-14/76 De Bloos v. Société en commandite par actions Bouyer, para. 7.

${ }^{924}$ See also the following case law: Case C-21/76 Bier v. Mines de Potasse d'Alsace SA, para. 11; Case C-220/88 Dumez France SA and Tracoba SARL, para. 17; Case C-68/93 Shevill and Others v. Presse Alliance, para. 19; Case C-364/93 Antonio Marinari v. Loyds Bank plc and Zubaidi Trading Company, para. 10; Case C-189/08 ZuidChemie BV v. Philippo's Mineralenfabriek NV/SA, para. 24; Joined cases C-509/09 and Case C-161/10 eDate Advertising GmbH v. Olivier Martinez and Robert Martinez v. MGN Limited, para. 40; Case C-228/11 Mezler v. MF Global UK Ltd., para. 26.

925 Opinion of Advocate General Cruz Villalón in the case C-523/10 Wintersteiger AG v. Products $4 U$ Sondermaschinenbau $\mathrm{GmbH}$, para. 17.

${ }_{926}$ Magnus \& Mankowski 2016, p. 143; Pertegás Sender 2002, p. 18.

${ }^{927}$ Recital 16 in the preamble to the Brussels Ibis Regulation.

${ }^{928}$ See, inter alia, Case C-21/76 Bier v. Mines de Potasse d'Alsace SA, para. 11; Case C-220/88 Dumez France SA and Tracoba SARL, para. 17; Case C-189/08 Zuid-Chemie BV v. Philippo's Mineralenfabriek NV/SA, para. 24. See also recital 16 in the preamble to the Brussels Ibis Regulation.

${ }^{929}$ See C-364/93 Antonio Marinari v. Loyds Bank plc and Zubaidi Trading Company, para. 20.
} 
facts of the case. ${ }^{930}$ From a perspective of sound administration of justice, the principle of 'a close connection' generally reduces multiplication of competent courts, ${ }^{931}$ and therefore the risk of irreconcilable decisions. ${ }^{932}$

To enhance the sound administration of justice can also be considered as a principle underlying Article 7(2) Brussels Ibis. ${ }^{933}$ According to the CJEU's case law, the interpretation of Article 7(2) Brussels Ibis should not lead to multiple competent courts that will increase parallel proceedings and therefore the risk of forum shopping and irreconcilable judgements. ${ }^{934}$ From a perspective of sound administration of justice, it is also important that the assessment whether the court seised has jurisdiction will not include a detailed assessment of the merits of the case; "a jurisdictional assessment is by definition a prima facie one". ${ }^{935}$ As mentioned above, the 'close connection' requirement enhances the sound administration of justice since the competent court will generally be in a good position to assess the facts of the case. "Firsthand knowledge of facts" and "proximity of evidence" are regarded as important features under the principle of sound administration of justice. ${ }^{936}$ The principle of sound administration of justices requires efficient organization of the proceedings. ${ }^{937}$ Hence, Pontier and Burg argued that the principle of a sound administration justice includes the principle that related cases should be decided by a single court. ${ }^{938}$

Both the principle of predictability and the principle of 'a close connection' enhance a fair procedural balance between the parties involved, also referred to as the principle of "level playing field". ${ }^{939}$ The latter principle of balancing the procedural interests of the litigants, that means the copyright holder and the infringer, will also be a part of the assessment framework of this dissertation. As mentioned in paragraph 2.1.2.1.3, the Brussels Ibis Regulation does not consider copyright holders as weaker parties that require special procedural protection. In chapter six, a scholarly proposal will be discussed that advocates special procedural protection under Article 7(2) Brussels Ibis to copyright holders who are economically weak. ${ }^{940}$

\footnotetext{
${ }^{930}$ See, inter alia, Case C-21/76 Handelskwekerij G.J. Bier v. Mines de Potasse d'Alsace SA, para. 25; C-68/93 Shevill and Others v. Presse Alliance para. 19-21. See also Pontier \& Burg 2004, p. 162.

${ }^{931}$ See Pontier \& Burg 2004, pp. 100-101. See also Case C-14/76 De Bloos v. Société en commandite par actions Bouyer, para. 7.

932 Pontier \& Burg 2004, p. 109. See also C-220/88 Dumez France SA and Tracoba SARL, para. 18.

${ }^{933}$ Pontier \& Burg 2004, p. 160.

${ }^{934}$ See C-220/88 Dumez France SA and Tracoba SARL, para. 18. See also recital 21 in the preamble to the Brussels Ibis Regulation.

935 See Opinion of Advocate General Bobek delivered on 28 February 2018 in the case C-27/17 $A B$ ' flyLALLithianian Airlines v. starptautiskä lidosta Riga VAS, para. 92. See also Case C-27/17 AB 'flyLAL-Lithianian Airlines v. starptautiskä lidosta Riga VAS, para. 54. Opinion of Advocate General Jääskinen delivered on 21 November 2013 in the case C-360/12 Coty Germany GmbHv First Note Perfumes NV, para. 60.

936 Pontier \& Burg 2004, p. 160.

${ }^{937}$ Pontier \& Burg 2004, p. 161.

${ }^{938}$ Pontier \& Burg 2004, p. 161.

${ }^{939}$ De Groote 2004, p. 41. See also Magnus \& Mankowski 2016, p. 143; Pertegás Sender 2002, p. 33. According to Advocate General Jääskinen, the interpretation of the special jurisdiction rule in Article 7(2) Brussels Ibis should "ensure a reasonable balance between the interests of the person claimed to be liable and the person who has sustained damage" as stipulated in recital 16 Rome II Regulation. See Opinion of Advocate General Jääskinen delivered on 29 November 2012 in the case C-228/11 Melzer v. MF Global UK Ltd, para. 63.

${ }^{940}$ See paragraph 6.2 .3 on the 'case-specific copyright holder's centre of interest' approach proposed by the scholars Kono and Jurcys.
} 
As mentioned in paragraph 1.2, from a broad perspective, it is desirable that the connecting factors also balance the interests between copyright holders, on the one hand, and traders and users of information, on the other hand. ${ }^{941}$ In paragraph 4.4, it will therefore be argued to include this principle of balancing the interests related to copyrights into the assessment framework. Paragraph 4.4.2.1.1 will demonstrate that Kegel in particular advocated a broad interest-based approach to rules of private international law.

\subsubsection{The comparative law method}

The comparative law method can be considered as a part of the European Union law interpretative framework. ${ }^{942}$ As mentioned in paragraph 4.2.3, comparative arguments may also be subsumed under the method of contextual interpretation. ${ }^{943}$ In order to maintain "the autonomy of the European legal order," the CJEU usually does not explicitly discuss a preliminary question from a comparative view. ${ }^{944}$ The opinions of Advocates General regularly contain comparatives studies. ${ }^{945}$

To interpret European Union law, the comparative law method may focus on national laws of Member States or other states. ${ }^{946}$ As argued by Kiikeri, the latter "third law" comparisons "may even appear relevant in justifying the drastic changes to the European legal systems". ${ }^{947}$ Another argument in favour of the use of the comparative law method is the general desirability to establish unified jurisdiction rules applicable to civil matters such as cross-border copyright infringement cases. ${ }^{948}$ Although it has not been the main aim of this dissertation to provide unified jurisdiction rules for cross-border copyright infringement cases, it is worth to consider this possibility with respect to courts that obtain jurisdiction based on effects caused by copyright infringing activities. ${ }^{949}$

To rethink the CJEU's approach to jurisdiction in cross-border copyright infringement cases, chapter six will refer to several decisions of Member State courts on this matter. In addition, chapter seven will set out various connecting factors adopted by courts in states of the

\footnotetext{
${ }^{941}$ See the Preamble to the CLIP Principles No 2 and 6. See the final text of the Principles on Conflict of Laws in Intellectual Property of 1 December 2011 enacted by the European Max Planck Group on Conflict of Laws in Intellectual Property. See also Pertegás Sender 2002, pp. 28-33.

942 Garcimartín Alférez 2013, p. 170. See also Kutscher 1976, pp. 1-23-29; Lenaerts \& Gutman 2016, p. 842.

943 See Beck 2012, p. 215.

${ }^{944}$ Kiikeri 2001, pp. 284-286. See also Beck 2012, p. 219.

945 See Bengoetxea 1993, p. 245; Kutscher 1979, p. I-28. For example, Opinion of Advocate General Jääskinen delivered 13 June 2013 in the case C-170/12 Peter Pinckney v. KGD Mediatech AG, para. 59 note 52. See also the Opinion of Advocate General Cruz Villalón delivered on 11 September 2014 in case C-441/13 Pez Hejduk v. EnergieAgentur. NRW GmbH, para. 29 note 14.

946 See Kiikeri 2001, p. 119; Lenaerts \& Gutman 2016, pp. 841-864.

947 Kiikeri 2001, p. 287. As an example of external comparison, Kiikeri referred to the opinion of Advocate General Tesauro delivered on 6 April 1995 in the case C-450/93 Eckhard Kalanke v. Freie Hansestadt Bremen. Tesauro employed the United States case law to support his "institutional interpretation" of the equality principle. See Kiikeri 2001, p. 251.

${ }^{948}$ The attempts of the Hague Conference on Private International Law to unify jurisdiction rules related to civil and commercial matters illustrate this general desire, see paragraphs 1.1.2 and 6.4.2.

${ }^{949}$ See paragraph 8.5 on the possibility of a codified uniform approach to jurisdiction in cross-border copyright infringement cases.
} 
United States of America to establish jurisdiction in cross-border copyright infringement disputes. Yet, as argued by Advocate General Poiares Maduro, the "best solution" is "the solution that best fits the underlying goals and requirements of the EU legal order and its particular context of application." 950 Therefore, the teleological method demonstrated in paragraph 4.2.4 will also be important when applying the comparative method to interpret European Union law. ${ }^{951}$

\subsection{The precedent-based method of interpretation}

It has been argued that the CJEU's rulings usually do not contain extensive legal reasoning. ${ }^{952}$ As noted by Lenaerts, the persuasiveness of the CJEU's "argumentative discourse" is often built up progressively that means "stone-by-stone". ${ }^{953}$ Thus, "to fully apprehend the approach of the CJEU in an area of EU law", one should examine not only the case involved but also previous related case law as well as subsequent case law. ${ }^{954}$ According to Beck, "case law interpretation" may play a significant part of the CJEU's legal argumentation. ${ }^{955}$ Although, "there is no formal doctrine of precedent, or stare decisis, in EU law", the CJEU tends to follow its own decisions. ${ }^{956}$ This approach provides legal certainty and predictability. ${ }^{957}$ From a perspective of judicial legitimacy this is also important since inconsistent decisions would likely undermine the public acceptance of these decisions. ${ }^{958}$

Previous rulings may thus confine the leeway of the CJEU's interpretation of Article 7(2) Brussels Ibis in cross-border copyright infringement cases. The next paragraph will briefly describe seminal rulings on the interpretation of the special jurisdiction rule, in particular 'the place where the damage occurred' as connecting factor, under Article 7(2) Brussels Ibis. The table in paragraph 4.6.2 will also mention other rulings that will be relevant in this dissertation to rethink the CJEU's approach to jurisdiction in cross-border copyright infringement cases. While the precedent-based method of interpretation has generally not been regarded as a common method of interpretation in the European Union, it could be subsumed under the contextual method of interpretation.

\footnotetext{
${ }^{950}$ Poiares Maduro 2007, p. 141. With respect to the "best solution" approach, Poiares Maduro referred to the Opinion of Advocate General Lagrange in Case C-14/61 Hoogovens v. High Authority. See paragraph 1.2.

${ }^{951}$ Kakouris 1994, pp. 273-275.

952 Lenaerts 2013, p. 1350.

${ }^{953}$ Lenaerts 2013, p. 1351. See also Beck 2012, pp. 99, 250, 263-266; Jacob 2014, pp. 1-3, 8.

${ }_{954}$ Lenaerts 2013, p. 1351.

${ }^{955}$ Beck 2012, pp. 100, 180-183, 251-266. Beck advocates a heuristic approach to interpretation. See Beck 2012, pp. 153-157. See paragraph 4.2 on the heuristic method of interpretation.

${ }_{956}$ Beck 2012, p. 234. See also Arnull 2013, p. 217; Beck 2012, pp. 239-242; Jacob 2014, pp. 66, 243; Rosati 2013, p. 100.

957 Jacob 2014, p. 13.

${ }^{958}$ Beck 2012, p. 339.
} 


\subsubsection{Relevant rulings regarding "the place where the damage occurred"}

As demonstrated in paragraph 3.2.3, the CJEU explicitly built its ruling in the Pinckney case on previous case law. ${ }^{959}$ To interpret "the place where the damage occurred", the CJEU employed the rulings eDate and Martinez ${ }^{960}$ and Wintersteiger ${ }^{961}$. In this paragraph, the latter rulings will be briefly set out. But first it is important to mention the ruling of Bier v. Mines de Potasse d'Alsace ${ }^{962}$ that could be considered as the foundation stone regarding the interpretation of the special jurisdiction rule "the place where the harmful event occurred" of Article 7(2) Brussels Ibis.

In the case of Bier v. Mines de Potasse d'Alsace, involving cross-border water pollution, the CJEU (formerly known as the Court of Justice) gave the seminal preliminary ruling on the interpretation of the special jurisdiction rule enshrined in Article 7(2) Brussels Ibis Regulation, formerly Article 5(3) Brussels Convention of $1968 .{ }^{963}$ In this case, the CJEU construed that "the place where the harmful event occurred" must be understood as being intended to cover both "the place of the event giving rise to the damage", the so-called Handlungsort, and "the place where the damage occurred", the so-called Erfolgsort. ${ }^{964}$ Thus, whenever the Handlungsort and Erfolgsort are not coinciding in one Member State, the plaintiff may initiate proceedings related to tort matters in various Member States. The CJEU reasoned that these two connecting factors entail a particularly close connection between the court seised and the dispute that will be "particularly helpful from the point of view of the evidence and of the conduct of the proceedings". ${ }^{965}$ Therefore, these connecting factors enhance the sound administration of justice. ${ }^{966}$

In subsequent rulings, the CJEU crystallised the interpretation in the Bier ruling with respect to several type of torts. In the Shevill and Others $v$. Presse Alliance ruling, involving a cross-border defamatory newspaper article, the CJEU interpreted the Erfolgsort as the place where the newspaper was distributed and where the victim claims to have suffered injury to his reputation. ${ }^{967}$ The CJEU limited the jurisdiction of the courts of the Erfolgsort to the damage suffered in the territory of the forum state. ${ }^{968}$ Pursuant to the CJEU, this territorial limitation of jurisdiction, also referred to as mosaic principle, ${ }^{969}$ suits the objective of Article 7(2) Brussels Ibis to facilitate the sound administration of justice since these courts "are territorially best

\footnotetext{
${ }^{959}$ Case C-170/12 Peter Pinckney v. KGD Mediatech AG.

960 Joined Cases C-509/09 and C-161/10 eDate Advertising GmbH v. Olivier Martinez and Robert Martinez v. MGN Limited, para. 51.

${ }^{961}$ Case C-523/10 Wintersteiger AG v. Products $4 U$ Sondermaschinenbau GmbH, para. 25.

962 Case C-21/76 Bier v. Mines de Potasse d'Alsace SA. See also paragraph 2.1.2.2.2.

${ }^{963}$ Case C-21/76 Bier. See also paragraph 2.1.2.2.2.

964 Case C-21/76 Bier, para. 24-25.

965 Case C-21/76 Bier, para. 17.

${ }^{966}$ Case C-21/76 Bier, para. 11. See also Case C-189/08 Zuid-Chemie BV v. Philippo's Mineralenfabriek NV/SA, para. 24. Case C-167/00 Verein für Konsumenteninformation v. Karl Hein, para. 46.

${ }_{967}$ Case C-68/93 Shevill and Others v. Presse Alliance, para. 30. See also paragraph 2.1.2.2.2 of this dissertation.

${ }_{968}$ Case C-68/93 Shevill and Others v. Presse Alliance, para. 31.

${ }^{969}$ See paragraph 1.1.4.
} 
placed to assess the libel committed in that State and to determine the extent of the corresponding damage". 970

In the joined cases of eDate and Martinez, involving alleged online infringements of personality rights, the CJEU broadly construed the Erfolgsort as being each place where the infringing content is or has been online accessible. ${ }^{971}$ Nonetheless, in line with the abovementioned Shevill ruling, the CJEU limited the jurisdiction of these courts to the damage that occurred within the forum state. In addition, the CJEU attributed jurisdiction to the court of the place of the 'victim's centre of interests' regarding the entire damage. ${ }^{972}$ This connecting factor has been justified by the serious nature of the harm caused through the instant worldwide dissemination of online infringements of personality rights, and the consideration that it is difficult to quantify that distribution in relation to a particular Member State and, therefore, to assess the damage within that Member State. ${ }^{973}$ Furthermore, the CJEU reasoned that the publisher will generally be aware of the victim's centre of interests when he places the content online. ${ }^{974}$ Paragraph 6.2 will demonstrate that several scholars advocate to employ the 'victim's centre of interests' approach to establish jurisdiction in online copyright infringement disputes.

In the ruling of Bolagsupplysningen OÜ, Ingrid Ilsjan v. Svenk Handel AB, the CJEU confirmed that the aforementioned 'victim's centre of interests' approach is also applicable in case the plaintiff is a legal person pursuing an economic activity that claims its personality rights are infringed by the placing of defamatory content online by another legal person. ${ }^{975} \mathrm{In}$ addition, the CJEU focused on the scope of the court's jurisdiction based on the Erfolgsort. Pursuant to the CJEU, the court of the Member State in which the victim's centre of interests is located will obtain full jurisdiction and may therefore issue an injunction to remove and rectify the incorrect online information and assess all the damage sustained. ${ }^{976}$ In addition, the CJEU held that courts that have territorially limited jurisdiction based on the accessibility criterion will not have jurisdiction to issue an injunction to remove or rectify online infringing content. ${ }^{977}$ Paragraph 5.3.3 will return to this latter ruling regarding the scope of the court's jurisdiction in cross-border copyright infringement cases.

Paragraph 3.6.2 already demonstrated the case of Wintersteiger AG v. Products $4 U$ Sondermaschinenbau $\mathrm{GmbH}$, involving an alleged online infringement of a trademark, in which the CJEU confined "the place where the damage occurred" to the place where the trademark has been registered. ${ }^{978}$ Since trademark rights are only protected in the Member States where

\footnotetext{
${ }^{970}$ Case C-68/93 Shevill and Others v. Presse Alliance, para. 31.

971 Joined Cases C-509/09 and C-161/10 eDate Advertising GmbH v. Olivier Martinez and Robert Martinez v. $M G N$ Limited, para. 51. See also paragraph 2.1.2.2.2.

972 Joined Cases C-509/09 and C-161/10 eDate and Martinez, para. 48. The concept "centre of interests" generally refers to the plaintiff's habitual residence. However, a person may also have the centre of his interests in another Member State "in so far as other factors, such as the pursuit of a professional activity may establish the existence of a particularly close link with that State" (see para. 49). See paragraph 6.2 on the possibility to adopt the 'victim's centre of interests' approach under Article 7(2) Brussels Ibis in cross-border copyright infringement cases.

973 Joined Cases C-509/09 and C-161/10 eDate and Martinez, para. 45-47. See also paragraph 6.2.1.1.2.

974 Joined Cases C-509/09 and C-161/10 eDate and Martinez, para. 50.

${ }^{975}$ Case C-194/16 Bolagsupplysningen OÜ, Ingrid Ilsjan v. Svenk Handel AB, para. 32-49.

${ }^{976}$ Case C-194/16 Bolagsupplysningen OÜ, para. 48. See also paragraph 5.3.3 on the issue of territorially limited or cross-border injunctions issued by the court on the basis of the Erfolgsort under Article 7(2) Brussels Ibis.

977 Case C-194/16 Bolagsupplysningen OÜ, para. 45-49.

${ }^{978}$ Case C-523/10 Wintersteiger AG v. Products $4 U$ Sondermaschinenbau GmbH, para. 25.
} 
they have been registered, the CJEU reasoned that the courts of the Member State of registration are best able to assess whether the defendant's activities have actually infringed the national trademark. ${ }^{979}$ According to the CJEU, the place of registration of trademarks as connecting factor enhances predictability and the sound administration of justice. ${ }^{980}$

When rethinking the CJEU's interpretation of Article 7(2) Brussels Ibis in cross-border copyright infringement cases, this dissertation will frequently consider the abovementioned case law involving the interpretation of Article 7(2) Brussels Ibis. In addition, this dissertation will demonstrate other relevant rulings by the CJEU that may influence the approach to jurisdiction in cross-border copyright infringement disputes such as the so-called Pammer and Alpenhof ruling on the interpretation of the special jurisdiction rule in Article 17(1) Brussels Ibis that aims to protect consumers as 'weaker' parties. ${ }^{981}$

\subsubsection{Table on seminal rulings involving the interpretation of the special jurisdiction rule} under Article 7(2) Brussels Ibis

\begin{tabular}{|c|c|c|c|}
\hline $\begin{array}{l}\text { Rulings on the } \\
\text { interpretation of } \\
\text { "the place where } \\
\text { the harmful event } \\
\text { occurred or may } \\
\text { occur" } \\
\text { under Article 7(2) } \\
\text { Brussels Ibis }\end{array}$ & $\begin{array}{l}\text { Type of alleged cross- } \\
\text { border tortious } \\
\text { activity }\end{array}$ & $\begin{array}{l}\text { Connecting factors to } \\
\text { establish jurisdiction } \\
\text { under Article 7(2) } \\
\text { Brussels Ibis }\end{array}$ & $\begin{array}{l}\text { Scope of the } \\
\text { jurisdiction of the } \\
\text { court competent on } \\
\text { the basis of Article } \\
7(2) \text { Brussels Ibis }\end{array}$ \\
\hline \multirow[t]{2}{*}{$\begin{array}{l}\text { Bier } \\
\text { C- 21/76 }\end{array}$} & \multirow[t]{2}{*}{ water pollution } & $\begin{array}{l}\text { Handlungsort: the place of } \\
\text { the event giving rise to the } \\
\text { damage (para. 24). }\end{array}$ & \\
\hline & & $\begin{array}{l}\text { Erflogsort: the place where } \\
\text { the damage occurred (para. } \\
\text { 24). }\end{array}$ & \\
\hline \multirow[t]{2}{*}{$\begin{array}{l}\text { Shevill } \\
\text { C-68/93 }\end{array}$} & \multirow[t]{2}{*}{$\begin{array}{l}\text { defamatory publication } \\
\text { in a newspaper }\end{array}$} & $\begin{array}{l}\text { Handlungsort: the place } \\
\text { where the publisher of the } \\
\text { defamatory publication is } \\
\text { established (para. 24). }\end{array}$ & $\begin{array}{l}\text { Jurisdiction to hear the } \\
\text { action for all the } \\
\text { damage caused by the } \\
\text { alleged tortious activity } \\
\text { (para. } 25 \text { ). }\end{array}$ \\
\hline & & $\begin{array}{l}\text { Erfolgsort: the place where } \\
\text { the defamatory publication } \\
\text { has been distributed and } \\
\text { where the victim claims to }\end{array}$ & $\begin{array}{l}\text { Jurisdiction is limited to } \\
\text { assess the libel } \\
\text { committed in the forum } \\
\text { state and the }\end{array}$ \\
\hline
\end{tabular}

${ }^{979}$ Case C-523/10 Wintersteiger, para. 25-28.

${ }^{980}$ Case C-523/10 Wintersteiger, para. 25-28.

981 Joined cases C-585/08 and C-144/09 Peter Pammer v. Reederei Karl Schlüter GmbH \& Co. KG and Hotel Alpenhof GesmbH v. Oliver Heller. See paragraph 6.1.2 on the 'directed activities' approach in the Pammer and Alpenhof ruling. See table 4.6.2 on the method of precedent-based interpretation for other relevant rulings that will be considered in this dissertation.

982 See the list regarding the abbreviations of the case law. 


\begin{tabular}{|c|c|c|c|}
\hline & & $\begin{array}{l}\text { have suffered injury to his } \\
\text { reputation (para. 30). }\end{array}$ & $\begin{array}{l}\text { corresponding damage } \\
\text { caused within that state } \\
\text { (para. 30-31). }\end{array}$ \\
\hline $\begin{array}{l}\text { Marinari } \\
\text { C-364/93 }{ }^{983}\end{array}$ & $\begin{array}{l}\text { wrongly accusation } \\
\text { made by a bank that } \\
\text { caused financial } \\
\text { damage to the assets of } \\
\text { the victim }\end{array}$ & $\begin{array}{l}\text { Erfolgsort: the place where } \\
\text { the initial damage occurred, } \\
\text { not the place where the } \\
\text { victim claims to have } \\
\text { suffered financial damage } \\
\text { following upon the initial } \\
\text { damage (para. } 15 \text { ). Similar } \\
\text { rulings are C-220/88 } \\
\text { Dumez, C-168/02 } \\
\text { Kronhofer, C-375/13 } \\
\text { Kolassa. }\end{array}$ & \\
\hline \multirow[t]{3}{*}{$\begin{array}{l}\text { eDate and Martinez } \\
\text { Joined Cases C- } \\
509 / 09 \text { and C- } \\
161 / 10 \\
\text { Bolagsupplysningen } \\
\text { Ö̈ } \\
\text { Case C-194/16 }\end{array}$} & \multirow[t]{3}{*}{$\begin{array}{l}\text { infringements of } \\
\text { personality rights via } \\
\text { the Internet }\end{array}$} & $\begin{array}{l}\text { Handlungsort: the place } \\
\text { where the publisher of the } \\
\text { content is established } \\
\text { (eDate and Martinez } \\
\text { para. 52). }\end{array}$ & $\begin{array}{l}\text { Jurisdiction with } \\
\text { respect to all the } \\
\text { damage caused (para. } \\
52 \text { ) and to issue an } \\
\text { injunction to remove } \\
\text { and rectify online } \\
\text { infringing content } \\
\text { (Bolagsupplysningen } \\
\text { Ö̈ para. 44, 48). }\end{array}$ \\
\hline & & $\begin{array}{l}\text { Erfolgsort: the place where } \\
\text { the infringing content is or } \\
\text { has been accessible via the } \\
\text { Internet (eDate and } \\
\text { Martinez } \\
\text { para. 51). }\end{array}$ & $\begin{array}{l}\text { Jurisdiction is limited to } \\
\text { the damage caused in } \\
\text { the territory of the } \\
\text { forum state (eDate and } \\
\text { Martinez } \\
\text { para. } 51 \text { and } \\
\text { Bolagsupplysningen } \\
\text { OÜ para. 47). } \\
\text { No jurisdiction to } \\
\text { remove or rectify online } \\
\text { infringing content } \\
\text { (Bolagsupplysningen } \\
\text { OÜ para. 45-49). }\end{array}$ \\
\hline & & $\begin{array}{l}\text { The place of the victim's } \\
\text { centre of interests (eDate } \\
\text { and Martinez } \\
\text { para. 48). This place will } \\
\text { generally be the place of his } \\
\text { habitual residence but other } \\
\text { factors may also constitute }\end{array}$ & $\begin{array}{l}\text { Jurisdiction with } \\
\text { respect to all the } \\
\text { damage caused (eDate } \\
\text { and Martinez } \\
\text { para. } 48)^{984} \text { and to issue } \\
\text { an injunction to remove } \\
\text { and rectify online }\end{array}$ \\
\hline
\end{tabular}

${ }^{983}$ See paragraph 5.2.2 on the concept of damage under Article 7(2) Brussels Ibis.

${ }^{984}$ See paragraph 5.3.3.1 on the concept of 'full' damage under Article 7(2) Brussels Ibis. 


\begin{tabular}{|c|c|c|c|}
\hline & & $\begin{array}{l}\text { the existence of a } \\
\text { particularly close link with } \\
\text { the forum state, such as the } \\
\text { pursuit of a professional } \\
\text { activity (eDate and } \\
\text { Martinez } \\
\text { para. } 49 \text { ). With respect to a } \\
\text { legal person as victim, the } \\
\text { CJEU ruled that the centre } \\
\text { of interests must be } \\
\text { determined by reference to } \\
\text { the place where it carries } \\
\text { out the main part of its } \\
\text { economic activities } \\
\text { (Bolagsupplysningen para. } \\
\text { 41). }\end{array}$ & $\begin{array}{l}\text { infringing content } \\
\text { (Bolagsupplysningen } \\
\text { Ö̈ para. } 44,48 \text { ). }\end{array}$ \\
\hline \multirow[t]{2}{*}{$\begin{array}{l}\text { Wintersteiger } \\
\mathrm{C}-523 / 10\end{array}$} & \multirow[t]{2}{*}{$\begin{array}{l}\text { infringement of a } \\
\text { national trade mark via } \\
\text { the Internet }\end{array}$} & $\begin{array}{l}\text { Handlungsort: the place of } \\
\text { establishment of the alleged } \\
\text { infringer since the process } \\
\text { for technical display of the } \\
\text { photographs on the website } \\
\text { was activated can be } \\
\text { considered as the causal } \\
\text { event (para. } 37 \text { ). }\end{array}$ & \\
\hline & & $\begin{array}{l}\text { Erfolgsort: the place where } \\
\text { the trade mark involved is } \\
\text { registered (para. 25). }\end{array}$ & $\begin{array}{l}\text { Jurisdiction to } \\
\text { determine all the } \\
\text { alleged damage and to } \\
\text { hear an application } \\
\text { seeking cessation of all } \\
\text { infringements of the } \\
\text { trade mark (para. 28) }\end{array}$ \\
\hline $\begin{array}{l}\text { Pinckney } \\
\text { C-170/12 }\end{array}$ & $\begin{array}{l}\text { reproduction of } \\
\text { compact discs involving } \\
\text { copyright infringing } \\
\text { songs and the sale of } \\
\text { these discs via the } \\
\text { Internet committed by } \\
\text { several supposed } \\
\text { perpetrators }\end{array}$ & $\begin{array}{l}\text { Erfolgsort: the place of the } \\
\text { locus protectionis as } \\
\text { established by the CJEU } \\
\text { (see paragraph } 3.2 .3 \text { ) and } \\
\text { where the damage may } \\
\text { occur (the so-called } \\
\text { 'likelihood of damage' } \\
\text { criterion) (para 43). The } \\
\text { 'likelihood of damage' } \\
\text { criterion was satisfied due } \\
\text { to the possibility of } \\
\text { obtaining a reproduction of } \\
\text { the copyright infringing } \\
\text { work via an internet site } \\
\text { accessible in the forum state } \\
\text { (para. } 44 \text { ). }\end{array}$ & $\begin{array}{l}\text { Jurisdiction is limited to } \\
\text { the damage caused in } \\
\text { the territory of the } \\
\text { forum state (para. 45). }\end{array}$ \\
\hline
\end{tabular}




\begin{tabular}{|c|c|c|c|}
\hline \multirow[t]{2}{*}{$\begin{array}{l}\text { Hi Hotel } \\
\text { C-387/12 }\end{array}$} & \multirow[t]{2}{*}{$\begin{array}{l}\text { reproduction and } \\
\text { distribution of copyright } \\
\text { infringing photographs } \\
\text { committed by several } \\
\text { supposed perpetrators }\end{array}$} & $\begin{array}{l}\text { In case of several supposed } \\
\text { perpetrators causing alleged } \\
\text { damage, the Handlungsort } \\
\text { does not include the place } \\
\text { where one of the } \\
\text { perpetrators did not act } \\
\text { (para. } 31-32 \text { ). See also case } \\
\text { C-228/11 Melzer. See } \\
\text { paragraph } 5.2 .3 \text { on the so- } \\
\text { called third party-based } \\
\text { approach to jurisdiction. }\end{array}$ & \\
\hline & & $\begin{array}{l}\text { Erfolgsort: the place of the } \\
\text { locus protectionis, as } \\
\text { established by the CJEU } \\
\text { (see paragraph } 3.2 .3 \text { ) and } \\
\text { where the damage may } \\
\text { occur (the so-called } \\
\text { 'likelihood of damage' } \\
\text { criterion) (para. 35). The } \\
\text { 'likelihood of damage' was } \\
\text { satisfied since the fact that } \\
\text { the defendant provided the } \\
\text { copyrighted photographs to } \\
\text { one of the perpetrators gave } \\
\text { rise to the reproduction and } \\
\text { distribution of the } \\
\text { photographs and thereby to } \\
\text { the possibility that the } \\
\text { damage alleged might occur } \\
\text { within the forum state } \\
\text { (para. } 37 \text { ). }\end{array}$ & $\begin{array}{l}\text { Jurisdiction is limited to } \\
\text { the damage caused in } \\
\text { the territory of the } \\
\text { forum state (para. 38) }\end{array}$ \\
\hline \multirow[t]{2}{*}{$\begin{array}{l}\text { Pez Hejduk } \\
\text { C-411/13 }\end{array}$} & \multirow[t]{2}{*}{$\begin{array}{l}\text { making available of } \\
\text { copyright infringing } \\
\text { photographs via a } \\
\text { website for viewing and } \\
\text { downloading }\end{array}$} & $\begin{array}{l}\text { Handlungsort: the place } \\
\text { where the alleged infringer } \\
\text { has its seat since the } \\
\text { activation of the process for } \\
\text { technical display of the } \\
\text { photographs on the website } \\
\text { must be considered as the } \\
\text { causal event (para. 24-25). }\end{array}$ & \\
\hline & & $\begin{array}{l}\text { Erfolgsort: the place of the } \\
\text { locus protectionis, as } \\
\text { established by the CJEU } \\
\text { (see paragraph } 3.2 .3 \text { ) and } \\
\text { where the damage may } \\
\text { occur (para 30-34). The } \\
\text { 'likelihood of damage' } \\
\text { criterion was satisfied by } \\
\text { the mere accessibility of the }\end{array}$ & $\begin{array}{l}\text { Jurisdiction is limited to } \\
\text { the damage caused in } \\
\text { the territory of the } \\
\text { forum state (para. 36). }\end{array}$ \\
\hline
\end{tabular}




\begin{tabular}{|l|l|l|}
\hline & $\begin{array}{l}\text { alleged copyrighted } \\
\text { photographs via the website } \\
\text { in the forum state (para. } \\
34) .\end{array}$ & \\
\hline
\end{tabular}

\subsection{The principle of balancing the interests related to copyrights}

As indicated in paragraph 2.1.2.1.3, the CJEU's interpretation of the special jurisdiction rule of Article 7(2) Brussels Ibis in cross-border copyright infringement cases seems to favour copyright holders by ruling that copyrights should be protected in all Member States by virtue of the Information Society Directive. ${ }^{985}$ Instead of the "principle of favor auctoris", ${ }^{986}$ this dissertation will argue to adopt the principle of balancing the relevant interests involving copyrights.

Paragraph 4.2.4.2 explained that the CJEU should seek to balance the procedural interests of the litigants when interpreting Article 7(2) Brussels Ibis in cross-border copyright infringements disputes. In other words, the interests of the copyright holder and the alleged infringer have to be balanced. The following paragraphs will argue that the CJEU should also seek to balance the broader interests involved. Arguments will be provided to incorporate the principle of balancing certain interests related to copyrights in the assessment framework to rethink the CJEU's interpretation of Article 7(2) Brussels Ibis in cross-border copyright infringement cases. First, the next paragraph will outline the particular interests that will be included into the principle of interest-balancing. Second, from a perspective of legitimacy, the following paragraphs will provide various arguments to insert the principle of balancing the interests related to copyrights in the assessment framework.

\subsubsection{The interests of copyright holders, users of information and traders}

In chapter two, it has been demonstrated that the increasing interaction between interests of copyright holders and stakeholders requires to seek a balance. ${ }^{987}$ The attribution of jurisdiction in copyright infringement cases also involves an interaction between interests of copyright holders and stakeholders such as interests related to trade, access of information, innovation, education and public health. ${ }^{988}$ This dissertation will focus on the interests of copyright holders, users of information and traders in the context of the attribution of jurisdiction in cross-border copyright infringement cases. As will be demonstrated below, the interests of these stakeholders are often connected to broader interests such as innovation, cultural heritage, education and economic growth.

\footnotetext{
985 See Case C-170/12 Peter Pinckney v. KGD Mediatech AG, para. 39; Case C-387/12 Hi Hotel HCF SARL v. Uwe Spoering, para. 36; Case C-441/13 Pez Hejduk v. EnergieAgentur NWR GmbH, para. 36-37.

986 Ohly 2009, pp. 238-239.

987 See paragraphs $2.2 .2 .1 ; 2.2 .2 .1 .1 ; 2.2 .2 .1 .2$.

${ }^{988}$ See Peukert 2013, p. 38, PRE:C:32. See also paragraph 2.2.2.1.2.
} 
To enhance copyright protection, it is important that copyright holders will receive efficient redress in case of cross-border copyright infringements. Therefore, they should be able to easily identify before which court(s) an alleged infringer can get sued. The copyright holder will like to receive full redress in a court nearby. When adopting an approach to jurisdiction, it is desirable to consider the pressing problem of online piracy and copyright havens ${ }^{989}$. Efficient copyright protection will enhance other public interests such as creativity, innovation, knowledge, cultural heritage and economic growth. ${ }^{990}$ For instance, innovation may hamper if copyright holders cannot rely on the prospect to bring an infringement claim before a near court that can issue an injunction and award damages.

For the cross-border flow of information, it will be relevant that users of information can reasonably predict in which state(s) they may get sued for copyright infringement. ${ }^{991}$ As will be demonstrated in paragraph 4.4.2.4, the right to information generally includes the freedom to receive and share information. Both users and providers of information are important to maintain the cross-border flow of information. Since the use and exchange of information often merge, the concept of users of information in this dissertation will also involve providers of information. In particular the 'free' exchange of information via the Internet requires special attention when adopting an approach to jurisdiction in cross-border copyright infringement cases. Impeding the cross-border flow of information will likely have a negative effect on innovation and education. As mentioned in paragraph 2.2.2.1.1, developing countries highly dependent on access to information to enhance knowledge and education.

The interests of traders should also be involved regarding the issue which court may obtain jurisdiction in cross-border copyright disputes. ${ }^{992}$ Traders of copyrighted products have to be able to rely on the prospect that they can bring a copyright infringement claim before the nearest court to get their full damage recovered. ${ }^{993}$ At the same time, traders should not get unexpectedly sued in a state for copyright infringement. Unpredictability as regards in which states traders may get sued can impede the cross-border trade. Particularly small trading companies will seek to prevent to get sued in multiple states. It has been argued that jurisdiction rules should promote the digital economy. ${ }^{994}$ The foregoing indicates that both the internal market and the international trade ${ }^{995}$ could be negatively affected if the interests of traders are neglected when attributing jurisdiction to courts on the basis of Article 7(2) Brussels Ibis in cross-border copyright infringement disputes. This dissertation will include the interests of the

\footnotetext{
${ }^{989}$ See paragraph 1.1.4 on the definition of online piracy and paragraph 2.2.2.2 on the concept of copyright haven. ${ }^{990}$ See paragraph 2.2.2.1.1 on the trend of overprotection of copyrights.

${ }^{991}$ See also Neumann (2014, p. 511) who argues that providers and users of global internet services "need to know the competent courts and the applicable law in advance in order to adapt their conduct to foreseeable standards". 992 Austin 1997, p. 333.

993 See Peukert 2013, p. 29, PRE:C:09-C11, p. 38, PRE:C:32.

${ }^{994}$ See paragraphs 2.1 .2 .1 .5 .2 and 6.2.3.

${ }^{995}$ See Peukert 2013, p. 38, PRE:C:32. The preamble to the TRIPS-Agreement 1994 states that the Members desire "to reduce distortions and impediments to international trade, and taking into account the need to promote effective and adequate protection of intellectual property rights, and to ensure that measures and procedures to enforce intellectual property rights do not themselves become barriers to legitimate trade". The TRIPS-Agreement 1994 is an international agreement concluded between the Member States of the World Trade Organization. The European Union and its Member States are a member of the World Trade Organization. See https://www.wto.org/english/thewto_e/countries_e/european_communities_e.htm.
} 
traders as potential infringers into the principle of balancing the broader interests related to copyrights at jurisdictional level. As will be set out in paragraph 4.5, this dissertation will also include into the assessment framework the impact of the Geo-blocking Regulation on the approach to jurisdiction in cross-border copyright infringement cases. This Regulation will be applicable to traders as potential copyright infringers. ${ }^{996}$

With respect to rules of private international law involving intellectual property, the European Max Planck Group on Conflict of Laws in Intellectual Property ${ }^{997}$ argues that these rules "need to consider and balance all interests involved, including the interests of owners of intellectual property rights, their contracting partners and other users of intellectual property, and the broader public interest, in particular in access to, and use of, information as well as other public interests". ${ }^{998}$ To rethink the CJEU's approach to jurisdiction in cross-border copyright infringement cases, the following paragraphs will from a legitimate perspective provide arguments to include the principle of balancing the interests between copyright holders, on the one hand, and traders and users of information, on the other hand, in the assessment framework.

\subsubsection{Arguments in favour of balancing the interests involved}

\subsubsection{Balancing as common "interpretative technique"}

First of all, it has been claimed that the method of balancing the interests involved is an indispensable element of legal reasoning. ${ }^{999}$ In view of "the complex societal problems and issues", it has generally become difficult for legislators to address all the interests involved, courts are therefore "increasingly expected to weigh and reconcile the relevant interests themselves". ${ }^{1000}$ Particularly, if the case involves conflicting legal values or rights, the court should employ balancing as "interpretative technique". ${ }^{1001}$ Hart notes that the interpretation of open-textured provisions will often require a court to strike a balance between the competing interests. ${ }^{1002}$ Reich considers the principle of balancing opposing interests as an important interpretative principle with respect to civil law relations. ${ }^{1003}$

As explained in the previous paragraph, the attribution of jurisdiction to the court(s) in cross-border copyright infringement cases involves various conflicting interests. Since Article 7(2) Brussels Ibis can be considered as an open-textured provision, ${ }^{1004}$ the CJEU should thus interpret Article 7(2) Brussels Ibis in cross-border copyright infringement disputes in a way

\footnotetext{
${ }^{996}$ See paragraph 4.5 .1 on the scope and aim of the Geo-blocking Regulation.

${ }^{997}$ See paragraph 1.1.2. Chapter 6 will elaborate on the CLIP principles with respect to rules of jurisdiction in cross-border copyright infringements disputes.

${ }^{998}$ See Preamble No 6 of the Final text of the Principles on Conflict of Laws in Intellectual Property of 1 December 2011.

999 Sieckmann 2010, p. 101. See also De Vries, Groussot, Petursson 2012, pp. 51-53; Isola-Miettinen 2010, pp. 171-172; Smits 2006, p. 134.

${ }^{1000}$ See Adams, De Waele, Meeusen, \& Straetmans 2015, p. 2.

${ }^{1001}$ Stone-Sweet 2000, p. 98; Stone-Sweet 2004, pp. 10-11. See also Dworkin 2013, p. 124.

${ }^{1002}$ Hart 2012, p. 135.

${ }^{1003}$ Reich 2014, pp. 10, 131-153.

1004 See paragraph 4.2.1.
} 
that it balances the interests and rights involved. Yet, the interpretative technique of interestbalancing can be considered as autonomous law-finding. ${ }^{1005}$ As mentioned in paragraph 4.1.3, autonomous law-finding should be legitimate according to the prevailing scholarly view. ${ }^{1006}$ The next subparagraph will demonstrate Kegel's broad interest-based approach to rules of private international law. ${ }^{1007}$

\subsubsection{1 “Interessenjurisprudenz"}

This paragraph will demonstrate that according to Kegel's interest-based approach to private international law, the interests of stakeholders should be included when interpreting Article 7(2) Brussels Ibis in cross-border copyright infringement cases. The interest-based approach of Kegel finds its origins in the legal doctrine of "Interessenjurisprudenz" established by German scholars. ${ }^{1009}$ According to the latter doctrine, law has been the result of balancing conflicting interests in society. ${ }^{1010}$ When interpreting the law in a particular case, a court therefore has to consider which interests are involved and needs to weigh these interests. ${ }^{1011}$ These interests may involve, for instance, the society, economy or culture. ${ }^{1012}$

With respect to rules of private international law, Kegel distinguishes "Partei-, Verkehrsund Ordnungsinteressen". ${ }^{1013}$ The term Parteiinteressen refers to the interest of the parties involved; connecting factors should refer to the legal system to which the parties are most connected, such as nationality or place of domicile. ${ }^{1014}$ The concept Verkehrsinteressen refers to the interests of the society; connecting factors therefore have to be clear and provide legal certainty and predictability. ${ }^{1015}$ The concept of Ordnungsinteressen mainly concerns the objective of decisional harmony. ${ }^{1016}$

\footnotetext{
1005 Pontier 1998, p. 67.

${ }^{1006}$ As mentioned in paragraph 4.1.3, Pontier indicates that there are various scholarly views on legitimate lawfinding that relate to the rule of law, democratic authority, public support, and righteous or rational decisions. See Pontier 1998, pp. 13-15. For instance, the view that the court's interpretation should comport with the prevailing view on law according to the society. See De Waele 2009, p. 31. De Waele also argues that the court has to consider the negative consequences of its decision. See De Waele 2009, p. 37. See also paragraph 4.4.2.4 on consequentialist reasoning. Conway (2013) argues that the CJEU's interpretation of European Union law has to be in accordance with the rule of law and democracy. See also Bobek (2013, p. 199) on various perspectives regarding the issue of legitimacy regarding the case law of the CJEU.

${ }^{1007}$ With respect to the teleological interpretation method, paragraph 4.2.4 noted that De Winter argued that courts should consider the particular social interests involved when interpreting private international law.

${ }^{1008}$ Interessenjurisprudenz as "a mode of legal analysis and development of the law has been developed by Heck and others". See Hay 1991, p. 437. Hay refers to Heck 1932, Müller-Erzbach 1929 and Stoll 1931.

${ }^{1009}$ Hay 1991, p. 437. Bredimas refers to the term "jurisprudence of interests" as translation of the German term Interessenjurisprudenz. See Bredimas 1978, p. 6.

${ }^{1010}$ Pontier 1998, p. 65.

${ }^{1011}$ Pontier 1998, p. 65. See also Bredimas 1978, pp. 6-7.

1012 Pontier 1998, p. 65.

1013 Kegel 1953, pp. 274-277. Michaels (2017(b), pp. 1046-1047) demonstrates that while Kegel's interest-based approach to private international law mainly focuses on interest in choice of law, "German scholars developed a list of such interests for the law of jurisdiction".

${ }^{1014}$ Kegel 1953, p. 274; Kegel 1987, p. 83.

${ }^{1015}$ Kegel 1953, pp. 274-276; Kegel 1987, pp. 84-85.

${ }^{1016}$ Kegel 1953, pp. 276-277; Kegel 1987, pp. 86-89.
} 
It is noteworthy that in the states of the United States of America, Currie advocated to adopt an approach based on Interessenjurisprudenz with respect to private international law cases. ${ }^{1017}$ Pursuant to Currie's so-called governmental interest analysis, courts dealing with private international law cases have to consider in particular the interests of the states involved. ${ }^{1018}$ In view of Currie's interest analysis, private international law seems to be mainly a political instrument. ${ }^{1019}$

Since Currie's interest analysis provides courts a broad discretion to consider the interests involved, this approach lacks legal certainty which is a traditional aim of private international law in civil law states. ${ }^{1020}$ As mentioned in paragraph 2.1.2.1.2, European civil law systems do not prefer 'flexible' American methods to private international law. ${ }^{1021}$ Furthermore, Currie's interest analysis will frequently facilitate the forum court to apply the lex fori, ${ }^{1022}$ while European private international law generally can be characterised as multilateral. ${ }^{1023}$

In view of Kegel's interest-based approach to private international law, the principle of balancing the interests of copyright holders, users of information and traders could be adopted under Article 7(2) Brussels Ibis. As mentioned in the previous paragraph, an interest-based approach by courts can be considered as autonomous law-finding ${ }^{1024}$ that according to the prevailing scholarly view should be legitimate. ${ }^{1025}$ As mentioned in paragraph 4.2.4.2, in view of the teleological interpretation method, the principle of balancing the procedural interests between litigants, the Parteiinteressen, has been regarded as a principle underlying the special jurisdiction rule Article 7(2) Brussels Ibis. Interpreting rules of private international law in light of Kegel's concept of Verkehrsinteressen resembles the method of teleological interpretation in the broadest sense as set out in paragraph 4.2.4. Based on this method, the principle of balancing the broad interests of copyright holders, on the one hand, and users of information and traders, on the other hand, could be regarded as a principle underlying Article 7(2) Brussels Ibis.

Pertegás Sender argued that "the basic concern of any jurisdictional system should be the search for the appropriate balance between the conflicting interests arising in an international dispute". ${ }^{1026}$ When interpreting the special jurisdiction rule of Article 17(1) Brussels Ibis in cross-border consumer disputes, paragraph 6.1.2.1 will demonstrate that the CJEU also aimed to balance the broader competing interests of traders to employ the Internet as a customary

\footnotetext{
1017 See Flessner 1990, pp. 1-2. "In 1954 he [Currie] began to the series of articles developing his governmental interest analysis of choice in law problems." Most of these articles have been collected in 1963 in Selected Essays on the Conflict of Laws by Currie. See Latty 1966, p. 15.

${ }^{1018}$ Flessner 1990, pp. 5-6. See Currie 1963.

1019 Flessner 1990, p. 5.

${ }^{1020}$ Strikwerda 1978, p. 171.

1021 Yet De Boer (1990, pp. 4-5) enumerates European scholars who opposed the traditional method of Von Savigny. Notably, Strikwerda (1978) advocated the interest analysis as a suitable choice-of-law method in his dissertation. Schaafsma noted that Currie adhered to the forum rei rule to determine jurisdiction in cross-border tort cases that means that the court of the defendant's domicile may obtain jurisdiction. See Schaafsma 1994, p. 60 .

1022 Flessner 1990, p. 6; Symeonides 2016, p. 141.

${ }^{1023}$ Francq 2017, p. 1781. See paragraph 2.1.1 on the concept of multilateral.

${ }^{1024}$ Pontier 1998, p. 67.

${ }^{1025}$ See paragraph 4.1.3 and paragraph 4.4.2.1.

${ }^{1026}$ Pertegás Sender 2002, p. 44. See also Oster 2012, p. 123; Peukert 2013, p. 44, PRE:N07.
} 
means of engaging in trade, on the one hand, and the interests of consumers to sue the trader in their home state, on the other hand. ${ }^{1027}$ The foregoing supports the view that the aim to balance the competing broader interests involved could be regarded as a principle of private international law related to jurisdiction rules.

\subsubsection{Indirect horizontal effect of fundamental rights}

Pursuant to the legal doctrine, when courts interpret the law, they should also consider the international legal order that aims to protect fundamental rights and achieve economic prosperity. ${ }^{1028}$ This suits the desirable role of private international law in the context of global governance as demonstrated in paragraph 2.1.2.1.5.2. It has been argued that balancing fundamental rights "in the process of allocation of jurisdiction" must be an objective of private international law. ${ }^{1029}$

Based on the rule of law in a broad sense, ${ }^{1030}$ courts should protect human rights. ${ }^{1031}$ As mentioned in paragraph 4.1.3, the existence of a democracy will not guarantee that the rights of minorities will be respected. To interpret provisions of private law, European courts regularly indirectly employ fundamental rights. ${ }^{1032}$ In case of conflicting fundamental rights between private parties, European courts generally aim to balance these rights. ${ }^{1033}$ This so-called "indirect horizontal effects of fundamental rights" 1034 has especially been visible when European courts interpret tort law. ${ }^{1035}$ Tort cases frequently involve conflicting fundamental rights such as the right of privacy and the freedom of expression. ${ }^{1036}$

In the joined cases eDate Advertising GmbH v. X and Olivier Martinez and Robert Martinez v. MGN Limited, the indirect horizontal effect of fundamental rights has played a role with respect to the interpretation of the special jurisdiction rule of Article 7(2) Brussels Ibis. In these joined cases, the Advocate General argued that the CJEU should aim to balance the rights and interests involved when interpreting Article 7(2) Brussels Ibis regarding alleged infringements of personality rights. ${ }^{1037} \mathrm{He}$ referred to the underlying tension between the freedom of information and the right to privacy. ${ }^{1038}$ The CJEU seems to have followed the opinion of the Advocate General. ${ }^{1039}$ Paragraph 4.4.2.4 will demonstrate that the CJEU should interpret

\footnotetext{
${ }^{1027}$ See paragraph 6.1.2 on the 'directed activities' approach in the Pammer and Alpenhof ruling.

${ }^{1028}$ Nieuwenhuis, Heijer \& Hins 2017, p. 193. See also Van Hoecke 2002, p. 121.

1029 See Muir-Watt 2016, p. 881. See also paragraph 1.2.

1030 "The minimum content of the rule of law implies fidelity to law as written and enacted." See Conway 2013 , p. 115. Pursuant to the prevailing view in most European states, the rule of law in a broader sense refers to the broader concept of law that includes human rights. See paragraph 4.1.3.

1031 Tridimas 2006, p. 4; Nieuwenhuis, Heijer \& Hins 2017, p. 2; Van Hoecke 2002, p. 172.

${ }^{1032}$ Zoll 2011, p. XV; Busch 2011(a), p. 12. See also Nieuwenhuis, Heijer \& Hins 2017, p. 162.

${ }^{1033}$ Nieuwenhuis, Heijer \& Hins 2017, pp. 172-193. See also Busch 2011(a), p. 15.

${ }^{1034}$ See Busch 2011(a), pp. 11-12.

1035 See Busch 2011(b), p. 38.

1036 See Busch 2011 (b), p. 38.

${ }^{1037}$ See Opinion of Advocate General Cruz Villalón delivered on 29 March 2011 in the joined cases C-509/09 and C-161/10 eDate Advertising v. X and Martinez v. MGN Limited, para. 56.

${ }_{1038}$ Opinion AG Cruz Villalón in joined cases C-509/09 and C-161/10 eDate and Martinez, para. 39.

1039 C-509/09 and C-161/10 eDate Advertising GmbH v. X and Olivier Martinez and Robert Martinez v. MGN Limited, para. 44-50.
} 
European Union law conform fundamental rights since these rights are considered to be a primary source of European Union law.

\subsubsection{Consequentialist reasoning}

As mentioned in paragraph 4.2, the contextual and teleological method are commonly used by legal systems and accepted by the CJEU. ${ }^{1040}$ Consequentialist arguments can be classified under the teleological method of interpretation in a broad sense, ${ }^{1041}$ the contextual method, ${ }^{1042}$ or the functional method ${ }^{1043}$. When a court employs consequential reasoning, it will consider the consequences of the interpretation of a provision for the parties involved as well as for the public. ${ }^{1044}$ These consequences may be economic, social, or political. ${ }^{1045}$ Consequentialist reasoning suits the pragmatic approach of the European legal culture to pay more attention to the consequences of rules and legal decisions. ${ }^{1046}$ It also comports with the earlier mentioned development to use private (international) law as an instrument for social change. ${ }^{1047}$

Yet, consequential arguments have sometimes been referred to as policy-arguments. ${ }^{1048}$ Consequentialist reasoning is reminiscent of autonomous law-finding. In view of the arguments against judicial policy-making ${ }^{1049}$ and the prevailing view against unlimited autonomous lawfinding, ${ }^{1050}$ it is desirable to examine the legitimacy of consequentialist reasoning. ${ }^{1051}$ From a legal (or heteronomous) perspective, it may be legitimate if the CJEU includes the consequences for copyright holders, traders, and users of information regarding the interpretation of Article 7(2) Brussels Ibis in cross-border copyright infringement cases since European Union law frequently refers to the aim to protect the interests of copyright holders, ${ }^{1052}$ traders ${ }^{1053}$ and users of information. ${ }^{1054}$ Adherents of heteronomous law-finding may, however,

\footnotetext{
${ }^{1040}$ See paragraph 4.2. See also Beck 2012, p. 278.

${ }^{1041}$ See Beck 2012, pp. 132, 135, 152; Raitio 2013, p. 106.

${ }^{1042}$ Kutscher argues a "provision has to be interpreted in its context and having regard to its schematic relationship with other provisions in such a way that it has a reasonable and effective meaning. The rule must be understood in connection with the economic and social situations in which its to take effect". See Kutscher 1976, p. I-5.

1043 Pursuant to Bredimas, the functional method of interpretation includes "economic, political and social development, since the Treaties were not concluded in vacuo". See Bredimas 1978, p. 70.

1044 See Beck 2012, p. 212; MacCormick \& Bankowski 1989, p. 50.

1045 See Beck 2012, p. 212.

1046 Hesselink 2002, p. 73

1047 See Kwak 2003, pp. 67-71. See also Nonet \& Selznick 2001, pp. 73-77. See paragraph 2.1.2.1 up to and including paragraph 2.1.2.1.6 on the development of instrumentalisation of private international law.

1048 Beck 2012, p. 212.

1049 See paragraph 4.1.2 and 4.1.3.

${ }^{1050}$ See paragraph 4.1.3.

${ }^{1051}$ Kwak 2003, p. 70; Lenaerts \& Gutiérrez-Fons 2013, p. 27.

1052 Pursuant to the preamble of the Information Society Directive, the European Union aims to provide a high level of copyright protection. See also Article 17(2) of the Charter of Fundamental Rights of the European Union of 2000 that stipulates "intellectual copyright shall be protected".

${ }^{1053}$ For the proper functioning of the internal market, the European Union seeks to provide legal certainty to traders. See, for instance, the preamble to the Treaty establishing the European Community that states that the European Union aims to "guarantee steady expansion, balanced trade and fair competition".

${ }^{1054}$ Pursuant to recital 2 in the preamble of the Information Society Directive, the European Union aims to foster the development of the information society. Article 11 of the Charter of Fundamental Rights of the European Union of 2000 enshrines the freedom of information.
} 
argue that the legislator of Article 7(2) Brussels Ibis did not aim to protect these particular interests. ${ }^{1055}$

It has been argued that consequential reasoning can increase the so-called social legitimacy ${ }^{1056}$ of the court's decision. ${ }^{1057}$ When the CJEU explicitly takes into account social, economic, and political consequences of its ruling, the public will more likely accept this ruling. ${ }^{1058}$ Bengoetxea states that the CJEU "has taken an active role which can be considered from within the framework of the theory of social action". ${ }^{1059}$ Bengoetxea refers in this context to the method of "the interpretation of social action". ${ }^{1060}$ Dehousse argues that "the social role of courts confers on them a capital of legitimacy"; ${ }^{1061}$ the societal role of courts will likely be undermined when their decisions are systematically detrimental to the interests of a particular group of persons. ${ }^{1062}$ Since "neutrality is one of the essential elements of the societal legitimacy of judges", it is important that courts equally consider the interests of the parties involved. ${ }^{1063}$

In several rulings, the CJEU has employed consequentialist arguments when interpreting provisions of European Union law. ${ }^{1064}$ For instance, in the case of Gabrielle Defrenne v. Société anonyme belge de navigation aérienne Sabena, the CJEU explicitly referred to the social and economic effects in the Member States if the provision would be interpreted in a particular way. ${ }^{1065}$ In the case Van Gend \& Loos v. Nederlandse Administratie der Belastingen, the CJEU considered the effects on the legal protection of the individual rights of the nationals of the Member States when interpreting the provision involved. ${ }^{1066}$ In the latter ruling, the CJEU applied the principle of effet utile as interpretation technique that meant that the individuals whose rights were at stake had to be able to effectively enforce European Union law. ${ }^{1067}$ The CJEU therefore ruled that the provision involved had direct effect for individuals. ${ }^{1068}$

Adopting the principle of interest balancing into the assessment framework of this dissertation would suit the aforementioned method of consequentialist reasoning. This principle namely entails a consideration of the social and economic consequences of the attribution of jurisdiction under Article 7(2) Brussels Ibis in cross-border copyright infringement cases. As mentioned in paragraph 4.4.1, unpredictability regarding the attribution of jurisdiction under

\footnotetext{
1055 See also Pontier 1998, p. 67.

${ }^{1056}$ Dehousse distinguishes between formal and social legitimacy with respect to the CJEU's rulings. See Dehousse 1998, pp. 118, 122.

1057 Bengoetxea 1993, pp. 104-105; Rasmussen 1986. MacCormick argues that consequentialist arguments may entail justification of the court's decision. See MacCormick 1994, p. 100.

1058 Bengoetxea 1993, pp. 104-105; Rasmussen 1986.

${ }^{1059}$ See Bengoetxea's introduction (Bengoetxea 1993). See also Bengoetxea 1993, pp. 81-84.

${ }^{1060}$ See Bengoetxea 1993, pp. 84-91. Bengoetxea's method of the interpretation of social action relates to Weber's theory of sociology. See Bengoetxea 1993, p. 85. According to Weber's theory, "sociological interpretations is to establish statistical laws based on observation of what happens". See Bengoetxea 1993, p. 88. Bengoetxea refers to Winch 1967, chapter 4.

${ }^{1061}$ Dehousse 1998, p. 122.

1062 Dehousse 1998, p. 123.

${ }^{1063}$ Dehousse 1998, p. 124.

1064 See Beck 2012, pp. 212-214; Bengoetxea 1993, pp. 256-258.

1065 Case C-43/75 Gabrielle Defrenne v. Société anonyme belge de navigation aérienne Sabena.

${ }^{1066}$ Case C-26/62 Van Gend \& Loos v. Nederlandse Administratie der Belastingen, p. 13.

${ }^{1067}$ Case C-26/62 Van Gend \& Loos v. Nederlandse Administratie der Belastingen, p. 13. For the principle of effet utile as interpretation technique employed by the CJEU, see Sadl 2015, pp. 18-45; Tridimas 2006, pp. 418-476.

1068 Sadl 2015, p. 36.
} 
Article 7(2) Brussels Ibis in cross-border copyright infringement cases likely effects the broader interests of copyright holders, traders, and users of information and the ensuing public interests such as the flow of information, innovation, education, trade, the internal market, and economic globalisation.

\subsubsection{Fundamental rights as primary source of European Union law}

While the founding treaties of the European Communities ${ }^{1069}$ did not contain any provisions to protect human rights, the CJEU soon incorporated the protection of human rights into its rulings. ${ }^{1070}$ The CJEU repeatedly held that fundamental human rights have to be regarded as general principles of European Community law whose observance the CJEU ensures. ${ }^{1071}$ The CJEU emphasised that "the protection of such rights, whilst inspired by the constitutional traditions common to the Member States, must be ensured within the framework of the structure and objectives of the Community". ${ }^{1072}$ In addition, the CJEU held "international treaties for the protection of human rights on which the Member States have collaborated or of which they are signatories, can supply guidelines which should be followed within the framework of Community law". ${ }^{1073}$ Since the CJEU has considered fundamental rights as general principles of law that embody constitutional values, fundamental human rights became a source of primary law of the European Union. ${ }^{1074}$ Therefore, provisions of European Union law need to be interpreted in light of fundamental rights. ${ }^{1075}$

It is noteworthy that the concept of fundamental rights established by the CJEU deviates from the concept of human rights as employed by international treaties on human rights such as the ECHR. ${ }^{1076}$ While the enforcement of these fundamental rights depends on conditions

\footnotetext{
1069 See paragraph 4.1.1.

${ }^{1070}$ Dehousse 1998, p. 62; De Vries, Groussot, Petursson 2012, p. 10; Reding 2011, pp. VIII-X; Tridimas 2006, p. 289; Lenaerts, Van Nuffel, Bray \& Cambien 2011, pp. 825-829.

1071 See Case C-29/69 Erich Stauder v. City of Ulm-Socialamt, para. 7; Case C-11/70 Internationale Handelsgesellschaft v. EVGF, para 4; Case C-4/73 Nold KG v. Commission, para. 13; Case C-44/79 Liselotte Hauer v. Land Rheinland-Pfalz, para. 15; Case C-305/05 Ordre des barreaux francophones et Germanophone and Others v. Conseil des Ministres, para. 29.

1072 See Case C-11/70 Internationale Handelsgesellschaft mbH v. Einfuhr- und Vorratsstelle für Getreide und Futtermittel, para. 4. See also Case C-4/73 Nold KG v. Commission, para. 13. See also Beck 2012, p. 217; Griffiths 2013(b), p. 67; Tridimas 2006, pp. 298-311.

1073 See Case C-44/79 Liselotte Hauer v. Land Rheinland-Pfalz, para. 15. See also Case C-4/73 Nold v. Commission of the European Communities.

${ }^{1074}$ Ramalho 2016, p. 19; Tridimas 2006, pp. 19, 50-51. See also Lenaerts, Van Nuffel, Bray \& Cambien 2011, p. 826; "Within the EU legal order, the highest source is primary law" that consists of the Treaties (that means the TEU and the TFEU); the fundamental rights enshrined in the Charter of Fundamental Rights 2007 (See Article 6(1) TEU); and the general principles of European Union law established by the CJEU that have a constitutional status. See Ramalho 2016, p. 19. Not all general principles of law established by CJEU are considered as constitutional, see Case C-101/08 Audiolux SA and Others v. Groupe Bruxelles Lambert SA (GBL) and Others, para. 63; Case C-174/08 NCC Construction Danmark A/S v. Skatteministeriet, para. 42. In the joined rulings C402/05 and 415/05 Yassin Abdullah Kadi v. Al Brakaat International Foundation, (para 286), the CJEU held “...the constitutional principles of the EC Treaty, which include the principle that all Community acts must respect fundamental rights...”.

${ }^{1075}$ Lenaerts, Van Nuffel, Bray \& Cambien 2011, p. 826; Ramalho 2016, p. 19; Tridimas 2006, pp. 19, 50-51. See also Case C-305/05 Ordre des barreaux francophones et Germanophone and Others v. Conseil des Ministres, para. 28-29; Case C-578/08 Rhimou Chakroun v. Minister van Buitenlandse Zaken, para. 44.

${ }^{1076}$ Cassese, Clapham \& Weiler 1991, p. 14.
} 
related to the European Union, such as nationality, human rights are universal and granted to everyone regardless of nationality. ${ }^{1077}$ The fundamental rights established by the CJEU frequently involve economic life ${ }^{1078}$ such as the freedom to pursue trade or professional activities, ${ }^{1079}$ and social rights, for instance, the rights against discrimination on various grounds such as sex, race, and religion. ${ }^{1080}$

The protection of fundamental rights also became formally a part of the law of the European Union. ${ }^{1081}$ The preamble to the Treaty on European Union, as signed in Maastricht on 7 February 1992, proclaimed that the European Communities adhere to "principles of liberty, democracy, respect for human rights and fundamental freedoms and the rule of law". ${ }^{1082}$ As a result of the Treaty of Lisbon of 2007, Article 6(1) TEU states that the Charter of Fundamental Rights of the European Union of 2000 has the same legal value as the European Union Treaties. In addition, Article 6(3) TEU stipulates "fundamental rights, as guaranteed by the European Convention for the Protection of Human Rights and Fundamental Freedoms and as a result from the constitutional traditions common to the Member States, shall constitute general principles of the Union's law".

Since fundamental rights are a primary source of European Union law, European Union law must thus be interpreted in accordance with fundamental rights. ${ }^{1083}$ In view of the contextual method of interpretation, "fundamental rights may be used to uphold either an expansive or restrictive interpretation of Union law". ${ }^{1084}$ Since Article 7(2) Brussels Ibis should be interpreted in accordance with fundamental rights, it is relevant to consider the rights of copyright holders and users of information because these rights are involved in cross-border copyright infringement cases when establishing an approach to jurisdiction. As mentioned above, the CJEU also considers the freedom to pursue trade or professional activities as a fundamental right. ${ }^{1085}$ The next paragraph will demonstrate that the interests of traders can also been regarded as public interests that require to be balanced with the interests of copyright holders.

The CJEU held that the fundamental right to property includes intellectual property rights such as copyrights. ${ }^{1086}$ In view of Article 1 of the Protocol No. 1 European Convention on Human Rights of 1952, ${ }^{1087}$ the European Union legislators also laid down intellectual property

\footnotetext{
1077 Cassese, Clapham \& Weiler 1991, p. 14.

${ }^{1078}$ Cassese, Clapham \& Weiler 1991, p. 14.

1079 Case C-44/79 Liselotte Hauer v. Land Rheinland-Pfalz, para. 31-32.

${ }^{1080}$ Cassese, Clapham \& Weiler 1991, pp. 25-26.

${ }^{1081}$ See Tridimas 2006, pp. 11-12, 304-305.

1082 See Treaty on European Union established by the Treaty of Maastricht, signed on 7 February 1992, entered into force 1 November 1993, and alternated by the Treaty of Lisbon signed on 13 December 2007, entered into force 1 December 2009 (OJ C 326, 26.10.2012, pp. 13-46). See also Article 2 TEU that proclaims that the European "Union is founded on the values of respect for human dignity, freedom, democracy, equality, the rule of law and respect for human rights"

${ }^{1083}$ Lenaerts, Van Nuffel, Bray \& Cambien 2011, p. 825; Ramalho 2016, p. 19; Nieuwenhuis, Heijer \& Hins 2017 , p. 60; Tridimas 2006, pp. 4, 50-51, See also Horspool, Humpreys \& Wells-Greco 2016, pp. 122-123; Koopmans 2000, p. 54; Sever 2014, p. 187.

${ }^{1084}$ Beck 2012, p. 196.

1085 Case C-44/79 Liselotte Hauer v. Land Rheinland-Pfalz, para. 31-32.

${ }^{1086}$ See Case C-479/04 Laderdisken ApS v. Kulturministeriet, para. 65.

${ }^{1087}$ See paragraph 2.2.1.2.
} 
rights as fundamental rights in Article 17(2) Charter of Fundamental Rights of the European Union of 2000 "because of its growing importance and secondary Community legislation". ${ }^{1088}$

With respect to the right to information, Article 10 European Convention on Human Rights of 1950 "guarantees the freedom of expression which includes the freedom to receive and impart information". ${ }^{1089}$ In view of the latter article, the CJEU has recognized both the freedom of expression and the freedom to receive information as fundamental rights. ${ }^{1090}$ Article 11 of the Charter of Fundamental Rights of the European Union of 2000 also enshrines the freedom of information by stipulating "Everyone has the right to freedom of expression. This right shall include freedom to hold opinions and to receive and impart information and ideas without inference by public authority and regardless of frontiers". Thus, while the CJEU already recognised copyright ${ }^{1091}$ and the freedom of expression and information ${ }^{1092}$ as general principles of European Union law, these fundamental rights nowadays have a legal basis in the Charter of Fundamental Rights of the European Union of 2000 due to Article 6(1) TEU.

\subsection{Balancing competing fundamental rights and public interests such the interests of traders}

This paragraph will demonstrate that the CJEU should strike a balance between two competing fundamental rights namely copyrights and the right to information. In addition, this paragraph will explain that the CJEU has to balance copyrights as fundamental rights, on the one hand, and the interests of traders referred to as other public interests, on the other hand.

The previous paragraph demonstrated that copyrights and the freedom of expression and information are regarded as fundamental rights in the European Union that have a legal basis in the Charter of Fundamental Rights of the European Union of 2000. Similar to human rights, ${ }^{1093}$ fundamental rights generally do not have an absolute character and need to be weighed against other fundamental rights and public interests. ${ }^{1094} \mathrm{With}$ respect to the protection of intellectual property enshrined in Article 17(2) Charter of Fundamental Rights of the European Union of 2000, the CJEU stated that "nothing whatsoever in the wording of the provision or in the Court's case-law suggest that that right is inviolable and must for that reason be absolutely protected". ${ }^{1095}$

\footnotetext{
1088 See the report of Explanations Relating to the Charter of Fundamental Rights 2007, p. 23.

1089 Mendis 2011, p. 29. See also Opinion of Advocate General Cruz Villalón delivered on 29 March 2011 in the joined cases C-509/09 and C-161/10 eDate Advertising v. X and Martinez v. MGN Limited.

${ }^{1090}$ See Case C-260/89 Elliniki Radiophonia Tiléorassi AE and Panellinia v. Dimotiki and Others, para. 44; Case C-479/04 Laderdisken ApS v. Kulturministeriet, para. 62-65.

${ }^{1091}$ See C-347/03 Regione autonoma Friuli Venezia Giulia and Agenzia regionale v. Ministero delle Politiche Agricole e Forestali, para. 120.

1092 See Case C-260/89 Elliniki Radiophonia Tiléorassi AE and Panellinia v. Dimotiki and Others, para. 44; Case C-479/04 Laderdisken ApS v. Kulturministeriet, para. 62-65.

1093 Gerards 2012, p. 14. With respect to the abovementioned Article 1 of the Protocol No. 1 to the European Convention for the Protection of Human Rights and Fundamental Freedoms of 1952, the ECtHR held that "a "fair balance' need to be struck between the protected right and the general, public interest. See Griffiths 2013(b), p. 71.

1094 Tridimas 2006, p. 311. See also Article 52 Charter of Fundamental Rights of the European Union of 2000.

${ }^{1095}$ Case C-70/10 Scarlet Extended SA v. Société beige des auteur, compositeurs et éditeurs SCRL (SABAM), para. 43. Pursuant to the Explanations Relating to the Charter of Fundamental Rights 2007, the guarantees as laid down
} 
The CJEU ruled that the protection of fundamental rights "must be ensured within the framework of the structure and objectives of the Community". 1096 "This means that hum rights values will have to be interpreted and weighted in the light of the exigencies demanded by European integration". ${ }^{1097}$ With respect to the right to property, the CJEU held that this right "is not absolute, but must be viewed in relation to its social function". ${ }^{1098}$ Hence, the right to property "may be restricted, particularly in the context of a common organization of a market, provided that those restrictions in fact correspond to objectives of general interest pursued by the Community and do not constitute a disproportionate and intolerable interference, impairing the very substance of the rights guaranteed". 1099

Since the facilitation of trade is an objective of general interest pursued by the European Union, ${ }^{1100}$ the interests of traders can be considered as legitimate interests that may restrict the right to property such as copyrights. ${ }^{1101}$ The CJEU even considers the freedom of trade as general principle of European Union law. ${ }^{1102}$ In the seminal case Kadi, the CJEU held that interference with the right to property is only acceptable if "a fair balance has been struck between the demands of the public interest and the interest of the individuals concerned". ${ }^{1103}$ The foregoing indicates that the CJEU should not only strike a balance between competing fundamental rights, such as copyrights and the right to information, but also between fundamental rights and other public interests such as the interests of traders as mentioned in paragraph 4.4.1.

in Article 17(1) Charter of Fundamental Rights of the European Union will also be applicable to intellectual property, see p. 23. 17(1) Charter of Fundamental Rights of the European Union stipulates that ... "No one may be deprived of his or her possessions, except in the public interest and in the cases and under the conditions provided for by law, subject to fair compensation being paid in good time for their loss. The use of property may be regulated by law in so far is necessary for the general interest."

1096 See Case C-11/70 Internationale Handelsgesellschaft mbH v. Einfuhr- und Vorratsstelle für Getreide und Futtermittel, para 4; Case 4/73 Nold KG v. Commission, para. 13. See also Beck 2012, p. 217; Griffiths 2013(b), p. 67; Tridimas 2006, pp. 298-311.

${ }^{1097}$ Cassese, Clapham \& Weiler 1991, p. 16.

1098 Case C-280/93 Federal Republic of Germany v. Council of the European Union, para. 78. See also Case C44/79 Liselotte Hauer v. Land Rheinland-Pfalz, para. 32; Case C-265/87 Hermann Schräder HS Kraftfutter GmbH \& Co KG v. Hauptzollamt Gronau, para 15; Case C-347/03 Regione autonoma Friuli Venezia Giulia and Agenzia regionale v. Ministero delle Politiche Agricole e Forestali, para. 119.

1099 See Case C-280/93 Federal Republic of Germany v. Council of the European Union, para. 78. See also Case C-265/87 Hermann Schräder HS Kraftfutter GmbH \& Co KG v. Hauptzollamt Gronau, para 15; Case C-347/03 Regione autonoma Friuli Venezia Giulia and Agenzia regionale v. Ministero delle Politiche Agricole e Forestali, para. 119.

${ }^{1100}$ The European Union's trade policy aims, inter alia, to remove obstacles to guarantee 'balanced trade' (See preamble to the TFEU), "abolition of restrictions on international trade" (See preamble to the TFEU) and emphasises "the need to promote trade between Member States and third countries (Article 32 TFEU). The European Union and its Member States are also a member of the World Trade Organization (hereinafter the WTO) that concluded the Agreement on Trade Related Aspects of Intellectual Property Rights (TRIPS-Agreement 1994) that aims to protect traders at an international level.

${ }^{1101}$ Case C-280/93 Federal Republic of Germany v. Council of the European Union, para. 78. See also Case C347/03 Regione autonoma Friuli Venezia Giulia and Agenzia regionale v. Ministero delle Politiche Agricole e Forestali, para. 119.

${ }^{1102}$ See, inter alia, Case C-280/93 Federal Republic of Germany v. Council of the European Union, para. 78. Case C-44/79 Liselotte Hauer v. Land Rheinland-Pfalz, para. 31-32. Geiger and Schönherr noted that "intellectual property rights need to be weighed against other competing fundamental rights and freedoms, such as the freedom of expression or freedom to conduct business". See Geiger \& Schönherr 2014, p. 452.

${ }^{1103}$ See joined Cases C-402/05 and C-415/05 Yassin Abdullah Kadi v. Al Brakaat International Foundation, para. 360 . 
In the rulings related to copyright law, the CJEU has regularly made reference to several fundamental rights such as the right to property, which includes the right to intellectual property; the freedom of expression; the freedom of information; and the right to privacy. ${ }^{104}$ With respect to the interpretation of provisions in European Union Directives, the CJEU frequently held that "a fair balance must be struck between the various fundamental rights protected by the Community legal order" such as between the right to property, that includes copyrights, and the right to privacy. ${ }^{1105}$ The preamble to the Information Society Directive also explicitly states that a fair balance of rights and interests between copyright holders and stakeholders must be safeguarded. ${ }^{1106}$

Nonetheless, in the case of Martin Luksan v. Petrus van der Let involving the interpretation of several provisions of Directives related to copyright, the CJEU emphasised the aim to provide a high level of protection to copyright holders in view of recital 9 of the Information Society Directive and Article 17(2) Charter of Fundamental Rights of the European Union of 2000. ${ }^{1107}$ The CJEU's interpretation seems to lack the balancing between copyrights and other interests involved. ${ }^{1108}$ This ruling has therefore been criticised and arguably fits the CJEU's active role to harmonise copyrights in the European Union. ${ }^{109}$

Adopting the principle of balancing the interests related to copyrights into the assessment framework of this dissertation would be a step in the right direction to meet the critique on the alleged active role of the CJEU with respect to copyright protection at the expense of other legitimate interests ${ }^{1110}$. In addition, this principle is desirable in view of the trend of overprotection of copyrights as demonstrated in paragraph 2.2.2.1.1. To aim to balance the interests related to copyright when interpreting Article 7(2) Brussels Ibis also suits the development of instrumentalisation of private international law in the setting of global governance and human rights protection. ${ }^{111}$

Finally, the CJEU's interpretation in light of fundamental rights, especially the rights enshrined in the Charter of Fundamental Rights of the European Union, may alleviate the criticism of the European Union's legitimacy and democratic deficit ${ }^{1112}$. From a "rights-based view of democracy", the Charter of Fundamental Rights of the European Union can namely be seen as "a European consensus on rights" that "offer the basis of citizen allegiance to EU wide

${ }^{1104}$ Griffiths 2013(b), pp. 65-78. See Case C-280/93 Federal Republic of Germany v. Council of the European Union, para. 78; Case C-479/04 Laderdisken ApS v. Kulturministeriet, para. 62-65; Case C-70/10, Scarlet Extended SA v. Société beige des auteur, compositeurs et éditeurs SCRL (SABAM), para. 44-54.

${ }^{1105}$ Case C-275/06 Productores de Música de Espana (Promusicae) v. Telefónica de Espana SAU, para 65-6. See also Case C70/10, Scarlet Extended SA v. Société beige des auteur, compositeurs et éditeurs SCRL (SABAM), para. 44-46. See also De Vries, Groussot, Petursson 2012, p. 52.

${ }^{1106}$ Recital 31 in the preamble to the Information Society Directive.

${ }^{1107}$ Case C-277/10 Martin Luksan v. Petrus van der Let, para. 65-72.

${ }^{1108}$ Griffiths 2013(b), p. 76.

${ }^{1109}$ Griffiths 2013(b), p. 75.

1110 See Ohly 2012, p. 8.

${ }^{1111}$ See paragraph 2.1.2.1.5 and 4.4.2.6. See also Muir-Watt 2016, p. 881; Svantesson 2019(a), pp. 17-37.

1112 Bellamy attributes the problem of the EU's democratic deficit to "either sociocultural reasons, principally the lack of a demos and public sphere, or institutional factors, notably the lack of electoral accountability because of the limited ability of the European Parliament to legislate and control the executive powers of the Commission and the Council of Ministers". See Bellamy 2006, p. 725. See also De Waele 2009, p. 398; Hartley 1999, pp. 1819. 
democracy, thereby overcoming the demos deficit". ${ }^{1113}$ Since the CJEU suffers from "the problem of mass legitimacy", it is particularly important to induce acceptance of its decisions. ${ }^{1114}$

\subsubsection{The principle of interest balancing in substantive copyright law}

As explained in paragraph 2.2.2.1.2, the principle of balancing interests is considered of paramount importance in copyright law. Most legislators and scholars therefore aim to enact copyright laws that promote to balance the interests and rights of copyright holders and stakeholders. ${ }^{115}$ Due to globalisation and the Internet the tension between the rights and interests of copyright holders and stakeholders, such as users of information and traders, has been increased. ${ }^{1116}$ In particular the dissemination of information or other copyrighted content via internet, and the increasing piracy, necessitates to keep balancing the interests related to copyright. ${ }^{1117}$ Paragraph 2.2.2.1.1 already mentioned the hazards of the current development to overprotect copyrights such as decrease of innovation and the increase of economic disparity.

Within the European Union, the preamble to the Information Society Directive also recognizes that a fair balance between copyright holders and "users of protected subject-matter must be safeguarded". ${ }^{1118}$ On international level, the preambles to the World Intellectual Property Organization Copyright Treaty (hereinafter WIPO Copyright Treaty of 1996) and the World Intellectual Property Organization Performances and Phonograms Treaty, both signed at Geneva on 20 December 1996, state that the Contracting Parties recognize "the need to maintain a balance between the rights of authors and the larger public interest, particularly education, research and access to information, as reflected in the Berne Convention". ${ }^{119}$ These two treaties deal with the protection of works and the rights of their authors in the digital environment, and in particular seek to fight piracy worldwide. ${ }^{1120}$ Provisions of international agreements that bind the European Union, such as the WIPO Copyright Treaty of 1996, "act as sources of Union Law". ${ }^{1121}$ These international agreements are having precedence over secondary law ${ }^{1122}$ such as the Brussels Ibis Regulation. Hence, the CJEU has repeatedly held

\footnotetext{
1113 Bellamy 2006, p. 725.

1114 Gibson \& Caldeira 1993, p. 221.

1115 Hua 2014(b), p. 40; Mendis 2011, p. 15. See also Ramalho 2016, p. 114. See also paragraphs 2.2.2.1.1 and 2.2.2.1.2.

1116 See paragraph 2.2.2.1.2.

1117 Hua 2014(b), p. 40.

1118 See recital 31 to the preamble to the Information Society Directive.

1119 See the preambles to the World Intellectual Property Organization Copyright Treaty (known as the WIPO Copyright Treaty of 1996) signed at Geneva on 20 December 1996, entered into force on 6 March 2002, 2186 UNTS 152 and the World Intellectual Property Organization Performances and Phonograms Treaty signed at Geneva on 20 December 1996, entered into force on 20 May 2002, 2186 UNTS 250. The European Union and its Member States ratified these two treaties 14 December 2009. See http://europa.eu/rapid/press-release_IP-091916 en.htm.

1120 See recital 15 in the preamble to the Information Society Directive. See also http://www.wipo.int/treaties/en/ip/wct/.

${ }^{1121}$ Lenaerts, Van Nuffel, Bray \& Cambien 2011, p. 879. Article 216(2) TFEU stipulates "Agreements concluded by the Union are binding upon the institutions of the Union and its Member States".

${ }^{1122}$ Lenaerts, Van Nuffel, Bray \& Cambien 2011, p. 862.
} 
that secondary law "must as far as possible be interpreted in a manner that is consistent with those agreements". ${ }^{1123}$

Since it has generally been accepted that the principle of interest balancing is considered of paramount importance in copyright law, it can be argued that the CJEU should employ this principle to interpret the special jurisdiction of Article 7(2) Brussels Ibis in cross-border copyright infringement cases. General principles of substantive law "widely applicable within a particular branch of law" can namely be classified as contextual arguments. ${ }^{1124}$ According to settled case law, the CJEU interpreted several concepts in provisions of European Union Law by reference to "general principles which stem from the national legal systems as a whole". ${ }^{125}$

If the CJEU interprets the special jurisdiction of Article 7(2) Brussels Ibis in a way that it balances the relevant interests related to copyrights, this would also suit the development of instrumentalisation of private international law for global governance as explained in paragraph 2.1.2.1.4. ${ }^{1126}$ From a perspective of global governance, the problem of piracy demands active protection of copyrights but at the same time overprotection of copyrights need to be prevented. ${ }^{1127}$

\subsection{The possible impact of the Geo-blocking Regulation on the approach to jurisdiction in cross-border copyright infringement cases as part of the assessment framework}

In view of the contextual method of interpretation as set out in paragraph 4.2.3, the CJEU should consider European Union law when interpreting the special jurisdiction rule in Article 7(2) Brussels Ibis. Scholars have occasionally addressed the interaction between European private law and European private international law. ${ }^{1128}$ The rulings Pinckney, Hi Hotel and Pez Hejduk demonstrate that the CJEU employed the Information Society Directive to interpret the special jurisdiction rule of Article 7(2) Brussels Ibis in cross-border copyright infringement cases. $^{1129}$

In 2018, the European Union enacted the Regulation (EU) 2018/302 of the European Parliament and of the Council of 28 February 2018 on addressing unjustified geo-blocking and other forms of discrimination based on customers' nationality, place of residence or place of establishment within the internal market (hereinafter the Geo-blocking Regulation). ${ }^{1130}$ The

\footnotetext{
${ }^{1123}$ See joined Cases C-335/11 and C-337/11 HK Denmark v. Dansk, para. 29. For more rulings on this issue, see Lenaerts \& Gutiérrez-Fons 2013, p. 33, note 231.

${ }^{1124}$ Beck 2012, p. 131. See also MacCormick \& Summers 1991, p. 514. See also paragraph 4.2 .3 of this dissertation regarding the contextual method of interpretation.

${ }^{1125}$ See Case C-271/00 Gemeente Steenbergen v. Luc Baten, para. 28. See also Pontier \& Burg 2004, p. 87.

${ }^{1126}$ See also Muir-Watt 2016, p. 881.

1127 See paragraph 2.2.2.1.1 on the overprotection of copyrights. See also Reich (2014, pp. 141-144) on the balancing to avoid overprotection of a 'weaker party'.

${ }^{1128}$ See Campo Comba 2018, p. 518; Kramer 2010. See also Schaafsma 2014.

1129 See chapter 3 of this dissertation.

${ }^{1130}$ Regulation (EU) 2018/302 of the European Parliament and of the Council of 28 February 2018 on addressing unjustified geo-blocking and other forms of discrimination based on customers' nationality, place of residence or place of establishment within the internal market and amending Regulations (EC) No 2006/2004 and (EU) 2017/2394 and Directive 2009/22/EC (OJ L 60I, 2.3.2018, pp. 1-15), referred to as the Geo-blocking Regulation. The Geo-blocking Regulation has been applicable from 3 December 2018. See Article 11(1) Geo-blocking Regulation.
} 
following paragraphs will demonstrate that the Geo-blocking Regulation should be part of the assessment framework to rethink to CJEU's approach to jurisdiction in cross-border copyright infringement disputes. The aim, scope and prohibitions of the Geo-blocking Regulation will be set out and its interaction with the special jurisdiction rule related to consumer contract disputes under Article 17(1) Brussels Ibis.

\subsubsection{The aim and the scope of the Geo-blocking Regulation}

The Geo-blocking Regulation has been adopted as a part of the European Digital Single Market Strategy enacted in 2015. ${ }^{1131}$ As customers should have access to goods and services both online and offline in the European internal market, the Geo-blocking Regulation aims to prevent discrimination by traders based on nationality of the customers and their place of residence or establishment. ${ }^{1132}$ The Geo-blocking Regulation therefore prohibits traders operating within the European Union to employ geo-blocking and other discriminatory measures against customers based on their nationality, place of residence or place of establishment. ${ }^{1133}$ This Regulation only addresses cross-border issues, not "purely internal situations, where all relevant elements of the transaction are confined within one single Member State". ${ }^{1134}$

The Geo-blocking Regulation provides its own definitions of 'customers' and 'traders'. A 'customer' "means a consumer who is a national of, or has his or her place of residence in a Member State, or an undertaking which has its place of establishment in a Member State, and receives a service or purchases a good, or seeks to do so, within the Union, for the sole purpose of end use". ${ }^{1135}$ Unlike the common definition of consumers in European Union law, ${ }^{1136}$ the Geo-blocking Regulation considers thus a legal person that buys goods or services also as a customer provided that he can be regarded as an end user ${ }^{1137}$.

\footnotetext{
1131 European Commission, Proposal for a Regulation of the European Parliament and of the Council on addressing geo-blocking and other forms of discrimination based on customers' nationality, place of residence or place of establishment within the internal market and amending Regulation (EC) No 2006/2004 and Directive 2009/22/EC, Brussels, 25.5.2016, COM (2016) 289 final, p. 2.

${ }^{1132}$ See recital 3 in the preamble to the Geo-blocking Regulation. See also the European Commission, Proposal for a Regulation of the European Parliament and of the Council on addressing geo-blocking and other forms of discrimination based on customers' nationality, place of residence or place of establishment within the internal market and amending Regulation (EC) No 2006/2004 and Directive 2009/22/EC, Brussels, 25.5.2016, COM (2016) 289 final, p. 2.

${ }_{1133}$ Article 1(1) Geo-blocking Regulation.

${ }^{1134}$ Article 1(3) Geo-blocking Regulation. See also recital 7 in the preamble to the Geo-blocking Regulation.

${ }^{1135}$ Article 2(13) Geo-blocking Regulation.

1136 The concept of customer in European Union law generally denotes a natural person. See Manko 2013, p.1. See, for instance, the definition of consumer laid down in Article 2(2) Regulation (EU) 2017/1128 of the European Parliament and of the Council of 14 June 2017 on cross-border portability of online content services in the internal market (OJ L 168, 30.6.2017, pp. 1-11). In the context of European Union Private International Law, the concept of consumer also only includes a natural person since they are perceived as "weaker parties". See Campo Comba 2018, pp. 519-520.

1137 According to recital 16 in the preamble to the Geo-blocking Regulation, an 'end user' is a customer who "purchases a good or service for subsequent resale, transformation, processing, renting or subcontracting because that would affect widely used distribution schemes between undertakings in a business to business context, which are often negotiated bilaterally and directly linked to commercial strategies, both downstream and upstream".
} 
Pursuant to the Geo-blocking Regulation, a 'trader' "means any natural or legal person, irrespectively of whether privately or publicly owned, who is acting, including through any other person acting in name or on behalf of the trader, for purposes relating to the trade, business, craft or profession of the trader". ${ }^{138}$ Hence, the territorial scope of this Regulation is broad because it applies to "all traders, including online marketplaces, operating within the Union" regardless whether the trader is established in a Member State or in a third country. ${ }^{1139}$ Paragraph 4.5.2.3 will demonstrate that the Geo-blocking Regulation stipulates that certain services provided by traders will not be covered by the prohibitions of this Regulation and will therefore fall outside its material scope. ${ }^{1140}$

\subsubsection{The prohibitions under the Geo-blocking Regulation}

The Geo-blocking Regulation prohibits "unjustified geo-blocking and other forms of discrimination based on customers' nationality, place of residence or place of establishment within the internal market". ${ }^{1141}$ This Regulation contains four provisions, Article 3 up to and including Article 6, that demonstrate the prohibitions in more detail. The prohibitions in Articles 3, 4 and 5 will be set out in the next paragraphs since they can relate to traders who are accused of cross-border copyright infringing activities. The fourth provision of Article 6 Geoblocking Regulation, stipulating that this Regulation does not affect the application of European rules on competition, will not be further discussed. ${ }^{1142}$

The prohibitions in the Geo-blocking Regulation will, however, not apply if the geoblocking or other forms of discrimination are "objectively justified". ${ }^{1143}$ That means traders will be allowed to geo-block or apply other forms of discrimination "in order to ensure compliance with a legal requirement laid down in Union law, to which the trader is subject as a consequence of operating in that Member State". ${ }^{1144}$ Laws of Member States may also entail justified discrimination. ${ }^{145}$ For instance, traders should respect the rules on the pricing of books. ${ }^{146}$ Paragraph 4.5.2.3 will demonstrate that certain services provided by traders are excluded from the prohibitions in the Geo-blocking Regulation.

\footnotetext{
${ }^{1138}$ Article 2(18) Geo-blocking Regulation.

${ }^{1139}$ Recital 17 in the preamble to the Geo-blocking Regulation.

${ }_{1140}$ See also Campo Comba 2018, pp. 514-515.

${ }^{1141}$ Regulation (EU) 2018/302 of the European Parliament and of the Council of 28 February 2018 on addressing unjustified geo-blocking ad other forms of discrimination based on customers' nationality, place of residence or place of establishment within the internal market and amending Regulations (EC) No 2006/2004 and (EU) 2017/2394 and Directive 2009/22/EC (OJ L 60I, 2.3.2018, pp. 1-15).

${ }^{1142}$ See recital 34 in the preamble to the Geo-blocking Regulation and Article 6(1) Geo-blocking Regulation.

1143 See Article 3(3), Article 4(5), Article 5(2), Article 6(1) Geo-blocking Regulation.

${ }^{1144}$ Recital 21 in the preamble of the Geo-blocking Regulation.

${ }^{1145}$ Recital 31 in the preamble of the Geo-blocking Regulation.

${ }^{1146}$ Recital 31 in the preamble of the Geo-blocking Regulation.
} 


\subsubsection{The prohibitions in Article 3 Geo-blocking Regulation to use technologies that block or limit a customer's access to the trader's online interface}

Article 3 Geo-blocking Regulation can be regarded as the first provision that demonstrates the prohibitions under the Regulation. This provision prohibits "the use of technological measures or otherwise" that "block or limit a customer's access to the trader's online interface for reasons related to the customer's nationality, place of residence or place of establishment". ${ }^{1147}$ The term 'online interface' has been defined as "any software, including a website or a part and applications, including mobile applications, operated by or on behalf of a trader, which serves to give customers access to the trader's goods or services with a view of engaging in a transaction with respect to those goods or services". ${ }^{1148}$ Websites that merely provide information will therefore not be affected by the Geo-blocking Regulation.

Geo-location technologies generally enable geo-identification, geo-blocking, geo-filtering or geo-targeting. ${ }^{1149}$ Instead of blocking the access to a website based on the user's location, ${ }^{150}$ geo-location technologies can also deny users of certain states particular possibilities such as downloading, purchasing or delivering of goods to these states. ${ }^{1151}$ In addition, geo-location technologies can enable to differentiate "prices or other conditions on the basis of nationality, country of residence of customers or the location from which they are accessing the services". ${ }^{152}$ Traders regularly employ geo-blocking technologies if they do not want to address the consumers of particular states. Engaging cross-border transactions with consumers will often yield legal uncertainty, "risks as regards the applicable consumer protection laws, the environmental or labelling laws, taxation and fiscal issues, delivery costs or language requirements". ${ }^{1153}$

The prohibition of geo-blocking under Article 3 Geo-blocking Regulation appears to be broad because it concerns "any technologies used to determine the physical location of the customer, including tracking of that location by means of an IP address or coordinates obtained through a global navigation satellite system." "154 In addition, Article 3 Geo-blocking Regulation prohibits traders to redirect customers "to a version of the trader's online interface that is different from the online interface to which the customers initially sought access, by virtue of its layout, use of language or other characteristics that make it specific to customers with a particular nationality, place of residence or place of establishment, unless the customer has explicitly consented to such redirection". ${ }^{1155}$

\footnotetext{
1147 Article 3(1) Geo-blocking Regulation.

1148 Article 1(16) Geo-blocking Regulation.

${ }^{1149}$ Svantesson indicates that the term geo-location includes geo-identification, geo-blocking, geo-filtering or geotargeting. Svantesson 2016(a), pp. 521-522. See also Trimble (2012, pp. 586-599) on geo-location tools.

${ }^{1150}$ Svantesson 2016(a), pp. 519-522. See also Trimble \& Lionel 2016, p. 10. Svantesson (2016(a), pp. 524-568) sets out various types of geo-location technologies.

${ }^{1151}$ Svantesson 2016(a), p. 519. Geo-location technologies can nevertheless be circumvented which jeopardizes the accuracy of these technologies. Svantesson 2016(a), pp. 530-536. See also Boone 2006, p. 247.

1152 Svantesson 2016(a), p. 520.

${ }^{1153}$ Recital 2 in the preamble to the Geo-blocking Regulation.

1154 Recital 18 in the preamble to the Geo-blocking Regulation.

1155 Article 3(2) Geo-blocking Regulation.
} 


\subsubsection{The prohibitions in Article 4 and 5 Geo-blocking Regulation to use "other forms of discrimination" such as the application of different general conditions of access to goods and services}

The second provision involving prohibitions is Article 4 Geo-blocking Regulation that addresses "other forms of discrimination" namely the application of different general conditions of access to goods and services, both online or offline, with respect to customers from other Member States. ${ }^{1156}$ 'Goods' are defined as "any tangible movable item, with the exception of items sold by way of execution or otherwise by authority of law". ${ }^{1157}$ 'Services' are distinguished into electronically supplied services that require no physical delivery ${ }^{1158}$ and services that are received by the customer in a physical location within the territory where the trader operates ${ }^{1159}$. As will be demonstrated in the next paragraph, certain services are excluded from the scope of the Geo-blocking Regulation.

"General conditions of access include, inter alia, prices, payment conditions and delivery conditions." 1160 Trader are thus not allowed to employ different prices ${ }^{1161}$ or "different conditions for payment transactions within the range of means of payment accepted" based on the customer 's nationality or place of residence ${ }^{1162}$. With respect to delivery of goods, customers should be able to purchase goods under the same delivery conditions as local customers in the Member States. ${ }^{163}$ The foregoing nonetheless means that a foreign customer may have to pick up the goods in the Member States to which the trader used to deliver. ${ }^{164} \mathrm{~A}$ trader is thus not obliged to deliver their goods in all Member States. ${ }^{165}$

Article 4(2) Geo-blocking Regulation also stipulates that the prohibitions of discrimination against customers will not prevent "traders from offering general conditions of access, including net sales prices, which differ between Member States or within a Member State and which are offered to customers on a specific territory or to specific groups of customers on a non-discriminatory basis". ${ }^{1166}$ Traders are therefore allowed to employ different general

\footnotetext{
${ }^{1156}$ Article 4(1) Geo-blocking Regulation. See also recital 23 in the preamble to the Geo-blocking Regulation.

${ }^{1157}$ Article 2(15) Geo-blocking Regulation.

${ }^{1158}$ Article 4(1)(b) Geo-blocking Regulation. See also recital 24 in in the preamble to the Geo-blocking Regulation. Pursuant to Article 2(1) Geo-blocking Regulation, “electronically supplied services' means services which are delivered over the internet or an electronic network and the nature of which renders their supply essentially automated and involving minimal human intervention, and impossible to ensure in the absence of information technology". Recital 24 in the preamble to the Geo-blocking Regulation explains that no physical delivery is required and stipulates that electronically supplied services include for example cloud services, data warehousing services and website hosting.

${ }^{1159}$ Article 4(1)(c) Geo-blocking Regulation. Recital 25 in the preamble to the Geo-blocking Regulation provides the following examples: hotel accommodation, sports events, car rental, and entrance tickets for music festivals or leisure parks.

${ }^{1160}$ Recital 15 in the preamble to the Geo-blocking Regulation.

${ }^{1161}$ Article 1(5) Geo-blocking Regulation stipulates that with respect to the sale of books, the prohibition under the Geo-blocking Regulation "shall not prevent traders from applying different prices to customers in certain territories in so far as they are required to do so under the laws of Member States in accordance with Union law". 1162 Recital 13 and 23 in the preamble to the Geo-blocking Regulation. See also Article 5 Geo-blocking Regulation. 1163 Article 4(1)(a) Geo-blocking Regulation.

${ }^{1164}$ Recital 23 in the preamble to the Geo-blocking Regulation.

${ }^{1165}$ Recital 28 in the preamble to the Geo-blocking Regulation.

${ }^{1166}$ See also recital 27 in the preamble to the Geo-blocking Regulation.
} 
conditions of access, or based on membership, in different Member States, as long as they treat their customers in a similar way regardless of their nationality or place of residence or establishment. ${ }^{1167}$ With respect to online interfaces, traders can thus still operate different versions that target consumers from different Member States and use country code top-level domain names with respect to their websites. ${ }^{1168}$ They can also use different prices or particular languages on different versions of their websites. ${ }^{1169}$ Yet, traders are not allowed to "redirect consumers from one version of the online interface to another version without their explicit consent". ${ }^{1170}$

The prohibition of non-discrimination for reasons related to payment has been separately laid down in Article 5 Geo-blocking Regulation that can be regarded as the third provision that demonstrates the prohibitions under the Geo-blocking Regulation. ${ }^{1171}$

\subsubsection{Services that are excluded from the prohibitions in the Geo-blocking Regulation}

As mentioned in the previous two paragraphs, the prohibitions under the Geo-blocking Regulation will not be applicable to certain services. ${ }^{1172}$ Article 1(3) Geo-blocking Regulation stipulates that the Regulation does not apply to the services referred to in Article 2(2) Directive 2006/123/EC of the European Parliament and of the Council of 12 December 2006 on services in the internal market (hereinafter Service Directive). ${ }^{1173}$ Article 2(2) Service Directive proclaims that it shall not apply to the following activities: non-economic services of general interests; financial services; electronic communication services and networks; transport services; services of temporary employment agencies; healthcare services; audiovisual services; gambling services, activities connected with the exercise of official authority; certain social services; private security services; and services provided by notaries and bailiffs.

In addition, the Geo-blocking Regulation clarifies that the prohibitions will not be applicable to "audiovisual services, including services the principle purpose of which is the provision of access to broadcast of sports events and which are provided on the basis of exclusive territorial licenses", ${ }^{1174}$ financial services, and services in the field of transport. ${ }^{175}$

\footnotetext{
${ }^{1167}$ Recital 27 in the preamble to the Geo-blocking Regulation.

${ }^{1168}$ Recital 20 in the preamble to the Geo-blocking Regulation.

${ }^{1169}$ Recital 27 in the preamble to the Geo-blocking Regulation.

${ }^{1170}$ See Article 3(2) Geo-blocking Regulation. See also Recital 20 in the preamble to the Geo-blocking Regulation that stipulates: "Once the consumer's explicit consent has been given, including by explicit consent has been given, including by expressing a preference that applies to a personal account, that explicit consent should be deemed to be valid for all subsequent visits of the same customer to the same online interface. It should be possible for the customer to withdraw such consent at any point in time. All versions of the online interface should remain easily accessible to the customers at all times."

1171 See diagram in paragraph 4.5.2.4.

1172 See Article 1(3) and Article 4(1)(b) Geo-blocking Regulation. See also recitals 8 and 9 in the preamble to the Geo-blocking Regulation.

${ }^{1173}$ Directive 2006/123/EC of the European Parliament and of the Council of 12 December 2006 on services in the internal market (OJ L 376, 27.12.2006, pp. 36-68), referred to as the Service Directive.

${ }^{1174}$ Recital 8 in the preamble to the Geo-blocking Regulation. See also Article 1(3) Geo-blocking Regulation that refers to the activities in Article 2(2) Directive 2006123/EC of the European Parliament and of the Council of 12 December 2006 on services in the internal market, referred to as the Service Directive.

${ }^{1175}$ Article 1(3) Geo-blocking Regulation. See also recitals 8 and 9 in the preamble to the Geo-blocking Regulation.
} 
The Geo-blocking Regulation also stipulates that it does not concern electronically supplied services which main feature is "the provision of access to use and of copyright protected works or other protected subject matter, including the selling of copyright protected works or protected subject matter in an intangible form". 1176

The foregoing indicates that traders who offer audiovisual services or electronically services that contain copyright protected content, such as streaming or downloading of movies, music, computer games and e-books, will not be affected by the Geo-blocking Regulation. With respect to these services, traders can thus still block or limit the access to their websites and offer different general conditions based on customers' nationality and place of residence.

The territorially limited protection of copyrights has been the reason behind the abovementioned exclusion of audiovisual services and electronically supplied services involving copyrighted works from the scope of the Geo-blocking Regulation. ${ }^{1177}$ The Geoblocking Regulation does, however, not make an exception with respect to the access of goods, meaning tangible moveable items, that are protected by copyright. This difference in treatment between goods and services can be explained by the principle of exhaustion that has been adopted in the European Union regarding goods that involve copyrighted works. ${ }^{1178}$ Based on this principle, the first sale of those goods by the copyright holder, or with his consent, in European Union Member States exhausts the right to control resale of that object in the European Union. ${ }^{1179}$ Hence, the principle of exhaustion enables cross-border transactions related to goods that are protected by copyright within the European Union. With respect to services, in particular online services, the Information Society Directive clearly states that "every online service is in fact an act which should be subject to authorization where the copyright or related right so provides". ${ }^{1180}$ The principle of exhaustion has thus not been adopted regarding cross-border services involving copyright protected content. ${ }^{1181}$

After the implementation of the Information Society Directive, European Union law has regulated that certain services involving copyrighted content can be provided in all Member States based on multi-territorial licensing of rights. Examples are the Directive 2014/26/EU of the European Parliament and of the Council of 26 February 2014 on collective management of

1176 Article 4(1)(b) Geo-blocking Regulation. Unlike the Service Directive, the Geo-blocking Regulation thus excludes "non-audiovisual electronically applied services the main feature of which is the provision of access to and use of copyright protected works or other protected subject matter". See recital 8 in the preamble to the Geoblocking Regulation.

1177 See Campo Comba 2018, p. 515. See also Mazziotti (2015, pp. 1-15) on the Commission proposal of the Geoblocking Regulation regarding the exclusion of online services containing copyrighted content and the territorial principle. Article 1(5) Geo-blocking Regulation stipulates that "this Regulation shall not affect the rules applicable in the field of copyright and neighbouring rights, notably the rules provided for in Directive 2001/29/EC of the European Parliament and of the Council" [the Information Society Directive].

${ }^{1178}$ Recital 28-29 in the preamble to the Information Society Directive. In the case C-62/79 of Coditel v. Ciné Vog Films and Others, CJEU established the exhaustion principle with respect to goods involving copyright protected works. See Madiega 2015, p. 5.

${ }^{1179}$ Recital 28 in the preamble to the Information Society Directive. See Madiega 2015, p. 5.

${ }^{1180}$ Recital 29 in the preamble to the Information Society Directive.

${ }^{1181}$ In the case C-128/11 UsedSoft GmbH v. Oracle International Corp, the CJEU nevertheless appears to have applied the principle of exhaustion to the download from internet of a computer program. However, scholars argue that this ruling does not provide certainty on whether this principle could also be applied to other online services. See Madiega 2015, p. 5. See also Mazziotti 2015, pp. 3-6. In the case C-263/18 Nederlandse Uitgeversverbond $v$. Tom Kabinet, the CJEU held that the principle of exhaustion does not apply to the sale of e-books. 
copyright and related rights and multi-territorial licensing of rights in musical works for online use in the internal market (hereinafter Collective Rights Management Directive) ${ }^{1182}$ and the Regulation (EU) 2017/1128 of the European Parliament and of the Council of 14 June 2017 on cross-border portability of online content services in the internal market (hereinafter Portability Regulation). ${ }^{1183}$ Another illustration is the Directive (EU) 2019/789 of the European Parliament and of the Council of 17 April 2019 that laid down rules on the exercise of copyright and related rights applicable to online transmissions and retransmissions of television and radio programmes (hereinafter Satellite Cable Directive). ${ }^{1184}$

In view of the abovementioned European Union law, the Geo-blocking Regulation may in future be applicable to audiovisual services or electronically services that involve multiterritorial licensed rights. The first evaluation of the Geo-blocking Regulation in $2020^{1185}$ will concentrate on assessing the possible extension of the prohibition of different general conditions of access to electronically services which main feature is "the provision of access to and use of copyright protected works or other protected subject matter, including the selling of copyright protected works or protected subject matter in an intangible form, provided that the trader has the requisite rights for the relevant territories"1186. It will also be reviewed whether the scope of the Geo-blocking Regulation should be extended to audiovisual services and other services ${ }^{1187}$ as currently excluded on the basis of Article 2(2) Service Directive ${ }^{1188}$.

For the time being, audiovisual services, such as streaming or downloading of movies, remain outside the scope of the Geo-blocking Regulation. For instance, the company 'Netflix' that offers streaming of movies will still be allowed to block their websites for customers that are resided in particular Member States or maintain different conditions of access than for local customers. ${ }^{189}$ Traders who provide electronically supplied services that contain copyright protected content, such as the music platform 'Spotify', will also not (yet) be affected by the Geo-blocking Regulation.

\footnotetext{
1182 Directive 2014/26/EU of the European Parliament and of the Council of 26 February 2014 on collective management of copyright and related rights and multi-territorial licensing of rights in musical works for online use in the internal market (OJ L 84, 20.3.2014, pp. 72-98) referred to as the Collective Rights Management Directive.

${ }^{1183}$ See Regulation (EU) 2017/1128 of the European Parliament and of the Council of 14 June 2017 on crossborder portability of online content services in the internal market (OJ L 168, 30.6.2017, pp. 1-11), referred to as the Portability Regulation. See Trimble 2018, pp. 53-78.

${ }^{1184}$ Directive (EU) 2019/789 of the European Parliament and of the Council of 17 April 2019 laying down rules on the exercise of copyright and related rights applicable to online transmissions of broadcasting organisations and retransmissions of television and radio programmes, and amending the Council Directive 93/83/EEC (OJ L 130, 17.5.2019, pp. 82-91), referred to as the Satellite Cable Directive. With respect to online services involving acts of communication to the public of copyrighted works, such as certain radio and television programmes, Article 3(1) Satellite Cable Directive laid down the country of origin principle that "for the purpose of exercising copyright and related rights relevant for those acts, be deemed to occur solely in the Member State in which the broadcasting organisation has its principal establishment".

${ }_{1185}$ According to Article 9(1) Geo-blocking Regulation, "by 23 March 2020 and every five years thereafter, the Commission shall report on the evaluation of this Regulation to the European Parliament, the Council and the European Economic and Social Committee."

${ }^{1186}$ Article 9(2) Geo-blocking Regulation. See also recital 37 in the preamble of the Geo-blocking Regulation.

${ }^{1187}$ See recital 37 in the preamble of the Geo-blocking Regulation. See also the review clause in Article 9(2) Geoblocking Regulation.

${ }^{1188}$ See Article 1(3) Geo-blocking Regulation.

${ }^{1189}$ See Campo Comba 2018, p. 515.
} 
4.5.2.4 Diagram on the four main provisions related to prohibitions to unjustified geoblocking and other forms of discrimination under the Geo-blocking Regulation based on the customers' nationality or place of residence or establishment

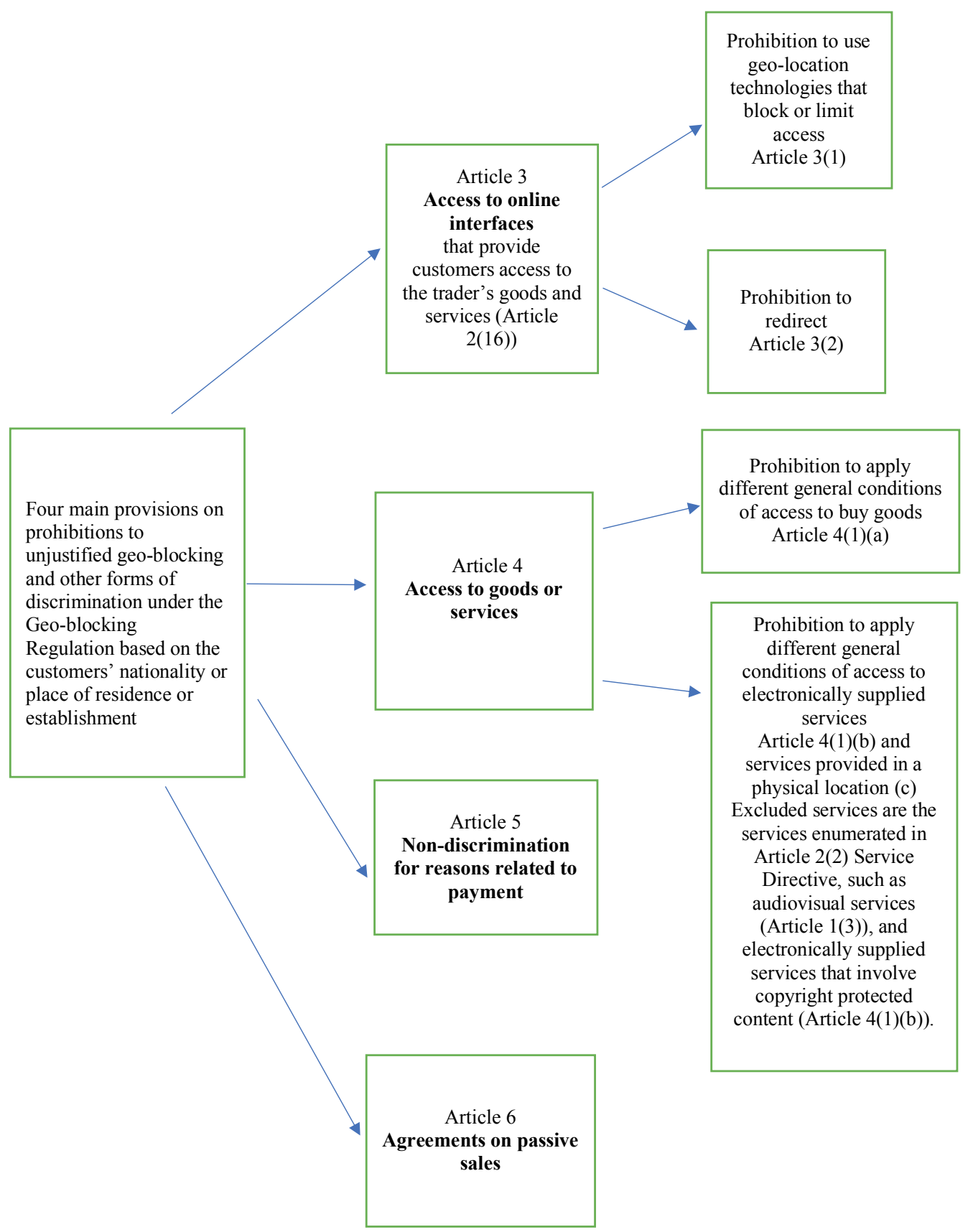




\subsubsection{The interaction between the Geo-blocking Regulation and the special jurisdiction rule related to consumers disputes in Article 17(1) Brussels Ibis}

The Geo-blocking Regulation explicitly addresses its relationship with European Union private international law related to disputes between consumers ${ }^{190}$ and traders as laid down in Article 6(1) Rome I and Article 17(1)(c) Brussels Ibis. ${ }^{1191}$ The latter provisions employ the connecting factor that the trader should have directed his activities to the country of the consumer's habitual residence in order to apply the law of the country of the consumer's habitual residence ${ }^{1192}$ or establish jurisdiction in the latter country ${ }^{1193}$. The Geo-blocking Regulation stipulates that "the mere fact that a trader complies with this Regulation should not be construed as implying that a trader directs activities to the consumer's Member State within the meaning of" Article 6(b) Rome I and 17(1)(c) Brussels Ibis. ${ }^{1194}$ Thus, when a trader complies with the Geo-blocking Regulation by offering access to goods or services, online or offline, to customers in all Member State, it will not automatically imply that the trader directed his activities to all these Member States. ${ }^{195}$ To assess the 'directed activities' criterion, it remains important whether the "trader has manifested an intention to establish commercial relations with the consumers from that Member State". ${ }^{1196}$ The latter consideration resembles the CJEU's interpretation of the 'directed activities' criterion under Article 17(1)(c) Brussels Ibis in the Pammer and Alpenhof ruling. ${ }^{197}$

In the joined cases of Pammer and Alpenhof involving internet-related consumers contract disputes, the CJEU interpreted the connecting factor 'directed activities' in Article 17(1)(c) Brussels Ibis to establish jurisdiction in the Member State where the consumer's habitual residence had been located. ${ }^{198}$ The CJEU held that among the evidence that the trader directed activities to the state where the consumer has his habitual residence are all clear expressions of the intention to establish commercial relations with consumers of that state. ${ }^{1199}$ In addition, the CJEU provided a non-exhaustive list of factors to determine whether activities are directed to the forum state like "the international nature of the activity at issue, such as certain tourist activities; mention of telephone numbers with international code; use of a top-level domain name other than that of the Member State in which the trader is established, for example '.de', or use of neutral top-level domain name such as '.com' or '.eu'; the description of itineraries from one or more other Member States to the place where the service is provided, and mention

\footnotetext{
${ }^{1190}$ Contrary to the broad definition of customer in Article 2(13) Geo-blocking Regulation (see paragraph 4.5.1), Campo Comba points out that the concept of consumer in European Union private international law only includes a natural person. See Campo Comba 2018, pp. 519-520.

${ }^{1191}$ See the recitals 12, 13 and 26 in the preamble of the Geo-blocking Regulation and Article 1(6) Geo-blocking Regulation.

1192 Article 6(1)(b) Rome I.

1193 Article 17(1)(c) Brussels Ibis.

${ }^{1194}$ Recital 13 in the preamble of the Geo-blocking Regulation. See also the recitals 12 and 26 in the preamble of the Geo-blocking Regulation and Article 1(6) Geo-blocking Regulation.

${ }^{1195}$ Recital 13 in the preamble of the Geo-blocking Regulation and Article 1(6) Geo-blocking Regulation.

${ }^{1196}$ Recital 26 in the preamble of the Geo-blocking Regulation.

1197 The joined cases C-585/08 and C-144/09 Peter Pammerv. Reederei Karl Schlüter GmbH \& Co. KG and Hotel Alpenhof GesmbH v. Oliver Heller, para. 80.

1198 Joined Cases C-585/08 and C-144/09 Pammer and Alpenhof.

1199 Joined Cases C-585/08 and C-144/09 Pammer and Alpenhof, para. 80.
} 
of an international clientele composed of customers domiciled in various Member States, in particular by presentation of accounts written by such customers". ${ }^{1200}$ Whenever the website involved allows consumers to use a different language or currency than generally used in the Member State from where the trader pursues its activities, this may also constitute evidence of 'directing'. ${ }^{1201}$ Yet, the mention of the trader's email address, geographical address, or telephone number without an international code, will not constitute relevant evidence. ${ }^{1202}$ Chapter six will again focus on the Pammer and Alpenhof ruling when assessing the 'directed activities' approach under Article 7(2) Brussels Ibis in cross-border copyright infringement cases.

The joined cases Pammer and Alpenhof have been ruled before the enactment of the Geoblocking Regulation. Due to this Regulation, traders are often not allowed anymore to block or limit their websites based on customers' nationality, place of residence or place of establishment within the European Union. As indicated in paragraph 4.5.2.2, traders can nevertheless still take certain measures to denote that their website has been directed to a particular Member State and therefore prevent getting sued in other Member States. Traders can limit their delivery possibilities to a particular Member State, they are not obligated to deliver goods in all Member States. ${ }^{1203}$ Traders who operate a website will also be allowed to use a country code top-level domain name. ${ }^{1204}$ Furthermore, the Regulation does not affect "any territorial or other limitation on after-sales customer assistance or after-sales services offered by the trader to the customer". ${ }^{1205}$ Despite the Geo-blocking Regulation, the abovementioned factors to indicate 'directed activities' as mentioned by the CJEU in the Pammer and Alpenhof ruling remain thus relevant.

Due to the Geo-blocking Regulation, it may nevertheless be more complicated to assess whether the website has been directed to a particular Member State based on the language that has been used by the website. The Regulation stipulates that traders are only allowed to redirect customers after their explicit consent to a website that uses another language than the version of the trader's online interface. ${ }^{1206}$ The foregoing indicates that the court seised need to examine the online use of a particular language in more detail to assess whether the trader directed his activities to certain Member States by using a particular language.

Thus, although the Geo-blocking Regulation appears to reject its influence on the assessment of the 'directed activities' criterion under the European Union private international law provisions related to consumers contract disputes, this Regulation will nonetheless force the court seised to look beyond first impressions when examining whether the alleged infringing

\footnotetext{
1200 Joined Cases C-585/08 and C-144/09 Pammer and Alpenhof, para. 83.

1201 Joined Cases C-585/08 and C-144/09 Pammer and Alpenhof, para. 84.

1202 Joined Cases C-585/08 and C-144/09 Pammer and Alpenhof, para. 77. This information has been mandatory by virtue of Article 5(1)(c) of Directive 2000/31/EC of the European Parliament and of the Council of 8 June 2000 on certain legal aspects of information society services, in particular electronic commerce, in the Internal Market (Directive on electronic commerce) (OJ L 178, 17.7.2000, pp. 1-16).

${ }^{1203}$ Recital 23 and 28 in the preamble to the Geo-blocking Regulation.

${ }^{1204}$ Recital 20 in the preamble to the Geo-blocking Regulation.

${ }^{1205}$ Recital 28 in the preamble to the Geo-blocking Regulation.

${ }^{1206}$ See Article 3(2) Geo-blocking Regulation.
} 
activities were directed to the forum state. ${ }^{1207}$ Moreover, the prohibition of geo-blocking in the Geo-blocking Regulation will often reduce the trader's tools to prevent jurisdiction in the country of the consumer's residence because they are not allowed anymore to block the access to their website or redirected consumers to another version of their websites to indicate that the trader's activities did not direct a particular state. ${ }^{1208}$ The foregoing indicates that there exists an interaction between the Geo-blocking Regulation and the establishment of jurisdiction in consumer contract disputes under Article 17(1) Brussels Ibis. ${ }^{1209}$

\subsubsection{The Geo-blocking Regulation as part of the assessment framework}

The Geo-blocking Regulation does not particularly address its relationship with other provisions of European private international law such as the special jurisdiction rule in Article 7(2) Brussels Ibis. This Regulation merely stipulates that its provisions "shall be without prejudice to Union law concerning judicial cooperation in civil matters". ${ }^{1210}$

When rethinking the CJEU's approach and alternative approaches to jurisdiction in crossborder copyright infringement disputes, this dissertation will examine the (possible) impact of the Geo-blocking Regulation. According to various of the alternative approaches that will be demonstrated in chapter six, the use of geo-blocking technologies has been a relevant factor to indicate whether courts can obtain jurisdiction in cross-border copyright infringement cases. Since these approaches have been proposed before the enactment of the Geo-blocking Regulation in 2018, it will be particularly relevant to include this Regulation into the assessment framework of this dissertation.

Due to the scope of the Geo-blocking Regulation as demonstrated in paragraph 4.5.1, this Regulation may only affect an approach to jurisdiction in cross-border copyright infringement cases if the alleged copyright infringer has been a trader who offers goods and services within the European Union. Furthermore, paragraph 4.5.2.3 has described the services that are excluded from the scope of the Geo-blocking Regulation. From a perspective of copyright infringing activities, it is relevant that audiovisual services and electronically services that contain copyright protected content are excluded. ${ }^{1211}$

\subsection{The assessment framework and the interpretation methods to rethink the CJEU's approach to jurisdiction in cross-border copyright infringement cases}

This chapter demonstrated several principles that the CJEU should observe in order to provide a legitimate interpretation of the special jurisdiction rule under Article 7(2) Brussels Ibis in cross-border copyright infringement cases. In view of the role of the CJEU as law-finder,

\footnotetext{
${ }^{1207}$ See Campo Comba 2018, pp. 524-525.

1208 See Campo Comba 2018, pp. 519, 523.

${ }^{1209}$ See also Campo Comba 2018, pp. 522-525.

${ }^{1210}$ See Article 1(6) Geo-blocking Regulation.

1211 See paragraph 4.5.2.3.
} 
these principles have been derived from various methods of interpretation as set out in this chapter.

In summary, the assessment framework to rethink the CJEU's interpretation of Article 7(2) Brussels Ibis in cross-border copyright infringement cases will include the following four principles. First, the principle of predictability in order to meet the reasonable expectations of the copyright holder and the alleged infringer as to which court(s) may obtain jurisdiction. Second, the principle of a close connection between the dispute and the court. Third, the approach to jurisdiction has to facilitate the sound administration of justice. Fourth, the principle of balancing the interests involved. The latter principle involves the procedural balance between the litigants that means the copyright holder and the infringer. ${ }^{1212}$ In addition, this principle comprises the balance between the broader interests of copyright holders, on the one hand, and traders and users of information and knowledge, on the other hand. ${ }^{1213}$

The principles of predictability, a close connection between dispute and forum, sound administration of justice, and a procedural balance between the litigants are derived from the field of private international law. The principle of balancing the broader interests involved suits both the field of copyright law and private international law. Whereas this latter principle reflects the development of instrumentalisation of private international law ${ }^{1214}$, the other principles meet the critics of this instrumentalisation who claim that the rationale of private international law should not be undermined. ${ }^{1215}$

In view of contextual interpretation, the Geo-blocking Regulation will also be a part of the assessment framework of this dissertation. When rethinking the CJEU's approach to jurisdiction in cross-border copyright infringement disputes and assessing alternative approaches as proposed by scholars and courts of Member States and states of the United States of America, the effect of the prohibitions to geo-block and employ other forms of discrimination based on customers' nationality, place of residence or place of establishment within the internal market will be considered.

Based on the contextual method of interpretation, the effect of the territorial principle related to copyrights on the approach to jurisdiction in cross-border copyright infringement cases should also be examined. As explained in paragraph 2.3.2, the territorial protection of copyrights can influence the jurisdiction rule under Article 7(2) Brussels Ibis in cross-border copyright infringement disputes by adopting the locus protectionis as jurisdiction criterion or limiting the scope of the court's jurisdiction. As demonstrated in paragraph 3.5.1, the CJEU did adopt the locus protectionis as jurisdiction criterion and territorially limited the court's jurisdiction under Article 7(2) Brussels Ibis in cross-border copyright infringement disputes. In chapter five, the (desirable) influence of the territorial principle on the approach to jurisdiction under Article 7(2) Brussels Ibis in cross-border copyright infringement cases will be discussed. Although the influence of the territorial principle related to copyrights will not be an explicit part of the assessment framework, it will thus be a recurring theme throughout this dissertation.

1212 See paragraph 4.2.4.2.

1213 See paragraph 4.4 .

1214 See paragraph 2.1.2.

1215 See paragraph 1.2. 
In addition, the influence of the field of public international law, namely the principles of sovereignty of states and territoriality, and the principle of international comity will be examined in chapter five.

With respect to the interpretation of law, Dworkin argued that courts should focus on the principles underlying the law. ${ }^{1216}$ As noted by Dworkin, principles provide directions that have to be weighed. ${ }^{1217}$ Based on the latter view, a balance should be struck between the principles of the assessment framework when rethinking the CJEU's approach to jurisdiction in crossborder copyright infringement cases. ${ }^{1218}$ In the next chapters, the abovementioned assessment framework will be applied to the CJEU's interpretation of Article 7(2) Brussels Ibis in the rulings Pinckney, Hi Hotel and Pez Hejduk. Furthermore, the assessment framework will be employed to alternative approaches to jurisdiction in cross-border copyright infringement cases established by scholars and courts of European Union Member States and states of the United States of America. The method of comparative law will thus also be employed in this dissertation. Paragraph 4.6.2 will provide a table on the methods of interpretation that will be employed in this dissertation to rethink the CJEU's approach to jurisdiction under Article 7(2) Brussels Ibis in cross-border copyright infringement cases. The next paragraph will demonstrate the principles of the assessment framework of this dissertation to provide jurisdiction under Article 7(2) Brussels Ibis in cross-border copyright infringement cases

\footnotetext{
${ }^{1216}$ See De Waele 2009, pp. 17-18. With respect to law-finding based on principles underlying the law involved, see Vranken 1995, no. 131-140; Wiarda 1999, pp. 25-26.

${ }^{1217}$ Dworkin 2013, p. 35.

${ }^{1218}$ Dworkin argues that an ideal judge, referred to as Hercules, should "create a basic legal theory, which brings the different elements of the legal order, including principles, into harmony with each other". See Dworkin 2013, p. 290. See Raitio 2013, p. 92.
} 
4.6.1 Diagram on the principles of the assessment framework to provide jurisdiction under Article 7(2) Brussels Ibis in cross-border copyright infringement cases

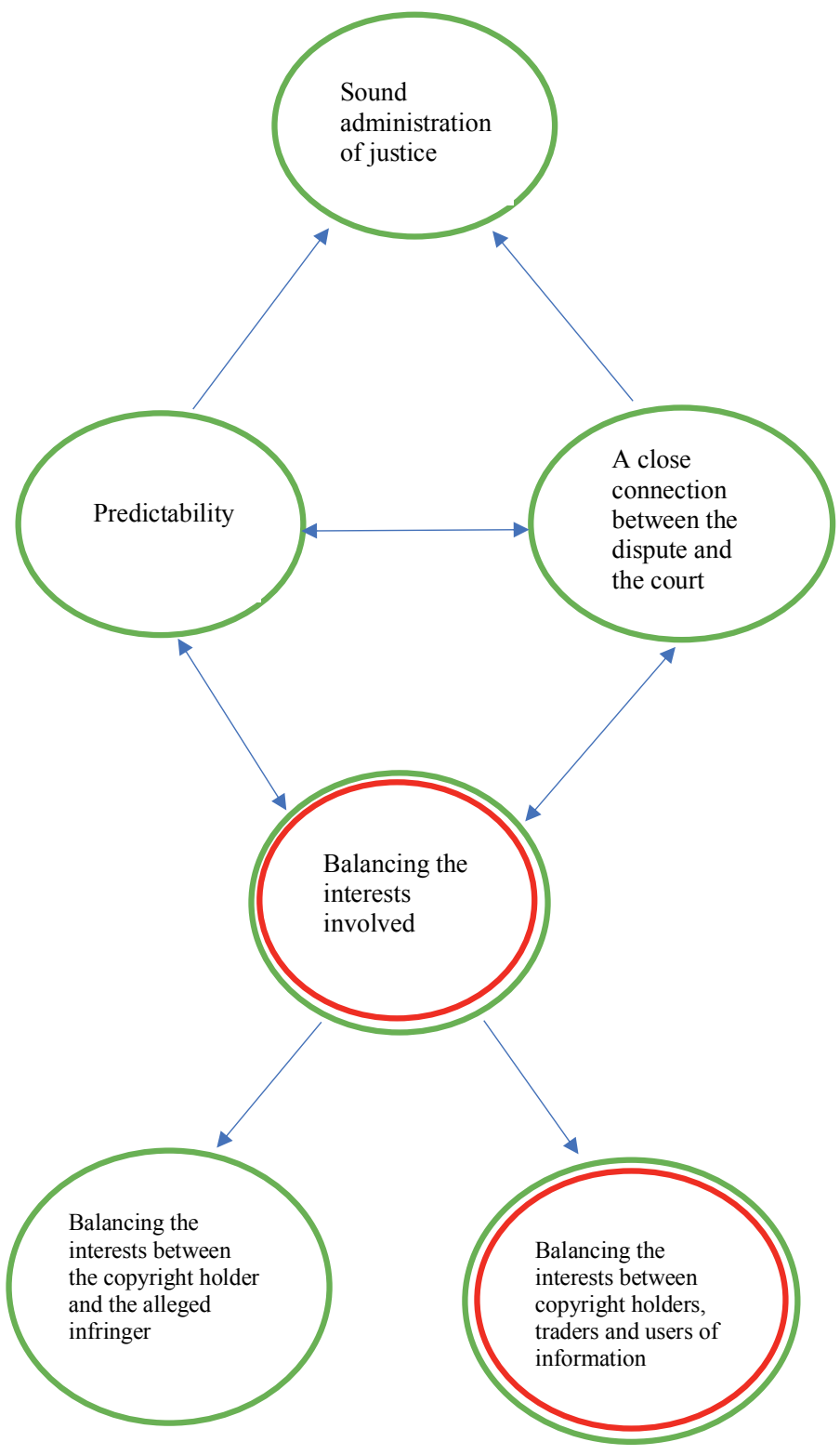

Principle of private international law

Principle related to copyright law 


\subsubsection{Table on the methods of interpretation that will be employed in this dissertation to rethink the CJEU's approach to jurisdiction}

\begin{tabular}{|c|c|c|}
\hline $\begin{array}{l}\text { Methods } \\
\text { of interpretation }\end{array}$ & & In this dissertation \\
\hline Teleological & $\begin{array}{l}\text { Principles underlying Article } \\
\text { 7(2) Brussels Ibis (see paragraph } \\
\text { 4.2.4.2): } \\
\text {-predictability } \\
\text {-a close connection between } \\
\text { dispute and forum state } \\
\text { (principle of proximity) } \\
\text {-sound administration of justice: } \\
\text { reduce parallel proceedings and } \\
\text { risk of irreconcilable decisions, } \\
\text { and the competent court should } \\
\text { have easily access to the facts } \\
\text { and evidence of the case } \\
\text {-procedural balance between the } \\
\text { litigants }\end{array}$ & \multirow[t]{3}{*}{$\begin{array}{l}\text { As a part of the assessment } \\
\text { framework of this dissertation } \\
\text {-to rethink the CJEU's approach } \\
\text { to jurisdiction in cross-border } \\
\text { copyright infringement cases } \\
\text { (Chapter 5) } \\
\text {-to assess alternative approaches } \\
\text { to jurisdiction in cross-border } \\
\text { copyright infringement cases } \\
\text { according to scholarly proposals } \\
\text { and case law of courts of } \\
\text { European Union Member States } \\
\text { (Chapter 6) } \\
\text {-to assess various approaches to } \\
\text { jurisdiction in cross-border } \\
\text { copyright infringement disputes } \\
\text { established by courts of states of } \\
\text { the United States of America } \\
\text { (Chapter 7) }\end{array}$} \\
\hline \multirow[t]{3}{*}{ Contextual } & $\begin{array}{l}\text { EU law: } \\
\text {-In light of the general forum rei } \\
\text { rule in Article } 4 \text { Brussels Ibis, } \\
\text { the special jurisdiction rule in } \\
\text { Article } 7(2) \text { Brussels Ibis need } \\
\text { to be interpreted in a restrictive } \\
\text { manner } \\
\text {-the (possible) effect of the Geo- } \\
\text { blocking Regulation }\end{array}$ & \\
\hline & $\begin{array}{l}\text { Copyright law: } \\
\text {-the principle of balancing the } \\
\text { interests related to copyrights }\end{array}$ & \\
\hline & $\begin{array}{l}\text {-the territorial principle related } \\
\text { to copyrights }\end{array}$ & $\begin{array}{l}\text {-Rethinking the locus } \\
\text { protectionis as jurisdiction } \\
\text { criterion (paragraph } 5.1 .3 \text { ) } \\
\text {-Rethinking the scope of the } \\
\text { court's jurisdiction in cross- } \\
\text { border copyright infringement } \\
\text { cases (paragraph 2.3.4.1; 5.3.2) }\end{array}$ \\
\hline
\end{tabular}




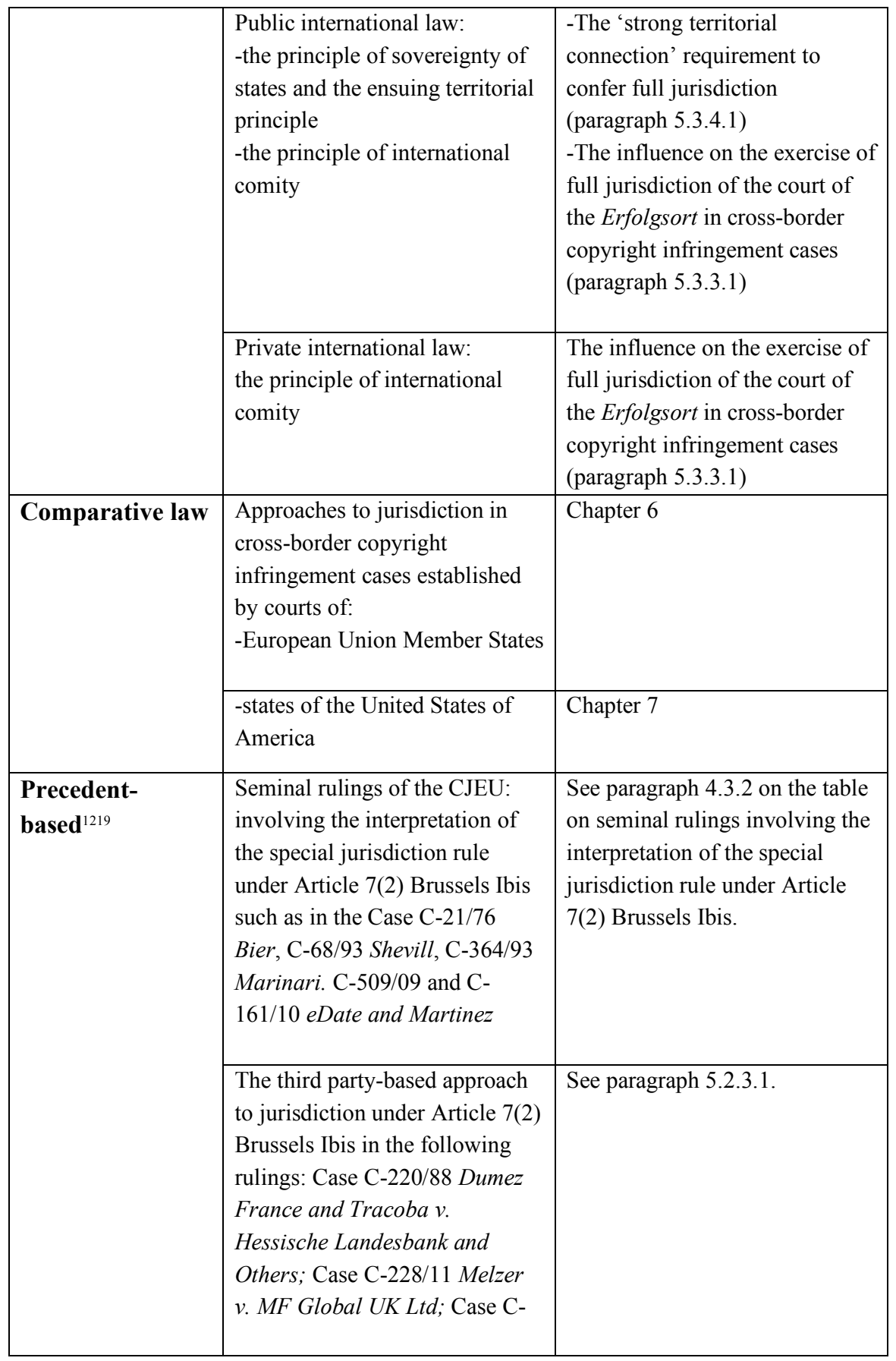

1219 While the precedent-based method of interpretation has generally not been regarded as a common method of interpretation in the European Union, it could also be subsumed under the contextual method of interpretation as it places the special jurisdiction rule of Article 7(2) Brussels Ibis in the context of previous rulings provided by the CJEU. See also paragraph 4.3. 


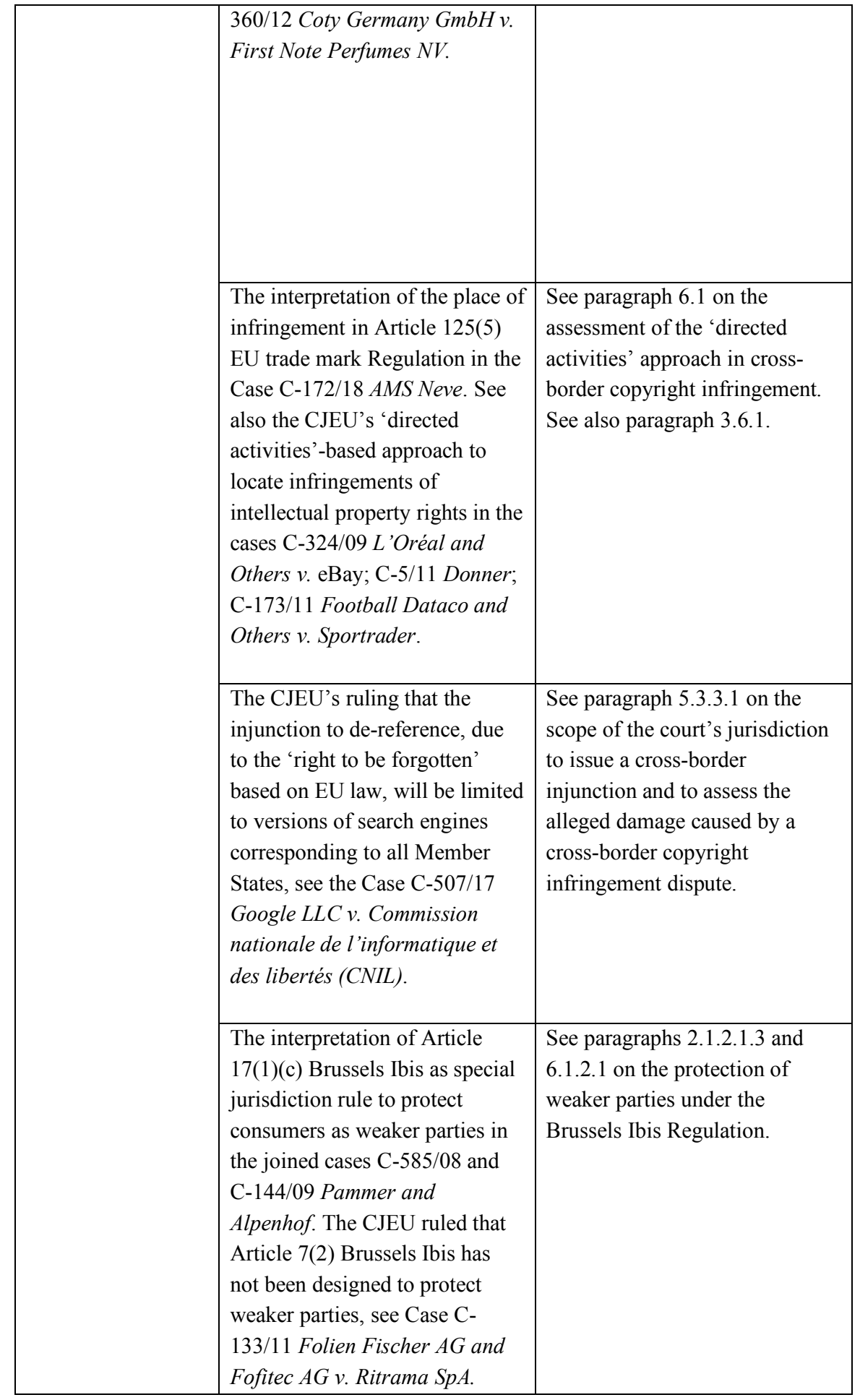




\section{Chapter 5}

Examining the CJEU's approach to jurisdiction in cross-border copyright infringement cases 

This chapter will examine the CJEU's approach to jurisdiction in cross-border copyright infringement cases referred to as the Pinckney doctrine ${ }^{1220}$. This doctrine exists of two connecting factors: the locus protectionis and the likelihood of damage. The jurisdiction of the courts based on these factors is limited to assess the damage caused in the territory of the forum state.

The first part of this chapter will focus on the jurisdiction criterion locus protectionis. The difference will be demonstrated between the prevailing concept of locus protectionis according to substantive copyright laws of the Member States, on the one hand, and the fictitious concept of locus protectionis established by the CJEU in the rulings Pinckney, Hi Hotel and Pez Hejduk, on the other hand. Subsequently, various views of scholars will be outlined regarding the locus protectionis as prerequisite to obtain jurisdiction in cross-border copyright infringement cases. Finally, the CJEU's locus protectionis criterion will be assessed on the basis of the assessment framework as set out in paragraph 4.6.

The second part of this chapter will assess the connecting factors 'likelihood of damage' and 'mere accessibility' in light of the framework of paragraph 4.6. Furthermore, the so-called third party-based approach to jurisdiction under Article 7(2) Brussels Ibis will be addressed. The final part of this chapter will examine the territorial limitation of the court's jurisdiction under the Pinckney doctrine. Arguments will be provided against this limitation in multistate or ubiquitous copyright infringement cases.

\subsection{The concept of locus protectionis as connecting factor}

\subsubsection{The CJEU's rulings involving the concept of locus protectionis under Article 7(2) Brussels Ibis}

In several rulings, the CJEU employed the concept of locus protectionis with respect to the interpretation of the place where the damage occurred, the Erfolgsort, under Article 7(2) Brussels Ibis. ${ }^{1221}$ In the Pinckney ruling, the CJEU held that "the likelihood of damage occurring in a particular Member State is subject to the requirement that the right in respect of which infringement is alleged is protected in that Member State". ${ }^{1222}$ In this context, the Pinckney ruling referred to two earlier rulings namely the case of eDate and Martinez concerning alleged online infringements of personality rights ${ }^{1223}$ and the Wintersteiger case involving an alleged online infringement of a national trade mark ${ }^{1224}$.

In the eDate and Martinez ruling, the CJEU did not employ the locus protectionis as an 'explicit' jurisdiction criterion. In the Wintersteiger ruling, the CJEU clarified that personality rights are protected in all Member States of the European Union, they can therefore be relied

\footnotetext{
${ }^{1220}$ See paragraph 3.5 on the so-called Pinckney doctrine.

${ }^{1221}$ See paragraphs 2.3.2 and 3.5 on the locus protectionis as connecting factor to establish jurisdiction.

1222 Case C-170/12 Peter Pinckney v. KGD Mediatech AG, para. 33. See paragraph 3.2.3.

${ }^{1223}$ Joined cases C-509/09 and C-161/10 eDate Advertising GmbH v. X and Olivier Martinez and Robert Martinez v. MGN Limited.

${ }^{1224}$ Case C-523/10 Wintersteiger AG v. Products $4 U$ Sondermaschinenbau GmbH.
} 
on in each Member State. ${ }^{1225}$ To obtain jurisdiction under Article 7(2) Brussels Ibis in case of alleged online infringements of personality rights, the court seised therefore does not need to examine whether the personality rights involved are protected in the forum state.

In the Wintersteiger ruling, the CJEU did employ the locus protectionis as an 'explicit' jurisdiction criterion under Article 7(2) Brussels Ibis. According to the CJEU, a national trade mark is only protected within the territory of the state in which it has been registered. ${ }^{1226}$ The CJEU argued that "both the objective of foreseeability and that of sound administration of justice militate in favour of conferring jurisdiction, in respect of the damage occurred, on the courts of the Member State in which the right at issue is protected". ${ }^{1227}$ In addition, the CJEU held that the courts of the Member State in which the trademark at issue is registered have full jurisdiction to determine all the damage involved and "to hear an application seeking cessation of all infringements of that right" since those courts are best able to assess whether a national trade mark has actually been infringed. ${ }^{1228}$

After the Pinckney ruling, the CJEU has employed the locus protectionis criterion in the case of Coty Germany GmbH v. First Note Perfumes NV involving an infringement of national law against unfair competition. ${ }^{122}$ In the latter case, the CJEU applied a similar locus protectionis requirement as in the rulings Wintersteiger and Pinckney namely that "the occurrence of damage in a particular Member State is subject to the protection, in that State, of the right in respect of which infringement is alleged". ${ }^{1230}$ Hence, the court of the Erfolgsort could obtain jurisdiction provided that the law against unfair competition in the forum state protected the alleged infringed right. ${ }^{1231}$ Similar to the cases Pinckney and Hi Hotel, the Coty case concerned the interpretation of the Erfolgsort regarding alleged damage that had been directly caused in the forum state by a so-called third party ${ }^{1232}$. Paragraph 5.2.3.1.3 will therefore discuss the Coty ruling in more detail.

The locus protectionis criterion has also been employed for the interpretation of Article 7(2) Brussels Ibis in the case of Concurrence SARL v. Samsung Electronics France SAS and Amazon Services Europe Sarl. ${ }^{123}$ This case concerned the infringement of a selective distribution agreement that prohibited the sale of products online. The question arose whether the court seised could obtain jurisdiction under Article 7(2) Brussels Ibis based on the mere accessibility of the website involving the prohibited sale of products. ${ }^{1234}$ Therefore, the CJEU

\footnotetext{
1225 Case C-523/10 Wintersteiger, para. 25; Case C-170/12 Peter Pinckney v. KGD Mediatech AG, para. 36.

${ }^{1226}$ Case C-523/10 Wintersteiger, para. 25.

1227 Case C-523/10 Wintersteiger, para. 27.

1228 Case C-523/10 Wintersteiger, para. 28.

${ }^{1229}$ Case C-360/12 Coty Germany GmbH v. First Note Perfumes NV.

${ }^{1230}$ Case C-360/12 Coty, para. 55-56. The CJEU referred to Case C-523/10 Wintersteiger, para. 25 and Case C170/12 Pinckney, para. 33 .

${ }^{1231}$ Case C-360/12 Coty, para. 55-56.

${ }^{1232}$ See paragraph 5.2.3 on the CJEU's case law involving the establishment of jurisdiction under Article 7(2) Brussels Ibis based on damage caused by a so-called third party.

${ }^{1233}$ Case C-618/15 Concurrence SARL v. Samsung Electronics France SAS and Amazon Services Europe Sarl.

${ }^{1234}$ Case C-618/15 Concurrence, para. 17.
} 
focused on the interpretation of the place where the alleged damage occurred under Article 7(2) Brussels Ibis. ${ }^{1235}$

The CJEU reiterated the Pinckney ruling that "the likelihood of damage in a particular Member State is subject to the condition that the right whose infringement is alleged is protected in that Member State"1236. Subsequently, the CJEU held that "the infringement of the prohibition on resale outside the distribution network is given effect by the law of the Member State of the court seised". ${ }^{1237}$ Hence, the CJEU argued "a natural link" exists between the forum state and the dispute that justifies the conferral of jurisdiction. ${ }^{1238}$

In the rulings Pinckney, Hi Hotel and Pez Hejduk, the CJEU interpreted the concept of locus protectionis in the following way. The CJEU argued that although copyrights are governed by the principle of territoriality, "copyrights must be automatically protected by virtue of the Directive 2001/29 [Information Society Directive], in all Member States, so that they may be infringed in each one in accordance with the applicable substantive law". ${ }^{1239}$ Therefore, the places where copyrights are protected, loci protectionis, appear to be in each Member State. Nonetheless, the CJEU ruled that the court of a Member State can only establish jurisdiction under Article 7(2) Brussels Ibis "if the Member State in which the court is situated protects the copyrights relied on by the plaintiff'. ${ }^{1240}$ The latter consideration seems to require that the court seised has to assess whether the forum state protects the alleged copyright in order to obtain jurisdiction. The CJEU's concept of locus protectionis as jurisdiction criterion under the Pinckney doctrine therefore seems to be ambiguous. ${ }^{1241}$

The following table will demonstrate the CJEU's rulings involving the concept of locus protectionis under Article 7(2) Brussels Ibis in the abovementioned tort cases. As indicated in this table, the place where the right is protected generally coincides with the locus protectionis as jurisdiction criterion. However, in the rulings Pinckney, Hi Hotel, Pez Hejduk, the CJEU's statement that copyrights are automatically protected in all Member States ${ }^{1242}$ appears to be not in accordance with the requirement that the court seised need to examine whether the copyright involved is protected in the forum state. ${ }^{1243}$ If copyrights are automatically protected in all Member States, it would be logical that the locus protectionis criterion remains an implicit criterion similar to the eDate and Martinez ruling.

\footnotetext{
1235 Case C-618/15 Concurrence, para. 29. The CJEU referred therefore to the Opinion of Advocate General Wathelet in the Case C-618/15 Concurrence SARL v. Samsung Electronics France SAS and Amazon Services Europe Sarl, para. 40.

1236 Case C-618/15 Concurrence, para. 30.

1237 Case C-618/15 Concurrence, para. 32.

1238 Case C-618/15 Concurrence, para. 32.

1239 Case C-170/12 Pinckney, para. 39. See also Case C-441/13 Pez Hejduk, para. 22.

${ }^{1240}$ Case C-170/12 Pinckney, para. 43; Case C-387/12 Hi Hotel, para. 35; Case C-441/13 Pez Hejduk, para. 29.

${ }^{1241}$ See paragraph 5.1.3 will further elaborate on the ambiguous concept of locus protectionis established by the CJEU under the Pinckney doctrine.

${ }^{1242}$ Case C-170/12 Pinckney, para. 39. See also Case C-441/13 Pez Hejduk, para. 22.

${ }^{1243}$ Case C-170/12 Pinckney, para. 43; Case C-387/12 Hi Hotel, para. 35; Case C-441/13 Pez Hejduk, para. 29.
} 


\begin{tabular}{|c|c|c|c|}
\hline Case $^{1244}$ & $\begin{array}{l}\text { Alleged infringed } \\
\text { right }\end{array}$ & $\begin{array}{l}\text { Place of protection } \\
\text { (locus protectionis) of the } \\
\text { right relied on }\end{array}$ & $\begin{array}{l}\text { Locus protectionis as } \\
\text { jurisdiction criterion } \\
\text { under Article 7(2) } \\
\text { Brussels Ibis }\end{array}$ \\
\hline $\begin{array}{l}\text { eDate and Martinez } \\
\text { C-509/09 and C- } \\
161 / 10\end{array}$ & Personality rights & $\begin{array}{l}\text { Protected in all Member } \\
\text { States (See Wintersteiger } \\
\text { para } 25 \text { and Pinckney } \\
\text { para. 36). }\end{array}$ & $\begin{array}{l}\text { While the locus } \\
\text { protectionis remains an } \\
\text { implicit criterion, it has } \\
\text { been mentioned by the } \\
\text { CJEU in the rulings } \\
\text { Wintersteiger para } 25 \\
\text { and Pinckney para. } 36 \text {. }\end{array}$ \\
\hline $\begin{array}{l}\text { Wintersteiger } \\
\text { C-523/10 }\end{array}$ & $\begin{array}{l}\text { A national } \\
\text { trademark }\end{array}$ & $\begin{array}{l}\text { Protection is limited to the } \\
\text { territory of the Member } \\
\text { State in which the } \\
\text { trademark is registered } \\
\text { (Wintersteiger } \\
\text { para. 25). }\end{array}$ & $\begin{array}{l}\text { The court seised obtains } \\
\text { jurisdiction if the } \\
\text { trademark is registered } \\
\text { in the forum state } \\
\text { (Wintersteiger } \\
\text { para. 27-29). }\end{array}$ \\
\hline $\begin{array}{l}\text { Pinckney } \\
\text { C-170/12 } \\
\text { Hi Hotel } \\
\text { C-387/12 } \\
\text { Pez Hejduk } \\
\text { C-441/13 }\end{array}$ & Copyrights & $\begin{array}{l}\text { The CJEU claims that } \\
\text { "copyrights must be } \\
\text { automatically protected, } \\
\text { in particular by virtue of } \\
\text { Directive } 2001 / 29 \\
\text { [Information Society } \\
\text { Directive], in all Member } \\
\text { States" (Pinckney para. } \\
\text { 39, Pez Hejduk para, 22). }\end{array}$ & $\begin{array}{l}\text { The court seised may } \\
\text { obtain jurisdiction "if } \\
\text { the Member State in } \\
\text { which the court is } \\
\text { situated protects the } \\
\text { copyrights relied on by } \\
\text { the plaintiff" (Pinckney } \\
\text { para. 43, Hi Hotel para. } \\
\text { 35, Pez Hejduk para, } \\
\text { 30). }\end{array}$ \\
\hline $\begin{array}{l}\text { Coty } \\
\text { C-360/12 }\end{array}$ & $\begin{array}{l}\text { Right protected by } \\
\text { national law against } \\
\text { unfair competition }\end{array}$ & $\begin{array}{l}\text { Protection in Member } \\
\text { States in which the law } \\
\text { against unfair competition } \\
\text { prohibits the alleged } \\
\text { infringing activities (Coty } \\
\text { para. 55-56). }\end{array}$ & $\begin{array}{l}\text { The court seised may } \\
\text { obtain jurisdiction if the } \\
\text { law against unfair } \\
\text { competition in the forum } \\
\text { state protects the alleged } \\
\text { infringed right (Coty } \\
\text { para. 55-56). }\end{array}$ \\
\hline
\end{tabular}

${ }^{1244}$ See list of abbreviations of case law. 


\begin{tabular}{|l|l|l|l|}
\hline & $\begin{array}{l}\text { Prohibition on } \\
\text { resale outside a } \\
\text { selective } \\
\text { distribution } \\
\text { network }\end{array}$ & $\begin{array}{l}\text { Protection in the Member } \\
\text { State which law protects } \\
\text { the prohibition on resale } \\
\text { (Concurrence para. 30- } \\
\text { C-618/15 }\end{array}$ & $\begin{array}{l}\text { The court seised may } \\
\text { obtain jurisdiction if the } \\
\text { infringement of the } \\
\text { prohibition on resale } \\
\text { outside the distribution } \\
\text { network is given effect } \\
\text { by the law of the } \\
\text { Member State of the } \\
\text { court seised } \\
\text { (Concurrence para. 32). }\end{array}$ \\
\hline
\end{tabular}

\subsubsection{Diverging concepts of locus protectionis}

As demonstrated in the previous paragraph, the CJEU established the Pinckney doctrine on the statement that "copyrights must be automatically protected, in particular by virtue of Directive 2001/29, in all Member States, so that they may be infringed in each one in accordance with the applicable substantive law". ${ }^{1245}$ Copyrights are, however, not automatically protected in the Member States by virtue of the Information Society Directive. Unlike a European Union Regulation, the provisions of a European Union Directive have to be implemented into the national laws of the Member States. ${ }^{1246}$

While the Information Society Directive purports to harmonise substantive copyright laws of the Member States, there are still significant differences between the copyright laws of the Member States. ${ }^{1247}$ Moreover, the Information Society Directive does not cover all areas of copyright law; the main focus lies on the rights of exploitation and the limitations of copyrights. ${ }^{1248}$ Copyright issues such as authorship or moral rights related to copyrights are not regulated by the Information Society Directive. ${ }^{1249}$ It is also uncertain which type of 'works' fall under the scope of the Information Society Directive. ${ }^{1250}$ This Directive contains no provision that enumerates certain types of works such as Article 2 of the Berne Convention of 1979 or Article 10 of the Dutch Copyright Law. ${ }^{1251}$

\footnotetext{
${ }^{1245}$ Case C-170/12 Pinckney, para. 39. See also Case C-441/13 Pez Hejduk, para. 22.

${ }^{1246}$ See Article 288 TFEU. Strowel (2014, p. 1135) notes "in the absence of a copyright Regulation, there are no directly applicable copyright rules in the EU".

1247 Among various scholars, Kur \& Dreier (2013, p. 244, 245, 271, 315) noted that "the piecemeal approach adopted by the Commission and the Member States in the harmonisation process has not led to complete harmonisation.” See also Picht \& Kopp 2016, p. 235; Rosati 2013, pp. 1-2. See also paragraph 2.2.1.

1248 Spoor, Verkade \& Visser 2019, p. 175.

${ }^{1249}$ Spoor, Verkade \& Visser 2019, p. 175. See also Van Eechoud 2012, p. 76. See Opinion of Advocate-General Szpunar delivered on 2 May 2019 in the Case C-683/17 Cofemel-Sociedade de Vestuário SA v. G-Star Raw CV, para. 44.

${ }^{1250}$ Griffiths 2014, pp. 1104-1105. See also Van Eechoud (2012, pp. 70-74) on the CJEU's incomplete harmonised concept of copyrighted work.

${ }^{1251}$ Pursuant to Griffiths (2014, pp. 1104-1105), the "central concept of work is not defined" in European Union law. Derclaye claims that the CJEU adopted an autonomous concept of work, yet the relationship between the concept of work and the concept of originality has not been clear. See Derclaye 2014, pp. 7-10. Article 2 of the
} 
Particular works may not be protected in all Member States. ${ }^{1252}$ Perfume is, for instance, a type of work that reflects the lack of consensus between the Member States concerning which works can be protected by copyright. ${ }^{1253}$ While the Dutch Supreme Court considered perfume as a work protected by copyright, the French Supreme Court rejected this possibility. ${ }^{1254}$ The Levola Hengelo BV v. Smilde Foods BV ruling demonstrates that the CJEU nonetheless aims to provide "a uniform interpretation of the concept of a 'work' throughout the European Union". ${ }^{1255}$ In this case, the CJEU ruled that the taste of a food product cannot be considered as a 'work' that is eligible for copyright protection under the Information Society Directive because this taste cannot "be pinned down with precision and objectivity". ${ }^{1256}$ Yet, it is disputable whether perfume can be pinned down with precision and objectivity. ${ }^{1257}$

While the CJEU's rulings on the Information Society Directive have to guide Member State courts regarding the interpretation of national copyright laws conform this Regulation, these courts still have a great deal of leeway. ${ }^{1258}$ In the case of Infopaq International A/S v. Danske Dagblades Forening, the CJEU ruled that the Information Society Directive protects a work provided that it "contains elements which are the expression of the intellectual creation of the author". ${ }^{259}$ Yet, this concept of originality is an 'open' standard that may be differently interpreted by the courts of each Member State. ${ }^{1260}$ For instance, in the case of The Newspaper Licensing Agency Ltd and others v. Meltwater Holding BV and Others of 27 July 2011, the Court of Appeal of England and Wales held that a headline in a newspaper could be protected

Berne Convention and Article 10 of the Dutch Copyright Law provide a non-exhaustive enumeration of productions in the literary, scientific and artistic domain may be regarded as protected works.

1252 Depreeuw \& Hubin 2014, p. 750.

1253 Chiou 2014, p. 854; Hugenholtz 2013, p. 278.

${ }^{1254}$ Hoge Raad (Dutch Supreme Court) 16 June 2006, Kecofa v. Lancôme. Cour de Cassation (French Supreme Court) 13 June 2006, Bsiri-Barbir/ Haarmann \& Reime and Cour de Cassation 10 December 2013, SNC Lancôme Parfums et Beauté and co., GA Modefine prestige et collection international v. M. X. See also Cohen Jehoram 2006, pp. 629-631.

1255 Case C-310/17 Levola Hengelo BV v. Smilde Foods BV, para. 45.

${ }^{1256}$ Case C-310/17 Levola Hengelo BV v. Smilde Foods BV, para. 42-44.

${ }^{1257}$ See, for instance, the following blogs of law firms: "The taste of cheese cannot be protected by copyright! What about fragrances of perfume?" see https:/www.lexgo.be/nl/artikels/ip-it-telecom/intellectueeleigendomsrecht/the-taste-of-cheese-cannot-be-protected-by-copyright-what-about-fragrances-of-

perfume,124051.html and "Levola/Smilde: copyright on taste or scent? Not according to Advocate General" see https://www.boelszanders.nl/en/publication/levola-smilde-copyright-on-taste-or-scent-not-according-to-

advocate-general/.

${ }^{1258}$ As argued by Hugenholtz (2012(b), p. 4), "harmonisation directives usually leave a broad measure of discretion to the Member States and are often vague as a result of political promise."

${ }^{1259}$ Case C-5/08 Infopaq International A/S v. Danske Dagblades Forening, para. 37 and 39. For subsequent case law of the CJEU related to the originality criterion, see joined Cases C-403/08 and C-429/08 Football Association Premier League Ltd. and Others and Karen Murphy v. Media Protection Services Ltd., para. 153-159; Case C393/09 Bezpecnostni softwarová asociace - Svaz softwaeové ochrany v. Ministerstvo kultury, para. 45-51; Case C145/10 Eva-Maria Painer v. Standard VerlagsGmbH and Others, para. 85-99; Case C-406/10 SAS Institute Inc v. World Programming Ltd., para. 30-46; Case C-604/10 Football Dataco Ltd and Others v. Yahoo! UK Ltd and Others, para. 37-46.

${ }^{1260}$ Cases Vallés 2009, pp. 102-132; Lopez-Tarruella 2012, p. 123. See also Ohly 2012, p. 9. Van Eechoud (2012, pp. 69-70) sets out various critical views on the CJEU's originality standard. See the critical note by Laurent (2012) on the interpretation of the CJEU's originality standard by the Belgian Supreme Court. See Rosati (2013, pp. 97127) on the interpretation of the CJEU's originality standard by the United Kingdom courts. 
by copyright as an original literary work. ${ }^{1261}$ Despite the Infopaq ruling, the Court of Appeal stated that "the word 'original' does not connote novelty but that it originated with the author". 1262

In the Pinckney ruling, the CJEU held that "the issue as to whether the conditions under which a right protected in a Member State in which the court seised is situated may be regarded as having been infringed and whether that infringement may be attributed to the defendant falls within the scope of the examination of the substance of the action by the court having jurisdiction". ${ }^{1263}$ The latter conditions, inter alia, concern whether the type of work involved is protected by the copyright law of the forum state and whether the particular work is original according to the abovementioned standard in the Infopaq ruling. As demonstrated above, which type of work is protected may differ in each Member State and the originalty standard is quite open. ${ }^{1264}$ The adoption of the prevailing concept of locus protectionis as connecting factor would thus entail legal uncertainty and unpredictability regarding the jurisdiction of the court seised. Moreover, according to settled case law, the CJEU explicitly ruled that the interpretation of the special jurisdiction rule of Article 7(2) Brussels Ibis should not be linked with national provisions regarding non-contractual civil liability because the Brussels system aims "to provide for a clear and certain attribution of jurisdiction". ${ }^{1265}$

Anyway, the CJEU formulated the concept of locus protectionis under the Pinckney doctrine as if every place in the European Union can automatically be considered as locus protectionis. As mentioned in paragraph 4.2.1, the CJEU generally interprets provisions under the Brussels system in an autonomous way, ${ }^{1266}$ therefore "legal concepts do not necessarily have the same meaning in Community Law and in the law of the various Member States"1267. The autonomous interpretation has to guarantee a uniform interpretation of European Union law. ${ }^{1268}$

As demonstrated in paragraph 5.1, the CJEU's concept of locus protectionis under the Pinckney doctrine nonetheless seems to be contradictory. On the one hand, the CJEU made the policy statement that copyrights must be automatically protected by virtue of the Information Society Directive. On the other hand, the CJEU held that the court of a Member State can only establish jurisdiction under Article 7(2) Brussels Ibis "if the Member State in which the court is situated protects the copyrights relied on by the plaintiff'. ${ }^{1269}$ The latter consideration seems to indicate that the CJEU did acknowledge the fact that there has been a lack of full

\footnotetext{
${ }^{1261}$ See the Court of Appeal of England and Wales 27 July 2011, The Newspaper Licensing Agency Ltd and others v. Meltwater Holding BV and Others, [2011] EWCA Civ 890.

${ }^{1262}$ See the Court of Appeal of England and Wales 27 July 2011, The Newspaper Licensing Agency Ltd and others v. Meltwater Holding BV and Others, [2011] EWCA Civ 890, para. 19. See Savvides \& Ibbetson 2016; Rosati 2013, pp. 115-119.

${ }_{1263}$ Case C-170/12 Pinckney, para. 40.

${ }^{1264}$ See also Picht \& Kopp 2016, p. 235.

${ }^{1265}$ Case C-364/93 Antonio Marinari v. Loyds Bank plc and Zubaidi Trading Company, para. 18-19. See also C228/11 Melzer v. MF Global UK Ltd., para. 34-35. See also Brachotte \& Nuyts 2014, pp. 239-240.

${ }^{1266}$ Case C-12/76 Industrie Tessili Italiana Como v. Dunlop AG, para. 10-11. See also Hertz 1998, p. 66.

${ }^{1267}$ Case C-283/81 CLIFIT and Lanifivio di Gavaro SpA v. Ministry of Health, para. 19.

${ }^{1268}$ Hertz 1998, pp. 65-67. See also Case C-34/82 Martin Peters Bauunternehmung GmbH v. Zuid Nederlandse Aannemers, para. 9; Case C-189/87 Kalfelis v. Schröder, para. 15.

${ }^{1269}$ See Case C-170/12 Pinckney, para. 39 and 43; Case C-387/12 Hi Hotel, para. 35-36. Case C-441/13 Pez Hejduk, para. 22 and 30.
} 
harmonization of copyright laws in the Member States. Nevertheless, the rulings Pinckney, Hi Hotel, and Pez Hejduk demonstrate that the CJEU appeared to be eager to subsume the alleged copyrights under the concept of locus protectionis in order to establish jurisdiction under Article 7(2) Brussels Ibis. For instance, in the Hi Hotel ruling, the CJEU held that the disputed pictures were copyrighted works that fell under the protection of the Information Society Directive. ${ }^{1270}$ Van Eechoud nevertheless argued that according to German case law the disputed pictures should be considered as Lichtbilder under the German neighbouring rights which are not protected by the Information Society Directive. ${ }^{1271}$

\subsubsection{The role of the locus protectionis regarding the attribution of jurisdiction in copyright infringement disputes}

The legal doctrine has been divided on the issue whether the concept of locus protectionis should play a role regarding the attribution of jurisdiction in copyright infringement disputes. On the one hand, based on the territorial character of copyrights, several scholars argue that the place of the harmful event under Article 7(2) Brussels Ibis should be the place where the copyright is protected. ${ }^{1272}$ According to these scholars the Handlungsort and the Erfolgsort will coincide in cross-border copyright infringement disputes, as explained in paragraph 2.3.2. Thus, they consider the locus protectionis criterion as a prerequisite for jurisdiction on the basis of Handlungsort and the Erfolgsort under Article 7(2) Brussels Ibis.

On the other hand, scholars assert that the territorial character of copyrights does not affect the realm of jurisdiction rules but concerns other legal issues such as the issue of liability, ${ }^{1273}$ the area of choice-of-laws, ${ }^{1274}$ or enforcement of foreign judgements. ${ }^{1275}$ It has also been pointed out that the locus protectionis is not a prerequisite to confer jurisdiction to a Member State court based on the alleged copyright infringer's domicile under Article 4 Brussels Ibis. ${ }^{1276}$ Even if a dispute involves infringements of foreign copyrights, the alleged infringer may be sued before the court of the Member State of his domicile. ${ }^{1277}$ As indicated in paragraph 2.3.4.1, several courts in United States of America also seem to have adopted a more flexible approach to the requirement of locus protectionis with respect the establishment of subject matter jurisdiction since they have ascertained copyright infringing activities that took place outside the forum state involving foreign copyrights.

\footnotetext{
${ }^{1270}$ Case C-387/12 Hi Hotel, para. 36.

1271 Van Eechoud 2014, p. 120. Van Eechoud refers to the case of the Bundesgerichtshof Beschluss vom 28.06.2012, Az. I ZR 35/11 and the case of the Oberlandesgericht Köln 5.05.2010, Az. 28 O 29/09.

1272 Jooris 1996, pp.127, 139-140. See also Neumann 2011 pp. 592-594; Schack 2013 p. 3630; Schaafsma 2016, pp. 399-401. Pansch (2000, p. 354, note 7) enumerates various scholars who held that the "venues of action and effect must always coincide for proprietary commercial rights and must at least lie in the venue where the protective right also lies". See also Kur 2013(a), pp. 69-70 commentary 2:204 C04.

${ }^{1273}$ Fawcett \& Torremans 2011, p. 163.

${ }^{1274}$ As explained in paragraph 2.3.2, the choice-of-law rule lex loci protectionis as laid down in Article 8(1) Rome II has been influenced by the territorial protection of copyrights.

${ }_{1275}$ Brachotte \& Nuyts 2014, p. 240; Magnus \& Mankowski 2016, p. 297; Nuyts 2008, pp. 121-127.

${ }^{1276}$ De Miguel Asensio 2009, p. 142; Pansch 2000, p. 355. See also paragraph 2.3.2.

1277 See Neumann 2014, p. 508; Pansch 2000, p. 355.
} 
Several scholars argue that the locus protectionis cannot be considered as a "jurisdictionally meaningful element constituting the place of damage". ${ }^{1278}$ In view of settled case law of the CJEU, ${ }^{1279}$ they assert that the Erfolgsort is "the place where the causal event directly produces its harmful effect on the victim". ${ }^{1280}$ Paragraph 5.2.2 will elaborate on the difficulties to localise damage with respect to cross-border copyright infringements. In case of infringements of intellectual property rights, some scholars endorse the view that the Handlungsort can lie in a "non-protecting State". ${ }^{1281}$ With respect to interpretation of the Handlungsort regarding an alleged infringement of a trade mark, the CJEU also did not require the locus protectionis as jurisdiction criterion. ${ }^{1282}$

As explained in paragraphs 5.1.1 and 5.1.2, the CJEU's concept of locus protectionis as jurisdiction criterion under the Pinckney doctrine seems to consist of two parts that are likely contradictory. In the first part, the CJEU postulated "copyrights must be automatically protected, in particular by virtue of Directive 2001/29, in all Member States, so that they may be infringed in each one in accordance with the applicable substantive law". ${ }^{1283}$ However, as explained in paragraph 5.1.2, a European Union Directive cannot serve as a basis for the automatic protection of copyrights in all Member States.

Unlike other intellectual property rights that require registration regulated by law, ${ }^{1284}$ copyrights generally come into existence without any formality due to the Berne Convention of $1979 .{ }^{1285}$ They therefore appear to be universal rights that come into existence independently of national copyright laws of states. ${ }^{1286}$ As mentioned in paragraph 2.2.2.2, Schack argued that a states does not grant copyrights but merely "recognises them as soon as the prerequisites of the substantive law are fulfilled". ${ }^{287}$ Yet as long as there is no uniform copyright and the territoriality principle still dominates substantive copyright laws, a copyright holder has a bundle of copyrights derived from national copyright laws of states that protect this right. ${ }^{1288}$ Instead of postulating the abovementioned statement, the CJEU could have made a reference to the non-formality requirement ${ }^{1289}$ and the principle of national treatment and non-

\footnotetext{
${ }^{1278}$ Brachotte \& Nuyts 2014, p. 240. See also Nuyts 2008, pp. 121-127. In the Wintersteiger ruling, the CJEU interpreted the 'place of damage' under Article 7(2) Brussels Ibis based on the locus protectionis namely the place of registration. See paragraph 3.6.2. Larsen argued that "in Wintersteiger the CJEU dismissed the need for connecting factors to locate the place of effect". See Larsen 2018(a), p. 182.

1279 See case law enumerated in paragraphs 2.1.2.2.2 and 5.2.2.

${ }^{1280}$ See Nuyts 2008, p. 123.

${ }^{1281}$ See Pansch 2000, pp. 354-355.

1282 See Case C-523/10 Wintersteiger, para. 30-39. See also Neumann 2014, p. 507.

1283 Case C-170/12 Pinckney, para. 39. See also Case C-441/13 Pez Hejduk, para. 22.

1284 Schack 2017, p. 468.

${ }^{1285}$ See the non-formality requirement of Article 5(2) of the Berne Convention 1979. The majority of states in the world are a Member of the Berne Convention 1979, see paragraph 2.2.1 of this dissertation.

${ }^{1286}$ Van Eechoud 2003, p. 99.

1287 Schack 2009, p. 90. See also Peukert 2012, p. 197.

1288 See paragraph 2.2.1. See also Schack 2017, p. 83.

${ }^{1289}$ See Article 5(2) Berne Convention.
} 
discrimination as stipulated in the Berne Convention of $1979^{1290}$ to indicate that a copyright holder can initially claim copyright protection in each Member State. ${ }^{1291}$

The second part of the abovementioned CJEU's concept of locus protectionis seems to resemble the prevailing concept of locus protectionis since the CJEU ruled that the court of a Member State can only establish jurisdiction under Article 7(2) Brussels Ibis "if the Member State in which the court is situated protects the copyrights relied on by the plaintiff'. ${ }^{1292}$ Yet as explained in paragraph 5.1.2, the adoption of the prevailing concept of locus protectionis as connecting factor would entail legal uncertainty and unpredictability regarding the jurisdiction of the court seised. The next paragraph will assess the locus protectionis criterion in light of the assessment framework in paragraph 4.6 of this dissertation.

\subsubsection{Assessing the locus protectionis criterion from a legitimate perspective}

The Pinckney doctrine appears to be grounded on the policy statement that "copyrights must be automatically protected, in particular by virtue of Directive 2001/29, in all Member States, so that they may be infringed in each one in accordance with the applicable substantive law". ${ }^{1293}$ This statement suits the policy considerations of the European Union enshrined in the Information Society Directive to achieve a high level of protection of copyrights for the proper functioning of the internal market of the European Union. ${ }^{1294}$ This pro-integrationist interpretation $^{1295}$ of Article 7(2) Brussels Ibis is also in line with the active role that the CJEU has been playing with respect to the harmonisation of copyrights. ${ }^{1296}$

The principles of the assessment framework as set out in paragraph 4.6 aim to guarantee the legitimacy of the pro-integrationist interpretation of Article 7(2) Brussels Ibis. Therefore, the interpretation of Article 7(2) Brussels Ibis in cross-border copyright infringement cases should satisfy the principle of predictability, the principle of balancing the interests involved, entail a close connection between the dispute and the court, and enhance sound administration of justice. These principles meet the criticism of scholars that principles of private international law should not be neglected to achieve policy aims. ${ }^{1297}$

While the CJEU reasoned that the locus protectionis criterion under Article 7(2) Brussels Ibis yields predictability and sound administration of justice in the trademark infringement case Wintersteiger, ${ }^{1298}$ these arguments cannot be used in copyright infringement cases. As

\footnotetext{
${ }^{1290}$ See paragraph 2.2.1. Pursuant to Article 3(1) and (2) of the Berne Convention 1979, the protection of the Convention shall apply to authors who are a national of one of the countries that are a member of the Convention and authors who are not nationals of these countries but published their works for the first time in one of these countries or have their habitual residence in one of these countries. Due to the Internet, the criterion of the state where the work was first published became meaningless and easily to manipulate. See Schaafsma 2009, pp. 438, 453.

${ }^{1291}$ The Member States of the European Union are all Contracting States of the Berne Convention of 1979 see http://www.wipo.int/treaties/en/ShowResults.jsp?treaty id=15.

${ }_{1292}$ Case C-170/12 Pinckney, para. 43; Case C-387/12 Hi Hotel, para. 35; Case C-441/13 Pez Hejduk, para. 29.

${ }^{1293}$ Case C-170/12 Pinckney, para. 39. Case C-441/13 Pez Hejduk, para. 22.

${ }^{1294}$ See recitals 1-11 in the preamble to the Information Society Directive.

${ }^{1295}$ See paragraphs 4.1.1 and 4.2.4.1.

${ }^{1296}$ See paragraph 1.1.3.

${ }^{1297}$ See paragraph 1.2 .

${ }^{1298}$ Case C-523/10 Wintersteiger, para. 27.
} 
explained in paragraph 5.1.2, the prevailing concept of locus protectionis as jurisdiction criterion in cross-border copyright infringement cases will entail uncertainty and unpredictability since there does not exist a unitary copyright. The CJEU's fictitious concept of locus protectionis as jurisdiction criterion will nonetheless likely entail multiple competent courts which increases unpredictability as regards where a potential copyright infringer may get sued. ${ }^{1299}$ In addition, multistate litigation will not enhance efficient adjudication and sound administration of justice. ${ }^{1300}$

Furthermore, the locus protectionis criterion will not guarantee the required close connection between the court and the facts of the copyright infringement dispute that facilitates the competent court to ascertain the alleged copyright infringement. ${ }^{1301}$ As mentioned in paragraph 5.1.3, several scholars pointed out that the locus protectionis cannot be considered as a "jurisdictionally meaningful element constituting the place of damage". ${ }^{1302}$

In view of the principle of balancing the interests involved, the CJEU's broad concept of locus protectionis seems to favour the interests of copyright holders. Instead of satisfying "the principle of favor auctoris" 1303 , paragraph 4.4 argued that the attribution of jurisdiction in crossborder copyright infringement disputes should aim to balance the interests between copyright holders, on the one hand, and users of information and traders, on the other hand. Moreover, the preamble to the Brussels Ibis Regulation clearly states that only "in relation to insurance, consumer and employment contracts, the weaker party should be protected by rules of jurisdiction more favourable to his interests than the general interests". ${ }^{1304}$ Thus, the Brussels Ibis Regulation does not consider the copyright holder as a 'weaker party' who needs special jurisdictional protection. In the Folien Fischer $A G$ and Foltitec AG v. Ritrama SpA ruling, the CJEU confirmed that the special jurisdiction rule of Article 7(2) Brussels Ibis "does not pursue the same objective" as the special rules on jurisdiction related to insurance, consumer and employment contracts "which are designed to offer the weaker party stronger protection". ${ }^{1305}$

\footnotetext{
${ }^{1299}$ See in a similar way the Opinion to the case C-172/18 AMS Neve in which Advocate General Szpunar pointed out that unlike national trademarks that are only protected in the state of registration "EU trade marks are given uniform protection and produce their effects throughout the entire area of the European Union (para 75). Based on the foregoing difference related to the locus protectionis, he argued that the accessibility criterion to establish jurisdiction regarding EU trade marks infringements would lead to multiplication of courts (para. 68-77).

1300 See also Advocate General Szpunar in the Opinion to the case C-172/18 AMS Neve who rejects the mere accessibility approach to jurisdiction in case of infringements of European Union trade marks. Szpunar advocated to adopt the 'directed activities' (referred to as targeting) approach to establish jurisdiction under Article 97(5) European trade mark Regulation regarding infringements of European Union trade marks (para. 84-91). See chapter 6 on the assessment of the 'directed activities' approach to establish jurisdiction in cross-border copyright infringement cases.

${ }^{1301}$ See Nuyts 2008, p. 123. See also Brachotte \& Nuyts 2014, p. 240. See Larsen (2018(a), p. 183) on the lack of proximity with respect to the employment of the locus protectionis as jurisdiction criterion in the Wintersteiger ruling.

${ }^{1302}$ Brachotte \& Nuyts 2014, p. 240. In the Wintersteiger ruling, the CJEU interpreted the 'place of damage' under Article 7(2) Brussels Ibis based on the locus protectionis namely the place of registration. See paragraph 3.6.2. Larsen argued that "in Wintersteiger the CJEU dismissed the need for connecting factors to locate the place of effect". See Larsen 2018(a), p. 182.

1303 Ohly 2009, pp. 238-239.

${ }^{1304}$ Recital 18 in the preamble to the Brussels Ibis Regulation.

${ }^{1305}$ Case C-133/11 Folien Fischer AG and Foltitec AG v. Ritrama SpA, para. 46.
} 
The following paragraphs will discuss whether the 'likelihood of damage' and 'mere accessibility' criterion under the Pinckney doctrine are able to correct the aforementioned lack of compatibility of the locus protectionis criterion with the principles underlying Article 7(2) Brussels Ibis and the principle of balancing the broader interests involved.

\subsection{The 'likelihood of damage' and 'mere accessibility' criterion as connecting factor}

The second part of this chapter will examine the 'likelihood of damage' and 'mere accessibility' criterion established by the CJEU in the cases Pinckney, Hi Hotel and Pez Hejduk. ${ }^{1306}$ First, the focus will be on the distinction between the Handlungs and Erfolgsort regarding cross-border copyright infringements. Second, the difference will be discussed between the concept of damage under Article 7(2) Brussels Ibis and the concept of damage related to copyright infringements at substantive level. Subsequent paragraphs will demonstrate that the CJEU's approach to jurisdiction under Article 7(2) Brussels Ibis in the rulings Pinckney, Hi Hotel and several other rulings has been based on damage caused by a so-called third party. Finally, the 'likelihood of damage' and 'mere accessibility' criterion will be assessed in light of the framework of paragraph 4.6.

\subsubsection{The Handlungs and the Erfolgsort in the context of cross-border copyright infringements}

Pursuant to copyright law, the exploitation of copyright protected subject matter may involve acts of reproduction, distribution, communication of works to the public or making available of works to the public. ${ }^{1307}$ Acts of reproduction are, for instance, the manufacturing of copyright infringing products. ${ }^{1308}$ The sale of copyright infringing products via the Internet involves activities related to distribution and communication, or making available, of works to the public. ${ }^{1309}$ When exploitation activities are performed without the permission of the copyright holder, the copyright holder may generally sue the infringer for copyright infringement. ${ }^{1310}$

To interpret Article 7(2) Brussels Ibis in the Pinckney case, Advocate General Jääskinen made a distinction between infringements of reproduction rights, on the one hand, and infringements of distribution rights or communication rights, on the other hand. ${ }^{1311}$ Jääskinen argued that an act of reproduction generally cannot have a cross-border character, the Handlungsort will therefore coincide with the Erfolgsort. ${ }^{1312}$ An infringement of a distribution

\footnotetext{
1306 See chapter 3.

${ }^{1307}$ Depreeuw \& Hubin 2014, pp. 758, 764. See also Article 2-4 of the Information Society Directive. See also Spoor, Verkade \& Visser 2019, p. 176.

${ }_{1308}$ Nuyts 2008, p. 127.

${ }^{1309}$ Depreeuw \& Hubin 2014, pp. 757-758.

${ }^{1310}$ Spoor, Verkade \& Visser 2019, pp. 172-173.

1311 Opinion of Advocate General Jääskinen delivered on 13 June 2013 in the case C-170/12 Peter Pinckney v. $K G D$ Mediatech $A G$, para. 53-58. See also paragraph 3.2.2.

1312 Opinion of Advocate General Jääskinen in case C-170/12 Peter Pinckney v. KGD Mediatech AG, para. 53. See also Depreeuw \& Hubin 2014, p. 751.
} 
or communication right can easily contain cross-border activities; the Handlungsort and the Erfolgsort may therefore not coincide. ${ }^{1313}$

According to Jääskinen, "harm resulting from infringements of distribution or communication of rights assumes a potential addressee or public, which may be in a different place from that act". ${ }^{1314}$ To localise the place where the damage occurred, Jääskinen advocated to adopt the targeting approach that means the infringing activities must reveal the intention to target persons in the Member State of the court seised. ${ }^{1315}$ Paragraph 6.1 will focus on the adoption of the targeting approach, referred to as the 'directed activities' approach, to localise the place where the damage occurred under Article 7(2) Brussels Ibis in cross-border copyright infringement disputes.

With respect to cross-border copyright infringements, most scholars do not prefer to make the distinction between Handlungsort and Erfolgsort since the territorial protection of copyrights entails that the harmful event and the damage coincide within the same place. ${ }^{1316}$ Schaafsma argues that an infringement itself can actually not be characterised as cross-border but an infringing activity can occur in more states. ${ }^{1317}$ When the infringing activity covers more states, a 'separate' infringement may thus occur in each of these states ${ }^{1318}$ and may constitute various infringements of national copyright laws in each state. ${ }^{1319}$ For instance, if an infringer uploads a copyright infringing content to the Internet, the act of making available to the public will be simultaneously committed in several states. ${ }^{1320}$ Instead of the Handlungsort and the Erfolgsort, "the place of infringement" has often been considered a more suitable connecting factor in cross-border copyright infringement cases. ${ }^{1321}$ The next chapter will demonstrate that the CLIP Principles adopted this connecting factor. ${ }^{1322}$ As set out in chapter three, the CJEU did in the rulings Pinckney, Hi Hotel and Pez Hejduk, however, make the distinction between Handlungsort and Erfolgsort to determine jurisdiction under Article 7(2) Brussels Ibis in copyright infringement disputes.

\footnotetext{
1313 Case C-170/12 Pinckney, para. 55. See also Depreeuw \& Hubin 2014, p. 751.

1314 Case C-170/12 Pinckney, para. 55.

1315 Case C-170/12 Pinckney, para. 61-64.

1316 See Kur 2013(a), pp. 69-70; Jooris 1996, pp. 139-140; Neumann 2011 pp. 592-594; Pontier 2015, p. 116; Schaafsma 2016, pp. 399-401; Schack 2013, p. 3630. Pansch (2000, p. 354, note 7) enumerates various scholars who held that the "venues of action and effect must always coincide for proprietary commercial rights and must at least lie in the venue where the protective right also lies". See also paragraph 2.3.2 of this dissertation.

1317 Schaafsma 2009, pp. 275-276; Schaafsma 2016, p. 399. See also Neumann 2011, p. 593; Goldstein \& Hugenholtz 2013, pp. 127-130.

1318 Schaafsma 2016, p. 400.

${ }^{1319}$ Kur 2013(a), p. 70, 2:202. C04.

${ }^{1320}$ Depreeuw \& Hubin 2014, p. 752.

${ }^{1321}$ See Jooris 1996, pp. 139-140; Nuyts 2008, pp. 126-127; Torremans 2017, pp. 239-240. Neumann employs the term infringement jurisdiction. See Neumann 2014, pp. 511-515. See also paragraph 2.3.2.

${ }^{1322}$ See Article 2:202 CLIP. See also Kur 2013(a), pp. 69-71.
} 


\subsubsection{Diverging concepts of damage}

From a private international law perspective, the CJEU held that the concept of damage related to the Erfolgsort under Article 7(2) Brussels Ibis concerns the initial damage, ${ }^{1323}$ not the consequential damage. ${ }^{1324}$ Thus, the Erfolgsort does not include the place(s) where the victim suffered consequential financial loss. ${ }^{1325}$ The fact that the plaintiff suffered economic loss in its place of domicile or business is therefore not sufficient to establish jurisdiction. ${ }^{1326}$ It has also been argued that the Erfolgsort does not include the place where the victim allegedly suffered physical or psychological damage caused by an injury in another place. ${ }^{1327}$ The concept of initial damage aims to prevent multiplication of competent courts. ${ }^{1328}$ Furthermore, it reduces the risk that Article 7(2) Brussels Ibis provides jurisdiction to the court of the plaintiff's domicile, the so-called forum actoris. ${ }^{1329}$

From a perspective of copyright law, damage is not a necessary element to constitute an infringement of a copyright; the alleged copyright infringing act itself may entail a tortious activity. ${ }^{1330}$ As noted by Heinze, "the act-based conception of intellectual property infringements" is a traditional feature that distinguishes intellectual property infringements from other wrongs. ${ }^{1331}$ Similar to the intangible nature of copyrights, copyright infringements can be characterised by its intangible nature. ${ }^{1332}$ Unlike most economic torts, copyright infringements will not always cause immediate financial damage. From a perspective of private

\footnotetext{
${ }^{1323}$ See the following settled case law: Case C-220/88 Dumez France SA and Traboca SARL v Hessische Landesbank and Others, para. 20-21; Case C-364/93 Marinari v. Lloyd's Bank and Zubaidi Trading Company, para. 14-21; Case C-168/02 Rudolf Kronhofer v. Marianne Maier and Others, para. 19-21. See also paragraph 2.1.2.2.2 of this dissertation.

${ }^{1324}$ Hertz 1998, p. 264; Stone 2014, pp. 99-101. See also Hess, Pfeiffer \& Schlosser 2007, pp. 96-98. See also the case of the Court of Appeal (Civil Division) of England and Wales 14 February 2002, Henderson v. Jacquen \& Anor, [2002] EWCA Civ 75.

${ }^{1325}$ See the following settled case law: Case C-220/88 Dumez France SA and Traboca SARL $v$ Hessische Landesbank and Others, para. 20-21; Case C-364/93 Marinari v. Lloyd's Bank and Zubaidi Trading Company, para. 14-21; Case C-168/02 Rudolf Kronhofer v. Marianne Maier and Others, para. 19-21.

${ }^{1326}$ Case C-168/02 Rudolf Kronhofer v. Marianne Maier and Others, para. 21; Case C-375/13 Harald Kolassa v. Barclays Bankplc, para. 48-49. See also Pertegás Sender 2002, p. 120.

${ }^{1327}$ See the Dutch Supreme Court (Hoge Raad) 7 December 2001, para. 3.3. See also the Conclusion of Advocate General Strikwerda, 21 September 2001, para. 10. The Conclusion of Advocate General Strikwerda, 1 February 2008, Zuid-Chemie B.V. v. Philippo's Mineralenfabriek N.V./S.A., para. 15. However, the Bundesgerichtshof (the Federal Court of Justice of Germany) provided a broad interpretation of the Erfolgsort, see BGH, Urt. V. 27.05.2008, VI ZR 69/07. This case concerned a patient, residing in Germany, who claimed to suffer from the side effects of a medicine that had been prescribed when he was consulting a doctor in a Swiss hospital. The Bundesgerichtshof ruled that the German court may establish jurisdiction based on the Erfolgsort.

${ }^{1328}$ See Case C-220/88 Dumez France SA and Traboca SARL v Hessische Landesbank and Others, para. 17-20. See also Van Calster 2016, p. 148; Saarloos 2019, p. 391.

${ }^{1329}$ Case C-51/97 Réunion Européenne SA and Others v. Spliethoff's Bevrachtingskantoor BV and the Master of the vessel Alblasgracht V002, para. 34. See also Case C-220/88 Dumez France SA and Traboca SARL v Hessische Landesbank and Others, para. 19. See also Pertegás Sender 2002, p. 120; Saarloos 2019, p. 391.

${ }^{1330}$ Fawcett \& Torremans 2011, pp. 163, 174; Heinze 2010, p. 63; Lundstedt 2001, pp. 136-137. See also Grusic, Heinze, Merrett, Mills, Carcia-Castrillón, Tang, Trimmings, Walker 2017, p. 275; Magnus \& Mankowski 2016, p. 337.

${ }^{1331}$ Heinze 2010, p. 64.

${ }^{1332}$ Fawcett \& Torremans 2011, p. 340; Nuyts 2008, p. 117.
} 
international law, it will therefore often be difficult to identify the initial damage in copyright infringement cases. ${ }^{1333}$

According to the CJEU's case law, Article 7(2) Brussels Ibis may also serve as a basis for jurisdiction in case a copyright holder merely seeks to establish liability for a copyright infringement in order to obtain an injunction. ${ }^{1334}$ A copyright holder who not (yet) sustains financial damage may request an injunction to prevent the dissemination of alleged copyright infringing products. ${ }^{1335}$ Due to the sale of copyright infringing products, copyright holders will likely also suffer financial damage as a result of future missed revenue opportunities. ${ }^{1336}$ With respect to infringements of moral rights related to copyrights, ${ }^{1337}$ a copyright holder will initially sustain non-material damage.

The dissemination of copyright infringing content via the Internet makes it difficult to localise the damage involved. In the case Pez Hejduk, Advocate-General Cruz Villalón argued that "delocalised" damage caused by the online dissemination of alleged copyrighted photographs makes it difficult to localise the place where the damage occurred. ${ }^{1338}$ Hence, he rejected to adopt the Erfolgsort as connecting factor in cases involving the dissemination of alleged dematerialised copyright infringing content via the Internet. ${ }^{1339}$

Despite the aforementioned difficulties to identify and localise damage in copyright infringement cases, it is undesirable to reject the adoption of the Erfolgsort. ${ }^{1340}$ As indicated in the Pez Hejduk ruling, the Handlungsort will often coincide with the place of the infringer's domicile $^{1341}$ so that Article 7(2) Brussels Ibis would lose its effectiveness as mentioned by the CJEU in the Bier ruling. ${ }^{1342}$ The risk that the alleged infringer initiates copyright infringing activities in a copyright haven ${ }^{1343}$ also militates in favour of the adoption of the Erfolgsort as connecting factor under Article 7(2) Brussels Ibis. ${ }^{1344}$ In light of the abovementioned difficulty to identify and localise damage in copyright infringement cases and the diverging concepts of damage, it has been argued that it "became necessary to artificially invent a concept of damage for the purpose" of Article 7(2) Brussels Ibis. ${ }^{1345}$

Since the mere infringement of the copyright may constitute a tort, scholars argued that the place of infringement is a more suitable criterion than the Erfolgsort to establish jurisdiction in

\footnotetext{
1333 Fawcett \& Torremans 2011, pp. 163, 174.

${ }^{1334}$ Grusic, Heinze, Merrett, Mills, Carcia-Castrillón, Tang, Trimmings, Walker 2017, p. 266. See the following case law: Case C-189/87 Kalfelis v. Schröder, para. 18; Case C-167/00 Verein für Konsumenteninformation v. Karl Hein, para. 36.

${ }^{1335}$ Fawcett \& Torremans 2011, p. 166; Spoor, Verkade \& Visser 2019, p. 647.

${ }^{1336}$ See also Fawcett \& Torremans 2011, p. 166.

${ }^{1337}$ See paragraphs 2.2.1.1 and 6.2.2.1 on the concept of moral rights.

${ }^{1338}$ Opinion of Advocate General Cruz Villalón delivered on 11 September 2014 in case C-441/13 Pez Hejduk v.

EnergieAgentur. NRW GmbH, para. 2, 41. See also paragraph 3.4.2.

1339 Opinion AG Cruz Villalón in case C-441/13 Pez Hejduk, para. 42.

${ }^{1340}$ See also Nuyts 2008, p. 117.

${ }^{1341}$ Nuyts 2008, p. 117; Schaafsma 2016, p. 406. Case C-441/13 Pez Hejduk, para. 24-26. See also paragraph 3.4.3.

1342 Case C-21/76 Handelskwekerij G.J. Bier v. Mines de Potasse d'Alsace SA, para. 20. See also paragraph 2.1.2.2.2.

${ }^{1343}$ See paragraph 2.2.2.2 on the concept of copyright havens.

${ }^{1344}$ See also Heinze 2010, p. 64; Matulionyte 2015, p. 137.

${ }^{1345}$ Fawcett \& Torremans 2011, p. 163.
} 
cross-border copyright infringement cases. ${ }^{1346}$ Nevertheless, most scholars proposed additional connecting factors to establish jurisdiction in copyright infringement cases because there may be no or insignificant damage in each place of infringement. ${ }^{1347}$ Particularly due to the Internet, copyright infringements regularly entail so-called spill-over effects. Providing jurisdiction to the court of a Member State where there is no (significant) damage does not "justify the cost and burden of litigation". ${ }^{1348}$ It has therefore been proposed to adopt the so-called targeting criterion to establish jurisdiction as the damage will usually be significant in the state where the public is targeted. ${ }^{1349}$ The next chapter will focus on the 'directed activities' approach that resembles the targeting approach. In addition, chapter six will address other connecting factors that 'artificially' invent a concept of damage to establish jurisdiction under Article 7(2) Brussels Ibis in cross-border copyright infringement cases.

\subsubsection{Jurisdiction based on damage caused by a third party}

Both the cases Pinckney and Hi Hotel involve a so-called third party who did not get sued but caused damage in the forum state as a consequence of copyright infringing activities related to the defendant's activities. ${ }^{1350}$ In these two cases, the defendant got sued for alleged copyright infringing activities committed outside the forum state. ${ }^{1351}$ Pursuant to the CJEU, the court of the Erfolgsort could obtain jurisdiction based on the alleged damage that had directly been caused by a third party in the forum state. ${ }^{1352}$

In the Pinckney case, the defendant Mediatech reproduced alleged copyright infringing compact discs in Austria, while third parties -companies established in the United Kingdomput these compact discs for sale via various websites accessible in France. ${ }^{1353}$ Nonetheless, it was Mediatech that got sued by Mr. Pinckney before a French court. This case did not provide information on the nature of the relationship between the defendant named Mediatech and the United Kingdom-based companies as so-called third parties. The Cour d'appel de Toulouse (Court of Appeal, Toulouse) noted that there had been no allegation of collusion between Mediatech and the United Kingdom companies. ${ }^{1354}$ The latter court therefore held that the French court lacked jurisdiction. ${ }^{1355}$ It was also uncertain whether Mr. Pinckney filed a claim against the United Kingdom companies. ${ }^{1356}$ As mentioned in paragraph 3.2.2, Advocate

\footnotetext{
${ }^{1346}$ Fawcett \& Torremans 2011, p. 165. See also Lundstedt 2001, p. 137. See also paragraph 2.3.2.

${ }^{1347}$ Depreeuw \& Hubin 2014, p. 764. See the escape clause in Article 2:202 CLIP that will be explained in paragraph 6.1.3.2. See also the 'directed activities'-based escape clause in Article 6(1)(c) Dreyfuss and GinsburgConvention that will be demonstrated in paragraph 6.4.3.

1348 Depreeuw \& Hubin 2014, p. 764.

1349 Depreeuw \& Hubin 2014, p. 764.

${ }^{1350}$ Several scholars have employed the term 'third party' to indicate an independent perpetrator who did not get sued in the Pinckney case. See Huvosec 2013 and Smith 2013.

${ }^{1351}$ See paragraph 3.2 and 3.3 .

1352 See paragraph 3.2 on the Pinckney ruling and paragraph 3.3 on the Hi Hotel ruling.

1353 See paragraph 3.2.1.

1354 Case C-170/12 Pinckney, para. 13.

${ }^{1355}$ Case C-170/12 Pinckney, para. 13.

${ }^{1356}$ Opinion of Advocate General Jääskinen in the case C-170/12 Peter Pinckney v. KGD Mediatech AG, para. 19.
} 
General Jääskinen argued that the request for a preliminary ruling in the Pinckney case was inadmissible due to the lack of information regarding the triangular relationship involved. ${ }^{1357}$

However, the CJEU did not require any information regarding the relationship between the defendant and the third party that could constitute a causal connection between the alleged damage caused in France and the initial copyright infringing activities allegedly committed in Austria. Based on the CJEU's ruling, the French court could obtain jurisdiction with respect to the copyright infringement claim against the defendant based on the mere accessibility of the website operated by the third party that sold the alleged copyright infringing compact discs. ${ }^{1358}$

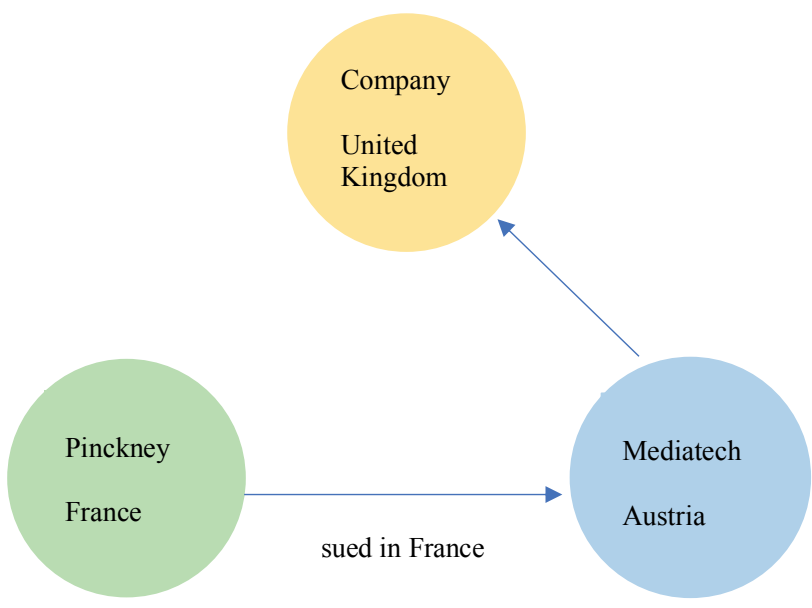

\section{Plaintiff \\ Defendant \\ Third party}

In the Hi Hotel case, the CJEU rejected the argument of the defendant Hi Hotel that they did not know that the French publisher, to whom they provided the copyright infringing photos, had handed these photos to its subsidiary company in Germany and that this subsidiary company sold the photos in Germany. ${ }^{1359}$ The CJEU reasoned that the mere fact that Hi Hotel handed the particular photos to the French publisher gave rise to the likelihood that the damage may occur in the forum state. ${ }^{1360}$

${ }^{1357}$ Opinion of Advocate General Jääskinen in the case C-170/12 Peter Pinckney v. KGD Mediatech AG, para. 19. ${ }^{1358}$ See paragraph 3.2.3.

${ }^{1359}$ See paragraph 3.3.1 on the facts of the Hi Hotel case.

${ }^{1360}$ Hi Hotel HCF SARL v. Uwe Spoering, para. 37. See also paragraph 3.3.2. 


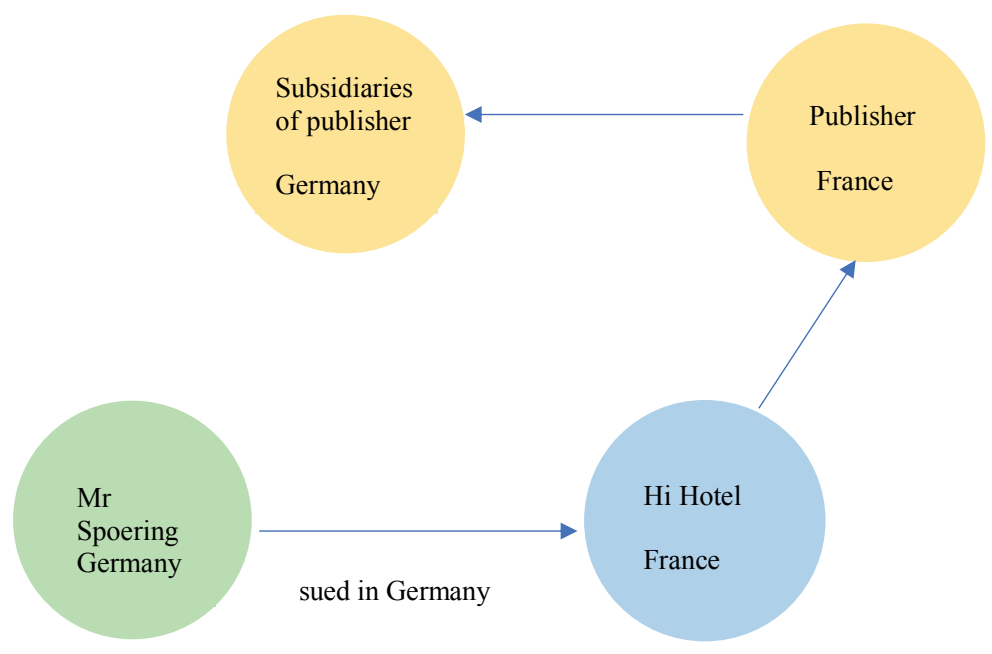

\section{Plaintiff}

Defendant

Third party

Thus, the rulings Pinckney and Hi Hotel indicate that a court may obtain jurisdiction under Article 7(2) Brussels Ibis in case of alleged copyright infringements based on damage that has been caused by a perpetrator, a so-called third party, who did not get sued and irrespectively of the defendant's relationship to the third party. ${ }^{1361}$ The latter can be referred to as a third partybased approach to jurisdiction under Article 7(2) Brussels Ibis. Considering the uncertainty regarding the relationship between the defendant and the third party in the cases Pinckney and $\mathrm{Hi} \mathrm{Hotel,} \mathrm{these} \mathrm{third} \mathrm{parties} \mathrm{may} \mathrm{not} \mathrm{be} \mathrm{considered} \mathrm{as} \mathrm{co-perpetrators} \mathrm{but} \mathrm{can} \mathrm{be} \mathrm{referred} \mathrm{to} \mathrm{as}$ successive perpetrators.

\subsubsection{Other rulings on the interpretation of Article 7(2) Brussels Ibis involving so-called third parties}

The next subparagraphs will demonstrate other rulings on the interpretation of Article 7(2) Brussels Ibis involving a third party. The third party-based approach in the rulings Pinckney and Hi Hotel will be examined in light of these rulings. In view of the precedent-based interpretation as set out in paragraph 4.3 , it is from a legitimate and authoritative perspective important that the CJEU follows its own rulings.

\footnotetext{
${ }^{1361}$ Several scholars have employed the term 'third party' to indicate the independent perpetrator who did not get sued in the Pinckney case. See Smith 2013 and Huvosec 2013.
} 


\subsection{The ruling of Dumez France and Tracoba v. Hessische Landesbank and Others involving successive victims}

The case of Dumez France and Tracoba v. Hessische Landesbank and Others concerned a company named Dumez, established in France, that claimed to have suffered damage as a result of insolvency of their subsidiaries that were established in Germany. Dumez argued that the Hessische Landesbank, established in Germany, was responsible for this damage by, inter alia, cancelling the loans to the subsidiaries. Hence, Dumez sued this bank before the French court for the financial losses that it has sustained thereafter. The question arose whether the French court could obtain jurisdiction on the basis of the place where the damage occurred under Article 7(2) Brussels Ibis.

According to the CJEU, Dumez only sustained the indirect consequences of the financial losses initially suffered by their subsidiaries as a result of alleged tortious activities by the bank. ${ }^{1362}$ The CJEU explicitly made a distinction between the German subsidiaries of Dumez as direct victim and Dumez as being merely an indirect victim that subsequently suffered harm. ${ }^{1363}$ In view of the strict interpretation of Article 7(2) Brussels Ibis, the sound administration of justice, and the anti-forum actoris approach to jurisdiction, the CJEU ruled that the Erfolgsort should be understood as the place where the event giving rise to the damage "directly produced its harmful effects upon the person who is the immediate victim of that event". ${ }^{1364}$ In sum, the Erfolgsort can be referred to as the place where the initial or direct damage occurred that has been suffered by the so-called immediate victim.

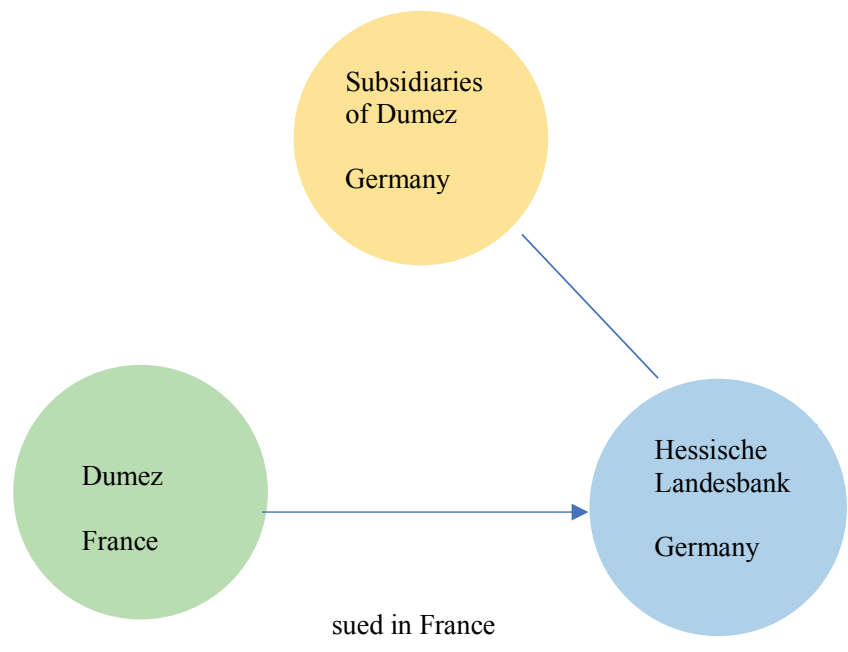

${ }^{1362}$ Case C-220/88 Dumez France and Tracoba v. Hessische Landesbank and Others, para. 13-14.

${ }^{1363}$ Case C-220/88 Dumez, para. 14.

${ }^{1364}$ Case C-220/88 Dumez, para. 17-21. 
Plaintiff

Defendant

Third party

\subsection{The Dumez ruling versus the rulings Pinckney and Hi Hotel}

The third parties in the Dumez case were the subsidiaries related to the plaintiff that suffered direct damage as a consequence of alleged tortious activities by the bank that got sued. Whereas the subsidiaries were regarded as direct victims, ${ }^{1365}$ the plaintiff Dumez could be regarded as a successive victim. In the rulings Pinckney and Hi Hotel, the CJEU seemed to have establish jurisdiction under Article 7(2) Brussels Ibis based on the causality of activities committed by successive perpetrators, without making a distinction between the initial (direct) and successive (indirect) perpetrator, or direct and indirect damage. ${ }^{1366}$ The CJEU conferred in these cases jurisdiction to the court of the Erfolgsort based on damage that had not been directly caused by the defendant. ${ }^{1367}$ As demonstrated in paragraph 5.2.2, consequential damage cannot constitute jurisdiction under Article 7(2) Brussels Ibis. Scholars have therefore argued that the CJEU's third party-based approach to jurisdiction is not in accordance with the rulings Dumez and Marinari in which the CJEU held that the damage under Article 7(2) Brussels Ibis must relate to the direct damage in the forum state as a result of alleged tortious activities committed by the defendant. ${ }^{1368}$

In the Hi Hotel case, the Hi Hotel claimed to be unaware of the copyright infringing activities in Germany committed by the subsidiary company of the French publisher. The CJEU has nonetheless placed the responsibility for an infinite chain of copyright infringing activities on the initial infringer by establishing jurisdiction based on copyright infringing activities that have been committed by, even unknown, third parties. In the Opinion of the case of Coty Germany GmbH v First Note Perfumes, Advocate General Jääskinen argued that "the place where the damage occurred, caused by the voluntary acts of persons other that the defendant, in a purported chain of causality, should not in itself establish a ground of jurisdiction with regard to that defendant, particularly as the scope of the chain is not clearly defined and could therefore be infinite". ${ }^{1369}$ In the Dumez ruling, the CJEU was also clearly not willing to confer jurisdiction based on causality of damage of successive victims by reasoning that there must be "a particularly close connection between the dispute and courts other than those of the State of the defendant's domicile". ${ }^{1370}$ Furthermore, the CJEU reasoned that "it is necessary to avoid

${ }^{1365}$ Case C-220/88 Dumez, para. 14.

1366 See paragraph 5.2.3.

1367 See paragraph 5.2.3.

${ }_{1368}$ Huvosec 2014, p. 372; Smith 2013.

${ }^{1369}$ Opinion of Advocate General Jääskinen delivered on 21 November 2013 in the case C-360/12 Coty Germany GmbH v First Note Perfumes, para. 64. This Opinion of Advocate General Jääskinen will be further discussed in paragraph 5.2.3.1.3.2. With respect to the Hi Hotel ruling, Van Eechoud (2013, p. 178) also pointed out the lack of causality.

${ }^{1370}$ Case C-220/88 Dumez France and Tracoba v. Hessische Landesbank and Others, para. 17. 
the multiplication of courts of competent jurisdiction which would heighten the risk of irreconcilable decisions" 1371 and the attribution of jurisdiction to forum actoris should be prevented. ${ }^{1372}$ These arguments can also be employed against the adoption of the third partybased approach to jurisdiction in the rulings Pinckney and Hi Hotel.

\subsection{The ruling of Melzer v. MF Global UK Ltd involving co-perpetrators}

As will be demonstrated in the next paragraph, the third party-based approach to jurisdiction in the rulings Pinckney and Hi Hotel also does not seem to be compatible with the ruling of Melzer v. MF Global UK Ltd. ${ }^{1373}$ In the latter case, Mr. Melzer, who had been domiciled in Berlin (Germany), was solicited as a client by telephone and his file was managed by Weise Wertpapier Handelsunternehmen (hereinafter WWH), established in Düsseldorf (Germany). The latter company opened an account for Mr. Melzer with the brokerage company MF Global established in London. MF Global traded in stock market futures for Mr. Melzer who made payments to a bank account in London. Due to alleged damage sustained as a result of this trade, Mr. Melzer sued MF Global before the court (Landgericht) in Düsseldorf. In support of his claim, Mr. Melzer argued that he was insufficiently informed about the risks of trading futures on stock exchanges by WWH or MF Global.

With respect to the jurisdiction of the German court, the question raised whether the provision of German law concerning "reciprocal attribution of the place where the event occurred" in case of "cross-border participation of several persons in a tort or delict" would be applicable to the interpretation of the Handlungsort under Article 7(2) Brussels Ibis. ${ }^{1374}$ Pursuant to Paragraph 830 of the German Code of Civil Procedure, jurisdiction in matters related to tort or delict -without a cross-border character- "may be founded on infringements committed by any one of the participants, since they all be held liable for such acts" based on Paragraph 32 of the German Civil Code. ${ }^{1375}$ According to the CJEU, the preliminary question referred by the German court boiled down to whether Article 7(2) Brussels Ibis "must be interpreted as permitting the courts of the place where a harmful event occurred which is imputed to one of the presumed perpetrators of damage who is not a party to the dispute, to take jurisdiction over another presumed perpetrator of that damage who has not acted within the jurisdiction of the court seised". 1376

The CJEU rejected the application of the abovementioned German law involving coperpetrators under Article 7(2) Brussels Ibis because that would require an assessment regarding the substance of the dispute. ${ }^{1377}$ In addition, the CJEU pointed out that the issue whether the acts of one of the perpetrators could be imputed to the other perpetrator has not

\footnotetext{
${ }^{1371}$ Case C-220/88 Dumez, para. 18.

${ }^{1372}$ Case C-220/88 Dumez, para. 16, 19.

${ }^{1373}$ Case C-228/11 Melzer v. MF Global UK Ltd. See also Opinion of Advocate General Jääskinen delivered on 21 November 2013 in the case C-360/12 Coty Germany GmbH v First Note Perfumes, para. 65.

${ }^{1374}$ Case C-228/11 Melzer v. MF Global UK Ltd, para. 18-20.

1375 Case C-228/11 Melzer v. MF Global UK Ltd, para. 33. See also Opinion of Advocate General Jääskinen delivered on 29 November 2012 in the case C-228/11 Melzer v. MF Global UK Ltd, para. 46.

${ }^{1376}$ Case C-228/11 Melzer v. MF Global UK Ltd, para. 19.

${ }^{1377}$ Case C-228/11 Melzer, para. 31.
} 
been commonly regulated by the Member States. ${ }^{1378}$ The use of national legal concepts will likely lead to different outcomes which does not suit the aim to unify the jurisdiction rules of the Member States. ${ }^{1379}$ This approach would also be contrary to the objective of legal certainty under Article 7(2) Brussels Ibis since it causes unpredictability for the defendant as regards in which court he may get sued. ${ }^{1380}$ Finally, the CJEU held that the Handlungsort does not provide jurisdiction based on an alleged tortious act committed by one of the presumed perpetrator in the forum state in case another perpetrator who did not act in the forum state got sued. ${ }^{1381}$

In the Melzer case, Advocate General Jääskinen pointed out that the jurisdiction rule of Article 8(1) Brussels Ibis has been specially designed for cross-border cases involving multiple defendants. ${ }^{1382}$ Pursuant to this special jurisdiction rule, the courts for the place where any one of them is domiciled may obtain jurisdiction "provided the claims are so closely connected that it is expedient to hear and determine them together to avoid the risk of irreconcilable judgments resulting from separate proceedings". ${ }^{1383}$ Yet, the CJEU did not interpret Article 8(1) Brussels Ibis in this particular case since Mr. Melzer did not sue WWH.

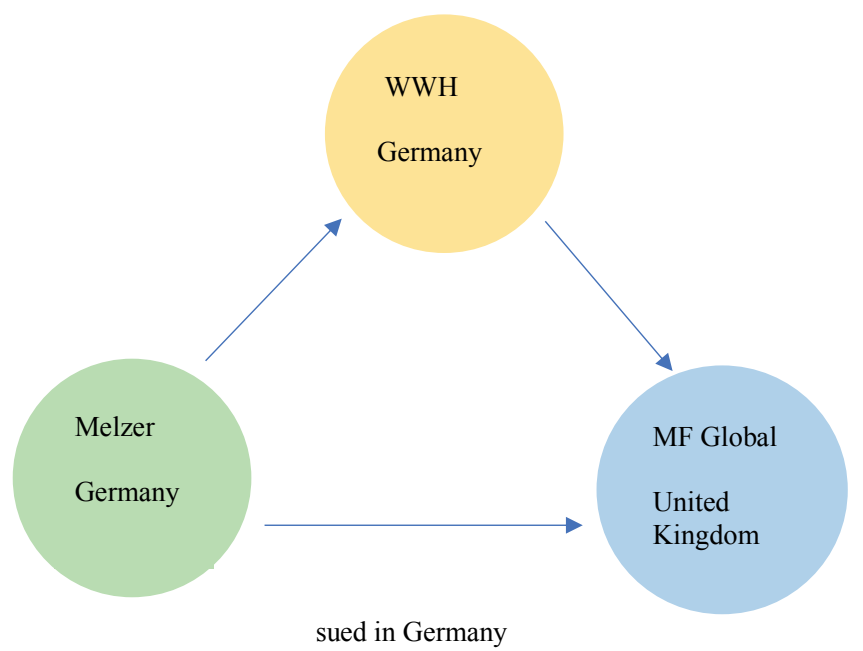

Plaintiff

Defendant

Third party

${ }^{1378}$ Case C-228/11 Melzer, para. 32.

${ }^{1379}$ Case C-228/11 Melzer, para. 34. The CJEU referred to the aim stipulated in recital 4 of the preamble to the Brussels Ibis Regulation to unify rules of jurisdiction of the Member States.

${ }^{1380}$ Case C-228/11 Melzer, para. 35.

${ }^{1381}$ Case C-228/11 Melzer, para. 29-30, 40.

1382 Case C-228/11 Melzer, para. 39. See also the Opinion of Advocate General Jääskinen delivered on 29 November 2012 in the case C-228/11 Melzer v. MF Global UK Ltd, para. 53.

${ }^{1383}$ See Article 8(1) Brussels Ibis Regulation. 


\subsection{The Melzer ruling versus the rulings Pinkney and Hi Hotel}

Similar to the Melzer case, the cases Pinkney and Hi Hotel concerned a cross-border tort that has allegedly been committed by several perpetrators in various Member States and the defendant did not act in the forum state. However, the rulings Pinckney and Hi Hotel involve the interpretation of the Erfolgsort under Article 7(2) Brussels Ibis instead of the Handlungsort. Furthermore, the latter two rulings concern so-called successive perpetrators as it was not clear whether the perpetrators had been related to each other, they cannot be denoted as coperpetrators as in the Melzer case.

In the Melzer case, WWH can be considered as the so-called third party who did not get sued but whose tortious activities served as basis for jurisdiction in the case against the defendant MF Global. The Melzer ruling emphasises that jurisdiction cannot be based on the Handlungsort in case it was not the defendant who acted in the forum state but another perpetrator because this connecting factor has been based on the defendant's act. ${ }^{1384}$ In view of this ruling, it is doubtful whether the Erfolgsort can provide jurisdiction on the basis of damage that has not directly been caused by the defendant but by another perpetrator since the latter connecting factor likely relates to damage caused by the defendant. Therefore, the rulings Pinckney and Hi Hotel seem to be not in accordance with the Melzer ruling. Moreover, particularly in light of the general rule forum rei of Article 4 Brussels Ibis, Advocate General Jääskinen argued that a third party-based approach to jurisdiction will be a too broad interpretation of Article 7(2) Brussels Ibis. ${ }^{1385}$

\subsection{The ruling of Coty Germany GmbH v. First Note Perfumes NV involving successive perpetrators}

Similar to the rulings Pinckney and Hi Hotel, the CJEU adopted in the case of Coty Germany GmbH v. First Note Perfumes $N V$ a third party-based approach to jurisdiction under Article 7(2) Brussels Ibis. ${ }^{1386}$ The latter case involved the company Coty, established in Germany, that produced and sold perfume bottles and has been the proprietor of rights to a Community trademark regarding the particular bottle. The company First Note Perfumes, established in Belgium, distributed perfume in similar bottles and sold these bottles in Belgium to a German trader who resold them in Germany. Coty therefore sued First Note Perfumes before a German court by claiming that this company infringed the Community trademark and the German law against unfair competition.

With respect to an alleged infringement of a Community trademark, the CJEU held that the Regulation No. 40/94 of 20 December 1993 on the Community trademark ${ }^{1387}$ exclusively

\footnotetext{
${ }^{1384}$ Case C-228/11 Melzer v. MF Global UK Ltd, para. 30.

${ }^{1385}$ See Opinion of Advocate General Jääskinen delivered on 29 November 2012 in the case C-228/11 Melzer v. MF Global UK Ltd, para. 65-66. See also Van Eechoud 2014, p. 120.

${ }^{1386}$ Case C-360/12 Coty Germany GmbH v. First Note Perfumes NV.

1387 The Council Regulation (EC) No. 40/94 of 20 December 1993 on the Community trade mark (OJ L 11, 14.01.1994, pp. 1-66) has been substituted by the Council Regulation (EC) No. 207/2009 of 26 February 2009 on the European Union trade mark (OJ L 78, 24.3.2009, p. 1) and subsequently by the current Regulation (EU) No
} 
regulates whether so-called Community trade mark courts have jurisdiction. ${ }^{1388}$ According to Article 93(5) of the Community trade mark Regulation, currently Article 125(2) European Union trade mark Regulation, "the courts of the Member State in which the infringement has been committed or threatened" may obtain jurisdiction. ${ }^{1389}$ The CJEU interpreted that this connecting factor implies "active conduct on the part of the person causing that infringement". ${ }^{1390}$ Therefore, "that provision refers to the Member State where the act giving rise to the infringement occurred or may occur, not the Member State where that infringement produces its effects". ${ }^{1391}$ The German court could thus not obtain jurisdiction because the defendant "did not act himself in the Member State where the court seised is situated". ${ }^{1392}$

Concerning the alleged infringement of German law against unfair competition, the CJEU held that the jurisdictional issue should be determined by interpreting Article 7(2) Brussels Ibis. ${ }^{1393}$ The CJEU referred to its earlier ruling of Melzer v. MF Global UK Ltd ${ }^{1394}$ that "in circumstances in which only one among several presumed perpetrators of the alleged harmful act is sued before a court within whose jurisdiction he has not acted, the event giving rise to the damage may not be regarded as taking place within the jurisdiction of that court". ${ }^{1395}$ Although the German trader acted in Germany, the German court could thus not establish jurisdiction on the basis of the Handlungsort since the defendant First Note Perfumes did not act in Germany. ${ }^{1396}$

With respect to the interpretation of the Erfolgsort, the CJEU reiterated the locus protectionis criterion of the rulings Wintersteiger and Pinckney that "the occurrence of damage in a particular Member State is subject to the protection, in that State, of the right in respect of which infringement is alleged" ${ }^{1397}$ Hence, the German court had to assess whether the sale of the bottles of perfume by First Note Perfumes in Belgium to the German trader "was capable

207/1001 of the European Parliament and of the Council of 14 June 2017 on the European Union trade mark (OJ L 154, 16.6.2017, pp. 1-99).

1388 Article 90(2)(a) and Article 92(a) Regulation on the Community trade mark precluded the application of Article 5(3) Brussels I, currently Article 7(2) Brussels Ibis, in case of an alleged infringement of a Community trade mark. See current Article 122-128 Regulation on the European Union trade mark. See Case C-360/12 Coty Germany GmbH v. First Note Perfumes NV, para. 25-27. Member States had to designate so-called Community trade mark courts to perform the functions assigned to them by this Regulation. See Article 91(1) Regulation (EC) No. 40/94 of 20 December 1993 on the Community trade mark. Currently these courts are referred to as "EU trade mark courts" by its successor in Article 123 Regulation (EU) No 207/1001 of the European Parliament and of the Council of 14 June 2017 on the European Union trade mark.

${ }^{1389}$ Case C-360/12 Coty Germany GmbH v. First Note Perfumes NV, para. 30.

${ }^{1390}$ Case C-360/12 Coty, para. 34. See also Opinion of Advocate General Jääskinen delivered on 21 November 2013 in the case C-360/12 Coty Germany GmbH v First Note Perfumes NV, para. 31.

${ }^{1391}$ Case C-360/12 Coty, para. 34. See paragraph 3.6.1 on the interpretation of 'the place of infringement' under Article 125(5) European Union trade mark Regulation in the case of C-172/18 AMS Neve Ltd and Others v. Heritage Audio SL, Pedro Rodriguez Arribas. In the latter case, the CJEU did establish jurisdiction under Article 125(5) European Union trade mark Regulation based on online activities that allegedly infringed a European Union trade mark which had been committed by the defendant in another state than the forum state but were directed to the residents of the forum state.

${ }_{1392}$ Case C-360/12 Coty, para. 38.

${ }^{1393}$ Case C-360/12 Coty, para. 39-42.

${ }^{1394}$ Case C-228/11 Melzer, para. 41.

${ }^{1395}$ Case C-360/12 Coty, para. 50.

${ }^{1396}$ Case C-360/12 Coty, para. 49-51.

${ }^{1397}$ Case C-360/12 Coty, para. 55. The CJEU referred to Case C-523/10 Wintersteiger, para. 25 and Case C-170/12 Pinckney, para. 33. 
of infringing provisions of the German law against unfair competition and, thereby, of causing damage within the jurisdiction of that court". ${ }^{1398}$ The CJEU limited the jurisdiction of the German court(s) to "the extent that the act committed in another Member State caused or may cause damage within the jurisdiction of the court seised". ${ }^{1399}$ This ruling indicates that the German court could obtain jurisdiction on the basis of the place where the damage caused by a third party occurred.

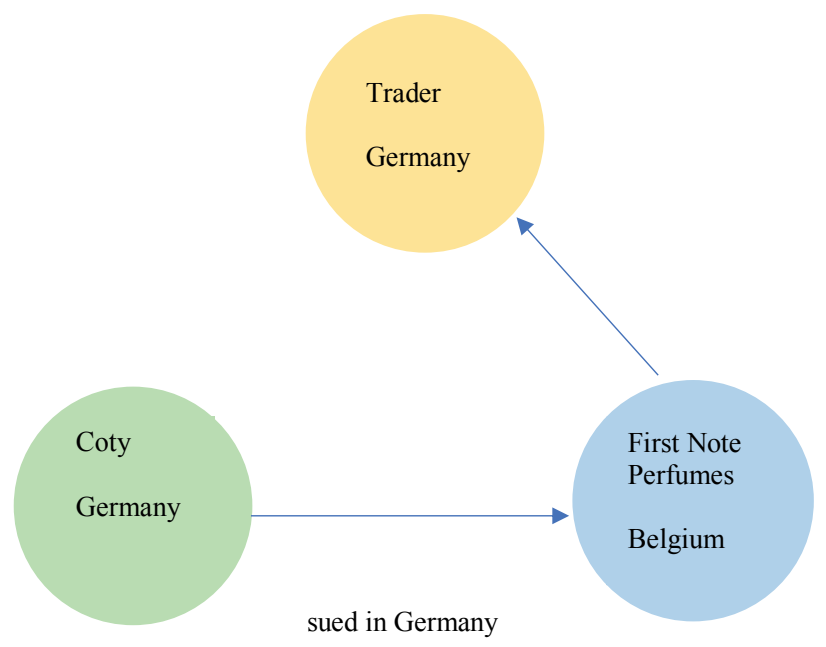

\section{Plaintiff \\ Defendant \\ Third party}

\subsection{The Coty ruling versus the rulings Pinkney and Hi Hotel}

In the Coty ruling, the CJEU appears to have rejected jurisdiction under Article 125(2) European Union trade mark Regulation based on effects of an alleged infringement of a European Union trade mark that are not directly caused by the defendant. The CJEU interpreted that 'the Member State where the act of infringement has been committed or threatened' as connecting factor implies "active conduct on the part of the person causing that infringement". ${ }^{1400}$ Applying this reasoning to the cases Pinckney and Hi Hotel, it seems that the defendants could not have been sued in the forum state since the alleged copyright

${ }^{1398}$ Case C-360/12 Coty, para. 58.

${ }^{1399}$ Case C-360/12 Coty, para. 57.

${ }^{1400}$ Case C-360/12 Coty Germany GmbH v. First Note Perfumes NV, para. 34. See also Opinion of Advocate General Jääskinen delivered on 21 November 2013 in the case C-360/12 Coty Germany GmbH v First Note Perfumes NV, para. 31. 
infringements did not have been a result of "active conduct on the part of the person causing that infringement". ${ }^{1401}$

In the Coty ruling, the CJEU did, however, not reject jurisdiction under Article 7(2) Brussels Ibis based on effects of an alleged infringement of German law against unfair competition that are not directly caused by the defendant. This third party-based approach to jurisdiction resembles the approach in the rulings Pinckney and Hi Hotel.

\subsection{Advocate General Jääskinen's rejection of a third party-based approach to jurisdiction in the cases Coty and Pinckney}

In the Opinion regarding the Coty case, Advocate General Jääskinen explicitly rejected an interpretation of the Erfolgsort under Article 7(2) Brussels Ibis as in the Pinckney ruling that establishes jurisdiction based on acts of a third party. ${ }^{1402}$ Jääskinen argued that "the place where the damage occurred, caused by the voluntary acts of persons other than the defendant, in a purported chain of causality, should not in itself establish a ground of jurisdiction with regard to that defendant, particularly as the scope of the chain is not clearly defined and could therefore be infinite". ${ }^{1403}$ He pointed out that "a quantitative and/or qualitative 'threshold' for imputation" in case there are "several participants in the commission of a tortious act" will require an examination of the merits of the case that will generally entail unpredictability for the parties to a dispute. ${ }^{1404}$ Furthermore, a broad interpretation of Article 7(2) Brussels Ibis "might lead to generalisation of the jurisdiction of the forum actoris and thereby encourage forum shopping". ${ }^{1405}$ While a multiplication of competent courts will increase the risk of irreconcilable decisions. ${ }^{1406}$

Moreover, Jääskinen asserted that the third party-based approach to jurisdiction does not entail a particularly close connection between the dispute and the court as required under Article 7(2) Brussels Ibis. ${ }^{1407}$ The latter court will therefore find it difficult "to assess the liability of a defendant who purportedly assisted in that tortious act by means of acts committed solely in another Member State". ${ }^{1408}$ Finally, the Advocate General pointed out that the third party-based approach to jurisdiction under Article 7(2) Brussels Ibis seems to circumvent the special jurisdiction rule of Article 8(1) Brussels Ibis that allows -based on certain conditions- the court to obtain jurisdiction regarding separate legal proceedings involving a number of defendants to be consolidated in order to avoid irreconcilable decisions. ${ }^{1409}$ The aforementioned arguments

\footnotetext{
${ }^{1401}$ Case C-360/12 Coty, para. 34. See also Opinion of AG Jääskinen in the case C-360/12 Coty, para. 31.

1402 Opinion of AG Jääskinen in the case C-360/12 Coty, para. 61-64.

1403 Opinion of AG Jääskinen in the case C-360/12 Coty, para. 64. See also paragraph 5.2.3.1.1.

1404 Opinion of AG Jääskinen in the case C-360/12 Coty, para. 59-60.

1405 Opinion of AG Jääskinen in the case C-360/12 Coty, para. 61.

${ }^{1406}$ Opinion of AG Jääskinen in the case C-360/12 Coty, para. 61. Advocate General Jääskinen refers to recital 15 to the preamble of the Brussels I Regulation, currently recital 21 to the preamble of the Brussels Ibis Regulation, and Article 34(3) Brussels I, currently 34(2) Brussels Ibis.

${ }^{1407}$ Opinion of AG Jääskinen in the case C-360/12 Coty, para. 62.

${ }^{1408}$ Opinion of AG Jääskinen in the case C-360/12 Coty, para. 62.

${ }^{1409}$ See also the Opinion of Advocate General Jääskinen delivered on 29 November 2012 in the case C-228/11 Melzer v. MF Global UK Ltd, para. 53. See paragraph 5.2.3.1.2 of this dissertation.
} 
clearly militate against the adoption of a third party-based approach under Article 7(2) Brussels Ibis. 


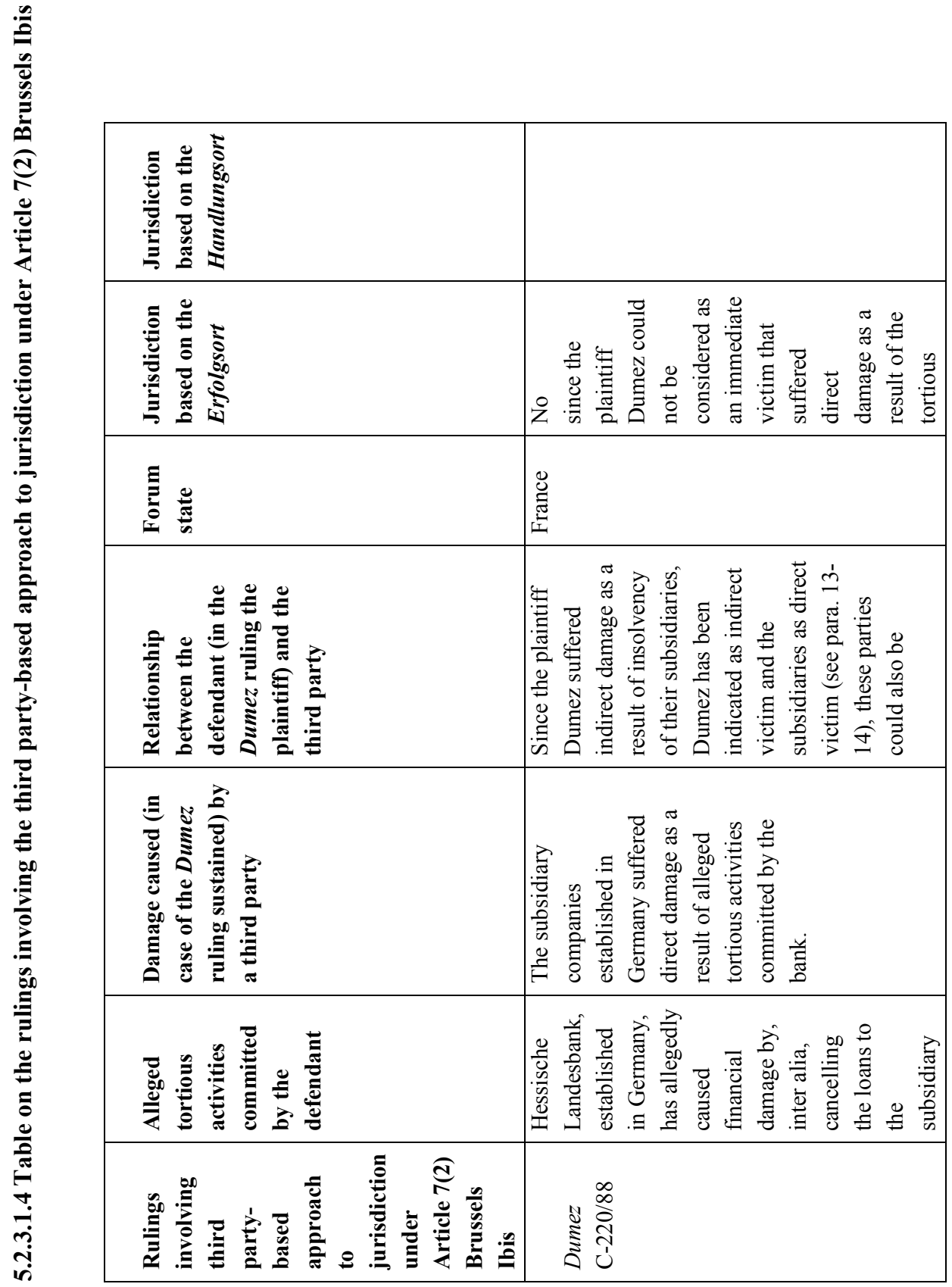




\begin{tabular}{|c|c|c|}
\hline & 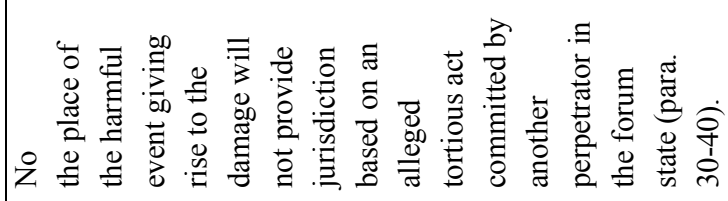 & 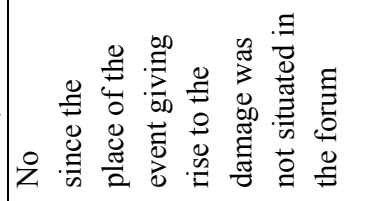 \\
\hline \multirow[t]{2}{*}{ 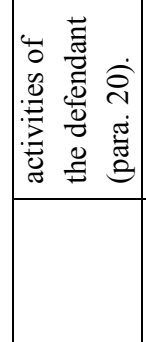 } & & 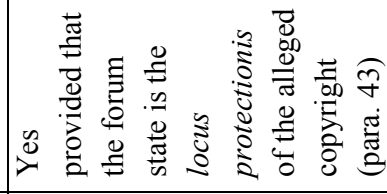 \\
\hline & 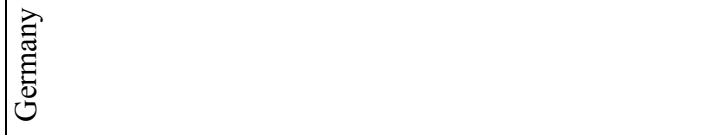 & 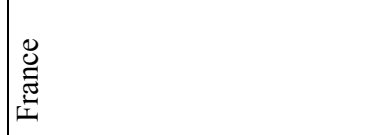 \\
\hline \multirow[t]{2}{*}{ 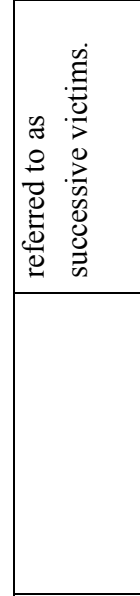 } & 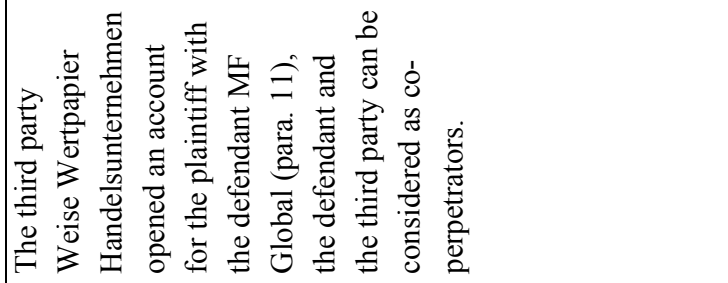 & 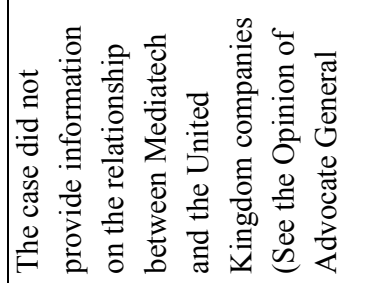 \\
\hline & 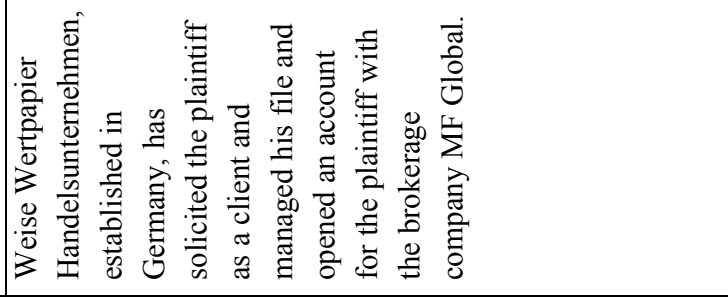 & 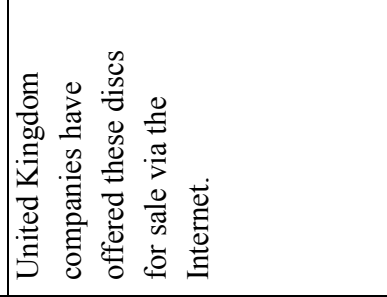 \\
\hline 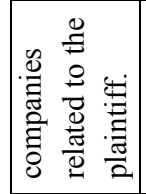 & 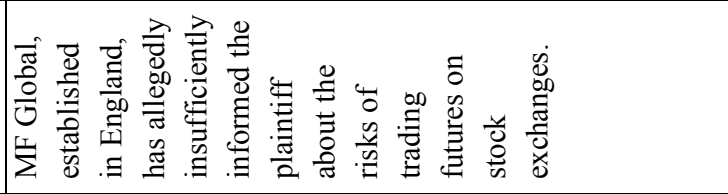 & 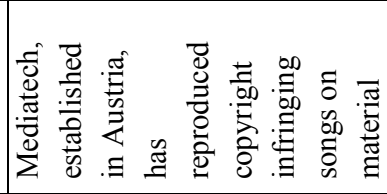 \\
\hline & 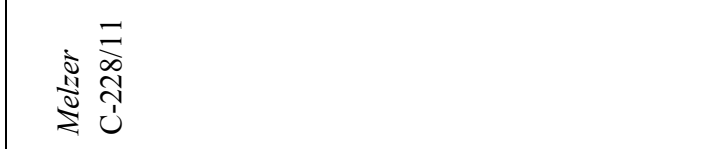 & 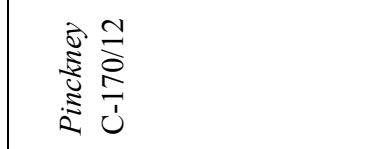 \\
\hline
\end{tabular}




\begin{tabular}{|c|c|}
\hline 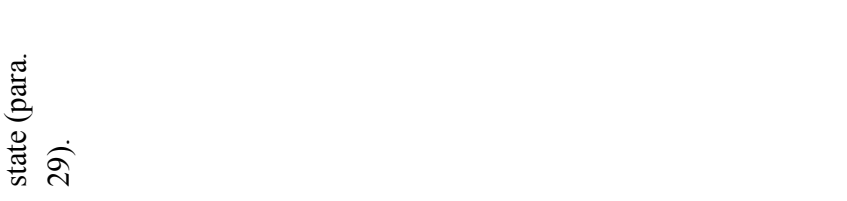 & 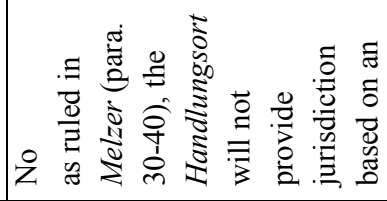 \\
\hline 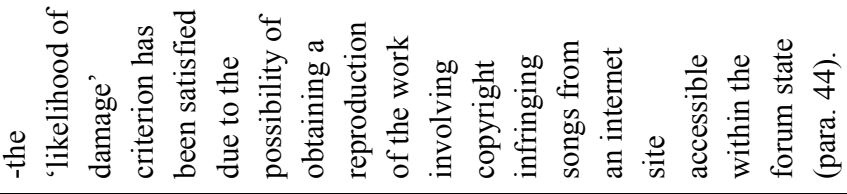 & 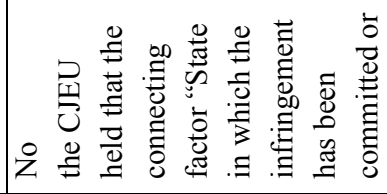 \\
\hline & 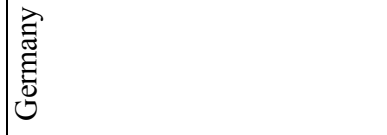 \\
\hline 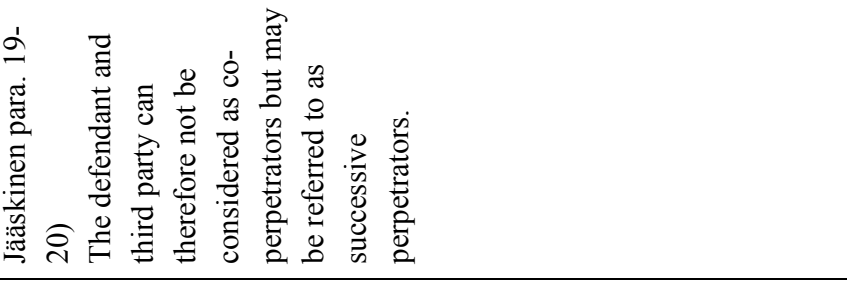 & 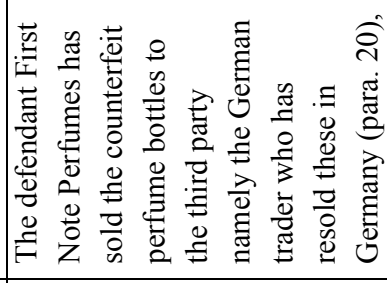 \\
\hline & 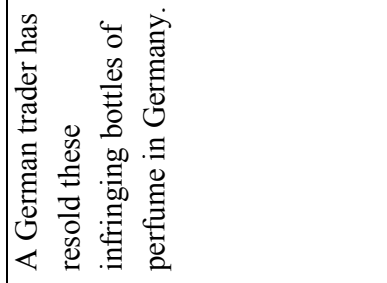 \\
\hline 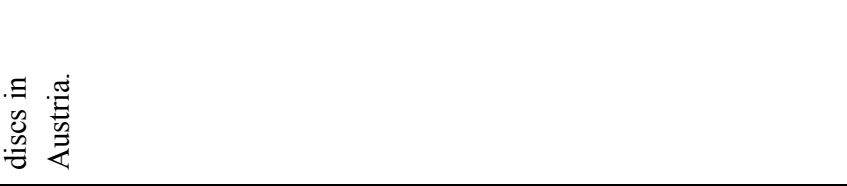 & 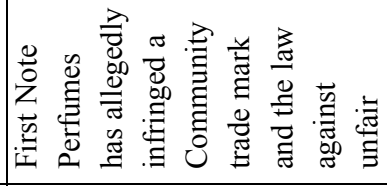 \\
\hline & 离 \\
\hline
\end{tabular}



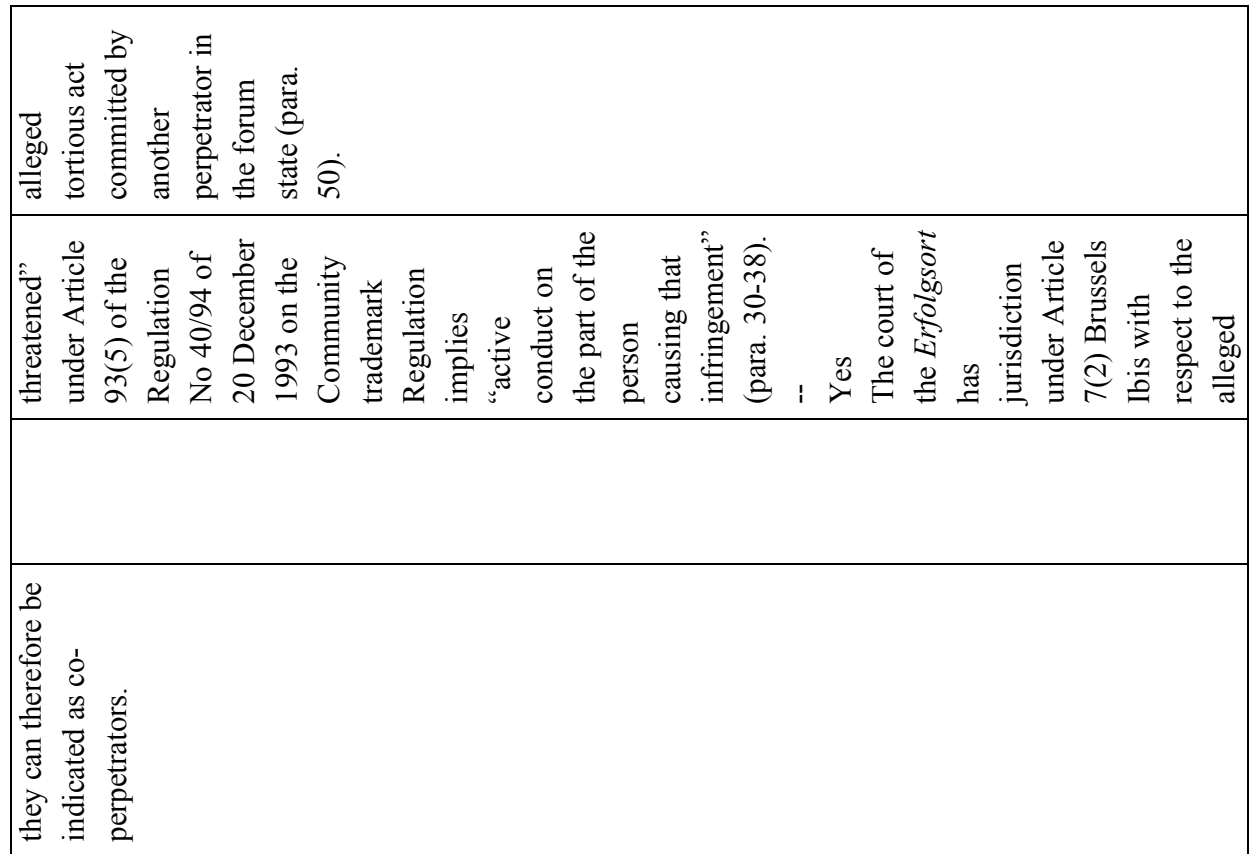

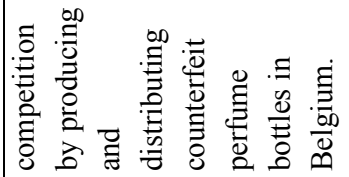




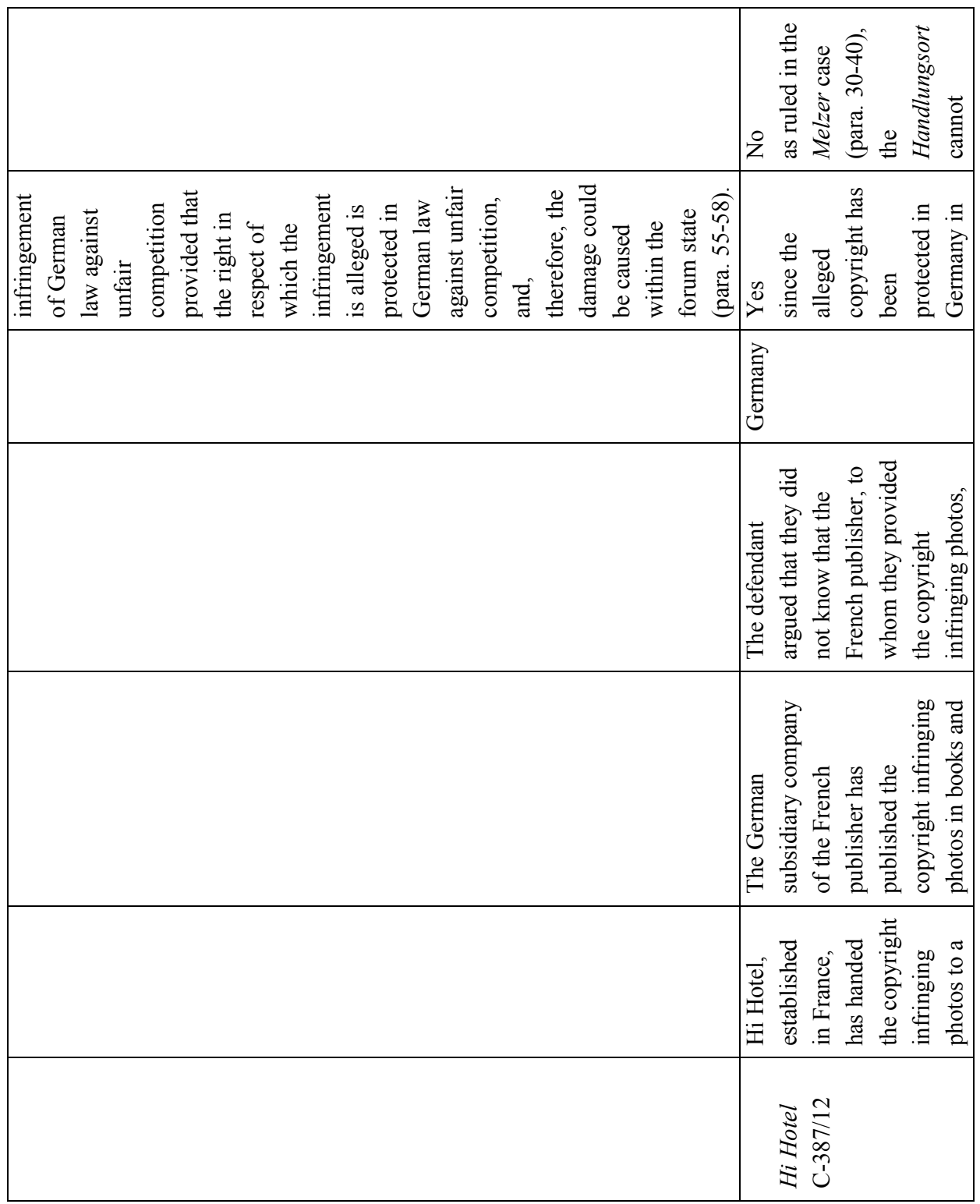




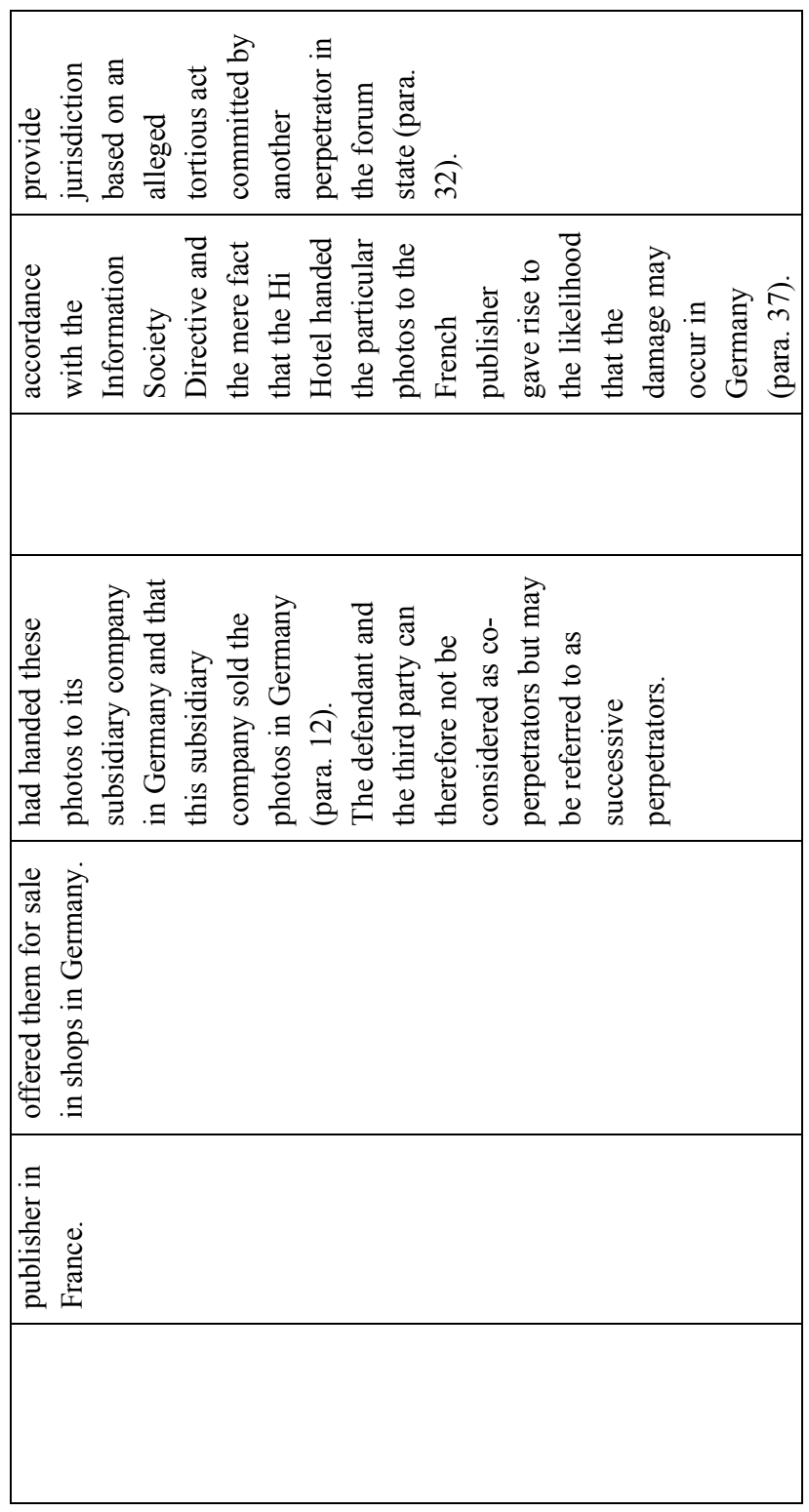




\subsubsection{Assessing the 'likelihood of damage' and 'mere accessibility' criterion from a legitimate perspective}

From a legitimate perspective, the following paragraphs will first assess the 'likelihood of damage' and 'mere accessibility' criterion combined with the territorially limited approach to jurisdiction, the so-called Pinckney doctrine, based on the principles as set out in paragraph 4.6. To repeat, these principles are the principle of predictability; the principle of a close connection between court and dispute; the principle of a sound administration of justice; and the principle of balancing the interests involved. Second, the Pinckney doctrine will be viewed in the context of the Geo-blocking Regulation as demonstrated in paragraph 4.5. Paragraph 5.3 will separately assess the territorially limited approach to jurisdiction under the Pinckney doctrine in more detail.

\subsubsection{The principle of predictability}

The 'likelihood of damage' criterion will be satisfied when the damage caused by the alleged copyright infringement may occur within the forum state. ${ }^{1410}$ The rulings Pinckney, Hi Hotel, and Pez Hejduk in chapter three demonstrate that this criterion will easily be satisfied. In the Pinckney case, this criterion was satisfied due to "the possibility of obtaining a reproduction of the work to which the rights relied on by the defendant pertain from an internet site accessible within the jurisdiction of the court seised". ${ }^{1411}$ In the Hi Hotel case, the mere fact that the Hi Hotel provided the photographs to the French publisher "gave rise to the reproduction and distribution of the photographs, and thereby to the possibility that the damage alleged might occur" within the jurisdiction of the court seised. ${ }^{1412}$ The 'likelihood of damage criterion' in the Pez Hejduk case seems to be identical to the so-called mere accessibility criterion since "the occurrence of damage and/or the likelihood of its occurrence arise" from the mere accessibility of the alleged copyrighted photographs via the website in the Member State of the court seised. ${ }^{1413}$

Due to the globalisation and the Internet, a copyright infringing work can easily be disseminated everywhere. Based on the 'likelihood of damage' criterion, the damage may therefore occur everywhere. Thus, the alleged copyright infringer may likely be sued before the court of each Member State. The infringer may therefore often not be able to foresee where he may get sued. ${ }^{1414}$ In sum, the 'likelihood of damage' and the 'mere accessibility' criterion do not satisfy the principle of predictability underlying the jurisdiction rules of the Brussels Ibis Regulation. ${ }^{1415}$

${ }^{1410}$ Case C-170/12 Pinckney, para. 43; Case C-387/12 Hi Hotel, para. 35. See also Case C-441/13 Pez Hejduk., para. 34.

${ }_{1411}$ Case C-170/12 Pinckney, para. 44.

${ }^{1412}$ Case C-170/12 Pinckney, para. 37.

${ }^{1413}$ Case C-170/12 Pinckney, para. 34.

${ }^{1414}$ Metzger 2009, pp. 255-256. See also Matulionyte 2015, p. 134.

${ }^{1415}$ Matulionyte 2015, pp. 133-134; Picht \& Kopp 2016, p. 235. See also Opinion of Advocate General Jääskinen delivered on 13 June 2013 in the case C-170/12 Peter Pinckney v. KGD Mediatech AG, para. 68. 
The third party-based approach to jurisdiction, as explained in paragraph 5.2.3, has increased the aforementioned unpredictability. ${ }^{1416}$ In the rulings Pinckney and Hi Hotel, the CJEU established jurisdiction based on damage caused by a third party without paying attention to the underlying relationship between the actions of the defendant and the third party. An infringer who produced a copyright infringing work may thus be sued in a Member State where a successive infringer -who has been unknown to the defendant being the initial infringer- has made this work available to public. The third party-based approach to jurisdiction can therefore even be indicated as an approach to jurisdiction that resembles strict liability.

With respect to third party-based jurisdiction, Jääskinen advocated that the requirement should be adopted under Article 7(2) Brussels Ibis that there has to be "a sufficiently clear and direct link between the actions of the defendant in a first Member State and the alleged unlawful act committed by a third party in the Member State where the court seised has its seat". ${ }^{1417}$ This requirement would likely provide (potential) copyright infringers predictability as regards where they may be sued. However, Jääskinen argued that this requirement will demand an examination of the merits of the case at jurisdictional level which does not enhance the sound administration of justice and causes unpredictability for the copyright holder. ${ }^{1418}$ Moreover, it will be difficult to formulate an autonomous concept of causality and allocation of the acts of several perpetrators, while the laws of the Member States regarding the liability of coperpetrators vary ${ }^{1419}$.

\subsubsection{A close connection between dispute and court/ sound administration of justice}

The 'likelihood of damage' and 'mere accessibility' criterion do not guarantee a close connection between the court and the relevant facts related to a cross-border copyright infringement dispute as required under Article 7(2) Brussels Ibis. ${ }^{1420}$ The following example will illustrate that the accessibility criterion does not guarantee a close connection between the dispute and the court. If a Chinese songwriter domiciled in China, notices that his song has been uploaded to the Internet by an infringer domiciled within the European Union, he can bring the copyright infringement claim before the courts of every Member State for the damage caused within each of these states. ${ }^{1421}$ Yet, when a Member State court in another place then the defendant's domicile establishes jurisdiction on the basis of the accessibility criterion, there

\footnotetext{
1416 See Müller 2014, p. 434.

${ }^{1417}$ Opinion of Advocate General Jääskinen delivered on 21 November 2013 in the case C-360/12 Coty Germany GmbH v First Note Perfumes, para. 60.

${ }_{1418}$ Opinion of AG Jääskinen in the case C-360/12 Coty, para. 60.

${ }^{1419}$ See also Case C-228/11 Melzer v. MF Global UK Ltd, para. 32-35.

${ }^{1420}$ Husovec 2014, p. 370; Matulionyte 2015, p. 134. See the Opinion of AG Jääskinen in the case C-360/12 Coty, para. 62. See also De Groote 2004, p. 279; Lopez-Tarruella 2012, p. 339.

${ }^{1421}$ Both the European Union Member States and China are Members of the Berne Convention for the Protection of Literary and Artistic works. Pursuant to Article 3(1)(a) and Article 5(2) Berne Convention 1979, a Chinese author may receive, by the very fact of creation of his or her work, a bundle of national copyrights throughout the territories of all Member States. According to the principle of national treatment, laid down in Article 5(1) Berne Convention 1979, the Chinese author receives in other Member States the same protection as these states grants its own nationals.
} 
may be no close connection between the dispute and the court. ${ }^{1422}$ The only connection of the dispute to the court might be the accessibility of the website in the forum state, the competent court will then not be in the best position to assess the copyright infringement dispute. ${ }^{1423}$

The mere accessibility criterion will frequently lead to "empty jurisdiction" as there may be no actual damage in the state where the website involved has been accessible. ${ }^{1424}$ Moreover, the accessibility criterion entails multiple competent courts ${ }^{1425}$ that increases the risk of empty jurisdiction. This approach to jurisdiction is therefore not in accordance with the ratio underlying the close connection requirement to enhance the sound administration of justice as explained by the CJEU in the Bier ruling. ${ }^{1426}$

The 'likelihood of damage' and accessibility criterion will facilitate the attribution of jurisdiction to the court of the place where the copyright holder is domiciled, the so-called forum actoris. Like in the cases Pinckney, Hi Hotel and Pez Hejduk, a copyright holder will likely sue the alleged infringer in the state of his domicile. ${ }^{1427}$ The forum actoris will, however, not always be the place where the copyright infringement causes most damage. ${ }^{1428}$ Moreover, the Brussels Ibis Regulation militates against providing jurisdiction to the forum actoris in view of the general forum rei-based jurisdiction rule. ${ }^{1429}$

The fact that the 'likelihood of damage' criterion can be satisfied by damage caused by a third party irrespectively of the defendant's relationship to the third party, as in the rulings Pinckney and Hi Hotel, will not yield a close connection between the court and the dispute. ${ }^{140}$ While the competent court may be able to assess the damage caused by the third party, the court will not be in the best position to ascertain the facts of the dispute between the copyright holder and the defendant who committed the copyright infringement in another state than the forum state. ${ }^{1431}$ Huvosec refers to the danger of "empty jurisdiction" that means unless the applicable substantive law provides a rule attributing damage caused by the third party to the defendant, such as the joint tort-feasorship, the plaintiff will not be able to receive compensation for the damage in the forum state. ${ }^{1432}$ Paragraph 7.7 will demonstrate that the United States Supreme

\footnotetext{
1422 Magnus \& Mankowski 2016, p. 316.

${ }^{1423}$ Magnus \& Mankowski 2016, pp. 316-317.

${ }^{1424}$ Matulionyte 2015, p. 135. See also Depreeuw \& Hubin 2014, pp. 763-764; Georgescu, Marin, Vasile \& Florecsu 2016, p. 18; Huvosec 2014, pp. 372-373; Torremans 2014, p. 386.

${ }^{1425}$ Brachotte \& Nuyts 2014, p. 252.

${ }^{1426}$ See the paragraphs 2.1.2.2.2 and 4.3.1. See also recital 16 in the preamble to the Brussels Ibis Regulation.

${ }_{1427}$ See the Pinckney, Hi Hotel and Pez Hejduk rulings in chapter 3.

${ }^{1428}$ Paragraph 6.2.4.3 will demonstrate that a copyright infringement dispute will not always cause most damage in the state in which the copyright holder is domiciled or established. While infringements of the moral sides of copyrights will likely cause most damage in the forum actoris, infringements of the economic sides may cause more damage in other states. See paragraph 2.2.1.1 on the difference between moral and economic rights. See also paragraph 6.2.2.2 on the difference between the localisation of damage caused by the infringement of economic rights and moral rights.

${ }^{1429}$ See Magnus \& Mankowski 2016, p. 241.

${ }^{1430}$ Müller 2014, p. 434. See also Opinion of AG Jääskinen in the case C-360/12 Coty, para. 62.

1431 As mentioned in paragraph 5.2.3.1.1.1, in the Dumez ruling, the CJEU was not willing to confer jurisdiction based on causality of damage of successive victims by reasoning that there must be "a particularly close connection between the dispute and courts other than those of the State of the defendant's domicile". See Case C-220/88 Dumez, para. 17.

${ }^{1432}$ Huvosec 2014, p. 372.
} 
Court did not adopt a third party-based approach to jurisdiction as it requires that "the defendant's suit-related conduct must create a substantial connection with the forum state" ${ }^{1433}$.

\subsubsection{The principle of balancing the interests and the influence of the Geo-blocking Regulation}

The Pinckney doctrine does not guarantee a procedural balance between the parties involved. ${ }^{1434}$ While the 'likelihood of damage' criterion will facilitate the copyright holder to sue the alleged infringer before the court of every Member State, the alleged infringer will often be unable to predict where he may get sued. ${ }^{1435}$ Due to the territorially limited approach to jurisdiction, the copyright holder may have to sue the infringer in multiple states in order to receive full redress. Particularly in case of ubiquitous copyright infringements, ${ }^{1436}$ multistate litigation can put an unreasonable burden on the copyright holder. ${ }^{1437}$ Paragraph 5.3.1 will illustrate that multistate litigation may put an unreasonable burden on the copyright holder in case the infringer is domiciled or operated in a copyright haven. As will be explained in chapter six, from a perspective of the protection of moral rights related to copyrights, it has especially been argued that the copyright infringer should be able to receive full redress in the state of his centre of interests.

From a broad perspective, the Pinckney doctrine will likely not balance the interests between copyright holders, on the one hand, and users of information and traders, on the other hand. As indicated above, the territorially limited approach to jurisdiction will often not entail efficient copyright protection at procedural level. Particularly in view of the problem of online piracy and copyright havens, the balance may shift to the detriment of copyright holders.

The 'likelihood of damage' criterion may have a chilling effect on the cross-border flow of information. Particularly internet users may hesitate to exchange information due to the fear of getting unexpectedly sued in many Member States for alleged copyright infringing content. Since the Geo-blocking Regulation addresses merely traders who provide goods and certain services, ${ }^{1438}$ this Regulation will not affect users who exchange information. Hence, providers of information can block their websites for residents of certain Member States if they do not want to get sued in those states. The latter will, however, hamper the cross-border flow of information and impede the access to knowledge.

The 'likelihood of damage' criterion can also negatively affect the trade within the European Union. ${ }^{1439}$ The risk of getting unexpectedly getting sued in many Member States may discourage cross-border trade. The third party-based approach to jurisdiction, as explained in

\footnotetext{
${ }^{1433}$ Walden v. Fiore, 571 U.S. 277, 134 S. Ct. 1115 (2014). See also Kulko v. California Superior Court, 436 U.S. 84 at 94 (1978).

${ }^{1434}$ See Heinze 2010, p. 64.

${ }^{1435}$ See also Matulionyte 2015, p. 134. See also paragraph 5.2.4.1.

${ }^{1436}$ See paragraph 2.3.4.1 on the term ubiquitous.

${ }^{1437}$ Kur 2013(b), p. 88, 2:203.C09; Metzger 2009, p. 261.

${ }^{1438}$ See the paragraphs 4.5 .1 and 4.5.2.3.

${ }^{1439}$ Matulionyte 2015, p. 134.
} 
paragraph 5.2.3, particularly increases this risk. ${ }^{1440}$ Since the enactment of the Geo-blocking Regulation, traders who provide goods and certain services ${ }^{1441}$ to customers of the European Union are not allowed to block or limit the access to their websites or employ other discriminatory measures based on the customers' nationality, place of residence or establishment in the European Union. ${ }^{142}$ The accessibility approach to jurisdiction can discourage especially small trading companies to provide online goods and services within the European Union due to the fear of multistate litigation which will be costly and timeconsuming. ${ }^{1443}$

As explained in paragraph 4.5.2.3, audiovisual services and electronically supplied services "the main feature of which is the provision of access to and use of copyright protected works and other protected subject matter including the selling of copyright protected works or protected subject matter in an intangible form" are for now excluded from the prohibitions under the Geo-blocking Regulation. ${ }^{1444}$ In view of the mere accessibility approach, traders who provide these excluded services may thus block their online interfaces for customers of certain Member States which will not enhance the proper functioning of the internal market. Madiega pointed out "a growing concern in the EU relates to geo-blocking practices that amount to the refusal to sell, or measures which discriminate between online shoppers and result in market segmented along national borders (territorial restrictions) without valid justification provided by national legislation (such as consumer law) or by acceptable business practices (for instance, higher delivery costs)". ${ }^{1445}$

\subsection{Assessing the territorially limited approach to jurisdiction under the Pinckney doctrine}

The final part of this chapter will assess the territorial limitation of the court's jurisdiction under the Pinckney doctrine. The CJEU's reasoning behind this limitation of jurisdiction has been a two-step process. First, the CJEU held that "the protection [of copyrights] granted by the Member State of the place of the court seised is applicable only in that Member State". ${ }^{1446}$ Second, the CJEU ruled that in the light of Article 7(2) Brussels Ibis and the principle of territoriality, the competent courts of each Member States under Article 7(2) Brussels Ibis "are best placed to ascertain whether the copyrights protected by the Member State concerned have been infringed" and to determine the damage caused within the forum state. ${ }^{1447}$ The first consideration reflects the ruling of Lagardère Active Broadcast v. SPRE and Others in which the CJEU emphasised that the territorial nature of copyrights limits the copyright protection to

\footnotetext{
${ }^{1440}$ See Opinion of Advocate General Jääskinen delivered on 29 November 2012 in the case C-228/11 Melzer v. MF Global UK Ltd, para. 64.

${ }^{1441}$ See paragraph 4.5.2.3 on the services that are excluded from the scope of the Geo-blocking Regulation.

1442 See paragraph 3 and 4 Geo-blocking Regulation. See also paragraph 4.5.2.

1443 See also Matulionyte 2015, p. 134.

1444 See Article 4(1)(b) Geo-blocking Regulation.

${ }^{1445}$ Madiega 2015, pp. 4-5.

${ }^{1446}$ Case C-170/12 Pinckney, para. 45; Case C-387/12 Hi Hotel, para. 38; Case C-441/13 Pez Hejduk, para. 36.

${ }^{1447}$ Case C-170/12 Pinckney, para. 46. Case C-387/12 Hi Hotel, para. 39; Case C-441/13 Pez Hejduk, para. 37.
} 
the territory of the Member State which law grants the copyright. ${ }^{1448}$ The second consideration is similar to the reasoning in the Shevill ruling to limit the jurisdiction of the court of the Erfolgsort for reasons of sound administration of justice. ${ }^{1449}$

The next paragraph will provide arguments against the approach of territorially limited jurisdiction, also referred to as mosaic approach, in cross-border copyright infringement disputes. ${ }^{1450}$ Paragraph 5.3.2 will point out the decreasing influence of the territorial protection of copyrights on the geographical scope of the court's jurisdiction in cross-border copyright infringement disputes. Paragraph 5.3.3 will discuss the territorial scope of the jurisdiction of the court of the Erfolgsort; in particular with respect to the alleged damage and an injunction to cease or prevent copyright infringing activities. Paragraph 5.3.3.1 will outline the concept of 'full' jurisdiction in this dissertation. Finally, paragraph 5.3.4 will demonstrate certain conditions that should be considered when conferring 'full' jurisdiction under Article $7(2)$ Brussels Ibis in cross-border copyright infringement cases.

\subsubsection{Arguments against the mosaic approach under the Pinckney doctrine}

The territorially limited approach to jurisdiction has been established by the CJEU in the Shevill ruling and has been referred to as the mosaic approach. ${ }^{1451}$ In the Shevill ruling, the CJEU reasoned that "the courts of each Contracting State in which the defamatory publication was distributed and in which the victim claims to have suffered injury to his reputation are territorially the best places to assess the libel committed in that State and to determine the extent of the corresponding damage". ${ }^{1452}$ The rationale behind the so-called mosaic approach established in the Shevill ruling may not always be applicable in the context of cross-border copyright infringement cases. It is doubtful whether in case of cross-border copyright infringements, the court of the place that satisfies the 'likelihood of damage' criterion will always be best placed to assess the damage within the forum state. Particularly in case of ubiquitous copyright infringements, ${ }^{1453}$ it will often be difficult to calculate the damage involving a cross-border copyright infringement dispute caused within the territory of the forum state. ${ }^{1454}$ If the court obtained jurisdiction based on the mere accessibility of the website there may even be no damage sustained in the forum state, referred to as "empty jurisdiction". ${ }^{145}$

\footnotetext{
${ }^{1448}$ Case C-192/04 Lagardère Active Broadcast v. SPRE and Others, para. 46.

1449 Case C-68/93 Shevill and Others v. Presse Alliance, para. 31.

${ }^{1450}$ According to Magnus and Mankowski, the CJEU developed in the case C-68/93 Shevill v. Press Alliance SA (para. 28-33) the so-called mosaic principle: "at the place where the damage was sustained, a claim can only be brought for damage sustained in the forum state, not for the world-wide damage." See Magnus and Mankowski 2016, p. 278. See also paragraph 1.1.4.

1451 See paragraph 1.1.4.

1452 Case C-68/93 Shevill and Others v. Presse Alliance, para. 31.

${ }^{1453}$ See paragraph 2.3.4.1 on the term ubiquitous.

${ }^{1454}$ In the case of eDate and Martinez, the CJEU rejected the distribution criterion and mosaic approach of the Shevill ruling since it will be difficult to quantify and assess the damage caused by worldwide dissemination of an infringement of a personality right within a particular Member State. See the joined Cases C-509/09 and C-161/10 eDate and Martinez, para. 46.

${ }^{1455}$ Huvosec 2014, p. 373; Matulionyte 2015, p. 135. See also Depreeuw \& Hubin 2014, pp. 763-764; Georgescu, Marin, Vasile \& Florecsu 2016, p. 18. See also paragraph 5.2.4.2.
} 
Scholars have raised the question "as to how jurisdiction will calculate the damage to be compensated in cases such as Pez Hejduk where no specific sales in the jurisdiction and the damage is indeed more general, as identified by Advocate General". ${ }^{1456}$ As mentioned in paragraph 3.4.2, Advocate General Cruz Villalón argued that a distinction should be made between the alleged damage caused by physical sale of copyright infringing products via the Internet, such as the material discs in the Pinckney case, and copyright infringing content disseminated via the Internet, such as photographs in the Pez Hejduk case. ${ }^{1457}$ The latter type of damage will be diffuse, "delocalised" damage and therefore difficult to quantify within the forum state. ${ }^{1458}$ With respect to "delocalised" damage, Cruz Villalón argued that the Erfolgsort should not confer jurisdiction because it will not facilitate sound administration of justice; legal certainty for both parties to the dispute; or provide proximity to the relevant facts of the dispute. ${ }^{1459}$ As explained in paragraph 5.2.2, despite the difficulties to identify and localise damage in copyright infringement cases, it is undesirable to reject the adoption of the Erfolgsort. ${ }^{1460}$

In the eDate and Martinez ruling, the CJEU pointed out that "it is not always possible, on a technical level," to identify the online distribution of an infringing content "with certainty and accuracy in relation to a particular Member State, or therefore, to assess the damage caused exclusively within that Member State". ${ }^{1461}$ Yet instead of rejecting the adoption of the Erfolgsort, the CJEU therefore decided to provide full jurisdiction to the court of the place where the victim's centre of interests is located. ${ }^{1462}$ In the next chapter, the possibility to adopt the 'victim's centre of interests' approach under Article 7(2) Brussels Ibis in case of copyright infringement disputes will be assessed.

It has been argued that the mosaic approach to jurisdiction reduces the risk of forum shopping. ${ }^{1463}$ Yet, the combination of the accessibility criterion and territorially limited jurisdiction may likely lead to fragmentation of litigation in case of ubiquitous infringements. ${ }^{1464}$ The abolishment of the exequatur procedure under the Brussels Ibis Regulation, which used to be required to recognise and enforce a judgment in another Member State, may even facilitate law- and forum shopping. ${ }^{1465}$ Several scholars have pointed out the negative effects of fragmentation of litigation namely unpredictability as regards where the defendant may get sued, increased litigation costs, and the risk of irreconcilable judgments. ${ }^{1466}$

\footnotetext{
1456 Smith \& Newton 2015, p. 460.

1457 See Opinion of Advocate General Cruz Villalón delivered on 11 September 2014 in the case C-441/13 Pez Hejduk v. EnergieAgentur. NRW GmbH, para. 2, 16-17.

${ }^{1458}$ See Opinion of AG Cruz Villalón in the case C-441/13 Pez Hejduk, para. 25-27, 42.

${ }^{1459}$ See Opinion of AG Cruz Villalón in the case C-441/13 Pez Hejduk, para. 41-44.

${ }^{1460}$ See also Nuyts 2008, p. 117.

${ }^{1461}$ Cases C-509/09 and C-161/10 eDate Advertising GmbH v. X and Olivier Martinez and Robert Martinez v. $M G N$ Limited, para. 46. See also paragraph 2.1.2.2.2 of this dissertation.

1462 Cases C-509/09 and C-161/10 eDate and Martinez, para. 48.

1463 See Metzger 2009, p. 260.

1464 Von Hein 2014-2015, p. 271.

${ }^{1465}$ Article 36-57 of the Brussels Ibis Regulation.

1466 De Miguel Asensio 2010, p. 6; Kono \& Jurcys 2015, pp. 12, 27-28; Metzger 2009, pp. 260-261; Müller 2014, p. 435; Neumann 2014, p. 509; Van Engelen 2007, p. 166. With respect to online infringements of personality rights, the application of the mosaic principle as established in the Shevill ruling has been criticised by Oster 2012, p. 117. See also Advocate General Cruz Villalón in the opinion in the joined cases of eDate and Martinez, para.
} 
The foregoing arguments can be classified under the main argument of efficient adjudication and the sound administration of justice. In view of this latter argument, consolidation of connected proceedings in one single forum has even been regarded as a principle "that may generally be of significant in deciding whether to assert jurisdiction over disputes involving foreign elements". ${ }^{1467}$

As mentioned in paragraph 5.2.4.3, territorially limited jurisdiction may also entail an unfair procedural balance between copyright holders and infringers in case of ubiquitous copyright infringement disputes. Due to the mosaic principle, the copyright holder may have to sue the alleged infringer before the court of each Member State where he sustained damage to obtain full redress. Fragmentation of litigation may put an unreasonable burden on the copyright holder. ${ }^{1468}$ In case of a multistate or ubiquitous copyright infringement dispute, it can be unreasonable that the copyright holder has to sue the infringer before the forum rei, or the court of the Handlungsort, to receive full redress if this state can be considered as copyright haven. ${ }^{1469}$ For instance, if the copyright holder sustained most damage in the state where he is domiciled and the latter state protects the copyright relied on. Particularly if the copyright infringer directed his activities to the latter state, multistate litigation or suing in the forum rei, or the Handlungsort, seems to put an unreasonable burden on the copyright holder. Chapter six will examine combined approaches to full jurisdiction that include the 'directed activities' approach and the copyright holder's centre of interests approach. Finally, it will also be burdensome for the alleged infringer to get sued in many Member States. There even exist a risk of harassment as already noted in relation to the mosaic principle in the Shevill ruling. ${ }^{1470}$

Another argument against the mosaic approach under the Pinckney doctrine could be that a territorially limited scope of an injunction will not be feasible. As mentioned earlier regarding the case of Bolagsupplysningen OÜ Ingrid Ilsjan v. Svensk Handel AB, the CJEU held that a territorially limited injunction to cease an infringement of a personality right via the Internet is not feasible. ${ }^{1471}$ Advocate General Bobek also pointed out that due to "the unitary nature" of the website, "it simply cannot be rectified or deleted only 'in proportion' to the harm suffered in a given territory". ${ }^{1472}$ With respect to alleged online copyright infringements, it has nevertheless been argued that the court can issue a territorially limited injunction to cease the infringement within the territory of the forum state. ${ }^{1473}$ Scholars therefore referred to various

51 and Advocate General Bobek in the opinion in the case C-194/16 Bolagsupplysningen Oü and Ingrid Ilsjan v. Svensk Handel $A B$, para. 73-90.

${ }^{1467}$ Pertegás Sender 2002, p. 18. Pertegás Sender refers to Heldrich 1969, pp. 118-119. See also Pontier 2006, p. 93. Pontier and Burg also argued that the principle of a sound administration justice includes the principle that related cases should be decided by a single court. See Pontier \& Burg 2004, p. 161. See paragraph 4.2.4.2.

${ }^{1468}$ Metzger 2009, p. 261.

1469 See paragraph 2.2.2.2 on the concept of copyright haven. See also Kur 2013(b), p. 88, 2:203.C09; Metzger 2009 , p. 261.

${ }^{1470}$ See Opinion of Advocate General Bobek delivered on 13 July 2017 in the case C-194/16 Bolagsupplysningen Oü and Ingrid Ilsjan v. Svensk Handel AB, para. 88. See also Torremans 2014, p. 386.

${ }^{1471}$ Case C-194/16 Bolagsupplysningen OÜ, para. 48. See paragraph 5.3.3.

1472 See Opinion of Advocate General Bobek delivered on 13 July 2017 in the case C-194/16 Bolagsupplysningen Oü and Ingrid Ilsjan v. Svensk Handel AB, para. 126. From a technological perspective, Jütte (2017(b)) noted that "partial injunctions are possible by geo-blocking allegedly infringing websites for the territories Member States in which an injunction has been ordered".

${ }^{1473}$ Lundstedt 2018, p. 1044. 
instruments that enable the territorial limitation of an injunction such as geo-blocking technologies and disclaimers. ${ }^{1474}$ As mentioned in paragraph 4.5, the Geo-blocking Regulation does not prohibit all internet users to block their websites, only traders who provide goods and certain services to customers of the European Union. For now, websites providing audiovisual services and electronically supplied services that provide access to copyrighted works can still be blocked. ${ }^{1475}$ In the context of an online copyright infringement dispute, a territorially limited injunction will nevertheless not be effective and satisfactory since the infringing content will generally be accessible in other states. ${ }^{1476}$ With respect to multistate copyright infringements, territorially limited injunctions will also increase the risk of irreconcilable decisions. ${ }^{1477}$

From a perspective of public interests, Kono and Jurcys argued that fragmentation of litigation does not "fit the needs of the digital economy". ${ }^{1478}$ Lack of efficient procedural protection of copyrights may even limit creativity of individuals or companies located in the European Union, or hamper trade within the Member States. ${ }^{1479}$ The flow of information via the Internet may also be reduced due to the fear of online users to get sued in multiple states. The foregoing indicates that the mosaic approach under the Pinckney doctrine likely encroaches upon the principle of balancing the broader interests related to copyright as explained in paragraph 4.4 .

The practical need to consolidate proceedings involving infringements of intellectual property rights committed in several states has been underscored by the Supreme Court of the Netherlands (Hoge Raad) in the case of Interlas v. Lincoln. ${ }^{1480}$ Considering the increasingly international contacts, the Dutch Supreme Court emphasised that in cross-border tort cases such as intellectual property infringements, unfair competition, or environmental pollution, it would be undesirable if the plaintiff has to initiate proceedings in all the states involved. ${ }^{1481}$ In this case, a holder of a Benelux trademark requested a Dutch court to issue a cross-border injunction to cease infringing activities in several states committed by a company established in the Netherlands. The Dutch Supreme Court held that the Dutch court could obtain jurisdiction to issue a cross-border injunction to cease the infringer's activities in the Netherlands, Belgium and Luxembourg. ${ }^{1482}$ In the case of Koninklijke Philips Electronics N. V. v. Postech Corporation and Others, the Dutch Supreme Court even ruled that regardless of the ground on which the Dutch court has obtained jurisdiction in case of an infringement of foreign intellectual property rights, the Dutch court may issue a cross-border injunction involving activities in other

\footnotetext{
${ }^{1474}$ Lundstedt 2018, p. 1044; Svantesson 2018, p. 124; Trimble 2019(a), p. 17. See also paragraph 4.5.2 on geoblocking technologies.

${ }^{1475}$ See paragraph 4.5.2.3 on the review of the Geo-blocking Regulation in May 2020.

1476 See Strowel 2014, p. 1131; Van der Plas 2018, para. 126.

1477 Van der Plas 2018, para. 129; Van Engelen 2007, p. 166. See also Opinion of Advocate General Bobek delivered on 13 July 2017 in the case C-194/16 Bolagsupplysningen Oü and Ingrid Ilsjan v. Svensk Handel AB, para. 129. See also Kessedjian 1996, p. 185.

${ }_{1478}$ Kono \& Jurcys 2015, p. 32.

1479 Solley 2008, p. 829.

${ }^{1480}$ Hoge Raad 24 November 1989 Interlas v. Lincoln, para. 4.2.4. See also Nuyts, Szychowska \& Hatzimihail 2008, p. 11.

${ }^{1481}$ Hoge Raad 24 November 1989 Interlas v. Lincoln, para. 4.2.4. See also Van Engelen 2007, p. 167.

${ }^{1482}$ Hoge Raad 24 November 1989 Interlas v. Lincoln, para. 4.2.4. For a similar decision of the Dutch Supreme Court see Hoge Raad 21 February 1992 MB International BV v. Mattel (referred to as the Barbie case).
} 
states. ${ }^{1483}$ The mosaic approach established by the CJEU in the Shevill ruling does not seem to limit the scope of an injunction to cease a cross-border copyright infringement. ${ }^{1484}$

\subsubsection{The declining role of the territorial protection of copyrights regarding the scope of the court's jurisdiction}

In the rulings Pinckney, Hi Hotel and Pez Hejduk, the CJEU held that based on the territorial protection of copyrights the jurisdiction of the court of the Erfolgsort will be limited to the damage allegedly caused by the copyright infringement within the forum state. ${ }^{1485}$ This paragraph will demonstrate that the territorial protection of copyrights does not necessarily need to limit the scope of the court's jurisdiction. Despite the territorial protection of intellectual property rights, court(s) may obtain 'full' jurisdiction under the Brussels Ibis Regulation in infringement cases. First of all, the territoriality principle does not limit the jurisdiction of the court of the alleged infringer's domicile under Article 4 Brussels Ibis to adjudicate the entire copyright infringement dispute. ${ }^{1486}$ While the CJEU did not explicitly rule on the scope of the court of the Handlungsort in cross-border copyright infringement cases, the latter court seems to have 'full' jurisdiction as in the Shevill ruling. ${ }^{1487}$ In the Wintersteiger ruling, the CJEU held that the court of the Erfolgsort, that means the Member State where the trademark involved has been registered, will be best able to assess whether the national trademark has been infringed, and therefore this court may ascertain all the alleged damage and issue an injunction to cease all infringements of that right. ${ }^{1488}$ In the latter case, the CJEU has particularly provided unlimited jurisdiction to the court of the Erfolgsort in light of "the objective of foreseeability and that of sound administration of justice". ${ }^{1489}$

Due to globalising economies and the Internet, the debate on the role of the territoriality principle related to copyrights in the field of private international law has increased. ${ }^{1490}$ Scholars have argued that "efficiency of court proceedings" may as a principle of private international law "constitute a counterweight to territoriality" inherent to intellectual property rights. ${ }^{1491}$ The principle of "efficiency in the sense of facilitating international transactions" can

1483 Hoge Raad 19 March 2004 Koninklijke Philips Electronics N. V. v. Postech Corporation and Others, para. 3.4.3. See also the Conclusion of Advocate General Strikwerda, 19 December 2003, para. 26.

${ }^{1484}$ Van Engelen 2007, p. 177.

1485 Case C-170/12 Pinckney, para. 45-46; Case C-387/12 Hi Hotel, para. 38-39; Case C-441/13 Pez Hejduk, para. 36-37. See paragraph 5.3.

${ }^{1486}$ Magnus \& Mankowski 2016, p. 297. See also Case C-189/87 Kalfelis v. Schröder, para. 20.

1487 Magnus and Mankowski claim that the court at the Handlungsort has "jurisdiction to entertain claims concerning the entire global damage inflicted”. See Magnus \& Mankowski 2016, p. 287. See also Schaafsma 2016, p. 405. See also Opinion of Advocate General Jääskinen delivered on 13 June 2013 in the case C-170/12 Pinckney, para 57. See Case C-68/93 Shevill, para. 25. See also the table in paragraph 4.3.2. Larsen (2018(b), pp. 549-561) nevertheless advocates that the courts competent under Article 7(2) Brussels Ibis can only obtain territorially limited jurisdiction in cross-border trade mark infringement cases similar to the court competent on the basis of Article 126(2) Trade mark Regulation.

${ }^{1488}$ Case C-523/10 Wintersteiger AG v. Products $4 U$ Sondermaschinenbau GmbH, para. 28.

${ }^{1489}$ Case C-523/10 Wintersteiger, para. 27.

${ }^{1490}$ Dinwoodie 2009(a), pp. 730-800; Fentiman 2005, pp. 129-148; Peukert 2012, p. 200; Solley 2008, pp. 813842; Van Eechoud 2003, pp. 169-238; Vicente 2016, pp. 724-729. See paragraph 2.2.2.2 on the rising criticism on the territoriality principle related to copyrights.

${ }^{1491}$ Kur 2009, p. 6. See also Kono \& Jurcys 2015, p. 29. 
also constitute a counterweight to territoriality related to copyrights. ${ }^{1492}$ On the jurisdiction level, paragraph 2.3.4.1 demonstrated a decreasing influence of the territorial principle related to copyrights. Chapters six and seven will address various proposals of scholars and courts of European Union Member States and states of the United States of America that provide 'full' jurisdiction in case of multistate or ubiquitous copyright infringement disputes.

\subsubsection{The territorial scope of the jurisdiction of the court of the Erfolgsort with respect to damage and an injunction to cease or prevent copyright infringing activities}

In the Pinckney, Hi Hotel and Pez Hejduk ruling, the CJEU held that the jurisdiction of the court on the basis of the Erfolgsort will be limited to the alleged damage caused within the forum state. ${ }^{1493}$ The CJEU did not explicitly rule whether the court(s) of the Erfolgsort can issue a cross-border or only a territorially limited injunction in a cross-border copyright infringement case. ${ }^{1494}$

As mentioned in paragraph 5.2.2, the copyright holder may request an injunction ${ }^{1495}$ to prevent or cease the dissemination of alleged copyright infringing products or content. A territorially limited injunction will merely concern infringing activities that affect the copyright protected under the national law applied by the competent court. These activities may nevertheless have occurred abroad "such as the manufacturing of the product" provided that the injunction "is designed only to prevent damage from occurring in the forum state" ${ }^{1496}$ A crossborder injunction reaches beyond the territory of the state of the court that issues the injunction ${ }^{1497}$ and may prohibit infringing activities in all states where the work has been protected by copyright based on national and foreign copyright laws. ${ }^{1498}$

As will be demonstrated in chapters six and seven, several scholars and courts advocate to confer -under certain conditions- on the court of the Erfolgsort jurisdiction regarding the entire cross-border copyright infringement dispute, referred to as full jurisdiction. Paragraph 5.3.1 demonstrated arguments in favour of full jurisdiction from a perspective of private international law, the cross-border flow of information and trade. Paragraph 5.3.2 pointed out that the territorial protection of copyrights does not necessarily have to limit the jurisdiction of the court of the Erfolgsort. This paragraph and the next paragraph will further discuss whether the court

\footnotetext{
1492 See Kur 2009, p. 6.

${ }_{1493}$ Case C-170/12 Pinckney, para. 45-46; Case C-387/12 Hi Hotel, para. 38-39; Case C-441/13 Pez Hejduk, para. 36-37. See chapter 3. See paragraph 1.1.4 on the concept of mosaic approach to jurisdiction established by the CJEU in the Shevill ruling.

${ }^{1494}$ The CJEU also did not provide a ruling on whether the court of the Handlungsort may issue a cross-border injunction in copyright infringement cases. Schaafsma provides various views on the issue whether the court of the Handlungsort may issue a cross-border injunction in copyright infringement cases. See Schaafsma 2016, pp. 405-407.

1495 "In a broad sense, the 'injunction' denotes a spectrum of orders within a court's arsenal which compel persons in some way". See Douglas 2018, p. 34. For instance, an injunction to withdraw copyright infringing products from the market.

${ }^{1496}$ See Nuyts 2008, p. 128. See also Pansch 2000, pp. 361-362.

1497 See Trimble 2019(b), p. 504.

${ }^{1498}$ See Nuyts 2008, p. 128. See also Nuyts, Szychowska \& Hatzimihail 2008, pp. 9-13 See also Article 2:604(2) CLIP Principles.
} 
of the Erfolgsort under Article 7(2) Brussels Ibis could be legally allowed to issue a worldwide injunction and to assess the entire damage in a cross-border copyright infringement dispute.

First of all, the CJEU's case law demonstrates that there appears to be a relationship between the territorial scope of the court's jurisdiction regarding the alleged damage and the territorial scope of an injunction in infringement cases. With respect to the interpretation of the Erfolgsort under Article 7(2) Brussels Ibis in case of an online infringement of a national trademark, the CJEU held that the courts of the Member State in which the trade mark at issue is registered "have the power to determine all the damage allegedly caused to the proprietor of the protected right because of an infringement of it and to hear an application seeking cessation of all infringements of that right". ${ }^{1499}$ In the case of Bolagsupplysningen OÜ Ingrid Ilsjan $v$. Svensk Handel $A B$, the question arose whether the court of the Erfolgort that has territorially limited jurisdiction can issue an injunction to remove online content that allegedly infringed the victim's personality rights. ${ }^{1500}$ The CJEU provided a negative answer "in light of the ubiquitous nature of the information and content placed online on a website and the fact that the scope of their distribution is, in principle, universal". ${ }^{1501}$ According to the CJEU, a claim to remove and rectify online infringing information "is a single and indivisible application and can, consequently, only be made before a court with jurisdiction to rule on the entirety of an application for damage" ${ }^{1502}$ such as the courts of the Member State in which the victim's centre of interests is located. ${ }^{1503}$

The foregoing case law seems to indicate that when the court of the Erfolgsort under Article 7(2) Brussels Ibis obtains jurisdiction regarding the entire damage, the latter court can issue a cross-border injunction to cease or prevent copyright infringing activities in all states. In view of international law, it has nevertheless been argued that the effects of a cross-border injunction may under certain circumstances be territorially limited. ${ }^{1504}$ In the context of the principle of international comity, the following paragraph will demonstrate that it can be debated whether a court competent under Article 7(2) Brussels Ibis in a cross-border copyright infringement dispute is allowed to issue a worldwide injunction or assess the damage worldwide. ${ }^{1505}$

\footnotetext{
${ }^{1499}$ Case C-523/10 Wintersteiger AG v. Products $4 U$ Sondermaschinenbau GmbH, para. 28.

${ }^{1500}$ Case C-194/16 Bolagsupplysningen OÜ and Ingrid Ilsjan v. Svensk Handel AB, para. 45-49. For more details on this case see chapter 6 of this dissertation.

${ }^{1501}$ Case C-194/16 Bolagsupplysningen OÜ, para. 48. The CJEU referred to the joined cases C-509/09 and C161/10 eDate and Martinez, para. 46.

1502 Case C-194/16 Bolagsupplysningen OÜ, para. 48.

${ }^{1503}$ See joined cases C-509/09 and C-161/10 eDate and Martinez para. 48. With respect to other courts that can obtain jurisdiction under Article 7(2) Brussels Ibis in respect of all the damage, the CJEU refers to Case C-68/93 Shevill, para. 25, 26 and 32 and the joined cases C-509/09 and C-161/10 eDate and Martinez para. 48. See Case C-194/16 Bolagsupplysningen Ö̈, para. 48.

${ }^{1504}$ See Svantesson 2018, pp. 113-125. See Opinion of Advocate General Szpunar delivered on 4 June 2019 in the case C-18/18 Eva Glawischnig-Piesczek v. Facebook Ireland Limited, para. 76-100. See also Opinion of Advocate General Szpunar delivered on 10 January 2019 in the case C-507/17 Google LLC v. Commission nationale de l'informatique et des libertés (CNIL), para. 54-63. See also Case C-18/18 Eva Glawischnig-Piesczek v. Facebook Ireland Limited, para. 53; Case C-507/17 Google LLC v. Commission nationale de l'informatique et des libertés (CNIL), para. 69-73.

${ }^{1505}$ Svantesson 2018, pp. 121-122.
} 


\subsubsection{The influence of the principle of international comity on the actual scope of full jurisdiction}

Due to globalization and the Internet, "overlapping claims of jurisdiction and overregulation" are rising "and trigger a quest for the indentification of 'second order' jurisdictional principles that limit the scope of application of first order principles like territoriality or nationality". ${ }^{1506}$ According to Ryngaert and Vagias, "second order principles are designed to make the exercise of jurisdiction reasonable."1507 Svantesson argues to adopt the core principle that "the exercise of jurisdiction should be "reasonable given the balance between the state's legitimate interests and other interests". ${ }^{1508}$ According to Svantesson, this core principle comprises the application of the "doctrine of comity, territorial sovereignty, due diligence, and the duty of non-intervention" in the jurisdictional context. ${ }^{1509}$ This paragraph will demonstrate that the principle of international comity, as a "second order" principle of jurisdiction, ${ }^{1510}$ may prevent the court of the Erfolgsort that has full jurisdiction under Article 7(2) Brussels Ibis to issue an injunction that has effects outside the European Union and to assess the damage caused outside the European Union.

Comity can be defined as "the respect that sovereign nations...owe each other", a state should therefore consider the rights and interests of other states. ${ }^{1511}$ It has been argued that "comity is not about politeness, deference... it is a logical and legal deduction from the principles of territorial sovereignty." 1512 From a perspective of public international law, the principle of comity reflects the principle of sovereign equality of states. ${ }^{1513}$ The principle of international comity has also been regarded as a method for describing the intersection between public and private international law". ${ }^{1514}$ The principle of comity has early on been adopted in private international law. ${ }^{1515}$ In the seventeenth century, the Dutch scholar Ulrich Huber proclaimed that 'the 'sovereign' of a state may 'by way of comity' recognize rights acquired under the laws of another state" 1516 to justify the application of foreign law ${ }^{1517}$. Since the twentieth century, the principle of comity has especially in the United States of America become broader by also focusing on the limitation of "domestic jurisdiction out of respect for

\footnotetext{
1506 Ryngaert \& Vagias 2019. According to Svantesson (2019(a), p. 49), "some extraterritorial claims of jurisdiction are clearly supported in international law, as is the case, for example, under the nationality principle". ${ }^{1507}$ Ryngaert \& Vagias 2019.

${ }^{1508}$ Svantesson 2017, p. 60.

${ }^{1509}$ Svantesson 2017, p. 60.

${ }^{1510}$ Ryngaert \& Vagias 2019.

${ }^{1511}$ Ramsey 1997-1998, p. 893. Ramsey refers to the case of Philips Med. Sys. Int'l B.V. v. Bruetman, 8 F.3d 600 at 604 (7th Cir.1993). The Latin term comitas (gentium) means "courtesy (of nations)", see https://www.oxfordreference.com/view/10.1093/acref/9780195369380.001.0001/acref-9780195369380-e-

374 ? rskey=MT8XeA\&result $=1$

1512 Briggs 2012, p. 118.

1513 Mills 2018, p. 18

1514 Maier 1982, pp. 285, 303. See also Mills 2018, pp. 16-18.

1515 See Lorenzen 1919, pp. 199-242; Paul 2008, pp. 22-38.

${ }^{1516}$ Lorenzen 1919, p. 378. Lorenzen referred to the third maxim that Huber laid down in the chapter "De Conflictu Legum" in his "Praelectiones" ("lectures"; 3 volume: 1687-1690). See Lorenzen 1919, pp. 378, 403. See also Maier 1982, pp. 281-284.

${ }^{1517}$ Paul 2008, p. 22.
} 
foreign sovereignty". ${ }^{1518}$ As will be demonstrated in this paragraph, the principle of comity has also been employed in Europe to territorially limit injunctions issued by courts in European Union Member States that have full jurisdiction.

In view of international law, the principle of comity has frequently limited the exercise of so-called prescriptive jurisdiction that has extraterritorial effects. ${ }^{1519}$ The exercise of prescriptive jurisdiction that has extraterritorial effects may concern the application of the law of the forum state with respect to effects or conduct in other states ${ }^{1520}$. As mentioned above, due to the increasing overlapping claims of jurisdiction and overregulation, it has been argued that the exercise of prescriptive jurisdiction should be reasonable; the principle of international comity has therefore frequently been used. ${ }^{1521}$ In the case of United States of America $v$. Mircosoft Corporation, the European Commission has claimed that the court involved must apply and interpret European Union law that creates cross-border obligations "in a manner that is mindful of the restrictions of international law and considerations of comity"1522. The principle of comity has regularly been employed in the context of private international law. ${ }^{1523}$ As will be demonstrated below, the principle of international comity may affect the exercise of full jurisdiction of the court of the Erfolgsort under Article 7(2) Brussels Ibis Regulation.

In the case of Eva Glawischnig-Piesczek v. Facebook Ireland Limited, the CJEU provided a ruling with respect to the territorial scope of an injunction that the court of the state in which the victim's centre of interests is located can issue. ${ }^{1524}$ This case involved a message on the social network Facebook harmful to the victim's reputation, the CJEU ruled that a host provider can be ordered "to remove information covered by the injunction or block access to that information worldwide within the framework of the relevant international law". ${ }^{1525}$ Based on international law, the court that has full jurisdiction under Article 7(2) Brussels Ibis may thus in pratice be restricted to issue a cross-border injunction. In view of international law, it has been questioned whether a worldwide injunction could be legitimate in the latter case since the right to the protection of reputation varies worldwide. ${ }^{1526}$

As will be demonstrated in paragraph 6.2.1.2, the CJEU appears to indicate in the Bolagsupplysningen $O \ddot{U}$ ruling that the court of the victim's centre of interests under Article

\footnotetext{
1518 See Paul 2008, p. 19.

1519 See Briggs 2012, pp. 77-115; Ryngaert 2015(b), pp. 50-75. See also Opinion of Advocate General Szpunar delivered on 4 June 2019 in the case C-18/18 Eva Glawischnig-Piesczek v. Facebook Ireland Limited, para. 100. See paragraph 2.1.2.2.1 on the concept of prescriptive jurisdiction.

${ }^{1520}$ Rice \& Gladstone (2003, p. 603) refer in this context to Restatement (Third) of the Foreign Relations Law of the United States $\$ 401 \mathrm{cmt}$. a (1987).

${ }^{1521}$ See Briggs 2012, pp. 77-115; Ryngaert 2015(b), pp. 50-75. See also Opinion of Advocate General Szpunar delivered on 4 June 2019 in the case C-18/18 Eva Glawischnig-Piesczek v. Facebook Ireland Limited, para. 100.

${ }^{1522}$ See Brief of the European Commission on Behalf of the European Union as Amicus Curiae in Support of Neither Party in the case of United States of America v. Mircosoft Corporation, 253 F. 3 d 34 (D. C. Cir. 2001). P.

7. Available at https://www.supremecourt.gov/DocketPDF/17/17-2/23655/20171213123137791 172\%20ac\%20European $\% 20$ Commission $\% 20$ for $\% 20$ filing.pdf

${ }^{1523}$ See Briggs 2012, pp. 77-182; Maier 1982, pp. 280-320; Schultz \& Ridi 2018, pp. 211-244.

${ }^{1524}$ Case C-18/18 Eva Glawischnig-Piesczek v. Facebook Ireland Limited.

1525 Case C-18/18 Eva Glawischnig-Piesczek v. Facebook Ireland Limited, para. 53.

${ }^{1526}$ See Svantesson 2019(b), available at https://www.linkedin.com/pulse/bad-news-internet-europes-top-courtopens-door-global-svantesson/. See Advocate General Szpunar in his Opinion delivered on 4 June 2019 in the case C-18/18 Eva Glawischnig-Piesczek v. Facebook Ireland Limited as will be discussed in this paragraph.
} 
7(2) Brussels Ibis can issue a worldwide injunction to rectificy and remove online defamed information. Svantesson nonetheless asserts that it is even disputable whether this injunction could have effect in the European Union since there has been no harmonised conflict-of-laws rule regarding infringements of personality rights and there are considerable differences "in the balancing of the right to reputation amongst Member States of the European Union". ${ }^{1527}$

As will be mentioned in paragraph 6.2.1.1.2, the CJEU held in the eDate and Martinez case that the court of the state in which the victim's centre of interests is located can obtain full jurisdiction under Article 7(2) Brussels Ibis in a cross-border infringement of personality rights case. Yet, the CJEU ruled that "that a person who has suffered an infringement of a personality right by means of the internet may bring an action in one forum in respect of all the damage caused, depending on the place in which the damage caused in the European Union by the infringement occurred". ${ }^{1528}$ The latter consideration seems to indicate that the court of the state in which the victim's centre of interests is located may only be allowed to assess the damage caused within the European Union. ${ }^{1529}$

In the abovementioned Eva Glawischnig case, Advocate General Spunzar pointed out that although the Brussels Ibis Regulation "may prove helpful as regards the effects of injunctions in the Member States, that is not the case as regards the effects produced outside the Union". ${ }^{1530}$ He argues that whether an injunction has effects outside the European Union, and the issue of the territorial scope of an obligation, should be assessed by public and private international law. ${ }^{1531}$ Although "the court of a member State may, in theory, adjudicate on the removal worldwide of information disseminated via the internet", in practice the court must "adopt an approach of self-limitation" as the right to protect private life and personality rights differs in national laws. ${ }^{1532}$ "In the interest of international comity", the court should therefore "as far as possible, limit the extraterritorial effects of its injunctions concerning harm to private life and personality rights". ${ }^{1533}$ As the "implementation of a removal obligation should not go beyond what is necessary to achive the protection of the injured person", the court may "order that acces to that information be disabled with the help of geo-blocking". ${ }^{1534}$

In the case of Google LLC v. CNIL, the CJEU limited the scope of an injunction for a search engine operator to de-reference based on the 'right to be forgotten', enshrined in Article 17 General Data Protection Regulation (EU) 2016/679. ${ }^{1535}$ The CJEU reasoned that the scope of

\footnotetext{
${ }^{1527}$ See Svantesson 2018, p. 122. See Article 1(2)(g) Rome II that excludes "non-contractual obligations arising out of violations of privacy and rights relating to personality, including defamation" from that Regulation.

1528 See joined cases C-509/09 and C-161/10 eDate Advertising GmbH v. X and Olivier Martinez and Robert Martinez v. MGN Limited, para. 48, italics added.

${ }^{1529}$ See also Svantesson 2018, p. 121.

${ }^{1530}$ Opinion of Advocate General Szpunar delivered on 4 June 2019 in the case C-18/18 Eva Glawischnig-Piesczek v. Facebook Ireland Limited, para. 91.

${ }^{1531}$ Opinion of AG Szpunar delivered on 4 June 2019 in the case C-18/18 Eva Glawischnig, para. 92.

1532 Opinion of AG Szpunar delivered on 4 June 2019 in the case C-18/18 Eva Glawischnig, para. 100.

1533 Opinion of AG Szpunar delivered on 4 June 2019 in the case C-18/18 Eva Glawischnig, para. 100.

${ }^{1534}$ Opinion of AG Szpunar delivered on 4 June 2019 in the case C-18/18 Eva Glawischnig, para. 100.

1535 Regulation (EU) 2016/679 of the European Parliament and of the Council of 27 April 2016 on the protection of natural persons with regard to the processing of personal data on the free movement of such data, and repealing Directive 95/46/EC (General Data Protection Regulation) (OJ L 119, 4.5.2016, pp. 1-88). With respect to the 'right to be forgotten', see Case C-507/17 Google LLC v. Commission nationale de l'informatique et des libertés (CNIL)
} 
the latter right will not go beyond the territories of the Member States ${ }^{1536}$ since "numerous third States do not recognize the right to de-referencing or have a different approach to that right"1537 and the balancing of the right to the protection of personal data against other fundamental rights will "vary significantly around the world"1538. Therefore, a search engine operator "is not required to carry out that de-referencing on all versions of its search engine [worldwide], but on the versions of that seach engine corresponding to all the Member States". 1539

In paragraph 3.6, the connecting factors in the EU trade mark Regulation to establish jurisdiction in European Union trade mark infringement disputes have been demonstrated. This Regulation stipulates that an EU trade mark court whose jurisdiction is based on the place in which "the act of infringement has been committed or threatened"1540 "shall have jurisdiction only in respect of acts committed or threatened within the territory of the Member State in which that court is situated". ${ }^{1541}$ With respect to the 'maximum' extent of jurisdiction of an EU trade mark court whose jurisdiction is based on the defendant's domicile or the plaintiff's domicile ${ }^{1542}$, the EU trade mark Regulation indicates that this extent will be limited to "acts of infringement committed or threatened within the territory of any of the Member States". 1543 Thus even if a court obtains so-called full jurisdiction under the EU trade mark Regulation, this appears to be limited to damage caused within the European Union and an injunction can only effect infringing activities within the European Union.

Although the Information Society Directive aims to harmonise the copyright laws of European Union Member States, these copyright laws still vary. ${ }^{1544}$ Due to the prevailing territorial principle related to copyrights, a copyright will only be protected within the state that granted the copyright. ${ }^{1545}$ While various international copyright conventions ${ }^{1546}$ seek to provide uniform copyright protection at worldwide level, there remain differences among national copyright laws that will likely impede global effects regarding cross-border injunctions. ${ }^{1547}$ Bennett and Granata point out the problem of enforcement with respect to "a worldwide injunction for infringement of an intellectual property right where no such right has been

refers to Case C-131/12 Google Spain SL and Google Inc v. Agencia Espanola de Protección de Datos (AEPD) and Mario Costeja Conzález.

${ }^{1536}$ Case C-507/17 Google LLC v. CNIL, para. 62.

${ }^{1537}$ Case C-507/17 Google LLC v. CNIL, para. 59.

${ }^{1538}$ Case C-507/17 Google LLC v. CNIL, para. 60.

${ }^{1539}$ Case C-507/17 Google LLC v. CNIL, para. 73.

${ }^{1540}$ See Article 125(5) EU trade mark Regulation.

${ }^{1541}$ See Article 126(2) EU trade mark Regulation.

1542 See Article 125(1) and (2) EU trade mark Regulation.

${ }^{1543}$ See Article 126(1) (a) EU trade mark Regulation.

${ }^{1544}$ See paragraphs 2.2.1 and 5.1.2.

${ }^{1545}$ See paragraph 2.2.1.

${ }^{1546}$ See paragraph 1.1.2.

${ }^{1547}$ See Trimble 2019(a), pp. 3-4. Trimble pointed out that "even if the copyright exists everywhere or in multiple countries, and even if the rights are identical across the countries, a copyright might not be owned and the rights enjoyed by the same copyright owner because the laws for initial ownership and subsequent ownership vary from country to country". See Trimble 2019(a), p. 4. 
granted in the requested State". ${ }^{1548}$ Based on public policy considerations, the latter state may refuse the enforcement of this injunction. ${ }^{1549}$

As a result of the lex loci protectionis rule in Article 8(1) Rome II, the court of a European Union Member State that obtains jurisdiction regarding the entire copyright infringement dispute must assess the case based on all national copyright laws involved. Whereas the lex loci protectionis rule is applicable in all European Union Member States, not all states outside the European Union adhere to this rule. ${ }^{1550}$ As demonstrated in this paragraph, in view of the principle of international comity, it can be questionable whether it would be legitimate for the court of the Erfolgsort under Article 7(2) Brussels Ibis to issue a worldwide injunction and to assess the entire damage in copyright infringement cases as long as there exists at worldwide level no uniform copyright law or conflict-of-laws rule. Based on the lex loci protectionis rule in Article 8(1) Rome II, it nonetheless seems to be warranted that the latter court issues a crossborder injunction that concerns infringing activities within the territories of the European Union Member States and assesses the damage caused within these territories.

The paragraphs 5.3.1 and 5.3.2 have demonstrated arguments in favour of conferring socalled full jurisdiction to the court of the Erfolgsort even despite the territorial protection of copyrights. This paragraph seeked to explain that as long as there is at worldwide level no uniform copyright law or conflict-of-laws rule for copyright infringements, in view of the principle of international comity, the exercise of 'full' jurisdiction by the latter court should in practice be limited to assess the damage within the territories of the European Union Member States and to issue an injunction that concerns alleged infringing activities within these territories. The next paragraph will set out certain conditions that should be taken into consideration when providing full jurisdiction to the court of the Erfolgsort under Article 7(2) Brussels Ibis.

\subsubsection{Certain conditions to consider when providing full jurisdiction ${ }^{1551}$ under Article 7(2) Brussels Ibis ${ }^{1552}$}

\subsubsection{A strong (territorial) connection between the dispute and the court}

From a legitimate perspective, chapter four demonstrated the 'basic' conditions to confer jurisdiction under Article 7(2) Brussels Ibis namely predictability as regards which court will be competent; a close connection between the court and the dispute; enhance the sound

\footnotetext{
${ }^{1548}$ Bennett \& Granata 2019, p. 69.

1549 Bennett \& Granata 2019, p. 69. Unfortunately, the Hague Judgments Convention of 2019 excludes matters related to intellectual property from its scope. See paragraph 6.4.2.

${ }^{1550}$ With respect to the conflict-of-laws rule in copyright infringement disputes, paragraph 2.3.3 demonstrates that not all states adopted the lex loci delicti rule. Some states even apply several conflict-of-laws rules in one crossborder copyright infringement dispute such as states in the United States of Amerika, see the case of Itar-Tass Russian News Agency v. Russian Kurier, Inc., 153 F.3d 82 (2d Cir. 1998). See Neumann 2011, p. 587.

${ }^{1551}$ See paragraph 5.3.3.1 on the concept of 'full 'jurisdiction in this dissertation.

1552 Since this dissertation rethinks the Pinckney doctrine, the focus will lie on the conferral of effects-based jurisdiction regarding the entire dispute instead of jurisdiction based on the so-called Handlungsort. See paragraph 2.1.2.2.2 on the difference between Erfolgsort and Handlungsort as demonstrated by the CJEU in the Bier ruling.
} 
administration of justice; and a procedural balance between the parties. ${ }^{1553}$ Paragraph 2.1.2.2.2 demonstrated that in view of the territorial principle related to jurisdiction there seems to be a common consensus that effects-based jurisdiction in tort case requires a substantial connection between the dispute and the court. As explained in paragraph 4.2.4.2 it is the 'close connection' requirement that justifies the conferral of jurisdiction under Article 7(2) Brussels Ibis for reasons of predictability and sound administration of justice. While this close connection appears to justify that the court obtains jurisdiction regarding the damage caused within the forum state, referred to as the mosaic approach, ${ }^{1554}$ it can be questionable whether this close connection will be strong enough to justify the conferral of jurisdiction with respect to the entire dispute.

It has been argued that full jurisdiction requires a particularly strong enough connection to the forum state. ${ }^{1555}$ With respect to cross-border patent infringements, Pertegás Sender argues that "...it has been submitted that the concentration of litigation requires a strong territorial link between the dispute and the forum". ${ }^{1556}$ Hence, concentration of litigation will only be possible in one or two States. ${ }^{1557}$ According to Pertegás Sender, "selecting the appropriate forum may require an examination of the economic repercussions of the alleged infringement in the several national markets involved" ${ }^{1558}$ To confer full jurisdiction to the court of the Erfolgsort, De Groote argued that the damage should be significant in the forum state. ${ }^{1559}$ As the next chapter will demonstrate, the CLIP Principles stipulate a quantitative effects-based approach to establish the court's jurisdiction regarding the entire intellectual property rights infringement dispute. ${ }^{1560}$ Several courts in the United States of America have also adopted a similar effectsbased approach to jurisdiction. ${ }^{1561}$

Besides effects-based approaches to jurisdiction, forum actoris-based approaches have been proposed to establish full jurisdiction in cross-border copyright cases ${ }^{1562}$. Paragraph 6.2.4.3 will explain that it is debatable whether the 'copyright holder's centre of interest' approach, or forum actoris approach, yields a strong enough connection to the forum state to justify full jurisdiction. Chapter seven will demonstrate the arguments provided by the New York Court of Appeals in the case of Penguin Group (USA) Inc. v. American Buddha to confer jurisdiction to the court of the copyright holder's residence or principal place of business regarding the entire internet-related copyright infringement dispute. ${ }^{1563}$

From a comparative point of view, it also appears that connecting factors should carry enough weight to justify the court's jurisdiction over the entire copyright infringement dispute. Scholars argued that courts in the United States of America may establish jurisdiction over the

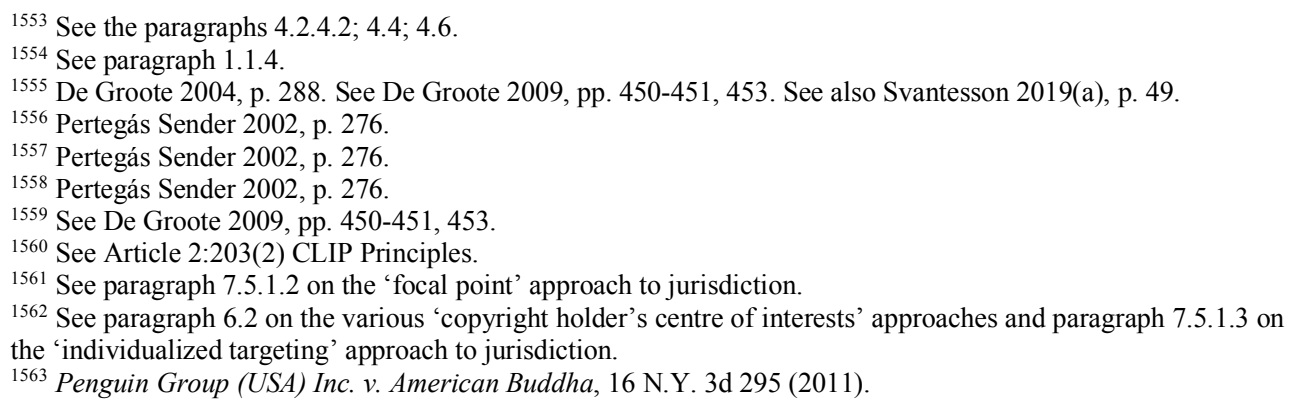


entire damage in cross-border copyright infringement disputes based on the so-called single publication rule. ${ }^{1564}$ This rule has originally been adopted by United States courts with respect to multistate alleged defamatory publications. It enables the victim to recover in one forum from all damage caused by these publications throughout the United States of America. ${ }^{1565}$ This approach to jurisdiction protect defendants "from harassment resulting from multiple suits". ${ }^{1566}$

Yet the single publication rule will not automatically confer jurisdiction to the state of the plaintiff's domicile, the attribution of jurisdiction has to comply with the Due Process Clause of the Constitution of the United States of America. ${ }^{1567}$ In the Keeton v. Hustler Magazine case, involving the distribution of an alleged defamatory newspaper article, the United States Supreme Court therefore held that the contacts between the defendant and the forum state must be such that it is "fair" to sue the defendant regarding the entire damage in the forum state. ${ }^{1568}$ With respect to the dissemination of infringing content via the internet, courts generally ruled that there should be "something more" than the mere accessibility of this content. ${ }^{1569}$ The United States Supreme Court held that the distribution of defamatory material must be intentional, foreseeable and of a substantial amount in order to establish jurisdiction. ${ }^{1570}$ The latter seems to indicate that a court can only obtain full jurisdiction if the alleged damage has been foreseeable and substantial in the forum state. Adopting the 'substantial damages' criterion under Article 7(2) Brussels Ibis will entail a close territorial link between the copyright infringement dispute and the forum. It is, however, questionable whether this link will be strong enough to justify full jurisdiction. Chapter six will examine several effects-based approaches to jurisdiction in cross-border copyright infringement cases. ${ }^{1571}$

In view of the principles of private international law, a strong enough connection between dispute and forum will be favourable from a perspective of the sound administration of justice; it will enable the court to be in a good position to assess the entire cross-border copyright infringement case. In addition, the potential copyright infringer will generally be able to predict to get sued in the state where there is a strong connection between the dispute and the court.

In view of public international law, it can be advocated to adopt the abovementioned 'strong territorial connection' requirement to justify that the court obtains jurisdiction regarding the entire copyright infringement dispute based on effects in the forum state. Pursuant to public

\footnotetext{
1564 Ginsburg 1998, pp. 239-406. See De Groote 2004, pp. 256-258.

1565 Anonymous 2010, pp. 1315-1338.

${ }^{1566}$ Keeton v. Hustler Magazine, 465 US 770 at 777 (1984).

${ }^{1567}$ De Groote 2004, p. 257. The Due Process clause of the Fifth Amendment of the Constitution of the United States of America binds the federal government and therefore the federal courts. See US Const., Amd. IV: "No person shall be... deprived of life, liberty, or property, without due process law". The Due Process clause of the Fourteenth Amendment binds the states and therefore the state courts. See US Const., Amd. XIV: "No State shall ... deprive any person of life, liberty, or property without due process of law." See chapter 7 on Due Process Clause-based approach to jurisdiction established by the United States Supreme Court.

${ }^{1568}$ Keeton v. Hustler Magazine, 465 US 770 at 775 (1984).

${ }^{1569}$ Hay, Borchers \& Symeonides 2010, p. 465. Chapter seven will demonstrate that courts in the United States of America generally require something more than mere effects in the forum state to establish jurisdiction in crossborder copyright infringement cases.

${ }^{1570}$ Keeton v. Hustler Magazine, 465 US 770 at 775 (1984).

${ }^{1571}$ See paragraph 6.4.3 on Article 6 of the Dreyfuss and Ginsburg-Convention of 2002; paragraph 6.4.4 on Article 12a MPI Proposal of 2001; paragraph 6.4.5 on Article 2:202 and 2:203(2) CLIP Principles of 2011.
} 
international law, "jurisdiction is an aspect of a State's sovereignty". ${ }^{1572}$ It seems legitimate that a state confers civil jurisdiction to courts regarding activities or persons within the forum state. ${ }^{1573}$ With respect to jurisdiction based on alleged tortious effects in the forum state, paragraph 2.1.2.2.2 indicates that this jurisdiction does not need to be regarded as extraterritorial as the effects constitute a territorial link with the forum state. ${ }^{1574}$ Yet, when the court obtains jurisdiction regarding the entire tort case, this will include effects and activities outside the forum state.

It has frequently been argued that globalisation and internet entail "competing claims for jurisdiction" as each state can generally adopt its own private international law rules related to jurisdiction. ${ }^{1575}$ "Concurrent claims can give rise to too great a regulatory burden thereby making legal compliance difficult". ${ }^{1576}$ Hence, it has been asserted to "adjust territorial accepted links" to establish jurisdiction, "in light of the new environment". 1577 "In an interconnected world, an entitling link must be a compromise between, on the one hand, the interests of States (and their subjects) in regulating transnational activity affecting them and, on the other hand, the need to limit the number of States asserting a regulatory right over the same activity."1578 Several scholars have therefore claimed to search for "the 'worthiest' State (or legal system), the one most closely connected to the facts of the case". ${ }^{1579}$

As demonstrated in the previous paragraph, considering the principle of international comity, a state must consider the rights and interests of other states. The principle of comity has been applied in the context of private international law related to adjudicative jurisdiction. ${ }^{1580}$ In view of international comity, a court may not adjudicate "when another court is better placed to adjudicate". ${ }^{1581}$ There can be a breach of comity if a court adjudicates a case in such a way

1572 Ryngaert 2015(b), p. 50. See also Mann 1964, p. 30; Mann 1984 p. 20; Michaels 2004, p. 106. See also paragraph 2.1.2.2.1.

${ }_{1573}$ Mann 1964, p. 74, 76. See also Briggs 2012, p. 116; Michaels 2004, p 112.

1574 See also Briggs 2012, p. 117.

1575 Wautelet 2004, p. 60. See also Kohl 2010, pp. 4-5, 19, 22; Ryngaert \& Vagias 2019. As mentioned in chapters one and two, the Member States of the European Union are nonetheless bounded by private international law enacted by the European Union.

${ }^{1576}$ Kohl 2010, p. 22. Svantesson argued that "in an era of jurisdictional hyperregulation, there is a clear metatrend of states making overly broad... claims of jurisdiction". Due to this trend, states "may become increasingly dependent on the cooperation of other states for the enforcement of those claims". See Svantesson 2019(a), p. 51. Particularly, "many states make broad claims of jurisdiction over internet activities- claims that cannot possibly back up with effective enforcement". See Svantesson 2019(a), p. 50.

1577 Kohl 2010, p. 23. Paragraph 2.1.2.1.5.1 on globalisation and global governance briefly describes that the position and power of the initial absolute sovereign states have changed in the new world order. See also Michaels's view on the shift of the meaning of territoriality in the context of jurisdiction as demonstrated in paragraph 2.1.2.1.1.

1578 Kohl 2010, p. 23.

${ }^{1579}$ Kohl 2010, p. 20. See also Mills 2014, p. 208. Mills argues that "private international law rules on jurisdiction may recognize that certain subject matters are so closely connected with a single state that the courts of that state should have exclusive jurisdiction". In case the concept of state will be replaced by the concept of communities, as suggested by Berman (see paragraphs 2.1.2.2.1 and 2.1.2.1.5.1), Ryngaert argues that "jurisdiction then becomes a function of which community has (the strongest) ties with the dispute". See Ryngaert 2015(c), p. 76.

${ }^{1580}$ Briggs 2012, pp. 116-144; Schultz \& Ridi 2018, pp. 227-233.

${ }^{1581}$ Briggs 2012, p. 85. 
that it interferes with the jurisdiction of a court in another state. ${ }^{1582}$ As a result the judgment may not be recognized outside the territory of the adjudicating court. ${ }^{1583}$

In light of the foregoing, it can be advocated that a 'strong territorial connection' between the cross-border copyright infringement dispute and the forum could justify full jurisdiction of the court of the Erfolgsort under Article 7(2) Brussels Ibis since the latter court will likely be more suitable to assess the entire dispute compared to courts in other states. Furthermore, this connecting factor has a "strong territorial component" that suits the territorial definition of states. ${ }^{1584}$

The next chapters will demonstrate that courts and scholars generally adopted 'additional' connecting factors to provide full jurisdiction to the court of the Erfolgsort in cross-border copyright infringement cases. Whether the alternative connecting factors 'carry enough weight' to confer full jurisdiction to the court of the Erfolgsort under Article 7(2) Brussels Ibis will foremost be assessed on the basis of the assessment framework in paragraph 4.6. Furthermore, it will be considered whether the close connection between the dispute and forum state is strong enough to justify full jurisdiction such as "a strong territorial link between the dispute and the forum" 1585 .

\subsubsection{The application of a single copyright law}

As demonstrated in paragraph 5.3.3.1, in view of the principle of international comity, the lack at worldwide level of a uniform copyright law or conflict-of-laws rule related to crossborder copyright infringements may impede the court of the Erfolgsort under Article 7(2) Brussels Ibis to issue a cross-border injunction that has worldwide effects and to assess the entire damage alleged caused by a copyright infringement dispute. Since the lex loci protectionis rule in Article 8(1) Rome II is applicable in all European Union Member States, a Member State court of the Erfolgsort under Article 7(2) Brussels Ibis seems to be allowed to assess the alleged damage that occurred in the European Union and to issue a cross-border injunction that has effects within the European Union. ${ }^{1586}$ Due to the lex loci protectionis rule, the court that has obtained full jurisdiction in a multistate copyright infringement dispute will have to apply various national copyright laws which increases the costs and the length of the procedure. ${ }^{1587}$ In view of efficient proceedings, it is therefore desirable that the latter court can apply only one copyright law, instead of multiple national copyright laws, to assess the entire cross-border copyright infringement dispute. ${ }^{1588}$

\footnotetext{
1582 Briggs 2012, p. 117.

1583 Briggs 2012, p. 117.

${ }^{1584}$ Michaels 2004, p. 113. See also paragraph 2.1.2.2.2.

${ }^{1585}$ Pertegás Sender 2002, p. 276.

${ }^{1586}$ See paragraph 5.3.3.1 on the view that divergences of conflict-of-laws rules in copyright infringement cases may limit the court's competence to issue an injunction with extraterritorial effects due to "the interests of international comity". See Opinion of Advocate General Szpunar delivered on 4 June 2019 in the case C-18/18 Eva Glawischnig-Piesczek v. Facebook Ireland Limited, para. 100-101.

${ }^{1587}$ See also Kur 2005, p. 326. See also Trimble on the problem of the availability and costs of evidence to prove multistate copyright infringements. See Trimble 2019(a), p. 7; Trimble 2019(b), pp. 512-514.

${ }^{1588}$ See the paragraph 2.2.2.2 and 2.3.4.2. See also Trimble 2019(b), pp. 512-514.
} 
The Dutch Supreme Court and the CLIP group appear to adhere to the view that consolidation of adjudication in infringement of intellectual property right cases requires the application of a single law. In the case of Interlas $v$. Lincoln, the Dutch Supreme Court issued a cross-border injunction regarding trade mark infringing activities in Netherlands, Belgium and Luxembourg ${ }^{1589}$ by applying the Benelux trademark law ${ }^{1590}$ that granted a unitary trade mark in the Member States of the Benelux Union. ${ }^{1591}$ The same line of reasoning can be found in the CLIP Principles regarding cross-border injunctions in ubiquitous infringements of intellectual property cases. Based on the conditions enumerated in Article 2:202 CLIP and Article 2:203(2) CLIP, the CLIP Principles confer full jurisdiction to the court of the place where the infringement occurred or may occur in respect of infringements carried out through ubiquitous media. ${ }^{1592}$ With respect to the scope of an injunction, Article 2:604(2) CLIP Principles stipulates "the injunction shall be presumed to concern intellectual property rights protected in all States where the signals can be received" provided that the competent court applied a single law as stipulated in Article 3:603 CLIP. According to Article 3:603 CLIP, "in disputes concerned with infringement carried out through ubiquitous media such as the Internet, the court may apply the law of the State having the closest connection with the infringement if the infringement arguably takes place in every State in which the signals can be received". Article 3:603(2) enumerates factors to be considered when determining the closest connection with the infringement. In addition, any party can also prove that another law is essential for the decision which the court has to take into account. ${ }^{1593}$

As long as there is no uniform copyright law, the application of a single copyright law in case of a multistate copyright infringement dispute will only be possible by establishing a conflict-of-laws rule that refers to the application of the copyright law of a particular state. As mentioned in paragraph 2.3.4.2, several scholars suggested connecting factors to apply a single copyright law, instead of multiple copyright laws based on the lex loci protectionis rule, in multistate copyright infringement disputes. A new European Union conflict-of-laws rule for infringements of copyrights that refers to the national copyright law of one Member State will enhance efficient adjudication and sound administration of justice. The establishment of a new conflict-of-laws rule is, however, a matter which falls outside the scope of this dissertation.

\subsubsection{European Union copyright courts or a Unified Copyright Court?}

As mentioned in paragraph 3.6, the European Union has forced Member States to establish several specialized courts for particular intellectual property disputes such as European Union

\footnotetext{
${ }^{1589}$ Netherlands, Belgium and Luxembourg are Member States of the Benelux Union established on 5 September 1944 and the renewal was signed on 17 June 2008.

${ }^{1590}$ Benelux trademark law entered into force 1 January 1971 and has been replaced by the Benelux Convention on Intellectual Property, which was signed on 25 February 2005 and entered into force 1 September 2006.

${ }^{1591}$ Hoge Raad 24 November 1989 Interlas v. Lincoln, para. 4.2.3. See also paragraph 5.3.1.

${ }^{1592}$ See paragraph 6.4.5 on the conditions of the combined approach to jurisdiction under Article 2:202 and 2:203(2) CLIP Principles.

${ }^{1593}$ Article 3:603(3) CLIP Principles.
} 
trade mark courts ${ }^{1594}$, Community design courts ${ }^{1595}$, and Community patent courts ${ }^{1596}$. These courts are national courts established by virtue of European Union law that contains specific procedural rules. ${ }^{1597}$ While the Brussels Ibis Regulation will generally be applicable, certain of these specific procedural rules overrule this Regulation, for instance, in infringements and validity issues. ${ }^{1598}$ At regional level, the European Union aims to establish the Unified Patent Court for the settlement of disputes relating to European patents and European patents with unitary effect. ${ }^{1599}$ To date, only sixteen Member States have ratified the Agreement on a Unified Patent Court. ${ }^{1600}$ When Germany ratifies this Agreement, the project will move to the phase of provisional application. ${ }^{1601}$

The abovementioned specialized courts are deemed to enhance the protection of the intellectual property rights involved for a proper functioning of the internal market. ${ }^{1602} \mathrm{De}$ Werra pointed out that there is actually no clear evidence that specialized courts will enhance the protection of intellectual property rights. ${ }^{1603}$ Instead of specialized courts for intellectual property disputes, De Werra suggested to create specialist intellectual property benches within regular courts or to ask legal advice from third party-experts. ${ }^{1604}$

There are advantages and disadvantages to specialised courts for intellectual property rights. ${ }^{1605}$ Due to specialized and experienced judges, specialized courts will generally ensure uniform and coherent decisions that "improve the quality of justice" available to intellectual property holder. ${ }^{1606}$ The procedures will also be efficient and the risk of forum shopping will be reduced. ${ }^{1607}$ However, the costs of operating specialized courts can be a major

\footnotetext{
${ }^{1594}$ Article 123-126 of the European Union trade mark Regulation.

1595 Article 80-83 of the Council Regulation (EC) No 6/2002 of 12 December 2001 on Community designs (OJ L 3, 5.1.2002, pp. 1-24), hereinafter the Community designs Regulation.

${ }^{1596}$ See the Protocol on the settlement of litigation concerning the infringement and validity of community patents (Protocol on litigation) (OJ L 401, 30.12.89, pp. 34-44) annexed to the Convention for the European Patent for the common market (OJ L 71, 26.1.1976, pp. 1-28).

1597 See the European Union trade mark Regulation; the Community designs Regulation; the Protocol on the settlement of litigation concerning the infringement and validity of community patents; the Convention for the European Patent for the common market.

${ }^{1598}$ Articles 122-126 of the European Union trade mark Regulation. See also Case C-360/12 Coty Germany GmbH v. First Note Perfumes NV, para. 25-38. For more details on the Coty ruling, see paragraph 5.2.3.1.3. Articles 8183 of the Community designs Regulation; Articles 13-19 of the Protocol on the settlement of litigation concerning the infringement and validity of community patents; Article 68-73 of the Convention for the European Patent for the common market.

1599 Agreement on a Unified Patent Court (OJ C 175, 20.6.2013, pp. 1-40). Regulation (EU) No 1257/2012 of the European Parliament and of the Council of 17 December 2012 implementing enhanced cooperation in the area of the creation of unitary patent protection (OJ L 361, 31.12.2012, pp. 1-8).

1600 The United Kingdom has already ratified the Agreement on a Unified Patent Court and intends to be bound after the Brexit. See for the progress on the Unified Patent Court Project: https://www.unified-patentcourt.org/news; https://www.consilium.europa.eu/en/documents-publications/treatiesagreements/agreement/?id=2013001\&DocLanguage=en.

${ }^{1601}$ See https://www.unified-patent-court.org/news/status-unified-patent-court-project-19-december-2018.

1602 Recitals 31 and 32 in the preamble to the European Union trade mark Regulation and recitals 1-6 in the preamble to the Community designs Regulation. See preamble to the Agreement on a Unified Patent Court.

${ }^{1603}$ De Werra 2016, p. 30.

${ }^{1604}$ De Werra 2016, p. 31

1605 De Werra 2016, pp. 28-31.

${ }^{1606}$ De Werra 2016, p. 30. See also Petersen, Riis \& Schovsbo 2015, p. 56.

${ }^{1607}$ De Werra 2016, p. 30. See also Petersen, Riis \& Schovsbo 2015, p. 56.
} 
disadvantage. ${ }^{1608}$ The high costs of pleading before these courts may impede the access to justice. ${ }^{1609}$ It has also been argued that specialized courts are more prone to political and economic influences than general courts. ${ }^{1610 ~ " C e n t r a l i s a t i o n ~ m a y ~ a l s o ~ i n h i b i t ~ t h e ~ e x c h a n g e ~ o f ~}$ legal ideas and lead to perpetuation of errors", "tunnel vision" will therefore be a risk. ${ }^{1611}$

This dissertation will not further elaborate on the issue whether there should exist specialized national copyright courts or a Unified Copyright Court. As long as, there does not exist a European Union copyright, it does not even seem possible that European Union copyright courts or a Unified Copyright Court will come into existence. When these courts do come into existence, they will require procedural rules including rules on jurisdiction. ${ }^{1612}$ The connecting factors that will be proposed in this dissertation could possible also be employed in the potential European Union copyright Regulation regarding specialized copyright courts.

\subsection{Concluding remarks}

This chapter has demonstrated that the CJEU's approach to jurisdiction in cross-border copyright infringement cases appears to encroach the main principles underlying the special jurisdiction rule of Article 7(2) Brussels namely to enhance predictability; a close connection between the dispute and the court; sound administration of justice; and a procedural balance between the litigants. ${ }^{1613}$ The CJEU's approach also seems to strike no balance between the broader interests related to copyrights. ${ }^{1614}$ In view of the CJEU's role as law-finder, the CJEU's interpretation could therefore be regarded as illegitimate judicial activism ${ }^{1615}$. While the Pinckney doctrine has been based on the policy aim that copyrights should be protected in all Member States, the CJEU neglected the principles of private international law. This conclusion meets the criticism of several scholars that the instrumentalisation of private international law in the European Union must not "degraded" private international law "into an auxiliary instrument" of European Union law. ${ }^{1616}$ Van Den Eeckhout even raised questions related to legitimacy: supposing that 'the dogma 'neutral PIL' is abandoned... what interest can or may PIL serve at the end of the day?". ${ }^{1617}$

This chapter has also examined the effects of the territorial protection of copyrights on the attribution of jurisdiction under Article 7(2) Brussels Ibis in cross-border copyright infringement cases. Arguments have been provided against the locus protectionis criterion as prerequisite for jurisdiction in copyright infringement cases. This connecting factor will not yield predictability or a 'close connection' between the dispute and court. In view of the Berne

\footnotetext{
${ }^{1608}$ De Werra 2016, p. 30.

${ }^{1609}$ De Werra 2016, p. 30.

${ }^{1610}$ De Werra 2016, p. 30; Petersen, Riis \& Schovsbo 2015, p. 46.

${ }^{1611}$ De Werra 2016, p. 30. See also Petersen, Riis \& Schovsbo 2015, p. 45.

1612 De Werra 2016, p. 30.

${ }^{1613}$ See the assessment framework of paragraph 4.6.

${ }^{1614}$ See the assessment framework of paragraph 4.6.

1615 See paragraph 4.1.1.1 on the concept of judicial activism and paragraph 4.1.3 on the concept of law-finder.

${ }^{1616}$ Meeusen 2007, p. 287. See also paragraph 1.2.

1617 Van Den Eeckhout 2013(a), p. 11. See also Van Den Eeckhout 2002, p. 145; Van Den Eeckhout 2013(b), p. 2.
} 
Convention of 1979, the locus protectionis criterion can remain an implicit criterion at the jurisdictional level. With respect to the scope of the court's jurisdiction under Article 7(2) Brussels Ibis, it has been argued that the principle of efficiency of court proceedings may prevent the limitation of jurisdiction based on the territorial principle related to copyrights. ${ }^{1618}$

Yet, in view of the principle of international comity, the lack at worldwide level of a uniform copyright law or conflict-of-laws rule related to cross-border copyright infringements may impede the court of the Erfolgsort under Article 7(2) Brussels Ibis to issue a cross-border injunction that has worldwide effects and to assess the entire damage alleged caused by a copyright infringement dispute. Based on the lex loci protectionis rule in Article 8(1) Rome II, the court of the Erfolgsort that obtains full jurisdiction under Article 7(2) Brussels Ibis nonetheless seems to be allowed to issue a cross-border injunction that concerns infringing activities within the territories of the European Union Member States and to assess the damage in these territories. In view of the sound administration of justice, it will be desirable to establish a conflict-of-laws rule that refers to one applicable copyright law in a ubiquitous copyright infringement dispute.

The next two chapters will demonstrate alternative approaches to jurisdiction proposed by scholars and adopted by courts of European Union Member States and states of the United States of America in cross-border copyright infringement cases. These factors will be examined in light of the assessment framework of paragraph 4.6. As argued in paragraph 5.3.4.1, the connection between the dispute and the court should be strong enough to justify jurisdiction with respect to the entire dispute.

1618 See paragraph 5.3.2. 


\section{Chapter 6}

Alternative approaches to jurisdiction in cross-border copyright infringement cases established by scholars and courts of European Union Member States 

Based on scholarly proposals and case law of courts of European Union Member States, this chapter will examine various approaches to jurisdiction in cross-border copyright infringement disputes. In order to be employed as a legitimate alternative to the Pinckney doctrine, ${ }^{1619}$ these approaches will be examined in light of the assessment framework of paragraph 4.6. This implies that the alternative approach has to satisfy the principle of predictability; entail a close connection between the dispute and forum state; and facilitate the sound administration of justice. ${ }^{1620}$ The approach to jurisdiction should also balance the procedural interests between the litigants as well as the broader interests between copyright holders, on the one hand, and users of information and traders, on the other hand. ${ }^{1621}$

In addition, this chapter will consider the impact of the Geo-blocking Regulation on the alternative approaches to jurisdiction in cross-border copyright infringement cases. ${ }^{1622}$ As will be demonstrated in this chapter, the use of geo-blocking technologies has frequently been a relevant factor to determine whether a court can obtain jurisdiction in cross-border copyright infringement cases. ${ }^{1623}$ The assessment in view of the Geo-blocking Regulation will be particularly relevant as the alternative approaches have been proposed before the enactment of this Regulation in 2018.

\subsection{The 'directed activities' approach ${ }^{1624}$}

Several legal scholars and European Union Member State courts have favoured the socalled 'directed activities' approach under Article 7(2) Brussels Ibis in cross-border copyright infringement disputes. ${ }^{1625}$ Pursuant to this approach, the court seised may only establish jurisdiction if the defendant's alleged infringing activities have been directed to the residents of the forum state. ${ }^{1626}$ The 'directed activities' criterion focuses on the "objective intention" of the alleged infringer to direct his activities to the residents of the forum state. ${ }^{1627}$ To assess the intention, the court seised has to consider all circumstances of the case. ${ }^{1628}$ The 'directed

1619 Paragraph 3.5 demonstrated the Pinckney doctrine derived from the three rulings: C-170/12 Peter Pinckney $v$. KGD Mediatech AG; Case C-387/12 Hi Hotel HCF SARL v. Uwe Spoering; Case C-441/13 Pez Hejduk v. EnergieAgentur NWR GmbH.

${ }^{1620}$ See paragraphs 4.2.4.2 and 4.6.

${ }^{1621}$ See paragraphs 4.2.4.2, 4.4 and 4.6.

${ }^{1622}$ See paragraphs 4.5 up to and including 4.5.4 on the Geo-blocking Regulation.

${ }^{1623}$ See, for instance, Article 6 of the Dreyfuss and Ginsburg-Convention of 2002 in paragraph 6.4.3.

1624 The 'directed activities' approach has also been referred to as the targeting approach, see for instance Advocate General Jääskinen in his Opinion delivered on 13 June 2013 in the case C-170/12 Peter Pinckney v. KGD Mediatech $A G$, para. 53-66. See paragraph 5.2.1. This dissertation will set out the difference between the 'directed activities' approach and the targeting approach in paragraph 7.5.3.1.

${ }^{1625}$ See, inter alia, Advocate General Jääskinen in his Opinion delivered on 13 June 2013 in the case C-170/12 Peter Pinckney v. KGD Mediatech AG, para. 53-66. See also Depreeuw \& Hubin 2014, p. 764; Husovec 2014, p. 373. Paragraph 6.1.3 will demonstrate the 'directed activities'-based escape clause proposed by the CLIP group in Article 2:202 CLIP. Paragraph 6.1.1 will set out case law of courts of European Union Member States that adopted the 'directed activities' approach in cross-border copyright infringement cases.

1626 See Maunsbach 2012, p. 182.

${ }^{1627}$ See Van Eechoud 2013, pp. 173-174. See paragraph 6.1.2 on the 'objective' criteria enumerated in the Pammer and Alpenhof ruling.

${ }^{1628}$ See Van Eechoud 2013, pp. 173-174. See the joined Cases C-585/08 and C-144/09 Peter Pammer v. Reederei Karl Schlütter GmbH \& Co. KG and Hotel Alpenhof GesmbH v. Oliver Heller, para 80-94. See also paragraph 6.1.2 on the 'directed activities' approach in the Pammer and Alpenhof ruling. With respect to the 'directed 
activities' criterion may, for instance, be satisfied when the online alleged infringing content has been available in the language of the forum state or the infringing products could be delivered in the forum state. ${ }^{1629}$

The jurisdiction of the court on the basis of the 'directed activities' criterion will generally be limited to the damage caused within the forum state. ${ }^{1630}$ Hence, the 'directed activities' approach usually consists of a combination of the 'directed activities' criterion and the mosaic approach. ${ }^{1631}$ Several scholars argue that the 'directed activities' approach usually entails a close connection between the factual elements of the copyright infringement dispute and the court. ${ }^{1632}$ In the AMS Neve ruling, the CJEU has also pointed out the principle of proximity to support the adoption of the 'directed activities' approach to establish jurisdiction in a EU trade mark infringement case. ${ }^{1633}$ From a perspective of lower costs and burden of litigation, the 'directed activities' approach has been favored since the damage will usually be significant in the state where the public is targeted. ${ }^{1634}$ It has been noted that the 'directed activities' approach is reminiscent of the commercial effects-based approach in the Joint Recommendation Concerning Provisions on the Protection of Marks, and Other Industrial Property Rights in Signs ${ }^{1635}$ that will be discussed in paragraph 6.1.3.2.

Advocate General Jääskinen has been a proponent of the 'directed activities' approach under Article 7(2) Brussels Ibis in internet-related copyright infringement disputes. ${ }^{1636}$ In the Pinckney case, Jääskinen argued that alleged infringements of distribution and communication rights via the Internet should be aimed at the public of the forum state in order to establish jurisdiction based on the Erfolgsort. ${ }^{1637} \mathrm{He}$ asserted that the 'directed activities' approach is in line with the territorial principle related to copyrights; it entails a link between the alleged conduct and a given territory. ${ }^{1638}$ Jääskinen also referred to the CJEU's approach of the

activities' approach to jurisdiction in Article 2:202 CLIP, see Kur 2013(a), p. 75, 2:202. C17. Paragraph 6.1.3 will demonstrate the 'directed activities'-based escape clause in Article 2:202 CLIP.

${ }^{1629}$ See Brachotte \& Nuyts 2014, p. 241. For more factors to determine the 'directed activities' criterion, see paragraph 6.1.2 on the 'directed activities' approach in the Pammer and Alpenhof ruling.

${ }^{1630}$ See the so-called mosaic approach demonstrated in paragraph 1.1.4. See also paragraphs 6.1.3.2 and 6.4.5 on the territorially limited approach of the 'directed activities'-based jurisdiction according to Article 2:202 and 2:203(1) CLIP.

${ }^{1631}$ See paragraph 1.1.4 on the mosaic approach.

1632 Brachotte \& Nuyts 2014, pp. 240-241; Van Eechoud 2013, p. 176.

1633 Case C-172/18 AMS Neve Ltd and Others v. Heritage Audio SL, Pedro Rodriguez Arribas. See paragraph 3.6.1.

${ }^{1634}$ Depreeuw \& Hubin 2014, p. 764.

1635 The Joint Recommendation Concerning Provisions on the Protection of Marks, and Other Industrial Property Rights in Signs, on the Internet adopted by the Assembly of the Paris Union for the Protection of Industrial Property and the General Assembly of the World Intellectual Property Organization (WIPO) at the Thirty Sixth Series of Meetings of the Assemblies of the Member States of WIPO 24 September to 3 October 2001.

${ }^{1636}$ See the Opinion of Advocate General Jääskinen in the case C-170/12 Peter Pinckney v KDG Mediatech AG.

1637 See paragraph 3.2 .2 on Jääskinen's view regarding the importance of the distinction between alleged infringement of the reproduction right, on the one hand, and the alleged infringements of the distribution right or communication right, on the other hand.

${ }^{1638}$ Opinion of Advocate General Jääskinen in the case C-170/12 Peter Pinckney v KDG Mediatech AG, para. 50. Although Advocate General Cruz Villalón in the Pez Hejduk case asserted that only the court of the place of the defendant's domicile or the court of the Handlungsort should obtain jurisdiction regarding alleged online copyright infringements (para. 45), he did indicate that another connecting factor might be possible in case the alleged infringements were particularly directed at one or more other Member States (para. 46). See paragraph 3.4.2. 
localisation of alleged intellectual property infringements at substantive level. ${ }^{1639}$ Based on the territorial protection of various rights, the CJEU held in several rulings that the alleged infringing conduct has to be aimed at the residents of the forum state to cause an infringement in that state. ${ }^{1640}$ According to Jääskinen, the adoption of the 'directed activities' approach both as jurisdiction criterion and to localise copyright infringements on substantive level would ensure "consistency in its case law". ${ }^{1641}$ In the Football Dataco and Others ruling, the CJEU even noted that the question of localisation of the infringing acts of generis rights in databases "is liable to have an influence on the question of the jurisdiction of the referring court". ${ }^{1642}$

To determine whether activities have been directed to the residents of the forum state, Jääskinen referred to the non-exhaustive list of criteria enumerated in the Pammer and Alpenhof ruling. ${ }^{1643}$ Yet, he argued that "those criteria should be applied by the national courts with a certain flexibility". ${ }^{1644}$ Paragraph 6.1.2 will discuss the Pammer and Alpenhof ruling. Based on case law, the next paragraph will demonstrate that several courts of European Union Member States have employed the 'directed activities' approach to establish jurisdiction in cross-border copyright, or trademark, infringement disputes.

\subsubsection{The 'directed activities' approach in case law of courts of European Union Member States}

With respect to an internet-related copyright infringement dispute, the German Court of Appeals (Oberlandesgericht) in Köln rejected the mere accessibility of the website as basis for jurisdiction under Article 5(3) Brussels I, currently Article 7(2) Brussels Ibis. ${ }^{1645}$ The Court of Appeals referred to the decision of the German Federal Court of Justice (Bundesgerichtshof) in the Hotel Maritime case involving an internet-related trademark infringement. ${ }^{1646}$ In the Hotel Maritime ruling, the German Federal Court of Justice held that the alleged online trademark infringement had to be directed to the residents of Germany to establish jurisdiction based on the Erfolgsort under former Article 5(3) Brussels Convention of 1968, current Article 7(2) Brussels Ibis. ${ }^{1647}$ In the latter case, the plaintiff had been the holder of a European Union and German trademark regarding the name 'Maritime' of a German hotel. The plaintiff claimed that the defendant infringed this trademark by employing the name 'Maritime' to online advertise for a hotel in Denmark. The particular website 'www.hotelmaritime.dk' was available in the

\footnotetext{
${ }^{1639}$ Opinion of Advocate General Jääskinen in the case C-170/12 Peter Pinckney v KDG Mediatech para. 59-65.

${ }^{1640}$ See the Cases C-324/09 L'Oréal and Others $v$. eBay, para 65, involving alleged infringements of national and Community trademarks; Case C-5/11 Donner, para. 28, concerning an alleged infringement of an author's exclusive distribution right; Case C-173/11 Football Dataco and Others v. Sportrader, para 39, involving an infringement of the sui generis right over a database. See also Van Eechoud 2013, pp. 169-178.

${ }^{1641}$ Opinion of Advocate General Jääskinen in the case C-170/12 Peter Pinckney v KDG Mediatech, para. 63. See also Husovec 2014, p. 373.

1642 See Case C-173/11 Football Dataco and Others, para. 30

1643 Joined Cases C-585/08 and C-144/09 Peter Pammer v. Reederei Karl Schlüter GmbH \& Co. KG and Hotel Alpenhof GesmbH v. Oliver Heller.

${ }^{1644}$ Opinion of Advocate General Jääskinen in the case C-170/12 Peter Pinckney v KDG Mediatech, para. 66.

1645 Oberlandesgericht Köln (OGL), 30 October 2007, 6 W 161/07 (Internet-Fotos), para. 5.

1646 Bundesgerichtshof (BGH), 13 October 2004, I ZR 163/02 (Hotel Maritime).

${ }^{1647}$ Bundesgerichtshof (BGH), 13 October 2004, I ZR 163/02 (Hotel Maritime). para. 18-20.
} 
Danish, English and German language and offered the possibility to make an online reservation in these languages. ${ }^{1648}$ In addition, it provided the possibility to request a brochure in German language that could be sent to Germany. ${ }^{1649}$ According to the German Federal Court of Justice, the content of the website had therefore been directed to Germany. ${ }^{1650}$

In view of the Hotel Maritime ruling, the Court of Appeals in Köln held that this 'directed activities' criterion also has to be applied to establish jurisdiction based on the Erfolgsort regarding internet-related copyright infringing activities committed with a commercial purpose. ${ }^{1651}$ The Court of Appeals argued that the website involving the alleged copyright infringing photos had not been directed to Germany. ${ }^{1652}$ Although the website provided the possibilities of worldwide delivery and to pay in euros, the German Court of Appeals found it crucial that the country code top-level domain name of the website was "uk" and the content of the website was not available in the German language. ${ }^{1653}$

With respect to the interpretation of the Erfolgsort in online trademark infringement disputes, the French Supreme Court (Cour de Cassation) has frequently employed the 'directed activities' approach. ${ }^{1654}$ In the case of Google v. Louis Vuitton, the French Supreme Court explicitly rejected the mere accessibility approach and ruled that the alleged infringing activities had to be directed to the consumers in France to establish jurisdiction in the Erfolgsort. ${ }^{165}$ The Court reasoned that the 'directed activities' approach entails a close connection between the dispute and the court that will be required in order to deviate from the main jurisdiction principle actor sequitur forum rei. ${ }^{1656}$ The Court emphasised that this 'close connection' requirement allows the defendant to reasonably foresee in which state he may get sued. ${ }^{1657}$ These considerations are in accordance with the preamble to the Brussels Ibis Regulation that "the existence of a close connection should ensure legal certainty and avoid the possibility of the defendant being sued in a court of a Member State which he could not reasonably have foreseen". ${ }^{1658}$

\footnotetext{
${ }^{1648}$ Bundesgerichtshof (BGH), 13 October 2004, I ZR 163/02 (Hotel Maritime), para 5.

1649 Bundesgerichtshof (BGH), 13 October 2004, I ZR 163/02 (Hotel Maritime), para 5.

1650 Bundesgerichtshof (BGH), 13 October 2004, I ZR 163/02 (Hotel Maritime), para. 18-20. See Metzger (2009, p. 256) on the case of Hotel Maritime and several other intellectual property infringements cases in which German courts adopted the 'directed activities' approach to establish jurisdiction.

${ }_{1651}$ Oberlandesgericht Köln (OGL), 30 October 2007, 6 W 161/07 (Internet-Fotos), para. 5.

1652 Oberlandesgericht Köln (OGL), 30 October 2007, 6 W 161/07 (Internet-Fotos), para. 6.

1653 Oberlandesgericht Köln (OGL), 30 October 2007, 6 W 161/07 (Internet-Fotos), para. 6.

${ }^{1654}$ Cour de Cassation, civile, Chambre commerciale 13 July 2010, no. 06-20.230 (Google v. Louis Vuitton); Cour de Cassation, civile, Chambre commerciale, 23 November 2010, no. 07-19.543 (Axe v. Google). See also Cour de Cassation, civile, Chambre commerciale 29 March 2011, no. 10-12.272 (eBay Europe v. Maceo). See LopezTarruella 2012, pp. 336-341.

${ }^{1655}$ Cour de Cassation, civile, Chambre commerciale 13 July 2010, no. 06-20.230 (Google v. Louis Vuitton). In the case of Google v. Louis Vuitton, the French Supreme Court (Cour de Cassation) refers to Article 46 French New Code of Civil Procedure in relation to the special jurisdiction rule of Article 7(2) Brussels Ibis. This case concerned the interpretation of Article 46 French New Code of Civil Procedure that stipulates "the plaintiff may bring his case, at his choosing, besides the court of the place where the defendant lives, before: ... in tort matters, the court of the place where the event causing liability or the one in whose district the damage was suffered".

${ }^{1656}$ Cour de Cassation, civile, Chambre commerciale 13 July 2010, no. 06-20.230 (Google v. Louis Vuitton), para. 1.

${ }_{1657}$ Cour de Cassation, civile, Chambre commerciale 13 July 2010, no. 06-20.230 (Google v. Louis Vuitton), para. 1.

${ }^{1658}$ See recital 16 in the preamble to the Brussels Ibis Regulation.
} 
In the case of Axa v. Google, the French Supreme Court provided factors that could indicate that the alleged trademark infringing activities were directed to the forum state. ${ }^{1659}$ The French Supreme Court held that the mere accessibility of the websites "google.de, google.co.uk and google.ca" involving the alleged infringing activities was not sufficient to establish jurisdiction. ${ }^{1660}$ The country code top-level domain names of these websites ${ }^{1661}$ and the fact that they employed the English and German language indicated that they were not directed to the residents in France. ${ }^{1662}$ The latter case provides thus the following two criteria to determine the 'directed activities' criterion: whether the website involved used the country code top-level domain name ${ }^{1663}$ of the forum state and whether the content of the website had been available in the language of the forum state. ${ }^{1664}$

Before the CJEU ruled in the Pinckney case, the Supreme Court of the Netherlands (Hoge RaAd) provided a remarkable interpretation of the Erfolgsort under Article 7(2) Brussels Ibis in a copyright infringement dispute. In the case of H\&Mv. G-Star, the Dutch company G-Star sued the multinational company H\&M, established in Sweden, for the sale of copyright infringing trousers in Dutch shops and via the website of H\&M "www.hm.com". ${ }^{665}$ The question raised whether the Dutch court could exercise jurisdiction based on the alleged copyright infringing products that had been offered for sale via the website involved. Analogue to the locus protectionis criterion of the Wintersteiger ruling, the Supreme Court noted that the alleged copyrights had been protected by Dutch law. ${ }^{1666}$ Subsequently, the Supreme Court argued that the Dutch court had jurisdiction because the alleged copyright infringing products had been available via the website involved and the website was directed to the residents of the Netherlands. ${ }^{1667}$ The latter seems to indicate that the Dutch Supreme Court applied the 'directed activities' approach to confer jurisdiction under Article 7(2) Brussels Ibis in cross-border copyright infringement cases. ${ }^{1668}$

\subsubsection{The 'directed activities' approach in the Pammer and Alpenhof ruling}

The joined cases of Peter Pammer v. Reederei Karl Schlüter GmbH \& Co. KG and Hotel Alpenhof GesmbH v. Oliver Heller concerned the issues whether the courts of the Member States in which consumers were domiciled could obtain jurisdiction under Article 17(1)(c)

\footnotetext{
${ }^{1659}$ Cour de Cassation, civile, Chambre commerciale, 23 November 2010, no. 07-19.543 (Axa v. Google).

${ }^{1660}$ Cour de Cassation, civile, Chambre commerciale, 23 November 2010, no. 07-19.543 (Axa v. Google).

${ }^{1661}$ Country code top-level domain names had been 'de' (Germany), 'uk' (United Kingdom of Great Britain and Northern Ireland) and 'ca' (Canada).

${ }^{1662}$ Cour de Cassation, civile, Chambre commerciale, 23 November 2010, no. 07-19.543 (Axa v. Google).

${ }^{1663}$ See also the Opinion of Advocate General Trstenjak delivered on 18 May 2010 in the joined cases C-585/08 and C-144/09 Peter Pammer v. Reederei Karl Schlütter GmbH \& Co. KG and Hotel Alpenhof GesmbH v. Oliver Heller, note 68.

${ }^{1664}$ See Lopez-Tarruella 2012, p. 341.

${ }^{1665}$ Hoge Raad 7 December 2012 H\&Mv. G-Star.

${ }^{1666}$ Hoge Raad 7 December 2012 H\&Mv. G-Star, para. 3.3.2.

${ }^{1667}$ Hoge Raad 7 December 2012 H\&Mv. G-Star, para. 3.3.2.

${ }^{1668}$ Based on Dutch case law between 2003 and 2010, Wefers Bettink demonstrated that Dutch courts have frequently adopted the 'directed activities' approach with respect to infringements of intellectual property rights. See case law referred to by Wefers Bettink 2011, note 16-32.
} 
Brussels Ibis in online consumer disputes. ${ }^{1669}$ Therefore, the CJEU had to interpret the connecting factor 'directed activities to the Member State of the consumer's domicile' laid down in the special jurisdiction rule of Article 17(1)(c) Brussels Ibis.

The CJEU interpreted "among the evidence related to directed activities are all clear expressions of the intention to solicit the custom of that State's consumers". ${ }^{1670}$ In addition, the CJEU provided a non-exhaustive list of factors to determine whether activities are directed to the forum state like "the international nature of the activity at issue, such as certain tourist activities; mention of telephone numbers with international code; use of a top-level domain name other than that of the Member State in which the trader is established, for example '.de', or use of neutral top-level domain name such as '.com' or '.eu'; the description of itineraries from one or more other Member States to the place where the service is provided, and mention of an international clientele composed of customers domiciled in various Member States, in particular by presentation of accounts written by such customers". ${ }^{1671}$ Whenever the website involved allows consumers to use a different language or currency than generally used in the Member State from where the trader pursues its activities, this may also constitute evidence of 'directing'. ${ }^{1672}$ Yet, the mention of the trader's email address, geographical address, or telephone number without an international code, will not constitute relevant evidence. ${ }^{1673}$

It has been argued that the CJEU's non-exhaustive list of factors in the Pammer and Alpenhof ruling could also be employed under Article 7(2) Brussels Ibis in cross-border copyright infringement cases to determine whether the infringing activities have been directed to the forum state. ${ }^{1674}$ According to Jääskinen, "those criteria should be applied by the national courts with a certain flexibility". ${ }^{1675}$ The criteria enumerated in the Pammer and Alpenhof ruling can be referred to as 'objective' factors since they do not relate to the actual intention of the defendant.

With respect to online infringements of European Union trade marks, the CJEU has adopted the 'directed activities' criterion and the related so-called Pammer and Alpenhof factors at both substantive and jurisdictional level. ${ }^{1676}$ In the case of L'Oréal and Others v. eBay, the CJEU seems to have applied a similar reasoning as in the Pammer and Alpenhof ruling to determine whether activities that allegedly infringed a European Union trade mark had been directed to

\footnotetext{
1669 Joined cases C-585/08 and C-144/09 Peter Pammer v. Reederei Karl Schlüter GmbH \& Co. KG and Hotel Alpenhof GesmbH v. Oliver Heller. Article 17(1)(c) Brussels Ibis has been the successor of Article 15(1)(c) Brussels I.

1670 Joined Cases C-585/08 and C-144/09 Peter Pammer v. Reederei Karl Schlüter GmbH \& Co. KG and Hotel Alpenhof GesmbH v. Oliver Heller, para. 80.

${ }^{1671}$ Joined Cases C-585/08 and C-144/09 Pammer and Alpenhof, para. 83.

1672 Joined Cases C-585/08 and C-144/09 Pammer and Alpenhof, para. 84.

1673 Joined Cases C-585/08 and C-144/09 Pammer and Alpenhof, para. 77. This information has been mandatory by virtue of Article 5(1)(c) of Directive 2000/31/EC of the European Parliament and of the Council of 8 June 2000 on certain legal aspects of information society services, in particular electronic commerce, in the Internal Market (Directive on Electronic Commerce) (OJ L 178, 17.7.2000, pp. 1-16).

${ }^{1674}$ See Advocate General Jääskinen in the Opinion to the case C-170/12 Peter Pinckney v KDG Mediatech, para. 66. See also Wefers Bettink 2011, pp. 157-163.

1675 Opinion of AG Jääskinen in the case C-170/12 Pinckney, para. 66.

${ }^{1676}$ See Case C-324/09 L'Oréal and Others v. eBay and Case C-172/18 AMS Neve v. Heritage Audio.
} 
the residents of the forum state in order to ascertain liability. ${ }^{1677}$ The CJEU held that the court seised should assess "on a case-by-case basis whether there are any relevant factors on the basis of which it may be concluded that an offer for sale, displayed on an online marketplace accessible from the territory covered by the trade mark, is targeted at consumers in that territory". ${ }^{1678}$ The CJEU found it particularly relevant the seller provided the possibility to delivery in the forum state. ${ }^{1679}$ Furthermore, "the website with the address 'www.ebay.co.uk' appear, in absence of any evidence to the contrary to be targeted at consumers" in the forum state the United Kingdom. ${ }^{1680}$ At jurisdictional level, the CJEU indicated in the AMS Neve ruling that the Pammer and Alpenhof factors could also be applied to determine whether the 'directed activities' criterion has been satisfied in case of an alleged online infringement of a European Union trade mark. ${ }^{1681}$ In the latter case, the CJEU found it crucial that the website involved mentioned the forum state as a geographical area were the products at issue could be delivered. ${ }^{1682}$

\subsubsection{The Pammer and Alpenhof ruling versus the rulings Pinckney, Hi Hotel and Pez Hejduk}

In the Pammer and Alpenhof ruling, the CJEU explicitly rejected to confer jurisdiction based on the mere accessibility of the website. ${ }^{1683}$ Although the European Union legislator has considered consumers as 'weak' parties who require special protection under the Brussels Ibis Regulation, ${ }^{1684}$ they opted for the concept of "directed activities" because they "did not want to go so far to lay down that mere use of a website, which has become a customary means of engaging in trade" could establish jurisdiction in the Member State of the consumer's domicile. ${ }^{1685}$ The 'directed activities' criterion of Article 17(1)(c) Brussels Ibis has been a result of the European Union legislator's balancing of the interests of the traders to employ the Internet as a customary means of engaging in trade, on the one hand, and the interests of consumers to sue the trader in their home state, on the other hand. ${ }^{1686}$

\footnotetext{
${ }^{1677}$ Case C-324/09 L'Oréal and Others v. eBay, para. 64.

1678 Case C-324/09 L'Oréal and Others v. eBay, para. 65.

${ }^{1679}$ Case C-324/09 L'Oréal and Others v. eBay, para. 65.

${ }^{1680}$ Case C-324/09 L'Oréal and Others v. eBay, para. 66.

${ }^{1681}$ Case C-172/18 AMS Neve v. Heritage Audio, para. 56. The CJEU referred to the case of C-324/09 L'Oréal and Others v. eBay, para. 64 and 65. See paragraph 3.6.1 on the AMS Neve ruling.

1682 Case C-172/18 AMS Neve v. Heritage Audio, para. 56. The CJEU referred to the case of C-324/09 L'Oréal and Others v. eBay, para. 64 and 65. See also paragraph 6.1.2 on the application of the factors of the Pammer and Alpenhof ruling with respect of the 'directed activities' approach to cross-border copyright infringement cases.

${ }^{1683}$ Joined Cases C-585/08 and C-144/09 Pammer and Alpenhof, para. 94.

${ }^{1684}$ Recital 18 in the preamble to the Brussels Ibis Regulation stipulates: "In relation to insurance, consumer and employment contracts, the weaker party should be protected by rules of jurisdiction more favourable to the interests than the general rules." In paragraph 59 of the Pammer and Alpenhof ruling, the CJEU also noted that the wordings of the former Article 13 of the Brussels Convention of 1968 had been alternated in the replacing Article 15(1) Brussels I Regulation, the predecessor of Article 17(1)(c) Brussels Ibis Regulation, "in order to ensure better protection for consumers with regard to new means of communication and the development of electronic commerce."

1685 Joined Cases C-585/08 and C-144/09 Pammer and Alpenhof, para. 72.

1686 Joined Cases C-585/08 and C-144/09 Pammer and Alpenhof, para. 70-74. See also Opinion of Advocate General Trstenjak in the joined cases C-585/08 and C-144/09 Pammer and Alpenhof, para. 64. Paragraph 4.4.2.1.1
} 
In light of the abovementioned Pammer and Alpenhof ruling, the CJEU seems to have provided a too broad interpretation of Article 7(2) Brussels Ibis in the rulings Pinckney and Pez Hejduk. As a Member State court may obtain jurisdiction based on the mere accessibility of the website involving the alleged copyright infringement, copyright holders will likely receive more procedural protection than the presumed 'weaker' consumers under the Brussels Ibis Regulation. Consumers in the European Union have been presumed to need special procedural protection as "economically weaker and less experienced in legal matters than the other, commercial, party to the contract". ${ }^{1687}$ Yet, the relationship between the copyright holder and the potential infringer can generally not be defined in a similar way. As asserted by Maunsbach, "there is no obvious weak party in relation to disputes regarding intellectual property." 1688

The Brussels Ibis Regulation does not consider the copyright holder as a 'weaker party' who needs special jurisdictional protection. ${ }^{1689}$ The special jurisdiction rule of Article $7(2)$ Brussels Ibis has also not been designed to protect 'weaker' parties. ${ }^{1690}$ The Bier ruling seems to indicate that this special jurisdiction provides jurisdiction to the court that will be in a good position to assess the facts of the case. ${ }^{1691}$ Besides the objective of sound administration of justice, the close connection between the court and the dispute "should ensure legal certainty and avoid the possibility of the defendant being sued in a court of a Member State which he could not reasonably have foreseen". ${ }^{1692}$ In the context of the special jurisdiction rule of Article 7(2) Brussels Ibis, it is important to create a "level-playing field with roughly equal chances for plaintiff and defendant". ${ }^{1693}$ Unlike the abovementioned balancing act by the European Union legislator, the CJEU did not seek to balance the interests between copyright holders to receive efficient redress, on the one hand, and the interests of users to exchange information and traders to sell products without running the risk to unexpectedly get sued in a particular Member State, on the other hand. ${ }^{1694}$

\subsubsection{The 'directed activities' approach as escape clause in Article 2:202 CLIP Principles of 2011}

As mentioned in paragraph 1.1.2, the so-called Principles on Conflict of Laws in Intellectual Property (hereinafter CLIP Principles) contain soft law related to private international law regarding intellectual property rights issues. Before demonstrating the

\footnotetext{
argued that the latter consideration supports the view that the aim to balance the competing broader interests involved could be regarded as a principle of private international law related to jurisdiction rules.

${ }^{1687}$ See joined Cases C-585/08 and C-144/09 Pammer and Alpenhof, para. 58. See also Case C-89/91 Shearson Lehmann Hutton Inc v TVB Treuhandgeschellschaft für Vermögensverwaltung und Beteiligung mbH, para. 18. ${ }^{1688}$ Maunsbach 2014, p. 219.

${ }^{1689}$ See paragraphs 2.1.2.1.3 and 5.1.4.

${ }^{1690}$ Case C-133/11 Folien Fischer AG and Foltitec AG v. Ritrama SpA, para. 46. See also Lopez-Tarruella 2012, p. 342.

${ }^{1691}$ See paragraph 2.1.2.2.2.

1692 Recital 16 in the preamble to the Brussels Ibis Regulation.

1693 See De Groote 2004, p. 41. See also Magnus \& Mankowski 2016, p. 143; Pertegás Sender 2002, p. 33. See paragraph 4.2.4.2 on the principles underlying the special jurisdiction rule of Article 7(2) Brussels Ibis.

${ }^{1694}$ See the rulings Pinckney, Hi Hotel and Pez Hejduk discussed in chapter 3 and the assessment of these rulings from a perspective of balancing the interests in the paragraphs 5.1.4, 5.2.4.3, 5.3.1.
} 
'directed activities' approach-based to jurisdiction under Article 2:202 CLIP Principles of 2011 applicable to cross-border copyright infringements, the next paragraph will set out the general objectives of the CLIP Principles.

\subsubsection{The general objectives of the CLIP Principles}

In 2004, the Max-Planck Institutes in Germany founded the European Max Planck Group on Conflict of Laws in Intellectual Property (hereinafter the CLIP group). ${ }^{1695}$ This group consists of scholars of different states of the European Union and the United States of America. ${ }^{1696}$ The CLIP group enacted several drafts of Principles on Conflict of Laws related to Intellectual Property, the so-called CLIP Principles. ${ }^{1697}$ This dissertation focuses on the final version of the CLIP Principles published in 2011. ${ }^{1698}$

In the United States of America, the American Law Institute (ALI) undertook a similar project to draft principles on private international law involving transnational intellectual property matters. ${ }^{1699}$ In May 2007, this project resulted into the ALI Principles on Intellectual Property Governing Jurisdiction, Choice of Law, and Judgements in Transnational Disputes (hereinafter the ALI Principles). ${ }^{1700}$ The ALI Principles and the CLIP Principles can be characterised as soft law. ${ }^{1701}$ While both of these Principles aim to be applicable in civil and common law countries, ${ }^{1702}$ the CLIP Principles have been more influenced by European civil law. ${ }^{1703}$ The CLIP Principles explicitly stipulate that they "may be used to interpret or supplement international and domestic law including the law of regional organisations for economic integration where applicable" such as European Union Law. ${ }^{1704}$ The foregoing indicates that the CJEU could be inspired by the CLIP Principles when interpreting Article 7(2) Brussels in cross-border copyright infringement cases. ${ }^{1705}$ The CLIP Principles applicable to cross-border copyright infringement cases will therefore be examined in the following paragraphs.

\footnotetext{
${ }^{1695}$ The CLIP group has been founded by the Max Planck Institute for Competition, Intellectual Property and Tax Law in Munich and the Max Planck Institute for Comparative and International Private Law in Hamburg. See Kono \& Jurcys 2012, p. 12. See Van Eechoud \& Kur (2012, p. 186) on the common term of the "CLIP group". ${ }^{1696}$ Kono \& Jurcys 2012, p. 12.

${ }^{1697}$ See Van Eechoud \& Kur 2012, pp. 185-192.

${ }^{1698}$ See the final text of the Principles on Conflict of laws in Intellectual Property of 1 December 2011. See https://www.ip.mpg.de/en/research/research-news/principles-on-conflict-of-laws-in-intellectual-propertyclip.html.

${ }^{1699}$ See, inter alia, Dreyfuss 2005, pp. 819-820; Kono \& Jurcys 2012, p. 11.

1700 See Kono \& Jurcys 2012, p. 11. See also https://www.ali.org/publications/show/intellectual-propertyprinciples-governing-jurisdiction-choice-law-and-judgments-transnational-disputes/.

${ }^{1701}$ See paragraph 1.1.2.

${ }^{1702}$ Dreyfuss 2005, pp. 827-828; Peukert 2013, pp. 26- 28, PRE:C05-PRE:C07, p. 43, PREN02.ii.

${ }^{1703}$ Jurcys 2012, p. 177. See also Peukert 2013, pp. 27-28, PRE:C05-PRE:C07, p. 35, PRE:C25; Van Eechoud \& Kur 2012, p. 187.

${ }^{1704}$ See the CLIP Principles Final Text 1 December 2011 Part 1: Purpose and Scope.

${ }^{1705}$ Van Eechoud pointed out that "a number of Advocates General refer to CLIP in their Opinions to the Court of Justice of the EU, so already this influence is visible". See Van Eechoud 2016, p. 720. Van Eechoud referred, for instance, to the Opinion of AG Cruz Villalón in the case C-523/10 Wintersteiger; Opinion of AG Jääskinen in the case C-170/12 Pinckey; Opinion of AG Cruz in the case C-441/13 Pez Hejduk.
} 
The objectives of the CLIP Principles are laid down in the Preamble. ${ }^{1706}$ The general objectives of the CLIP Principles appear to resemble the assessment framework of paragraph 4.6. In line with the principle of balancing the broader interests involved, as demonstrated in paragraph 4.4, the CLIP group underlines that the CLIP Principles "need to consider and balance all the interests involved, including the interests of owners of intellectual property rights, their contracting partners and other users of intellectual property, and the broader public interest, in particular in access to, and use of, information as well as other public interests". ${ }^{1707}$ The CLIP Principles explicitly aim to facilitate international trade, the flow of information, and take into account the development of digital communication technologies. ${ }^{1708}$ Similar to the special jurisdiction rule of Article 7(2) Brussels Ibis, ${ }^{1709}$ the CLIP group purports "to provide legal certainty and predictability as to the jurisdiction of courts"1710.

Although the CLIP Principles acknowledge the territoriality principle related to intellectual property rights, ${ }^{1711}$ they -under certain conditions- deviate from this principle in view of the globalised and internet-connected world. ${ }^{1712}$ With respect to the scope of the court's jurisdiction, paragraph 6.4.5 will demonstrate this deviation by discussing the combined approach to jurisdiction in ubiquitous infringement cases according to Article 2:202 and 2:203(2) CLIP.

\subsubsection{The 'directed activities' approach in the escape clause of Article 2:202 CLIP}

Based on the general jurisdiction rule in Article 2:101 CLIP, the court of the state in which the alleged copyright infringer is habitually resided obtains jurisdiction regarding the entire infringement dispute. ${ }^{1713}$ This rule resembles the general jurisdiction rule in Article 4 Brussels Ibis that employs the place of domicile as connecting factor. ${ }^{1714}$ With respect to infringements of intellectual property rights, Article 2:202 CLIP also confers jurisdiction to "the court of the State where the alleged infringement occurs or may occur, unless the alleged infringer has not

\footnotetext{
1706 "The Preamble is intended to guide the teleological interpretation of specific model provisions." See Peukert 2013, p. 26, PRE:C01.

${ }_{1707}$ Preamble to the CLIP Principles No 6.

${ }^{1708}$ See the preamble to the CLIP Principles Final Text 1 December 2011.

${ }^{1709}$ See paragraphs 4.2.4.2 and 4.6.

${ }^{1710}$ Preamble to the CLIP Principles No 5.

${ }^{1711}$ Preamble to the CLIP Principles No 7. See also Peukert 2013, pp. 38-39, PRE:C33-C35. See, for instance, the territorially limited jurisdiction of the court of the place of infringement according to Article 2:202 CLIP and 2:203(2) CLIP.

1712 See Peukert 2013, p. 40, PRE:C36. Based on the following CLIP Principles, certain courts are competent to adjudicate the entire dispute despite the territorial protection of intellectual property rights: the forum rei rule in Article 2:101 CLIP; the special jurisdiction rule regarding infringement disputes carried out through ubiquitous media in Article 2:203(2) CLIP (see paragraph 6.4.5) and the special jurisdiction rule on disputes involving multi defendants in Article 2:206 CLIP. In addition, the CLIP Principles stipulate that ubiquitous infringements and certain types of secondary infringements may be decided on the basis of one substantive law in Article 3:603 and Article 3:604 (see paragraph 5.3.4.2).

1713 See Heinze 2013, p. 56, 2:101.C01.

1714 Article 2:601 CLIP provides a definition on the location of the habitual residence of a legal person that is similar to Article 63 Brussels Ibis. The 'place of habitual residence' is nonetheless regarded as a more flexible connecting factor than the 'place of domicile'. See Heinze 2013, p. 58, 2:101, C05.
} 
acted in the State to initiate or further the infringement and her/his activity cannot reasonably be seen as having been directed to that State".

Unlike the special jurisdiction rule of Article 7(2) Brussels Ibis, Article 2:202 CLIP employs the 'place of infringement' as connecting factor. As explained in paragraph 2.3.2, due to the territorial principle related to copyrights, scholars generally favour to employ "the place of infringement" as connecting factor to establish jurisdiction regarding another court that the forum rei. The 'place of infringement' as connecting factor suits the prevailing view in legal literature and European case law that in case of copyright infringements no distinction can be made between the Handlungsort and the Erfolgsort. ${ }^{1715}$ This connecting factor implies that the "right exists in the State where infringement jurisdiction is to be established". ${ }^{1716}$ The requirement of locus protectionis has therefore been an implicit criterion.

The 'unless' exception in Article 2:202 CLIP has been referred to as the "escape clause". ${ }^{1717}$ This clause makes a distinction between act ("acted in") and effect ("activities...directed to") ${ }^{1718}$ that seems reminiscent of the dichotomy Handlungsort and Erfolgsort under Article 7(2) Brussels Ibis. However, the CJEU's interpretation of the Handlungsort as the place of the event giving rise to the damage has been narrower. ${ }^{1719}$ The Commentary to Article 2:202 CLIP explaines that the defendant is even assumed to have "acted" in the forum state if only "physical items are found in commerce that are claimed to infringe a right existing in the forum state". ${ }^{1720}$ With respect to jurisdiction based on the Erfolgsort, the escape clause of Article 2:202 CLIP indicates that the act of infringement has to be 'directed to' the forum state. Hence, it can be said that the 'directed activities' approach, as explained in paragraph 6.1, lies in Article 2:202 CLIP. This dissertation will therefore refer to the 'directed activities'-based escape clause of Article 2:202 CLIP.

It is the defendant who has to prove that the alleged infringing activity "cannot reasonably be seen as having been directed to" the forum state under Article 2:202 CLIP. ${ }^{1721}$ When the defendant invokes this escape clause, the court has to consider all circumstances of the case. ${ }^{1722}$ With respect to alleged online infringements, the court should focus on factors such as "the language, content and other aspects from which the territorial scope of the targeted area may be inferred". ${ }^{1723}$ The use of a "clear and unequivocal" disclaimer may denote that the alleged infringer tried to limit the territorial impact of his online activities. ${ }^{1724}$ The Commentary to the

\footnotetext{
1715 See also paragraph 5.2.1.

${ }^{1716}$ Kur 2013(a), p. 71, 2:202.C07.

${ }^{1717}$ Kur 2013(a), p. 74, 2:202.C13.

${ }^{1718}$ Kur 2013(a), p. 75, 2:202.C14.

1719 Case C-21/76 Bier v. Mines de Potasse d'Alsace SA, para. 24-25; Case C-170/12 Peter Pinckney v. KGD Mediatech $A G$, para. 29.

${ }^{1720}$ Kur 2013(a), p. 75, 2:202.C15.

${ }^{1721}$ Kur 2013(a), p. 75, 2:202.C16.

${ }^{1722}$ Kur 2013(a), p. 75, 2:202.C17.

${ }^{1723}$ Kur 2013(a), p. 75, 2:202.C17.

${ }^{1724}$ Kur 2013(a), p. 82, 2.202.N12. In the Pammer and Alpenhof ruling, Advocate General Trstenjak pointed out that it is important that a drafter of a disclaimer does in fact adhere to a disclaimer that stipulates that he does not direct his activities to a particular state. If the drafter nevertheless directs activities to that state, he cannot rely on the disclaimer. See Opinion of Advocate General Trstenjak delivered on 18 May 2010 in the joined cases C-585/08 and C-144/09 Peter Pammer v. Reederei Karl Schlütter GmbH \& Co. KG and Hotel Alpenhof GesmbH v. Oliver Heller, para. 91-92.
} 
CLIP Principles also refers to the CJEU's interpretation of the concept 'directed activities' in the Pammer and Alpenhof ruling. ${ }^{1725}$

The Commentary to the CLIP Principles provides the following arguments for the 'directed activities'-based escape clause of Article 2:202 CLIP. First, the escape clause "is to confine the application of the general rule establishing jurisdiction at the place where an infringement accurs to cases of actual relevance. ${ }^{1726}$ Second, the escape clause likely prevents jurisdiction based on minimal effects. ${ }^{1727}$ The escape clause will addresses unwanted so-called overspills ${ }^{1728}$ related to copyrights infringements by providing the defendant the opportunity to demonstrate that the effects in the forum state were fortuitous. ${ }^{1729}$ Overspills may particularly "occur when content is spread through (digital) media". ${ }^{1730}$

It has been argued that the 'directed activities'-based escape clause is reminiscent to the commercial effects-based approach recommended by the World Intellectual Property Organization in 2001 to impede liability based on overspills caused by alleged online trademark infringements. ${ }^{1731}$ Based on Article 2 of the Joint Recommendation Concerning Provisions on the Protection of Marks, and Other Industrial Property Rights in Signs (hereinafter Joint Recommendation WIPO), the use of a sign on the Internet will only constitute an infringement if the use has a commercial effect in that Member State. To determine whether the use of a sign has commercial effects in a state, Article 3 of the Joint Recommendation WIPO enumerates various factors like whether the user is (or planning to do) business in the state and "the level and character of commercial activity of the user" in the state such as delivery possibilities, currency used, an address, telephone number or other means of contact in the state, country code top-level domain name of the website involved, language used. Since the determination of commercial effect will depend upon the particular circumstances of that case, the factors enumerated in Article 3 of the Joint Recommendation WIPO are not decisive. ${ }^{1732}$

It is noteworthy that Article 2:203 CLIP contains a separate provision regarding the scope of the court's jurisdiction based on the place of infringement under Article 2:202 CLIP. Pursuant to Article 2:203(1) CLIP, the scope of the jurisdiction of the latter court is limited to "infringements that occur or may occur within the territory of the State in which that court is situated". Similar to the Pinckney doctrine, this territorial limitation of jurisdiction has been based on the territorial principle related to copyrights and the consideration that the court of the

\footnotetext{
${ }^{1725}$ Kur 2013(a), p. 83, 2.202.N13. See paragraph 6.1.2 on the 'directed activities' approach in the joined cases cases C-585/08 and C-144/09 Pammer and Alpenhof, para. 80.

${ }^{1726}$ Kur 2013(c), p. 308, 3:602.C03. See also Heinze 2010, p. 68.

${ }^{1727}$ Kur 2013(a), p. 74, 2:202.C13. See also Torremans 2014, p. 387.

${ }^{1728}$ See Van Eechoud \& Kur 2012, p. 187. See also Torremans 2014, p. 387. Matulionyte illustrates there will be "overspills" effects if "a defendant is actually and clearly targeting some countries but the website can still be accessed in other countries". See Matulionyte 2015, p. 134.

${ }^{1729}$ Kur 2013(a), p. 69, 2:202.C02, p. 75, 2:202.C14.

${ }^{1730}$ Kur 2013(a), p. 69, 2:202.C03.

${ }^{1731}$ Kur 2013(a), pp. 80-81, 2:202 N07. See also Heinze 2010, p. 67; Van Eechoud \& Kur 2012, p. 189. See the Joint Recommendation Concerning Provisions on the Protection of Marks, and Other Industrial Property Rights in Signs, on the Internet adopted by the Assembly of the Paris Union for the Protection of Industrial Property and the General Assembly of the World Intellectual Property Organization (WIPO) at the Thirty Sixth Series of Meetings of the Assemblies of the Member States of WIPO 24 September to 3 October 2001. See https://www.wipo.int/publications/en/details.jsp?id=345\&plang=RU.

${ }^{1732}$ See Article 3(2) of the Joint Recommendation WIPO.
} 
place of the infringement will usually be in the best position to assess the facts of the case. ${ }^{1733}$ Yet, as will be demonstrated in paragraph 6.4.5, Article 2:203(2) CLIP makes an exception for alleged infringements carried out by ubiquitous media such as the Internet. Based on the effectsbased connecting factors in Article 2:203(2) CLIP, the court competent on the basis of Article 2:202 CLIP will obtain jurisdiction regarding the entire infringement dispute. Paragraph 6.4.5.2 will further assess the combination of the 'directed activities'-based escape clause in Article 2:202 CLIP and the effects-based approach under Article 2:203(2) CLIP. Based on the assessment framework of paragraph 4.6, the following paragraphs will examine the 'directed activities'-based approach to jurisdiction in general, that has also been laid down in the escape clause of Article 2:202 CLIP, in combination with the territorially limited approach to jurisdiction, as also laid down in Article 2:203(1) CLIP.

\subsubsection{Assessing the 'directed activities' approach}

In the rulings Pinckney and Pez Hejduk, the CJEU explicitly rejected the 'directed activities' approach to jurisdiction because the localisation of the place where the harmful event occurred or may occur under Article 7(2) Brussels Ibis "cannot depend on criteria which are specific to the examination of the substance of the action and which do not appear in that provision". ${ }^{1734}$ It has nevertheless been argued that the assessment of 'directed activities' will not require a "substantially more of a 'closer look' than any regular assessment" regarding the localisation of the Handlungsort and the Erfolgsort. ${ }^{1735}$ With respect to the interpretation of the Erfolgsort in tort cases, the CJEU has frequently held that the "circumstances specific to the case" should also be considered when attributing jurisdiction. ${ }^{1736}$ Furthermore, the CJEU adopted the 'victim's centre of interest' approach under Article 7(2) Brussels Ibis ${ }^{1737}$ even though this criterion has not been mentioned in that provision. ${ }^{1738}$

As an alternative for the Pinckney doctrine under Article 7(2) Brussels Ibis, the following paragraphs will assess the 'directed activities' approach in light of the assessment framework of paragraph 4.6. As mentioned in paragraph 6.1, the 'directed activities' approach generally consists of the 'directed activities' criterion and the mosaic approach. Although Jääskinen and the courts of European Union Member States appear to have adopted the 'directed activities' approach only in internet-related copyright infringement disputes, ${ }^{1739}$ this approach can be applied in a technological neutral manner. A technology neutral approach to jurisdiction will

\footnotetext{
${ }^{1733}$ Peukert 2013, pp. 38-39, PRE:C34 and C35.

1734 Case C-170/12 Peter Pinckney v. KGD Mediatech AG, para. 41. See also C-441/13 Pez Hejduk v. EnergieAgentur NWR GmbH, para. 32-35.

${ }^{1735}$ Huvosec 2014, p. 373. See also Von Hein 2014-2015, p. 270.

1736 See Case C-12/15 Universal Music Holding BV v. Michael Tétreault Schilling, Irwin Schwartz, Josef Broz, para. 39. See also Case C-304/17 Helga Löber v. Barclays Bank plc, para. 29-36; Case C-343/19 Verein für Konstumenteninformation $v$. Volkswagen $A G$, para. 36.

${ }^{1737}$ See paragraph 6.2 .

${ }^{1738}$ See paragraph 6.2 .1 on the 'victim's centre of interests' approach established by the CJEU regarding online infringement of personality rights in the joined cases C-509/09 and C-161/10 eDate and Martinez.

${ }^{1739}$ See paragraphs 6.1. and 6.1.1.
} 
be applicable to copyright infringing activities regardless of their means of dissemination. ${ }^{1740}$ Kuipers pointed out that the Brussels Ibis Regulation seems to make no distinction regarding the means of dissemination of infringements; CJEU adopted a technology neutral approach to jurisdiction in the rulings Pammer and Alpenhof and Wintersteiger. ${ }^{1741}$ Cruz Villalón advocated a technology neutral approach to jurisdiction under Article 7(2) Brussels Ibis since infringing content "is fungible and its formats are interchangeable". ${ }^{1742}$ For instance, copyright infringing content published in newspapers will often also be available in a digital edition.

\subsubsection{The principle of predictability}

The 'directed activities' criterion will generally enable the potential copyright infringer to reasonably foresee in which Member State he may get sued. ${ }^{1743}$ Since the alleged infringing activities have to be directed to the forum state, so-called fortuitous overspills will be insufficient to establish jurisdiction. Due to the focus on the 'objective' intention to determine whether the infringer has directed activities to a particular state, ${ }^{1744}$ the copyright holder will reasonably foresee in which state(s) he may sue the alleged infringer. In line with the Pammer and Alpenhof ruling, the 'objective' intention should be assessed on the basis of all circumstances of the case. ${ }^{1745}$ As argued by Advocate General Jääskinen, the non-exhaustive list of 'objective' criteria enumerated in the Pammer and Alpenhof ruling ${ }^{1746}$ can be applied to determine whether copyright infringing activities are directed to the forum state. ${ }^{1747}$

In favour of the 'directed activities' approach in European Union trade mark infringement cases, Advocate General Szpunar argued that the content of the website should directly provide clarity on whether the infringer's activities have been directed to the residents of a particular state. ${ }^{1748}$ Szpunar also refers to other factors of particular importance such as a website with a country code top-level domain name, national currency of prices or telephone numbers with a national prefix. ${ }^{1749}$ For instance, if a blogger publishes an article via the Internet regarding a news item that includes a copyright infringing photo, the content, the language used and the country code top-level domain name of the website may indicate that the infringing activities

\footnotetext{
1740 The European Union Commission frequently expressed to favour technology neutral regulations. See, for instance, Communication from the Commission to the Council, the European Parliament, the Economic and Social Committee and the Committee of the Regions. Principles and guidelines for the Community's audiovisual policy in the digital age, Brussels, 14.12.1999 COM (1999) 657 final, pp. 9-10.

${ }^{1741}$ Kuipers 2012(a), p. 395; Kuipers 2018, p. 543.

1742 Opinion of Advocate General Cruz Villalón delivered on 29 March 2011 in joined cases C-509/09 and C161/10 eDate Advertising GmbH v. X and Martinez v. MGN Limited, para. 53. See also paragraph 6.2.1.1.3.

${ }^{1743}$ See also Matulionyte 2015, p. 136. See also Advocate General Szpunar on the predictability of jurisdiction in cross-border European Union trade mark infringement cases based on the targeting approach. See Opinion of Advocate General Szpunar delivered on 28 March 2019 in the case of C-172/18 AMS Neve Ltd, Barnett Waddingham Trustees, Mark Crabtree v. Heritage Audio SL, Pedro Rodriguez Arribas, para. 83-84.

${ }^{1744}$ See paragraph 6.1 .

${ }^{1745}$ See joined cases C-585/08 and C-144/09 Peter Pammer v. Reederei Karl Schlüter GmbH \& Co. KG and Hotel Alpenhof GesmbH v. Oliver Heller, para. 80.

${ }^{1746}$ See paragraph 6.1.2.

${ }^{1747}$ Opinion of Advocate General Jääskinen in the case C-170/12 Peter Pinckney v KDG Mediatech, para. 66.

1748 Opinion of Advocate General Szpunar delivered on 28 March 2019 in the case of C-172/18 AMS Neve Ltd, Barnett Waddingham Trustees, Mark Crabtree v. Heritage Audio SL, Pedro Rodriguez Arribas, para. 88.

${ }^{1749}$ Opinion of AG Szpunar delivered on 28 March 2019 in the case of C-172/18 AMS Neve, para. 89.
} 
had been directed to residents of a particular state. ${ }^{1750}$ With respect to the factor language, Szupnar notes that some languages are frequently used in several Member States and third States and will therefore not always be a relevant factor. ${ }^{1751}$ Furthermore, a website may be directed to residents of a particular Member State, even though its content is not written in a language that is widely understood in that state; for instance, if "a website targets a community of foreign nationals residing in that Member State". ${ }^{1752}$

\subsubsection{A close connection between dispute and court/ sound administration of justice}

The 'directed activities' approach will generally yield a close connection between the copyright infringement dispute and the court. ${ }^{1753}$ This approach suits the traditional principle of territorial as basis for jurisdiction ${ }^{1754}$ since the objective intention of the alleged infringer has to indicate that the alleged infringing activites are aimed at the territory of the forum state. ${ }^{1755}$ Jurisdiction based on overspills will be prevented as the court seised can only obtain jurisdiction if the defendant's copyright infringing activities have been directed to the forum state. This court will usually be in a good position to ascertain the damage within the forum state. ${ }^{1756}$ Therefore, it has generally not been advocated to provide full jurisdiction to the court of the state where the infringing activities have been directed to. Paragraph 6.4 will demonstrate that so-called combined approaches to jurisdiction have nevertheless been proposed that provide full jurisdiction to the court on the basis of the 'directed activities' criterion by adding a connecting factor.

The 'directed activities' criterion will reduce the risk of jurisdiction based on minimum effects. ${ }^{1757}$ Providing jurisdiction to the court of a Member State where there has been no (significant) damage will not "justify the cost and burden of litigation" 1758 and can easily lead to so-called empty jurisdiction. ${ }^{1759}$ Furthermore, the 'directed activities' approach usually reduces the number of competent courts and therefore the risk of forum shopping. ${ }^{1760}$ Since the court seised should only consider the objective intention of the alleged infringer based on objective factors as explained in the previous paragraph, the assessment at the jurisdiction level will be lesser thoroughly then the following liability assessment at the substantive level. It has frequently been argued that applying the 'directed activities' approach to cross-border copyright infringement cases at jurisdictional level will reduce the risk of empty jurisdiction. ${ }^{1761}$ The

\footnotetext{
${ }^{1750}$ See joined cases C-585/08 and C-144/09 Peter Pammer v. Reederei Karl Schlüter GmbH \& Co. KG and Hotel Alpenhof GesmbH v. Oliver Heller, para. 83, 93.

${ }^{1751}$ Opinion of AG Szpunar delivered on 28 March 2019 in the case of C-172/18 AMS Neve, para. 92.

1752 Opinion of AG Szpunar delivered on 28 March 2019 in the case of C-172/18 AMS Neve, para. 92.

${ }^{1753}$ Matulionyte 2015, p. 136.

${ }^{1754}$ See paragraphs 2.1.2.2.1 and 2.1.2.2.2.

1755 See also Michaels 2004, pp. 119-120.

${ }^{1756}$ Matulionyte 2015, p. 136.

${ }^{1757}$ Kur 2013(a), p. 69, 2:202.C02, p. 75, 2:202 C14. See also paragraph 6.1.2.2.

${ }^{1758}$ Depreeuw \& Hubin 2014, p. 764. See paragraph 5.2.2.

1759 Matulionyte 2015, p. 135. See also Depreeuw \& Hubin 2014, pp. 763-764; Georgescu, Marin, Vasile \& Florecsu 2016, p. 18; Huvosec 2014, p. 372. See also paragraph 5.2.4.2.

${ }^{1760}$ Matulionyte 2015, p. 136.

${ }^{1761}$ See Depreeuw \& Hubin 2014, pp. 763-764; Georgescu, Marin, Vasile \& Florecsu 2016, p. 18; Matulionyte 2015 , p. 135.
} 
foregoing indicates that the 'directed activities' approach will generally enhance the sound administration of justice that has been considered as a principle under Article 7(2) Brussels Ibis. ${ }^{1762}$

However, in case alleged copyrighted infringing activities are directed to many states, the 'directed activities' approach will entail multiple competent courts. This will increase the risk of forum shopping and irreconcilable decisions that does not facilitate the sound administration of justice. As mentioned above, paragraph 6.4 will examine proposals that confer jurisdiction based on the 'directed activities' criterion and additional connecting factors regarding to the entire copyright infringement dispute for reasons of efficient adjudication.

\subsubsection{The principle of balancing the interests}

The 'directed activities' approach will likely strike a procedural balance between the parties to a cross-border copyright infringement dispute. ${ }^{1763}$ As mentioned in paragraph 6.1.4.1, both parties will generally be able to predict which court will be competent in cross-border copyright infringement cases. On the one hand, the copyright holder will have the possibility to sue the infringer in all states where alleged copyright infringing activities have been directed to. On the other hand, a potential copyright infringer will generally reasonably foresee in which states he may get sued. ${ }^{1764}$

Similar to the 'directed activities'-based escape clause in Article 2:202 CLIP, Huvosec advocated to adopt a so-called negative 'directed activities' criterion under Article 7(2) Brussels Ibis that allows the defendant to prove that he did not direct infringing activities to the forum state. ${ }^{1765}$ It has been argued that "the defendant possesses more information about the access and usage of the website" and should therefore invoke and prove the 'directed activities' criterion. ${ }^{1766}$ Yet, this negative 'directed activities' criterion does not seem to suit the settled case law of the CJEU with respect to the assessment of jurisdiction under Article 7(2) Brussels Ibis. The CJEU held that the court seised is not "obliged, if the defendant contests the applicant's allegations, to conduct a comprehensive taking of evidence at the stage of determining jurisdiction"; however, both the objective of the sound administration of justice and "respect for the independence of the national court in the exercise of its functions require the national court seised to be able to examine its international jurisdiction in light of all the information available to it, including, where appropriate, the defendant's allegations". ${ }^{1767}$

With respect to alleged copyright infringing activities directed to many states, for instance by ubiquitous media such as the Internet, the 'directed activities' approach may nevertheless not balance the procedural interests of the litigants. The defendant can get sued in multiple states which puts a heavy burden on him. To receive full redress, the copyright holder will be

\footnotetext{
1762 See paragraph 4.2.4.2.

${ }^{1763}$ Matulionyte 2015, p. 136.

${ }^{1764}$ Matulionyte 2015, p. 136.

1765 See Huvosec 2014, p. 373.

${ }^{1766}$ See Matulionyte 2015, p. 136. See also Huvosec 2014, p. 373.

1767 See Case C-375/13 Harald Kolassa v. Barclays Bank plc, para. 64; Case C-12/15 Universal Music Holding BV v. Michael Tétreault Schilling, Irwin Schwartz, Josef Broz, para. 45.
} 
forced to sue either before the court of the state of the infringer's domicile, or Handlungsort, or before the courts of each state where the copyright infringing content has been directed to. The latter can be unreasonable in case the infringer has been located and operated in a copyright haven. ${ }^{1768}$ For instance, if the latter infringer directed his activities to the forum state that protects the copyright relied on and where the copyright holder has been domiciled or substantial damage has occurred. Due to the territorially limited approach to jurisdiction, it will also be difficult to cease or prevent all copyright infringing activities because the effect of an injunction will be territorially limited to the forum state. ${ }^{1769}$

From a broad perspective, the 'directed activities' approach seems to balance the interests between copyright holders, on the one hand, and traders and users of information, on the other hand. The 'directed activities' approach will generally enhance copyright protection at procedural level and provide predictability to traders and users of information as regards where they may get sued. Nonetheless, in view of multistate or ubiquitous copyright infringements, these broader interests may not be balanced as result of the combination of the 'directed activities' and mosaic approach. This combined approach to jurisdiction will likely not provide efficient protection to copyright holders that can be considered particularly unreasonable in case of infringers who are located and operated in copyright havens as illustrated above. Hence, this approach will not adequately address the problem of copyright havens and online piracy. This lack of protection may decrease creativity and innovation.

The risk to get sued in multiple states may impede the use of information. Providers of information can block their websites for residents of particular Member States if they do not want to get sued in those states. ${ }^{1770}$ Hence, the cross-border flow of information may hamper which will be detrimental for users of information and can decrease knowledge and innovation. ${ }^{1771}$ The risk of getting sued in multiple states can also negatively affect cross-border trade. As will be demonstrated in the next paragraph, the traders' tools to prevent getting sued in particular Member States based on the 'directed activities' approach has frequently been reduced by the enactment of the Geo-blocking Regulation in 2018. ${ }^{1772}$ Hence, traders may be discouraged to sell their products via the Internet to customers in the European Union. ${ }^{1773}$ Multistate litigation will particularly put a heavy financial burden on small trading companies.

\subsubsection{The Geo-blocking Regulation and the 'directed activities' approach}

This paragraph will consider the impact of the Geo-blocking Regulation on the directed activities' approach to jurisdiction in cross-border copyright infringement cases. ${ }^{1774}$ Paragraph

\footnotetext{
${ }^{1768}$ See paragraph 2.2.2.2 on the concept of copyright havens. See also paragraph 5.3.1.

1769 See paragraph 5.3.1.

${ }^{1770}$ See paragraph 5.2.4.3

${ }^{1771}$ See paragraph 4.4.1.

1772 Regulation (EU) 2018/302 of the European Parliament and of the Council of 28 February 2018 on addressing unjustified geo-blocking and other forms of discrimination based on customers' nationality, place of residence or place of establishment within the internal market and amending Regulations (EC) No 2006/2004 and (EU) 2017/2394 and Directive 2009/22/EC (OJ L 60I, 2.3.2018, pp. 1-15)

1773 Matulionyte 2015, p. 137.

${ }^{1774}$ See paragraphs 4.5 up to and including 4.5.4 on the Geo-blocking Regulation.
} 
4.5 demonstrated that the Geo-blocking Regulation will often prevent traders to employ unjustified geo-blocking and other discriminatory measures against customers based on their nationality, place of residence or place of establishment. ${ }^{1775}$ As will be set out below, the effect of the Geo-blocking Regulation will be limited to certain cross-border copyright infringement disputes.

First, the Geo-blocking Regulation only addresses traders who provide their goods or services to customers within the European Union. ${ }^{1776}$ A potential copyright infringer who cannot be denoted as a trader under the Geo-blocking Regulation will thus not be affected by this Regulation. ${ }^{1777}$ Furthermore, a trader who provides merely online information about his goods or services without "a view of engaging in a transaction with respect to those goods or services' will not be governed by the prohibitions under the Geo-blocking Regulation. ${ }^{1778}$

Second, as explained in paragraph 4.5.2.3, many services are excluded from the prohibitions under the Geo-blocking Regulation. ${ }^{1779}$ Hence, alleged copyright infringers who are accused to have provided these services will not be affected by the Geo-blocking Regulation. From a perspective of copyrights, the Geo-blocking Regulation excluded audiovisual services, like streaming or downloading of movies, and other electronically supplied services that contain copyright protected content such as music, e-books and computer games. ${ }^{1780}$ Potential copyright infringers who offer these services can thus block or limit their websites or employ other discriminatory measures against customers based on their nationality, place of residence or place of establishment. In sum, the Geo-blocking Regulation will only influence the 'directed activities' approach to jurisdiction in cross-border copyright infringement disputes if the potential copyright infringer can be regarded as a trader who provides goods or certain services to customers within the European Union.

The Geo-blocking Regulation explicitly indicates that its provisions do not affect the 'directed activities' approach to establish jurisdiction regarding consumer contracts disputes under Article 17(1)(c) Brussels Ibis. ${ }^{1781}$ As argued in paragraph 4.5.3, the Geo-blocking Regulation nevertheless affects the 'directed activities' approach since traders will often not be allowed anymore to block their websites for customers of certain Member States that could prevent getting sued in these states. In addition, traders can generally not prevent jurisdiction by impeding the access of goods or certain services to particular customers through the adoption of different general conditions of access based on the customers' nationality, place of residence

\footnotetext{
1775 The Geo-blocking Regulation prohibits geo-blocking and other forms of discrimination based on customers' nationality, place of residence or place of establishment within the internal market unless it has been justified by European Union law or national law in accordance with European law, see paragraph 4.5.

1776 See paragraph 4.5.1.

${ }^{1777}$ See paragraph 4.5.1 on the definition of trader in Article 2(18) Geo-blocking Regulation. See also Recital 17 in the preamble to the Geo-blocking Regulation.

${ }^{1778}$ See paragraph 4.5.2.1 on the definition of online interface in Article 1(16) Geo-blocking Regulation.

${ }^{1779}$ Article 1(3) and Article 4(1)(b) Geo-blocking Regulation. See also recitals 8 and 9 in the preamble to the Geoblocking Regulation.

${ }^{1780}$ As demonstrated in paragraph 4.5.2.3, the Geo-blocking Regulation may in future be applicable to audiovisual services or electronically services that involve multi-territorial licensed rights. The first review of this Regulation will be on 23 March 2020.

1781 See recitals 12, 13, 26 in the preamble of the Geo-blocking Regulation and Article 1(6) Geo-blocking Regulation. See also paragraph 4.5.3.
} 
or place of establishment. ${ }^{1782}$ The traders' tools to prevent that their activities are directed to a particular Member State will thus often be limited by the Geo-blocking Regulation.

With respect to the jurisdiction rule in consumer contract disputes, the Geo-blocking Regulation stipulates that the trader's mere compliance with this Regulation will, however, not constitute 'directed activities'. ${ }^{1783}$ Hence, when a trader does not block his website or provides similar conditions of access to customers of all Member States, this will not imply that this trader directed his activities to all of these Member States. ${ }^{1784}$ To determine whether the trader directed his activities to a particular Member State, the Geo-blocking Regulation stipulates that it is important if "the trader has manifested an intention to establish commercial relations with consumers from that Member State" 1785 . As mentioned in paragraph 4.5.3, the factors of the Pammer and Alpenhof ruling to assess the 'directed activities' criterion remain relevant. Despite the Geo-blocking Regulation, the trader will thus still have certain tools to indicate that his activities are not directed to a particular state and can therefore prevent to get sued in that state. For instance, the trader can limit the delivery of goods to a particular state, use a country code top-level domain name for its website ${ }^{1786}$ or employ a particular language ${ }^{1787}$.

Due to the Geo-blocking Regulation, the court seised will nonetheless need to examine the trader's activities more thoroughly to assess the 'directed activities' criterion. ${ }^{1788}$ The following example will illustrate this. According to the Pammer and Alpenhof ruling, the language used by the website involved can be one among of the factors to determine whether the trader directed its activities to a particular Member State. Based on the Geo-blocking Regulation, traders are, however, only allowed to redirect customers after their explicit consent to a website that uses another language than the version of the trader's online interface. ${ }^{1789}$ The court seised therefore has to examine the website in more detail to determine whether the activities have been directed to the forum state.

The preamble to the Geo-blocking Regulation stipulates that "this Regulation should be without prejudice to Union law concerning judicial cooperation in civil matters, and in particular the provisions on the law applicable to contractual obligations and on court jurisdiction set out in Regulations (EC) No 593/2008 and (EU) No 1215/2012". ${ }^{1790}$ The foregoing seems to indicate that the Geo-blocking Regulation does not intend to affect the 'directed activities' approach to establish jurisdiction under Article 7(2) Brussels Ibis in crossborder copyright infringing cases. Yet, due to this Regulation, traders will frequently not be allowed to employ unjustified geo-blocking technologies and other forms of discrimination based on customers' nationality, place of residence or place of establishment within the

1782 See Article 4 Geo-blocking Regulation.

${ }^{1783}$ See recitals 13, 26 in the preamble of the Geo-blocking Regulation and Article 1(6) Geo-blocking Regulation. See also paragraph 4.5.3.

${ }^{1784}$ See recitals 13, 26 in the preamble of the Geo-blocking Regulation and Article 1(6) Geo-blocking Regulation.

1785 See recital 26 in the preamble of the Geo-blocking Regulation. This consideration appears to resemble the CJEU's concept of directed activities under Article 17(1)(c) Brussels Ibis in the ruling of Pammer and Alpenhof, para. 80. See also paragraph 4.5.3.

${ }_{1786}$ Recital 20 in the preamble to the Geo-blocking Regulation.

${ }^{1787}$ Recital 27 in the preamble to the Geo-blocking Regulation.

1788 See paragraph 4.5.3.

${ }^{1789}$ See Article 3(2) Geo-blocking Regulation.

${ }^{1790}$ See recital 13 in the preamble to the Geo-blocking Regulation (italics have been added). 
European Union. ${ }^{1791}$ Hence, the trader's tools to indicate whether his activities are directed to customers of certain Member States will be reduced. As illustrated above, the court seised will have to look beyond first impressions when examining whether the alleged infringing activities by the trader were directed to the forum state. ${ }^{1792}$ As argued above, the trader will nonetheless have other means to prevent directing his activities to certain Member States and therefore to reduce the risk of getting sued in these states. Furthermore, as explained in paragraph 4.5.2.3, traders can still block online interfaces that offer audiovisual services and electronically supplied services "the main feature of which is the provision of access to and use of copyright protected works and other protected subject matter including the selling of copyright protected works or protected subject matter in an intangible form". ${ }^{1793}$

\subsection{The 'victim's centre of interests' approach}

The following paragraphs will demonstrate that it has been argued that the court of the place where the copyright holder's so-called centre of interests is located could -under certain conditions- obtain jurisdiction regarding the entire damage. ${ }^{1794}$ The CJEU adopted the 'victim's centre of interests' approach under Article 7(2) Brussels Ibis in two rulings involving online infringements of personality rights. ${ }^{1795}$ The next paragraph will discuss the 'victim's centre of interests' approach established by the CJEU. Paragraph 6.2.2.2 will demonstrate that the Swedish Supreme Court applied the 'centre of interests' approach regarding the infringement of the moral sides of copyright. In paragraph 6.2.3, the so-called 'case-specific copyright holder's centre of interests' approach suggested by Kono and Jurcys will be set out. Finally, the various 'victim's centre of interests' approaches will be assessed in light of the assessment framework of paragraph 4.6. ${ }^{1796}$

\subsubsection{The 'victim's centre of interests' approach established by the CJEU regarding online infringement of personality rights}

\subsubsection{The joined cases of eDate and Martinez}

\subsection{The facts}

The joined cases eDate and Martinez involved victims who alleged that their personality rights, namely the right to reputation and the right to privacy, had been infringed by defamatory content disseminated via the Internet. In the first case of eDate Advertising GmbH v. $X$, two

\footnotetext{
${ }^{1791}$ See Article 3 and 4 Geo-blocking Regulation. See paragraph 4.5.2.

${ }^{1792}$ See Campo Comba 2018, p. 524. See also paragraph 4.5.3.

1793 See Article 4(1)(b) Geo-blocking Regulation.

${ }^{1794}$ Kono \& Jurcys 2015; Maunsbach 2012, pp. 56-57. The Swedish Supreme Court in the case Michael Engström v. Tylden \&Co AS (Norway), NJA 2012 s 483 decided on 4 July 2012. See paragraph 6.2.1.1.2 on the CJEU's concept of 'centre of interests'.

1795 Joined Cases C-509/09 and C-161/10 eDate Advertising GmbH v. X and Olivier Martinez and Robert Martinez v. MGN Limited.

${ }^{1796}$ See paragraph 6.2.4 up to and including paragraph 6.2.4.5.
} 
brothers requested the company 'eDate Advertising', established in Austria, to cease using their full name when reporting on a crime via the website 'www.rainbow.at' ${ }^{1797}$ Since the brothers had been domiciled in Germany, they sued eDate Advertising before a German court to obtain an injunction to refrain from publishing any information about them. The German Federal Court of Justice (Bundesgerichtshof) requested the CJEU to provide a preliminary ruling on the jurisdictional issue whether the German court could obtain jurisdiction based on the mere accessibility of the website involved or that there should be a "special connection between the contested content of the website and the state of the court seised". ${ }^{1798}$

In the second case of Olivier Martinez and Robert Martinez v. MGN Limited, the French actor Olivier Martinez and his father Robert Martinez sued the company MGN, established in England, before a French court for posting defamatory content on the website 'www.sundaymirror.co.uk' that infringed the actor's private life. ${ }^{1799}$ The Paris Regional Court (Tribunal de grande instance de Paris) requested the CJEU to provide a preliminary ruling on the jurisdictional issue whether the French court had jurisdiction under Article 7(2) Brussels Ibis based on the mere accessibility of the website. ${ }^{1800}$

\subsection{The preliminary ruling}

The CJEU decided to join the cases of eDate and Martinez as they both concerned the interpretation of the special jurisdiction rule of Article 7(2) Brussels Ibis in case of alleged online infringements of personality rights. ${ }^{1801}$ With respect to infringements of personality rights, the CJEU already interpreted this special jurisdiction rule in the Shevill ruling involving the distribution of a defamatory newspaper article. ${ }^{1802}$ In the latter case, the CJEU ruled that the victim of a defamatory newspaper distributed in several Member States may sue the publisher before the court of the Member State in which the publisher is established. ${ }^{1803}$ The latter court related to the Handlungsort will obtain jurisdiction regarding the entire dispute. ${ }^{1804}$ In addition, the victim may sue the publisher "before the courts of each Member State where the defamatory newspaper has been distributed and the victim claims to have suffered injury to this reputation". ${ }^{1805}$ The latter court of the Erfolgsort has only jurisdiction under Article 7(2) Brussels Ibis with respect to the damage caused within the forum state. ${ }^{1806}$

\footnotetext{
1797 Joined Cases C-509/09 and C-161/10 eDate and Martinez, para. 15-18.

1798 Joined Cases C-509/09 and C-161/10 eDate and Martinez, para. 24. The German Federal Court of Justice (Bundesgerichtshof) reference for a preliminary ruling also involved the interpretation of Article 3(1) and (2) Directive on Electronic Commerce.

1799 Joined Cases C-509/09 and C-161/10 eDate and Martinez, para. 25-26.

${ }^{1800}$ Joined Cases C-509/09 and C-161/10 eDate and Martinez, para. 29.

1801 Joined Cases C-509/09 and C-161/10 eDate and Martinez, para. 30, 37. See also the Opinion of Advocate General Cruz Villalón delivered on 29 March 2011 in the joined cases C-509/09 and C-161/10 eDate Advertising GmbH v. X and Martinez v. MGN Limited, para. 28-30.

1802 Case C-68/93 Shevill and Others v. Presse Alliance. See the Opinion of AG Cruz Villalón in the joined cases C-509/09 and C-161/10 eDate and Martinez, para. 30.

${ }^{1803}$ Case C-68/93 Shevill and Others v. Presse Alliance, para. 24-25. See also paragraph 4.3.

${ }^{1804}$ Case C-68/93 Shevill, para. 24-25.

1805 Case C-68/93 Shevill, para. 30.

1806 Case C-68/93 Shevill, para. 30. The approach to territorially limit the jurisdiction of the court to the damage within the forum state has been referred to as the mosaic approach. See paragraph 1.1.4.
} 
In the eDate and Martinez ruling, the CJEU largely alternated the aforementioned Shevill approach to the digital environment. ${ }^{1807}$ The CJEU gave importance to the following two factors related to the ubiquity of infringing content disseminated via the Internet. The first factor concerns the difficulty to apply the distribution criterion of the Shevill ruling to ubiquitous content since "that content may be consulted instantly by an unlimited number of internet users throughout the world, irrespective of any intention on the part of the person who placed it in regard to its consultation beyond that person's Member State of establishment and outside of that person's control". ${ }^{1808}$ At a technical level, it will be difficult to quantify and assess the damage caused by worldwide dissemination of an infringement of a personality right within a particular Member State. ${ }^{1809}$ The second factor is "the serious nature of the harm which may be suffered by the holder of a personality right who establishes that information injurious to that right is available on world-wide basis". ${ }^{1810}$

Hence, the CJEU adopted a new connecting factor under Article 7(2) Brussels Ibis namely the victim's centre of interests. ${ }^{1811}$ The court of the place in which the victim's centre of interests is located will obtain jurisdiction regarding the entire damage caused by an alleged infringement of personality rights by means of content placed online. ${ }^{1812}$ In view of the objective of the sound administration of justice, the CJEU reasoned that "given that the impact which material placed online is liable to have on an individual's personality rights might be best assessed by the court of the place where the victim has its centre of interests". ${ }^{1813}$ Furthermore, the CJEU argued that the 'victim's centre of interests' criterion "is in accordance with the aim of predictability governing jurisdiction" as it "allows both the applicant easily to identify the court in which he may sue and the defendant reasonably foresee before which court he may be sued". ${ }^{1814}$ In particular, the publisher of harmful content will "at the time at which that content is placed online, be in a position to know the centres of interests of the persons who are the subject of that content". ${ }^{1815}$

The latter consideration indicates that there can be more centres of interests. According to the CJEU, the concept of "centre of interests" generally covers the victim's habitual residence. ${ }^{1816}$ Yet "other factors, such as the pursuit of a professional activity," may also "establish the existence of a particularly close link" with a Member State and therefore constitute a centre of the victim's interests. ${ }^{1817}$

\footnotetext{
1807 Joined Cases C-509/09 and C-161/10 eDate Advertising GmbH v. X and Oliver Martinez and Robert Martinez v. MGN Limited, para. 45-48. See also Kuipers 2012(b), p. 1220.

1808 Joined Cases C-509/09 and C-161/10 eDate and Martinez, para. 45.

1809 Joined Cases C-509/09 and C-161/10 eDate and Martinez, para. 46.

${ }^{1810}$ Joined Cases C-509/09 and C-161/10 eDate and Martinez, para. 47. See also the Opinion of Advocate General Cruz Villalón delivered on 29 March 2011 in the joined Cases C-509/09 and C-161/10 eDate and Martinez, para. 56.

1811 Joined Cases C-509/09 and C-161/10 eDate and Martinez, para. 48.

1812 Joined Cases C-509/09 and C-161/10 eDate and Martinez, para. 48. See paragraph 5.3.3.1 on the scope of full jurisdiction.

1813 Joined Cases C-509/09 and C-161/10 eDate and Martinez, para. 48.

1814 Joined Cases C-509/09 and C-161/10 eDate and Martinez, para. 50.

1815 Joined Cases C-509/09 and C-161/10 eDate and Martinez, para. 50.

1816 Joined Cases C-509/09 and C-161/10 eDate and Martinez, para. 49.

1817 Joined Cases C-509/09 and C-161/10 eDate and Martinez, para. 49.
} 
Instead of the distribution criterion in the Shevill ruling, the CJEU held that the courts of each Member State in which the website involving the infringing content is or has been accessible can obtain jurisdiction regarding the damage caused within the forum state. ${ }^{1818}$ With respect to the interpretation of the Handlungsort, the CJEU ruled in line with the Shevill ruling that the court of the Member State in which the publisher of the infringing content is established will obtain jurisdiction regarding the entire damage. ${ }^{1819}$

\subsection{The Opinion of Advocate General Cruz Villalón}

In the Opinion in the eDate and Martinez case, Advocate General Cruz Villalón argued that the Shevill approach to jurisdiction had to be alternated with respect to infringements of personality rights allegedly committed via the Internet. ${ }^{1820}$ Cruz Villalón pointed out the worldwide instantaneous and uncontrolled dissemination of content via the Internet and the serious nature of the harm. ${ }^{1821}$ Unlike the CJEU, Cruz Villalón rejected to adopt the accessibility criterion combined with the mosaic approach because it would likely lead to fragmentation of litigation, unpredictability and forum shopping. ${ }^{1822}$ Moreover, Cruz Villalón emphasised that "any approach which entails altering the Shevill case-law must of necessity take into account the requirement of technological neutrality". ${ }^{1823}$ "Information content is fungible and its formats are interchangeable". ${ }^{1824}$ Connecting factors to establish jurisdiction should therefore be applicable irrespectively whether the alleged infringement occurred via the Internet or offline. ${ }^{1825}$

Cruz Villalón maintained the part of the Shevill ruling that the court of the Member State in which the publisher of the infringing content is established will obtain jurisdiction regarding the entire damage. ${ }^{1826}$ In addition, he held that "the courts of each Member State in which the information was published and in which the holder of personality claims to have been the victim of an attack on his reputation" can obtain jurisdiction regarding the damage caused within the forum state. ${ }^{1827}$

Instead of the CJEU's 'victim's centre of interests' criterion, Cruz Villalón proposed to adopt "the 'centre of gravity of the dispute' among the rights and interests at issue" as additional connecting factor under Article 7(2) Brussels Ibis. ${ }^{1828}$ The courts of the Member State where the 'centre of gravity of the dispute' is located will obtain jurisdiction regarding the entire damage caused by an infringement of personality rights. ${ }^{1829}$ According to Cruz Villalón, the

\footnotetext{
1818 Joined Cases C-509/09 and C-161/10 eDate and Martinez, para. 51.

1819 Joined Cases C-509/09 and C-161/10 eDate and Martinez, para. 51.

${ }^{1820}$ Opinion of Advocate General Cruz Villalón delivered on 29 March 2011 in the joined cases C-509/09 and C161/10 eDate and Martinez, para. 40-54.

${ }^{1821}$ See joined Cases C-509/09 and C-161/10 eDate and Martinez, para. 44-48.

${ }^{1822}$ Opinion of AG Cruz Villalón in the joined cases C-509/09 and C-161/10 eDate and Martinez, para. 51, 56.

1823 Opinion of AG Cruz Villalón in the joined cases C-509/09 and C-161/10 eDate and Martinez, para. 53. ${ }^{1824}$ Opinion of AG Cruz Villalón in the joined cases C-509/09 and C-161/10 eDate and Martinez, para. 53.

${ }^{1825}$ Opinion of AG Cruz Villalón in the joined cases C-509/09 and C-161/10 eDate and Martinez, para. 53.

${ }^{1826}$ Opinion of AG Cruz Villalón in the joined cases C-509/09 and C-161/10 eDate and Martinez, para 67.

1827 Opinion of AG Cruz Villalón in the joined cases C-509/09 and C-161/10 eDate and Martinez, para 82.

${ }_{1828}$ Opinion of AG Cruz Villalón in the joined cases C-509/09 and C-161/10 eDate and Martinez, para. 32, 55-67.

${ }^{1829}$ Opinion of AG Cruz Villalón in the joined cases C-509/09 and C-161/10 eDate and Martinez, para. 32, 66-67.
} 
'centre of gravity of the dispute' approach consist of two elements namely the place where the holder of personality rights has his 'centre of interests' and where the information is objectively relevant. ${ }^{1830}$ The suggested approach could therefore be denoted as a so-called combined approach to jurisdiction that will be discussed in paragraph 6.4. Paragraph 6.4.1 will assess the 'centre of gravity of the dispute' approach in the context of cross-border copyright infringement disputes.

The first element of the 'centre of gravity' approach refers to the place where the victim is known ${ }^{1831}$ and "carries out his life plan". ${ }^{1832}$ The latter criterion resembles the 'victim's centre of interests' criterion established in the eDate and Martinez ruling. The second element includes the place where the information is objectively relevant. ${ }^{1833}$ That means the place where users will likely access the information involved. ${ }^{1834}$ The potential infringer should reasonably foresee that the information will be objectively relevant in that state. ${ }^{1835}$ For instance, "a media outlet may reasonably foresee that the information published in its electronic edition is 'newsworthy' in a specific territory, thereby encouraging readers in that territory to access it". 1836

According to Cruz Villalón, the criterion of 'the place where the information is objectively relevant' will establish a close connection with the territory of the forum state. ${ }^{1837}$ To indicate whether information is objectively relevant, "it is necessary to examine the subject-matter of the information at issue". ${ }^{1838}$ Other factors are whether the website involved uses the top-level domain name of the forum state and the language of the website. ${ }^{1839}$ Unlike the 'directed activities' criterion under Article 17(1)(c) Brussels Ibis, the criterion of 'objectively relevant information' does not focus on the intent of the defendant to direct the alleged activities to the forum state but whether the infringing content is objectively relevant in that state. ${ }^{1840} \mathrm{Cruz}$ Villalón argued that the criterion of subjective intent does not fit Article 7(2) Brussels Ibis and "gives rise to wide-ranging evidential difficulties". ${ }^{1841}$ Paragraph 6.1 argued that the 'directed activities' approach under Article 7(2) Brussels Ibis will focus on the objective intent of the alleged infringer to direct his activities to the forum state.

According to Cruz Villalón, the 'centre of gravity of the dispute' approach denotes the place where the holder of personality rights will suffer the most extensive and serious harm. ${ }^{1842}$ From a perspective of predictability, the potential infringer should have foreseen the harm in

\footnotetext{
${ }^{1830}$ Opinion of AG Cruz Villalón in the joined cases C-509/09 and C-161/10 eDate and Martinez, para. 32, 59-67. See also Kuipers 2012(b), p. 1217.

${ }^{1831}$ This criterion has been first established by the CJEU in the case C-68/93 Shevill and Others v. Presse Alliance, para. 29.

1832 Opinion of AG Cruz Villalón in the joined cases C-509/09 and C-161/10 eDate and Martinez, para. 59.

${ }^{1833}$ Opinion of AG Cruz Villalón in the joined cases C-509/09 and C-161/10 eDate and Martinez, para. 60-65.

${ }^{1834}$ Opinion of AG Cruz Villalón in the joined cases C-509/09 and C-161/10 eDate and Martinez, para. 60.

${ }^{1835}$ Opinion of AG Cruz Villalón in the joined cases C-509/09 and C-161/10 eDate and Martinez, para. 60-63.

${ }^{1836}$ Opinion of AG Cruz Villalón in the joined cases C-509/09 and C-161/10 eDate and Martinez, para. 63. ${ }^{1837}$ Opinion of AG Cruz Villalón in the joined cases C-509/09 and C-161/10 eDate and Martinez, para. 65. ${ }^{1838}$ Opinion of AG Cruz Villalón in the joined cases C-509/09 and C-161/10 eDate and Martinez, para. 64. ${ }^{1839}$ Opinion of AG Cruz Villalón in the joined cases C-509/09 and C-161/10 eDate and Martinez, para. 65. 1840 Opinion of AG Cruz Villalón in the joined cases C-509/09 and C-161/10 eDate and Martinez, para. 62. ${ }^{1841}$ Opinion of AG Cruz Villalón in the joined cases C-509/09 and C-161/10 eDate and Martinez, para. 62. 1842 Opinion of AG Cruz Villalón in the joined cases C-509/09 and C-161/10 eDate and Martinez, para. 58, 61.
} 
this place and therefore the risk that he may get sued there. ${ }^{1843}$ Furthermore, "the centre of gravity will be the place where a court is best placed to understand fully the conflict between the interests involved". ${ }^{1844}$ As mentioned above, paragraph 6.4.1 will assess the "centre of gravity' approach to jurisdiction in the context of cross-border copyright infringement disputes.

\subsubsection{The case of Bolagsupplysningen OÜ and Ingrid Ilsjan v. Svensk Handel AB}

In the case of Bolagsupplysningen OÜ and Ingrid Ilsjan v. Svensk Handel AB, the CJEU confirmed that the 'victim's centre of interests' criterion established in the eDate and Martinez ruling is also applicable when a legal person suffers from an online infringement of personality rights. ${ }^{1845}$ In addition, the CJEU clarified the scope of the court's jurisdiction under Article 7(2) Brussels Ibis regarding the claim to remove and rectify the online infringing content. ${ }^{1846}$

The company named Bolagsupplysningen OÜ, established in Estonia with its main business activities in Sweden, sued the company Svensk Handel AB, established in Sweden, before the court of Estonia due to the publication of defamatory information on their website. Bolagsupplysningen OÜ requested compensation for all the damage and to remove and rectify the infringing content. The issue arose whether the Estonian court could obtain jurisdiction under Article 7(2) Brussels Ibis as the alleged infringing online information was published in the Swedish language and the fall in turnover was in the Swedish currency. ${ }^{1847}$ Bolagsupplysningen OÜ argued that the Estonian court had jurisdiction because its centre of interests has been in Estonia. ${ }^{1848}$ The management, economic activity, accounting, business development and personnel departments of the company had been located in Estonia and its income had been transferred from Sweden to Estonia. ${ }^{1849}$

The Supreme Court of Estonia referred the following three questions to the CJEU: whether the court on the basis of the accessibility criterion could issue an injunction to rectify or remove incorrect information; whether the 'victim's centre of interests' approach of the eDate and Martinez ruling could also be applied in case of a legal person as victim; and where the 'centre of interests' of a legal person would be located. ${ }^{1850}$

The CJEU first ruled that the 'victim's centre of interests' criterion of the eDate and Martinez ruling will also be applicable under Article 7(2) Brussels Ibis in case a legal person suffers from an online infringement of personality rights. ${ }^{1851}$ With respect to the location of the 'centre of interests' of a legal person, the CJEU held that this "must reflect the place where its commercial reputation is most firmly establishes and must therefore be determined by the

\footnotetext{
${ }^{1843}$ Opinion of AG Cruz Villalón in the joined cases C-509/09 and C-161/10 eDate and Martinez, para. 58. ${ }^{1844}$ Opinion of AG Cruz Villalón in the joined cases C-509/09 and C-161/10 eDate and Martinez, para. 58.

${ }^{1845}$ Case C-194/16 Bolagsupplysningen OÜ and Ingrid Ilsjan v. Svensk Handel AB, para. 44. See annotations by Kuipers 2018, pp. 541-548 and Van der Plas 2018, 3.

${ }^{1846}$ Case C-194/16 Bolagsupplysningen OÜ, para. 45-49.

${ }^{1847}$ Case C-194/16 Bolagsupplysningen Ö̈, para. 11.

1848 Opinion of Advocate General Bobek delivered on 13 July 2017 in the case C-194/16 Bolagsupplysningen Oü and Ingrid Ilsjan v. Svensk Handel AB, para. 17.

1849 Opinion of AG Bobek delivered on 13 July 2017 in the case C-194/16 Bolagsupplysningen Oü, para. 17.

${ }^{1850}$ Case C-194/16 Bolagsupplysningen OÜ, para. 21.

${ }^{1851}$ Case C-194/16 Bolagsupplysningen OÜ, para. 32-44.
} 
reference to the place where it carries at the main part of the its economic activities". ${ }^{1852}$ The place of the registered office is therefore not a conclusive criterion. ${ }^{1853}$ If it is not clear from the evidence where the legal person carries out the main part of its economic activities, the 'victim's centre of interests' criterion will not establish jurisdiction. ${ }^{1854}$ Nonetheless, the legal person may still bring his claim before the courts of each Member State where the infringing content is or has been accessible. ${ }^{1855}$ Thus, the accessibility criterion of the eDate and Martinez ruling is also applicable in case a legal person suffers from an online infringement of personality rights. ${ }^{1856}$

With respect to the scope of the court's jurisdiction, the CEJU reiterated that the jurisdiction of the courts based on the accessibility criterion will be limited to the damage caused within the territory of the forum state. ${ }^{1857}$ Pursuant to the CJEU, these courts will therefore not have jurisdiction to issue an injunction to remove or rectify the online infringing content. ${ }^{1858}$ The CJEU supported this ruling by pointing out the ubiquitous nature of online content and the fact that the removal and rectification is "a single and indivisible application". ${ }^{1859}$ Hence, the CJEU held that an injunction to remove and rectify the incorrect information can "only be made before a court with jurisdiction to rule on the entirety of an application for compensation for damage" such as the court of the place where the victim has his centre of interests. ${ }^{1860}$

The latter considerations on the impossibility of the court that has territorially limited jurisdiction to issue a cross-border injunction in an online infringement case could also be applied to an online copyright infringement case. ${ }^{1861}$ However, as mentioned in paragraph 5.3.1, a territorially limited injunction to cease online copyright infringing activities may often be feasible due to geo-blocking technologies. This type of injunction will nevertheless not provide efficient and satisfactory redress as the copyright infringing content will generally be accessible in other states. ${ }^{1862}$

\subsection{The Opinion of Advocate General Bobek}

In the Opinion of Bolagsupplysningen OÜ and Ingrid Ilsjan v. Svensk Handel AB, Advocate General Bobek argued to largely alternate the CJEU's approach to jurisdiction established in

\footnotetext{
${ }^{1852}$ Case C-194/16 Bolagsupplysningen Ö̈, para. 41.

${ }^{1853}$ Case C-194/16 Bolagsupplysningen OÜ, para. 41.

${ }^{1854}$ Case C-194/16 Bolagsupplysningen OÜ, para. 43.

1855 Case C-194/16 Bolagsupplysningen OÜ, para. 47.

${ }^{1856}$ See paragraph 6.2.1.1.2.

1857 Case C-194/16 Bolagsupplysningen OÜ, para. 47. The CJEU referred to the eDate and Martinez ruling, see paragraph 6.2.1.1.2 of this dissertation.

1858 Case C-194/16 Bolagsupplysningen Ö̈, para. 45-49.

${ }^{1859}$ Case C-194/16 Bolagsupplysningen OÜ, para. 48.

${ }^{1860}$ Case C-194/16 Bolagsupplysningen OÜ, para. 48. With respect to courts that obtain jurisdiction in respect of all the damage, the CJEU refers to Case C-68/93 Shevill para. 25, 26 and 32) and the joined cases C-509/09 and C-161/10 eDate and Martinez para. 42, 48.

${ }^{1861}$ See paragraph 5.3.3 on territorially limited or cross-border injunctions issued by the court on the basis of the Erfolgsort under Article 7(2) Brussels Ibis.

${ }^{1862}$ See Strowel 2014, p. 1131; Van der Plas 2018, para. 126. See also paragraph 5.3.1.
} 
the eDate and Martinez ruling with respect to alleged online defamatory content. ${ }^{1863}$ First of all, Bobek advocated to discard the approach of territorially limited jurisdiction, the so-called mosaic approach, because it "brings about a multiplication of fora that does not serve the legitimate interest of any party and defies the objectives of predictability and sound administration of justice". ${ }^{1864}$ In addition, he rejected the mere accessibility criterion. ${ }^{1865}$ The Opinion of Advocate General Bobek therefore resembles the Opinion of Advocate General Cruz Villalón in the eDate and Martinez case. ${ }^{1866}$

Bobek nevertheless argued to maintain the 'victim's centre of interests' criterion of the eDate and Martinez ruling that confers full jurisdiction to the court(s) of the place of the claimant's centre of interests. ${ }^{1867}$ Since the latter criterion indicates the place where the reputation of the victim has been most strongly affected. ${ }^{1868}$ From a perspective of the sound administration of justice, the 'victim's centre of interests' criterion will entail "the closest link to the claimant's centre of interests", this court "will be best placed to assess the overall impact of the entirety of the harm caused". ${ }^{1869}$

Bobek suggested to locate the 'centre of interests' for a legal person at the place where the main professional activities are located. ${ }^{1870}$ This place should be determined by "reference to turnover or number of customers or other professional contacts". ${ }^{1871}$ "The seat may be taken into account as one of the factual elements." ${ }^{1872}$ With respect to both natural and legal persons, Bobek noted that there may "be more centres of interests in respect of a specific claim". ${ }^{1873}$

In regard of the jurisdictional issue involving the claim to rectify and remove the allegedly harmful information, Bobek pointed out that "there is just one website" that can be regarded as the source of the damage; therefore, this information "simply cannot be rectified or deleted only 'in proportion; to the harm suffered in a given territory". ${ }^{1874} \mathrm{He}$ considered the requested injunction as a remedy that "is by nature indivisible". ${ }^{1875}$ Although Bobek advocated to discard the approach of territorially limited jurisdiction, as explained above, he emphasised that territorially limited jurisdiction would only be feasible with respect to claims for damages since "such claims are, by nature, quantitatively adjustable". ${ }^{1876}$

Similar to the CJEU's approach in the Shevill ruling, Bobek also interpreted the Handlungsort as the place where the defendant has been seated or domiciled which coincides

\footnotetext{
${ }^{1863}$ Opinion of Advocate General Bobek delivered on 13 July 2017 in the case C-194/16 Bolagsupplysningen Oü, para. 71-72.

${ }^{1864}$ Opinion of AG Bobek delivered on 13 July 2017 in the case C-194/16 Bolagsupplysningen Oü, para. 90. See paragraph 5.3.1 of this dissertation for arguments against the mosaic approach under the Pinckney doctrine.

1865 Opinion of AG Bobek delivered on 13 July 2017 in the case C-194/16 Bolagsupplysningen Oü, para. 91-97.

${ }^{1866}$ See paragraph 6.2.1.1.3.

${ }^{1867}$ Opinion of AG Bobek delivered on 13 July 2017 in the case C-194/16 Bolagsupplysningen Oü, para. 91-97.

${ }_{1868}$ Opinion of AG Bobek delivered on 13 July 2017 in the case C-194/16 Bolagsupplysningen Oü, para. 91, 96.

${ }^{1869}$ Opinion of AG Bobek delivered on 13 July 2017 in the case C-194/16 Bolagsupplysningen Oü, para. 98.

${ }^{1870}$ Opinion of AG Bobek delivered on 13 July 2017 in the case C-194/16 Bolagsupplysningen Oü, para. 112.

${ }^{1871}$ Opinion of AG Bobek delivered on 13 July 2017 in the case C-194/16 Bolagsupplysningen Oü, para. 113.

1872 Opinion of AG Bobek delivered on 13 July 2017 in the case C-194/16 Bolagsupplysningen Oü, para. 113.

1873 Opinion of AG Bobek delivered on 13 July 2017 in the case C-194/16 Bolagsupplysningen Oü, para. 116.

1874 Opinion of AG Bobek delivered on 13 July 2017 in the case C-194/16 Bolagsupplysningen Oü, para. 126.

1875 Opinion of AG Bobek delivered on 13 July 2017 in the case C-194/16 Bolagsupplysningen Oü, para. 84.

${ }^{1876}$ Opinion of AG Bobek delivered on 13 July 2017 in the case C-194/16 Bolagsupplysningen Oü, para. 84.
} 
with the general jurisdiction rule of Article 4 Brussels Ibis. ${ }^{1877}$ According to Bobek, there are thus only two types of fora open to the victim of online defamatory content, the domicile of the defendant and the centre of interests of the claimant. ${ }^{1878}$ Both these type of courts will obtain full jurisdiction to determine the entire damage and to issue an injunction ordering the rectification and removal of allegedly harmful information. ${ }^{1879}$

\subsubsection{The 'victim's centre of interests' approach applied to infringements of moral rights}

\subsubsection{Moral rights}

Paragraph 2.2.1.1 mentioned that copyrights can be distinguished in economic rights and moral rights. Economic rights relate to the work that requires copyright protection and can be transferred. ${ }^{1880}$ Economic rights include the reproduction right, the distribution right, and the right of communication to the public. ${ }^{1881}$ Moral rights are not transferrable since they reflect the bond between a copyright holder and its work. ${ }^{1882}$ Due to this special bond, moral rights are often regarded as personality rights. ${ }^{1883}$ The concept of moral rights originated in France and Germany. ${ }^{1884}$

While a number of moral rights can be identified, ${ }^{1885}$ the following four types of moral rights are generally distinguished. ${ }^{1886}$ First, the right of disclosure, also known as droit de publication or droit de divulgation, concerns the right to decide whether, and under which conditions, a work may be made available to the public. ${ }^{1887}$ Second, the right to withdrawal, referred to as droit de repentir, that means the right to withdrawal the work from public appearance. ${ }^{1888}$ Third, the right of integrity, also known as droit au respect, includes the right to oppose alternations or impairment of the work. ${ }^{1889}$ Fourth, the right of attribution, also known as droit á la paternité, involves the right of recognition of the authorship. ${ }^{1890}$

\footnotetext{
${ }^{1877}$ Opinion of AG Bobek delivered on 13 July 2017 in the case C-194/16 Bolagsupplysningen Oü, para. 93-94. 1878 Opinion of AG Bobek delivered on 13 July 2017 in the case C-194/16 Bolagsupplysningen Oü, para. 97-98. 1879 Opinion of AG Bobek delivered on 13 July 2017 in the case C-194/16 Bolagsupplysningen Oü, para. 130.

${ }^{1880}$ See Spoor, Verkade \& Visser 2019, p. 433.

${ }^{1881}$ Goldstein \& Hugenholtz 2013, pp. 303-336. See also paragraph 2.2.1.1.

1882 Goldstein \& Hugenholtz 2013, pp. 358; Spoor, Verkade \& Visser 2019, pp. 433, 437.

${ }^{1883}$ See Spoor, Verkade \& Visser 2019, pp. 433. See also paragraph 2.2.1.1 on the "personality-rights dimension" of copyrights.

1884 See Sundara Rajan 2011, p. 49. For on detailed description of the history of moral rights in France and Germany, see Adeney 2006, pp. 165-276.

${ }^{1885}$ Sundara Rajan 2011, p. 35.

${ }^{1886}$ Goldstein \& Hugenholtz 2013, pp. 365-367; Rushton 1998, p. 16; Spoor, Verkade \& Visser 2019, p. 433.

${ }^{1887}$ Goldstein \& Hugenholtz 2013, pp. 365-366; Rushton 1998, p. 16; Spoor, Verkade \& Visser 2019, p. 433. See also Sundara Rajan 2011, p. 65.

1888 Goldstein \& Hugenholtz 2013, p. 367; Rushton 1998, p. 16; Spoor, Verkade \& Visser 2019, p. 433. See also Sundara Rajan 2011, p. 65.

1889 Goldstein \& Hugenholtz 2013, pp. 363-365; Rushton 1998, p. 16; Spoor, Verkade \& Visser 2019, p. 433. Sundara Rajan (2011, p. 74) points out that some states have adopted "a clear distinction between a moral right of integrity and a moral right of "reputation". Article 6bis Berne Convention 1979 also contains the right of integrity, see paragraph 2.2.1.1.

1890 Goldstein \& Hugenholtz 2013, pp. 361-363; Rushton 1998, p. 16; Spoor, Verkade \& Visser 2019, p. 433. See also Sundara Rajan 2011, p. 33. Article 6bis Berne Convention 1979 also contains the right of attribution, see paragraph 2.2.1.1.
} 
Moral rights have not been harmonized in the European Union. ${ }^{1891}$ Based on the so-called author's rights tradition, ${ }^{1892}$ Member States "with a civil law approach have all included provisions in their copyright legislation on moral rights for authors"1893. There are, however, differences between these codifications regarding the content of the protected moral rights and the exercise of these rights after the death of the copyright holder. ${ }^{1894}$ As indicated in paragraph 2.2.1.1, common law states that adhere to the so-called copyright tradition offer less or no protection to moral rights. ${ }^{1895}$ Due to the Berne Convention 1979, many common law states are nonetheless deemed to protect certain moral rights. ${ }^{1896}$

\subsubsection{The 'copyright holder's centre of interests' approach related to infringements of moral rights}

In the case of Micael Engström v. Tylden \& Co As, the Swedish Supreme Court employed the 'victim's centre of interests' approach of the eDate and Martinez ruling to establish jurisdiction under Article 7(2) Brussels Ibis with respect to the infringement of the moral sides of copyright. ${ }^{1897}$ In this case, the copyright holder, domiciled in Sweden, sued the alleged copyright infringer, established in Norway, before the court in Sweden. The plaintiff asserted that the infringer had used a copyrighted image on music CD's that were put for sale on an Internet site with a Norwegian top-level domain name. The question arose whether the Swedish court could obtain jurisdiction under Article 7(2) Brussels Ibis to adjudicate this entire case.

The Swedish Supreme Court considered infringements of the moral sides of copyrights similar to infringements of personality rights such as the right to protect the reputation as mentioned in the eDate and Martinez ruling. ${ }^{1898}$ Analogue to the eDate and Martinez ruling, the Swedish Supreme Court therefore applied the 'victim's centre of interests' approach with

\footnotetext{
1891 Hugenholtz 2013, p. 278. Sirvinskaite (2010, pp. 263-288) particularly demonstrates the difference of protection of moral rights between the copyright laws of the France and Germany. See also paragraph 2.2.2.2.

1892 See paragraph 2.2.1.1.

${ }^{1893}$ Commission of European Communities, Follow-up to the Green Paper on Copyright and Related Rights in the Information Society, COM (1996) 586 final, Brussels 20.11.1996, p. 28. The European Commission underscored the importance to harmonize moral rights. See Sirvinskaite 2010, pp. 283-288 on the European Commission's initiatives over moral rights.

1894 See Rushton 1998, p. 16; Spoor, Verkade \& Visser 2019, pp. 444, 445. See Axhamn (2010, pp. 505-535) on the moral rights protected by Nordic copyright law. See Sirvinskaite (2010 pp. 278-282) on the difference regarding the content of moral rights according to the French legal system and the German legal system. See also Adeney 2006, pp. 165-276.

1895 Sirvinskaite 2010, p. 264. See, for instance, Adeney (2006, pp. 441-540) on the minimal protection of moral rights related to copyright in the United States of America. See also Goldstein and Hugenholtz 2013, pp. 358-359. Griffiths $(2015$, p. 87) pointed out that "at an international level, the exclusion of the obligations imposed under Article 6bis of Berne from the TRIPS Agreement is important and symbolic". See Article 9(1) Agreement on Trade Related Aspects of Intellectual Property Rights 1994.

1896 The United States of America and the United Kingdom are, for instance, common law countries that are a Contracting State of the Berne Convention 1979. For a list of the Contracting States of the Berne Convention 1979 see https://www.wipo.int/treaties/en/ip/berne/. See paragraph 2.2.1.1 on Article 6bis Berne Convention 1979 that includes the right of integrity and the right of paternity.

1897 Swedish Supreme Court in the case of Micael Engström v. Tylden \& Co AS (Norway), NJA 2012 s 483 decided on 4 July 2012.

${ }^{1898}$ Maunsbach 2010-2012, p. 191.
} 
respect to the infringement of the moral sides of copyright. ${ }^{1899}$ The Swedish court could thus obtain jurisdiction over the entire moral losses. ${ }^{1900}$ However, based on the territorial protection of copyrights, the Swedish Supreme Court limited the Swedish court's jurisdiction regarding the infringement of the economic sides of copyright to the damage that occurred in Sweden. ${ }^{1901}$

With respect to the localisation of damage, Maunsbach explained the difference between damage caused by the infringement of economic rights and moral rights. 1902 "The economic side of copyright manages on its own;" it "can be transferred and must likely be regarded as a form of subject matter that can be divested from the original creator". ${ }^{1903}$ Hence, the damage related to the economic sides of the copyright will occur where the right is located and not always where the creator or current right holder is located. ${ }^{1904}$ The moral sides of copyrights comprise personal rights that "remain with the original creator," the damage related to these moral rights will therefore occur in the place where the creator is located. ${ }^{1905}$ Similar to the Swedish Supreme Court, several scholars have demonstrated that based on the personality rights theory ${ }^{1906}$ ubiquitous infringements of moral rights may be adjudicated in the state where the copyright holder's centre of interests has been located. ${ }^{1907}$

\subsubsection{The 'case-specific copyright holder's centre of interests' approach}

The scholars Kono and Jurcys advocated in ubiquitous copyright infringement disputes to confer -under certain conditions- jurisdiction to the court of the place where the copyright holder's centre of interests is located. ${ }^{1908}$ They argue that concentration of litigation at the latter place entails efficient adjudication, suits the needs of the digital economy, and increases legal certainty and predictability for the parties and courts. ${ }^{1909}$ According to Kono and Jurycs, the "market effects test" could play a role in deciding whether the court of the copyright holder's centre of interest may issue cross-border injunctions and exercise jurisdiction over damage

\footnotetext{
${ }^{1899}$ Maunsbach 2010-2012, p. 191.

${ }^{1900}$ Maunsbach 2010-2012, p. 191.

${ }^{1901}$ Maunsbach 2010-2012, p. 191.

1902 Maunsbach 2012, p. 58. See paragraph 2.2.1.1 on the difference between moral and economic rights.

${ }^{1903}$ Maunsbach 2012, p. 58.

${ }^{1904}$ Maunsbach 2012, p. 58.

${ }^{1905}$ Maunsbach 2012, p. 58. Maunsbach adopted the view of Davies who argued that the moral sides of copyrights comprise personality rights, see Davis 2012(b), pp. 37-46. See also Rigamonti 2006, pp. 355-367.

1906 Davis (2012(b), pp. 37-46) describes the intersection between personality rights and copyrights. See also the "personality theory" set out by Hughes 1988, pp. 287-366. For more information on the theory of the moral rights, see Rigamonti 2006, pp. 355-367.

${ }^{1907}$ Kono \& Jurcys 2015, pp. 29-30; Lundstedt 2018, pp. 1035-1037, 1045; Maunsbach 2012, pp. 58-59.

${ }^{1908}$ Kono \& Jurcys 2015, pp. 1-33. With respect to the concept of the copyright holder's centre of interests, Kono and Jurcys refer to "the state where the copyright holder has his residence or centre of economic interests". See Kono \& Jurcys 2015 , p. 28. The 'case specific copyright holder's centre of interests' approach suggested by Kono and Jurcys will be applicable to ubiquitous copyright infringement disputes. See the definition of 'ubiquitous' in paragraph 2.3.4.1 that seems to be broader than 'internet-related'. Kono has been a Member of the Committee on Intellectual Property and Private International Law, created under the auspices of the International Law Association in November 2010. This Committee has established guidelines that can be adopted by international organisations, such as the Hague Conference on Private International Law and WIPO, as well as regional and national lawmakers. See http://www.ila-hq.org/en/committees/index.cfm/cid/1037 See paragraph 6.4.6 on Draft Guidelines named 'Intellectual Property and Private International Law' established by this Committee.

${ }^{1909}$ Kono \& Jurcys 2015, pp. 28-32.
} 
sustained in other states. ${ }^{1910}$ Therefore, targeting elements can be employed such as "accessibility, language, domain name, number of hits, or the location of the server/PC, as well as the effects on the potential market of the allegedly infringed works". ${ }^{1911}$ Besides the aforementioned targeting elements, the court should also take into account whether the defendant "makes profits from the dissemination of the infringing content in the forum state". ${ }^{1912}$ They argue that "the application of the "market effects test" could also function as a de minimis threshold" helping to avoid that the competent court needs to adjudicate a ubiquitous copyright infringement dispute that bears little connection with the forum state. ${ }^{1913}$ Due to the combination of the 'market effects' test and the 'centre of interests' criterion, the approach suggested by Kono and Jurcys could have been subsumed under combined jurisdictional approaches in paragraph 6.4 of this dissertation.

Pursuant to Kono and Jurycs, it is important that the conferral of jurisdiction to the court of the place where the copyright holder's centre of interests is located strikes a reasonable balance between the interests of the litigants. ${ }^{1914}$ The court particularly needs to focus on the economic power of the litigants. ${ }^{1915}$ Whereas the 'victim's centre of interest' approach may not be reasonable if the copyright holder can be considered as an economically powerful corporation, this approach may be justified in case of an economically weaker copyright holder such as a free-lance photographer, performer, or author. ${ }^{1916}$ Kono and Jurycs pointed out that the Brussels Ibis Regulation also protects economically weaker parties such as consumers and employees. ${ }^{1917}$ The court of the place where the copyright holder's centre of interests is located should consider all factual circumstances of the dispute in order to strike a reasonable balance between the interests of the parties. ${ }^{1918}$ Since Kono and Jurcys argue that "center of interests should be conceptualized as a case-specific criterion", their approach will be referred to as the 'case-specific copyright holder's centre of interests' approach. ${ }^{1919}$

\subsubsection{Assessing the various 'victim's centre of interests' approaches}

The following paragraphs will assess the various 'victim's centre of interests' approaches as discussed in the paragraphs above. As mentioned in paragraph 6.2.1.1.3 the 'centre of

\footnotetext{
${ }^{1910}$ Kono \& Jurcys 2015, p. 30.

${ }^{1911}$ Kono \& Jurcys 2015, p. 30.

1912 Kono \& Jurcys 2015, p. 32.

1913 Kono \& Jurcys 2015, p. 31.

1914 Kono \& Jurcys 2015, p. 31.

1915 Kono \& Jurcys 2015, p. 31.

${ }^{1916}$ Kono \& Jurcys 2015, p. 31.

${ }^{1917}$ Kono \& Jurcys 2015, p. 31. See Articles 10-16 Brussels Ibis on special jurisdiction rules in matters relating to insurance; Articles 17-19 Brussels Ibis on special jurisdiction rules in matters relating to consumer contracts. Recital 18 in the preamble to the Brussels Ibis Regulation stipulates in relation to insurance, consumer and employment contracts, the weaker party should be protected by rules of jurisdiction more favourable to his interests that the general rules".

${ }^{1918}$ Kono \& Jurcys 2015, p. 31.

${ }^{1919}$ Kono \& Jurcys 2015, p. 31. In line with Kono and Jurcys, De Groote advocated a flexible approach under Article 7(2) Brussels Ibis regarding torts that the court seised should assess all factual circumstances of the case to determine whether the exercise of jurisdiction under Article 7(2) Brussels Ibis would be reasonable. See De Groote 2004, pp. 281-287; De Groote 2009, pp. 447-454.
} 
gravity' approach proposed by Advocate General Cruz Villalón will be examined in paragraph 6.4.1.

\subsubsection{Pro and contra arguments of the 'victim's centre of interests' approach in cross- border copyright infringement disputes}

In the Wintersteiger case, the CJEU and Advocate General Cruz Villalón rejected the applicability of the 'victim's centre of interests' approach regarding an alleged online trademark infringement dispute. ${ }^{1920}$ They reasoned that unlike personality rights that are protected in all Member States, intellectual property rights are territorial protected by the Member State that granted the right. ${ }^{1921}$ Paragraph 5.1.3 already addressed the debated issue regarding the locus protectionis criterion in cross-border copyright infringement disputes; contrary to trademarks, copyrights appear to obtain almost universal protection under the Berne Convention of 1979 by their mere creation. ${ }^{1922}$ Copyrights therefore seem to resemble personality rights that are protected in each Member State. Furthermore, it has been argued that the locus protectionis criterion can be regarded as a substantive criterion that does not seem to fit at the jurisdictional level. ${ }^{1923}$ Despite the territorial protection of copyrights, several scholars have advocated to confer full jurisdiction to a particular court in multistate or ubiquitous copyright infringement cases for reasons of efficient and fair adjudication. ${ }^{1924}$ Under Article 4 Brussels Ibis, the court of the state where the copyright holder is domiciled will also have jurisdiction regarding copyrights protected by other states. ${ }^{1925}$

In the eDate and Martinez ruling, the CJEU employed two factors related to the ubiquity of infringing content disseminated via the Internet to justify the conferral of full jurisdiction under Article 7(2) Brussels Ibis to the court of the place where the victim's centre of interests

${ }^{1920}$ See C-523/10 Wintersteiger AG v. Products $4 U$ Sondermaschinenbau GmbH, para. 24-25. See also Opinion of Advocate General Cruz Villalón delivered on 16 February 2012 in the case C523/10 Wintersteiger AG v. Products 4U Sondermaschinenbau GmbH, para. 20. Lundstedt 2018, p. 1029.

1921 Case C-523/10 Wintersteiger, para. 25. See also Opinion of AG Cruz Villalón in the case C523/10 Wintersteiger, para. 20.

${ }^{1922}$ See in a similar way the Opinion of Advocate General Szpunar in the case C-172/18 AMS Neve. In regard of the locus protectionis as connecting factor to establish jurisdiction regarding online infringements of national trademarks in the Wintersteiger ruling, Szpunar pointed out that unlike national trademarks that are only protected in the state of registration "EU trade marks are given uniform protection and produce their effects throughout the entire area of the European Union (para 75). Based on the foregoing difference related to the locus protectionis, he argued that the accessibility criterion to establish jurisdiction regarding EU trade marks infringements would lead to multiplication of courts (para. 68-77). In view of the objective of foreseeability and the sound administration of justice, Szpunar advocated to adopt the 'directed activities' (referred to as targeting) approach to establish jurisdiction under Article 97(5) of Regulation No 207/2009 regarding infringements of European Union trade marks (para. 84-91). Due to the Berne Convention, copyrights seem to enjoy protection within the European Union in a similar way as European Union trademarks. Szpunar's arguments in favour of the 'directed activities' approach to jurisdiction could therefore also be applied in the context of cross-border copyright infringement cases. See also paragraph 5.1.4.

1923 See paragraph 5.1.3.

${ }^{1924}$ See paragraphs 2.3.4.1 and 5.3.2. See in this chapter, inter alia, the 'case specific copyright holder's centre of interests' approach suggested by Kono and Jurcys (paragraph 6.2.3); Article 6(1)(b) and Article 6(2) Dreyfuss and Ginsburg Convention of 2002 (paragraph 6.4.3); Article 12a Paragraph 5 MPI Proposal of 2001 (paragraph 6.4.4); Article 2:202 CLIP and Article 2:203(2) CLIP of 2011 (paragraph 6.4.5).

1925 See paragraph 5.1.3. 
is located. ${ }^{1926}$ These two factors could likely also be applied with respect to online copyright infringements disputes. ${ }^{1927}$ First, online copyright infringing content will generally be instantly worldwide available irrespectively of the intention of the person who placed it and it will be difficult to quantify and assess the local damage caused by this content within the forum state. ${ }^{1928}$ Second, copyright infringements via the Internet will cause serious harm to copyright holders. ${ }^{1929}$ In regard of the first factor, Kuipers pointed out that the CJEU emphasised in the eDate and Martinez ruling the fact that irrespectively of the intention of the person who placed infringing content, this content will be instantly worldwide available; nevertheless, the CJEU did not incorporate the intention of the infringer as a connecting factor such as the 'directed activities' approach that has been discussed in paragraph 6.1. ${ }^{1930}$ The second factor suits the 'author's rights tradition' in civil law states that underscores the need to protect the 'private' rights of copyright holders. ${ }^{1931}$ An infringement may even be considered as an encroachment on the copyright holder's human right to have property rights protected. ${ }^{1932}$ The following paragraphs will discuss whether the 'victim's centre of interests' approach under Article 7(2) Brussels Ibis could be justified in ubiquitous copyright infringements from a perspective of the moral sides of copyrights.

In case of a natural person as victim, the CJEU held that the concept of 'centre of interests' generally covers the victim's habitual residence. ${ }^{1933}$ De Boer advocated to adopt 'the place of the plaintiff's domicile' as connecting factor regarding the conflict-of-laws rule in tort cases. ${ }^{1934}$ According to De Boer, this factor has been based on the principle that favors the weaker party such as the victim related to the tort. ${ }^{1935}$ Furthermore, he argued that this connecting factor suits the current aim of tort law. ${ }^{1936}$ In the $20^{\text {th }}$ century, the aim of tort law has changed from the prevention of torts to the compensation of the damage caused by torts. ${ }^{1937}$ From a perspective of "functional allocation", De Boer has regarded the domicile of the victim to be the most suitable connecting factor. ${ }^{1938}$ According to De Boer, the interests of the tort victim to receive

\footnotetext{
1926 See paragraph 6.2.1.1.2. See joined Cases C-509/09 and C-161/10 eDate Advertising GmbH v. X and Olivier Martinez and Robert Martinez v. MGN Limited, para. 46-47.

1927 These two factors in the eDate and Martinez ruling resemble the New York Court of Appeals' reasoning in the case of Penguin Group (USA) Inc., v. American Buddha, 16 N.Y. 3d 295 (2011) to confer jurisdiction to the court of the copyright holder's principal place of business, see paragraph 7.3.2.1.

1928 See also joined Cases C-509/09 and C-161/10 eDate and Martinez, para. 45.

${ }^{1929}$ See also joined Cases C-509/09 and C-161/10 eDate and Martinez, para 47.

${ }^{1930}$ Kuipers 2012(b), p. 1220. See also Kuipers 2018, pp. 543-544.

1931 See paragraph 2.2.1.1.

1932 Article 7 of the Charter of Fundamental Rights of the European Union concerning the right to property also emphasises the fact that "intellectual property shall be protected". See paragraph 2.2.1.2 on the discussion whether copyright should be considered as human rights.

1933 Joined Cases C-509/09 and C-161/10 eDate and Martinez, para. 49.

1934 De Boer 1982, pp. 45-61. See also De Boer 1987, p. 497.

${ }^{1935}$ De Boer 1998, p. 42. See also paragraph 2.1.2.1.3 on the principle of protecting or favouring certain persons or concepts in private international law.

${ }^{1936}$ De Boer 1982, pp. 24, 46, 61. See also paragraph 2.1.2.1.2.

${ }^{1937}$ De Boer (1982, pp. 24, 46, 61) also referred to the shift from fault-based liability to strict liability. See also Strikwerda 2015, p. 189; Roelvink 1998, pp. 31-32. With respect to rules related to tort law, Symeonides differentiates between the two general objectives deterrence (conduct-regulating rules) and compensation (lossdistribution rules). See Symeonides 2017(a), pp. 44-52.

${ }^{1938}$ De Boer 1987, p. 497. According to De Boer, "the functional conflicts rule" is a connecting factor that has been "derived from the function attributed to the corresponding substantive law" (De Boer 1987, p. 24).
} 
compensation should thus be served by private international law. ${ }^{1939}$ This view fits the trend of instrumentalization of private international law as mentioned in chapter two. ${ }^{1940}$

De Boer's reasoning could also be applied in the jurisdictional context. However, the Brussels Ibis Regulation does not consider copyright holders as weaker parties that require protection at jurisdictional level. ${ }^{1941}$ Moreover, scholars argued that the adoption of the 'victim's centre of interests' approach under Article 7(2) Brussels Ibis in cross-border copyright infringement disputes would lead to generalization of the jurisdiction of the forum actoris and encroach the general rule of the forum rei under Article 4 Brussels Ibis. ${ }^{1942}$ With respect the interpretation of Article 7(2) Brussels Ibis, the CJEU repeatedly rejected an interpretation that would lead to generalization of the jurisdiction of the forum actoris. ${ }^{1943}$

As mentioned earlier, it is important that the instrumentalization of private international law does not undermine the main principles underlying this field. ${ }^{1944}$ De Boer did underline the importance of predictability by requiring that the defendant knew or should have known the identity of the victim and the location of the victim's domicile. ${ }^{1945} \mathrm{He}$ therefore suggested that the law of the victim's domicile may only be applied in case of an intentional tort. ${ }^{1946}$ Applying this so-called intentional tort or knowledge criterion in the context of jurisdiction could satisfy the aim of private international law that the defendant should reasonably foresee in which state he may get sued. Chapter seven of this dissertation will demonstrate that several courts of states of the United States of America employ the so-called knowledge criterion to establish jurisdiction in cross-border copyright infringement cases. The latter chapter will examine the so-called knowledge criterion under Article 7(2) Brussels Ibis on the basis of the assessment framework of paragraph 4.6. ${ }^{1947}$

It should be mentioned that the 'victim's centre of interests' approach adopted by the CJEU is a "technology-specific" approach since it will only apply to infringements of personality rights committed via the Internet. ${ }^{1948}$ According to Maunsbach, the eDate and Martinez ruling indicates that the CJEU "is willing to introduce flexible instruments designed to address technology-related challenges... by interpreting Article 7(2) "into a rule that embraces three jurisdictional heads: the place of action (covering all damages), the place of interest (covering

\footnotetext{
${ }^{1939}$ De Boer 1998, p. 42. With respect to the lex loci damni rule in Article 4 Rome II Regulation, this Regulation stipulates that "a connection with the country where the direct damage occurred (lex loci damni) strikes a fair balance between the interests of the person claimed to be liable and the person sustaining the damage, and also reflects the modern approach to civil liability and the development of systems of strict liability". See recital 16 in the preamble to the Rome II Regulation.

${ }^{1940}$ See paragraphs 2.1 .2 up to and including 2.1.2.1.6.

${ }^{1941}$ See paragraph 6.2.4.4.

1942 Opinion of Advocate General Jääskinen delivered on 13 June 2013 in the case C-170/12 Peter Pinckney v. KGD Mediatech AG, para. 69. See also Kuipers 2012(b), pp. 1220-1221.

${ }^{1943}$ Lehmann 2011, p. 539. See C-364/93 Antonio Marinari v. Loyds Bank plc and Zubaidi Trading Company, para. 13; C-168/02 Rudolf Kronhofer v Marianne Maier and Others, para. 20. See paragraph 4.2.3 on the contextual method of interpretation.

${ }^{1944}$ See paragraphs 1.2 and 2.1.2.1.6.

1945 De Boer 1982, p. 57.

${ }^{1946}$ De Boer 1982, p. 57.

${ }^{1947}$ See paragraph 7.5.1.2.1 on the assessment of the 'focal point' approach and paragraph 5.1.3.1 on the assessment of the 'individualized targeting' approach.

${ }^{1948}$ Svantesson 2016(a), p. 484. See the joined cases C-509/09 and C-161/10 eDate Advertising GmbH v. X and Martinez v. MGN Limited, para. 52.
} 
all the damages) and the place of effect (covering damages in the country of the court)". ${ }^{1949}$ Several scholars nonetheless advocated to adopt a technology neutral approach to jurisdiction because that would provide flexibility and legal certainty. ${ }^{1950}$ As argued by Cruz Villalón, "information content is fungible and its formats are interchangeable". ${ }^{1951}$ Kuipers pointed out that the eDate and Martinez ruling is not in accordance with the rulings Pammer and Alpenhof and Wintersteiger in which the CJEU adopted a technology neutral approach to jurisdiction under the Brussels Ibis Regulation. ${ }^{1952}$

In the rulings Pinckney, Hi Hotel and Pez Hejduk, the CJEU also appears to have adopted a technology neutral approach by employing the 'likelihood of damage' criterion ${ }^{1953}$. In the internet-related copyright infringement cases Pinckney and Pez Hejduk, the latter criterion can nonetheless be referred to as the accessibility criterion ${ }^{1954}$. In the eDate and Martinez ruling, the CJEU also adopted the accessibility criterion combined with the mosaic approach. The latter accessibility approach resembles the accessibility approach in the rulings Pinckney and Pez Hejduk. ${ }^{1955}$ In paragraph 5.2, the accessibility approach has already been examined under Article 7(2) Brussels Ibis in copyright infringement cases based on the assessment framework of paragraph 4.6. The following paragraphs will not assess the accessibility approach but focus on the 'victim's centre of interest' approach established in the eDate and Martinez ruling.

On the basis of the assessment framework set out in paragraph 4.6, the following paragraphs will assess the various 'victim's centre of interests' approaches as demonstrated in the previous paragraphs in order to be a legitimate alternative for the Pinckney doctrine. Based on these 'victim's centre of interests' approaches, the court may obtain full jurisdiction in internetrelated infringement cases. ${ }^{1956}$ The paragraphs 5.3.1 and 5.3.2 have already set out arguments against territorially limited jurisdiction in cross-border copyright infringement disputes. As mentioned in paragraph 5.3.4.1, a connecting factor should nonetheless carry enough weight to justify full jurisdiction. ${ }^{1957}$ Paragraph 6.2.4.3 will focus on the issue whether the various 'victim's centre of interests' approaches carry enough weight to justify full jurisdiction.

\subsubsection{The principle of predictability}

First, the 'victim's centre of interests' approach has to be considered in view of the principle of predictability. In the eDate and Martinez ruling, the CJEU reasoned that the 'victim's centre of interests' criterion "is in accordance with the aim of predictability governing jurisdiction" because it "allows both the applicant easily to identify the court in which he may sue and the

1949 Maunsbach 2010-2012, p. 182.

${ }^{1950}$ Kuipers 2012(a), pp. 393, 395. See also Hestermeyer 2006, p. 286. See also the Opinion of Advocate General Cruz Villalón delivered on 29 March 2011 in the joined cases C-509/09 and C-161/10 eDate Advertising GmbH v. $X$ and Martinez v. MGN Limited, para. 53.

${ }^{1951}$ See the Opinion of AG Cruz Villalón in the joined cases C-509/09 and C-161/10 eDate and Martinez, para. 53. See also Kuipers 2012(a), p. 393.

1952 Kuipers 2012(a), p. 395.

1953 See paragraph 3.5 .

1954 See paragraph 3.5 .

1955 See paragraphs $3.2 .3,3.4 .3,3.5$.

${ }^{1956}$ See paragraph 5.3 .3 on the concept of full jurisdiction according to this dissertation.

${ }^{1957}$ De Groote 2004, p. 257. See paragraph 5.3.4. 
defendant reasonably foresee before which court he may be sued". ${ }^{1958}$ The publisher of harmful content will "at the time at which that content is placed online, be in a position to know the centres of interests of the persons who are the subject of that content". ${ }^{1959}$ Pursuant to the CJEU, the 'victim's centre of interests' approach has thus been justified by the presumed knowledge of the potential infringer regarding the location of the victim's centre of interest. Yet, the alleged copyright infringer will often not know the identity of the copyright holder or in which place the copyright holder's centre of interests is located. Due to this frequent lack of knowledge, the 'victim's centre of interests' approach will generally not provide the same predictability to potential copyright infringers as to alleged infringers of personality rights.

As mentioned in the previous paragraph, De Boer proposed the so-called knowledge, or intentional tort, criterion that the defendant knew, or should have known, the identity of the victim and the location of the victim's domicile. It may be questioned whether the 'victim's centre of interests' approach could be applied to merely intentional copyright infringement cases. Based on De Boer's view, for instance, a trader who sells copyrighted products via the Internet, should be aware of the place where the copyright holder's centre of interests is located and therefore the possibility of being sued in that state. A blogger, on the other hand, may use a copyrighted photograph for his online blog without the knowledge of the copyright holder's identity or centre of interests. The question remains how to draw a clear line between intentional and not intentional copyright infringements, or between an infringer who acted 'in good faith' or 'in bad faith'. As mentioned in the previous paragraph, chapter seven will demonstrate and examine the so-called knowledge criterion adopted by several courts in the United States of America to establish jurisdiction in cross-border copyright infringement cases. ${ }^{1960}$

To limit the 'victim's centre of interest' approach to cross-border copyright infringements related to the moral sides will not provide more predictability to potential copyright infringers. As explained above, potential copyright infringers may often not be aware of the place where the copyright holder's centre of interests is located. Due to the territorially limited approach to jurisdiction regarding the infringement of the economic sides of copyright, the copyright holder may sue the infringer in multiple states to receive full redress which will cause unpredictability.

The 'case-specific copyright holder's centre of interests' approach may satisfy the objective of predictability because the court should strike a reasonable balance between the interests of the litigants and therefore consider the expectations of both litigants. ${ }^{1961}$ Due to the 'targeting' elements of the 'market effects' test, the potential infringer may also reasonably expect in which state(s) to get sued. ${ }^{1962}$ However, the 'case-specific copyright holder's centre of interests' approach depends on a value-based assessment by the court that does not guarantee ex ante predictability to copyright holders as whether they can sue in the state of the 'centre and interests' and to potential infringers as regards where they may get sued.

\footnotetext{
1958 Joined Cases C-509/09 and C-161/10 eDate and Martinez, para. 50.

1959 Joined Cases C-509/09 and C-161/10 eDate and Martinez, para. 50.

1960 See paragraph 7.5.1.2.1 on the assessment of the 'focal point' approach and paragraph 5.1.3.1 on the assessment of the 'individualized targeting' approach.

${ }^{1961}$ Kono \& Jurcys 2015, pp. 31.

${ }^{1962}$ Kono \& Jurcys 2015, pp. 30-32. See paragraph 6.2 .3 on the targeting elements of the 'case specific centre of interests' approach suggested by Kono and Jurcys.
} 


\subsubsection{A close connection between dispute and court/ sound administration of justice}

The 'victim's centre of interests' approach to jurisdiction will often not entail a close connection between the cross-border copyright infringement dispute and the court. In the Pinckney case, Jääskinen particularly argued that the 'victim's centre of interests' approach will not guarantee the legislature's intention of a close connection between an internet-related copyright infringement dispute and the competent court under Article 7(2) Brussels Ibis. ${ }^{1963}$ The damage caused by an online infringement of personality rights, like the right to respect one's private life, will generally be "most intense" in the place where the victim has the centre of his interests. ${ }^{1964}$ Yet, a copyright infringement dispute will not always cause most damage in the state in which the copyright holder's centre of interests is located. ${ }^{1965}$ For instance, the online sale of copyright infringing products may be directed to another state than the state of the copyright holder's centre of interests. Particularly the infringement of the economic sides of copyright may occur in other states than the copyright holder's centre of interest. ${ }^{1966}$ While it has been argued that consolidation of litigation in one single court enhances efficient litigation, ${ }^{1967}$ the court of the place in which the copyright holder's centre of interests has been located may not be in a good position to assess the entire copyright infringement case. If substantial damage caused by the infringement of the economic side(s) related to the copyright occurred in another state, the court of the place where the copyright holder's centre of interests is located will not be in the best position to assess the entire case.

As mentioned in paragraph 5.3.4.1, a connecting factor should carry enough weight to justify full jurisdiction ${ }^{1968}$ such as a strong territorial link ${ }^{1969}$. As indicated above, the 'victim's centre of interests' criterion will not guarantee a strong territorial connection between the crossborder copyright infringement dispute and the forum: the infringing activities may be directed to another state and substantial damage may occur in another state. Instead of a strong territorial link, conferral of full jurisdiction in ubiquitous copyright infringement cases could be justified by the strong link between the alleged infringement of the moral side(s) related to copyright and the court of the state where the copyright holder's centre of interests is located. ${ }^{1970}$ In the eDate and Martinez ruling, the CJEU argued that the serious harm caused by infringements of personality rights via Internet justifies the conferral of full jurisdiction. With respect to the eDate and Martinez ruling, Kuipers nonetheless argued that the conferral of full jurisdiction to the court based on the 'victim's centre of interests' criterion cannot be justified since it lacks foreesability regarding jurisdiction over all the damage. ${ }^{1971}$ Based on criteria relating to the

\footnotetext{
1963 Opinion of AG Jääskinen delivered on 13 June 2013 in the case C-170/12 Pinckney, para. 69.

1964 Opinion of AG Jääskinen delivered on 13 June 2013 in the case C-170/12 Pinckney, para. 70.

1965 Opinion of AG Jääskinen delivered on 13 June 2013 in the case C-170/12 Pinckney, para. 70. See also Opinion of AG Cruz Villalón in the case C-441/13 Pez Hejduk, para. 26-27. See also Lopez-Tarruella 2012, p. 341.

${ }^{1966}$ See paragraph 2.2.1.1 on the distinction between economic and moral rights. See also paragraph 6.2.2.2 on the difference between the localisation of damage caused by infringements of economic rights and moral rights.

${ }^{1967}$ See paragraph 4.2.4.2.

${ }^{1968}$ De Groote 2004, p. 257. See paragraph 5.3.4.

1969 Pertegás Sender 2002, p. 276.

${ }^{1970}$ See paragraph 6.2.2.1 on moral rights. See paragraph 6.2.2.2 on the difference between the localisation of damage caused by the infringement of economic rights and moral rights.

${ }^{1971}$ Kuipers 2012(b), p. 1221.
} 
online infringing publication, such as the language or the domain name of the website, he advocated that there may exist a closer connection with another state than the state where the victim's centre of interests is located. ${ }^{1972}$ In a similar way, with respect to online copyright infringing activities, Jääskinen argued that the focus should not lie on "the localization of the centre of the author's interests, but rather with the localization of his public". ${ }^{1973}$ His view reflects the 'directed activities' criterion as set out in paragraph 6.1. In paragraph 6.4.3.2, the combination of the 'directed activities' approach and the forum actoris approach as proposed by Dreyfuss and Ginsburg will be examined in light of the assessment framework of paragraph 4.6. ${ }^{1974}$

However, a copyright infringement dispute will often not only involve the infringement of the moral side(s) of copyright but can also include the infringement of the economic side(s) of copyright. As demonstrated in paragraph 6.2.2.2, the infringement of economic rights may frequently occur in another state than where the copyright holder's centre of interests is located. It is therefore questionable whether the connection between the cross-border copyright infringement dispute and the court of the state where the 'copyright holder's centre of interests' is located will be strong enough to justify full jurisdiction. The latter court may not be in the best position to assess the entire cross-border copyright infringement dispute.

Adopting the 'victim's centre of interests' approach merely in case of infringements of moral rights will likely entail a strong close connection between the dispute and the court as damage related to the moral sides will only occur in the state where the copyright holder is located. ${ }^{1975}$ Therefore, the court of the state where the copyright holder's 'centre of interest' is located will generally be in a good position to assess the entire damage caused by the infringement(s) of moral rights. Yet, despite the consolidation of litigation related to the moral losses in a single court, the copyright holder may likely have to sue the infringer before the courts in other states to receive full redress due to the court's territorially limited jurisdiction related to infringements of the economic side(s) of copyright. From a perspective of sound administration of justice, the moral rights-based 'centre of interests' approach will therefore not enhance efficient litigation; it increases the risk of forum shopping, litigation costs, and irreconcilable decisions. The distinction between moral and economic rights may also be undesirable in view of "the monistic conception of copyright" as traditionally adhered by several European states. ${ }^{1976}$

The adoption of the 'case-specific copyright holder's centre of interests' approach under Article 7(2) Brussels Ibis would likely entail a close connection between a ubiquitous copyright infringement dispute and the court. In particular "the market effects test could function as a de minimis threshold helping to avoid adjudication of ubiquitous copyright disputes... that bear

\footnotetext{
1972 Kuipers 2012(b), p. 1221.

1973 Opinion of Advocate General Jääskinen delivered on 13 June 2013 in the case C-170/12 Pinckney, para. 70.

${ }^{1974}$ See Article 6(1)(b) of the Dreyfuss and Ginsburg-Convention of 2002 that will be demonstrated in paragraph 6.4.3.

${ }^{1975}$ Maunsbach 2012, p. 58. See paragraph 6.2.2.2.

1976 Van Eechoud 2003, p. 140. See also Schack 2000, p. 61; Torremans 2012, p. 31. See paragraph 2.2.1.1 on the monistic conception of copyrights.
} 
little connection to the actual infringement". ${ }^{1977}$ However, a 'case-specific' approach will force the court to assess the circumstances of the dispute quite extensive which may hamper the sound administration of justice and jeopardizes legal certainty and ex ante predictability. ${ }^{1978}$ Whenever the court does not obtain jurisdiction over the dispute, this approach can be rather expensive and time-consuming for both the litigants and the forum state.

\subsubsection{The principle of balancing the interests}

Adopting the 'victim's centre of interests' approach will often not entail a procedural balance between the interests of the copyright holder and the alleged infringer. This approach will provide the copyright holder the advantage to sue in the so-called home state. ${ }^{1979}$ In paragraph 5.3.1, it has been argued that it can put an unreasonable burden on the copyright holder to sue the infringer in multiple states in order to receive full redress, particularly in case the infringer is domiciled and operated in a copyright haven and directed his infringing activities to the state of the copyright holder's centre of interests. On the one hand, it can also be advantageous to the infringer to get sued before one court instead of multiple courts. On the other hand, the potential copyright infringer will often not know in which state the copyright holder's centre of interests has been located and can therefore not predict get sued in that state. Hence, the balance of interests will frequently tip in favor of the copyright holder.

It has been argued that the interests of the tort victim should be protected by rules of private international law. ${ }^{1980}$ From an economic perspective, the alleged infringer may nonetheless be weaker than the copyright holder. The copyright holder can, for instance, be a multinational corporation. As mentioned in paragraph 2.1.2.1.3, the Brussels Ibis Regulation does not consider the copyright holder as a 'weaker party' that needs special jurisdictional protection.

The European Union did enact a special jurisdiction rule for tort cases in Article 7(2) Brussels Ibis. However, the rationale behind this rule does not seem to protect the victim as weaker party. ${ }^{1981}$ In the Bier ruling, the CJEU held that this special jurisdiction rule provides the opportunity to the court of the place where the harmful event occurred to obtain jurisdiction since it will be "particularly helpful from the point of view of the evidence and of the conduct of the proceedings". ${ }^{1982}$ Due to the close connection between the dispute and the forum state, the court will be in a good position to assess the case. As argued in the previous paragraph, the victim's centre of interests' approach does not guarantee this close connection.

From a broader perspective, the 'victim's centre of interests' approach does not seem to balance the interests of copyright holders, on the one hand, and users of information and traders, on the other hand. The 'victim's centre of interests' approach will enhance copyright protection at procedural level; copyright holders will receive efficient redress as they can sue the infringer

\footnotetext{
1977 Kono \& Jurcys 2015, p. 31.

${ }^{1978}$ See also Van der Plas (2018, para. 68) on the objections against the assessment of the power of litigants in case of infringements of personality rights.

1979 See Kono and Jurcys 2015, p. 28.

${ }^{1980}$ De Boer 1998, p. 42.

1981 See paragraph 5.1.4.

1982 Case C-21/76 Handelskwekerij G.J. Bier v. Mines de Potasse d'Alsace SA, para. 17. See paragraph 2.1.2.2.2.
} 
before the court of the place of their centre of interests for the entire damage or to obtain a cross-border injunction to cease or prevent the infringement. ${ }^{1983}$

Yet, providers of online information and traders operating via the Internet will as potential copyright infringer often not be aware of the state where the copyright holder's centre of interests has been located. Due to the lack of predictability as regards where potential infringers may get sued, small trading companies may hesitate to provide their products or services via the Internet to customers in the European Union. This unpredictability may also affect the exchange of online information and impede the cross-border flow of information within the European Union. The abovementioned considerations are also applicable to the moral rightsbased 'copyright holder's centre of interests' approach.

The 'case-specific copyright holder's centre of interests' approach will enable the court to strike a fair procedural balance between the interests of the litigants. This approach will particularly require the court seised to balance the interests of an economically weaker copyright holder and an economically powerful infringer. Due to the lack of special protection of copyright holders under the Brussels Ibis Regulation, ${ }^{1984}$ it is nevertheless disputable whether economically weak copyright holders should receive special procedural protection under Article 7(2) Brussels Ibis. It will also be difficult to establish criteria to determine when a party will be economically weak. ${ }^{1985}$ With respect to the special jurisdiction rules in the Brussels Ibis Regulation on matters relating to insurance, the CJEU has frequently rejected "a case-by-case assessment" of the question whether an injured person can be regarded as "the economically weaker party" because it would yield legal uncertainty and unpredictability as regards which court(s) will be competent. ${ }^{1986}$

From a broad perspective, the 'case-specific copyright holder's centre of interests' approach will likely not balance the interests of copyright holders, on the one hand, and users of information and traders, on the other hand. While the 'case-specific copyright holder's centre of interests' approach appears to favour copyright holders who can be considered as economically weaker parties, it may be difficult to predict the court's assessment. The lack of unpredictability as regards whether potential infringers may get sued in the state of the copyright holder's centre of interests may decrease creativity and innovation. The value-based 'case-specific copyright holder's centre of interests' approach ${ }^{1987}$ will also not offer providers of information and traders ex ante predictability as regards where they may get sued. Therefore, this approach to jurisdiction could hamper cross-border trade and the flow of information.

\footnotetext{
${ }^{1983}$ See paragraph 5.3.3 on the injunction to cease a cross-border copyright infringement and paragraph 5.3.3.1 on the concept of full jurisdiction under Article 7(2) Brussels Ibis in cross-border copyright infringement cases.

1984 See recital 18 of the preamble to the Brussels Ibis Regulation and the special jurisdiction rules laid down in Article 10-23 Brussels Ibis. See also paragraph 5.1.4.

1985 See Van der Plas (2018, para. 64-68) on the objections against the assessment of the power of litigants under Article 7(2) Brussels Ibis in case of infringements of personality rights.

1986 See Case C-340/16 Landeskrankenanstalten-Betriebsgeschellschaft-KABEG, para. 34; Case C-106/17 Pawel Hofsoe v. LVM Landwirtschaftlicher Versicherungsverein Münster AG, para. 45; Case C-803/18 AAS 'Balta' v. $U A B$ 'Grifs $A G$ ', para. 42.

${ }^{1987}$ See paragraph 6.2.4.2.
} 


\subsubsection{The Geo-blocking Regulation and the 'victim's centre of interests' approach}

The prohibitions in the Geo-blocking Regulation will not influence the 'victim's centre of interests' approach to jurisdiction. The latter approach focuses on the state where the copyright holder' $s$ centre of interest has been located regardless whether the alleged copyright infringer blocked the access to his website, or employed other forms of discrimination, to customers' nationality, place of residence or place of establishment. Even if the alleged copyright infringer blocked his website for customers of the state where the copyright holder's centre of interests has been located, the court of the latter state can obtain jurisdiction based on the 'victim's centre of interests' approach.

6.3 Table 1: The assessment of various approaches to jurisdiction in cross-border copyright infringement cases

\begin{tabular}{|c|c|c|c|c|}
\hline $\begin{array}{l}\text { Connecting } \\
\text { factors }\end{array}$ & $\begin{array}{l}\text { 'Directed } \\
\text { activities' } \\
\text { approach }\end{array}$ & $\begin{array}{l}\text { 'Victim's centre } \\
\text { of interests' } \\
\text { approach }\end{array}$ & $\begin{array}{l}\text { 'Copyright } \\
\text { holder's centre } \\
\text { of interests' } \\
\text { approach } \\
\text { related to the } \\
\text { moral sides of } \\
\text { copyright }\end{array}$ & $\begin{array}{l}\text { 'Case-specific } \\
\text { copyright } \\
\text { holder's centre } \\
\text { of interests' } \\
\text { approach }\end{array}$ \\
\hline $\begin{array}{l}\text { Scope of the } \\
\text { court's } \\
\text { jurisdiction }\end{array}$ & $\begin{array}{l}\text { Jurisdiction } \\
\text { limited to the } \\
\text { damage caused } \\
\text { within the } \\
\text { territory of the } \\
\text { forum state. }\end{array}$ & $\begin{array}{l}\text { Jurisdiction with } \\
\text { respect to the } \\
\text { entire } \\
\text { infringement } \\
\text { dispute. }\end{array}$ & $\begin{array}{l}\text { Jurisdiction with } \\
\text { respect to the } \\
\text { entire } \\
\text { infringement } \\
\text { dispute. }\end{array}$ & $\begin{array}{l}\text { Jurisdiction with } \\
\text { respect to the } \\
\text { entire } \\
\text { infringement } \\
\text { dispute. }\end{array}$ \\
\hline $\begin{array}{l}\text { Technology } \\
\text { neutral }\end{array}$ & Yes & No & No & No \\
\hline $\begin{array}{l}\text { Predictability } \\
\text { as regards } \\
\text { which court } \\
\text { may be } \\
\text { competent }\end{array}$ & $\begin{array}{l}\text { Yes } \\
\text { The potential } \\
\text { copyright } \\
\text { infringer will } \\
\text { generally expect } \\
\text { to get sued in } \\
\text { the state(s) to } \\
\text { which his } \\
\text { activities have } \\
\text { been directed. } \\
\text { Due to the } \\
\text { 'objective } \\
\text { intention' } \\
\text { criterion, the } \\
\text { copyright holder }\end{array}$ & $\begin{array}{l}\text { No } \\
\text { The alleged } \\
\text { infringer may } \\
\text { often not know } \\
\text { in which place } \\
\text { the copyright } \\
\text { holder's centre } \\
\text { of interests is } \\
\text { located. }\end{array}$ & $\begin{array}{l}\text { No } \\
\text { The alleged } \\
\text { infringer may } \\
\text { often not know in } \\
\text { which state the } \\
\text { copyright } \\
\text { holder's centre of } \\
\text { interests is } \\
\text { located. }\end{array}$ & $\begin{array}{l}\text { No } \\
\text { The case-specific } \\
\text { value-based } \\
\text { approach will not } \\
\text { guarantee ex ante } \\
\text { predictability as } \\
\text { regards which } \\
\text { court will be } \\
\text { competent. }\end{array}$ \\
\hline
\end{tabular}




\begin{tabular}{|c|c|c|c|c|}
\hline & $\begin{array}{l}\text { should } \\
\text { reasonably } \\
\text { foresee in which } \\
\text { state(s) he may } \\
\text { sue the alleged } \\
\text { infringer. }\end{array}$ & & & \\
\hline $\begin{array}{l}\text { Close } \\
\text { Connection } \\
\text { between } \\
\text { dispute and } \\
\text { court }\end{array}$ & $\begin{array}{l}\text { Yes } \\
\text { There will } \\
\text { generally be a } \\
\text { close connection } \\
\text { between the } \\
\text { copyright } \\
\text { infringement } \\
\text { dispute and the } \\
\text { court of the state } \\
\text { to which the } \\
\text { alleged } \\
\text { infringing } \\
\text { activities have } \\
\text { been directed. }\end{array}$ & $\begin{array}{l}\text { No } \\
\text { There will be a } \\
\text { close connection } \\
\text { between the } \\
\text { alleged } \\
\text { infringement of } \\
\text { the moral side(s) } \\
\text { of copyright and } \\
\text { the court of the } \\
\text { state in which } \\
\text { the copyright } \\
\text { holder's centre } \\
\text { of interests is } \\
\text { located. } \\
\text { Yet, alleged } \\
\text { infringements of } \\
\text { the economic } \\
\text { side(s) of } \\
\text { copyright may } \\
\text { occur in another } \\
\text { state than where } \\
\text { the copyright } \\
\text { holder's centre } \\
\text { of interests is } \\
\text { located; there } \\
\text { may therefore be } \\
\text { no close } \\
\text { connection } \\
\text { between the } \\
\text { alleged } \\
\text { infringements of } \\
\text { the economic } \\
\text { side(s) of } \\
\text { copyright and } \\
\text { the court of the } \\
\text { state in which } \\
\text { the copyright } \\
\text { holder's centre } \\
\text { of interests is } \\
\text { located. }\end{array}$ & $\begin{array}{l}\text { Yes } \\
\text { There will be a } \\
\text { close connection } \\
\text { between the } \\
\text { alleged } \\
\text { infringement of } \\
\text { the moral side(s) } \\
\text { of copyright and } \\
\text { the court of the } \\
\text { state in which the } \\
\text { copyright } \\
\text { holder's centre of } \\
\text { interests is } \\
\text { located. }\end{array}$ & $\begin{array}{l}\text { Yes } \\
\text { Due to the } \\
\text { 'market effects' } \\
\text { tests, there will } \\
\text { generally be a } \\
\text { close connection } \\
\text { between the } \\
\text { copyright } \\
\text { infringement } \\
\text { dispute and the } \\
\text { court of the state } \\
\text { to which the } \\
\text { alleged copyright } \\
\text { infringing } \\
\text { activities are } \\
\text { directed. }\end{array}$ \\
\hline
\end{tabular}




\begin{tabular}{|c|c|c|c|c|}
\hline $\begin{array}{l}\text { Sound } \\
\text { administration } \\
\text { of justice }\end{array}$ & $\begin{array}{l}\text { Yes } \\
\text { The court will } \\
\text { generally be in a } \\
\text { good position to } \\
\text { assess the facts } \\
\text { of the case. The } \\
\text { 'directed } \\
\text { activities' } \\
\text { criterion will } \\
\text { generally reduce } \\
\text { the risk of forum } \\
\text { shopping and } \\
\text { so-called empty } \\
\text { jurisdiction. } \\
\\
\text { However, } \\
\text { in case of a } \\
\text { multistate or } \\
\text { ubiquitous } \\
\text { copyright } \\
\text { infringement } \\
\text { dispute, there } \\
\text { may be multiple } \\
\text { competent } \\
\text { courts which } \\
\text { will not enhance } \\
\text { efficient } \\
\text { litigation and } \\
\text { increases the } \\
\text { risk of forum } \\
\text { shopping, } \\
\text { litigation costs, } \\
\text { and } \\
\text { irreconcilable } \\
\text { decisions. }\end{array}$ & $\begin{array}{l}\text { No } \\
\text { The court of the } \\
\text { place where the } \\
\text { copyright } \\
\text { holder's centre } \\
\text { of interests is } \\
\text { located may not } \\
\text { always be in a } \\
\text { good position to } \\
\text { assess the case. } \\
\text { For instance, if } \\
\text { substantial } \\
\text { damage caused } \\
\text { by the } \\
\text { infringement of } \\
\text { the economic } \\
\text { sides of the } \\
\text { copyright took } \\
\text { place in another } \\
\text { state. }\end{array}$ & $\begin{array}{l}\text { No } \\
\text { The court of the } \\
\text { place where the } \\
\text { centre of the } \\
\text { copyright } \\
\text { holder's interests } \\
\text { is located will be } \\
\text { in the best } \\
\text { position to assess } \\
\text { the } \\
\text { infringement(s) } \\
\text { of the moral sides } \\
\text { of copyright(s). } \\
\text { However, the } \\
\text { copyright holder } \\
\text { may likely have } \\
\text { to sue the } \\
\text { infringer in other } \\
\text { states to receive } \\
\text { full redress } \\
\text { regarding the } \\
\text { infringement(s) } \\
\text { of economic } \\
\text { rights related to } \\
\text { copyright(s). The } \\
\text { latter will not } \\
\text { enhance efficient } \\
\text { litigation and } \\
\text { increases the risk } \\
\text { of forum } \\
\text { shopping, } \\
\text { litigation costs, } \\
\text { and irreconcilable } \\
\text { decisions. }\end{array}$ & $\begin{array}{l}\text { No } \\
\text { The court seised } \\
\text { has to assess all } \\
\text { circumstances of } \\
\text { the case quite } \\
\text { extensively to } \\
\text { balance the } \\
\text { interests of the } \\
\text { litigants which } \\
\text { may hamper the } \\
\text { sound } \\
\text { administration of } \\
\text { justice. }\end{array}$ \\
\hline $\begin{array}{l}\text { Procedural } \\
\text { balance of } \\
\text { interests } \\
\text { between parties }\end{array}$ & $\begin{array}{l}\text { Yes } \\
\text { On the hand, the } \\
\text { copyright holder } \\
\text { may sue the } \\
\text { infringer in all } \\
\text { states to which } \\
\text { the activities are } \\
\text { directed. On the } \\
\text { other hand, the } \\
\text { infringer can } \\
\text { reasonably }\end{array}$ & $\begin{array}{l}\text { No } \\
\text { As the potential } \\
\text { copyright } \\
\text { infringer may } \\
\text { not know the } \\
\text { place where the } \\
\text { copyright } \\
\text { holder's centre } \\
\text { of interests is } \\
\text { located, the } \\
\text { alleged infringer }\end{array}$ & $\begin{array}{l}\text { No } \\
\text { As the potential } \\
\text { copyright } \\
\text { infringer may not } \\
\text { know the place } \\
\text { where the } \\
\text { copyright } \\
\text { holder's centre of } \\
\text { interests is } \\
\text { located, the } \\
\text { alleged infringer }\end{array}$ & $\begin{array}{l}\text { Yes } \\
\text { The court seised } \\
\text { should assess } \\
\text { whether the } \\
\text { interests of the } \\
\text { parties are } \\
\text { balanced. }\end{array}$ \\
\hline
\end{tabular}




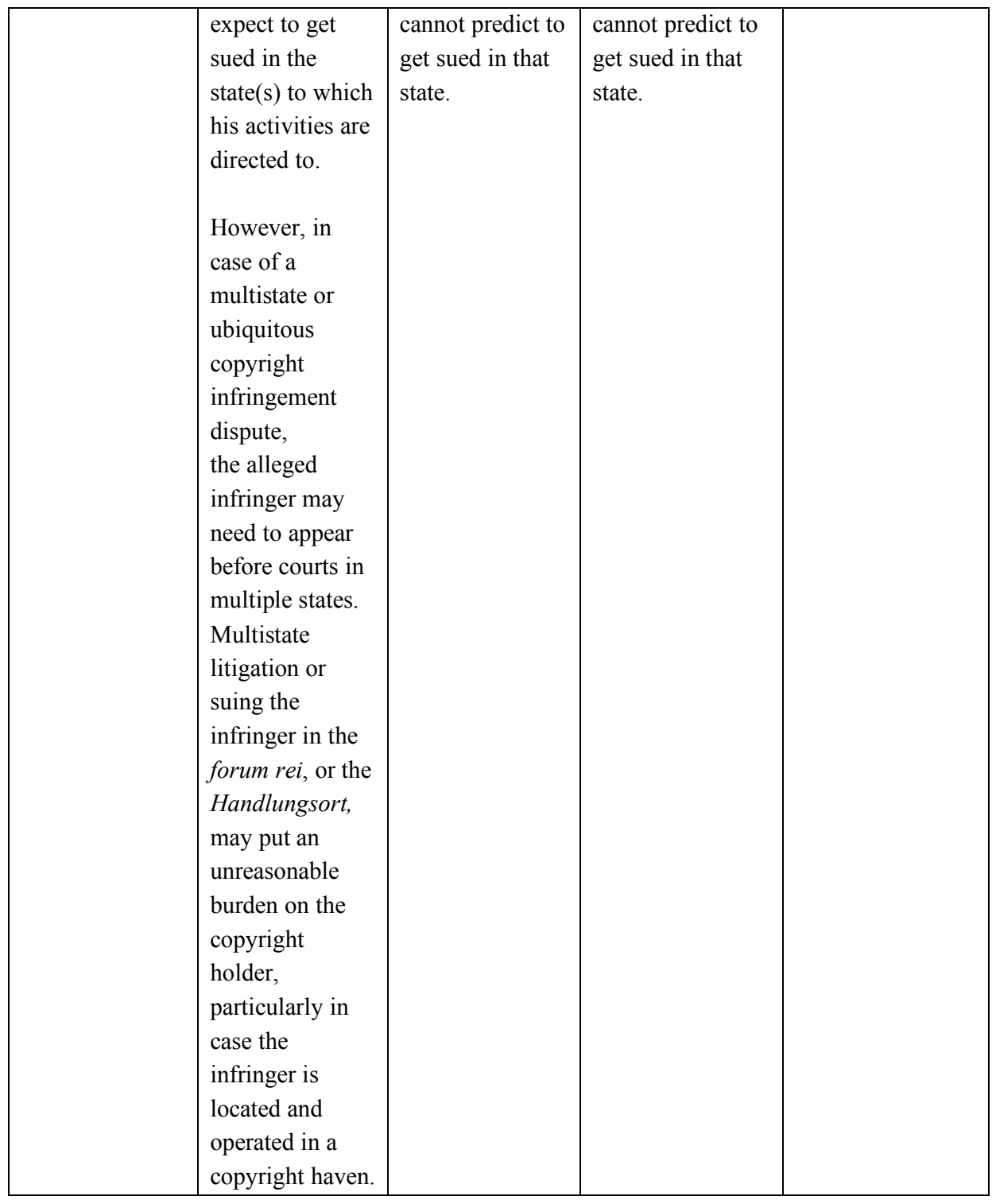




\begin{tabular}{|c|c|c|c|c|}
\hline $\begin{array}{l}\text { Balance of } \\
\text { broader } \\
\text { interests } \\
\text { involved }\end{array}$ & $\begin{array}{l}\text { Yes } \\
\text { On the one } \\
\text { hand, the } \\
\text { 'directed } \\
\text { activities' } \\
\text { approach will } \\
\text { generally } \\
\text { enhance } \\
\text { copyright } \\
\text { protection. On } \\
\text { the other hand, } \\
\text { it will provide } \\
\text { predictability to } \\
\text { traders and } \\
\text { providers of } \\
\text { information as } \\
\text { regards where } \\
\text { they may get } \\
\text { sued. } \\
\text { However, in } \\
\text { view of } \\
\text { multistate or } \\
\text { ubiquitous } \\
\text { copyright } \\
\text { infringements, } \\
\text { the 'directed } \\
\text { activities' } \\
\text { criterion and the } \\
\text { mosaic approach } \\
\text { do not provide } \\
\text { efficient } \\
\text { protection for } \\
\text { copyright } \\
\text { holders, } \\
\text { particularly in } \\
\text { case of online } \\
\text { piracy and } \\
\text { copyright } \\
\text { havens. In } \\
\text { addition, } \\
\text { the cross-border } \\
\text { flow of } \\
\text { information and } \\
\text { trade may be } \\
\text { impeded due to }\end{array}$ & $\begin{array}{l}\text { No } \\
\text { On the one hand, } \\
\text { this approach } \\
\text { will enhance } \\
\text { copyright } \\
\text { protection in } \\
\text { case of online } \\
\text { copyright } \\
\text { infringement } \\
\text { disputes. } \\
\text { On the other } \\
\text { hand, the online } \\
\text { flow of } \\
\text { information and } \\
\text { trade may be } \\
\text { impeded due to } \\
\text { the } \\
\text { unpredictability } \\
\text { for providers of } \\
\text { information and } \\
\text { traders as } \\
\text { regards where } \\
\text { they may get } \\
\text { sued. }\end{array}$ & $\begin{array}{l}\text { No } \\
\text { On the one hand, } \\
\text { this approach will } \\
\text { enhance the } \\
\text { protection of the } \\
\text { moral sides of } \\
\text { copyrights in case } \\
\text { of online } \\
\text { copyright } \\
\text { infringement } \\
\text { disputes. } \\
\text { On the other } \\
\text { hand, the online } \\
\text { flow of } \\
\text { information and } \\
\text { trade may be } \\
\text { impeded due to } \\
\text { the } \\
\text { unpredictability } \\
\text { for providers of } \\
\text { information and } \\
\text { traders as regards } \\
\text { where they may } \\
\text { get sued. }\end{array}$ & $\begin{array}{l}\text { No } \\
\text { Since the value- } \\
\text { based 'victim's } \\
\text { centre of } \\
\text { interests' test does } \\
\text { not provide ex } \\
\text { ante predictability } \\
\text { as regards which } \\
\text { court may obtain } \\
\text { jurisdiction, this } \\
\text { approach will not } \\
\text { enhance copyright } \\
\text { protection and } \\
\text { may impede the } \\
\text { online flow of } \\
\text { information and } \\
\text { trade. }\end{array}$ \\
\hline
\end{tabular}




\begin{tabular}{|c|c|c|c|c|}
\hline & $\begin{array}{l}\text { the fear to get } \\
\text { sued in multiple } \\
\text { states. }\end{array}$ & & & \\
\hline $\begin{array}{l}\text { Geo-blocking } \\
\text { Regulation }\end{array}$ & $\begin{array}{l}\text { If the alleged } \\
\text { copyright } \\
\text { infringer has } \\
\text { been a trader } \\
\text { who provides } \\
\text { goods and } \\
\text { services that are } \\
\text { not excluded } \\
\text { under this } \\
\text { Regulation, the } \\
\text { court seised has } \\
\text { to examine the } \\
\text { trader's } \\
\text { activities more } \\
\text { thoroughly to } \\
\text { assess whether } \\
\text { the alleged } \\
\text { infringer's } \\
\text { activities have } \\
\text { been directed to } \\
\text { the forum state. } \\
\text { Due to the } \\
\text { prohibitions } \\
\text { under the } \\
\text { Regulation, the } \\
\text { trader's tools to } \\
\text { prevent } \\
\text { directing his } \\
\text { activities to } \\
\text { particular } \\
\text { Member States } \\
\text { have been } \\
\text { reduced. }\end{array}$ & No effect & No effect & No effect \\
\hline
\end{tabular}




\subsection{Combined approaches to jurisdiction}

The following paragraphs will focus on so-called combined approaches to establish jurisdiction in cross-border copyright infringement cases. Most of these approaches have been suggested by scholarly groups particularly to enhance efficient adjudication in intellectual property infringement cases. ${ }^{1988}$ The provisions that will be discussed consists of a combination of alternative or complementary connecting factors that confer jurisdiction in cross-border infringement cases. Some of these approaches consists of connecting factors that have already been demonstrated in this chapter. The combined jurisdictional approaches related to the Erfolgsort will be examined on the basis of the assessment framework of paragraph 4.6. The next paragraph will assess the so-called 'centre of gravity of the dispute' approach to jurisdiction as demonstrated in paragraph 6.2.1.1.3.

\subsubsection{Assessing the 'centre of gravity of the dispute' approach}

In the Opinion of the eDate and Martinez ruling, Advocate General Cruz Villalón proposed the 'centre of gravity of the dispute' approach under Article 7(2) Brussels Ibis in case of crossborder infringements of personality rights. ${ }^{1989}$ As mentioned in paragraph 6.2.1.1.3, the latter approach consists of two complementary connecting factors: the place where the holder of personality rights has his 'centre of interests' and the place where the information is objectively relevant. ${ }^{1990}$ The first factor resembles the 'victim's centre of interest' criterion of the eDate and Martinez ruling. ${ }^{1991}$ The second factor is reminiscent of the 'directed activities' criterion as set out in paragraph 6.1.

Yet, Cruz Villalón pointed out that unlike the 'directed activities' criterion of Article 17(c) Brussels Ibis, the criterion of 'the place where the information is objectively relevant' does not focus on the intention of the defendant but whether the residents of a state will likely access the information involved. ${ }^{1992}$ The criterion of 'objective relevant information' requires to first examine the subject-matter of the information at issue. ${ }^{1993}$ In regard of online alleged defamatory content, it will be important whether this content will be "newsworthy" in the forum state. ${ }^{1994}$ Cruz Villalón stated "the more newsworthy a particular news item is in one national territory, the greater the likelihood that infringements o§f rights committed there will, in principle, have a connection with the courts of that territory". ${ }^{1995}$ In case of a newspaper article containing copyright infringing photos, it could be possible to assess the subject-matter of the

\footnotetext{
${ }^{1988}$ The 'centre of gravity of the dispute' approach (paragraph 6.4.1) and Article 10 of the Draft Hague Convention of 1999 (paragraph 6.4.2) do not particularly relate to infringements of intellectual property rights.

1989 Opinion of Advocate General Cruz Villalón delivered on 29 March 2011 in the joined cases C-509/09 and C161/10 eDate Advertising GmbH v. X and Martinez v. MGN Limited. See paragraph 6.2.1.1.3.

${ }^{1990}$ The Opinion of AG Cruz Villalón in the joined cases C-509/09 and C-161/10 eDate and Martinez, para. 32, 59-67. See also Kuipers 2012(b), p. 1217.

${ }^{1991}$ See paragraph 6.2.1.1.3.

1992 Opinion of AG Cruz Villalón in the joined cases C-509/09 and C-161/10 eDate and Martinez, para. 62-64.

1993 Opinion of AG Cruz Villalón in the joined cases C-509/09 and C-161/10 eDate and Martinez, para. 64.

${ }^{1994}$ Opinion of AG Cruz Villalón in the joined cases C-509/09 and C-161/10 eDate and Martinez, para. 64.

1995 Opinion of AG Cruz Villalón in the joined cases C-509/09 and C-161/10 eDate and Martinez, para. 64.
} 
infringing content. To determine 'the place where the information is objectively relevant', Cruz Villalón also referred to similar factors as employed by the CJEU in the Pammer and Alpenhof ruling such as language used or country code top level-domain name of the website. ${ }^{1996}$ As mentioned in the paragraphs 6.1 and 6.1.4.1, these factors may be applicable in case of copyright infringement disputes.

However, it will not always be feasible to determine the 'objective relevance' of copyright infringing content in the forum state. With respect to copyright infringing products, it will often be difficult to determine whether these products will be 'objectively relevant' in the forum state. Since the adoption of the 'objectively relevant content' criterion will not be suitable in all copyright infringement disputes, Cruz Villalón's 'centre of gravity of the dispute' approach will not be further assessed in this dissertation. Oster argued that the 'centre of gravity of the dispute' approach resembles the forum non conveniens doctrine that has been applied by courts in common law states but rejected by the CJEU in the case of Andrew Owusu v. N.B. Jackson. ${ }^{1997}$ Nonetheless, Cruz Villalón's suggested approach to jurisdiction raises the following three pitoval issues to consider when rethinking the CJEU's approach to jurisdiction in cross-border copyright infringement disputes.

First, 'the centre of gravity of the dispute' criterion demonstrates that the 'victim's centre of interests' criterion combined with 'the place where the information is objectively relevant' criterion will provide predictability and a close connection between the forum state and a dispute involving the infringement of personality rights. ${ }^{1998}$ As explained in the paragraphs 6.2.4.2 and 6.2.4.3, the adoption of the 'victim's centre of interests' criterion will generally lack predictability and does not guarantee a close connection between the court and the dispute in cross-border copyright infringement disputes. Similar to 'the place where the information is objectively relevant' criterion, the 'directed activities' criterion could entail a territorial connection to the forum state and provide predictability in cross-border copyright infringement cases ${ }^{1999}$. It may therefore be considered whether the 'copyright holder's centre of interests' criterion combined with the 'directed activities' criterion could be a suitable approach under Article 7(2) Brussels Ibis in cross-border copyright infringement cases. Paragraph 6.4.3.2 will demonstrate that Dreyfuss and Ginsburg proposed a combined approach to jurisdiction for cases involving infringements of intellectual property rights that appears to consists of the 'directed activities' criterion and the forum actoris approach that resembles the 'victim's centre of interests' approach. ${ }^{2000}$ The paragraphs 6.4.3.2.1 up to and including 6.4.3.2.4 will assess this combined approach on the basis of the assessment framework of paragraph 4.6. This chapter will also demonstrate various approaches to jurisdiction that combine the 'directed activities' criterion, or 'victim's centre of interests' criterion, with other connecting factors. ${ }^{2001}$

\footnotetext{
1996 Opinion of AG Cruz Villalón in the joined cases C-509/09 and C-161/10 eDate and Martinez, para. 65.

${ }^{1997}$ Case C-281/02 Andrew Owusu v. N.B. Jackson, para. 23-47. See Oster 2012, p. 121.

${ }^{1998}$ See paragraph 6.2.1.1.3.

${ }^{1999}$ See paragraphs 6.1.4.1 and 6.1.4.2.

${ }^{2000}$ See Article 6(1)(b) and Article 6(2) Dreyfuss and Ginsburg Convention of 2002 (paragraph 6.4.3).

2001 See the 'case-specific copyright holder's centre of interests' approach suggested by Kono and Jurcys (paragraph 6.2.3); Article 10(1)(b) and (4) Draft Hague Convention of 1999 (paragraph 6.4.2); Article 6(1)(c) and Article 6(3) Dreyfuss and Ginsburg-Convention of 2002 (paragraph 6.4.3); Paragraph 6(1) of Article 12a MPI Proposal (paragraph 6.4.4); Article 2:202 CLIP and Article 2:203(2) CLIP (paragraph 6.4.5).
} 
Second, Cruz Villalón advocated the abolishment of territorially limited jurisdiction based on the accessibility criterion for reasons of sound administration of justice. ${ }^{2002} \mathrm{He}$ argued that the accessibility criterion and the mosaic principle will likely lead to fragmentation of litigation, unpredictability and forum shopping. ${ }^{2003}$ Paragraph 6.2.1.2.1 described that Advocate General Bobek also advocated to discard the mosaic approach to jurisdiction for reasons of predictability and sound administration of justice. ${ }^{2004}$ In addition, Bobek rejected the mere accessibility criterion in case of online infringements of personality rights. ${ }^{2005}$ Considering the views of Cruz Villalón and Bobek, the issue raises whether the mosaic approach should be totally abolished in cross-border copyright infringement cases. ${ }^{2006}$ The paragraphs 5.3.1 and 5.3.2 provided arguments against the mosaic approach under Article 7(2) Brussels Ibis in cross-border copyright infringement disputes. This chapter will examine several approaches that propose consolidation of litigation before one court in cross-border copyright infringement cases. ${ }^{2007}$

Instead of the accessibility criterion and the mosaic approach, Cruz Villalón and Bobek both advocated to adopt a 'victim's centre of interests'-based jurisdictional approach that confers full jurisdiction. ${ }^{2008}$ Nonetheless, they disagreed whether this approach should only be applied regarding internet-related infringements. Cruz Villalón has favoured a technology neutral approach to jurisdiction. ${ }^{2009} \mathrm{He}$ argued that the media through which infringing content has been disseminated are interchangeable. ${ }^{2010}$ From a perspective of legal certainty, several scholars have advocated a technology neutral approach to jurisdiction. ${ }^{2011}$ Although Bobek shares the desire for jurisdictional criteria that are technology neutral as advocated by Cruz Villalón, he sees "difficulties in treating situations that are objectively very different, as the same". ${ }^{2012}$ The foregoing indicates the third issue that should be considered in this dissertation: whether a technology neutral or technology-based approach to jurisdiction should be adopted under Article 7(2) Brussels Ibis in copyright infringement disputes.

\footnotetext{
2002 Opinion of Advocate General Cruz Villalón delivered on 29 March 2011 in the joined cases C-509/09 and C161/10 eDate Advertising GmbH v. X and Martinez v. MGN Limited, para. 51, 56.

${ }^{2003}$ The Opinion of AG Cruz Villalón in the joined cases C-509/09 and C-161/10 eDate and Martinez, para. 51, 56.

${ }^{2004}$ Opinion of Advocate General Bobek delivered on 13 July 2017 in the case C-194/16 Bolagsupplysningen Oü and Ingrid Ilsjan v. Svensk Handel AB, para. 90. See paragraph 5.3.1 on arguments against the mosaic approach under the Pinckney doctrine.

${ }^{2005}$ Opinion of AG Bobek in the case C-194/16 Bolagsupplysningen Oü, para. 91-97.

${ }^{2006}$ See also Kuipers 2018, p. 545.

${ }^{2007}$ See the 'copyright holder's centre of interests' approach related to infringements of moral rights (paragraph 6.2.2.2); the 'case specific copyright holder's centre of interests' approach suggested by Kono and Jurcys (paragraph 6.2.3); Article 10(1)(b) and (4) Draft Hague Convention of 1999 (paragraph 6.4.2); Article 6(1)(b) and Article 6(2) Dreyfuss and Ginsburg Convention of 2002 (paragraph 6.4.3); Article 2:202 CLIP and Article 2:203(2) CLIP (paragraph 6.4.5).

${ }^{2008}$ See paragraph 6.2.1.1.3 and 6.2.1.2.1.

${ }^{2009}$ Opinion of Advocate General Cruz Villalón in the joined cases C-509/09 and C-161/10 eDate and Martinez, para. 53.

${ }^{2010}$ Opinion of AG Cruz Villalón in the joined cases C-509/09 and C-161/10 eDate and Martinez, para. 53.

2011 Opinion of AG Cruz Villalón in the joined cases C-509/09 and C-161/10 eDate and Martinez, para. 53.

See also Hestermeyer 2006, p. 286; Kuipers 2012(a), p. 395.

2012 Opinion of AG Bobek in the case C-194/16 Bolagsupplysningen Oü, note 46.
} 


\subsubsection{Article 10 of the Draft Hague Convention of 1999}

The Hague Conference on Private International Law is an intergovernmental organisation founded in 1893. ${ }^{2013}$ "Its mandate is 'the progressive unification of the rules of private international law' at global level". ${ }^{2014}$ In 2007, the European Union became one of the Contracting Parties of this organisation. ${ }^{2015}$ As mentioned in paragraph 1.1.2, the Hague Conference on Private International Law has purported to unify private international law rules on jurisdiction in civil and commercial matters at worldwide level by drafting the Convention on Jurisdiction and Foreign Judgments in Civil and Commercial Matters adopted by the Special Commission on 30 October 1999. ${ }^{2016}$ The Draft Convention on Jurisdiction and Foreign Judgments in Civil and Commercial Matters (hereinafter Draft Hague Convention of 1999) contains provisions on jurisdiction to adjudicate and recognition and enforcement of foreign judgments. The provisions on jurisdiction comprise "direct forms of jurisdiction" 2017 that should be applied by courts on the territory of Contracting States in international litigation "between parties who are all subjects of private law, or who are acting for private activities". 2018

However, the Draft Hague Convention of 1999 failed to come into force due to the disagreement on fundamental issues between the Contracting States. ${ }^{2019}$ It is nevertheless interesting to consider the approach to jurisdiction that would be applicable to cross-border copyright infringements disputes as stipulated in the Draft Hague Convention of 1999. The following paragraphs will assess whether this approach could be adopted under Article 7(2) Brussels Ibis in cross-border copyright infringement cases.

In the context of private international law rules related to jurisdiction in civil cases, the Hague Conference on Private International Law did achieve success with respect to the Hague Convention on Choice of Court Agreements of 30 June 2005. ${ }^{2020}$ The latter Convention

2013 Article 1 Statute of 15 July 1955 of the Hague Conference on Private International Law, see https://www.hcch.net/en/instruments/conventions/full-text. For more information on the Hague Conference on Private International Law, see Pertegás Sender 2017, pp. 870-875.

${ }^{2014}$ Bennett \& Granata 2019, p. 9.

2015 2006/719/EC: Council Decision of 5 October 2006 on the accession of the Community to the Hague Conference on Private International Law (OJ L 297, 26.10.2006, pp. 1-14). See also https://www.hcch.net/en/states/hcch-members for a list of the current Contracting States of the Hague Conference on Private International Law.

2016 See the Draft Hague Convention on Jurisdiction and Foreign Judgments in Civil and Commercial Matters adopted by the Special Commission on 30 October 1999 (hereinafter the Draft Hague Convention of 1999), in: the report by Nygh and Pocar, Preliminary document No. 11, August 2000 for the attention of the Nineteenth Session of June 2001, available at https://www.hcch.net/en/publications-and-studies/details4/?pid=3494\&dtid=35. See https://www.hcch.net/en/projects/legislative-projects/judgments/preparation-of-a-preliminary-draft-convention1997-1999- on the various preliminary documents related to the work of the Special Commission on International Jurisdiction and the Effects of Foreign Judgments in Civil and Commercial Matters drawn up between 1997 and 2000 .

${ }^{2017}$ Kessedjian 1997, pp. 18, 20 .

${ }^{2018}$ Kessedjian 1997, p. 13.

${ }^{2019}$ Kono \& Jurcys 2012, p. 11; Kur 2002, pp. 175-183. See also paragraph 1.1.2.

${ }^{2020}$ See Hague Convention on Choice of Court Agreements of 30 June 2005, entered into force 1 October 2015. See https://www.hcch.net/en/instruments/conventions/full-text/?cid=98. With respect to the adoption of the Hague Convention on Choice of Court Agreements of 30 June 2005 by the European Union, see the Council Decision of 26 February 2009 on the signing on behalf of the European Community of the Convention on Choice of Court Agreements (OJ L 133, 29.5.2009, pp. 1-13) and the Council Decision 2014/887/EU of 4 December 2014 on the 
"addressed the intersection between intellectual property and private international law" and "provides a sophisticated intellectual property regime" with respect to exclusive choice of court agreements. ${ }^{2021}$ In 2019, the Hague Convention on the Recognition and Enforcement of Foreign Judgments in Civil or Commercial Matters has been concluded, this so-called Hague Judgments Convention has not entered into force yet. ${ }^{2022}$ Unfortunately, the Hague Judgments Convention of 2019 had to exclude matters related to intellectual property from its scope due to lack of consensus. $^{2023}$

In 2019, the Hague Conference on Private International Law and the World Intellectual Property Organisation jointly drafted a guide titled "When Private International Law meets Intellectual Property Law. A Guide for Judges" (hereinafter the HCCH-WIPO Guide). ${ }^{2024}$ This Guide provides a non-exhaustive overview of the intersection between private international law and intellectual property law under various legal frameworks that can be used by judges who have to deal with this matter. ${ }^{2025}$ With respect to jurisdiction rules regarding infringement, the HCCH-WIPO Guide briefly describes the common law approach and the civil law-based approach. $^{2026}$

To determine which court is competent to decide a dispute involving private international law and intellectual property law, the HCCH-WIPO Guide contains a figure indicating that the court seised first has to consider whether there are any applicable international or regional instruments regarding jurisdiction rules, if not it has to apply the national rules. ${ }^{2027}$ Thereafter, the figure points out the main concepts related to jurisdiction rules, such as whether the defendant is domiciled in the forum or there is a choice of court agreement; however, it does not specify which connecting factors are applicable in infringement cases. ${ }^{2028}$ To determine whether a court can obtain jurisdiction in case of online infringements of intellectual property rights, the HCCH-WIPO Guide demonstrates various connectioning factors that can be applied which relate to the test for locating an online activity that may vary between jurisdictions. ${ }^{2029}$ With respect to copyright online infringements, the $\mathrm{HCCH}-\mathrm{WIPO}$ Guide particularly points out that the CJEU established the accessibility approach under Article 7(2) Brussels Ibis in the Pez

approval, on behalf of the European Union, of the Hague Convention of 30 June 2005 of Choice of Court Agreements (OJ L 353, 10.12.2014, pp. 5-8). Van Eechoud (2016, pp. 718-719) discusses the reference of the Hague Convention on Choice of Court Agreements of 2005 to intellectual property.

${ }^{2021}$ See also Bennett \& Granata 2019, pp. 36-38.

${ }^{2022}$ Hague Convention of 2 July 2019 on the Recognition and Enforcement of Foreign Judgments in Civil or Commercial Matters (hereinafter Hague Judgments Convention of 2019). See https://www.hcch.net/en/instruments/conventions/full-text/?cid=137. Till 1 July 2020, the Hague Judgments Convention of 2019 has only been signed by Ukraine and Uruguay.

${ }^{2023}$ See Article 2(1)(m) Hague Judgments Convention of 2019. See Lundstedt 2019.

${ }^{2024}$ See Bennett \& Granata 2019, pp. 1-88. See also https://www.wipo.int/edocs/pubdocs/en/wipo_pub_1053.pdf

${ }^{2025}$ See also Bennett \& Granata 2019, p. 7.

${ }^{2026}$ See Bennett \& Granata 2019, pp. 38-39.

${ }^{2027}$ See also Bennett \& Granata 2019, p. 31.

${ }^{2028}$ See Bennett \& Granata 2019, p. 31.

${ }^{2029}$ See Bennett \& Granata 2019, p. 39. "To establish a connecting factor, links may be asserted with courts: where the person infringing is physically located; where the damage occurred, which may be the location of the copyright owner; where people can receive or view the copyright work; where the target audience for the website is located; where the technical process making the copyright work visable on the Internet was activated; or where the date are physically located (the location of the server)". 
Hejduk ruling. ${ }^{2030}$ Yet, it argues that "courts of other jurisdictions may reject mere accessibility as a sufficient connection and require closer links to the forum, such as targeting or actual harm". ${ }^{2031}$ This dissertation has examined both the accessibility approach ${ }^{2032}$ and the targeting, or 'directed activities' approach ${ }^{2033}$.

\subsubsection{The combined approach to jurisdiction in infringement cases under Article 10 Draft Hague Convention of 1999}

This paragraph will demonstrate the jurisdictional rules under the Draft Hague Convention of 1999 that intended to be applicable to in cross-border tort cases such as copyright infringement cases. Besides the general jurisdiction rule actor sequitur forum rei in Article 3 Draft Hague Convention of $1999,{ }^{2034}$ Article 10 of this Convention contains a special jurisdiction rule regarding cross-border torts such as copyright infringement disputes. Pursuant to Article 10(1) Draft Hague Convention of 1999, a plaintiff may bring a copyright infringement dispute before the court of the state "in which the act or omission that caused the injury occurred" 2035 or "in which the injury arose, unless the defendant establishes that the person claimed to be responsible could not reasonably have foreseen that the act or omission could result in an injury of the same nature in that State". 2036

Article 10(1) Draft Hague Convention of 1999 reflects the dichotomy of the jurisdictional approach related to tort cases as generally laid down in national codifications and international conventions: it provides the injured party a choice between the forum of the place of the act or omission that caused the injury (Handlungsort) ${ }^{2037}$ and that of the place where the injury $\operatorname{arose}^{2038}$ that means the place where its direct effects are felt (Erfolgsort). ${ }^{2039}$ The 'unless' clause related to the Erfolgsort in Article 10(1)(b) Draft Hague Convention of 1999 comprises "the concept of predictability of the effects of the wrongful act", ${ }^{2040}$ in this dissertation referred to as the 'unpredictability of the effects' escape clause. According to the Commentary to the Draft, "the burden of proving that the injury was not predictable falls on the defendant." 2041

With respect to the scope of the jurisdiction of these courts, Article 10(4) Draft Hague Convention of 1999 regulates "if an action is brought in the courts of a State only on the basis that the injury arose or may occur there, those courts shall have jurisdiction only in respect of

\footnotetext{
${ }^{2030}$ See Bennett \& Granata 2019, p. 40.

2031 See Bennett \& Granata 2019, p. 40.

2032 See paragraph 5.2.4.

2033 See paragaphs 6.1.4. and 7.5.3.1.

${ }^{2034}$ See Nygh \& Pocar 2000, p. 39. See also paragraph 2.1.2.2.2.

2035 See Article 10 (1)(a) Draft Hague Convention of 1999. Article 10(3) Draft Hague Convention of 1999 stipulates that "a plaintiff may also bring an action in accordance with paragraph 1 when the act or omission, or the injury may occur". See Nygh \& Pocar 2000, p. 7.

2036 See Article 10 (1)(b) Draft Hague Convention of 1999. Article 10(3) Draft Hague Convention of 1999 stipulates that "a plaintiff may also bring an action in accordance with paragraph 1 when the act or omission, or the injury may occur". See Nygh \& Pocar 2000, p. 7.

${ }^{2037}$ See Article 10(1)(a) Draft Hague Convention of 1999.

${ }^{2038}$ See Article 10(1)(b) Draft Hague Convention of 1999.

${ }^{2039}$ See Nygh \& Pocar 2000, pp. 59-61.

${ }^{2040}$ See Nygh \& Pocar 2000, p. 61.

2041 See Nygh \& Pocar 2000, p. 61.
} 
the injury that occurred or may occur in that State, unless the injured person has his or her habitual residence in that State". In regard of a legal person, Article 3(2) Draft Hague Convention of 1999 provides the following alternative connecting factors: "(a) where it has its the statutory seat, (b) under whose law it was incorporated or formed, (c) where it has its central administration, or (d) where it has its principal place of business. ${ }^{2042}$

The Special Commission that drafted this Convention added the abovementioned forum actoris approach in Article 10(4) Draft Hague Convention of 1999 by reasoning that in multistate infringement cases the injured person would be forced to sue the infringer in multiple states or in the Handlungsort in order to receive full compensation. ${ }^{2043}$ The Commission argued that the forum actoris approach avoids the multiplication of courts and takes account of the interests involved. ${ }^{2044}$ The Special Commission explicitly rejected a jurisdictional approach that would depend on the quantity of effects because "the difficulty with this solution is how to determine from the outset the amount of the damage, something which cannot in principle be quantified until the application has been heard on its merits". ${ }^{2045}$

\begin{tabular}{|l|l|l|}
\hline $\begin{array}{l}\text { Article 10 Draft Hague } \\
\text { Convention of 1999 }\end{array}$ & Connecting factors & $\begin{array}{l}\text { Scope of the court's } \\
\text { jurisdiction }\end{array}$ \\
\hline Article 10(1)(a) & $\begin{array}{l}\text { The state in which the act or } \\
\text { omission that caused the } \\
\text { injury occurred or may occur } \\
\text { (Article 10(3)) }\end{array}$ & Full jurisdiction Article 10(4) \\
\hline Article 10(1)(b) & $\begin{array}{l}\text { The state in which the injury } \\
\text { arose or may occur (Article } \\
10(3))\end{array}$ & $\begin{array}{l}\text { Jurisdiction limited to the } \\
\text { injury that occurred or may } \\
\text { occur in the forum state. } \\
\text { 'unless the defendant } \\
\text { establishes that the person } \\
\text { claimed to be responsible } \\
\text { could not reasonably have } \\
\text { foreseen that the act or } \\
\text { omission could result in an } \\
\text { injury of the same nature in } \\
\text { that State", referred to as the } \\
\text { 'unpredictability of the } \\
\text { his or her habitual } \\
\text { residence } \\
\text { jurisdiction regarding } \\
\text { entire dispute, referred to as } \\
\text { the forum actoris } \text { approach } \\
\text { Article 10(4). }\end{array}$ \\
\hline
\end{tabular}

\footnotetext{
2042 See Nygh \& Pocar 2000, pp. 40-42.

2043 See Nygh \& Pocar 2000, p. 62.

${ }^{2044}$ See Nygh \& Pocar 2000, p. 62.

2045 See Nygh \& Pocar 2000, p. 62.

${ }^{2046}$ With respect to a legal person, Article 3(2) Draft Hague Convention of 1999 provides the following alternative connecting factors: "(a) where it has its the statutory seat, (b) under whose law it was incorporated or formed, (c) where it has its central administration, or (d) where it has its principal place of business. See also See Nygh \& Pocar 2000, pp. 40-42.
} 


\subsubsection{Assessing the combined approach to jurisdiction under Article 10 Hague Draft Convention of 1999}

The jurisdictional rule in Article 10(1) Draft Hague Convention of 1999 appears to apply the dichotomy of the special jurisdiction rule of Article 7(2) Brussels Ibis: both rules provide the copyright holder the option to sue the alleged infringer before the court in the Handlungsort ${ }^{2047}$ or Erfolgsort ${ }^{2048} .{ }^{2049}$ According to Article 10(4) Draft Hague Convention of 1999, the jurisdiction of the Erfolgsort is generally territorially limited to the injury that occurred or may occur within the forum state. ${ }^{2050}$ This territorially limited jurisdiction reflects the mosaic approach established by the CJEU in the Shevill ruling. ${ }^{2051}$ Similar to Article 7(2) Brussels Ibis, Article 10 Hague Draft Convention of 1999 has not been particularly drafted for cross-border copyright infringement cases but concerns tort cases in general such as crossborder copyright infringement cases. The jurisdictional approach under Article 10 Hague Draft Convention of 1999 is technology neutral; it has, however, been drafted before the use of the Internet became intensive. Since the rethinking of the CJEU's approach to jurisdiction in crossborder copyright infringement cases does not focus on the Handlungsort, Article 10(1)(a) Draft Hague Convention of 1999 will not be further assessed.

Article 10 of the Draft Hague Convention of 1999 contains two additional connecting factors related to the Erfolgsort. First, Article 10(1)(b) Draft Hague Convention of 1999 consist of an escape clause that prevents jurisdiction based on the Erfolgsort if the defendant proves that he could not have reasonably foreseen the occurrence of the alleged tortious effects in the forum state. The latter escape clause will be referred to as the 'unpredictability of the effects' criterion. Second, Article 10(4) Draft Hague Convention of 1999 provides full jurisdiction to the court of the Erfolgsort where the injured person has his habitual residence, the forum actoris approach. $^{2052}$

Due to the two abovementioned connecting factors related to the Erfolgsort, Article 10 Hague Draft Convention of 1999 comprises a combined approach to jurisdiction. Based on the assessment framework as set out in paragraph 4.6, the following paragraphs will examine the combination of the 'unpredictability of the effects' escape clause and the forum actoris approach to jurisdiction in cross-border copyright infringement cases.

\footnotetext{
${ }^{2047}$ Article 10(1)(a) Draft Hague Convention of 1999.

2048 Article 10(1)(b) Draft Hague Convention of 1999.

2049 See Nygh \& Pocar 2000, p. 59.

${ }^{2050}$ See Article 10(4) Draft Hague Convention of 1999. With respect to the territorially limited jurisdiction under Article 7(2) Brussels Ibis, see the rulings Shevill (para. 28-33); eDate and Martinez (para. 51); Pinckney (para. 45); Hi Hotel (para. 39); Pez Hejduk (para. 36-37).

${ }^{2051}$ See paragraph 1.1.4.

${ }^{2052}$ With respect to a legal person, Article 3(2) Draft Hague Convention of 1999 provides the following alternative connecting factors: "(a) where it has its the statutory seat, (b) under whose law it was incorporated or formed, (c) where it has its central administration, or (d) where it has its principal place of business. See also See Nygh \& Pocar 2000, pp. 40-42.
} 


\subsection{The principle of predictability}

The 'unpredictability of the effects' escape clause in Article 10(1)(b) Draft Hague Convention seems to provide the alleged copyright infringer broad discretion to prove that he reasonably could not foresee the harmful effects in the forum state. The concept of "foreseeability" has been regarded as a rather vague term. ${ }^{2053}$ The "unpredictability of the effects' escape clause will likely leave the court a broad leeway to determine whether the effects were predictable in the forum state. The outcome of the assessment of the 'unpredictability of the effects' criterion will frequently be uncertain. Therefore, the 'unpredictability of the effects' criterion will likely yield less ex ante predictability as regards which court may be competent.

The second additional criterion related to the Erfolgsort, laid down in Article 10(4) Draft Hague Convention of 1999, confers full jurisdiction to the court of the Erfolgsort where the injured person has his habitual residence. ${ }^{2054}$ This forum actoris approach resembles the 'victim's centre of interests' approach adopted by the CJEU in the eDate and Martinez ruling ${ }^{2055}$. Yet, unlike the 'victim's centre of interests' approach, Article 10(1)(b) Draft Hague Convention of 1999 comprises the 'unpredictability of the effects' escape clause that aims to prevent jurisdiction based on unpredictable effects, so-called overspills. The defendant can invoke this escape clause if he could not have reasonably foreseen the alleged tortious effects in the state of the injured person's habitual residence. Although the 'unpredictability of the effects' escape clause provides less ex ante predictability as explained above, it will likely satisfy the principle of predictability more than the mere 'victim's centre of interests' approach $^{2056}$.

\subsection{A close connection between dispute and court/ sound administration of justice}

The 'unpredictability of the effects' escape clause in Article 10(1)(b) Draft Hague Convention of 1999 will likely entail a close connection between the copyright infringement dispute and the court because jurisdiction based on spillover effects can be avoided by the 'unpredictably of the effects' escape clause. The 'unpredictably of the effects' criterion can alleviate the lack of a close connection related to the forum actoris approach as demonstrated in paragraph 6.2.4.3. For instance, the infringer can invoke this escape clause if his activities have not been directed to the forum actoris. It is noteworthy, that the Commission of the Draft Hague Convention of 1999 found that "the domicile, habitual or temporary residence, or presence of the plaintiff" would be insufficient as mere ground to establish jurisdiction. ${ }^{2057}$ The reason for the rejection of the mere forum actoris approach lies in the "prohibition" under the

\footnotetext{
2053 Lau 2000, p. 18.

${ }^{2054}$ With respect to a legal person, Article 3(2) Draft Hague Convention of 1999 provides the following alternative connecting factors: "(a) where it has its the statutory seat, (b) under whose law it was incorporated or formed, (c) where it has its central administration, or (d) where it has its principal place of business. See also See Nygh \& Pocar 2000, pp. 40-42.

${ }^{2055}$ See paragraph 6.2.1.1.2.

${ }^{2056}$ See paragraph 6.2.4.2.

2057 See Article 18(2)(c) Draft Hague Convention of 1999. See Nygh \& Pocar 2000, pp. 9-10.
} 
Draft Hague Convention of 1999 to confer jurisdiction "if there is no substantial connection between that State and the dispute". ${ }^{2058}$

However, paragraph 5.3.4.1 argued that full jurisdiction requires a particularly strong enough connection to between the dispute and the forum. The combination of 'unpredictability of the effects' escape clause and the forum actoris approach does not seem to satisfy the latter strong connection requirement. While there will be a strong close connection between the alleged infringement of moral right(s) related to copyright and the forum actoris, infringement of economic rights related to copyright may occur in other states than the forum actoris. ${ }^{2059}$ Therefore, this combined approach to jurisdiction will not guarantee a particularly strong close connection between the entire dispute and the forum actoris.

From a perspective of sound administration of justice, the conferral of jurisdiction to one single court will particularly enhance efficient adjudication in multistate or ubiquitous copyright infringement disputes as it impedes forum shopping, reduces litigation costs and the risk of irreconcilable decisions. ${ }^{2060}$ Yet, the 'unpredictability of the effects' escape clause may involve a quite extensive assessment on the merits of the case ${ }^{2061}$ and therefore hamper the sound administration of justice. As mentioned above, infringement of economic rights may occur in other states than the forum actoris, the forum actoris will therefore not always be in the best position to asses the entire cross-border copyright infringement case.

\subsection{The principle of balancing the interests}

The combination of the 'unpredictability of the effects' escape clause and the forum actoris approach to jurisdiction in Article 10(1)(b) and 10(4) Draft Hague Convention of 1999 will likely strike a balance between the procedural interests of the copyright holder and the alleged infringer. The Special Commission argued that the combined approach to jurisdiction in Article 10 Draft Hague Convention of 1999 takes account of the interests involved. ${ }^{2062}$ In case of a multistate or ubiquitous copyright infringement dispute, it will be especially favourable to the copyright holder to receive efficient redress in its home state. If the alleged infringer is located and operated in a copyright haven, it can be considered reasonable that the copyright holder can receive full redress in the forum actoris, particularly if the alleged infringing activities have been directed to the forum actoris. ${ }^{2063}$ For the alleged copyright infringer, it will likely also be beneficial to get sued before the court of a single state instead of multiple states. In addition, the 'unpredictably of the effects' escape clause seems to favour the defendant. Yet, as explained in paragraph 6.4.2.2.1, the broad and value-based 'unpredictably of the effects' criterion does not guarantee ex ante predictability as regards where the potential infringer may get sued.

\footnotetext{
2058 Article 18(1) Draft Hague Convention of 1999. See Nygh \& Pocar 2000, pp. 9.

${ }^{2059}$ See paragraph 6.2.4.3.

${ }^{2060}$ See also Nygh \& Pocar 2000, p. 62.

${ }^{2061}$ See also Drexl \& Kur 2005, p. 332.

${ }^{2062}$ See Nygh \& Pocar 2000, p. 62.

${ }^{2063}$ See paragraph 2.2.2.2 on the concept of copyright havens and paragraph 5.3.1 on the arguments against territorially limited jurisdiction under the Pinckney doctrine.
} 
From a broad perspective, the combined approach in Article 10(1)(b) and 10(4) Draft Hague Convention of 1999 does not seem to strike a balance between the interests of copyright holders, on the one hand, and traders and users of information, on the other hand. As explained above, the 'unpredictably of the effects' criterion does not provide certainty as regards which court will be competent. This uncertainty does not enhance copyright protection at procedural level. The uncertainty as regards where providers of information may get sued can impede the cross-border flow of information. The lack of certainty may also discourage traders to sell their products to customers in the European Union. Due to the effect of the Geo-blocking Regulation, as will be described in the next paragraph, particularly small trading companies may not favour to online provide products and services to customers in the European Union. Nonetheless, traders can still block online interfaces that offer audiovisual services and electronically supplied services "the main feature of which is the provision of access to and use of copyright protected works and other protected subject matter including the selling of copyright protected works or protected subject matter in an intangible form". ${ }^{2064}$ The latter will, however, not enhance the internal market of the European Union.

\subsection{The Geo-blocking Regulation and Article 10 Draft Hague Convention of 1999}

This paragraph will consider the impact of the Geo-blocking Regulation on the combined approach to jurisdiction under Article 10(1)(b) and (4) Draft Hague Convention of 1999 in cross-border copyright infringement cases. The 'unpredictability of the effects' escape clause in Article 10(1)(b) Draft Hague Convention of 1999 will provide the alleged copyright infringer broad discretion to prove that he reasonably could not foresee the harmful effects in the forum state. Due to the Geo-blocking Regulation, potential copyright infringers who can be regarded as traders under this Regulation and provide goods or certain services ${ }^{2065}$ to customers in the European Union will not be allowed anymore to use unjustified geo-blocking technologies or other forms of discrimination based on customers' nationality, place of residence or place of establishment within the internal market. ${ }^{2066}$

The traders' tools to prevent jurisdiction by invoking the 'unpredictability of the effects' clause under Article 10(1)(b) Draft Hague Convention of 1999 will thus be reduced. For instance, the alleged copyright infringer cannot assert that he did not direct the alleged infringing activities to the residents of the forum state by using geo-blocking technologies that prevent these residents to access the website involved. When an alleged copyright infringer

\footnotetext{
${ }^{2064}$ See Article 4(1)(b) Geo-blocking Regulation. See paragraph 4.5.2.3 on services that are excluded from the prohibitions in the Geo-blocking Regulation.

${ }^{2065}$ See paragraph 4.5.1 on the definition of trader and paragraph 4.5.2.3 on the services that have been excluded under the prohibitions of the Geo-blocking Regulation. For instance, traders can still block websites to customers of certain Member States that offer audiovisual services and electronically supplied services "the main feature of which is the provision of access to and use of copyright protected works and other protected subject matter including the selling of copyright protected works or protected subject matter in an intangible form" since these services are for now excluded from the prohibitions under the Geo-blocking Regulation. See Article 4(1)(b) Geoblocking Regulation.

${ }^{2066}$ The Geo-blocking Regulation prohibits geo-blocking and other forms of discrimination based on customers' nationality, place of residence or place of establishment within the internal market unless it has been justified by European Union law or national law in accordance with European law, see paragraph 4.5.
} 
invokes the escape clause of Article 10(1)(b) Draft Hague Convention of 1999, the court seised will have to assess whether the infringer could reasonably not foresee that the act or omission would result in an injury in the forum state. The court may therefore consider whether the infringer directed his activities to the forum state. As indicated in paragraph 6.1.4.4, the trader's mere compliance with the Geo-blocking Regulation will not constitute 'directed activities' ${ }^{2067}$ When the trader does not block his website, or provides similar conditions of access to customers of all Member States, this will not imply that the trader directed his activities to all of these Member States. ${ }^{2068}$ To determine whether the trader directed his activities to a particular state, it is important if "the trader has manifested an intention to establish commercial relations with consumers from that Member State"2069. Traders can direct their activities to particular Member States by employing tools such as the delivery of goods to a particular Member State, the use a country code top-level domain name for its website ${ }^{2070}$ or the use a particular language ${ }^{2071}$. As illustrated in paragraph 6.1.4.4, the Geo-blocking Regulation will force the court seised to examine the trader's activities in more detail to assess whether his activities have been directed to the forum state. ${ }^{2072}$

In sum, the effect of the Geo-blocking Regulation on the combined approach to jurisdiction under Article 10(1)(b) and (4) Draft Hague Convention of 1999 will be limited to traders who offer goods and services as stipulated under this Regulation. As mentioned above, the prohibitions under this Regulation will generally reduce the trader's tools to prove that he reasonably could not foresee the harmful effects in the forum state. Furthermore, the court seised may have to examine the trader's activities more thoroughly to assess the 'unpredictability of the effects' clause..$^{2073}$

\subsubsection{Article 6 of the Dreyfuss and Ginsburg-Convention of 2002}

Inspired by the abovementioned Draft Hague Convention of 1999, the scholars Dreyfuss and Ginsburg drafted a convention especially for cross-border intellectual property cases referred to as the Draft Convention on Jurisdiction and Recognition of Judgments in Intellectual Property Matters (hereinafter Dreyfuss and Ginsburg-Convention of 2002). ${ }^{2074}$ Dreyfuss and Ginsburg presented their draft at the World Intellectual Property Organization (WIPO) Forum on Private International Law and Intellectual Property in 2001. ${ }^{2075}$ According to Dreyfuss and

\footnotetext{
${ }^{2067}$ See recitals 13, 26 in the preamble of the Geo-blocking Regulation and Article 1(6) Geo-blocking Regulation. ${ }^{2068}$ See recitals 13, 26 in the preamble of the Geo-blocking Regulation and Article 1(6) Geo-blocking Regulation. See also paragraph 6.1.4.4.

${ }^{2069}$ See recital 26 in the preamble of the Geo-blocking Regulation. This consideration appears to resemble the CJEU's concept of directed activities under Article 17(1)(c) Brussels Ibis in the ruling of Pammer and Alpenhof, para. 80. See also paragraph 4.5.3.

${ }^{2070}$ Recital 20 in the preamble to the Geo-blocking Regulation.

${ }^{2071}$ Recital 27 in the preamble to the Geo-blocking Regulation. See paragraph 6.1.4.4.

2072 See also paragraph 4.5.3.

${ }^{2073}$ See also paragraph 6.1.4.4.

${ }^{2074}$ Xalabarder 2002, pp. 93-94. See also Dreyfuss \& Ginsburg 2002, pp. 1065-1153.

${ }^{2075}$ Draft Convention on Jurisdiction and Recognition of judgments in Intellectual Property Matters by R. C. Dreyfuss and J. C. Ginsburg at the World Intellectual Property Organization (WIPO) Forum on Private International Law and Intellectual Property, Geneva, January 30 and 31, 2001, see: http://www.wipo.int/meetings/en/doc details.jsp?doc id=12386.
} 
Ginsburg, the "convention could be adopted under the auspices of the World Trade Intellectual Property Organization (hereinafter WIPO) or through the World Trade Organization (hereinafter WTO). ${ }^{2076}$ All European Union Member States are Contracting States of the WIPO. ${ }^{2077}$ The European Union has been a WTO member since $1995 .{ }^{2078}$ It is noteworthy that some provisions of the so-called Dreyfuss and Ginsburg-Convention of $2002^{2079}$ slightly deviate from the draft presented by Dreyfuss and Ginsburg at the WIPO Forum. This dissertation will focus on the Dreyfuss and Ginsburg-Convention published in 2002 that contains an elaborate Commentary by Dreyfuss and Ginsburg. ${ }^{2080}$

According to Dreyfuss and Ginsburg, "efficiency should be a principal target" regarding the litigation of intellectual property disputes. ${ }^{2081}$ "Modern distribution methods, particularly satellite and Internet transmissions, make it increasing likely that intellectual property rights will be exploited simultaneously in more than one territory." ${ }^{2082}$ Hence, they found it necessary "to adapt the traditional fora for tort claims (place of impact of the injury, place from which the harmful conduct originated) to the digital environment". ${ }^{2083}$ Their approach to jurisdiction can therefore be characterised as technology-based.

The approach to jurisdiction established by Dreyfuss and Ginsburg "enlarges the scope of the forum's competence in the case of multiterritorial infringements". ${ }^{2084}$ In view of the Internet, consolidation of adjudication in multinational disputes has been one of the main objectives of the Dreyfuss and Ginsburg-Convention of 2002 in order to achieve efficient enforcement of intellectual property rights. ${ }^{2085}$ Furthermore, the Dreyfuss and GinsburgConvention of 2002 aims to strike a balance "between the rights of intellectual property users and owners". 2086

The proposal related to infringements of intellectual property has been laid down in Article 6 of the Dreyfuss and Ginsburg-Convention of 2002. The latter provision has been inspired by Article 10 Draft Hague Convention of 1999. ${ }^{2087}$ The Dreyfuss and Ginsburg-Convention of 2002 nonetheless employs 'the place of infringement' as connecting factor instead of the distinction Handlungsort or Erfolgort like regular jurisdiction rules related to torts. ${ }^{2088}$ Pursuant to Article 6(1) Dreyfuss and Ginsburg-Convention of 2002, "a plaintiff may bring an infringement action in the courts of: (a) any State where the defendant substantially acted (including preparatory acts) in furtherance of the alleged infringement; or (b) any State to which

\footnotetext{
2076 See Dreyfuss \& Ginsburg 2002, pp. 1065-1066.

2077 See https://www.wipo.int/about-wipo/en/.

${ }^{2078}$ See https://www.wto.org/english/thewto_e/countries_e/european_communities_e.htm.

${ }^{2079}$ See Dreyfuss \& Ginsburg 2002, pp. 1065-1153.

${ }^{2080}$ See Dreyfuss \& Ginsburg 2002, pp. 1065-1153.

${ }^{2081}$ Dreyfuss \& Ginsburg 2002, p. 1066.

${ }^{2082}$ Dreyfuss \& Ginsburg 2002, p. 1066.

${ }^{2083}$ Dreyfuss \& Ginsburg 2002, p. 1108.

${ }^{2084}$ Dreyfuss \& Ginsburg 2002, p. 1108.

${ }^{2085}$ Dreyfuss \& Ginsburg 2002, pp. 1067, 1070-1071, 1073.

${ }^{2086}$ Dreyfuss \& Ginsburg 2002, p. 1067.

${ }^{2087}$ Dreyfuss \& Ginsburg 2002, p. 1109. See also Commentary to the Draft Convention on Jurisdiction and Recognition of judgments in Intellectual Property Matters by R. C. Dreyfuss and J. C. Ginsburg at the World Intellectual Property Organization (WIPO) Forum on Private International Law and Intellectual Property, Geneva, January 30 and 31,2001, p. 21.

${ }^{2088}$ Dreyfuss \& Ginsburg 2002, p. 1066.
} 
the alleged infringement was intentionally directed, including those States for which defendant took no reasonable steps to avoid acting in or directing activity to that State; ${ }^{2089}$ or (c) any State in which the infringement foreseeably occurred unless the defendant took reasonable steps to avoid acting or directing activity to that State". 2090

With respect to the scope of the court's jurisdiction, Article 6(2) Dreyfuss and GinsburgConvention of 2002 states that "if an action is brought in the courts of a State only on the basis of the intentional direction of the infringement of that State, then those courts shall have jurisdiction only in respect of the injury arising out of unauthorized use occurring in that State, unless the injured person has his habitual residence or principal place of business in that State". In addition, Article 6(3) Dreyfuss and Ginsburg-Convention of 2002 stipulates that "if an action is brought in the courts of a State only on the basis of the occurrence of the infringement of that State, then those courts shall have jurisdiction only in respect of the injury arising out of unauthorized use occurring in that State".

\subsubsection{The two combined approaches to jurisdiction in infringement cases under Article 6 Dreyfuss and Ginsburg Convention of 2002}

\begin{tabular}{|l|l|l|}
\hline $\begin{array}{l}\text { Article 6 Dreyfuss and } \\
\text { Ginsburg- Convention }\end{array}$ & Connecting factors & $\begin{array}{l}\text { Scope of the court's } \\
\text { jurisdiction }\end{array}$ \\
\hline Article 6(1)(a) & $\begin{array}{l}\text { "any State where defendant } \\
\text { substantially acted (including } \\
\text { preparatory acts) in } \\
\text { furtherance of the alleged } \\
\text { infringement" }\end{array}$ & $\begin{array}{l}\text { Full jurisdiction Article 6(2) } \\
\text { and Article 6(3) }\end{array}$ \\
\hline
\end{tabular}

${ }^{2089}$ Article 6(1)(b) of the Dreyfuss and Ginsburg-Convention of 2002 slightly deviates from Article 6(1)(b) of the Draft Convention on Jurisdiction and Recognition of judgments in Intellectual Property Matters established by R. C. Dreyfuss and J. C. Ginsburg and presented at the World Intellectual Property Organization (WIPO) Forum on Private International Law and Intellectual Property, Geneva, January 30 and 31, 2001, see: http://www.wipo.int/meetings/en/doc details.jsp?doc id=12386. Article 6(1)(b) of the draft presented by Dreyfuss and Ginsburg at the WIPO Forum Geneva stipulates "any State to which the alleged infringement was intentionally directed, including those States for which the defendant took no substantial measures to deflect the communication of the infringement to that State". See the Draft Convention on Jurisdiction and Recognition of judgments in Intellectual Property Matters by R. C. Dreyfuss and J. C. Ginsburg at the World Intellectual Property Organization (WIPO) Forum on Private International Law and Intellectual Property, Geneva, January 30 and 31 , 2001 , p. 11.

${ }^{2090}$ See Dreyfuss \& Ginsburg 2002, p. 1077. Unlike the special jurisdiction rule in Article 7(2) Brussels Ibis, the Dreyfuss and Ginsburg-Convention of 2002 does not confer jurisdiction in case of infringements that may occur. Article 6(1)(c) of the Dreyfuss and Ginsburg-Convention of 2002 slightly deviates from Article 6(1)(c) of the draft presented by Dreyfuss and Ginsburg at the WIPO Forum Geneva. The latter article stipulates "any State in which the infringement foreseeably occurred, including those States for which defendant took no substantial measures to deflect the communication of the infringement of that State". See the Draft Convention on Jurisdiction and Recognition of judgments in Intellectual Property Matters by R. C. Dreyfuss and J. C. Ginsburg at the World Intellectual Property Organization (WIPO) Forum on Private International Law and Intellectual Property, Geneva, January 30 and 31, 2001, p. 11. 


\begin{tabular}{|l|l|l|}
\hline Article 6(1)(b) & $\begin{array}{l}\text { "any State to which the } \\
\text { alleged infringement was } \\
\text { intentionally directed, } \\
\text { including those States for } \\
\text { which defendant took no } \\
\text { reasonable steps to avoid } \\
\text { acting in or directing activity } \\
\text { to that State", referred to as } \\
\text { the 'intentionally directed' } \\
\text { criterion }\end{array}$ & $\begin{array}{l}\text { Territorially limited to the } \\
\text { injury arising within the } \\
\text { forum state unless the injured } \\
\text { person has his habitual } \\
\text { residence or principal place } \\
\text { of business in that state, } \\
\text { referred to as the 'forum } \\
\text { actoris' approach. Article } \\
6(2)\end{array}$ \\
\hline Article 6(1)(c) & $\begin{array}{l}\text { "any State in which the } \\
\text { alleged infringement } \\
\text { foreseeably occurred", } \\
\text { referred to as the } \\
\text { 'foreseeable infringement' } \\
\text { criterion }\end{array}$ & $\begin{array}{l}\text { Territorially limited to the } \\
\text { injury arising within the } \\
\text { forum state. Article 6(3) }\end{array}$ \\
& $\begin{array}{l}\text { "unless the defendant took } \\
\text { reasonable steps to avoid } \\
\text { acting or directing activity to } \\
\text { that State", referred to as the } \\
\text { 'directed activities'- based } \\
\text { escape clause. }\end{array}$ & \\
\hline
\end{tabular}

\subsubsection{Assessing the two combined approaches under Article 6 Dreyfuss and Ginsburg- Convention of 2002}

While Article 6(1) Dreyfuss and Ginsburg-Convention of 2002 employs the place of infringement as connecting factor, Article 6(1)(a) relates to the Handlungsort and Article 6(1)(b) and (c) to the Erfolgsort. The Dreyfuss and Ginsburg-Convention of 2002 attached additional conditions to the Handlungsort and the Erfolgsort that have to be satisfied. The courts of the Handlungsort will only obtain jurisdiction if the defendant substantially acted in the forum state. ${ }^{2091}$ Since this dissertation does not involve the rethinking of the CJEU's approach to jurisdiction based on the Handlungsort, the latter connecting factor will not be further explored. Pursuant to the Article 6(1)(b) and (c) Dreyfuss and Ginsburg-Convention of 2002, the courts of the Erfolgsort will only obtain jurisdiction based on the following two alternative connecting factors. As will be demonstrated below, these alternative connecting factors both involve combined approaches to jurisdiction that will be further examined in the next paragraphs.

First, the 'intentionally directed' criterion in Article 6(1)(b) Dreyfuss and GinsburgConvention of 2002: "any State to which the alleged infringement was intentionally directed, including those States for which defendant took no reasonable steps to avoid acting in or

${ }^{2091}$ Article 6(1)(a) Dreyfuss and Ginsburg-Convention of 2002. 
directing activity to that State". ${ }^{2092}$ The 'intentionally directed' criterion in Article 6(1)(b) Dreyfuss and Ginsburg-Convention of 2002 is reminiscent of the 'directed activities' approach as discussed in paragraph 6.1. Yet, Dreyfuss and Ginsburg provided a broad interpretation in Article 6(1)(b) since it includes the situation that the defendant "did not turn away consumers who responded to the availability of the communication of that State". ${ }^{2093}$ With respect to traders, paragraph 6.4.3.2.4 will demonstrate that the Geo-blocking Regulation can prohibit traders to prevent access to customers of European Union Member States. Dreyfuss and Ginsburg did not define whether the 'intentionally directed' criterion focuses on the 'subjective' or the 'objective' intention of the infringer.

Article 6(2) Dreyfuss and Ginsburg-Convention of 2002 provides full jurisdiction to the court of the state where "the injured person has his habitual residence or principal place of business" provided that the infringement has been intentionally directed to that state. ${ }^{2094}$ The latter forum actoris approach reflects the 'victim's centre of interests' approach established in the eDate and Martinez ruling ${ }^{2095}$. Yet, the forum actoris approach under the Dreyfuss and Ginsburg-Convention of 2002 has been combined with the abovementioned intentionally directed' criterion in Article 6(1)(b) Dreyfuss and Ginsburg-Convention of 2002. The combined approach to jurisdiction in Article 6(1)(b) and 6(2) Dreyfuss and Ginsburg-Convention of 2002 aims to address the situation in which the infringer is located or initiated the infringement in a copyright haven. ${ }^{2096}$

The second alternative connecting factor related to the Erfolgsort is the 'foreseeable infringement' criterion in Article 6(1)(c) Dreyfuss and Ginsburg-Convention of 2002: "any State in which the infringement foreseeably occurred unless the defendant took reasonable steps to avoid acting or directing activity to that State". ${ }^{2097}$ This 'foreseeable infringement' criterion is reminiscent of the 'unpredictability of the effects' escape clause of Article 10(1)(b) Draft Hague Convention of 1999 as mentioned in paragraph 6.4.2. Pursuant to Article 6(3) Dreyfuss and Ginsburg-Convention of 2002, the scope of the court's jurisdiction based on the 'foreseeable infringement' criterion will be territorially limited to the injury that occurred within the forum state. ${ }^{2098}$ This approach is in accordance with the mosaic approach established in the Shevill ruling ${ }^{2099}$ and reflects the influence of the territorial protection of intellectual property rights $^{2100}$.

The territorially limited approach to jurisdiction under Article 6(1)(c) Dreyfuss and Ginsburg-Convention could be regarded as a combined approach to jurisdiction since the 'foreseeable infringement' criterion consists of an escape clause to prevent jurisdiction if "the

\footnotetext{
2092 Article 6(1)(b) Dreyfuss and Ginsburg-Convention of 2002.

2093 Dreyfuss \& Ginsburg 2002, p. 1109.

${ }^{2094}$ In view of the concept of full jurisdiction in paragraph 5.3.3.1, the exercise of the court's jurisdiction based on the forum actoris approach in Article 6(2) Dreyfuss and Ginsburg-Convention of 2002 would be limited to the territories of the Contracting States of the Dreyfuss and Ginsburg-Convention of 2002.

2095 See paragraph 6.2.1.

${ }^{2096}$ Dreyfuss \& Ginsburg 2002, p. 1109. See paragraph 2.2.2.2 on the concept of copyright haven.

${ }^{2097}$ Article 6(1)(c) Dreyfuss and Ginsburg-Convention of 2002. See Dreyfuss \& Ginsburg 2002, p. 1077.

2098 Article 6(2) and (3) Dreyfuss and Ginsburg-Convention of 2002.

${ }^{2099}$ Dreyfuss \& Ginsburg 2002, p. 1109.

${ }^{2100}$ See paragraph 3.5.1 on the CJEU's view of the influence of the territorial principle related to copyrights on the scope of the court's jurisdiction in cross-border copyright infringement cases.
} 
defendant took reasonable steps to avoid acting or directing activity to" the forum state ${ }^{2101}$. The latter escape clause appears to resemble the 'directed activities'-based escape clause in Article 2:202 CLIP. ${ }^{2102}$ With respect to the escape clause in Article 6(1)(c) Dreyfuss and GinsburgConvention of 2002, Dreyfuss and Ginsburg likely employ an 'objective' intention-based 'directed activities' criterion by commenting that whether the defendant took reasonable steps to avoid acting in or directing activity to that State "refers to efforts to screen out access from particular jurisdictions, for example, by requiring users to identify their country of residence". ${ }^{2103}$ Dreyfuss and Ginsburg argue that technological measures make it possible "to limit internet communications to particular countries". ${ }^{2104}$ Yet, as will be demonstrated in paragraph 6.4.3.2.4, due to the Geo-blocking Regulation, traders who operate in the European Union will often not be allowed anymore to prevent internet access to customers of Member States.

Based on the assessment framework of paragraph 4.6, the next paragraphs will examine the abovementioned two combined approaches to jurisdiction related to the Erfolgsort under the Dreyfuss and Ginsburg-Convention of 2002. First, the 'intentionally directed' criterion combined with the forum actoris approach. ${ }^{2105}$ Second, the 'foreseeable infringement' criterion combined with the 'directed activities'-based escape clause. ${ }^{2106}$

\subsection{The principle of predictability}

The combination of the 'intentionally directed' criterion and the forum actoris approach in Article 6(1)(b) and (2) Dreyfuss and Ginsburg-Convention of 2002 will yield more predictability than the mere 'victim's centre of interests' approach as discussed in paragraph 6.2.4.2. The 'intentionally directed' criterion will, however, not entail as much predictability for the potential copyright infringer as regards where he may get sued as the 'directed activities'-based approach ${ }^{2107}$. First, the 'intentionally directed' criterion is quite broad since it includes the situation that the defendant "did not turn away consumers who responded to the availability of the communication of that State". ${ }^{2108}$ Second, as mentioned in the previous paragraph, it is uncertain whether the 'intentionally directed' criterion focuses on the 'subjective' or 'objective' intention of the alleged infringer. If this criterion focuses on the 'subjective' intention of the alleged infringer to direct activities to the forum state, the valuebased assessment will entail lesser predictability that an 'intentionally directed' criterion based on the 'objective' intention ${ }^{2109}$. As argued by Cruz Villalón, the criterion of 'subjective' intent

\footnotetext{
${ }^{2101}$ Article 6(1) (c) Dreyfuss and Ginsburg-Convention of 2002.

${ }^{2102}$ See paragraph 6.1.4.2.

${ }^{2103}$ Dreyfuss \& Ginsburg 2002, p. 1109.

${ }^{2104}$ Dreyfuss \& Ginsburg 2002, pp. 1109-1110. They refer to Geist 2001, pp. 1345-1406. For more information about Geist's view on jurisdiction see paragraph 7.5.3 on the targeting approach in the United States of America.

${ }^{2105}$ Article 6(1)(b) and (2) Dreyfuss and Ginsburg-Convention of 2002.

${ }^{2106}$ Article 6(1) (c) and (3) Dreyfuss and Ginsburg-Convention of 2002.

${ }^{2107}$ See paragraph 6.1.4.1.

${ }^{2108}$ Dreyfuss \& Ginsburg 2002, p. 1109.

${ }^{2109}$ See paragraph 6.1.4.1 on the 'objective' intention criterion.
} 
would not fit Article 7(2) Brussels Ibis and "gives rise to wide-ranging evidential difficulties". 2110

With respect to the second combined approach to jurisdiction laid down in Article 6(1)(c) Dreyfuss and Ginsburg-Convention of 2002, the 'foreseeable infringement' criterion can be regarded as a broad connecting factor that provides less ex ante predictability as regards which court may be competent. ${ }^{2111}$ The potential infringer may nevertheless invoke the 'directed activities'-based escape clause in Article 6(1)(c) Dreyfuss and Ginsburg-Convention of 2002 if he took reasonable steps to avoid directing activity to the forum state. As mentioned in the previous paragraph, Dreyfuss and Ginsburg seem to employ an 'objective' intention-based 'directed activities' criterion. The 'directed activities'-based escape clause in Article 6(1)(c) Dreyfuss and Ginsburg-Convention of 2002 therefore resembles the 'directed activities'-based escape clause in Article 2:202 CLIP. ${ }^{212}$ With respect to the combination of the 'foreseeable infringement' criterion and the 'directed activities'-based escape clause in Article 6(1)(c) Dreyfuss and Ginsburg-Convention of 2002, it is this latter escape clause that will yield predictability as regards which court will be competent. ${ }^{2113}$ Yet, as argued in paragraph 6.1.4.3, adopting the 'directed activities' approach as a 'negative' criterion under Article 7(2) Brussels Ibis that the defendant has to prove does not seem to suit the settled case law of the CJEU on the assessment of jurisdiction under Article 7(2) Brussels Ibis.

\subsection{A close connection between dispute and court/sound administration of justice}

The combination of the 'intentionally directed' criterion and the forum actoris approach in Article 6(2) Dreyfuss and Ginsburg-Convention of 2002 will likely entail a close connection between the dispute and the court. The 'intentionally directed' criterion under Article 6(1)(b) Dreyfuss and Ginsburg-Convention of 2002 will guarantee a close connection between the infringing activities directed to the forum actoris and the court. Hence, the court will generally be in a good position to assess the damage within the forum actoris. ${ }^{2114}$ In case of copyrighted infringing activities directed to many states, the mere 'intentionally directed' criterion will nonetheless entail multiple competent courts.

On the one hand, the forum actoris approach under Article 6(2) Dreyfuss and GinsburgConvention of 2002 will alleviate the disadvantageous related to multiple competent courts such as unpredictability, irreconcilable decisions, high litigation costs, and the lack of full redress. ${ }^{2115}$ In view of sound administration of justice, consolidation of litigation in one single court will enhance efficient adjudication. On the other hand, it is questionable whether the forum actoris will be in the best position to assess the entire damage if infringing activities have

${ }^{2110}$ The Opinion of Advocate General Cruz Villalón delivered on 29 March 2011 in the joined cases C-509/09 and C-161/10 eDate Advertising GmbH v. X and Martinez v. MGN Limited, para. 62. See paragraph 6.2.1.1.3.

${ }^{2111}$ See also paragraph 6.4.2.2.1 on the 'unpredictability of the effects' escape clause of Article 10(1) Draft Hague Convention of 1999.

${ }^{2112}$ See paragraph 6.1.3.

${ }^{2113}$ See also paragraph 6.1.4.1.

${ }^{2114}$ See also paragraph 6.1.4.2 regarding the 'directed activities' approach.

${ }^{2115}$ See paragraph 6.1.4.2 on the disadvantageous regarding the mosaic approach related to the 'directed activities' approach. 
also been directed to other states. Paragraph 6.2.4.3 demonstrated that the infringement of the economic side(s) of copyright may occur and cause substantial damage in another state than the forum actoris.

As argued in paragraph 5.3.4.1, connecting factors should carry enough weight to justify full jurisdiction such as a strong territorial link between the dispute and forum. Paragraph 6.2.4.3 argued that the mere forum actoris approach does not guarantee a close connection between the cross-border copyright infringement dispute and the court. Adding the 'intentionally directed' criterion to the forum actoris approach will likely entail a territorial closer connection between the dispute and the forum actoris. Yet, will this territorial connection be strong enough to justify full jurisdiction? Copyright infringing activities may be directed to many states. As argued in paragraph 6.2.4.3, the infringement of the economic side(s) of the copyright can occur in another state than the forum actoris. While infringements of moral rights will cause most damage in the forum actoris, the infringement of economic rights may cause substantial damage in another state. ${ }^{2116}$ The foregoing indicates that the forum actoris may thus not be in a good position to assess the entire copyright infringement dispute; the connection between the dispute and the forum actoris may not be strong enough to justify that the forum actoris obtains full jurisdiction.

With respect to the second combined approach under Article 6(1)(c) Dreyfuss and Ginsburg-Convention of 2002, the 'directed activities'-based escape clause combined with the mosaic approach in Article 6(3) will likely yield a close connection between the dispute and the court. From a perspective of sound administration of justice, the 'foreseeable infringement' criterion in Article 6(1)(c) Dreyfuss and Ginsburg-Convention of 2002 may force the court to assess the facts quite extensively which will not suit at the jurisdictional level. In case of a multistate or ubiquitous copyright infringement dispute, the latter combined approach can entail multiple competent courts that increases the risk of forum shopping, irreconcilable decisions and higher litigation costs.

\subsection{Principle of balancing the interests}

The combination of the 'intentionally directed' criterion and the forum actoris approach under Article 6(1)(b) and (2) Dreyfuss and Ginsburg-Convention of 2002 will likely strike a procedural balance between the interests of the copyright holder and the alleged infringer. Due to the 'intentionally directed' criterion, the litigants will generally be able to predict in which state(s) the alleged infringer may get sued provided that the criterion focuses on the 'objective' intention as mentioned in paragraph 6.4.3.2.1. In case of a multistate or ubiquitous copyright infringement dispute, the combined 'intentionally directed' and forum actoris approach will likely balance the interests of the litigants. On the one hand, the forum actoris approach will increase the possibility that the copyright holder can sue the infringer in his home state. Particularly if the alleged infringer is located and operated in a copyright haven and intentionally directed his activities to the forum actoris, it seems reasonable that the copyright

${ }^{2116}$ See paragraph 6.2.2.2 
holder can receive efficient and full redress in the forum actoris. ${ }^{217}$ On the other hand, the infringer will generally be able to predict to get sued in the forum actoris due to intentionally directed' criterion. ${ }^{2118}$ Furthermore, it will be beneficial to the alleged infringer to get sued before the court of one state instead of multiple states.

From a broad perspective, the combination of the 'intentionally directed' criterion and the forum actoris approach will likely balance the interests between copyright holders, on the one hand, and users of online information and traders who operate via the Internet, on the other hand. The forum actoris approach will generally enhance efficient copyright protection. This approach to jurisdiction will particularly address copyright havens and piracy. ${ }^{2119}$ The 'intentionally directed' criterion will yield a certain level of predictability to traders who operate via the Internet and providers of online information as regards in which state(s) they may get sued. This level will be particularly sufficient if the 'intentionally directed' criterion is based on the 'objective' intention of the potential infringer. Furthermore, the combination of the 'intentionally directed' criterion and the forum actoris approach reduces the risk that providers of information and traders will get sued in multiple states.

The combination of the 'foreseeable infringement' criterion and the 'directed activities'based escape clause in Article 6(1)(c) Dreyfuss and Ginsburg-Convention of 2002 may not always yield a procedural balance between the litigants. Due to the mosaic approach in Article 6(3) Dreyfuss and Ginsburg-Convention of 2002, the latter combined approach will likely not provide a procedural balance between the litigants in multistate or ubiquitous copyright infringement disputes. To receive full redress, the copyright holder may have to sue the infringer in multiple states. This seems particularly unreasonable if the infringer is located and operated in a copyright haven and directed his infringing activities to the forum actoris. ${ }^{2120} \mathrm{It}$ will also put a heavy burden on the infringer to get sued in multiple states.

From a broad perspective, the foregoing indicates that the latter combined approach does not entail efficient copyright protection. Due to the risk of getting sued in multiple states, it may impede the cross-border trade and flow of information. ${ }^{2121}$ The next paragraph will demonstrate the influence of the Geo-blocking Regulation on the means of traders to prevent jurisdiction under the combined approaches in Article 6 Dreyfuss and Ginsburg-Convention of 2002.

\subsection{The Geo-location Regulation and Article 6 of the Dreyfuss and Ginsburg- Convention of 2002}

This paragraph will consider the impact of the Geo-blocking Regulation on the two combined approaches to jurisdiction under Article 6 of the Dreyfuss and Ginsburg-Convention

\footnotetext{
${ }^{2117}$ See paragraph 2.2.2.2 on the concept of copyright havens and paragraph 5.3.1 on the arguments against territorially limited jurisdiction under the Pinckney doctrine.

${ }^{2118}$ See paragraph 6.4.3.2.1.

${ }^{2119}$ See also Dreyfuss \& Ginsburg 2002, p. 1109.

2120 See paragraph 5.3.1.

${ }^{2121}$ See paragraph 6.1.4.3 on the assessment of the 'directed activities' approach with respect to the principle of balancing the interests between copyright holders, on the one hand, and traders and users of information, on the other hand.
} 
of 2002 in cross-border copyright infringement cases. This Regulation prohibits geo-blocking and other forms of discrimination based on customers' nationality, place of residence or place of establishment within the internal market unless it has been justified by European Union law or national law in accordance with European law. ${ }^{2122}$ As demonstrated in paragraph 4.5, the Geo-blocking Regulation only affects traders who offer their goods and certain services to customers in the European Union. For now, audiovisual services and electronically supplied services "the main feature of which is the provision of access to and use of copyright protected works and other protected subject matter including the selling of copyright protected works or protected subject matter in an intangible form" are excluded from the prohibitions under the Geo-blocking Regulation. ${ }^{2123}$

The two combined approaches under Dreyfuss and Ginsburg-Convention of 2002 include the criterion whether the defendant took "no reasonable steps", 2124 or "reasonable steps", 125 "to avoid acting or directing activity to" the forum state. Dreyfuss and Ginsburg particularly argue that technological measures make it possible "to limit internet communications to particular countries". ${ }^{2126}$ They refer "to efforts to screen out access from particular jurisdictions, for example, by requiring users to identify their country of residence". ${ }^{2127}$ Yet, due to the Geoblocking Regulation, traders who offer goods and certain services within the European Union $^{2128}$ will not be allowed anymore to use geo-technologies to block or limit access to their websites or other forms of discrimination based on customers' nationality, place of residence or establishment. ${ }^{2129}$ As a result of the Geo-blocking Regulation, the tools of traders to prevent jurisdiction based on the two combined approaches under Article 6(1) Dreyfuss and GinsburgConvention of 2002 will thus be highly reduced.

As mentioned in paragraph 6.1.4.4, the Geo-blocking Regulation stipulates that the trader's mere compliance with this Regulation will not constitute 'directed activities'. ${ }^{2130}$ This consideration can likely also be applied to the abovementioned criterion whether the defendant took reasonable steps to avoid directing activities to the forum state. When a trader does not block his website or provides similar conditions of access to customers of all Member States; this will not indicate that the defendant did not take reasonable steps to prevent directing activities to the forum state. ${ }^{2131}$ As demonstrated in paragraph 6.1.4.4, the factors of the Pammer and Alpenhof ruling to assess the 'directed activities' criterion remain relevant and could also be applied to assess the 'reasonable steps' criterion. Despite the Geo-blocking Regulation, the

\footnotetext{
${ }^{2122}$ See paragraphs 4.5 up to and including 4.5.4.

2123 See Article 4(1)(b) Geo-blocking Regulation and Article 9 Geo-blocking on the review clause. See also paragraph 4.5.2.3 on other services that are excluded from the prohibitions under the Geo-blocking Regulation.

${ }^{2124}$ See Article 6(1)(b) Dreyfuss and Ginsburg-Convention of 2002.

${ }^{2125}$ See Article 6(1)(c) Dreyfuss and Ginsburg-Convention of 2002.

${ }^{2126}$ Dreyfuss \& Ginsburg 2002, pp. 1109-1110. They refer to Geist 2001, pp. 1345-1406. For more information about Geist's view on jurisdiction see paragraph 7.5.3 on the targeting approach in the United States of America. ${ }^{2127}$ Dreyfuss \& Ginsburg 2002, p. 1109.

${ }^{2128}$ See paragraph 4.5 .1 on the definition of traders and paragraph 4.5.2 on the services that are excluded under the Geo-blocking Regulation.

${ }^{2129}$ Article 3 and 4 Geo-blocking Regulation. See paragraph 4.5 on the Geo-blocking Regulation.

${ }^{2130}$ See recitals 13, 26 in the preamble of the Geo-blocking Regulation and Article 1(6) Geo-blocking Regulation. See also paragraph 6.1.4.4.

${ }^{2131}$ See recitals 13, 26 in the preamble of the Geo-blocking Regulation and Article 1(6) Geo-blocking Regulation.
} 
trader still has 'tools' to indicate that he took reasonable steps to prevent directing activities to a particular state and can therefore reduce the risk to get sued in that state. For instance, the trader can limit the delivery of goods to a particular state, use a country code top-level domain name for its website ${ }^{2132}$ or employ a particular language ${ }^{2133}$. As illustrated in paragraph 6.1.4.4, the Geo-blocking Regulation may nonetheless force the court seised to examine more thoroughly whether the defendant took reasonable steps to direct activities to the forum state as stipulated by Article 6(1)(b) and (c) Dreyfuss and Ginsburg-Convention of 2002. ${ }^{2134}$

\subsubsection{Article 12a MPI Proposal of 2001}

In 2001, the Max Planck Institute for Intellectual Property, Competition and Tax Law drafted the so-called Max Planck Institute Proposal, hereinafter the MPI Proposal of 2001.2135 Similar to the abovementioned Dreyfuss and Ginsburg-Convention of 2002, the MPI Proposal of 2001 aimed "to help fill the vacuum created by" the failed attempt of the Hague Conference on Private International law regarding intellectual property infringement matters. ${ }^{2136}$ Article 12a Paragraph 6(1) MPI Proposal consists of the following alternative connecting factors to establish jurisdiction in case of alleged infringements of intellectual property rights. ${ }^{2137}$ First, Paragraph 6(1)(a) MPI Proposal confers jurisdiction to the court of the state in which the infringing activities have "commercial effect or, if commercial effect is lacking, a substantial impact" in that state ${ }^{2138}$. Second, Paragraph 6(1)(b) MPI Proposal provides jurisdiction to the court of the state to which the infringing activity has been intentionally directed. ${ }^{2139}$ With respect to the aforementioned connecting factors, Article 12a Paragraph 6(2) MPI Proposal comprises the following 'escape clause': unless "the defendant has taken reasonable steps to avoid creating a commercial effect in, or directing activity to" the forum state. ${ }^{2140}$ Based on Article 12a Paragraph 4(2) MPI Proposal, the jurisdiction of these courts will be territorially limited to the infringement occurring in the forum state.

The influence of the territorial protection of intellectual property rights on rules of jurisdiction can be found in the MPI Proposal. First, Article 12a Paragraph 6(1) MPI Proposal stipulates that jurisdiction can only be established if the infringement occurs in the state where the right exists, ${ }^{2141}$ the so-called locus protectionis criterion as mentioned in paragraph 5.1 . Second, the court's jurisdiction under Article 12a Paragraph 6 MPI Proposal will be limited to infringements occurring within the forum state. ${ }^{2142}$

\footnotetext{
${ }^{2132}$ Recital 20 in the preamble to the Geo-blocking Regulation.

${ }^{2133}$ Recital 27 in the preamble to the Geo-blocking Regulation.

2134 See paragraph 4.5.3.

2135 See Drexl \& Kur 2005, pp. 309-311, 330-332; Kur 2005, pp. 21-34.

2136 See Kur 2005, p. 21.

${ }^{2137}$ Drexl \& Kur 2005, pp. 310-311.

${ }^{2138}$ Article 12a Paragraph 6(1)(a) MPI Proposal.

${ }^{2139}$ Article 12a Paragraph 6(1)(b) MPI Proposal.

${ }^{2140}$ Article 12a Paragraph 6(2) MPI Proposal.

${ }^{2141}$ Drexl \& Kur 2005, p. 311.

${ }^{2142}$ See Article 12a Paragraph 4(2) MPI Proposal.
} 
With respect to alleged infringements of intellectual property rights "related to the Internet or similar ubiquitous media", Article 12a Paragraph 5 MPI Proposal contains a special jurisdiction rule that confers full jurisdiction. ${ }^{2143}$ Paragraph 5 stipulates that "courts in other Contracting States than the Contracting State where the defendant is habitually resident pursuant to Article 3 MPI Proposal shall have jurisdiction with respect to infringements occurring in other territories, if a) an essential part of the activities which are claimed to have caused the infringement has been carried out by the defendant in the Forum State, and b) the activities which are claimed to have caused the infringement are not aimed at the market in the Contracting State where the defendant is habitually resident, and have no substantial commercial effects there". ${ }^{2144}$

6.4.4.1 The combined approaches to jurisdiction in infringement cases under Article 12a MPI Proposal of 2001

\begin{tabular}{|c|c|c|c|}
\hline $\begin{array}{l}\text { Jurisdictional } \\
\text { approach }\end{array}$ & $\begin{array}{l}\text { Article 12a MPI } \\
\text { Proposal of } 2001\end{array}$ & Connecting factors & $\begin{array}{l}\text { Scope of the court's } \\
\text { jurisdiction }\end{array}$ \\
\hline \multirow{3}{*}{$\begin{array}{l}\text { For alleged } \\
\text { infringements of } \\
\text { intellectual } \\
\text { property rights. } \\
\text { According to } \\
\text { Paragraph 6(1) } \\
\text { MPI Proposal } \\
\text { jurisdiction can } \\
\text { only be established } \\
\text { if the infringement } \\
\text { occurs in the state } \\
\text { where the right } \\
\text { exists, the so-called } \\
\text { locus protectionis } \\
\text { criterion. }\end{array}$} & Paragraph 6(1)(a) & $\begin{array}{l}\text { The state in which the } \\
\text { infringing activities have } \\
\text { "commercial effect or, if } \\
\text { commercial effect is } \\
\text { lacking, a substantial } \\
\text { impact", referred to as } \\
\text { the 'commercial } \\
\text { effects' criterion or } \\
\text { 'substantial impact' } \\
\text { criterion, }\end{array}$ & \multirow[t]{2}{*}{$\begin{array}{l}\text { Territorially limited to } \\
\text { the infringement } \\
\text { occurring in the forum } \\
\text { state Paragraph } 4(2) \\
\text { MPI Proposal. }\end{array}$} \\
\hline & & $\begin{array}{l}\text { unless "the defendant } \\
\text { has taken reasonable } \\
\text { steps to avoid creating a } \\
\text { commercial effect in, or } \\
\text { directing activity to" the } \\
\text { forum state, referred to } \\
\text { as the 'directed } \\
\text { activities'- based } \\
\text { escape clause Paragraph } \\
\text { 6(2) MPI Proposal. }\end{array}$ & \\
\hline & Paragraph 6(1)(b) & $\begin{array}{l}\text { The state to which the } \\
\text { infringing activity has } \\
\text { been intentionally } \\
\text { directed, referred to as } \\
\text { the 'intentionally } \\
\text { directed' criterion, }\end{array}$ & $\begin{array}{l}\text { Territorially limited to } \\
\text { the infringement } \\
\text { occurring in the forum } \\
\text { state Paragraph } 4(2) \\
\text { MPI Proposal. }\end{array}$ \\
\hline
\end{tabular}

${ }^{2143}$ Drexl \& Kur 2005, p. 310.

${ }^{2144}$ Drexl \& Kur 2005, p. 310. 


\begin{tabular}{|l|l|l|l|}
\hline & & $\begin{array}{l}\text { unless "the defendant } \\
\text { has taken reasonable } \\
\text { steps to avoid creating a } \\
\text { commercial effect in, or } \\
\text { directing activity to" the } \\
\text { forum state, referred to } \\
\text { as the 'directed } \\
\text { activities'- based } \\
\text { escape clause Paragraph } \\
\text { 6(2) MPI Proposal. }\end{array}$ & \\
\hline $\begin{array}{l}\text { For alleged } \\
\text { infringements of } \\
\text { intellectual } \\
\text { property rights } \\
\text { "related to the }\end{array}$ & Paragraph 5 & $\begin{array}{l}\text { "if a) an essential part of } \\
\text { the activities which are } \\
\text { ubiquitous media". }\end{array}$ & $\begin{array}{l}\text { Full jurisdiction with } \\
\text { respect to infringements } \\
\text { claimed to have caused } \\
\text { the infringement has } \\
\text { occurring in other } \\
\text { been carried out by the } \\
\text { defendant in the Forum } \\
\text { State, and b) the } \\
\text { activities which are } \\
\text { claimed to have caused } \\
\text { the infringement are not } \\
\text { aimed at the market in } \\
\text { the Contracting State } \\
\text { where the defendant is } \\
\text { habitually resident, and } \\
\text { have no substantial } \\
\text { commercial effects } \\
\text { there". }\end{array}$ \\
\hline
\end{tabular}

\subsubsection{Assessing Article 12a MPI Proposal of 2001}

Similar to the common view on infringements of intellectual property, ${ }^{2145}$ the connecting factors related to alleged infringements of intellectual property rights in Article 12a MPI Proposal of 2001 do not explicitly distinguish between the Handlungsort and the Erfolgsort. Nevertheless, a distinction can be made between the connecting factors in Paragraph 6(1)(a) and (b) and Paragraph 4(2) that relate to the Erfolgsort and the connecting factors in Paragraph 5 that relate to the Handlungsort. As will be demonstrated below, the connecting factors in these Paragraphs of the MPI Proposal of 2001 resemble several approaches that have been discussed in this dissertation.

Paragraph 5 of Article 12a MPI Proposal confers full jurisdiction in case of alleged infringements of intellectual property rights "related to the Internet or similar ubiquitous media". The "an essential part of the activities" criterion in Article 12a Paragraph 5(a) MPI

${ }^{2145}$ Paragraph 5.2.1. 
Proposal "does not live up to the standards of clarity and certainty". ${ }^{2146}$ The "positive" criterion of Article 12a Paragraph 5(a) MPI Proposal aims to uphold the general jurisdiction rule of the forum rei. ${ }^{2147}$ This suits the view of the CJEU that the jurisdiction of the forum actoris should not be generalized under the Brussels Ibis Regulation. ${ }^{2148}$ Since the connecting factors in Article 12a Paragraph 5 MPI Proposal relate to the Handlungsort, they will not be assessed in this dissertation as an alternative to the Pinckney doctrine. ${ }^{2149}$

The paragraphs below will assess the technology neutral connecting factors related to the Erfolgsort under Paragraph 6(1) of Article 12a MPI Proposal. The court's jurisdiction based on these factors will be territorially limited to the infringement occurring in the forum state due to Article 12a Paragraph 4(2) MPI Proposal that reflects the mosaic approach established by the CJEU in the Shevill ruling ${ }^{2150}$. Paragraph 6(1)(a) of Article 12a MPI Proposal contains the 'commercial effects' criterion to establish jurisdiction in infringement disputes. The related Annex explicitly states that this criterion resembles the commonly accepted 'commercial effects'-based approach as stipulated in the Joint Recommendation WIPO regarding infringements of trade marks at substantive level. ${ }^{2151}$ Article 12a Paragraph 6(1)(a) MPI Proposal also comprises the 'substantial impact' criterion for infringements of non-commercial character. An example of a copyright infringement that caused substantial impact outside the commercial sphere is "if the moral rights of an author are severely encroached upon". ${ }^{2152}$ The moral rights will generally be located in the copyright holder's place of residence. ${ }^{2153}$ Therefore, the 'substantial impact' criterion resembles the 'victim's centre of interests' approach related to moral rights as discussed in paragraph 6.2.2.2. Unlike the 'victim's centre of interests' approach, the jurisdiction of the court based on the 'substantial impact' criterion will be territorially limited and the defendant can invoke the 'directed activities'-based escape clause in Paragraph 6(2) of Article 12a MPI Proposal. ${ }^{2154}$

The alternative jurisdiction rule for infringement disputes in Paragraph 6(1)(b) and 6(2) of Article 12a MPI Proposal comprises the combination of the 'intentionally directed' criterion and the 'directed activities'-based escape clause. While the former criterion is reminiscent of the 'intentionally directed' criterion in Article 6(1)(b) Dreyfuss and Ginsburg-Convention of $2002,{ }^{2155}$ the latter escape clause resembles the 'directed activities'-escape clause as employed in Article 2:202 CLIP. ${ }^{2156}$

The foregoing indicates that Paragraph 6 of Article 12a Proposal contains alternative connecting factors for infringement cases; they confer jurisdiction based on either the effectsbased connecting factors in sub (a) or the 'intentionally directed' criterion in sub (b). Both

${ }^{2146}$ Kur 2005, p. 26

${ }^{2147}$ Kur 2005, p. 26.

2148 See paragraph 5.3.4.

${ }^{2149}$ Paragraph 6.4.5.2 will nonetheless point out the resemblance between the effects-based approach in Article 2:203(2) CLIP and Article 12a Paragraph 5 of the MPI Proposal of 2001.

2150 Paragraph 1.1.4.

${ }^{2151}$ Drexl \& Kur 2005, p. 331.

${ }^{2152}$ Drexl \& Kur 2005, pp. 331-332.

${ }^{2153}$ See paragraph 6.2.2.2.

2154 See Article 12a Paragraph 4(2) MPI Proposal.

${ }^{2155}$ Drexl \& Kur 2005, p. 332.

${ }^{2156}$ Drexl \& Kur 2005, p. 332. 
alternative factors are combined with the escape clause in Article 12a Paragraph 6(2) MPI Proposal; therefore, they can be denoted as combined approaches to jurisdiction. The following paragraphs will examine these combined approaches that both confer territorially limited jurisdiction $^{2157}$.

\subsection{The principle of predictability}

With respect to commercial-related copyright infringements, the 'commercial effects' criterion in Article 12a Paragraph 6(1)(a) MPI Proposal will be applicable. The related Annex explicitly states that this criterion resembles the commonly accepted 'commercial effects'based approach as stipulated in the Joint Recommendation WIPO regarding infringement of trade marks at substantive level. ${ }^{2158}$ Based on this Joint Recommendation, 'objective' criteria will determine whether there have been commercial effects in the forum state such as delivery possibilities, currency used, an address, telephone number or other means of contact in the state, country code top-level domain name of the website involved, language used. ${ }^{2159}$ Due to the 'objective' criteria of the Joint Recommendation WIPO, the 'commercial effects' approach in Article 12a Paragraph 6(1)(a) MPI Proposal will entail predictability as regards which court may be competent. Based on the 'directed activities'-based escape clause in Article 12a Paragraph 6(2) MPI Proposal, the alleged infringer may prevent jurisdiction by proving that he has taken reasonable steps to avoid creating commercial effects in the forum state. This escape clause will also entail predictability provided that the 'objective' criteria of the Joint Recommendation WIPO will be applied.

With respect to non-commercial related copyright infringements, the 'substantial impact' criterion in Article 12a Paragraph 6(1)(a) MPI Proposal may not provide sufficient predictability. While the effects of the infringement of moral rights will generally be substantial in the state where the copyright holder has been located, ${ }^{2160}$ the copyright infringer may not be aware of this location. ${ }^{2161}$ Similar to the 'victim's centre of interests' approach related to moral rights ${ }^{2162}$ the 'substantial impact' criterion will not guarantee predictability in case of infringements of moral rights. The escape clause in Paragraph 6(2) MPI Proposal may nevertheless prevent jurisdiction if "the defendant has taken reasonable steps to avoid...directing activity to" the forum state. This 'directed activities'-based escape clause may entail predictability provided that it focuses on the 'objective intention of the defendant to direct the alleged infringing activities to the forum state. ${ }^{2163}$

Whether the 'intentionally directed' criterion in Article 12a Paragraph 6(1)(b) MPI Proposal yields predictability depends on its definition. ${ }^{2164}$ The MPI Proposal of 2001 lacked

\footnotetext{
${ }^{2157}$ Article 12a Paragraph 4(2) MPI Proposal.

${ }^{2158}$ Drexl \& Kur 2005, p. 331.

${ }^{2159}$ See paragraph 6.1.3.2.

${ }^{2160}$ Drexl \& Kur 2005, pp. 331-332.

${ }^{2161}$ See paragraph 6.2.4.2.

${ }^{2162}$ See paragraph 6.2.4.2.

${ }^{2163}$ See paragraph 6.4.3.2.1. See also paragraph 6.1.4.1.

${ }^{2164}$ See also the 'intentionally directed' criterion of Article 6(1)(b) Dreyfuss and Ginsburg-Convention of 2002 in paragraph 6.4.3.2.1.
} 
to define the 'intentionally directed' criterion. If this criterion focuses on the 'subjective' intention of the infringer to direct activities to the forum state, the value-based assessment will entail lesser predictability than an 'intentionally directed' criterion based on the 'objective' intention. ${ }^{2165}$ Assuming that the 'intentionally directed' criterion focuses on the 'objective' intention, this criterion will provide the same predictability as the 'directed activities' criterion. ${ }^{2166}$ As mentioned above, the escape clause in Paragraph 6(2) MPI Proposal will also entail predictability provided that it focuses on the 'objective' intention of the defendant to direct the alleged infringing activities to the forum state.

\subsection{A close connection between dispute and court/ sound administration of justice}

The combination of the 'directed activities'-based escape clause in Article 12a Paragraph 6(2) MPI Proposal and the effects-based connecting factors in Article 12a Paragraph 6(1)(a) MPI Proposal, or the 'intentionally directed' criterion in Article 12a Paragraph 6(1)(b) MPI Proposal, will generally entail a close connection between the dispute and the court. These connecting factors will prevent so-called empty jurisdiction or jurisdiction based on overspills. Due to the connecting factors under Article 12a Paragraph 6(1)(a) and (b) MPI Proposal and the mosaic approach, ${ }^{2167}$ the court will usually be in a good position to assess the infringement that occurred within the forum state.

From a perspective of sound administration of justice, the combination of the "commercial effects' criterion, or the 'intentionally directed' criterion, and the mosaic principle in Article 12a Paragraph 4(2) MPI Proposal will likely entail multiple competent courts in case of a multistate or ubiquitous copyright infringement dispute which increases the risk of forum shopping, irreconcilable decisions and higher litigation costs.

\subsection{The principle of balancing the interests}

With respect to commercial-related copyright infringements, the 'commercial effects' criterion in Article 12a Paragraph 6(1)(a) MPI Proposal combined with the 'directed activities'based escape clause in Article 12a Paragraph 6(2) MPI Proposal will likely strike a procedural balance between the litigants of a cross-border copyright infringement dispute. Due to the objective factors of the Joint Recommendation WIPO, the copyright holder and potential infringer can reasonably predict which court will be competent. In addition, the alleged infringer may invoke the 'directed activities'-based escape clause. In case of multistate or ubiquitous copyright infringement disputes, this balance may nevertheless be disturbed by the mosaic approach in Article 12a Paragraph 4(2) MPI Proposal. The alleged infringer can get sued in multiple states which will be time-consuming, costly and entails unpredictability. From a perspective of the copyright holder, multistate litigation or suing in the forum rei, or the

\footnotetext{
${ }^{2165}$ See also paragraph 6.4.3.2.1 on the 'intentionally directed' criterion in Article 6(1)(b) Dreyfuss and GinsburgConvention of 2002 .

${ }^{2166}$ See paragraph 6.1.4.2.

${ }^{2167}$ See Article 12a Paragraph 4(2) MPI Proposal.
} 
Handlungsort, can seem unreasonable if the infringer is located and operated in a so-called copyright haven. ${ }^{2168}$ For instance, if the infringer directed his activities to the forum state and the infringement caused substantial commercial effects in that state.

With respect to non-commercial related infringements, the 'substantial impact' criterion in Article 12a Paragraph 6(1)(a) MPI Proposal combined with the 'directed activities'-based escape clause in Article 12a Paragraph 6(2) MPI Proposal will often entail a procedural balance between the litigants of a cross-border copyright infringement dispute. Based on the 'substantial impact' criterion, the copyright holder will be able to sue the infringer in the state where is he domiciled since the impact of the infringement of moral rights will be substantial in that state. Due to the mosaic approach in Article 12a Paragraph 4(2) MPI Proposal, the copyright holder may not easily receive full redress. With respect to a multistate or ubiquitous copyright infringement dispute, the latter seems unreasonable in case the infringer is located and operated in a copyright haven and directed his activities to the copyright holder's state of domicile or centre of interests. ${ }^{2169}$ As mentioned in paragraph 6.4.4.2.1, the 'substantial impact' criterion does not seem to guarantee predictability for potential copyright infringers who will often not be able to predict where the infringing activities cause substantial impact. The 'directed activities'-based escape clause in Article 12a Paragraph 6(2) MPI Proposal may nonetheless provide the unknowing infringer a possibility to prevent jurisdiction.

The combination of the 'intentionally directed' criterion in Article 12a Paragraph 6(1)(b) MPI Proposal and the escape clause in Article 12a Paragraph 6(2) MPI Proposal will generally yield a procedural balance between the litigants of a cross-border copyright infringement dispute. Due to the 'intentionally directed' criterion, the litigants will usually be able to predict in which state(s) the alleged infringer may get sued provided that the criterion focuses on the 'objective' intention as mentioned in paragraph 6.4.4.2.1. Furthermore, the escape clause in Article 12a Paragraph 6(2) MPI Proposal will provide the alleged infringer the opportunity to prevent jurisdiction in case he did not directed his activities to the forum state.

Yet, in view of multistate or ubiquitous copyright infringement disputes, the balance will likely be disturbed by the mosaic approach in Article 12a Paragraph 4(2) MPI Proposal. The alleged infringer may get sued in multiple states which will be time-consuming, costly and entails unpredictability. For the copyright holder, it will also be burdensome to sue the infringer in multiple states to receive full redress. As indicated above, it can be unreasonable that the copyright holder cannot receive full redress if the infringer directed his activities to the forum state and the infringer is located and operated in a copyright haven.

From a broad perspective, the abovementioned two combined approaches will not always entail a balance between the interests of copyright holders, on the one hand, and traders and users of information, on the other hand. In view of multistate or ubiquitous copyright infringement disputes, the mosaic approach in Article 12a Paragraph 4(2) MPI Proposal will reduce efficient copyright protection at procedural level. To receive full redress, the copyright holder may have to sue the infringer in multiple states. As demonstrated above, this can be

\footnotetext{
${ }^{2168}$ See paragraph 2.2.2.2 on the concept of copyright haven. See also paragraph 5.3.1 on arguments against the mosaic principle under the Pinckney doctrine.

${ }^{2169}$ See paragraph 5.3.1.
} 
unreasonable if the infringer is located and operated in a copyright haven. Lack of sufficient copyright protection at procedural level can decrease creativity and innovation.

It is the 'directed activities'-based escape clause ${ }^{2170}$ with respect to the combined approaches under Article 12a Paragraph 6(1)(a) and(b) MPI Proposal that will yield a certain level of predictability to traders and providers of information as regards in which state(s) they may get sued. This level will be adequate if the issue whether "the defendant has taken reasonable steps to avoid creating a commercial effect in, or directing activity to" the forum state will be determined by the objective intention of the alleged infringer ${ }^{2171}$ and by 'objective' criteria as enumerated under the Joint Recommendation WIPO ${ }^{2172}$. The next paragraph will demonstrate the influence of the Geo-blocking Regulation on the possibility of traders to invoke the escape clause in Article 12a Paragraph 6(2) MPI Proposal. In view of multistate or ubiquitous copyright infringement disputes, the fear of being sued in multiple states as a result of the mosaic approach may nevertheless impede the cross-border flow of information and trade. $^{2173}$

\subsection{The Geo-blocking Regulation and Article 12a MPI Proposal of 2001}

This paragraph will consider the impact of the Geo-blocking Regulation on the abovementioned two combined approaches to jurisdiction under Article 12a MPI Proposal in cross-border copyright infringement cases. As demonstrated in paragraph 6.1.4.4, the Geoblocking Regulation will only affect traders who offer their goods and certain services to customers in the European Union. This Regulation generally prohibits traders to block or limit their online interfaces or access to goods and certain services by other forms of discrimination based on customers' nationality, place of residence or establishment. ${ }^{2174}$ The traders' tools to avoid creating commercial effects in, or directing activities to the forum state as stipulated by the escape clause in Article 12a Paragraph 6(2) MPI Proposal will therefore be reduced. For instance, traders can frequently not prevent jurisdiction in certain European Union Member States anymore by blocking their websites for customers of those states.

As argued in paragraph 6.1.4.4, the Geo-blocking Regulation seems to indicate that the provisions will be without prejudice to the 'directed activities' approach to establish jurisdiction under Article 7(2) Brussels Ibis in cross-border copyright infringing cases. Pursuant to the Geoblocking Regulation, the trader's mere compliance with this Regulation will not constitute 'directed activities'. ${ }^{2175}$ When a trader does not block his website or provides similar conditions

\footnotetext{
${ }^{2170}$ Paragraph 6(2) MPI Proposal.

2171 See paragraph 6.4.4.2.1.

${ }^{2172}$ See paragraphs 6.1.3.2 and 6.5.4.2.1.

${ }^{2173}$ See paragraph 6.1.4.3 on the assessment of the 'directed activities' approach in view of the principle of balancing the interests involved.

${ }^{2174}$ See paragraphs 4.5 up to and including 4.5.4. The Geo-blocking Regulation prohibits geo-blocking and other forms of discrimination based on customers' nationality, place of residence or place of establishment within the internal market unless it has been justified by European Union law or national law in accordance with European Union law, see paragraph 4.5 .

${ }^{2175}$ See recitals 13, 26 in the preamble of the Geo-blocking Regulation and Article 1(6) Geo-blocking Regulation. See also paragraph 6.1.4.4.
} 
of access to customers of all Member States, this will not imply that the trader directed his activities to all of these Member States. ${ }^{2176}$ To determine whether the trader directed his activities to a particular Member State, it is important if "the trader has manifested an intention to establish commercial relations with consumers from that Member State"2177. As mentioned in paragraph 6.1.4.4, the factors of the Pammer and Alpenhof ruling to assess the 'directed activities' criterion remain relevant.

Thus, despite the Geo-blocking Regulation, the trader still has tools to indicate that his activities were not directed to a particular state and can therefore invoke the 'directed activities'based escape clause in Article 12a Paragraph 6(2) MPI Proposal to prevent to get sued in that state. For instance, the trader can argue that he limited the delivery of goods to a particular state, used a country code-top level-domain name for its website, ${ }^{2178}$ or employed a particular language ${ }^{2179}$. Furthermore, as explained in paragraph 4.5.2.3, traders can still block online interfaces that offer audiovisual services and electronically supplied services "the main feature of which is the provision of access to and use of copyright protected works and other protected subject matter including the selling of copyright protected works or protected subject matter in an intangible form". ${ }^{2180}$ As explained in paragraph 6.1.4.4, due to the Geo-blocking Regulation, the court seised will nonetheless need to examine the trader's activities more thoroughly to assess the 'directed activities'-based escape clause. ${ }^{2181}$

\subsubsection{Article 2:202 and 2:203(2) CLIP Principles of 2011}

Paragraph 6.1.3 focused on the 'directed activities' approach in the escape clause of Article 2:202 CLIP Principles (hereinafter CLIP) as drafted in the final text of the Principles on Conflict of laws in Intellectual Property of 1 December 2011 by the CLIP group. ${ }^{2182}$ Article 2:203 CLIP contains a separate provision on scope of the court's jurisdiction based on the place of infringement of intellectual property under Article 2:202 CLIP. ${ }^{2183}$ Pursuant to Article 2:203(1) CLIP, the scope of the jurisdiction will generally be limited to "infringements that occur or may occur within the territory of the State in which that court is situated". Yet, Article 2:203(2) CLIP contains an exception in case of an "infringement carried out through ubiquitous media such as the Internet".

\footnotetext{
${ }^{2176}$ See recitals 13, 26 in the preamble of the Geo-blocking Regulation and Article 1(6) Geo-blocking Regulation. See also paragraph 6.1.4.4.

${ }^{2177}$ See recital 26 in the preamble of the Geo-blocking Regulation. This consideration appears to resemble the CJEU's concept of 'directed activities' under Article 17(1)(c) Brussels Ibis in the ruling of Pammer and Alpenhof, para. 80. See also paragraph 4.5.3.

${ }^{2178}$ Recital 20 in the preamble to the Geo-blocking Regulation.

${ }^{2179}$ Recital 27 in the preamble to the Geo-blocking Regulation.

${ }^{2180}$ See Article 4(1)(b) Geo-blocking Regulation. See Article 9 of the Geo-blocking Regulation on the review that will take place in March 2020.

${ }^{2181}$ See paragraph 4.5.3.

${ }^{2182}$ See https://www.ip.mpg.de/fileadmin/ipmpg/content/clip/the_draft-clip-principles-25-03-20117.pdf.

${ }^{2183}$ See paragraphs 6.1.4 till 6.1.4.2 on the place of infringement and the 'directed activities'-based escape clause under Article 2:202 CLIP.
} 
Although there is no universal accepted definition of the term 'ubiquitous' related to intellectual property rights, ${ }^{2184}$ the term has been denoted as "concurrent multi-territorial infringements evoked by a single act of operation" 2185 . Hence, copyright infringing content disseminated via the Internet are ubiquitous infringements. Broadcasting copyright infringing content via radio or television can also be indicated as infringements carried out through ubiquitous media.

Based on the exception of Article 2:203(2) CLIP, the competent court under Article 2:202 CLIP can exercise jurisdiction in respect of infringements carried out through ubiquitous media that occur or may occur within the territory of any other states under the following conditions. First, the activities that gave rise to the infringement should not have a substantial effect in the state(s) of the infringer's habitually residence. ${ }^{2186}$ Second, it is necessary that either "substantial activities in furtherance of the infringement in its entirety have been carried out within the territory" of the forum state, ${ }^{2187}$ or the harm caused by the infringement in the forum state "has been substantial in relation to the infringement in its entirety" 2188 .

While Article 2:202 CLIP employs 'the place of infringement' as connecting factor, Article 2:203(2) CLIP makes an implicit distinction between the Handlungsort and the Erfolgsort. Article 2:203(2)(a) CLIP provides an effect-based approach to full jurisdiction related to the Handlungsort: "the state where a person has substantially acted covers all injuries arising out of that act, wherever they may occur". Article 2:203(2)(b) CLIP consists of an effect-based approach to full jurisdiction related to the Erfolgsort; it will provide the plaintiff the opportunity to gain full redress before the court of the state where the infringement dispute caused substantial effects in relation to the infringement in its entirety. ${ }^{2189}$ As this dissertation rethinks the CJEU's approach to jurisdiction in cross-border copyright infringement disputes related to the Erfolgsort, the following paragraphs will focus on the effects-based connecting factors under Article 2:203(2)(b) CLIP.

The effects-based connecting factors in Article 2:203(2) CLIP aim to address "cases of abusive conduct when the alleged infringer seeks to evade an efficient pursuit of justice and the plaintiff would be unfairly disadvantaged if denied the possibility to establish infringement jurisdiction extending beyond national borders in an alternative forum, independent of the State of the defendant's habitual residence". ${ }^{2190}$ Illustrative is the case of an infringer who has been located, or initiated a ubiquitous infringement, in a country that does not provide adequate legal protection, the so-called infringer haven. ${ }^{2191}$

Article 2:203(2) CLIP demonstrates that the CLIP principles are under certain conditions deviating from the territoriality principle inherent to intellectual property rights for reasons of

\footnotetext{
${ }^{2184}$ Christie 2017, p. 174; Kono \& Jurcys 2012, p. 153.

${ }^{2185}$ Chaen, Kono \& Yokomizo 2010, p. 98. See paragraph 2.3.4.1.

${ }^{2186}$ Article 2:203(2) CLIP.

2187 Article 2:203(2)(a) CLIP.

2188 Article 2:203(2)(b) CLIP.

${ }^{2189}$ Kur 2013(b), p. 94, 2:203.N09. Article 2:203(2)(b) CLIP reflects the so-called 'root copy' approach adopted by several courts in the United States of America.

${ }^{2190}$ Kur 2013(b), p. 89, 2:203.C11.

${ }^{2191}$ Kur 2013(b), p. 88, 2:203.C09. See also Kur 2013(b), p. 94, 2:203.N12. This dissertation employed the term copyright haven, see paragraph 2.2.2.2.
} 
efficient and fair adjudication. ${ }^{2192}$ The approach to jurisdiction in Article 2:203(2) CLIP also suits the objectives of the CLIP Principles to facilitate international trade, the flow of information, and take into account the development of digital communication technologies. ${ }^{2193}$

\subsubsection{The combined approach to jurisdiction in infringement cases under Article 2:202 CLIP and Article 2:203(2) CLIP}

\begin{tabular}{|c|c|c|}
\hline & \multicolumn{2}{|c|}{$\begin{array}{l}\text { Article } 2: 202 \\
\text { The "State where the alleged infringement occurs or may occur, } \\
\text { unless the alleged infringer has not acted in the State to initiate or further the } \\
\text { infringement and her/his activity cannot reasonably be seen as having been } \\
\text { directed to that State", the latter has been referred to as the 'directed activities'- } \\
\text { based escape clause (see paragraph } 6.1 .4 \text { ). }\end{array}$} \\
\hline $\begin{array}{l}\text { Scope of } \\
\text { jurisdiction } \\
\text { based and } \\
\text { additional } \\
\text { connecting } \\
\text { factors }\end{array}$ & $\begin{array}{l}\text { Limited } \\
\text { to the infringement } \\
\text { that occur or may } \\
\text { occur within the } \\
\text { forum state Article } \\
\mathbf{2 : 2 0 3 ( 1 )}\end{array}$ & $\begin{array}{l}\text { Unlimited } \\
\text { in case of an "infringement carried out through } \\
\text { ubiquitous media such as the Internet" provided that the } \\
\text { activities that gave rise to the infringement did not have a } \\
\text { substantial effect in the state(s) of the infringer's habitually } \\
\text { residence (Article 2:203(2)) and } \\
\text {-the "substantial activities in furtherance of the } \\
\text { infringement in its entirety have been carried out within } \\
\text { the territory" of the forum state Article 2:203(2)(a) or } \\
\text { - the harm caused by the infringement in the forum state } \\
\text { "has been substantial in relation to the infringement in its } \\
\text { entirety" Article 2:203(2)(b), referred to as the } \\
\text { 'substantial effects in relation to the infringement in its } \\
\text { entirety' criterion }\end{array}$ \\
\hline
\end{tabular}

6.4.5.2 Assessing the combined approach to jurisdiction under Article 2:202 CLIP and Article 2:203(2)(b) CLIP

As the table above demonstrates, the 'full jurisdiction' approach related to the Erfolgsort under Article 2:202 CLIP and Article 2:203(2) CLIP consist of a combination of cumulative connecting factors: the 'place of infringement', the 'directive activities'-based escape clause in Article 2:202 CLIP, ${ }^{2194}$ and the two effects-based connecting factors under Article 2:203(2)(b) CLIP. According to the first connecting factor in Article 2:203(2) CLIP, "the activities that gave rise to the infringement did not have a substantial effect in the state(s) of the infringer's habitually residence". This factor aims to prevent that the general jurisdiction rule of the forum rei will be circumvented. ${ }^{2195}$ The second connecting factor in Article 2:202(2)(b) CLIP requires

${ }^{2192}$ Kur 2013(b), pp. 88-89, 2:203.C09-C12; Peukert 2013, p. 29, PRE:C11. See also paragraph 6.1.4.1.

${ }^{2193}$ See the preamble to the CLIP Principles Final Text 1 December 2011.

2194 See paragraph 6.1.4.

${ }^{2195}$ See also paragraph 6.4.4.2 on Paragraph 5 of Article 12a MPI Proposal of 2001. 
that the state where the harm caused by the infringement in the forum state "has been substantial in relation to the infringement in its entirety". ${ }^{2196}$

Article 2:203(2) CLIP has been inspired by Article 12a Paragraph 5 of the Max Planck Institute Proposal of 2001 as set out in paragraph 6.4.4. ${ }^{2197}$ While Article 2:203(2) CLIP relates to both the Handlungsort ${ }^{2198}$ and the Erfolgsort ${ }^{2199}$, Article 12a Paragraph 5 MPI Proposal of 2001 confers only full jurisdiction to the Handlungsort. ${ }^{2200}$

Maunsbach argued that the 'victim's centre of interests' approach in the eDate and Martinez ruling is similar to the 'substantial effects in relation to the infringement in its entirety" criterion in Article 2:203(2)(b) CLIP. ${ }^{2201}$ Yet, unlike the 'victim's centre of interest' approach, the effects-based connecting factor of Article 2:203(2)(b) CLIP compels the court seised to quantify the effects caused by the alleged ubiquitous copyright infringement. As argued in paragraph 6.2.4.3, infringements of economic rights related copyrights will not always cause substantial damage in the state in which the copyright holder's centre of interests is located. ${ }^{2202}$

\subsection{The principle of predictability}

The alleged infringer who did not direct his activities to the state where substantial harm occurred can invoke the 'directed activities'-based escape clause in Article 2:202 CLIP. As argued in paragraph 6.1.4.1, the 'directed activities' criterion will generally yield predictability for potential copyright infringers as regards where they may get sued. Due to the focus on the 'objective' intention of the alleged infringer to direct activities, both the copyright holder and the alleged infringer should be able to predict which court will be competent. ${ }^{2203}$

Yet, the outcome of the effects-based assessment under Article 2:203(2)(b) CLIP may be uncertain; this approach to jurisdiction will therefore not guarantee ex ante predictability as regards which court may be competent. The effects-based connecting factors related to the Erfolgsort in Article 2:203(2) CLIP will force the court seised to localise and quantify the effects. First of all, Article 2:203(2) CLIP requires that the activities that gave rise to the infringement did not have a substantial effect in the state(s) of the infringer's habitually residence, the forum rei. Second, based on Article 2:203(2)(b) CLIP, the harm caused by the infringement in the forum state should be substantial in relation to the infringement in its entirety. The abovementioned effects-based connecting factors may require a quite extensive assessment of the facts of the case since both the effects in the forum rei and the forum state

\footnotetext{
${ }^{2196}$ See Article 2:203(2)(b) CLIP.

${ }^{2197}$ See Kur 2013(b), p. 89, 2:203.C12.

2198 Article 2:203(2)(a) CLIP.

2199 Article 2:203(2)(b) CLIP.

${ }^{2200}$ See paragraph 6.4.4.2.

${ }^{2201}$ Maunsbach 2010-2012, p. 56.

${ }^{2202}$ See also Opinion of Advocate General Jääskinen delivered on 13 June 2013 in the case C-170/12 Peter Pinckney v. KGD Mediatech AG, para. 70. See also Opinion of Advocate General Cruz Villalón delivered on 11 September 2014 in the case C-441/13 Pez Hejduk v. EnergieAgentur. NRW GmbH, para. 26-27. See also LopezTarruella 2012, p. 341.

${ }^{2203}$ See paragraph 6.1.4.1.
} 
have to be assessed. Substantial effects caused by alleged infringements of moral rights will generally be localised in the state where the copyright holder is domiciled. To localise and quantify effects caused by alleged infringements of economic rights related to copyrights may be more difficult without assessing the merits of the case more thoroughly. ${ }^{2204}$ As the outcome of the assessment of the abovementioned effects-based connecting factors can be uncertain, these factors will not guarantee ex ante predictability as regards which court may be competent.

\subsection{A close connection between dispute and court/ sound administration of justice}

Pursuant to the combined approach to full jurisdiction under Article 2:202 CLIP and Article 2:203(2)(b) CLIP, there will be a close territorial connection between the dispute and the court because alleged infringing activities have been directed to the forum state and the harm caused in that state is substantial in relation to the infringement in its entirety. ${ }^{2205}$ This combined approach to jurisdiction seems to entail a strong territorial link between the dispute and the forum that could justify the conferral of full jurisdiction as indicated in paragraph 5.3.4.1.

Consolidation of multistate litigation in a single court will generally facilitate the sound administration of justice. Due to the 'directed activities'-based escape clause in Article 2:202 CLIP and the 'substantial harm in relation to the infringement in its entirety' criterion in Article 2:203(2)(b) CLIP, the competent court will generally be in a good position to assess the entire ubiquitous infringement dispute. Yet, as mentioned in the previous paragraph, the effects-based connecting factors under Article 2:203(2)(b) CLIP will likely require the court to assess the facts more extensively than normal at the jurisdictional level. ${ }^{2206}$ It will be particularly difficult for the court seised to assess the effects caused in the forum rei as required by Article 2:203(2) CLIP without going deep into the facts of the case. As indicated in the previous paragraph, it may also be difficult to localise and quantify effects caused by alleged infringements of economic rights related to copyrights. As mentioned in paragraph 4.2.4.2, the facts of the case should not be thoroughly assessed at the jurisdictional level in view of the sound administration of justice. With respect to the Draft Hague Convention of 1999, the Special Commission of the Hague Conference on Private International Law explicitly rejected an effects-based approach to jurisdiction since it is difficult to quantify the effects from the outset. ${ }^{2207}$

\subsection{The principle of balancing the interests}

The combination of the 'directed activities'-based escape clause in Article 2:202 CLIP and the effects-based criteria in Article 2:203(2)(b) CLIP will likely strike a procedural balance between the copyright holder and the alleged infringer. The 'directed activities'-based escape clause will prevent jurisdiction if the defendant reasonably did not expect to get sued in the forum state. The 'full jurisdiction'-based approach under 2:203(2) CLIP will alleviate the

\footnotetext{
${ }^{2204}$ See also paragraphs 6.2.2.2 and 6.2.4.3.

${ }^{2205}$ Matulionyte 2015, p. 136. See also paragraph 6.1 regarding the 'directed activities' approach.

${ }^{2206}$ Nygh \& Pocar 2000, p. 62.

${ }^{2207}$ Nygh \& Pocar 2000, p. 62.
} 
procedural disadvantageous related to fragmentated litigation in case of an alleged copyright infringement directed to many states via ubiquitous media such as the Internet. ${ }^{2208}$ It will put a lesser heavy burden on the infringer to get sued in one state instead of all the states to which the copyrighted activities are directed to. ${ }^{209}$ Particularly if the infringer is located and operated in a copyright haven, the copyright holder will likely have the possibility to receive efficient redress. ${ }^{2210}$

From a broad perspective, the combined approach under Article 2:202 CLIP and Article 2:203(2)(b) CLIP seems to balance the broader interests between copyright holders, on the one hand, and users of information and traders, on the other hand. On the one hand, Article 2:203(2)(b) CLIP yields efficient copyright protection by facilitating jurisdiction before the court of the state where the alleged effects have been substantial. In view of online piracy and copyright havens, the effects-based approach to full jurisdiction can especially enhance copyright protection.

On the other hand, due to the escape clause in Article 2:202 CLIP, providers of information and traders will not run the risk to get unexpectedly sued in a particular state. ${ }^{2211}$ Furthermore, the 'full jurisdiction' approach will reduce the possibility that providers of online information and traders who operate via the Internet get sued in multiple states.

\subsection{The Geo-blocking Regulation and the combined approach to jurisdiction under Article 2:202 CLIP and Article 2:203(2)(b) CLIP}

This paragraph will examine the effect of the Geo-blocking Regulation on the combined approach to jurisdiction under Article 2:202 CLIP and Article 2:203(2)(b) CLIP in cross-border copyright infringement disputes. As demonstrated in paragraph 6.1.4.4, the prohibitions under the Geo-blocking Regulation will only be applicable in certain cross-border copyright infringement cases. These cases concern alleged copyright infringers who can be regarded as traders under this Regulation and provide goods and certain services to customers in the European Union. ${ }^{2212}$ Websites that merely provide information seem to be not affected by the Geo-blocking Regulation. ${ }^{2213}$ Furthermore, the Geo-blocking Regulation excludes certain services from its prohibitions such as audiovisual services and electronically supplied services that contain copyright protected content. ${ }^{2214}$

The Geo-blocking Regulation prohibits traders who provide goods or certain services in the European Union to employ unjustified geo-blocking technologies and other forms of discrimination based on customers' nationality, place of residence or establishment within the

\footnotetext{
${ }^{2208}$ See paragraph 6.1.4.2 and 5.1.5.3. See also Kur 2013(a), p. 88, 2:203.C09.

${ }^{2209}$ Fawcett \& Torremans 2011 p. 649.

${ }^{2210}$ Kur 2013(b), p. 88, 2:203.C09.

2211 See paragraph 6.1.4.3 on the assessment of the 'directed activities' approach in view of the principle of balancing the interests involved.

${ }^{2212}$ See paragraph 4.5.1 on the definition of trader in Article 2(18) Geo-blocking Regulation. See also recital 17 in the preamble to the Geo-blocking Regulation. See paragraph 4.5.2.3 on the services excluded by the Geoblocking Regulation.

${ }^{2213}$ See paragraph 4.5.1. See the definition of 'online interface' in Article 2(16) Geo-blocking Regulation.

${ }^{2214}$ See paragraph 4.5.2.3.
} 
European Union. ${ }^{2215}$ With respect to the combined approach to jurisdiction under Article 2:202 CLIP and Article 2:203(2) CLIP, the trader's tools to prevent jurisdiction based on the 'directed activities'-based escape clause in Article 2:202 CLIP will therefore be reduced. For instance, traders will frequently not be allowed anymore to block their websites for customers of particular Member States.

As argued in paragraph 6.1.4.4, the trader's mere compliance with the Geo-blocking Regulation will not constitute 'directed activities'. ${ }^{2216}$ When a trader does not block his website or provides similar conditions of access to customers of all Member States, this will thus not imply that the trader directed his activities to all of these Member States. ${ }^{2217}$ To determine whether the trader directed his activities to a particular state, it is relevant if "the trader has manifested an intention to establish commercial relations with consumers from that Member State". ${ }^{2218}$ Traders can still direct their activities to particular Member States by employing tools such as the delivery of goods to a particular Member State, the use a country code top-level domain name for its website ${ }^{2219}$ or the use a particular language ${ }^{2220}$. Nonetheless, as illustrated in paragraph 6.1.4.4, the court seised will need to examine the trader's activities more thoroughly to assess the 'directed activities'-based escape clause. ${ }^{2221}$

\subsubsection{Article 5 of the Draft Guidelines ILA 'Intellectual Property and Private International Law' of 2018}

Under the auspices of the International Law Association (ILA), the Committee on Intellectual Property and Private International Law (hereinafter the ILA Committee) has been created in November 2010. ${ }^{2222}$ Based on comparative research, ${ }^{2223}$ the ILA Committee has provided "a set of recommendations to promote a more efficient resolution of cross-border IP

\footnotetext{
2215 See Article 3 and 4 Geo-blocking Regulation. See also paragraph 4.5.

${ }^{2216}$ See recitals 13, 26 in the preamble of the Geo-blocking Regulation and Article 1(6) Geo-blocking Regulation.

${ }^{2217}$ See recitals 13, 26 in the preamble of the Geo-blocking Regulation and Article 1(6) Geo-blocking Regulation. See also paragraph 6.1.4.4.

2218 See recital 26 in the preamble of the Geo-blocking Regulation. This consideration appears to resemble the CJEU's concept of directed activities under Article 17(1)(c) Brussels Ibis in the ruling of Pammer and Alpenhof, para. 80. See also paragraph 4.5.3.

${ }^{2219}$ Recital 20 in the preamble to the Geo-blocking Regulation.

${ }^{2220}$ Recital 27 in the preamble to the Geo-blocking Regulation. See paragraph 6.1.4.4.

${ }^{2221}$ See also paragraph 4.5.3.

2222 See International Law Association Committee on Intellectual Property and Private International Law (hereinafter the ILA Committee) http://www.ila-hq.org/index.php/committees. From 2012 onwards, the ILA Committee has held several meetings. As a result of these meetings the editors Kono, De Miguel Asensio and Metzger enacted the following four reports: Report International Law Association Sofia Conference (2012) Intellectual Property and Private International; Report International Law Association Washington Conference (2014) Intellectual Property and Private International; Report International Law Association, Johannesburg Conference (2016) Intellectual Property and Private International; Report International Law Association Sydney Conference (2018) Intellectual Property and Private International Law. See also Van Eechoud (2016, pp. 716723 ) on the ILA Committee on Intellectual Property and Private International Law.

2223 Through a comparative analysis of legislative proposals related to private international law aspects of intellectual property, the ILA Committee has been aiming to find a balanced solution based on these proposals. See Report International Law Association, Sofia Conference (2012) Intellectual Property and Private International Law, p. 2.
} 
disputes and provide a model for national and international legislative initiatives" 2224 . "In particular, the work of the ILA Committee builds upon the earlier projects conducted by the Hague Conference on Private International Law as well as several academic initiatives that followed it." 2225

With respect to infringements of intellectual property rights, the ILA Committee drafted Article 5 of the Draft Guidelines 'Intellectual Property and Private International Law' of 25 May 2016 (hereinafter Draft Guidelines ILA of 2016) (226 $^{226}$ and the similar Article 5 Draft Guidelines ILA as of 22 May 2018 (hereinafter Draft Guidelines ILA of 2018)2227. Both provisions stipulate "a person may be sued a) in the courts of the States where the alleged infringer has acted to initiate or further the alleged infringement; the courts' jurisdiction shall be territorially unlimited with regard to any damages caused by those acts; or b) in the courts of the States where the infringement may have caused direct substantial damages unless it could not be anticipated that the infringement would cause those damages; the courts' jurisdiction shall be territorially limited to the State in which the court is situated."2228

With respect to the scope of injunctions, Article 13 Draft Guidelines ILA of 2016 stipulates that "the scope of an injunction is limited both by the extent of the jurisdiction of the court and by the territorial reach of the intellectual property right enforced". Pursuant to Article 33 Draft Guidelines ILA of 2018 "the effects of a foreign judgment, including its enforceability, in the requested State shall to the extent possible be the same, and under no circumstances greater, than in the State of origin". The ALI Committee appears to have adopted a territorially limited approach to jurisdiction due to the territorial principle related to intellectual property rights and the difficulty with respect to the enforcement of judgments. The jurisdiction of the court of the defendant's forum will nonetheless be territorially unlimited. ${ }^{2229}$

The ALI Committee also expressed the need of consolidation in certain cases. They drafted a provision that under certain conditions consolidates claims against several defendants. ${ }^{2230}$ Furthermore, the ALI Committee acknowledged that in complex multistate IP disputes, there

\footnotetext{
${ }^{2224}$ See Report International Law Association Washington Conference (2014) Intellectual Property and Private International Law, p. 2.

2225 See Report International Law Association Washington Conference (2014) Intellectual Property and Private International Law, p. 2. The 'several academic initiatives that followed it' refers to the principles of soft law mentioned in paragraph 1.1.2 namely the American Law Institute's (ALI) Principles on Intellectual Property; the Conflict of Laws in Intellectual Property (CLIP) Principles; the Joint Japanese-Korean Proposal; the Transparency Proposal; and the Principles on International Intellectual Property Litigation. See Report International Law Association, Sofia Conference (2012) Intellectual Property and Private International Law, p. 3.

${ }^{2226}$ See Report International Law Association Johannesburg Conference (2016) Intellectual Property and Private International Law, p. 3.

2227 See Report International Law Association Sydney Conference (2018) Intellectual Property and Private International Law, p. 10.

${ }^{2228}$ See Article 5 of the Draft Guidelines 'Intellectual Property and Private International Law' of 22 May 2018 (hereinafter Draft Guidelines ILA of 2018) in the Report International Law Association Sydney Conference (2018) Intellectual Property and Private International Law, p. 10. See also former Article 5 of the Draft Guidelines 'Intellectual Property and Private International Law' as of 25 May 2016 (hereinafter Draft Guidelines ILA of 2016) in the Report International Law Association Johannesburg Conference (2016) Intellectual Property and Private International Law, p. 3.

2229 See Article 3 Draft ILA Guidelines as of 25 May 2016 in the Report International Law Association Johannesburg Conference (2016) Intellectual Property and Private International Law.

2230 See Article 6 Draft ILA Guidelines as of 25 May 2016 in the Report International Law Association Johannesburg Conference (2016) Intellectual Property and Private International Law.
} 
may be situations where there is a need to consolidate objectively related claims. They pointed out that "at the heart of the discussion is the question about the minimum connection that has to be met in order to consolidate objectively related claims"2231. It is noteworthy that at the level of conflict-of-laws, Article 26 Draft Guidelines ILA of 2018 deviates from the lex loci protectionis rule by providing the competent court that has full jurisdiction the possibility to apply one single law to the entire dispute 'when the infringement in multiple states is pleaded in connection with the use of ubiquitous or multinational media". ${ }^{2232}$

\subsubsection{Approach to jurisdiction in infringement cases under Article 5 of the Draft Guidelines ILA 'Intellectual Property and Private International Law' of 2018}

\begin{tabular}{|c|c|c|}
\hline $\begin{array}{l}\text { Article } 5 \text { of the Draft } \\
\text { Guidelines 'Intellectual } \\
\text { Property and Private } \\
\text { International Law' as of } 22 \\
\text { May } 2018\end{array}$ & Connecting factors & $\begin{array}{l}\text { Scope of the court's } \\
\text { jurisdiction }\end{array}$ \\
\hline $\begin{array}{l}\text { Article 5(a) Draft Guidelines } \\
\text { ILA }\end{array}$ & $\begin{array}{l}\text { The state "where the alleged } \\
\text { infringer has acted to initiate or } \\
\text { further the alleged } \\
\text { infringement". }\end{array}$ & $\begin{array}{l}\text { "Territorially unlimited with } \\
\text { regard to any damages caused } \\
\text { by those acts." }\end{array}$ \\
\hline $\begin{array}{l}\text { Article 5(b) Draft Guidelines } \\
\text { ILA }\end{array}$ & $\begin{array}{l}\text { The state "where the } \\
\text { infringement may have caused } \\
\text { direct substantial damages, } \\
\text { referred to as the 'substantial } \\
\text { damages' criterion, } \\
\text { unless it could not be } \\
\text { anticipated that the } \\
\text { infringement would cause } \\
\text { those damages", referred to as } \\
\text { the 'unforeseeability of } \\
\text { substantial damages' escape } \\
\text { clause. }\end{array}$ & $\begin{array}{l}\text { Territorially limited to the } \\
\text { forum state, referred to as the } \\
\text { mosaic approach. }\end{array}$ \\
\hline
\end{tabular}

${ }^{2231}$ See Report International Law Association Washington Conference (2014) Intellectual Property and Private International, p. 4.

${ }^{2232}$ See Article 26 Draft Guidelines ILA of 22 May 2018 in the Report International Law Association Sydney Conference (2018) Intellectual Property and Private International Law, p. 15. See also Article 25 Draft Guidelines ILA of 25 May 2016 in the Report International Law Association Johannesburg Conference (2016) Intellectual Property and Private International Law, p. 7. 


\subsubsection{Assessing the effects-based approach in Article 5(b) Draft Guidelines ILA 'Intellectual Property and Private International Law' of 2018}

Article 5 Draft Guidelines ILA of 2018 can be regarded as a technology neutral approach as it does not particularly focus on ubiquitous infringements. In line with several scholarly views, Article 5(b) Draft Guidelines ILA of 2018 employs 'the place of infringement' as connecting factor to establish jurisdiction regarding another court that the forum rei. ${ }^{2233}$ Since the connecting factor in Article 5(a) Draft Guidelines ILA of 2018 relates to the Handlungsort, this factor will not be further assessed. Article 5(b) Draft Guidelines ILA of 2018 contains an effects-based approach to jurisdiction related to the Erfolgsort and will be further examined in the next paragraphs in light of the assessment framework of paragraph 4.6. The combined approach under Article 5(b) Draft Guidelines ILA of 2018 consists of the 'substantive damages' criterion and the 'unforeseeability of substantial damages' escape clause combined with the mosaic approach. These connecting factors resemble several approaches to jurisdiction that have been discussed in this chapter.

The 'unforeseeability of substantial damages' escape clause in Article 5(b) Draft Guidelines ILA of 2018 is reminiscent of the 'unpredictability of the effects' escape clause in Article 10(4) Draft Hague Convention of 1999. The 'substantial damages' criterion in Article 5(b) Draft Guidelines ILA of 2018 resembles the effects-based approach under Article 2:203(2)(b) CLIP of 2011. Unlike the effects-based approach in Article 2:203(2)(b) CLIP, Article 5(b) Draft Guidelines ILA of 2018 confers territorially limited jurisdiction to the court of the Erfolgsort. As mentioned in the previous paragraph, although the ILA Committee acknowledges the need to consolidate the entire dispute before one single court in complex multistate intellectual property disputes, "at the heart of the discussion is the question about the minimum connection that has to be met in order to consolidate objectively related claims". 2234

It is noteworthy that the draft of Article 2:202 CLIP also comprised the 'substantial effects' criterion as connecting factor to establish jurisdiction. ${ }^{2235}$ "However, the rule drew criticism because it appeared to be tailored to accidental 'overspills' which are characteristic of mediarelated infringements, whereas it did not provide an equitable result in cases in which the alleged infringement is caused by the dissemination of physical articles." ${ }^{2236}$ Based on the place of the infringement under the current Article 2:202 CLIP, jurisdiction may even be established if a single copyright infringing product has occurred in the forum state. ${ }^{2237}$

In common law-based states, the 'de minimis' principle has generally been used to establish jurisdiction in internet-related cases, "in particular regarding allegedly infringing use of trade marks". 2238 "In Europe, courts have been more reluctant to deny jurisdiction, even when the

\footnotetext{
${ }^{2233}$ See also paragraph 5.2.1. See also 6.1.3.2 on Article 2:202 CLIP of 2011.

${ }^{2234}$ See Report International Law Association Washington Conference (2014) Intellectual Property and Private International Law, p. 4.

${ }^{2235}$ Kur 2013(a), p. 83, 2:202.N14.

${ }^{2236}$ Kur 2013(a), p. 83, 2:202.N14.

${ }^{2237}$ See paragraph 6.1.4.2.

${ }^{2238}$ Kur 2013(c), p. 311, 3:602.N01. See also Kur 2013(a), p. 81, 2:202.N08. See chapter 7 on the so-called Zippo approach to jurisdiction established by several courts of the states of the United States of America.
} 
impact of the alleged infringement was very small, and rather prefer to address the issue as one of substantive law." 2239

\subsection{The principle of predictability}

The mere 'substantial damages' criterion in Article 5(b) Draft Guidelines ILA of 2018 will not guarantee predictability as regards which court may be competent. A potential infringer cannot always foresee in which state(s) the effects of the infringing activities will be substantial. Therefore, Article 5(b) Draft Guidelines ILA of 2018 stipulates that the court does not obtain jurisdiction if "it could not be anticipated that the infringement would cause those damages", referred to as the 'unforeseeability of substantial damages' escape clause. The latter clause will provide the alleged infringer the opportunity to prove that he could not have foreseen that substantial damages would occur in the forum state.

With respect to the 'unpredictability of the effects' escape clause in Article 10(4) Draft Hague Convention of 1999, it has been argued that the concept of "foreseeability" has been regarded as a rather vague term. ${ }^{2240}$ The 'unforeseeability of substantial damages' escape clause seems to provide the potential copyright infringer broad discretion to prove that he reasonably could not foresee that substantial harmful effects would occur in the forum state. Hence, it will likely leave the court a broad leeway to determine whether the effects were unforeseeable in the forum state. The outcome of the assessment of the 'unforeseeability of substantial damages' escape clause will therefore frequently be uncertain. In sum, the combination of the 'substantial damages' criterion and the 'unforeseeability of substantial damages' escape clause will likely yield less ex ante predictability as regards which court may be competent.

\subsection{A close connection between dispute and court/ sound administration of justice}

The combination of the 'substantial damages' criterion, the 'unforeseeability of substantial damages' escape clause, and the mosaic approach under Article 5(b) Draft Guidelines ALI of 2018 will guarantee a close connection between the dispute and the court. The court will generally be in a good position to assess the damage caused within the forum state. In line with the Draft Hague Convention of 1999, the ILA Committee pointed out the importance of "the requirement of substantial connection" between the dispute and the court. ${ }^{241}$ They used the phrase 'substantial damages' under Article 5(b) Draft Guidelines ALI of 2018 "to limit this ground of jurisdiction and to exclude its application on the basis of the mere accessibility of Internet content without any significant connection with the forum". ${ }^{2242}$ Von Hein advised the

\footnotetext{
${ }^{2239}$ For examples of cases, such as the Hotel Maritime ruling, see Kur 2013(a), p. 81, 2:202.N08; Kur 2013(b), p. 312, 3:602.N03 and 3:602.N04.

${ }^{2240}$ Lau 2000, p. 18. See paragraph 6.4.2.2.1 on the 'unpredictability of the effects' escape clause in Article 10(4) Draft Hague Convention of 1999.

2241 See Report International Law Association, Sofia Conference (2012) Intellectual Property and Private International Law, p. 4. See paragraph 6.4.2.2.2 on Article 18 Draft Hague Convention of 1999.

${ }^{2242}$ Intellectual Property and Private international Law Working Session 10 August 2016 report Johannesburg Conference 2016, p. 3. Available at https://www.ila-hq.org/index.php/committees.
} 
ALI Committee to clarify that the concept of 'substantial damages' concerns merely "immediate damages", "indirect consequential damages should be excluded". 2243

Compared to the mere 'directed activities' approach as set out in paragraph 6.1 , the 'substantial damages' criterion under Article 5(b) Draft Guidelines ALI of 2018 will likely reduce the amount of competent courts in multistate or ubiquitous copyright infringement cases. From a perspective of sound administration of justice, the combined approach under Article 5(b) Draft Guidelines ALI of 2018 will therefore decrease the risk of multistate litigation, forum shopping and irreconcilable decisions.

Due to the 'substantial damages' criterion, the court seised has to quantity the effects caused by the alleged infringement. With respect to the infringement of moral rights, the effects will be substantial in the forum actoris. ${ }^{2244}$ Substantial effects caused by the infringement of economic rights may be more difficult to identify and localise. ${ }^{2245}$ As argued regarding the effects-based approach under Article 2:203(2) CLIP, the localisation and quantification of effects may require a quite extensive assessment of the facts before ascertaining the case on its merits. ${ }^{2246}$ The 'unforeseeability of substantial damages' escape clause may also involve a quite extensive assessment of the merits of the case in the setting of determining jurisdiction. ${ }^{247}$ As mentioned in the previous paragraph, the court will likely have a broad leeway to determine whether the effects were unforeseeable in the forum state.

Compared to the assessment of the effects-based connecting factors under Article 2:203(2)(b) CLIP, the 'substantial damages' criterion in Article 5(b) Draft Guidelines ALI of 2018 seems to be less extensive since it does not require the court seised to assess whether the harm caused by the infringement in the forum state is substantial in relation to the infringement in its entirety. The court seised therefore does not have to examine the alleged damage in other states. Furthermore, unlike the 'substantial damages' criterion in Article 5(b) Draft Guidelines ALI of 2018, Article 2:203(2) CLIP requires the court to assess whether the activities that gave rise to the infringement did not have a substantial effect in the state(s) of the infringer's habitually residence. The foregoing indicates that the assessment of the 'substantial damages' criterion under Article 5(b) Draft Guidelines ALI of 2018 will be lesser extensive than the effects-based jurisdiction approach in Article 2:203(2)(b) CLIP. In view of the sound administration of justice, a lesser extensive assessment of the merits of the case will be favorable at the jurisdictional stage. ${ }^{2248}$

\subsection{The principle of balancing the interests}

The connecting factors in Article 5(b) Draft Guidelines ILA of 2018 will likely not strike a procedural balance between the interests of the litigants. On the one hand, the alleged infringer

\footnotetext{
${ }^{2243}$ Intellectual Property and Private international Law Working Session 10 August 2016 report Johannesburg Conference 2016, p. 5.

${ }^{2244}$ See paragraphs 6.2.2.2 and 6.2.4.3.

${ }^{2245}$ See paragraph 6.4.5.2.1. See also paragraphs 6.2.2.2 and 6.2.4.3.

${ }^{2246}$ See paragraph 6.4.5.2.2.

${ }^{2247}$ See also Drexl \& Kur 2005, p. 332.

${ }^{2248}$ See paragraph 4.2.4.2.
} 
may often not predict in which state(s) the effects will be substantial. Although the infringer can invoke the 'unforeseeability of substantial damages' escape clause, the court seems to have a broad leeway to assess this rather vague criterion. The outcome of this escape clause is therefore uncertain. On the other hand, the 'substantial damages' criterion will increase the chance that the copyright holder can sue the infringer in the forum actoris. Yet, due to the mosaic approach, the copyright holder may not receive efficient redress in case of a multistate or ubiquitous copyright infringement dispute. Particularly if the infringer is located and operated in a copyright haven, the latter may seem unreasonable.

From a broader perspective, the jurisdictional approach in Article 5(b) Draft Guidelines ILA of 2018 does not appear to balance the interests between copyright holders, on the one hand, and users of information and traders, on the other hand. As mentioned above, the mosaic principle may not guarantee efficient copyright protection at procedural level. Due to the ex ante unpredictability as regards where potential infringers can get sued, ${ }^{2249}$ the cross-border flow of information and trade may be negatively affected. Providers of online information may block their websites for certain users of certain Member States. Particularly small trading companies may hesitate to offer their products and services online to customers in the European Union. Due to the Geo-blocking Regulation, traders will frequently not be able to prevent to get sued in certain Member States by blocking their websites as will be demonstrated in the next paragraph.

\subsection{The Geo-blocking Regulation and Article 5(b) Draft Guidelines ILA of 2018}

This paragraph will examine the impact of the Geo-blocking Regulation on the approach to jurisdiction under Article 5(b) Draft Guidelines ILA of 2018. As demonstrated in paragraph 6.1.4.4, the Geo-blocking Regulation will only affect certain cross-border copyright infringement cases. The alleged copyright infringer has to be regarded as a trader under the Geo-blocking Regulation. ${ }^{2250}$ Furthermore, traders will only be governed by the prohibitions under the Geo-blocking Regulation when they provide goods and services to customers in the European Union that are not excluded by this Regulation. ${ }^{2251}$

Pursuant to Article 5(b) Draft Guidelines ILA of 2018, the defendant can prevent jurisdiction by invoking the 'unforeseeability of substantial damages' escape clause. ${ }^{2252}$ Due to the Geo-blocking Regulation, traders will often not be allowed to use unjustified geo-blocking and other forms of discrimination based on customers' nationality, place of residence or place of establishment within the internal market. ${ }^{2253}$ Whenever this Regulation is applicable, the trader can thus not use these tools anymore to prevent jurisdiction based on the 'unforeseeable of substantial damages' escape clause.

\footnotetext{
${ }^{2249}$ See paragraph 6.4.6.2.1.

${ }^{2250}$ See Article 2(18) Geo-blocking Regulation. Recital 17 in the preamble to the Geo-blocking Regulation. See also paragraph 4.5.1.

${ }^{2251}$ See paragraph 4.5.2.3 on the services excluded by the Geo-blocking Regulation. See also paragraph 6.1.4.4.

${ }^{2252}$ See paragraph 6.6.1.1.

${ }^{2253}$ See paragraph 4.5.2 on the prohibitions under the Geo-blocking Regulation.
} 
The 'unforeseeability of substantial damages' escape clause nonetheless seems to provide the potential copyright infringer broad discretion to prove that he reasonably could not foresee the harmful effects in the forum state. ${ }^{2254}$ Paragraph 6.1.4.4 demonstrated that traders will still have tools to indicate that they did not direct their activities to the forum state and could therefore not foresee that substantial damage would occur in that state. Moreover, this escape clause will leave the court a broad leeway to determine whether the occurrence of substantial effects had been unforeseeable in the forum state. ${ }^{2255}$ 


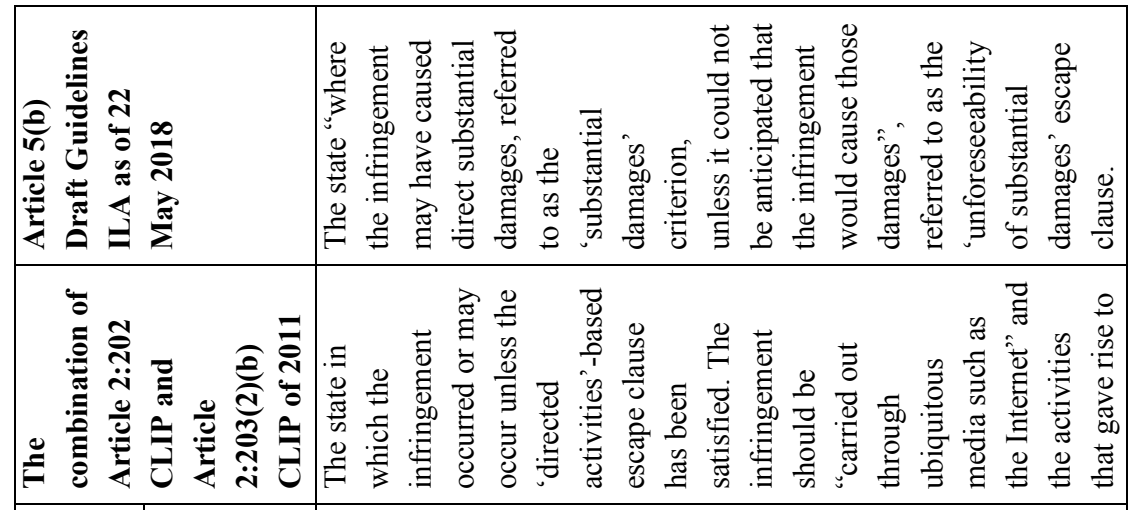

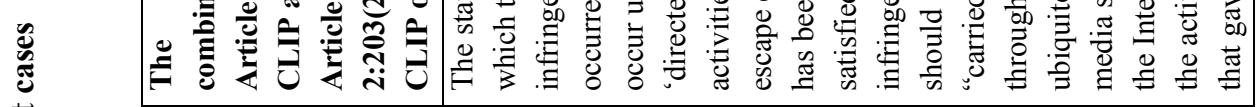

:

\begin{tabular}{|c|c|c|c|c|c|}
\hline 0 & 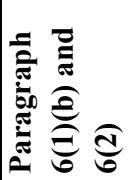 & 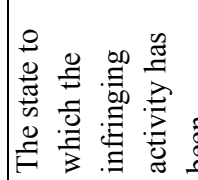 & 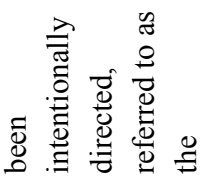 & 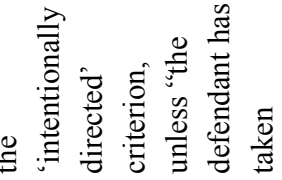 & 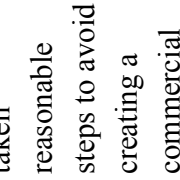 \\
\hline
\end{tabular}

:

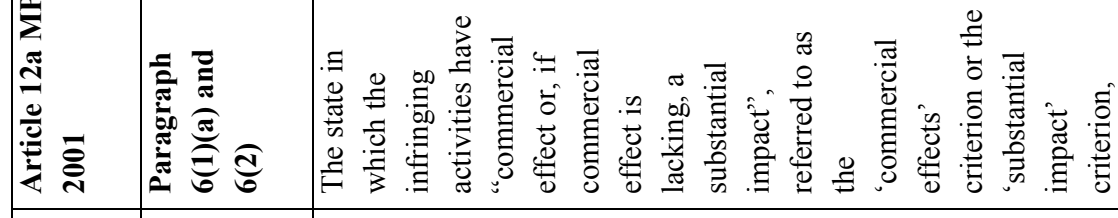

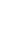

年

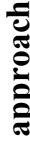

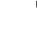

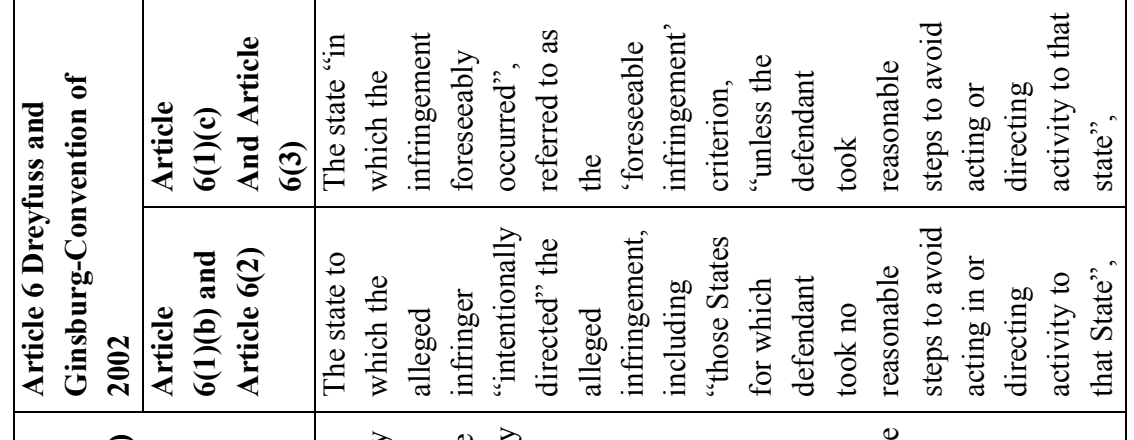

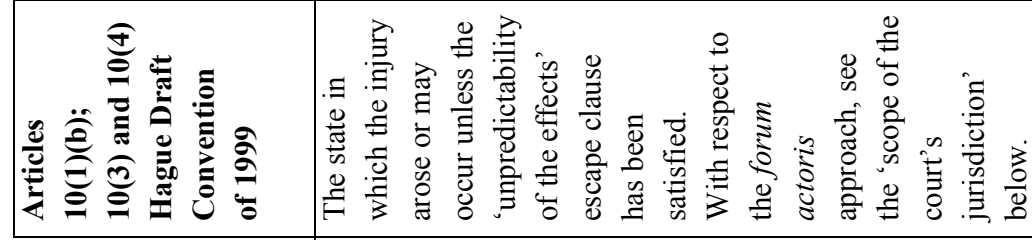




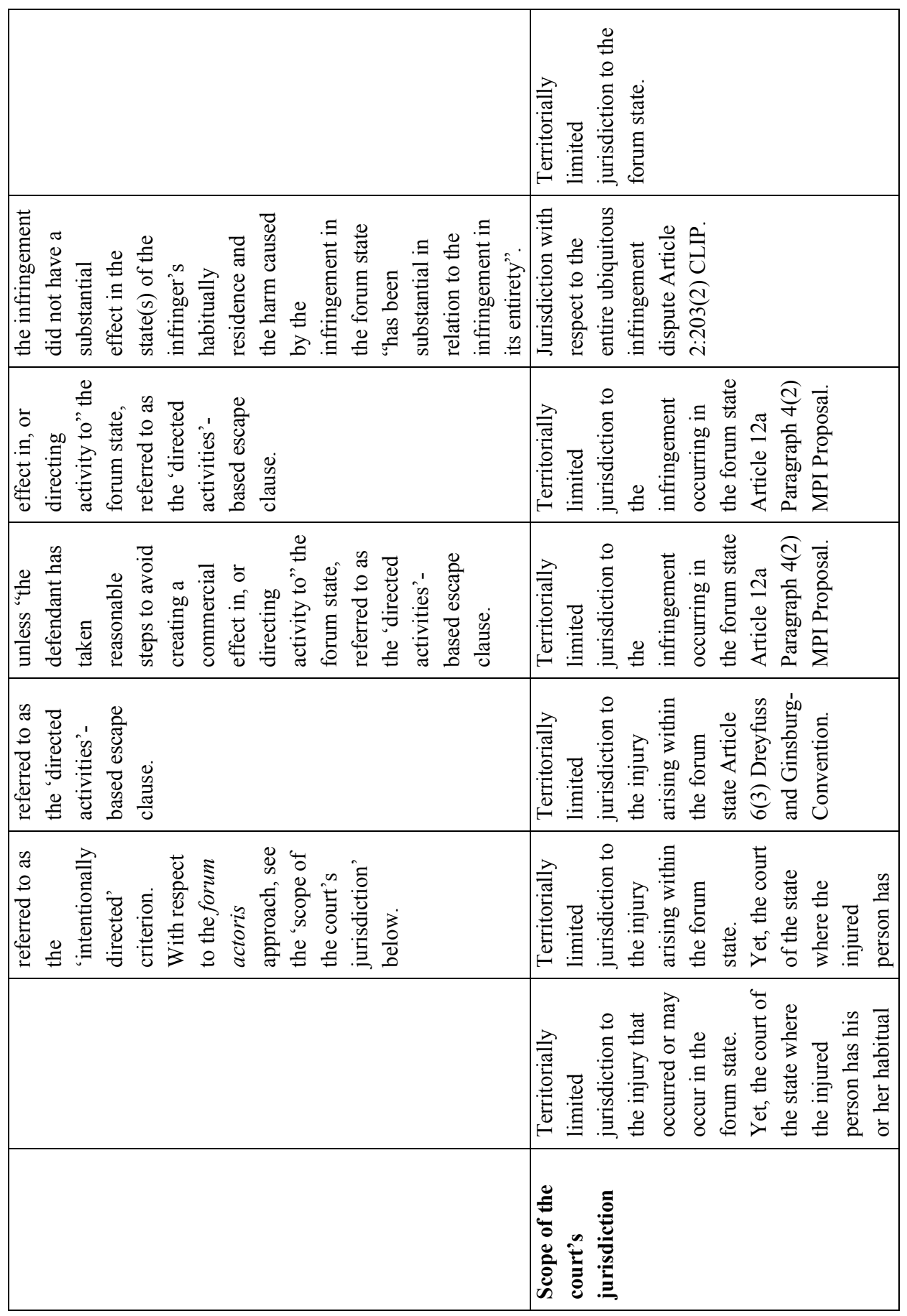




\begin{tabular}{|c|c|c|}
\hline & $\sum^{\infty}$ & 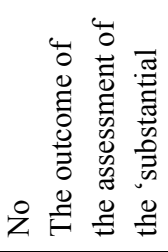 \\
\hline & $\ddot{z}$ & 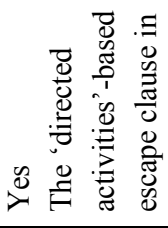 \\
\hline & $\stackrel{\infty}{\infty}$ & 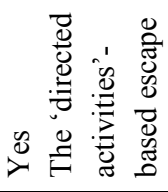 \\
\hline & $\sum^{\infty}$ & 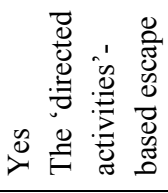 \\
\hline & $\stackrel{\circ}{z}$ & 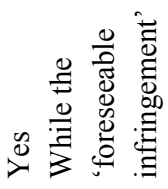 \\
\hline 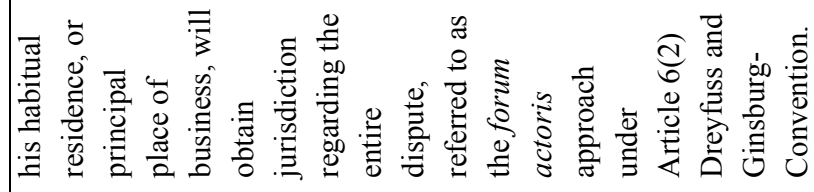 & そ̊ & 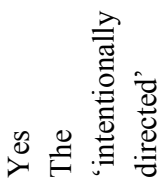 \\
\hline 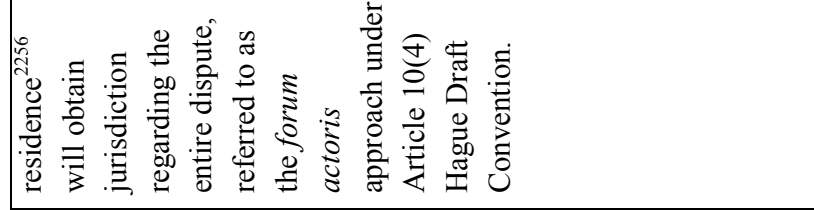 & $\overbrace{}^{\infty}$ & 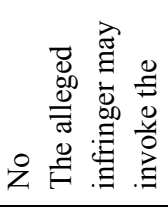 \\
\hline & 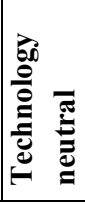 & 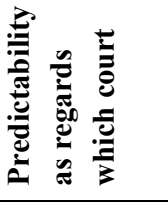 \\
\hline
\end{tabular}




\begin{tabular}{|c|c|}
\hline 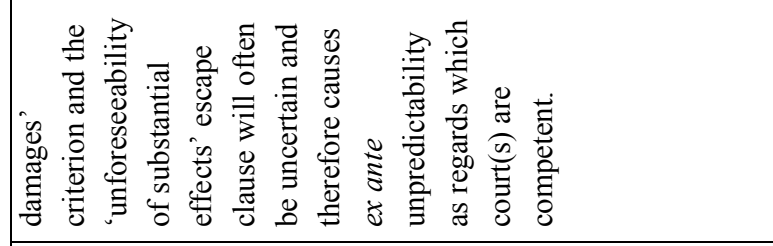 & 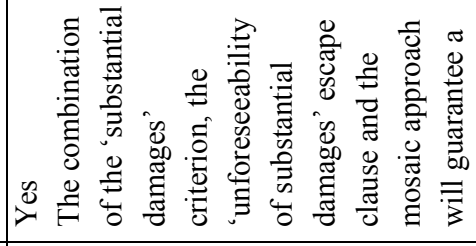 \\
\hline 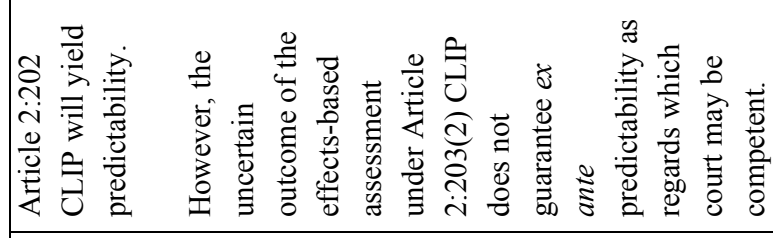 & 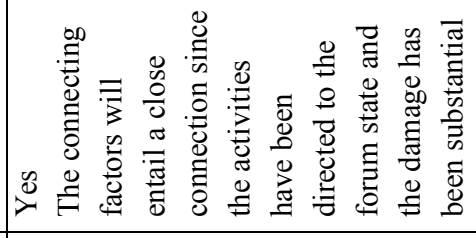 \\
\hline 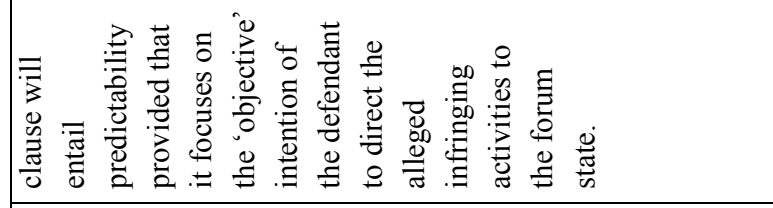 & 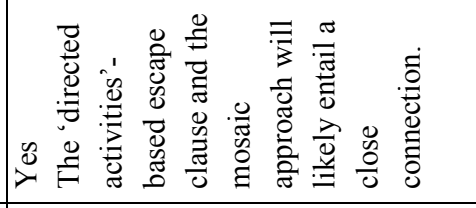 \\
\hline 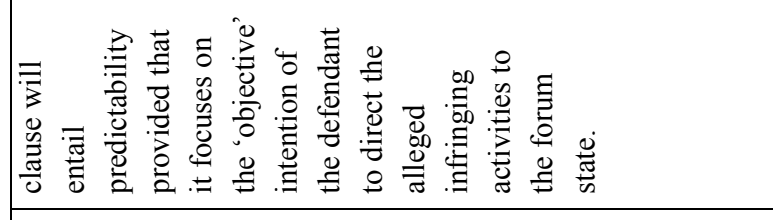 & 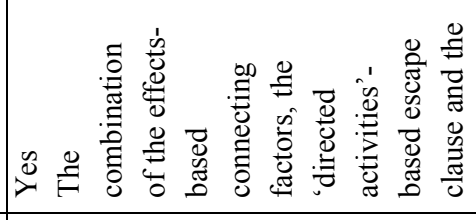 \\
\hline 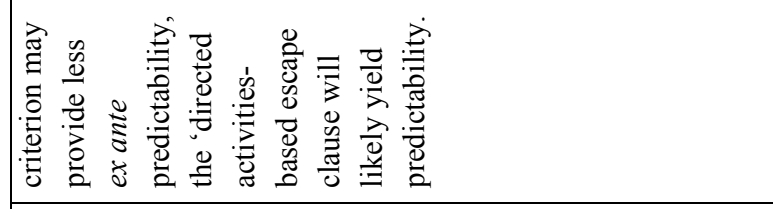 & 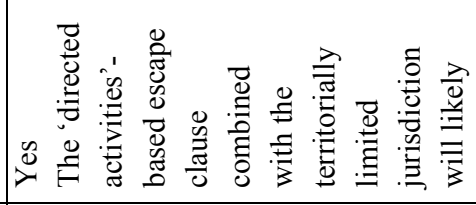 \\
\hline 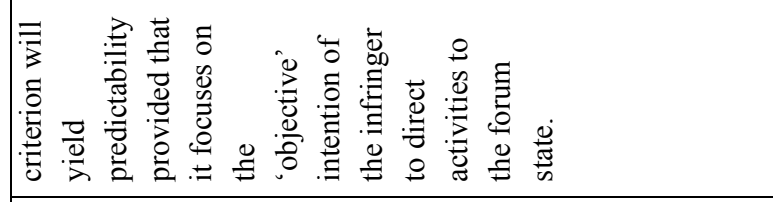 & 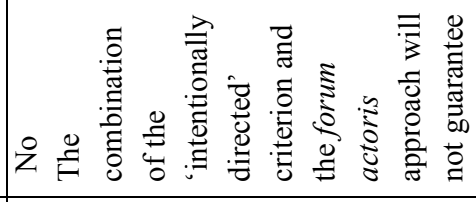 \\
\hline 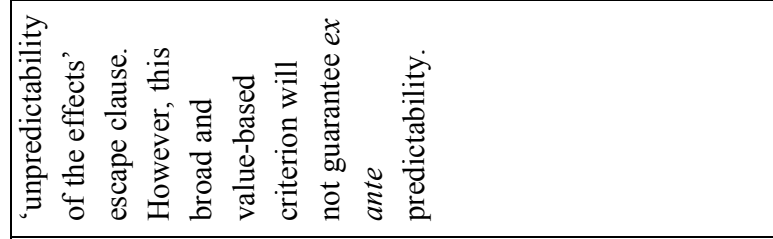 & 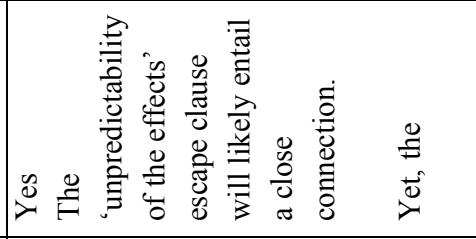 \\
\hline 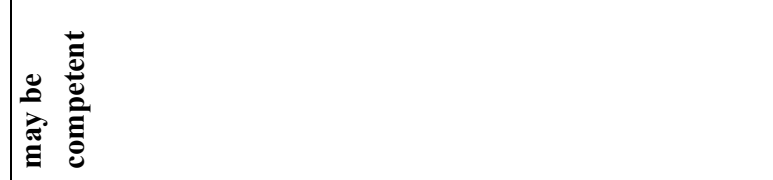 & 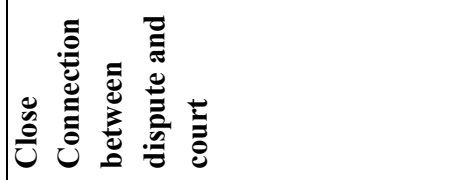 \\
\hline
\end{tabular}




\begin{tabular}{|c|c|}
\hline 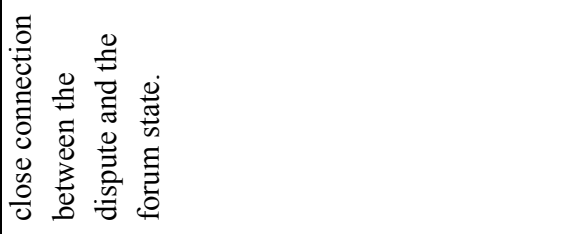 & 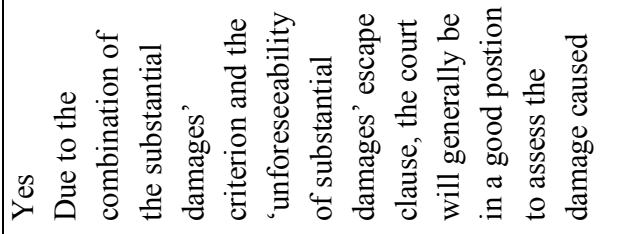 \\
\hline 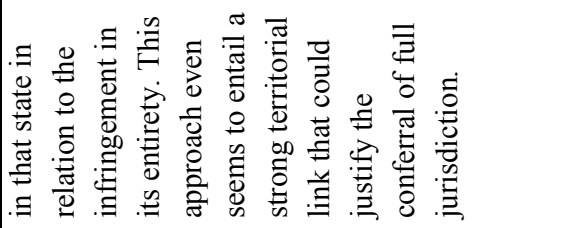 & 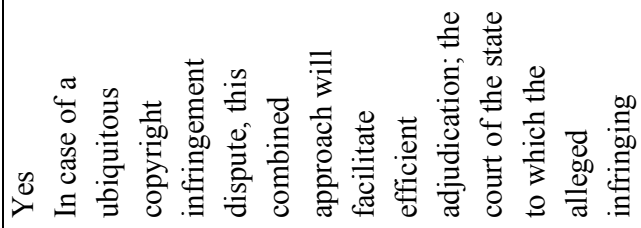 \\
\hline & 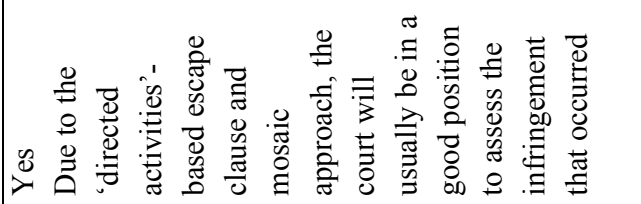 \\
\hline 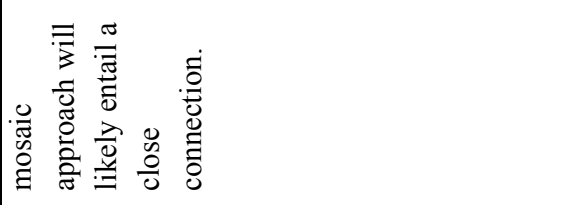 & 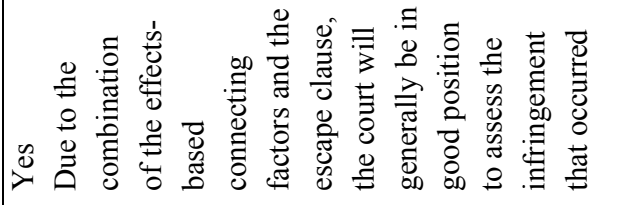 \\
\hline 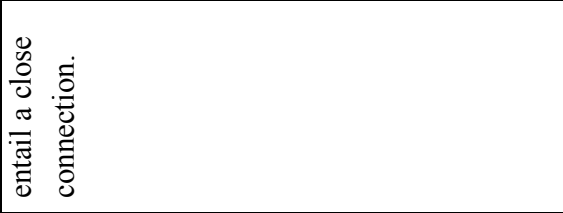 & 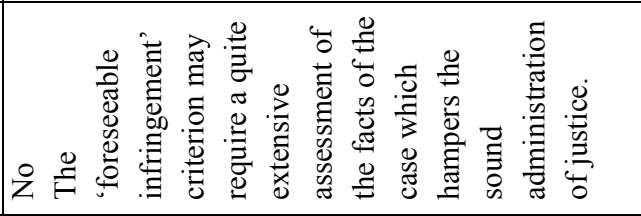 \\
\hline 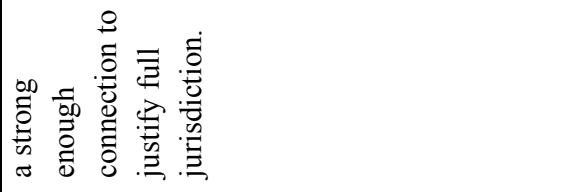 & 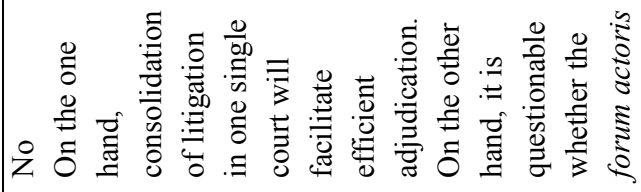 \\
\hline 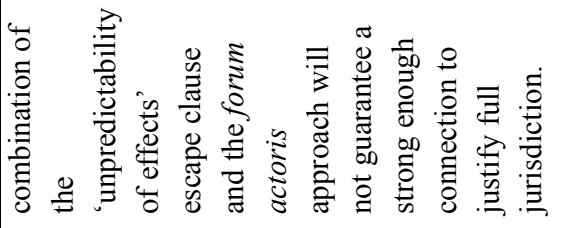 & 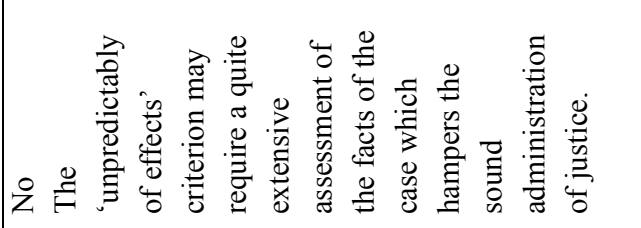 \\
\hline & (2) \\
\hline
\end{tabular}




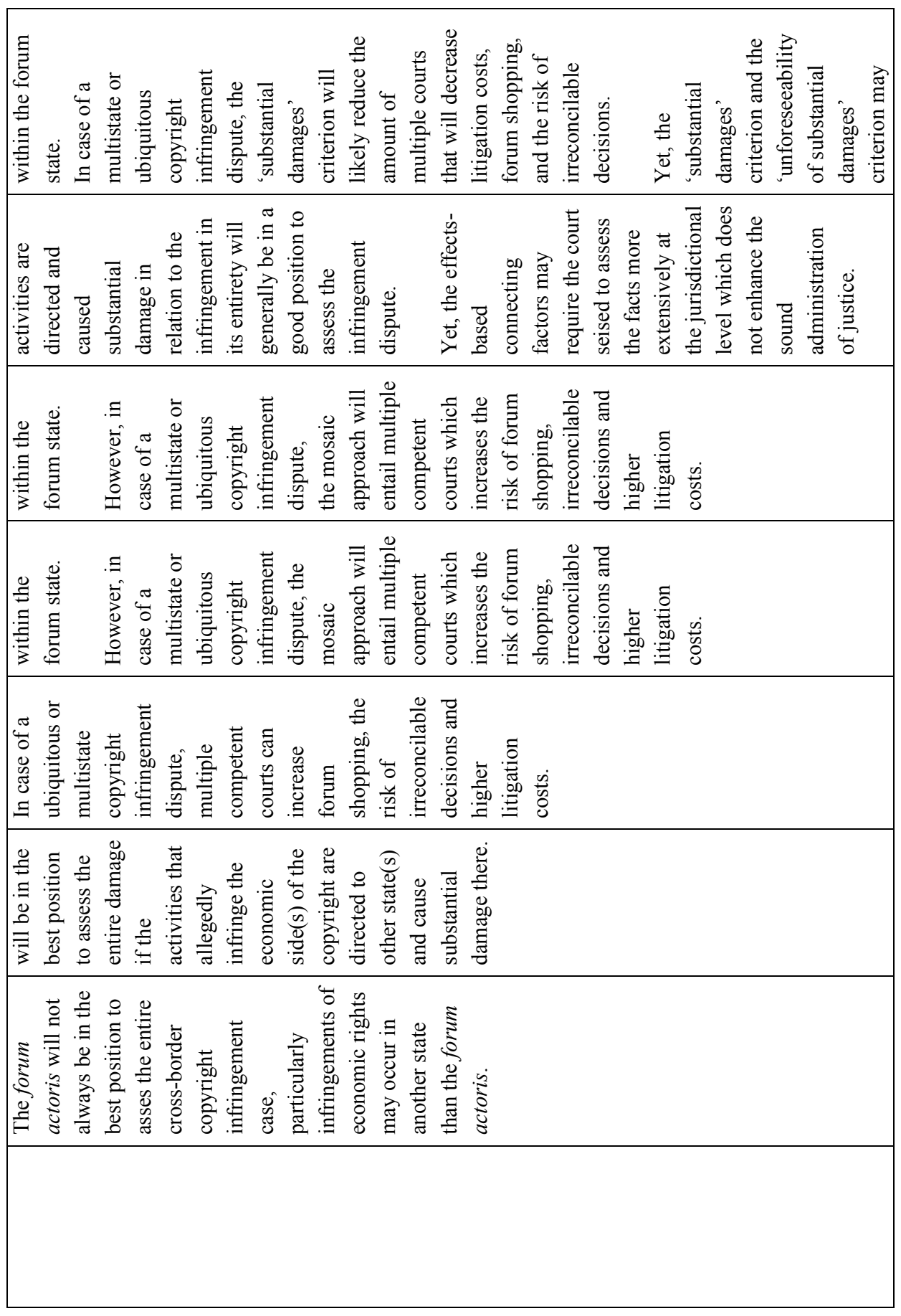




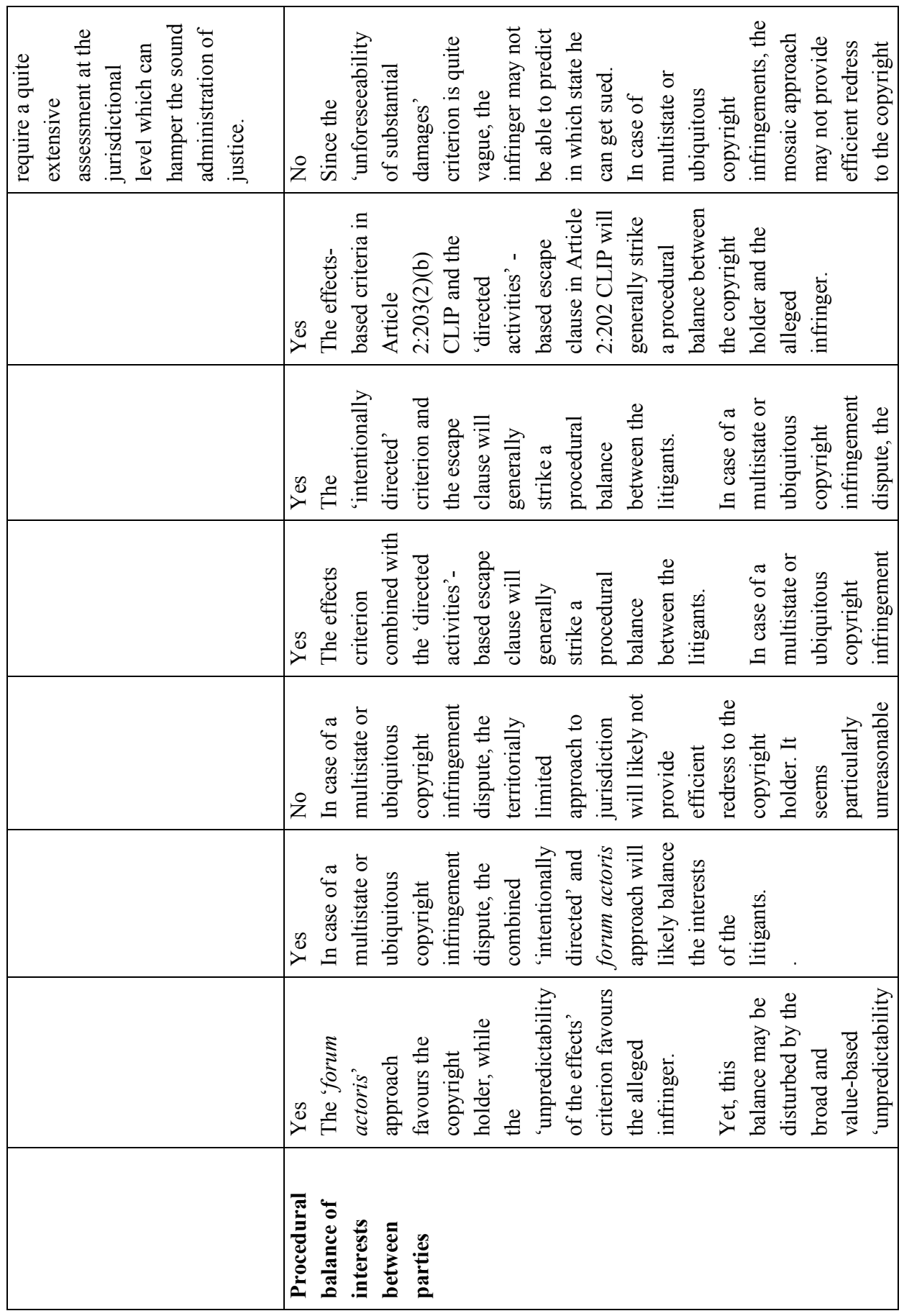




\begin{tabular}{|c|c|}
\hline 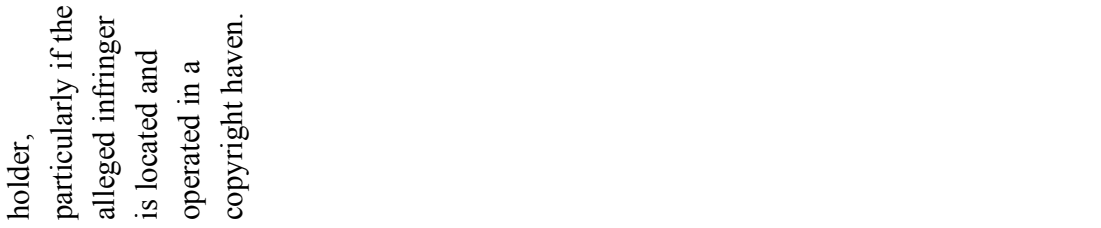 & 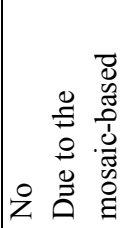 \\
\hline & 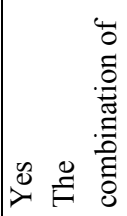 \\
\hline 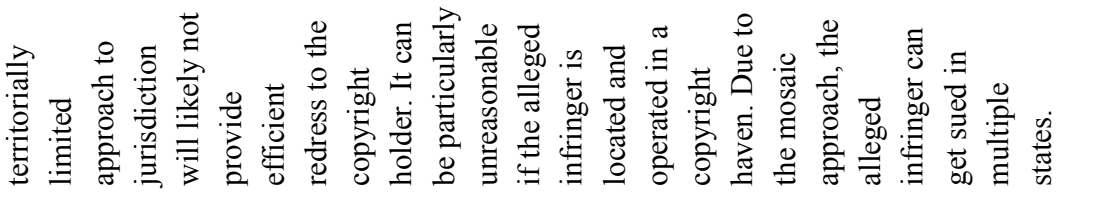 & 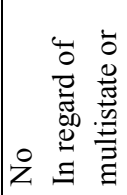 \\
\hline 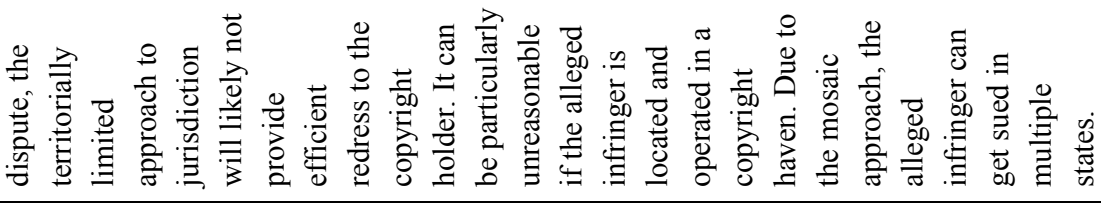 & 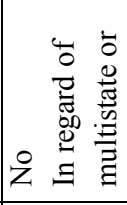 \\
\hline 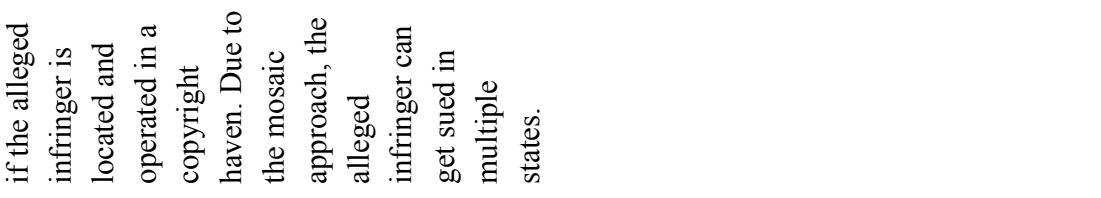 & 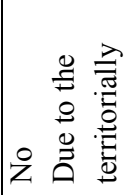 \\
\hline & 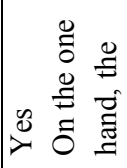 \\
\hline 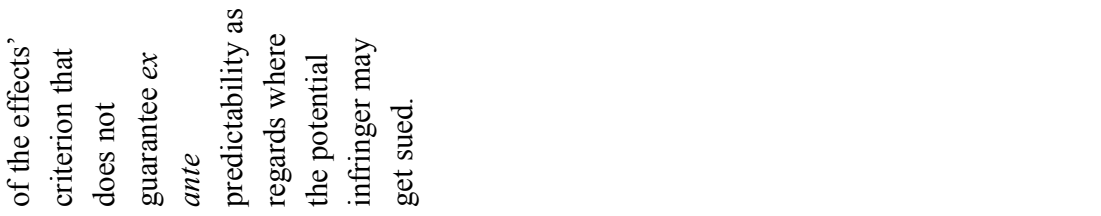 & 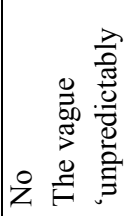 \\
\hline & 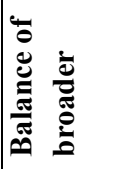 \\
\hline
\end{tabular}




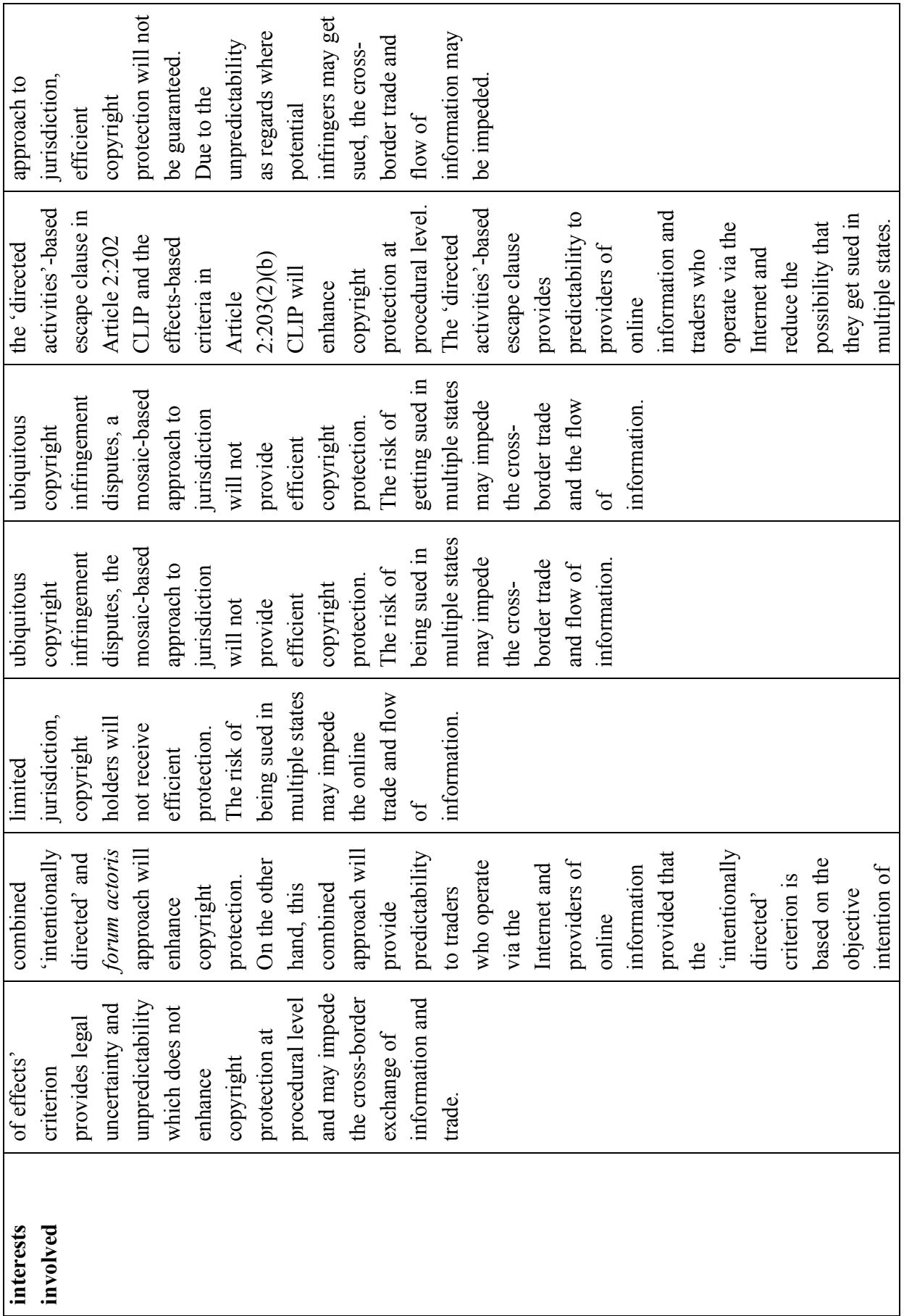




\begin{tabular}{|c|c|}
\hline & 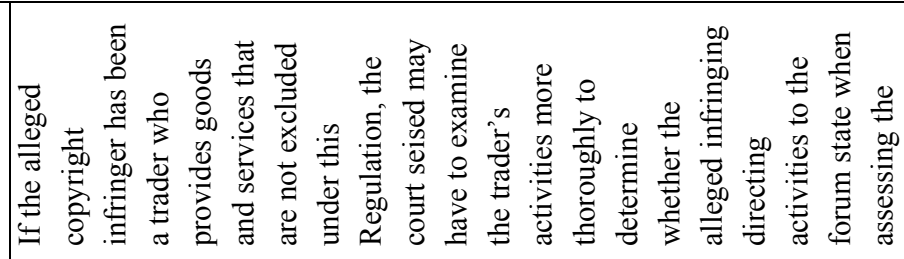 \\
\hline & 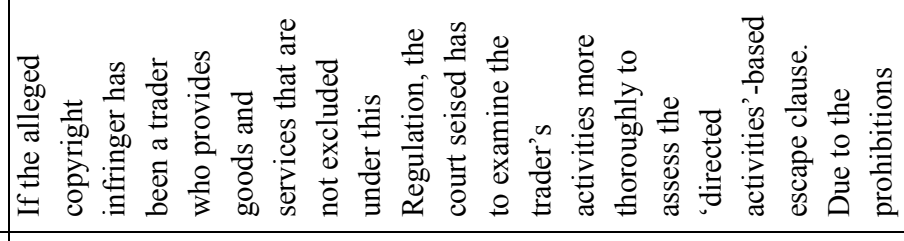 \\
\hline & 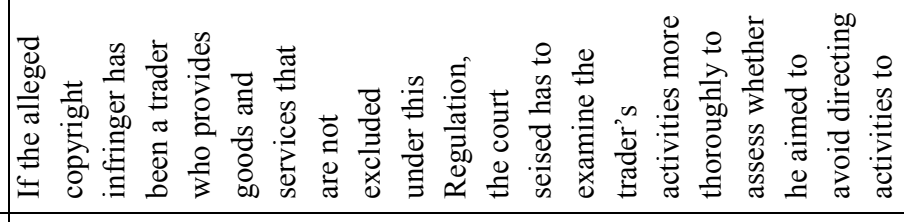 \\
\hline & 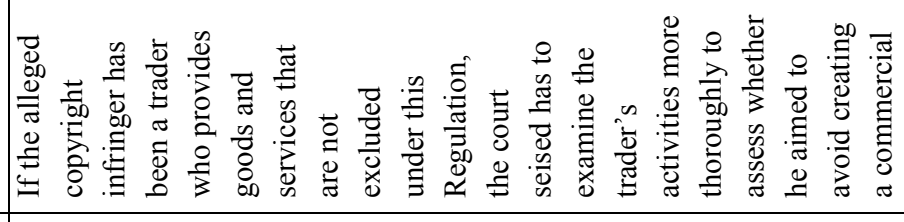 \\
\hline & 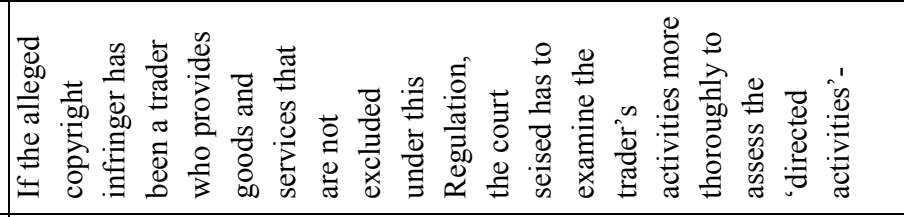 \\
\hline 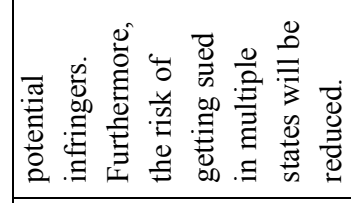 & 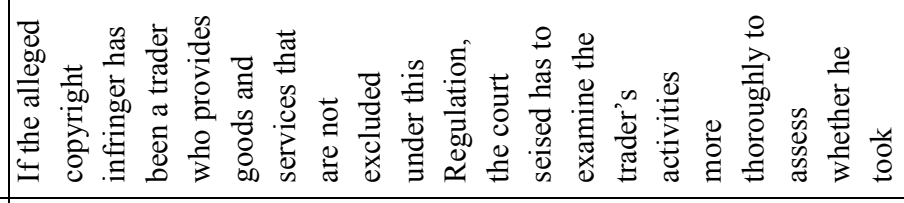 \\
\hline & 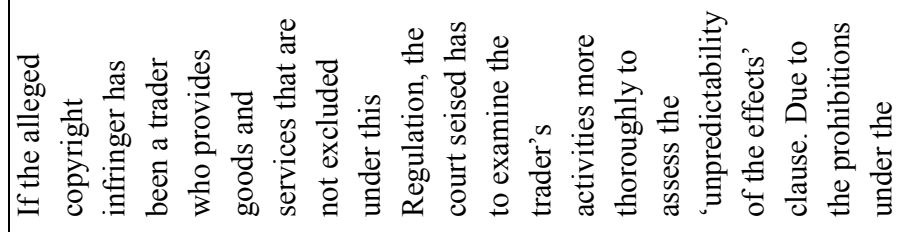 \\
\hline & 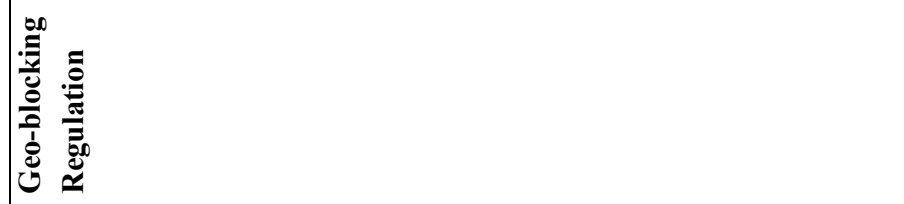 \\
\hline
\end{tabular}




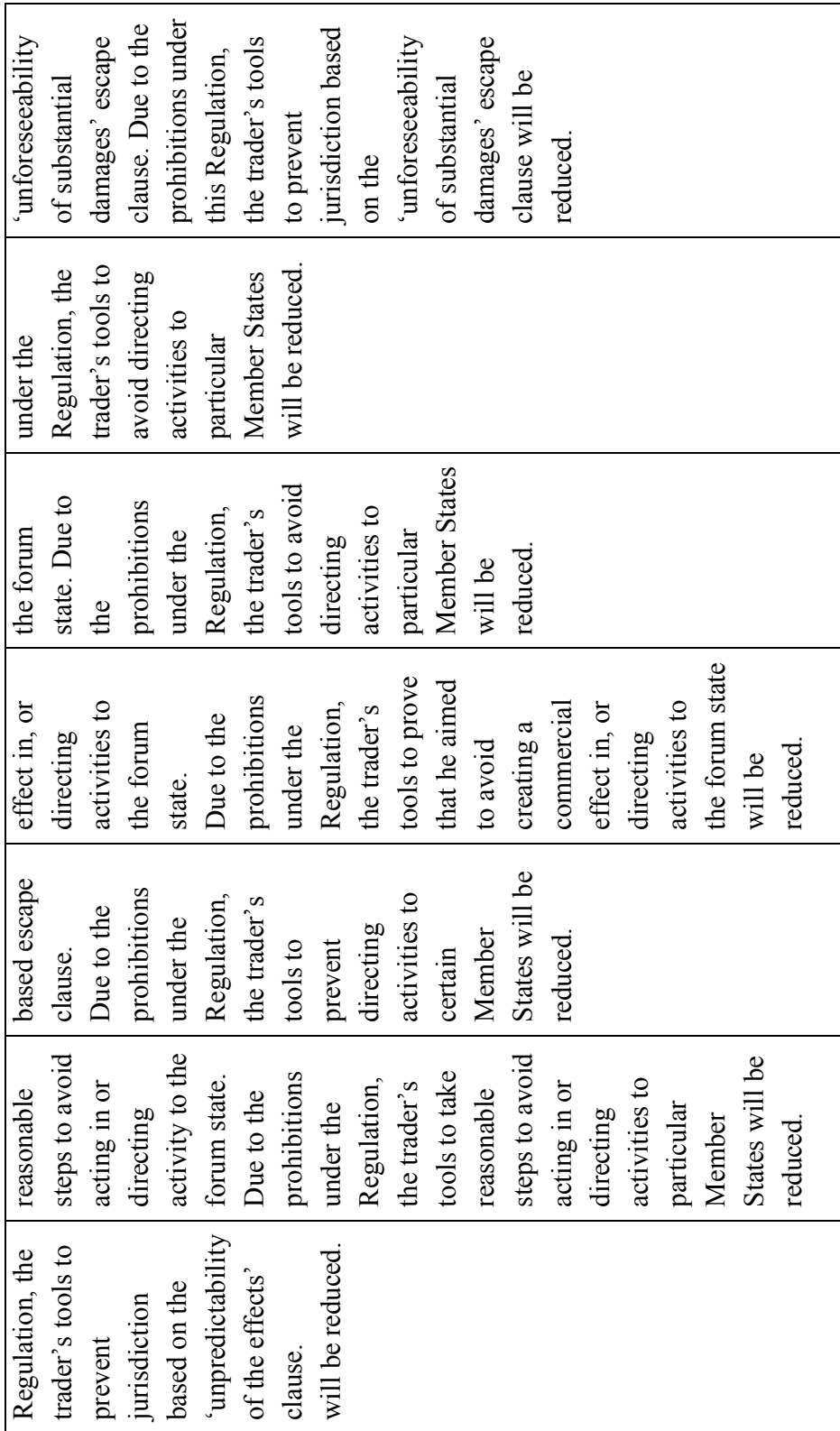




\subsection{Concluding remarks}

Considering the assessment of the various approaches to jurisdiction in cross-border copyright infringement cases, ${ }^{2257}$ the 'directed activities' approach seems to satisfy most of the conditions of the assessment framework of paragraph 4.6. Due to criteria that focus on the 'objective' intention of the alleged copyright infringer, the 'directed activities' approach will yield more ex ante predictability than the broad and value-based escape clauses that are based on the unforeseeability of the effects in the forum state 2258 . The 'directed activities' approach will generally entail a close connection between the court and the alleged infringing activities directed to the forum state. Hence, the court will usually be in a good position to assess the damage within the forum state. The directed activities' approach will likely yield a procedural balance between litigants and the broader interests related to copyrights. In light of previous case law of the CJEU, namely the Pammer and Alpenhof ruling and the AMS Neve ruling, the 'directed activities' approach can also be advocated under Article 7(2) Brussels Ibis in crossborder copyright infringement cases $^{2259}$.

Yet, in view of multistate or ubiquitous copyright infringement cases, the directed activities' approach may entail multiple competent courts. From a perspective of sound administration of justice, this approach increases the risk of irreconcilable decisions, forum shopping and high litigation costs. The procedural balance between litigants will likely become unsteady. It will put a heavy burden on the alleged infringer to be sued in multiple states. It will often also be burdensome for the copyright holder to receive full redress. Particularly in case of infringers who are located and operated in copyright havens, it can be unreasonable that the copyright holder cannot receive efficient redress. ${ }^{2260}$ From a broader perspective, the 'directed activities' approach may therefore not provide efficient copyright protection and can impede the cross-border flow of information and trade. The prohibitions under the Geo-blocking Regulation will generally limit the trader's tools to prevent directing activities to certain Member States and therefore increase the risk that the trader get sued in these Member States.

For reasons of efficient and fair adjudication, this chapter demonstrated that various scholarly proposals confer 'full' jurisdiction to particular courts related to the Erfolgsort in cross-border copyright infringement cases. ${ }^{2261}$ Most of these 'full jurisdiction'-based proposals employ a 'directed activities-based' criterion either as additional connecting factor or escape

\footnotetext{
${ }^{2257}$ See the assessment tables in paragraph 6.3 (Table 1) and paragraph 6.5 (Table 2).

${ }^{2258}$ See the 'unpredictability of the effects' escape clause in Article 10(1)(b) Draft Hague Convention of 1999 (see paragraph 6.4.2.2.1); the 'unforeseeability of substantial damages' clause in Article 5(b) Draft Guidelines ILA (see paragraph 6.6.1.1). See also the 'foreseeable infringement' criterion in Article 6(1)(c) Dreyfuss and Ginsburg Convention (see paragraph 6.4.3.2.1).

${ }^{2259}$ See paragraphs 3.6.1, 6.1, 6.1.2 and 6.1.2.1.

${ }^{2260}$ See paragraphs 5.3.1 and 6.1.4.3.

${ }^{2261}$ See the 'copyright holder's centre of interests' approach related to infringements of moral rights (paragraph 6.2.2.2); the 'case-specific copyright holder's centre of interests' approach suggested by Kono and Jurcys (paragraph 6.2.3). See also the following combined approaches to jurisdiction as discussed in this chapter: Article 10(1)(b) and (4) Draft Hague Convention of 1999 (paragraph 6.4.2); Article 6(1)(b) and Article 6(2) Dreyfuss and Ginsburg Convention of 2002 (paragraph 6.4.3); Article 2:202 CLIP and Article 2:203(2) CLIP (paragraph 6.4.5). See paragraph 5.3.3.1 on the concept of so-called full jurisdiction in this dissertation.
} 
clause. $^{2262}$ To establish 'full' jurisdiction in a copyright infringement dispute, the CLIP Principles of 2011 combine the 'directed activities'-based escape clause in Article 2:202 CLIP with effects-based connecting factors in Article 2:203(2)(b) CLIP. The assessment of the effects-based connecting factors under Article 2:203(2)(b) CLIP may, however, require an assessment of the merits of the case that is too extensive at the jurisdictional level and will therefore not entail predictability or facilitate sound administration of justice. ${ }^{2263}$ For the court seised it can be particularly difficult to assess whether the effects are substantial in the forum $r e i{ }^{2264}$ The assessment of whether the harm caused by the infringement in the forum state "has been substantial in relation to the infringement in its entirety" 2265 may also require an extensive assessment of the merits of the case. The damage caused by alleged infringements of moral rights will generally be substantial in the forum actoris. Yet, the damage caused by alleged infringements of economic rights may be difficult to localise and quantify without assessing the facts of the case in more detail. The 'substantial damages' criterion as stipulated in Article 5(b) Draft Guidelines ALI of 2018 seems to require a 'lighter' assessment of the facts of the case. $^{2266}$ Pursuant to Article 5(b) Draft Guidelines ALI of 2018, the 'substantial damages' criterion will nevertheless only confer territorially limited jurisdiction. It is questionable whether the combination of the 'directed activities' criterion and the 'substantial damages' criterion could entail a strong territorial link to justify the conferral of full jurisdiction.

This chapter demonstrated that besides effect-based approaches to 'full' jurisdiction, scholars have advocated to adopt the 'victim's centre of interest', or forum actoris, approach in cross-border copyright infringement cases. ${ }^{2267}$ Several so-called combined approaches in this chapter demonstrated that the lack of predictability and a close connection between dispute and court related to the forum actoris approach can be alleviated by adding a 'directed activities'based criterion. ${ }^{2268}$ The question arises whether the combination of the 'directed activities' criterion and the 'victim's centre of interests' criterion carries sufficient weight to justify full jurisdiction. ${ }^{2269}$ The copyright holder's 'centre of interest' will generally be the place where the infringement of moral rights will cause most damage. ${ }^{270}$ Yet, in case of the infringement of economic rights, most damage may occur in another state than the copyright holder's centre of

\footnotetext{
${ }^{2262}$ See Article 6(1)(b) and Article 6(2) Dreyfuss and Ginsburg Convention of 2002 (paragraph 6.4.3); Article 2:202 CLIP and Article 2:203(2) CLIP (paragraph 6.4.5). The 'case-specific copyright holder's centre of interests' approach suggested by Kono and Jurcys employs the 'market effects' test that resembles the 'directed activities' approach (paragraph 6.2.3).

${ }^{2263}$ See paragraphs 6.4.5.2.1 and 6.4.5.2.2.

2264 Article 2:203(2) CLIP.

2265 Article 2:203(2)(b) CLIP.

${ }^{2266}$ See paragraph 6.4.6.2.2.

${ }^{2267}$ See the 'copyright holder's centre of interests' approach (paragraph 6.2.2.2); the 'case-specific copyright holder's centre of interests' approach suggested by Kono and Jurcys (paragraph 6.2.3); 'forum actoris' approach in Article 6(2) Dreyfuss and Ginsburg-Convention of 2002 (paragraph 6.4.3). With respect to tort cases in general, see the forum actoris approach in Article 10(4) Draft Hague Convention (paragraph 6.4.2).

${ }^{2268}$ See paragraphs 6.4.3.2.1 and 6.4.3.2.2 on the combination of the 'intentionally directed' criterion and the forum actoris approach under Article 6(1)(b) and Article 6(2) Dreyfuss and Ginsburg Convention. See paragraphs 6.4.2.2.1 and 6.4.2.2.2 on the combination of the 'unpredictability of the effects' escape clause and forum actoris approach under Article 10(1)(b) and Article 10(4) Draft Hague Convention. See also paragraph 6.4.1 on the assessment of the 'centre of gravity of the dispute' approach.

${ }^{2269}$ See paragraphs 5.3.4.1 and 6.2.4.3.

${ }^{2270}$ See paragraph 6.2.4.3.
} 
interests. ${ }^{2271}$ The following chapter will examine the arguments provided by the New York Court of Appeals in the case of Penguin Group (USA) Inc. v. American Buddha to confer jurisdiction to the court of the copyright holder's residence or principal place of business regarding the entire infringement dispute. ${ }^{2272}$

As indicated in paragraph 6.4.1, two relevant issues have to be considered when adopting an approach to jurisdiction under Article 7(2) Brussels Ibis. ${ }^{2273}$ The first issue concerns whether the territorially limited approach to jurisdiction should be abolished in cross-border copyright infringement cases. The mosaic approach suits the territorial principle related to copyrights. Due to globalisation and the internet, the influence of this principle on the field of private international law has nevertheless been criticised. ${ }^{2274}$ From a perspective of private international law, multiple competent courts will not entail predictability, sound administration of justice or a balance between the interests of the litigants. ${ }^{2275}$ This chapter demonstrated several approaches to jurisdiction that confer 'full' jurisdiction in multistate or ubiquitous infringements for reasons of efficient and fair litigation. ${ }^{2276}$

The second issue that has to be considered is whether the approach to jurisdiction under Article 7(2) Brussels Ibis in cross-border copyright infringement cases should be technology neutral. ${ }^{2277}$ Several scholars favour a technology neutral approach to provide predictability in view of changing technologies. ${ }^{2278}$ This chapter demonstrated that various scholarly proposals nonetheless confer 'full' jurisdiction in case of an alleged copyright infringement carried out by ubiquitous media. ${ }^{2279}$ The next chapter will demonstrate that courts of states of the United States of America have adopted both technology neutral and technology-based approaches to jurisdiction in copyright infringement disputes.

\footnotetext{
${ }^{2271}$ See paragraph 6.2.4.3.

${ }^{2272}$ Penguin Group (USA) Inc. v. American Buddha, 16 N.Y. 3d 295 (2011).

${ }^{2273}$ As mentioned earlier, this dissertation does not focus on the Handlungsort as connecting factor under Article 7(2) Brussels Ibis in cross-border copyright infringement cases.

2274 Paragraph 5.3.2.

2275 See paragraph 5.3.1. See also Opinion of Advocate General Bobek delivered on 13 July 2017 in the case C194/16 Bolagsupplysningen Oü and Ingrid Ilsjan v. Svensk Handel AB, para. 90. See paragraph 6.2.1.1.3 on the Opinion of Advocate General Cruz Villalón delivered on 29 March 2011 in the joined cases C-509/09 and C161/10 eDate Advertising GmbH v. X and Martinez v. MGN Limited, para. 51, 56.

2276 See the 'copyright holder's centre of interests' approach (paragraph 6.2.2.2); the 'case-specific copyright holder's centre of interests' approach suggested by Kono and Jurcys (paragraph 6.2.3); Article 10(1)(b) and (4) Draft Hague Convention of 1999 (paragraph 6.4.2); Article 6(1)(b) and Article 6(2) Dreyfuss and Ginsburg Convention of 2002 (paragraph 6.4.3); Article 2:202 CLIP and Article 2:203(2) CLIP of 2011 (paragraph 6.4.5). See paragraph 5.3.3.1 on the concept of so-called full jurisdiction in this dissertation.

2277 See paragraph 6.4.1.

${ }^{2278}$ See the Opinion of Advocate General Cruz Villalón delivered on 29 March 2011 in the joined cases C-509/09 and C-161/10 eDate Advertising GmbH v. X and Martinez v. MGN Limited, para. 53. See also Kuipers 2012(a), pp. 393,395 .

2279 See the 'case-specific copyright holder's centre of interests' approach suggested by Kono and Jurcys (paragraph 6.2.3); Article 6(1)(b) and Article 6(2) Dreyfuss and Ginsburg-Convention of 2002 (paragraph 6.4.3); Article 2:202 CLIP and Article 2:203(2) CLIP of 2011 (paragraph 6.4.5); Article 12a MPI Paragraph 5 (paragraph 6.4.4). As mentioned in paragraph 6.4.4.2, Article 12a MPI Paragraph 5 of 2001 confers full jurisdiction to the court of Handlungsort instead of the Erfolgsort which is the focus of this dissertation.
} 



\section{Chapter 7}

Various approaches to jurisdiction in cross-border copyright infringement disputes established by courts of states of the United States of America 



\subsection{Applying the method of comparative law under Article 7(2) Brussels Ibis}

As mentioned in paragraph 4.2.5, the method of comparative law can be considered as a part of "the European Law interpretative framework". ${ }^{2280}$ To maintain "the autonomy of the European legal order," the CJEU usually does not explicitly discuss a preliminary question from a comparative view. ${ }^{2281}$ Yet, the opinions of Advocates General are regularly based on comparatives studies. ${ }^{2282}$ As argued by Kiikeri, "third law" comparisons, that means comparisons to laws outside the European Union Member States, "may even appear relevant in justifying the drastic changes to the European legal systems". ${ }^{2283}$ From an evolutive perspective of Article 7(2) Brussels Ibis, it is thus important to consider the development of connecting factors in the United States of America related to jurisdiction in cross-border copyright infringement disputes. ${ }^{2284}$ As demonstrated by the attempts of the Hague Conference on Private International Law, ${ }^{2285}$ it is also desirable to adopt an uniform approach to jurisdiction in crossborder copyright infringement cases at worldwide level.

In view of the mainly uncodified common law system of the United States of America, ${ }^{2286}$ it may seem difficult to 'transplant' ${ }^{2287}$ these connecting factors for the interpretation of Article 7(2) Brussels Ibis. While states of the United States of America have adopted the common lawbased system that provides broad discretion to courts to adjudicate cases, ${ }^{2288}$ European Union Member States generally adhere to the civil law-based system that has a preference for formal rules which bind courts when assessing cases. ${ }^{2289}$ However, as argued by Pejovic, both legal systems converge by "their common goal of creating a fair and just legal system which can provide legal certainty and protection to all citizens and legal persons." 2290 This common goal reflects the main principle underlying the Brussels system to "strengthen the legal protection of

\footnotetext{
${ }^{2280}$ Garcimartín Alférez 2013, p. 170. See also Kutscher 1976, pp. I-23-29; Lenaerts \& Gutman 2016, p. 842.

${ }^{2281}$ Kiikeri 2001, pp. 284-286.

2282 See, for instance, the Opinion of Advocate General Jääskinen delivered 13 June 2013 in the case C-170/12 Peter Pinckney v. KGD Mediatech AG, para. 59 note 52. See also the Opinion of Advocate General Cruz Villalón delivered on 11 September 2014 in the case C-441/13 Pez Hejduk v. EnergieAgentur. NRW GmbH, para. 29 note 14.

${ }^{2283}$ As an example of external comparison, Kiikeri referred to opinion of Advocate General Tesauro delivered on 6 April 1995 in the case C-450/93 Eckhard Kalanke v. Freie Hansestadt Bremen. Tesauro employed case law in the United States of America to support his "institutional interpretation" of the equality principle. See Kiikeri 2001, pp. 251, 287.

${ }^{2284}$ Kiikeri 2001, pp. 5, 286. Kiikeri (2001, p. 104) pointed out that the use of the method of comparative law with respect to European Union law can also been seen as a method for "lacune filling" as "a means of revealing all possible solutions and as an extremely important part of the Community law." Kiikeri (2001, p. 107) argued that "methods of reasoning, discussion of procedural questions, and the role of oral hearings and case law have changed gradually based on influences from common law countries." See also Koopmans 1991, p. 500.

${ }^{2285}$ See paragraphs 1.1.2 and 6.4.2. See also Reimann 2019, pp. 1352-1353.

${ }^{2286}$ Olson 2009, pp. 2-5. Symeonides (2008, p. 29) points out that "unlike American choice of law which owes its origins to continental sources, the American law of jurisdiction owes its origin to English common law sources".

${ }^{2287}$ As mentioned in paragraph 1.2, Watson coined the methodology of so-called legal transplants that allows legal rules to be transferred from one legal system to another.

${ }^{2288}$ Silberman 2002, pp. 328-329. See also Boone 2006, pp. 273-274.

${ }^{2289}$ Silberman 2002, pp. 328-329. See also Boone 2006, pp. 273-274.

${ }^{2290}$ Pejovic 2001, p. 841.
} 
persons" within the European Union. ${ }^{2291}$ Moreover, it suits the aim of the jurisdiction rules under Brussels Ibis Regulation to provide "the greatest possible degree of legal certainty". 2292

The common law-based system of the United States of America employs different terminology and concepts regarding jurisdiction than the Brussels Ibis Regulation that mainly follows the civil law-based system. ${ }^{2293}$ This chapter will explain the legal concepts of 'subjectmatter jurisdiction' and 'personal jurisdiction' as employed by United States courts in crossborder copyright infringement disputes. Since the CJEU ruled that the doctrine of forum non conveniens is not compatible with the Brussels system, ${ }^{2294}$ this concept will not be discussed in this dissertation.

For the purpose of rethinking the Pinckney doctrine, this chapter will demonstrate various connecting factors adopted by courts of states of the United States of America to establish jurisdiction in cross-border copyright infringement disputes. These connection factors will be examined on the basis of the assessment framework of paragraph 4.6 provided that they are likely to suit the connecting factor 'the place where the harmful event occurred' under Article 7(2) Brussels Ibis. The "best" connecting factors ${ }^{2295}$ to establish jurisdiction in cross-border copyright infringement cases under Article 7(2) Brussels Ibis should entail predictability; establish a close connection between the dispute and the forum; enhance efficient adjudication; and strike a fair balance between the interests involved. ${ }^{2296}$ The impact of the Geo-blocking Regulation on the connecting factors that will be derived from case law of courts of states of the United States of America will also be examined.

\subsection{Subject-matter jurisdiction related to cross-border copyright infringement disputes}

When a copyright holder files a cross-border copyright infringement claim before a court of a state of the United States of America, this court first has to assess whether "it has jurisdiction over the substance of the case" referred to as subject-matter jurisdiction.2297 Pursuant to Title 28 United States Code $§ 1338(a)$, “district courts have original jurisdiction of any civil action arising under Act of Congress relating to ... copyrights". ${ }^{2298}$ The latter provision seems to indicate that courts may only obtain jurisdiction if the copyright relied on has been protected by copyright law of the United States of America. ${ }^{2299}$ Nonetheless, as mentioned in

\footnotetext{
${ }^{2291}$ Pontier \& Burg 2004, pp. 3, 23. See also case law of the CJEU as mentioned in paragraph 4.2.4.2.

2292 Jenard Report on the Brussels Convention of 1968, p. C 59/15. Recital 15 of the preamble to the Brussels Ibis Regulation also stipulates that "the rules of jurisdiction should be highly predictable." See also case law of the CJEU as mentioned in paragraph 4.2.4.2.

2293 Symeonides 2008, p. 29 no. 31.

${ }^{2294}$ Case C-281/02 Andrew Owusu v. N.B. Jackson. According to Brand, legal systems following the continental civil law system generally reject the doctrine of forum non conveniens in the context of jurisdiction rules because they purport to provide greater predictability. See Brand 2002, pp. 467-468.

${ }^{2295}$ See the "best solution" approach by Poiares Maduro in paragraphs 1.2 and 4.2.5.

${ }^{2296}$ See paragraph 4.6.

${ }^{2297}$ Kono \& Jurcys 2015, p. 11. See also Svantesson 2016, p. 18.

${ }^{2298}$ District courts are part of the United States federal court system. The United States federal court system consists of the United States Supreme Court, United States Courts of Appeals, and Unites States District Courts. Cohen (1993, pp. 337-398) focuses on the issue when a claim arises under the Act of Congress relating to copyrights.

${ }^{2299}$ See also Kono \& Jurcys 2015, p 10. See also paragraph 2.3.2.
} 
paragraph 2.3.4.1, courts have nowadays been localising alleged foreign copyright infringements within the United States of America by extensive interpretation of substantive provisions of United States copyright law. Particularly due to the case of Lucasfilm Ltd. v. Ainsworth, a ruling of the United Kingdom Supreme Court in 2011, scholars have been advocating a flexible approach to the justiciability of foreign intellectual property rights. ${ }^{2300}$

Based on the conditions under Title 28 United States Code $\$ 1332(a)(2)$, district courts can obtain subject-matter jurisdiction with respect to infringements of foreign copyright laws that took place outside the United States of America. ${ }^{2301}$ The illustrative case of London Film Productions, Ltd. v. Intercontinental Communications has been demonstrated in paragraph 2.3.4.1. Due to the latter provision, referred to as 'diversity of citizenship', "district courts shall have original jurisdiction of all civil actions where the matter in controversy exceeds the sum or value of $\$ 75,000$, exclusive of interest and costs, and is between

1) citizens of different States $^{2302}$;

2) citizens of a State and citizens or subjects of a foreign state...;

3) citizens of different States and in which citizens or subjects of a foreign state are additional parties; and

4) a foreign state, defined in section 1603(a) of this title ${ }^{2303}$, as plaintiff and citizens of a State or of different States."

\subsection{Personal jurisdiction related to cross-border copyright infringement disputes}

Once the court has subject-matter jurisdiction over a cross-border copyright infringement case, the court has to assess whether it can exercise so-called personal jurisdiction over the parties. ${ }^{2304}$ Based on the interpretation of the Due Process Clauses of the United States Constitution, ${ }^{2305}$ the United States Supreme Court established principles regarding personal jurisdiction. ${ }^{2306}$ Although the case law related to personal jurisdiction has often been characterized as a labyrinth, ${ }^{2307}$ this chapter will seek to map out various approaches to jurisdiction in cross-border copyright infringement disputes adopted by courts of states of the United States of America. Whenever one of these approaches to jurisdiction appears to fit the connecting factor "the place where the harmful event occurred or may occur" in Article 7(2) Brussels Ibis, this approach will be assessed in light of the framework of paragraph 4.6.

\footnotetext{
${ }^{2300}$ Kono \& Jurcys 2015, p. 12. See United Kingdom Supreme Court 27 July 2011, Lucasfilm Ltd. and Others v. Andrew Ainsworth and Another [2011] UKSC 39 [2012] 1 AC 208. See paragraph 2.3.2.

${ }^{2301}$ See, for instance, the case of London Film Productions, Ltd. v. Intercontinental Communications, Inc. $580 \mathrm{~F}$. Supp. 47 (S.D.N.Y. 1984).

${ }^{2302}$ The term 'states' refers to the fifty states of the United States of America, other states have been denoted by the term 'foreign states'.

${ }^{2303}$ Title 28 United States Code $§ 1603$ (a) stipulates that a foreign state includes "a political subdivision of a foreign state or an agency or instrumentality of a foreign state".

${ }^{2304}$ Kono \& Jurcys 2015, p. 14; Svantesson 2016, p. 18.

${ }^{2305}$ The Due Process clause of the Fifth Amendment ("No person shall be....... deprived of life, liberty, or property, without due process law") binds the federal government and therefore the federal courts. The Due Process clause of the Fourteenth Amendment ("No State shall.... deprive any person of life, liberty, or property without due process of law") binds the states and therefore the state courts.

${ }^{2306}$ Barbosa 2007, p. 109.

${ }^{2307}$ Russell 1995, p. 534.
} 
Similar to the general jurisdiction rule of Article 4 Brussels Ibis, the United States Supreme Court ruled that a defendant can always be sued in the state of his domicile. ${ }^{2308}$ In view of case law of the United States Supreme Court, this paragraph will demonstrate that a defendant who is not resided in the state of the court seised may -under certain conditions- get sued in that state. First of all, courts of the states of the United States of America can exercise personal jurisdiction over a non-resident defendant who appears and does not explicitly object the court's jurisdiction. ${ }^{2309}$ This type of tacit jurisdiction has also been acknowledged in Article 26 Brussels Ibis. $^{2310}$

Traditionally, courts of the United States of America can also exercise personal jurisdiction over a non-resident defendant who has been served while being physical presence in the forum state. $^{2311}$ This so-called tag jurisdiction has been characterized as exorbitant by civil law systems. ${ }^{2312}$ Scholars in the United States of America even argue that the exercise of tag jurisdiction violates the principles of due process because "the forum does not have a sufficient relationship to the parties and the cause of action". ${ }^{2313}$ In any case, the aforementioned approaches to jurisdiction cannot be employed under Article 7(2) Brussels Ibis because they do not relate to 'the place where the harmful event occurred or may occur'.

In the seminal case of International Shoe Co. v. Washington, the United States Supreme Court held that courts may exercise personal jurisdiction over a non-resident defendant who is not present within the territory of the forum state when being served. ${ }^{2314}$ Based on the due process clause, the latter defendant must "have certain minimum contacts" with the forum state, from which the complaint arises, such that the exercise of jurisdiction does not offend "traditional notions of fair play and substantial justice". ${ }^{2315}$ The concept of personal jurisdiction has been distinguished into general and specific personal jurisdiction. ${ }^{2316}$

\subsubsection{General personal jurisdiction}

Pursuant to the concept of so-called general personal jurisdiction, a non-resident defendant can get sued in a state based on "continuous, substantial and systematic" activities, such as

\footnotetext{
${ }^{2308}$ Milliken v. Meyer, 311 U.S. 457 (1940). A company may be sued in the state of incorporation or the state in which it has his principal place of business. See Goodyear Dunlop Tires Operations S.A. v. Brown, 564 U.S. 915 (2011). See also Brilmayer, Haverkamp, Logan, Lynch, Neuwirth \& O'Brien 1988, pp. 728-735; Heinze 2013, p. 59; Silberman, Stein \& Wolff 2017, p. 81; Symeonides 2008, p. 31, no. 39.

${ }^{2309}$ Symeonides 2008, p. 32 no. 41. See Pennoyer v. Neff 95 U.S. 714 (1878).

${ }^{2310}$ Article 26 Brussels Ibis stipulates that "this rule shall not apply where appearance was entered to contest the jurisdiction, or where another court has exclusive jurisdiction by virtue of Article 24."

${ }^{2311}$ Pennoyer v. Neff, 95 U.S. 714, 720 (1878). Burnham v. Superior Court of California 495 U.S. 604 (1990).

${ }^{2312}$ Borchers 1992, pp. 134-135.

${ }^{2313}$ Maier \& Mccoy 1991, pp. 256-257. Maier and Mccoy referred to the test adopted by the United States Supreme Court in the case of Shaffer v. Heitner that "a forum has jurisdiction only when there is a sufficient relationship between the defendant, the forum and the cause of action to make it not unfair to adjudicate the case there". See Shaffer v. Heitner, 433 U.S. 186 (1977). In the latter case, the United States Supreme Court rejected jurisdiction based on the mere present of the defendant's property in the forum state. See also Juenger 1984, p. 1197.

${ }^{2314}$ International Shoe Co. v. Washington, 326 U.S. 310 (1945).

${ }^{2315}$ International Shoe Co. v. Washington, 326 U.S. 310 at 316 (1945).

${ }^{2316}$ The United States Supreme Court employed the terminology 'specific' and 'general' jurisdiction for the first time in the case of Helicopteros Nationales de Columbia S.S. v Hall, 466 U.S. 408 (1984). See Condlin 2004, p. 96.
} 
doing intense business, in that state. ${ }^{2317}$ The latter defendant can even be sued for actions unrelated to these 'continuous, substantial and systematic' activities. ${ }^{2318}$ The general personal jurisdiction approach will therefore not provide predictability, nor guarantee a close connection between the dispute and the court. ${ }^{2319}$

Due to the 'general jurisdiction' approach, the competent court can thus obtain jurisdiction based on tortious activities that were committed or caused damage in other states. ${ }^{2320}$ Since the forum state does not need to be the place where the harmful event occurred or may occur, the general approach to jurisdiction will not be examined to rethink the CJEU's approach to jurisdiction under Article 7(2) Brussels Ibis in cross-border copyright infringement cases.

\subsubsection{Specific personal jurisdiction}

Instead of general personal jurisdiction, courts of the states of the United States of America can obtain so-called specific personal jurisdiction over a non-resident defendant based on "single or occasional acts occurring or having their impact within the forum State". ${ }^{2321}$ Whether the principles of due process have been satisfied depends on "the quality and nature of the activity". ${ }^{2322}$ The United States Supreme Court held that the defendant should have "purposefully availed" himself of "the privilege of conducting activities within the forum State, thus invoking the benefits and protections of its laws". ${ }^{2323}$ Furthermore, the defendant's contacts with the forum state should relate to the suit. ${ }^{2324}$ Paragraph 7.4 will demonstrate the so-called three-pronged test that has generally been employed by courts of the states of the United States of America to determine specific personal jurisdiction.

The main difference with general personal jurisdiction is that specific personal jurisdiction requires that the cause of action arises out of the defendant's activities that occurred or had effects in the forum state. ${ }^{2325}$ Since this "case-linked" approach ${ }^{2326}$ of specific personal

\footnotetext{
${ }^{2317}$ International Shoe Co. v. Washington, 326 U.S. 310 at 317 (1945). Helicopteros Nationales de Columbia S.S. v Hall, 466 U.S. 408 at 415-16 (1984); Goodyear Dunlop Tires Corporation S.A. v. Brown, 131 S. CT. 2846 (2011). See Juenger 1984, p. 1198; Schack 1983, pp. 37-39. Juenger compared the evolution of jurisdictional principles in the United States of America and in the former European Communities. See Juenger 1984, p. 1195.

${ }^{2318}$ Helicopteros Nationales de Columbia S.S. v Hall, 466 U.S. 408, 415-16 (1984). See also Goodyear Dunlop Tires Operations S.A. v. Brown, 564 U.S. 915 at 919 (2011). While general personal jurisdiction has also been referred to as "all-purpose" jurisdiction, specific personal jurisdiction can be denoted as "case-linked" jurisdiction. See also Juenger 1984, p. 1198.

2319 Juenger 1984, p. 1201.

${ }^{2320}$ Silberman, Stein \& Wolff 2017, p. 81.

${ }^{2321}$ Goodyear Dunlop Tires Corporation S.A. v. Brown, 564 U.S. 915 (2011). See also International Shoe Co. v. Washington, 326 U.S. 310 at 318 (1945).

${ }^{2322}$ International Shoe Co. v. Washington, 326 U.S. 310 at 319 (1945).

2323 Hanson v. Denckla, 357 U.S. 235 at 253 (1958). See also International Shoe Co. v. Washington, 326 U.S. 310 at 319 (1945). Paragraph 7.4 will demonstrate that the United States Supreme Court also employed the so-called 'purposeful directed' requirement besides the 'purposeful availment' requirement. See Burger King Corp. $v$. Rudzewicz, 471 U.S. 462 at 475-476 (1985). As will be explained in paragraph 7.4, the reasonableness test is also a part of the constitutional analysis related to specific personal jurisdiction.

${ }^{2324}$ Borchers 2017, p. 416. See Bristol-Myers Squibb Co. v. Superior Court of California, San Francisco County, et Al., 582 U.S. 137 S. Ct. 1773 (2017).

2325 Schack 1983, pp. 30-31; Von Mehren 2007, p. 136. See paragraph 7.4.

${ }^{2326}$ Goodyear Dunlop Tires Corporation S.A. v. Brown, 564 U.S. 915 (2011). See also International Shoe Co. v. Washington, 326 U.S. 310 at 319 (1945).
} 
jurisdiction appears to fit the jurisdiction ground 'the place where the harmful event occurred' of Article 7(2) Brussels Ibis, ${ }^{2327}$ this approach will be further examined in this dissertation to rethink the Pinckney doctrine.

The conditions to determine whether a United States court may exercise specific personal jurisdiction can be divided into statutory and constitutional conditions. ${ }^{2328}$ The court seised first has to apply the long-arm statute of the forum state to determine whether a non-resident defendant can be subjected to specific personal jurisdiction in that state. ${ }^{2329}$ Similar to the dichotomy of Handlungsort and Erfolgsort under Article 7 (2) Brussels Ibis, long-arm statutes often employ "the place of the wrongful act" and "the place of the damage" among other connecting factors. ${ }^{2330}$ Most long-arm statutes also require that the defendant "regularly does or solicits business, engages in any other persistent course of conduct, or derives substantial revenue from goods used or consumed, or services rendered" in the forum state. ${ }^{2331}$ Some longarm statutes stipulate that the court's personal jurisdiction reaches to the full extent allowed under the United States Constitution. ${ }^{2332}$ The court seised then has to proceed directly to the constitutional analysis related to personal jurisdiction that will be set out in paragraph 7.4. The following paragraph will demonstrate a copyright infringement case in which the New York Court of Appeals gave an interesting interpretation of 'the place of the injury' as connecting factor in the New York long-arm statute. ${ }^{2333}$

\subsubsection{The case of Penguin Group (USA) Inc. v. American Buddha}

In the case of Penguin Group (USA) Inc. v. American Buddha, the New York Court of Appeals gave an elaborated interpretation of 'the place of the injury' as connecting factor in the New York long-arm statute. ${ }^{234}$ The book publishing company Penguin Group alleged that the company American Buddha uploaded copyrighted literary works onto its online library that was freely accessible for its members. As the Penguin Group had its principal place of business in New York, they sued American Buddha before the United States District Court for the Southern District of New York (hereinafter district court of New York). ${ }^{2335}$ American Buddha had been incorporated in Oregon and had uploaded the copyright infringing works from servers located in Oregon and Arizona. The legal issue arose whether the court of the state where the

\footnotetext{
2327 See Juenger 1984, pp. 1203-1204.

${ }^{2328}$ See Brand 1998, pp. 130-142.

${ }^{2329}$ See Brand 1998, p. 130.

${ }^{2330}$ De Groote 2004, p. 192 , no. 339.

${ }^{2331}$ See the Columbia long-arm statute D.C. Code $\$ 13-4234(d)$. For similar examples, see the New York longarm statute (N.Y. C.P.L.R.) §302; the Georgia long-arm statute Ga. Code Ann. §9-10-91 (3), the Delaware longarm statute Del. Code. Ann. Tit. 3, §3104.

${ }^{2332}$ See, for example, California Code, Code of Civil Procedure- CCP $§$ 410.10. See also Juenger 1984, p. 1200.

${ }^{2333}$ Penguin Group (USA) Inc. v. American Buddha, 16 N.Y. 3d 295 (2011) (Am. Buddha III). See the long-arm statute of the New York Civil Practice Law and Rules (N. Y. C.P.L.R.) §302(a)(3)(ii).

${ }^{2334}$ Penguin Group (USA) Inc. v. American Buddha, 16 N.Y. 3d 295 (2011). See the long-arm statute in the New York Civil Practice Law and Rules (N.Y. C.P.L.R.) §302(a)(3)(ii).

2335 Penguin Group (USA) Inc. v. American Buddha, No. 09-cv-528, 2009 WL 1069158, 2009 U.S. Dist. LEXIS 34032 (S.D.N.Y. April 21, 2009) (Am. Buddha I).
} 
copyright holder the Penguin Group had his principal place of business could obtain jurisdiction..$^{2336}$

To establish personal jurisdiction under the long-arm statute of New York Civil Practice Law and Rules (hereinafter N.Y. C.P.L.R.) §302(a)(3)(ii), the Penguin Group needed to demonstrate the following conditions: "(1) the defendant's tortious act was committed outside New York, (2) the cause of action arose from that act, (3) the tortious act caused an injury to a person or property in New York, (4) the defendant expected or should reasonably have expected that his or her action would have consequences in New York, and (5) the defendant derives substantial revenue from interstate or international commerce." The focus of the Penguin case had been on the interpretation of the place (situs) of the injury related to the abovementioned third condition of the long-arm statute.

The district court of New York held the place where the alleged copyrighted works were uploaded, that means Arizona and Oregon, as the place of injury. ${ }^{2337}$ The court explicitly rejected the place of the injured party's residence, or the place of indirect financial loss, as place of the injury because "jurisdiction must be based upon a more direct injury within the state and a closer expectation of consequences within the state than the indirect financial loss resulting from the fact that the injured person resides or is domiciled there". ${ }^{2338}$ According to the court, the plaintiff's loss of business occurred where the books where uploaded, that means Oregon or Arizona, not where they were downloaded or used. ${ }^{2339}$

On appeal, the United States Court of Appeals for the Second Circuit certified a question to the New York Court of Appeals ${ }^{2340}$ that got reformulated into the following question: "In copyright infringement cases involving the uploading of a copyrighted printed literary work onto the Internet, is the situs of injury for purposes of determining long-arm jurisdiction under N.Y.C.P.L.R. \$302(a)(3)(ii) the location of the infringing action or the residence or the location of the principal place of business of the copyright holder?". 2341 Contrary to the district court of New York, the New York Court of Appeals considered the ubiquity of the Internet as a relevant factor that should be taken into account regarding the interpretation of the place of the injury. ${ }^{2342}$

The New York Court of Appeals regarded the copyright holder's principal place of business as the place of the injury under the long arm-statute. ${ }^{2343}$ This decision has been based on the following two factors. ${ }^{2344}$ First, the New York Court of Appeals focused on the Internet-based nature of the case. In view of the instantaneous and worldwide dissemination of online

\footnotetext{
${ }^{2336}$ Penguin Group (USA) Inc. v. American Buddha, No. 09-cv-528, 2009 WL 1069158, 2009 U.S. Dist. LEXIS 34032 (S.D.N.Y. April 21, 2009).

${ }^{2337}$ Penguin Group (USA) Inc. v. Am. Buddha, No. 09-cv-528, 2009 WL 1069158, at*1 (S.N.D.Y. April 21. 2009).

${ }^{2338}$ Penguin Group (USA) Inc. v. Am. Buddha, No. 09-cv-528, 2009 WL 1069158, at*3-*4, 2009 U.S. Dist. LEXIS 34032, at *9, *11 (S.N.D.Y. April 21. 2009) (Am. Buddha I). The district court referred to the case of Fantis Foods, Inc. v. Standard Importing Co., Inc., 49 N.Y.2d 317 at 326 (1980).

${ }^{2339}$ Penguin Group (USA) Inc. v. Am. Buddha, No. 09-cv-528, 2009 WL 1069158, at *4, 2009 U.S. Dist. LEXIS 34032 , at *12 (S.N.D.Y. April 21. 2009). The district court referred to the case of American Eutectic Welding Alloys Sales Co. Inc. v. Dytron Alloys Corp., 439 F. 2d 428 at 433 (2d Cir. 1971).

2340 Penguin Group (USA) Inc. v. American Buddha, 609 F.3d 30 at 32 (2d Cir. 2010) (Am. Buddha II).

${ }^{2341}$ Penguin Group (USA) Inc. v. American Buddha, 16 N.Y. 3d 295 at 302 (2011).

2342 Penguin Group (USA) Inc. v. American Buddha, 16 N.Y. 3d 295 at 302, 304 (2011).

${ }^{2343}$ Penguin Group (USA) Inc. v. American Buddha, 16 N.Y. 3d 295 at 304-307 (2011).

${ }^{2344}$ See also Josephs 2013, p. 1030.
} 
copyright infringements, the New York Court of Appeals found it "illogical" to extend the traditional tort approach ${ }^{2345}$ that "equates a plaintiff's injury with the place where its business is lost or threatened... to online copyright infringement cases where the place of uploading is inconsequential, and difficult, if not impossible, to correlate lost sales to a particular geographic area". ${ }^{2346}$ In addition, the Court of Appeals pointed out that digital pirates are posing "a unique threat to the rights of the copyright owners". ${ }^{2347}$

The New York Court of Appeals held that "the second factor that tips the balance in favor of identifying New York as the situs derives from the unique bundle of rights granted to copyright owners". 2348 The latter court referred to the "multifaceted nature" of copyrights, including the "overarching" "right to exclude others from using his property"; 2349 a copyright infringement itself can be considered as an injury regardless of any specific financial loss. ${ }^{2350}$ "For instance, one of the harms arising from copyright infringement is the loss or diminishment of the incentive to publish or write." 2351 In addition, "the harm to a plaintiff's property interest in copyright infringement cases 'has often been characterized as irreparable in light of possible market confusion'." 2352 The New York Court of Appeals also pointed out that courts have often issued injunctive relief in copyright infringement cases regardless of specific financial loss which has frequently been difficult to prove. ${ }^{2353}$ The foregoing reflects the difference between the concept of damage related to regular tort cases and the concept of damage regarding copyright infringements as demonstrated in paragraph 5.2.2. After referring the Penguin case back, the district court of New York nevertheless held it could not obtain jurisdiction because the defendant did not derive substantial revenue from interstate or international commerce as required by $\S 302(a)(3)(i i)$ sub (5) of the New York long arm-statute. ${ }^{2354}$

\subsection{Assessing the Penguin ruling}

The abovementioned second factor in the Penguin ruling suits the tendency of the CJEU to refer in its rulings on copyright law to the right to property based on human rights laws. ${ }^{2355}$ Article 17 of the Charter of Fundamental Rights of the European Union of 2000 concerning the right to property also emphasises the fact that "intellectual property shall be protected" 2356 .

\footnotetext{
2345 The New York Court of Appeals referred to the case of American Eutectic Welding Alloys Sales Co v. Dytron Alloys Corp. (439 F2d 428 at 433 (2d Cir. 1971).

${ }^{2346}$ Penguin Group (USA) Inc. v. American Buddha, 16 N.Y. 3d 295 at 305 (2011).

${ }^{2347}$ Penguin Group (USA) Inc. v. American Buddha, 16 N.Y. 3d 295 at 304 (2011).

${ }^{2348}$ Penguin Group (USA) Inc. v. American Buddha, 16 N.Y. 3d 295 at 305 (2011).

${ }^{2349}$ The New York Court of Appeals referred to the case of eBay Inc. v. MercExchange, L.L.C., 547 U.S. 388 at 392 (2006).

${ }^{2350}$ Penguin Group (USA) Inc. v. American Buddha, 16 N.Y. 3d 295 at 306 (2011).

${ }^{2351}$ Penguin Group (USA) Inc. v. American Buddha, 16 N.Y. 3d 295 at 305 (2011).

2352 Penguin Group (USA) Inc. v. American Buddha, 16 N.Y. 3d 295 at 306 (2011). The New York Court of Appeals referred to the case of Salinger v. Colting, 607 F. 3d 68 at 81 (2d Cir. 2009).

${ }^{2353}$ Penguin Group (USA) Inc. v. American Buddha, 16 N.Y. 3d 295 at 307 (2011). The New York Court of Appeals referred to the case of Salinger v. Colting, 607 F. 3d 68 at 81 (2d Cir. 2009).

${ }^{2354}$ Penguin Group (USA) Inc. v. American Buddha, No. 09 Civ. 528 (RA), 2013 WL 865486 * *7 (S.D.N.Y. March 9, 2013).

2355 See Griffiths 2013(b), pp. 65-78.

${ }^{2356}$ See Article 17(2) of the Charter of Fundamental Rights of the European Union of 2000.
} 
Whereas the Anglo-American legal system used to consider copyright protection merely as a goal of economically benefiting society, ${ }^{2357}$ the Penguin ruling appears to acknowledge the human rights aspect of copyrights. Therefore, the Penguin ruling might be seen as a move towards the continental European droit d'auteur approach to copyrights. ${ }^{2358}$

The two factors employed by the New York Court of Appeals in favour of the copyright holder's place of business as connecting factor are consistent with the CJEU's reasoning in the eDate and Martinez ruling to confer jurisdiction to the court of the victim's centre of interests ${ }^{2359}$. Both courts based their decision on the difficulty to assess the damage caused by worldwide dissemination of the infringements via the Internet and the serious nature of the harm that will be suffered by copyright holders. ${ }^{2360}$ The Penguin ruling supports the scholarly proposals to provide jurisdiction to the copyright holder's centre of interests in online copyright infringement disputes as discussed in paragraph 6.2. In the Penguin ruling, the New York Court of Appeals opted for a technology-based approach to jurisdiction by clearly emphasising the role of the Internet to determine jurisdiction in a cross-border copyright infringement case. ${ }^{2361}$

As argued in paragraph 6.2.4.2, the 'victim's centre of interests' approach will generally not yield predictability for potential copyright infringers. Yet, the New York Court of Appeals emphasised that the Penguin ruling only allows the alleged copyright infringer to get sued in New York provided that all conditions under the New York long-arm statute are satisfied such as that "the defendant expected or should reasonably have expected that his or her action would have consequences in New York"2362.2363 This latter criterion is reminiscent of the unpredictability of the effects' escape clause in Article 10(1)(b) Draft Hague Convention of $1999^{2364}$ and the 'unforeseeability of substantial damages' escape clause in Article 5(b) Draft Guidelines ILA of $2018^{2365}$. According to the assessments of these escape clauses, they will likely yield less ex ante predictability as regards which court may be competent. ${ }^{2366}$

\subsection{The constitutional analysis arising from the International Shoe ruling}

The abovementioned Penguin ruling has been a broad approach to specific personal jurisdiction in internet-related copyright infringement disputes. Yet, the exercise of personal jurisdiction under the New York long-arm statute has to be in accordance with the Due Process Clause of the United States Constitution. ${ }^{2367}$ In the seminal case of International Shoe Co. v.

\footnotetext{
${ }^{2357}$ Monticello 1999, p. 120. See also Vaver 2001.

${ }^{2358}$ See paragraph 2.2.1.1 on the European droit d'auteur approach to copyrights. See Rigamonti (2006, pp. 354412) on the development of the concept of moral rights to common law countries.

${ }^{2359}$ See paragraph 6.2.1

${ }^{2360}$ Penguin Group (USA) Inc. v. American Buddha, 16 N.Y. 3d 295 at 304-305 (2011). Joined Cases C-509/09 and C-161/10 eDate Advertising GmbH v. Olivier Martinez and Robert Martinez v. MGN Limited, para. 45-49.

${ }^{2361}$ Josephs 2013, p. 1026. Josephs pointed out that "the court reformulated the inquiry and limited its holding to cases in which the alleged infringement was an unconsented uploading of a work to the Internet".

${ }^{2362}$ New York Civil Practice Law and Rules $\$ 302$ (a)(3)(ii)(4).

${ }^{2363}$ Penguin Group (USA) Inc. v. American Buddha, 16 N.Y. 3d 295 at 307 (2011).

2364 See paragraph 6.4.2.

2365 See paragraph 6.4.6.

${ }^{2366}$ See paragraphs 6.4.2.2.1 and 6.4.6.2.1.

${ }^{2367}$ See paragraph 7.3.
} 
State of Washington, the Supreme Court of the United States of America provided the constitutional analysis that must always be applied to determine personal jurisdiction regardless whether the exercise of jurisdiction has been allowed under the long-arm statute of the forum state. $^{2368}$

As explained in paragraph 7.3, this dissertation will focus on the concept of so-called specific personal jurisdiction to rethink the CJEU's interpretation of the special jurisdiction rule of Article 7(2) Brussels Ibis in cross-border copyright infringement cases. Through subsequent case law related to specific personal jurisdiction, the constitutional analysis in the International Shoe ruling evolved into the following so-called three-pronged test ${ }^{2369}$. Pursuant to the first prong, also referred to as the 'minimum contacts' test, the plaintiff has to demonstrate that the non-resident defendant "purposefully availed" himself of "the privilege of conducting activities within the forum state, thus invoking the benefits and protection of the it's laws" 2370 or the defendant "purposefully directed" its activities at the residents of the forum state. ${ }^{2371}$ Second, the plaintiff's claim must arise from the defendant's forum state-related activities. ${ }^{2372}$ Third, the exercise of jurisdiction by the court must be reasonable. ${ }^{2373}$

This last prong comprises a balancing test consisting of five-factors: the defendant's burden; the forum state's interests; the plaintiff's interest in convenient and effective relief; the interests of the judicial system of the United States of America; and potential foreign state policy interests in efficient resolution of controversies. ${ }^{2374}$ It is the defendant who has to prove that the court's exercise of jurisdiction would be unreasonable in the forum state. ${ }^{2375}$ "The clearest case illustrating an unreasonable exercise of jurisdiction is where both the plaintiff and the defendant are foreign." 2376

The first prong involving the 'minimum contacts' requirement will be addressed in the next paragraphs in the context of copyright infringement cases. The second prong will be further discussed in paragraph 7.7 on the rejection of a third party-based approach to personal jurisdiction by the United States Supreme Court. The third prong of the test to determine personal jurisdiction clearly indicates that the United States courts generally employ a broader concept of procedural fairness than the Brussels Ibis Regulation. While the Brussels Ibis

\footnotetext{
${ }^{2368}$ International Shoe Co. v. Washington, 326 U.S. 310 (1945).

${ }^{2369}$ See, inter alia, Zippo Manufacturing Co v. Zippo Dot Com. Inc., 952 F. Supp. 1119 at 1122-1123 (W.D. Pa. 1997).

${ }^{2370}$ Hanson v. Denckla, 357 U.S. 235 at 251 (1958). See also International Shoe Co. v. Washington, 326 U.S. 310 at 319 (1945). The 'purposeful availment' test has traditionally been employed in cases related to contracts. See Schwarzenegger v. Fred Martin Motor Co., 374 F. 3d 797 at 802 (9 $9^{\text {th }}$ Cir. 2004).

${ }^{2371}$ World-Wide Volkswagen Corp v. Woodson, 444 U.S. 286 (1980). Burger King Corp v. Rudzewicz, 471 U.S. 462 at 473, 476 (1985). Many courts have applied the so-called 'purposefully directed' test to assess the 'minimum contacts' requirement when an alleged copyright infringer caused effects in the forum state. Wanat 2008, pp. 566584 .

${ }^{2372}$ See Silberman, Stein \& Wolff 2017, p. 90. See case law Burger King Corp. v. Rudzewicz, 471 U.S. 462 at $472-$ 473 (1985); Helicopteros Nationales de Columbia S.S. v. Hall, 466 U.S. 408 at 414 (1984). See also paragraph 7.7 on the United States Supreme Court rejection of a third party-based approach to specific personal jurisdiction.

${ }^{2373}$ World-Wide Volkswagen Corp v. Woodson, 444 U.S. 286 at 292 (1980).

2374 World-Wide Volkswagen Corp v. Woodson, 444 U.S. 286 at 292 (1980). See also Burger King Corp v. Rudzewicz, 471 U.S. 462 at 476-477 (1985); Asahi Metal Industry Co. v. Superior Court, 480 U.S. 102 (1987).

${ }^{2375}$ Burger King Corp v. Rudzewicz, 471 U.S. 462 at 476-747 (1985).

${ }^{2376}$ Rose 1994, p. 1556.
} 
Regulation mainly aims to provide predictability to the defendant, United States courts also consider economic reasons not to sue a defendant in a far-away forum. ${ }^{2377}$ Although the reasonable test may be compatible with the objective of sound administration of justice under Article 7(2) Brussels Ibis, it does not focus on the place where the harmful event occurred. Due to the unpredictable outcome of the value-based character of this reasonableness test, it also does not provide predictability. ${ }^{2378}$ This reasonableness test will therefore not be further examined in this dissertation.

\subsubsection{The rationale behind the 'minimum contacts' requirement and the resemblance with the principles underlying Article 7(2) Brussels Ibis}

In view of the abovementioned International Shoe ruling, the alleged copyright infringer must thus have "certain minimum contacts" with the forum state such that the exercise of jurisdiction does not offend "traditional notions of fair play and substantial justice". ${ }^{2379}$ The reasons behind the concept of 'minimum contacts' have been twofold..$^{2380}$

First, the 'minimum contacts' requirement purports to establish fairness in litigation, substantial justice, and the orderly administration of the laws. ${ }^{2381}$ Hence, the "defendant's conduct and connection with the forum state" must be such that "he should reasonably anticipate being haled into the court there". 2382 The latter so-called "fair warning" requirement ${ }^{2383}$ aims to provide a degree of predictability similar to the objective of Article $7(2)$ Brussels Ibis to "ensure legal certainty and avoid the possibility of the defendant being sued in a court which he could not reasonably have foreseen". 2384

The United States Supreme Court also reasoned that according to the 'minimum contacts' requirement the defendant's activities must create a "substantial connection" with the forum state $^{2385}$. Therefore, the defendant must have established "meaningful "contacts, ties or relations" with the forum state. ${ }^{2386}$ The United States Supreme Court emphasised the latter consideration with respect to the interpretation of the second prong of the constitutional analysis

\footnotetext{
2377 Von Mehren (2007, p. 100) argued that the International Shoe ruling is based on "convenience, fairness and justice." In the case of World-Wide Volkswagen Corp v. Woodson, 444 U.S. 286 at 292 (1980), the United States Supreme Court explicitly noted that the 'minimum contacts' requirement "protects the defendant against the burdens of litigating in a distant or inconvenient forum".

${ }^{2378}$ Kohl (2010, p. 82 note 57) noted that this balancing test depends on vague notions and resembles the forum non conveniens doctrine.

${ }^{2379}$ International Shoe Co. v. Washington, 326 U.S. 310 at 316 (1945).

${ }^{2380}$ World-Wide Volkswagen Corp v. Woodson, 444 U.S. 286 at 291-292 (1980). See Schack 1983, pp. 7-8.

${ }^{2381}$ See Von Mehren 2007, pp. 100-118. See International Shoe Co. v. Washington, 326 U.S. 310 at 319 (1945); World-Wide Volkswagen Corp v. Woodson, 444 U.S. 286 at 294 (1980).

${ }^{2382}$ World-Wide Volkswagen Corp v. Woodson, 444 U.S. 286 at 297 (1980). See Schack 1983, pp. 7, 10.

${ }^{2383}$ Burger King Corp v. Rudzewicz, 471 U.S. 462 at 472 (1985). See also Shaffer v. Heitner, 433 U.S. 186 at 218 (1977). The United States Supreme Court employed the concept of "fair warning" in the case of Burger King Corp v. Rudzewicz, 471 U.S. 462 at 472 (1985).

${ }^{2384}$ Recital 16 of the preamble to the Brussels Ibis Regulation.

${ }^{2385}$ Burger King Corp v. Rudzewicz, 471 U.S. 462 at 475 (1985). See also Kulko v. California Superior Court, 436 U.S. 84 at 91-94 (1978); Walden v. Fiore, 571 U.S. 277, 134 S. Ct. 1115 (2014).

${ }^{2386}$ Burger King v. Rudzewicz, 471 U.S. 462 at 472 (1985). See also International Shoe Co. v. Washington, 326 U.S. 310 at 319 (1945).
} 
that the cause of action should arise out of the defendant's activities. ${ }^{2387}$ Since the defendant's activities have to create a substantial connection with the forum state, the rationale is reminiscent of the principle that the special jurisdiction rule of Article 7(2) Brussels Ibis has been "based on a close connection between the court and the action in order to facilitate the sound administration of justice". ${ }^{2388}$ Paragraph 7.7 will demonstrate that the United States Supreme Court did not adopt the CJEU's third party-based approach to jurisdiction ${ }^{2389}$.

Second, the 'minimum contacts' requirement aims to ensure the maintenance of the concept of state sovereignty inherent to the interstate federalism within the US. ${ }^{2390}$ It is interesting that Maerowitz argued that a less restrictive minimum contact test should be applied to residents who are not resided in the states of the United States of America "since the principles of federalism, which restrict the ability of state courts to exercise jurisdiction over defendants, are applicable only to United States residents". ${ }^{2391}$

\subsection{The various interpretations of the 'minimum contacts' requirement in copyright infringement disputes}

The lower courts have been employing various interpretations regarding the 'minimum contacts' requirement, also known as the 'fair warning' requirement. ${ }^{2392}$ On the basis of case law, the next paragraphs will set out various of these interpretations related to specific personal jurisdiction in copyright infringement cases. In addition, it will be examined whether the approaches to jurisdiction could be a legitimate alternative to the approach established by the CJEU in cross-border copyright infringement cases. ${ }^{2393}$ The assessment framework of paragraph 4.6 will therefore be employed that means the alternative approach to jurisdiction will be examined in light of the principles underlying Article 7(2) Brussels Ibis and the impact of the Geo-blocking Regulation.

\subsubsection{The Calder effects approach}

The next paragraphs will demonstrate that courts of states of the United States of America have frequently employed the so-called Calder effects approach in cross-border copyright

\footnotetext{
${ }^{2387}$ See paragraph 7.4. See also paragraph 7.7 on the United States Supreme Court's rejection of a third partybased approach to specific personal jurisdiction.

${ }^{2388}$ Recital 16 of the preamble to the Brussels Ibis Regulation.

${ }^{2389}$ See paragraph 5.2.3.

${ }^{2390}$ In the case of World-Wide Volkswagen Corp v. Woodson (444 U.S. 286 at 292), the Supreme Court of the United States held that the concept of 'minimum contacts' requirement has been developed "to ensure that the States, through their courts, do not reach beyond the limits imposed on them by their status as coequal sovereigns in a federal system." See also Schack 1983, pp. 7-8.

${ }^{2391}$ Maerowitz 1981, p. 627.

${ }^{2392}$ See Floyd \& Baradaran-Robinson (2006, pp. 601-666) on the various interpretations of the 'minimum contacts' test.

${ }^{2393}$ See paragraph 3.5 on the Pinckney doctrine derived from the rulings Pinckney (Case C-170/12), Hi Hotel (C387/12), Pez Hejduk (C-441/13).
} 
infringement cases. ${ }^{2394}$ This approach has been established by the United States Supreme Court in the case of Calder $v$ Jones. In this case, a professional entertainer who lived and worked in the state of California sued the authors of an allegedly libellous article before the Superior Court of California. ${ }^{2395}$ The defendants resided in Florida and the article involved had been published in a magazine there. They objected the court's jurisdiction by claiming that they were not responsible for the circulation of this article in the forum state California.

Nonetheless, the United States Supreme Court held that the California court obtained jurisdiction because the defendants" activities were not "mere untargeted negligence" but "their intentional, and allegedly tortious, actions were expressly aimed at California". ${ }^{2396}$ The defendants also knew that the article "would have a potentially devastating impact upon" the plaintiff. ${ }^{2397}$ In addition, "they knew that the brunt of the injury would be felt" by the plaintiff in the forum state in which she lived and worked and in which the magazine has its largest circulation. ${ }^{2398}$ The United States Supreme Court held that the defendants must therefore have reasonably anticipated to get sued in the forum state California. ${ }^{2399}$

The next paragraphs will demonstrate that courts have employed different interpretations of the so-called Calder effects approach in cross-border copyright infringement cases. ${ }^{2400}$ Particularly with respect to the requirement that the tortious activities must be expressly aimed at the forum state, courts have provided various interpretations.

\subsubsection{The mere effects-based approach}

The case of Janmark, Inc $v$. Reidy, involving a cross-border copyright infringement dispute, ${ }^{2401}$ demonstrates a very broad interpretation of the Calder effects approach. ${ }^{2402}$ In this case, the Seventh Circuit Court of Appeals construed that "the state in which the victim of a tort suffers the injury may entertain a suit against the accused tortfeasor". ${ }^{2403}$ Most courts of states of the United States of America rejected this mere effects-based approach to jurisdiction because it causes legal uncertainty for the defendant and would always allow the plaintiff to

\footnotetext{
${ }^{2394}$ See Rice and Gladstone (2003, pp. 608- 615) on different interpretations of the Calder effects test by courts of states of the United States of America in tort cases. See also the case of Griffis v. Luban, 646 N.W. 2 d 527 at 533-534 (Minn. 2002).

${ }^{2395}$ Calder v. Jones, 465 U.S. 783 (1984).

${ }^{2396}$ Calder v. Jones, 465 U.S. 783 at 789 (1984).

${ }^{2397}$ Calder v. Jones, 465 U.S. 783 at $789-790$ (1984).

${ }^{2398}$ Calder v. Jones, 465 U.S. 783 at 789-790 (1984).

2399 The United States Supreme Court referred to its previous rulings in the cases of World-Wide Volkswagen Corp v. Woods, 444 U.S. 297. Kulko v. California Superior Court, 436 U.S. 84 at 97-98 (1978). Shaffer v. Heitner, 433 U.S. 186 at 216 (1977).

${ }^{2400}$ See also Rice and Gladstone (2003, pp. 608- 615) on different interpretations of the Calder effects test in torts cases by courts of states of the United States of America.

${ }^{2401}$ The case of Janmark, Inc v. Reidy, 132 F. 3d 1200 ( $7^{\text {th }}$ Cir. 1997). With respect to cross-border copyright infringement cases, the term 'cross-border' will include in this dissertation both international (involving a state of the United States of America and a foreign state) and interstate (involving two copyright infringement disputes). See paragraph 2.1.1.

2402 Janmark, Inc. v. Reidy, 132 F. 3d 1200 at 1202 ( $7^{\text {th }}$ Cir. 1997). See also Indianapolis Colts, Inc. v. Metropolitan Baltimore Football Club Ltd. Partnership, 34 F.3d 410 at 411-12 (7 $7^{\text {th }}$ Cir. 1994).

${ }^{2403}$ Janmark, Inc v. Reidy, 132 F. 3d 1200 at 1202 ( $7^{\text {th }}$ Cir. 1997).
} 
sue in his home state. ${ }^{2404}$ The United States Supreme Court has also repeatedly held that "a defendant cannot be haled into a jurisdiction solely as a result of 'random', 'fortuitous', or 'attenuated' contacts". 2405

The abovementioned interpretation of the Calder effects approach in the Janmark case resembles the broad 'likelihood of damage' criterion of the Pinckney doctrine. In chapter five, this broad approach has already been examined on the basis of the assessment framework of paragraph 4.6. ${ }^{2406}$ The following paragraphs will demonstrate that courts of states of the United States of America will generally require "something more than mere effects in the forum state" to satisfy the 'minimum contacts' requirement. ${ }^{2407}$

\subsubsection{The 'focal point' approach}

Pursuant to a narrow interpretation of the Calder effects approach "the forum state need to be the focal point of the tort and its harm". ${ }^{2408}$ This approach will be referred to as the "focal point' approach. In the case of IMO Indus, Inc. v. Kiekert $A G$ involving a business related interstate tort, the Court of Appeals for the Third Circuit set out the 'focal point' approach related to the Calder effects test by formulating the following three-prong effects test, also referred to as the IMO Industries test. ${ }^{2409}$ Pursuant to this test, the plaintiff has to demonstrate that: (1) "the defendant committed an intentional tort," (2) "the plaintiff felt the brunt of the harm in the forum such that the forum can be said to be the focal point of the harm suffered by the plaintiff as a result of that tort," and (3) "the defendant expressly aimed his tortious conduct at the forum such that the forum can be said to be the focal point of the tortious activity". 2410 To satisfy the latter "express aiming" prong "the plaintiff must show that the defendant knew that the plaintiff would suffer the brunt of the harm caused by the tortious conduct in the forum, and point to specific activity indicating that the defendant expressly aimed its tortious conduct at the forum". ${ }^{2411}$

In the case of Dudnikov v. Chalk \& Vermillion Fine Arts Inc., the 'focal point' approach has been applied to determine jurisdiction in an online copyright infringement dispute. ${ }^{2412}$ In this case, the United States Court of Appeals for the Tenth Circuit held that the 'express aiming' prong of the Calder effects test focuses on whether the "focal point" of the defendant's "purposive efforts" had been aimed at the forum state. ${ }^{2413}$

\footnotetext{
${ }^{2404}$ See, inter alia, IMO Indus, Inc. v. Kiekert AG, 155 F. 3d 254 at 265 (3 ${ }^{\text {rd }}$ Cir. 1998).

${ }^{2405}$ Burger King Corp. v. Rudzewicz, 471 U.S. 462 at 475 (1985). See also Hanson v. Denckla, 357 U.S. 235 at 253 (1958); Keeton v. Hustler Magazine, 465 U.S. 774 (1984); World-Wide Volkswagen Corp v. Woodson, 444 U.S. 286 at 299 (1980).

2406 See paragraph 5.2.4.

${ }^{2407}$ See case law referred to in the case of Griffis v. Luban, 646 N.W. 2d 527, 533-34 (Minn. 2002).

${ }^{2408}$ See the Tenth Circuit Court of Appeals in the case of Far West Capital, Inc. v. Towne, 46 F.3d 1071, 1080

(10 $0^{\text {th }}$ Cir. 1995). Retchless 2011, p. 417. See also Griffis v Luban, 646 N.W. 2d 527 (Minn. 2002).

${ }^{2409}$ IMO Indus, Inc. v. Kiekert AG, 155 F.3d 254 ( $3^{\text {rd }}$ Cir. 1998).

${ }^{2410}$ IMO Indus, Inc. v. Kiekert $A G, 155$ F.3d 254 at 265 ( $3^{\text {rd }}$ Cir. 1998).

${ }^{2411}$ IMO Indus, Inc. v. Kiekert AG, 155 F.3d 254 at 266 ( $3^{\text {rd }}$ Cir. 1998).

${ }^{2412}$ Dudnikov v. Chalk \& Vermillion Fine Arts, Inc., 514 F.3d 1063 (10 ${ }^{\text {th }}$ Cir. 2008).

${ }^{2413}$ Dudnikov v. Chalk \& Vermillion Fine Arts, Inc., 514 F.3d 1063 at 1075 (10 ${ }^{\text {th }}$ Cir. 2008).
} 
Courts provided the following arguments for the 'focal point' approach. The Court of Appeals for the Third Circuit argued that the Calder ruling did not "carve out a special intentional torts exception to the traditional specific jurisdiction analysis, so that the plaintiff could always sue in his or her home state". 2414 "The focus of the jurisdictional inquiry in intentional torts has to be on the relations among the defendant, the forum, and the litigation." 2415 The Supreme Court of Minnesota reasoned that a broad interpretation of the Calder effects test would not correspond with the settled case law of the United States Supreme Court that the foreseeability of causing an injury in the forum state is not a "sufficient benchmark" for exercising personal jurisdiction. ${ }^{2416}$

\subsection{Assessing the 'focal point' approach}

The following paragraphs will assess the abovementioned three-pronged 'focal point' approach of the IMO Industries test in light of the assessment framework of paragraph 4.6 in order to be employed under Article 7(2) Brussels Ibis in cross-border copyright infringement cases. Several approaches to jurisdiction that have been demonstrated in chapter six can be identified in the 'focal point' approach. According to the first prong of the 'focal point' approach set out by the Court of Appeals for the Third Circuit, the so-called IMO Industries test, the defendant should have committed an intentional tort. ${ }^{2417}$ As mentioned in paragraph 6.2.4.2, De Boer has suggested to add the 'intentional tort' criterion to the 'victim's centre of interests' approach to provide predictability as regards where the defendant may get sued.

The second prong of the IMO Industries test requires that "the plaintiff felt the brunt of the harm in the forum such that the forum can be said to be the focal point of the harm suffered by the plaintiff as a result of that tort". ${ }^{2418}$ The second prong can be denoted as the "focal point of the harm' criterion. This criterion is reminiscent of the criterion under Article 2:203(2)(b) CLIP that the harm caused by the infringement in the forum state "has been substantial in relation to the infringement in its entirety". 2419

As the 'focal point' approach confers jurisdiction to the court of the state where the focal point of the harm has been suffered by the copyright holder, it can be assumed that the 'focal point' approach will provide jurisdiction regarding the entire copyright infringement dispute. ${ }^{2420}$ The 'focal point' approach seems to provide full jurisdiction regardless of whether the alleged copyright infringement has been disseminated via the Internet. As demonstrated in

\footnotetext{
${ }^{2414}$ IMO Indus, Inc. v. Kiekert $A G, 155$ F. 3d 254 at 265 ( $3^{\text {rd }}$ Cir. 1998).

2415 The United States Courts of Appeals for the Third Circuit referred in the case of Imo Indus, Inc. v. Kiekert AG, 155 F.3d 254 and the case of Shaffer v. Heitner, 433 U.S. 186 at 204 (1977). See also Walden v. Fiore, 571 U.S. 277, 134 S. Ct. 1115 (2014).

${ }^{2416}$ Griffis v. Luban, 646 N.W. 2d 527, 534 (Minn. 2002) referring to World-Wide Volkswagen Corp v. Woodson, 444 U.S. 286 at 295 (1980). See also Burger King Corp. v. Rudzewicz, 471 U.S. 462 at 474 (1985).

${ }^{2417}$ See IMO Indus, Inc. v. Kiekert AG, 155 F.3d 265 ( ${ }^{\text {rd }}$ Cir. 1998). See paragraph 7.5.1.2 on the 'focal point' approach established by the Court of Appeals for the Third Circuit.

${ }^{2418}$ See IMO Indus, Inc. v. Kiekert AG, 155 F.3d 265 ( ${ }^{\text {rd }}$ Cir. 1998). See paragraph 7.5.1.2 on the 'focal point' approach established by the Court of Appeals for the Third Circuit.

${ }^{2419}$ See paragraph 6.4.5.

${ }^{2420}$ See paragraph 5.3.4.1 on the analogue application of the single publication rule in cross-border copyright infringement disputes.
} 
paragraph 5.3.4.1, it has been argued in the United States of America to confer full jurisdiction in cross-border copyright infringement disputes based on the so-called single publication rule.

While the third prong of the IMO Industries test is reminiscent of the 'directed activities' approach as explained in paragraph 6.1, there are differences. First, the third prong requires that "the defendant expressly aimed his tortious conduct at the forum such that the forum can be said to be the focal point of the tortious activity", referred to as the "focal point of the tortious activities' criterion. ${ }^{2421}$ Second, the plaintiff must also show that the defendant knew that the plaintiff would suffer the brunt of the harm caused by the tortious conduct in the forum. ${ }^{2422}$ The latter connecting factor resembles the so-called knowledge criterion suggested by De Boer. ${ }^{2423}$

\subsection{The principle of predictability}

Due to the knowledge criterion and the 'focal point of the purposive efforts' criterion, the infringer will likely predict in which state he can get sued. Yet, the criteria of the 'focal point' approach may require a value-based or extensive assessment that does not guarantee ex ante predictability as regards which court will be competent. With respect to the first prong, the 'intentional tort' criterion, it may be difficult to draw a clear line between intentional and not intentional copyright infringements, or between an infringer who acted 'in good faith' or 'in bad faith'. ${ }^{2424}$ The mere criterion of an intentional copyright infringement will therefore not entail predictability.

According to the second prong, the forum state must be the focal point of the harm suffered by the plaintiff as a result of that tort. The 'focal point of the harm' criterion is an effects-based connecting factor. While the brunt of the harm related to the infringement of the moral side(s) of copyright will generally occur in the state where the copyright holder has been located, the brunt of the harm related to the infringement of the economic side(s) may occur in another state. ${ }^{2425}$ The 'focal point of the harm' criterion may require an extensive assessment of the facts of the case when it is not obvious where the focal point of the harm has been suffered. Hence, the 'focal point of the harm' criterion will not guarantee ex ante predictability.

According to the third prong, the plaintiff has to demonstrate that the alleged infringer knew that he would suffer the brunt of the harm caused by the tortious conduct in the forum state. This knowledge criterion aims to guarantee that copyright infringers can predict to get sued in the forum state. This criterion especially aims to address malicious infringers who purposefully directed their activities to a particular state. This criterion may nonetheless require an extensive assessment of the merits of the case. In addition, this "subjective" criterion may be difficult to prove for the copyright holder. ${ }^{2426}$ It can be difficult to draw a clear line between an infringer

\footnotetext{
${ }^{2421}$ IMO Indus, Inc. v. Kiekert $A G, 155$ F.3d 254 at 265 ( $3^{\text {rd }}$ Cir. 1998).

${ }^{2422}$ IMO Indus, Inc. v. Kiekert $A G, 155$ F.3d 254 at 266 ( $3^{\text {rd }}$ Cir. 1998).

${ }^{2423}$ See paragraph 6.2.4.1.

${ }^{2424}$ See paragraph 6.2.4.2.

${ }^{2425}$ See paragraph 6.2.2.2 on the difference between the localisation of damage caused by infringements of economic rights and moral rights related to copyrights. See also paragraph 6.2.4.3 on the assessment of the 'victim's centre of interests approach' with respect to the close connection requirement between the dispute and the forum state.

${ }^{2426}$ Ferster 2002, p. 359
} 
who acted 'in good faith' or 'in bad faith'. ${ }^{2427}$ The foregoing indicates that the knowledge criterion will not guarantee ex ante predictability as regards where a potential copyright infringer may get sued.

The third prong of the 'focal point' approach also requires that the forum state has been the state where the "focal point" of the defendant's "purposive efforts" have been aimed to. ${ }^{2428}$ The latter so-called focal point of the purposive efforts criterion will yield predictability to the defendant as regards where he may get sued since he will usually know in which state the "focal point" of his "purposive efforts" have been aimed to. Whenever an alleged infringer directed his activities to many states, it may nonetheless be difficult to prove that the forum state can be regarded as the focal point to which the purposive efforts have been aimed to. The latter criterion will therefore not yield ex ante predictability for the copyright holder as regards where the infringer may get sued.

\subsection{A close connection between dispute and court/ sound administration of justice}

The 'focal point' approach guarantees a close connection between the dispute and the court as required under Article 7(2) Brussels Ibis. The court of the state where the focal point of the infringer's purposive efforts have been aimed to and where the copyright holder suffered the focal point of the harm will be in a good position to adjudicate the case. This so-called focal point of the purposive efforts' criterion and the 'focal point of the harm' criterion will even entail a strong territorial connection with the forum state. As mentioned in paragraph 5.3.4.1, Pertegás Sender argued "...it has been submitted that the concentration of litigation requires a strong territorial link between the dispute and the forum". ${ }^{2429}$

Adjudication in a single court generally entails efficient litigation. Nonetheless, it may require an extensive assessment to determine whether the forum state has been the focal point of the harm and whether the "focal point" of the defendant's "purposive efforts" had been aimed at the forum state. ${ }^{2430}$ An extensive assessment of the merits of the case will not suit at the jurisdictional phase under Article 7(2) Brussels Ibis. ${ }^{2431}$ Furthermore, it can put a heavy evidential burden on the plaintiff to prove the knowledge criterion and the 'focal point of the purposive efforts' criterion. ${ }^{2432}$ Particularly when the court appears to be incompetent, this approach does not seem to yield efficient and sound administration of justice.

\footnotetext{
${ }^{2427}$ See paragraph 6.2.4.2.

${ }^{2428}$ Dudnikov v. Chalk \& Vermillion Fine Arts, Inc., 514 F.3d 1063 at 1075 (10 ${ }^{\text {th }}$ Cir. 2008).

${ }^{2429}$ Pertegás Sender 2002, p. 276.

${ }^{2430}$ Dudnikov v. Chalk \& Vermillion Fine Arts, Inc., 514 F.3d 1063 at 1075 (10 ${ }^{\text {th }}$ Cir. 2008). See Ferster 2002, p. 359.

${ }^{2431}$ See paragraph 4.2.4.2.

${ }^{2432}$ IMO Indus, Inc. v. Kiekert AG, 155 F.3d 254 at 266 ( $3^{\text {rd }}$ Cir. 1998). See Ferster 2002, p. 359. See also paragraph 7.5.1.2.1.1.
} 


\subsection{The principle of balancing the interests}

The 'focal point' approach will generally provide a procedural balance between the interests of the litigants. On the one hand, the potential copyright infringer should be able to predict where to get sued due to the knowledge criterion and the 'focal harm of the purposive efforts' criterion. On the other hand, the copyright holder will often be able to sue a malicious infringer in the state where he has been located or has his centre of interests. Particularly in case the infringer is located and operated in a copyright haven, the copyright holder will likely be able to receive efficient and full redress. However, it may nonetheless put a heavy evidential burden on the plaintiff to prove the criteria under the 'focal point' approach and the outcome of the court's assessment of these criteria will not guarantee ex ante predictability as regards which court will be competent.

From a broad perspective, the 'focal point' approach will generally strike a balance between the interests of copyright holders, on the one hand, users of information and traders, on the other hand. In view of copyright havens and online piracy, the 'focal point' approach will enhance copyright protection at procedural level. The knowledge criterion will particularly address malicious infringers. However, this 'subjective' criterion may not always provide suitable copyright protection as it may be difficult to prove whether the alleged copyright infringer acted in good faith or bad faith. The 'focal point of the purposive efforts' criterion will generally yield predictability to providers of information and traders as regards where he may get sued. Hence, the 'focal point' approach to jurisdiction will likely not impede the cross-border flow of information and trade.

\subsection{The Geo-blocking Regulation and the 'focal point' approach}

The influence of the Geo-blocking Regulation on the 'focal point' approach will be limited to certain copyright infringement cases. As demonstrated in paragraph 6.1.4.4, this Regulation only addresses traders who provide their goods or services to customers within the European Union. ${ }^{243}$ Furthermore, certain services are excluded from the prohibitions under the Geoblocking Regulation. ${ }^{2434}$ In particular, traders who offer audiovisual services and electronic services that involve copyright protected content will not be affected by the Geo-blocking Regulation. ${ }^{2435}$

With respect to the 'focal point' approach, the trader's tools to indicate that his activities are not purposefully directed to a particular state will be limited by the prohibitions under the Geo-blocking Regulation. Traders will often not be allowed to block their websites or use different general conditions of access to goods and services based on customers' nationality, place of residence or place of establishment. ${ }^{2436}$ As demonstrated in paragraph 6.1.4.4, the

\footnotetext{
2433 See paragraph 4.5.1.

${ }^{2434}$ See Article 1(3) and Article 4(1)(b) Geo-blocking Regulation. See also recitals 8 and 9 in the preamble to the Geo-blocking Regulation. See paragraph 4.5.2.3.

${ }^{2435}$ Article 1(3) and Article 4(1)(b) Geo-blocking Regulation. See also recitals 8 and 9 in the preamble to the Geoblocking Regulation.

${ }^{2436}$ See paragraph 4.5.2.
} 
trader can nonetheless still indicate that his activities are not directed to a particular state. ${ }^{2437}$ For instance, the trader can limit the delivery of goods to a particular state, use a country code top-level domain name for its website ${ }^{2438}$ or employ a particular language ${ }^{2439}$. As illustrated in paragraph 6.1.4.4, the court seised may have to examine the website in more detail to determine whether the activities have been directed to the forum state.

\subsubsection{The 'individualized targeting' approach}

The Court of Appeals for the Ninth Circuit has construed the Calder effects test broader than the abovementioned 'focal point' approach. ${ }^{2440}$ According to the Court of Appeals for the Ninth Circuit, the Calder effects test consists of the following three-prong test: "the defendant allegedly [must] have (1) committed an intentional act, (2) expressly aimed at the forum state, (3) causing harm that the defendant knows is likely to be suffered in the forum state."2441

In the copyright infringement case of Washington Shoe Company v. A-Z Sporting Goods, the Court of Appeals for the Ninth Circuit gave a special interpretation of the second "express aiming" prong that has been referred to as "individualized targeting". ${ }^{2442}$ In this case the manufacturing company named Washington Shoe Company (hereinafter Washington Shoe), established in Washington, filed a copyright infringement claim in the District Court for the Western District of Washington (hereinafter district court of Washington) against the retailer A-Z Sporting Goods, Inc. (hereinafter A-Z), located in the state Arkansas. Washington Shoe alleged that A-Z infringed their copyrights by selling boots that were designed by Washington Shoe. A-Z used to purchase shoes from Washington Shoe but the alleged copyrighted boots were purchased from a Chinese company and put for sale in their shop in Arkansas. Although Washington Shoe sent several cease and desist letters to A-Z, they nevertheless continued to sell the particular shoes. A-Z claimed that the district court of Washington lacked personal jurisdiction because A-Z did not do business in the state Washington and therefore did not purposefully directed its activities to the forum state.

To determine whether the district court of Washington could exercise personal jurisdiction over A-Z, the Court of Appeals for the Ninth Circuit adopted the abovementioned three-prong Calder effects test. With respect to the first prong, the Court of Appeals held that A-Z committed an intentional act by willfully violating the copyrights of Washington Shoe since A$\mathrm{Z}$ received proper notice that they infringed Washington Shoe's copyrights. ${ }^{2443}$

\footnotetext{
2437 See paragraph 4.5.3.

${ }^{2438}$ Recital 20 in the preamble to the Geo-blocking Regulation.

${ }^{2439}$ Recital 27 in the preamble to the Geo-blocking Regulation.

${ }^{2440}$ According to Rice \& Gladstone (2003, p. 612), the Ninth Circuit employs "a soft effects test".

${ }^{2441}$ See Schwarzenegger v. Fred Martin Motor Co., 347 F. $3 d 797$ at 802, 803 (9 $9^{\text {th }}$ Circuit 2004). See also, inter alia, Dole Food Co. Inc. v. Watts, 303 F.3d 1104 at 1111 (2002). In the case of Yahoo v. La Ligue Contre Le Racisme, 433 F.3d 1199 at 1207 ( $9^{\text {th }}$ Cir. 2006), the Court of Appeals for the Ninth Circuit pointed out that the former formulation of the third prong, that "the brunt of the harm need to be suffered in the forum state, has been disavowed by the Supreme Court.

${ }^{2442}$ Washington Shoe Company v. A-Z Sporting Goods Inc., No. 11-35166 and 11-35206 (9 $9^{\text {th }}$ Cir. 2012).

${ }^{2443}$ The Court of Appeals for the Ninth Circuit noted that in order "to prove willfulness, plaintiffs must show that the infringer had actual or constructive knowledge that it was infringing the plaintiffs' copyrights or else acted in
} 
In regard of the second 'express aiming' prong, the Court of Appeals held that "particularly in the case of a willful copyright infringement, the intentional act constituting the violation may occur solely within one state while the known impact of that copyright infringement is directed at another state". ${ }^{244}$ Even though A-Z did not sell the particular boots in the forum state, the A-Z knew that the impact of the infringing activities would be felt in the forum state. ${ }^{2445}$ Referring to the Penguin case, the Court of Appeals pointed out that a copyright infringement not only entails financial loss but "strikes at the heart of the rights conferred by the Copyright Act, the holder's right to control his copyright on his own terms". 2446 The Court of Appeals concluded that the 'express aiming' prong had been satisfied based on A-Z's "knowledge of both the existence of the copyright and the forum of the copyright holder". ${ }^{2447}$ This interpretation of the 'express aiming' prong has been referred to as "individualized targeting". 2448

According to the Court of Appeals, the third prong had also been satisfied because A-Z could likely have foreseen that the copyright holder would suffer economic harm in the forum state where it has its principal place of business. ${ }^{2449}$

The case of Brayton Purcell, LLP v. Recordon \& Recordon exemplifies the abovementioned broad interpretation of the Calder test in an internet-related copyright infringement case. ${ }^{2450}$ The law firm Brayton Purcell, established in the Northern District of California, alleged that another law firm named Recordon \& Recordon, established in the Southern District of California, made commercial use on its website of copyrighted material derived from Brayton Purcell's website. Recordon \& Recordon appealed the denial of the district court to dismiss the case for lack of personal jurisdiction. The Court of Appeals for the Ninth Circuit applied the abovementioned three-part Calder effects test, with respect to the 'minimum contacts' requirement.

In regard to the second 'express aiming' prong of the Calder effects test, the Court of Appeals required 'something more' than mere foreseeability that the alleged tortious activities would cause effects in the forum state; 'something more' refers to "conduct expressly aimed at the forum". ${ }^{2451}$ The Court of Appeals held that Recordon "individually targeted" Brayton Purcell since he knew of the existence of Brayton Purcell's copyright but made "wilfully,

reckless disregard of high probability that it was infringing plaintiffs' copyrights." See Arclightz \& Films Pvt. Ltd v. Video Palace Inc., 303 F. Supp. 2d 356 at 361-62 (S.D.N.Y. 2003).

${ }^{2444}$ Washington Shoe Company v. A-Z Sporting Goods Inc., No. 11-35166 and 11-35206 (9 ${ }^{\text {th }}$ Cir. 2012).

${ }^{2445}$ The Court of Appeals for the Ninth Circuit referred to the cases of Columbia Pictures Television v Krypton $B C, 106$ F.3d 284 at 289 (9 $9^{\text {th }}$ Cir. 1997) and Calder v. Jones, 465 U.S. 783 at 789-90.

${ }^{2446}$ Penguin Group (USA) Inc. v. Am. Buddha, 946 N.E.2d 159, 165 (N.Y. 2011).

${ }^{2447}$ Washington Shoe Company v. A-Z Sporting Goods Inc., No. 11-35166 and 11-35206 (9 ${ }^{\text {th }}$ Cir. 2012).

${ }^{2448}$ Washington Shoe Company v. A-Z Sporting Goods Inc., No. 11-35166 and 11-35206 (9 th $^{\text {th }}$. 2012). See also Bancroft \& Masters, Inc., v. Augusta National Inc., 223 F.3d 1082 at 1087 ( ${ }^{\text {th }}$ Cir. 2000) related to an online trademark dispute.

${ }^{2449}$ The Court of Appeals for the Ninth Circuit referred to the case of Mavrix Photo v. Inc. Brand Technologies, 647 F.3d 1218 at 1231 ( $9^{\text {th }}$ Cir. 2011).

${ }^{2450}$ Brayton Purcell LLP v. Recordon \& Recordon, 606 F.3d 1082 at 1124 (9 ${ }^{\text {th }}$ Cir. 2010).

${ }^{2451}$ The Court of Appeals in the case of Brayton Purcell LLP v. Recordon \& Recordon referred to the following case law: Pebble Beach Co. v. Caddy, 453 F.3d 1151 at 1156 ( $9^{\text {th }}$ Cir. 2009); Schwarzenegger v. Fred Martin Motors Co., 374 F.3d 797 at 805 (9th Cir. 2004); Bancroft \& Masters, Inc. v. Augusta National, 223 F.3d 1082 at 1087 ( $9^{\text {th }}$ Cir. 2000). 
deliberately and knowingly" commercial use on its website of the copyrighted material for the purpose of competing with Brayton Purcell in the forum state Northern California. ${ }^{2452}$ Similar to the Washington Shoe v. A-Z ruling, the Court of Appeals employed thus the 'individualized targeting' criterion with respect to the second so-called express aiming prong of the Calder effects test.

\subsection{Assessing the 'individualized targeting' approach}

Unlike the 'focal point' approach, the 'individualized targeting' approach does not require that the activities of the alleged infringer are directed to the forum state. The individualized targeting' approach basically confers jurisdiction to the court of the state where the copyright holder has been resided, established, or has his centre of interests provided that the infringer had knowledge of both the existence of the copyright and the forum of the copyright holder.

The 'individualized targeting' approach could thus be regarded as a combination of the 'victim's centre of interests' approach and the knowledge criterion as suggested by De Boer in paragraph 6.2.4.1. In chapter six, the 'victim's centre of interests' approach has already been assessed under Article 7(2) Brussels Ibis in cross-border copyright infringement cases. As argued in paragraph 6.2.4.2, the mere 'victim's centre of interests' approach does not yield predictability to potential copyright infringers as regards where they may get sued. De Boer argued to add the knowledge criterion to guarantee predictability for the defendant. ${ }^{245}$

The following paragraphs will assess the combination of the 'victim's centre of interests' approach and the knowledge criterion in light of the assessment framework of paragraph 4.6 in order to be employ as a legitimate approach under Article 7(2) Brussels Ibis Regulation. Unlike the various 'victim's centre of interests' approaches that have been examined in chapter six, the case law in the previous paragraph demonstrates that the 'individualized targeting' approach appears to be technology neutral. Similar to the 'victim's centre of interests' approaches as discussed in paragraph 6.2, it can be assumed that the 'individualized targeting' approach provides jurisdiction regarding the entire copyright infringement dispute.

\subsection{The principle of predictability}

The combination of the 'victim's centre of interests' approach and the knowledge criterion aims to guarantee that the alleged infringer can only be sued in the forum state if he is aware of both the copyright and the copyright holder's location in the forum state. This combined approach to jurisdiction will therefore likely provide predictability as regards where the potential copyright infringer may get sued. ${ }^{2454}$

Yet, the knowledge criterion entails a value-based assessment of the 'subjective' knowledge of the potential infringer that will not guarantee ex ante predictability as regards

\footnotetext{
${ }^{2452}$ Brayton Purcell LLP v. Recordon \& Recordon, 606 F.3d 1124 at 1130 (9 $9^{\text {th }}$ Cir. 2010).

${ }^{2453}$ See paragraph 6.2.4.2.

${ }^{2454}$ See also De Boer in paragraphs 6.2.4.1 and 6.2.4.2.
} 
where the defendant may get sued. It may also be difficult for the copyright holder to prove whether the alleged copyright infringer acted in good faith or bad faith.

\subsection{A close connection between dispute and court/ sound administration of justice}

As argued in paragraph 6.2.4.3, the 'victim's centre of interests' approach will not guarantee a close connection between the dispute and the court. There will generally be a close connection between the infringement of the moral sides of the copyright and the court of the state where the copyright holder has his centre of interests. Yet, the infringement of economic sides of copyright may not occur in the latter state. ${ }^{2455}$ The infringement of economic rights can be directed to, or cause damage in, another state than the state in which the copyright holder's centre of interests is located. ${ }^{2456}$ Adding the knowledge criterion to the 'victim's centre of interests' approach will not guarantee a close connection between the dispute and the court.

Whenever there is a lack of a close connection between the dispute and the court of the state where the copyright holder has his centre of interests, the court will not be in a good position to assess the facts of the case. With respect to the knowledge criterion, it may be difficult to prove whether the alleged copyright infringer acted in good faith or bad faith. In addition, this criterion may require an extensive assessment of the merits of the case that does not suit the jurisdictional stage.

It has been argued that consolidation of litigation in one single court facilitates efficient litigation and the sound administration of justice. ${ }^{2457}$ As argued in paragraph 6.2.4.1, it is questionable whether the 'centre of interests' approach carries enough weight to justify full jurisdiction. ${ }^{2458}$ Similar to the case of eDate and Martinez, the Penguin ruling argued that the court of the state where the copyright holder has his centre of interests may obtain full jurisdiction in internet-related copyright infringement cases due to the worldwide and instantaneous dissemination via the Internet and the human-right based character of copyrights. ${ }^{2459}$ Yet, as demonstrated above, the combination of the 'victim's centre of interests' approach and the knowledge criterion cannot guarantee a close connection between the crossborder copyright infringement dispute and the court. Therefore, there appears to be a lack of justification to confer full jurisdiction to the court under Article 7(2) Brussels Ibis based on this combined approach.

\footnotetext{
${ }^{2455}$ See paragraph 6.2.2.2 on the difference between the localisation of damage caused by infringements of economic rights and moral rights related to copyrights. See also paragraph 6.2.4.3 on the assessment of the 'victim's centre of interests approach' with respect to the close connection requirement between the dispute and the forum state.

${ }^{2456}$ Opinion of Advocate General Jääskinen delivered on 13 June 2013 in the case C-170/12 Peter Pinckney v. KGD Mediatech AG, para. 70. See also Opinion of Advocate General Cruz Villalón delivered on 11 September 2014 in the case C-441/13 Pez Hejduk v. EnergieAgentur. NRW GmbH, para. 26-27. See also Lopez-Tarruella 2012, p. 341 .

2457 See paragraph 5.3.1.

${ }^{2458}$ De Groote 2004, p. 257. See paragraph 5.3.4.1.

${ }^{2459}$ See paragraph 7.3.2.1.1.
} 


\subsection{The principle of balancing the interests}

Adopting the 'individualized targeting' approach seems to strike a procedural balance between the copyright holder and the alleged infringer. In case of a malicious infringer, this approach will likely provide the copyright holder the possibility to sue in the so-called home state. It may, however, sometimes be burdensome for the copyright holder to prove that the infringer was in bad faith. Contrary to the mere 'victim's centre of interests' approach, ${ }^{2460}$ the knowledge criterion aims to guarantee that the potential copyright infringer can predict to get sued in the state where the copyright holder centre of interests has been located. It will also be advantageous to the infringer to get sued before one court instead of multiple courts.

From a broad perspective, the 'individualized targeting' approach appears to balance the interests of copyright holders, on the one hand, and users of information and traders, on the other hand. This approach will enhance copyright protection as malicious infringers can often be sued in the state of the copyright holder's centre of interests for the entire damage or to obtain a cross-border injunction to cease the infringement. Particularly in view of copyright havens and online piracy of copyrights, the knowledge criterion will increase the possibility of a fair balance between the interests of copyright holders and malicious infringers. Furthermore, this criterion will generally provide predictability to traders and users of information as regards where they may get sued. Therefore, this criterion will likely not impede cross-border trade or the flow of information.

\subsection{The Geo-blocking Regulation and the 'individualized targeting' approach}

The prohibitions under the Geo-blocking Regulation will not affect the 'individualized targeting' approach since this approach focuses on whether the alleged infringer knew the copyright holder and the location of the copyright holder's centre of interests. It is therefore not important whether the alleged copyright infringer blocked the access to his website, or employed other forms of discrimination, with respect to customers of the state where the copyright holder's centre of interest has been located. Even if the alleged copyright infringer blocked his website for customers of the state where the copyright holder's centre of interests has been located, the court in the latter state can obtain jurisdiction based on the 'individualized targeting' approach as long as the knowledge criterion has been satisfied.

\subsubsection{The Zippo approach}

The United States Supreme Court has not (yet) established a special test to determine personal jurisdiction involving internet-related contacts. ${ }^{2461}$ In the beginning of the Internet, a few courts in the United States of America established jurisdiction solely based on the website's

\footnotetext{
${ }^{2460}$ See paragraph 6.2.4.2.

${ }^{2461}$ Kleven 2018, p. 785. In the case of Walden v. Fiore, 571 U.S. 277, 134 S. Ct. 1115 (2014), the Supreme Court of the United States emphasised that they leave "questions whether and how a defendant's virtual 'presence' and conduct translate into 'contacts' with a particular State" for another day (see footnote 9).
} 
accessibility to the forum state residents. ${ }^{2462}$ Some courts, on the other hand, plainly denied jurisdiction over internet-related contacts. ${ }^{2463}$ Based on the International Shoe ruling, courts have generally employed the ensuing three-pronged constitutional test as demonstrated in paragraph 7.4. ${ }^{2464}$ With respect to the 'minimum contacts' requirement of this test, several courts have been applying the technology neutral Calder effects approach to internet-related copyright infringement disputes. ${ }^{2465}$ There are, however, courts that have adopted a technologybased approach to assess the 'minimum contacts' requirement regarding internet-related activities namely the so-called Zippo approach that will be demonstrated below.

In 1997, the United States District Court for the Western District of Pennsylvania established the so-called Zippo test in the case of Zippo Manufacturing Co v. Zippo Dot Com involving an alleged online trademark infringement. ${ }^{2466}$ In this case, the United States District Court for the Western District of Pennsylvania held that the website of the defendant named Zippo indicated that it had been doing business over the Internet as it maintained actively contact with its subscribers and internet access providers in Pennsylvania. ${ }^{2467}$ Based on "the purposeful availment of doing business in Pennsylvania", the 'minimum contacts' requirement to establish jurisdiction had been satisfied. ${ }^{2468}$

To determine the 'minimum contacts' requirement to establish jurisdiction, the United States District Court for the Western District of Pennsylvania formulated the so-called Zippo test that focuses on "the nature and quality of commercial activity that an entity conducts over the Internet". ${ }^{2469}$ Hence, the Zippo test consists of a "sliding scale" that indicates three categories of websites based on the interactivity of the activities. ${ }^{2470}$ At one end of the spectrum are the so-called active websites through which the defendant is actively doing business with users by "knowing and repeated transmission of the computer files over the internet". ${ }^{2471}$ In any country where these types of websites are accessible the 'minimum contacts' requirement is by definition satisfied.

At the opposite end of the spectrum are the so-called passive websites that provide only information, for example advertisements, without any possibility for users to make online inquiries. $^{2472}$ These passive websites do not establish 'minimum contacts'; therefore, no jurisdiction can be exercised over a non-resident defendant who is acting through passive

\footnotetext{
${ }^{2462}$ Inset Systems, Inc v. Instruction Set, Inc., 937 F. Supp. 161 at 165 (D. Conn.1996); Maritz, Inc. v. Cybergold, Inc., 947 F. Supp.1328 at 1332-33 (E.D. Mo 1996).

${ }^{2463}$ See Swedlow 1997, pp. 361-365.

${ }^{2464}$ See, for example, CompuServe, Inc. v. Patterson, 89 F.3d 1257 (6 $6^{\text {th }}$ Cir. 1996). See Logue 1997, pp. 12311254.

${ }^{2465}$ See Brayton Purcell LLP v Recordon \& Recordon, 606 F.3d 1124 (9 ${ }^{\text {th }}$ Cir. 2010); Mavrix Photo v. Inc. Brand Technologies, 647 F.3d 1218 ( $9^{\text {th }}$ Cir. 2011).

${ }^{2466}$ Zippo Manufacturing Co. v. Zippo Dot Com, Inc., 952 F. Supp. 1119 (W.D. Pa. 1997).

${ }^{2467}$ Zippo Manufacturing Co. v. Zippo Dot Com, Inc., 952 F. Supp. 1119 at 1126 (W.D. Pa. 1997).

${ }^{2468}$ Zippo Manufacturing Co. v. Zippo Dot Com, Inc., 952 F. Supp. 1119 at 1126 (W.D. Pa. 1997).

${ }^{2469}$ Zippo Manufacturing Co. v. Zippo Dot Com, Inc., 952 F. Supp. 1119 at 1124 (W.D. Pa. 1997).

${ }^{2470}$ Zippo Manufacturing Co. v. Zippo Dot Com, Inc., 952 F. Supp. 1119 at 1124 (W.D. Pa. 1997).

${ }^{2471}$ Zippo Manufacturing Co. v. Zippo Dot Com, Inc., 952 F. Supp. 1119 at 1124 (W.D. Pa. 1997). The United States District Court for the Western District of Pennsylvania referred as illustration for this category of websites to the case of CompuServe, Inc. v. Patterson, 89 F.3d 1257 ( $6^{\text {th }}$ Cir. 1996).

2472 Zippo Manufacturing Co. v. Zippo Dot Com, Inc., 952 F. Supp. 1119 at 1124 (W.D. Pa. 1997).
} 
websites. ${ }^{2473}$ In the middle of the spectrum are the so-called interactive websites that provide the defendant the possibility to exchange information with users of the website. ${ }^{2474}$ Whether these websites can establish jurisdiction depends on "the interactivity and commercial nature of the exchange of information that occurs on these website". ${ }^{2475}$ Several United States courts have been applying the Zippo test to assess the 'minimum contacts' requirement regarding internet-related contacts. ${ }^{2476}$

The case of Mink v. AAAA Development LLC exemplifies the application of the Zippo test with respect to a copyright infringement dispute. ${ }^{2477}$ This case concerned a non-resident defendant who maintained a website involving advertisements that offered alleged copyrighted products for sale. The website contained information about these products, a printable mail-in order form, an email address, and a telephone number for further information. But the website did not provide the residents of the forum state the possibility to directly order or purchase the alleged copyrighted products via the website. The Court of Appeals for the Fifth Circuit concluded that the court could not obtain jurisdiction based on this passive website. ${ }^{2478}$

In the case of Jagex Limited $v$. Impulse Software, the owner of an interactive computer game named Jagex alleged that the company Impulse Software infringed Jagex's copyrights on software programs by selling this software via the Internet. ${ }^{2479}$ The District Court for the District of Massachusetts held that the Zippo test had to be applied to assess personal jurisdiction "in cases involving internet commerce". ${ }^{2480}$ The district court characterised the website as interactive because it enabled the residents of the forum state to sign electronics contracts and exchange payment information to purchase the software codes. Hence, the district court established jurisdiction by ruling that the defendant purposefully availed himself of the privileges of the forum state. ${ }^{2481}$

Based on similar case law, it appears that the 'minimum contacts' requirement has been satisfied under the Zippo approach when residents of the forum state have been able to purchase the alleged copyrighted products directly through the defendant's website. ${ }^{2482}$ Even if the residents of the forum state did not actually buy alleged copyright infringing products via the

${ }^{2473}$ See, inter alia, Cybersell, Inc. v. Cybersell, Inc., 130 F. 3d. 414 at 418-419 (9 $9^{\text {th }}$ Cir. 1997); Bensusan Restaurant v. Corp. v. King, 937 F. Supp. 295 (S.D.N.Y. 1996) aff'd 126 F. 3 d 25 (2d Cir. 1997); Weber v. Jolly Hotels, 977 F. Supp. 327 (D.N.J. 1997).

${ }^{2474}$ Zippo Manufacturing Co. v. Zippo Dot Com, Inc., 952 F. Supp. 1119 at 1124 (W.D. Pa. 1997).

2475 Zippo Manufacturing Co. v. Zippo Dot Com, Inc., 952 F. Supp. 1119 at 1124 (W.D. Pa. 1997). The United States District Court for the Western District of Pennsylvania referred to the case of Maritz, Inc. v. Cybergold, Inc., 947 F. Supp. 1328 (E.D. Mo 1996). See also Snowney v. Harrah's Entertainment, Inc., 35 Cal $4^{\text {th }} 1054$ (2006). ${ }^{2476}$ See Gedid 1999; Reymond 2013, p. 240. See also Berman 2002, p. 415, note 427 on the case law related to the Zippo test. See also Geist 2001, p. 1367, note 114 on the case law related to the Zippo test.

${ }^{2477}$ Mink v. AAAA Development LLC, 190 F. 3d. 333 (5 ${ }^{\text {th }}$ Cir. 1999).

${ }^{2478}$ Mink v. AAAA Development LLC, 190 F. 3d. 337 (5 ${ }^{\text {th }}$ Cir. 1999).

2479 Jagex Limited v. Impulse Software, 750 F. Supp. 2d 228 at 233 (D. Mass. 2010).

${ }^{2480}$ Jagex Limited v. Impulse Software, 750 F. Supp. 2d 228 at 233 (D. Mass. 2010).

${ }^{2481}$ Jagex Limited v. Impulse Software, 750 F. Supp. 2d 228 at 233 (D. Mass. 2010).

${ }^{2482}$ Images of the World, Inc. v. Continental American Industries, Inc., No. 04C 7002, 2005 WL 2171193 (N.D. III. Aug. 30, 2005); Columbia Pictures Industries, Inc. v. Fysh, No. 5:06-CV-37, 2007 WL541988 (W.D. Mich. Feb. 16, 2007). 
(inter)active website, the court of the state in which this website has been accessible may establish jurisdiction. ${ }^{2483}$

\subsubsection{Assessing the Zippo approach}

The Zippo approach seems to resemble the accessibility approach that confers jurisdiction based on the mere accessibility of the alleged copyright infringing content via the Internet. Yet, according to the Zippo approach, the court may only obtain jurisdiction in copyright infringement cases that involve so-called interactive or active websites. In commercial-related copyright infringement cases, the case law in paragraph 7.5.2 demonstrates that the website involved has to enable customers to buy the copyright infringing content or products via the Internet. Similar to the accessibility approach, the Zippo approach has been assumed to provide territorially limited jurisdiction to the competent court.

The following paragraphs will examine the Zippo approach to jurisdiction in light of the assessment framework of paragraph 4.6 in order to be employed under Article 7(2) Brussels Ibis in cross-border copyright infringement cases.

\subsection{The principle of predictability}

Several scholars argued that the sliding scale of the Zippo approach causes unpredictability because it is too vague and not well defined. ${ }^{2484}$ While the Zippo test was established at the onset of the Internet, it is nowadays more difficult and time-consuming to draw a line between inactive and active websites. ${ }^{2485}$ It has been argued that the majority of websites can be regarded as active. ${ }^{2486}$ In view of "the ever-changing technological environment", the Zippo sliding scale will not provide legal certainty. ${ }^{2487}$ The foregoing indicates that the Zippo approach will likely not provide sufficient predictability to potential copyright infringers and copyright holders as regards which court may be competent.

\subsection{A close connection between dispute and court/ sound administration of justice}

Jurisdiction based on the mere (inter)activity of the website involving the copyright infringing activities will not guarantee a close connection between the dispute and the court. Compared to the mere accessibility approach, the Zippo approach will nonetheless likely entail

\footnotetext{
${ }^{2483}$ See also the case of Images of the World, Inc. v. Continental American Industries in which the district court referred to the case of International Star Registry v. Bowman-Haight Ventures, Inc., 1999 U.S. Dist. LEXIS 7009 at 20 .

${ }^{2484}$ Reymond 2013, p. 241. See also Beldner 2011, pp. 330-331; Condlin 2004, pp. 137, 146; Geist 2001, pp. 13791380; Yokoyama 2005, pp. 1166-1167.

${ }^{2485}$ Geist 2001, p. 1379. See also Beldner 2011, p. 131. Beldner referred to the case of Sportchannel New Engeland Ltd. P'Ship v. Fancaster, Inc., No. 09cv 11884-NG 2010 WL 3895177 dt •5 (D. Mass Oct 1, 2010) in which the judge Gertner pointed out the risk that "the increased interactivity of websites today might lead to universal personal jurisdiction under Zippo."

${ }^{2486}$ Geist 2001, p. 1380; Reymond 2013, pp. 241-242.

${ }^{2487}$ Geist 2001, p. 1380. See also Van der Hof 2002, p. 76.
} 
a closer connection between the dispute and the court with respect to commercial-related copyright infringement cases; since the website involved has to enable customers in the forum state to buy the copyright infringing content or products via the Internet ${ }^{2488}$.

The Zippo approach will not enhance the sound administration of justice as the court may not be in the best position to assess the facts of the copyright infringement dispute. Due to the territorially limited jurisdiction, the Zippo approach may yield multiple of competent courts which increases the risk of forum shopping and irreconcilable decisions.

\subsection{The principle of balancing the interests}

The Zippo approach will frequently not balance the procedural interests of the copyright holder and the infringer. If the alleged copyright infringing activities have been committed via so-called passive websites, the copyright holder will not be able to sue the infringer in another state than the forum rei. When the latter infringing activities have been directed to a particular state, it appears unreasonable that the copyright holder cannot sue the infringer in that state. Due to the vague Zippo test, the alleged copyright infringer may not be able to predict where he can get sued. Furthermore, due to the territorial limited approach to jurisdiction, the alleged copyright infringer may need to appear before courts in multiple states. Multistate litigation or suing the infringer in the forum rei, or the Handlungsort, may put an unreasonable burden on the copyright holder, particularly in case the infringer is located and operated in a copyright haven.

From a broad perspective, the Zippo approach does not seem to balance the interests of copyright holders, on the one hand, and users of information and traders, on the other hand. As demonstrated above, this approach will not guarantee efficient copyright protection at procedural level. To prevent getting sued in multiple states based on the interactivity of the website, providers of information may block their websites for certain Member States which will impede the cross-border flow of information. The vague Zippo test may also discourage traders to sell their products via (inter)active websites to customers in Member States which will have a negative effect on e-commerce. ${ }^{2489}$ It will particularly cause financial distress to small companies to get sued in multiple states. As will be demonstrated in the next paragraph, the trader's tools to prevent jurisdiction on the basis of the Zippo approach will generally be limited by the Geo-blocking Regulation.

\subsection{The Geo-blocking Regulation and the Zippo approach}

This paragraph will consider the impact of the Geo-blocking Regulation on the Zippo approach to jurisdiction in cross-border copyright infringement cases. As explained in paragraph 6.1.4.4, the effect of the Geo-blocking Regulation will be limited to certain crossborder copyright infringement cases. First, the Geo-blocking Regulation only addresses traders

\footnotetext{
${ }^{2488}$ See paragraph 7.5.2.

${ }^{2489}$ Geist 2001, p. 1378; Illar 2010, p. 14.
} 
who provide their goods and certain services to customers within the European Union. ${ }^{2490}$ Second, as explained in paragraph 4.5.2.3, many services are excluded from the prohibitions under the Geo-blocking Regulation. ${ }^{2491}$ From a perspective of copyright infringing content, it is particularly relevant that audiovisual services and electronically services that contain copyright protected content are (for now) excluded from the prohibitions of the Geo-blocking Regulation. ${ }^{2492}$

As explained in paragraph 5.2.4.3, the Geo-blocking Regulation will often affect the approach to jurisdiction based on the accessibility of the website involved. Due to this Regulation, traders who operate websites within the European Union will generally not be allowed to block or limit their access anymore. ${ }^{2493}$ The risk to get sued on the basis of the Zippo approach will therefore be increased. As explained in paragraph 7.5.2.1.1, the Zippo approach causes unpredictability as regards where potential copyright infringers may get sued. Particularly small companies may therefore hesitate to sell their goods and services online to customers in the European Union Member States.

\subsubsection{The targeting approach}

Previous paragraphs demonstrated that various interpretations of the 'express aiming' prong of the Calder effects test contain the condition that the defendant has targeted the forum state. ${ }^{2494}$ Pursuant to scholars and several courts of states of the United States of America, the so-called targeting approach has been identified as a separate approach to assess whether there are sufficient 'minimum contacts' to establish jurisdiction. ${ }^{2495}$ There has been no uniform definition of the requirement of targeting. ${ }^{2496}$ According to Geist, the courts must focus on "the intentions of parties and to assess the steps taken to either enter or avoid a particular jurisdiction". ${ }^{2497}$ Condlin argued that the concept of targeting "requires a kind of 'geographical marker" "in the defendant's alleged infringing activities, referred to as "geo-targeting". 2498 "A geographical reference does not invariably evidence a wilful or malicious state of mind."2499 The foregoing indicates that the targeting approach seems to focus on the objective intention of the defendant to target the residents of a particular state.

\footnotetext{
${ }^{2490}$ See paragraph 4.5.1.

${ }^{2491}$ Article 1(3) and Article 4(1)(b) Geo-blocking Regulation. See also recitals 8 and 9 in the preamble to the Geoblocking Regulation.

${ }^{2492}$ Article 1(3) and Article 4(1)(b) Geo-blocking Regulation. See also recitals 8 and 9 in the preamble to the Geoblocking Regulation. See also Article 9 Geo-blocking Regulation on the review in May 2020.

${ }^{2493}$ See paragraph 4.5.2.3 on certain services that are excluded from the scope of the Geo-blocking Regulation.

${ }^{2494}$ See paragraph 7.5.1.2 on the 'focal point' approach and paragraph 7.5.1.3 on the 'individualized targeting' approach.

${ }^{2495}$ Geist 2001, pp. 1380-1405; Hestermeyer 2006, pp. 279-288. See also Boone 2006, pp. 265-271; Meehan 2008, p. 358. See, for instance, Stewart v. Vista Point Verlag, 56 U.S.P.Q. 2d 1842 (S.D.N.Y. 2000); ALS Scan, Inc. v. Digital Service Consultants, Inc. 293 F.3d 707 (4 ${ }^{\text {th }}$ Cir. 2002). See also case law Geist 2001, pp. 1381-1382.

2496 See Illar 2004, p. 14

2497 Geist 2001, p. 1380.

${ }^{2498}$ Condlin 2004, p. 145.

${ }^{2499}$ Condlin 2004, p. 144. Geist pointed out that the "targeting factor assesses the knowledge the parties had or ought to have had about the geographic location of the online activity" See Geist 2001, p. 1402.
} 
According to several scholars, the targeting approach compels the court to ascertain all circumstances of the case to determine the defendant's intent, referred to as a "totality-of-the circumstances analysis". ${ }^{2500}$ To provide more legal certainty, scholars have regularly drafted non-exhaustive lists consisting of factors that may indicate whether a website targeted the forum state such as the language used; the currencies required; ${ }^{2501}$ disclaimers; the usage of geolocation technologies; top-level domain used; ${ }^{2502}$ market participation. ${ }^{2503}$

\subsubsection{Assessing the targeting approach}

The targeting approach bears similarities with the 'directed activities' approach as set out in paragraph 6.1. Both approaches compel the court seised to consider all circumstances of the case. In addition, the courts have to assess objective elements related to geographic locations such as the language used or the top-level domain name of the website. Similar to the 'directed activities' approach, the targeting approach seems to rely on the 'objective' intention of the defendant to target the residents of a particular state.

The targeting approach nonetheless appears to be quite broad since it has been argued that this approach is "flexible enough to consider the particularities of each case". ${ }^{2504}$ As mentioned in the previous paragraph, the targeting approach has also been referred to as the "totality-ofthe circumstances analysis'. The foregoing reflects the difference between the common law and civil law-based approaches to jurisdiction. While the common law-based system in the United States of America aims to enhance litigational fairness by taking into account the particular circumstances of individual cases, the civil law-based systems in the Europe Union mainly purport to provide legal certainty and predictability through clear abstract rules. ${ }^{2505}$

This dissertation will assume that the targeting approach provides territorially limited jurisdiction such as the 'directed activities' approach demonstrated in paragraph 6.1. Furthermore, the targeting approach can be considered as technology neutral. ${ }^{2506}$ In view of new technologies, Geist pointed out that the technological neutrality of the targeting test will provide legal certainty. ${ }^{2507}$ The following paragraphs will examine the targeting approach in light of the assessment framework of paragraph 4.6.

\footnotetext{
${ }^{2500}$ Illar 2010, p. 14. See also Hestermeyer 2006, p. 279; Meehan 2008, p. 359.

${ }^{2501}$ Rice and Gladstone (2003, p. 653) argued that widely used currencies, like U.S. dollars and Euros, or widely used languages, such as English and Spanish, should not be considered as evidence of targeting.

2502 "The top-level domain refers to the last part of a domain name." Unlike 'com', a country code such as 'fr' can tie the website to a geographic location. See Meehan 2008, p. 359.

${ }^{2503}$ Meehan 2008, p. 359. See also Illar 2010, p. 14; Hestermeyer 2006, pp. 286-287; Kohl 2010, p. 137.

${ }^{2504}$ Hestermeyer 2006, p. 286.

${ }^{2505}$ With respect to designing provisions of jurisdiction applicable to multistate litigation, Von Mehren argued that there need to be a balance between the formal policies of ease of administration and predictability, on the one hand, and litigational fairness related to normative issues, on the other hand. He noted that common law judges generally give greater weight to litigational justice than civil law judges who are ought to apply the legal rules in a rather strict sense. See Von Mehren 2007, pp. 51-55.

${ }^{2506}$ Hestermeyer 2006, p. 286.

${ }^{2507}$ Geist 2001, pp. 1384-1385.
} 


\subsection{The principle of predictability}

Similar to the 'directed activities' approach, the targeting approach likely yields predictability for parties as regards where the alleged copyright infringer may get sued. ${ }^{2508}$ Since the targeting approach can be considered as more flexible, ${ }^{2509}$ it may entail lesser ex ante predictability as regards which court will be competent. ${ }^{2510}$

\subsection{A close connection between dispute and court/ sound administration of justice}

The targeting approach guarantees a relatively strong connection between the dispute and the court. ${ }^{2511}$ Since the defendant's copyright infringing activities have been directed to the forum state, the court will not obtain jurisdiction based on so-called overspills. ${ }^{2512}$ This court will usually be in a good position to ascertain the damage within the forum state.

From a perspective of sound administration of justice, the targeting approach will generally reduce the number of competent courts and therefore the risk of forum shopping. ${ }^{2513}$ However, in multistate or ubiquitous copyright infringement cases, the targeting approach may lead to multiple competent courts which would entail the "jurisdiction everywhere problem". ${ }^{2514}$ In the latter cases, the targeting approach will increase the risk of forum shopping and irreconcilable decisions that does not facilitate the sound administration of justice.

\subsection{The principle of balancing the interests}

The targeting approach will likely provide a procedural balance between the litigants. On the one hand, the copyright holder may sue the infringer in all states to which his activities are targeted. On the other hand, the infringer will generally expect to be sued in these states. Due to the territorial limited approach to jurisdiction, the alleged infringer may nonetheless get sued in multiple states. In case of multistate or ubiquitous copyright infringements, it can also put a heavy burden on the copyright holder to sue in many states. ${ }^{2515}$ The latter may be particularly unreasonable for the copyright holder if the infringer is located and operated in a copyright haven. ${ }^{2516}$

From a broad perspective, the targeting approach appears to balance the interests of copyright holders, on the one hand, and traders and users of information, on the other hand. The targeting approach will generally enhance copyright protection at procedural level. Furthermore, it yields predictability to traders and providers of information as regards where they may get sued. Compared to the mere accessibility approach to jurisdiction, it has

${ }^{2508}$ Condlin 2004, p. 145. See also Geist 2001, p. 406.

${ }^{2509}$ See paragraph 7.5.3.1.

${ }^{2510}$ See also Hörnle 2009, p. 145.

${ }^{2511}$ Kohl 2010, p. 140.

${ }^{2512}$ See also the assessment of the 'directed activities' approach in paragraph 6.1.4.2.

${ }^{2513}$ See Matulionyte (2015, p. 136) on the 'directed activities' approach in paragraph 6.1.4.2.

2514 Condlin 2004, p. 145.

${ }^{2515}$ See also paragraph 6.1.4.2 on the 'directed activities' approach.

${ }^{2516}$ See also paragraph 6.1.4.2 on the 'directed activities' approach. 
particularly been argued that the targeting approach will keep the Internet more "open". ${ }^{2517}$ The latter will be important for the cross-border flow of information and the proper functioning of the digital economy.

In view of multistate or ubiquitous copyright infringements, the broader interests may not be balanced as a result of the combination of the targeting and mosaic approach. ${ }^{2518}$ As copyright holders may have to sue infringers in many states to get full redress, this approach will not yield efficient copyright protection at procedural level. Hence, this approach will not adequately address the problem of copyright havens and online piracy. The risk to get sued in multiple states may also impede providers to exchange information and discourage traders to sell their products and services in the European Union. The next paragraph will address the possible impact of the Geo-blocking Regulation on the targeting approach.

\subsection{The Geo-blocking Regulation and the targeting approach}

The influence of the Geo-blocking Regulation on the targeting approach will be limited to certain copyright infringement cases. As demonstrated in paragraph 6.1.4.4, this Regulation only addresses alleged copyright infringers who are traders providing their goods or services to customers within the European Union. ${ }^{2519}$ Furthermore, certain services are excluded from the prohibitions under the Geo-blocking Regulation. ${ }^{2520}$ For instance, traders who offer audiovisual services and electronic services that involve copyright protected content will not be affected by the Geo-blocking Regulation. ${ }^{2521}$

The Geo-blocking Regulation prohibits "unjustified geo-blocking and other forms of discrimination based on customers' nationality, place of residence or place of establishment within the internal market". ${ }^{2522}$ The use of geo-location technologies that block or limit the access to residents of a particular state has generally been indicated as one of the factors that denote whether the defendant targeted that state. ${ }^{2523}$ Hence, the Geo-blocking Regulation may reduce the tools of traders to prevent jurisdiction based on the targeting approach. As explained in paragraph 6.1.4.4, traders nonetheless still have other tools to indicate that their activities are not targeted to a particular state. For instance, traders can limit the delivery of goods to a particular state, use a country code top-level domain name for its website ${ }^{2524}$ or employ a particular language ${ }^{2525}$. As illustrated in paragraph 6.1.4.4, due to the Geo-blocking Regulation,

${ }^{2517}$ Kohl 2010, p. 140. See also Stein 2004, p. 412.

${ }^{2518}$ See also paragraph 6.1.4.3 on the assessment of the 'directed activities' approach in light of the principle of balancing the interests involved.

2519 See paragraph 4.5.1.

${ }^{2520}$ See Article 1(3) and Article 4(1)(b) Geo-blocking Regulation. See also recitals 8 and 9 in the preamble to the Geo-blocking Regulation. See paragraph 4.5.2.3.

${ }^{2521}$ Article 1(3) and Article 4(1)(b) Geo-blocking Regulation. See also recitals 8 and 9 in the preamble to the Geoblocking Regulation.

${ }^{2522}$ Regulation (EU) 2018/302 of the European Parliament and of the Council of 28 February 2018 on addressing unjustified geo-blocking and other forms of discrimination based on customers' nationality, place of residence or place of establishment within the internal market and amending Regulations (EC) No 2006/2004 and (EU) 2017/2394 and Directive 2009/22/EC (OJ L 60I, 2.3.2018, pp. 1-15).

2523 See paragraph 7.5.3.

${ }^{2524}$ Recital 20 in the preamble to the Geo-blocking Regulation.

${ }^{2525}$ Recital 27 in the preamble to the Geo-blocking Regulation. 
the court seised may need to examine the trader's activities more thoroughly to assess the targeting approach.

7.6 Table on the assessment of various approaches to jurisdiction in the United States of America

\begin{tabular}{|c|c|c|c|c|}
\hline & $\begin{array}{l}\text { 'focal point' } \\
\text { approach }\end{array}$ & $\begin{array}{l}\text { 'individualized } \\
\text { targeting' } \\
\text { approach }\end{array}$ & $\begin{array}{l}\text { Zippo } \\
\text { approach }\end{array}$ & $\begin{array}{l}\text { targeting } \\
\text { approach }\end{array}$ \\
\hline $\begin{array}{l}\text { Connecting } \\
\text { factors }\end{array}$ & $\begin{array}{l}\text { - 'intentional tort' } \\
\text { criterion } \\
\text { - 'focal point of the } \\
\text { harm' criterion } \\
\text { - 'focal point of the } \\
\text { purposive efforts' } \\
\text { criterion } \\
\text {-knowledge } \\
\text { criterion }\end{array}$ & $\begin{array}{l}\text {-'victim's centre } \\
\text { of interests' } \\
\text { approach } \\
\text {-knowledge } \\
\text { criterion }\end{array}$ & $\begin{array}{l}\text { Sliding scale } \\
\text { test that } \\
\text { focuses on the } \\
\text { nature and } \\
\text { quality of } \\
\text { commercial } \\
\text { activity that } \\
\text { the alleged } \\
\text { infringer } \\
\text { conducts over } \\
\text { the Internet }\end{array}$ & $\begin{array}{l}\text { 'Totality-of-the } \\
\text { circumstances } \\
\text { analysis' }\end{array}$ \\
\hline $\begin{array}{l}\text { Scope of the } \\
\text { court's } \\
\text { jurisdiction }\end{array}$ & Full & Full & $\begin{array}{l}\text { Territorially } \\
\text { limited }\end{array}$ & $\begin{array}{l}\text { Territorially } \\
\text { limited }\end{array}$ \\
\hline $\begin{array}{l}\text { Technology } \\
\text { neutral }\end{array}$ & Yes & Yes & No & Yes \\
\hline $\begin{array}{l}\text { Predictability as } \\
\text { regards which } \\
\text { court may be } \\
\text { competent }\end{array}$ & $\begin{array}{l}\text { No } \\
\text { The knowledge } \\
\text { criterion and the } \\
\text { 'focal point of the } \\
\text { purposive efforts' } \\
\text { criterion will } \\
\text { generally provide } \\
\text { predictability to the } \\
\text { infringer as regards } \\
\text { where he may get } \\
\text { sued. } \\
\text { Yet, the criteria of } \\
\text { the 'focal point' } \\
\text { approach may } \\
\text { require a value- } \\
\text { based or extensive } \\
\text { assessment that } \\
\text { does not guarantee } \\
\text { ex ante } \\
\text { predictability as }\end{array}$ & $\begin{array}{l}\text { No } \\
\text { Although the } \\
\text { knowledge } \\
\text { criterion aims to } \\
\text { provide } \\
\text { predictability, it } \\
\text { may require a } \\
\text { value-based and } \\
\text { extensive } \\
\text { assessment that } \\
\text { does not } \\
\text { guarantee ex ante } \\
\text { predictability. }\end{array}$ & $\begin{array}{l}\text { No } \\
\text { The vague } \\
\text { sliding scale } \\
\text { test provides } \\
\text { less } \\
\text { predictability } \\
\text { as regards } \\
\text { which court } \\
\text { will be } \\
\text { competent. }\end{array}$ & $\begin{array}{l}\text { Yes } \\
\text { However, instead } \\
\text { of relying on } \\
\text { merely objective } \\
\text { factors to indicate } \\
\text { targeting of a } \\
\text { particular state, the } \\
\text { targeting approach } \\
\text { tends to include a } \\
\text { flexible 'totality- } \\
\text { of-the } \\
\text { circumstances } \\
\text { analysis' which } \\
\text { may decrease ex } \\
\text { ante predictability. }\end{array}$ \\
\hline
\end{tabular}




\begin{tabular}{|c|c|c|c|c|}
\hline & $\begin{array}{l}\text { regards which court } \\
\text { will be competent. }\end{array}$ & & & \\
\hline $\begin{array}{l}\text { Close connection } \\
\text { between dispute } \\
\text { and court }\end{array}$ & $\begin{array}{l}\text { Yes } \\
\text { The combination of } \\
\text { the 'focal point of } \\
\text { the harm' criterion } \\
\text { and the 'focal point } \\
\text { of the purposive } \\
\text { efforts' criterion } \\
\text { will entail a strong } \\
\text { territorial link that } \\
\text { could justify the } \\
\text { conferral of full } \\
\text { jurisdiction. }\end{array}$ & $\begin{array}{l}\text { No } \\
\text { The infringement } \\
\text { of economic } \\
\text { rights may be } \\
\text { directed to, or } \\
\text { cause damage in, } \\
\text { another state than } \\
\text { the state in which } \\
\text { the copyright } \\
\text { holder's centre of } \\
\text { interests is } \\
\text { located. }\end{array}$ & $\begin{array}{l}\text { No } \\
\text { Jurisdiction } \\
\text { based on the } \\
\text { mere } \\
\text { (inter)activity } \\
\text { of the website } \\
\text { involving the } \\
\text { copyright } \\
\text { infringing } \\
\text { activities will } \\
\text { not guarantee } \\
\text { a close } \\
\text { connection } \\
\text { between } \\
\text { dispute and } \\
\text { court. }\end{array}$ & $\begin{array}{l}\text { Yes } \\
\text { There will } \\
\text { generally be a } \\
\text { close connection } \\
\text { between dispute } \\
\text { and court. }\end{array}$ \\
\hline $\begin{array}{l}\text { Sound } \\
\text { administration } \\
\text { of justice }\end{array}$ & $\begin{array}{l}\text { No } \\
\text { The connecting } \\
\text { factors of the 'focal } \\
\text { point' approach } \\
\text { may require an } \\
\text { extensive } \\
\text { assessment of the } \\
\text { merits of the case } \\
\text { that does not suit } \\
\text { the jurisdictional } \\
\text { stage. }\end{array}$ & $\begin{array}{l}\text { No } \\
\text { Due to the } \\
\text { possible lack of a } \\
\text { close connection } \\
\text { between the } \\
\text { infringement of } \\
\text { economic rights } \\
\text { and the court of } \\
\text { the state where } \\
\text { the copyright } \\
\text { holder's centre of } \\
\text { interests is } \\
\text { located, the court } \\
\text { may not be in a } \\
\text { good position to } \\
\text { assess the entire } \\
\text { case. } \\
\text { The knowledge } \\
\text { criterion may } \\
\text { require an } \\
\text { extensive } \\
\text { assessment of the } \\
\text { merits of the case } \\
\text { that does not suit } \\
\text { the jurisdictional } \\
\text { stage. }\end{array}$ & $\begin{array}{l}\text { No } \\
\text { Due to the } \\
\text { lack of a close } \\
\text { connection, } \\
\text { the court may } \\
\text { not be in a } \\
\text { good position } \\
\text { to assess the } \\
\text { case. } \\
\text { Based on the } \\
\text { territorially } \\
\text { limited } \\
\text { jurisdiction, } \\
\text { the Zippo } \\
\text { approach may } \\
\text { also yield } \\
\text { multiple of } \\
\text { competent } \\
\text { courts which } \\
\text { increases the } \\
\text { risk of forum } \\
\text { shopping and } \\
\text { irreconcilable } \\
\text { decisions. }\end{array}$ & $\begin{array}{l}\text { Yes } \\
\text { The court will } \\
\text { generally be in a } \\
\text { good position to } \\
\text { assess the facts of } \\
\text { the case. } \\
\text { However, in } \\
\text { ubiquitous or } \\
\text { multistate } \\
\text { copyright } \\
\text { infringement } \\
\text { cases, the targeting } \\
\text { approach may lead } \\
\text { to multiple } \\
\text { competent courts } \\
\text { which will } \\
\text { increase the risk of } \\
\text { forum shopping } \\
\text { and irreconcilable } \\
\text { decisions. }\end{array}$ \\
\hline
\end{tabular}




\begin{tabular}{|c|c|c|c|c|}
\hline $\begin{array}{l}\text { Procedural } \\
\text { balance of } \\
\text { interests between } \\
\text { parties }\end{array}$ & $\begin{array}{l}\text { Yes } \\
\text { On the one hand, } \\
\text { the copyright } \\
\text { holder can often } \\
\text { sue the alleged } \\
\text { infringer in the } \\
\text { state where he has } \\
\text { suffered the focal } \\
\text { point of his harm. } \\
\text { Yet, it may put a } \\
\text { heavy evidential } \\
\text { burden on the } \\
\text { copyright holder to } \\
\text { prove the criteria of } \\
\text { the 'focal point' } \\
\text { approach. } \\
\text { On the other hand, } \\
\text { due to the 'focal } \\
\text { point of the } \\
\text { purposive efforts' } \\
\text { and the knowledge } \\
\text { criteria, the alleged } \\
\text { infringer should } \\
\text { generally be able to } \\
\text { predict where to get } \\
\text { sued. }\end{array}$ & $\begin{array}{l}\text { Yes } \\
\text { On the one hand, } \\
\text { in case of a } \\
\text { malicious } \\
\text { infringer, this } \\
\text { approach will } \\
\text { likely provide the } \\
\text { copyright holder } \\
\text { the possibility to } \\
\text { sue in the so- } \\
\text { called home state. } \\
\text { On the other } \\
\text { hand, the } \\
\text { knowledge } \\
\text { criterion aims to } \\
\text { guarantee that the } \\
\text { potential } \\
\text { copyright } \\
\text { infringer can } \\
\text { predict to get } \\
\text { sued in the state } \\
\text { where the } \\
\text { copyright holder } \\
\text { centre of interests } \\
\text { has been located. }\end{array}$ & $\begin{array}{l}\text { No } \\
\text { In case the } \\
\text { alleged } \\
\text { copyright } \\
\text { infringing } \\
\text { activities } \\
\text { disseminated } \\
\text { via a passive } \\
\text { website that } \\
\text { have been } \\
\text { directed to a } \\
\text { particular } \\
\text { state, it seems } \\
\text { unreasonable } \\
\text { that the } \\
\text { copyright } \\
\text { holder cannot } \\
\text { sue the alleged } \\
\text { infringer in } \\
\text { that state. } \\
\text { Due to the } \\
\text { vague Zippo } \\
\text { test, the } \\
\text { alleged } \\
\text { copyright } \\
\text { infringer may } \\
\text { not predict in } \\
\text { which state he } \\
\text { may get sued. } \\
\text { Due to the } \\
\text { territorially } \\
\text { limited } \\
\text { jurisdiction, } \\
\text { the alleged } \\
\text { infringer may } \\
\text { need to appear } \\
\text { before courts } \\
\text { in multiple } \\
\text { states. } \\
\text { Multistate } \\
\text { litigation or } \\
\text { suing the } \\
\text { infringer in the } \\
\text { forum rei, or } \\
\text { the }\end{array}$ & $\begin{array}{l}\text { Yes } \\
\text { On the hand, the } \\
\text { copyright holder } \\
\text { may sue the } \\
\text { infringer in all } \\
\text { states to which the } \\
\text { activities are } \\
\text { directed. On the } \\
\text { other hand, the } \\
\text { infringer will } \\
\text { generally expect to } \\
\text { be sued in these } \\
\text { states. } \\
\text { However, due to } \\
\text { the territorially } \\
\text { limited } \\
\text { jurisdiction, the } \\
\text { alleged infringer } \\
\text { may need to } \\
\text { appear before } \\
\text { courts in multiple } \\
\text { states. } \\
\text { Multistate } \\
\text { litigation or suing } \\
\text { the infringer in the } \\
\text { forum rei, or the } \\
\text { Handlungsort, } \\
\text { may put an } \\
\text { unreasonable } \\
\text { burden on the } \\
\text { copyright holder, } \\
\text { particularly in case } \\
\text { the infringer is } \\
\text { located and } \\
\text { operated in a } \\
\text { copyright haven. }\end{array}$ \\
\hline
\end{tabular}




\begin{tabular}{|c|c|c|c|c|}
\hline & & & $\begin{array}{l}\text { Handlungsort, } \\
\text { may put an } \\
\text { unreasonable } \\
\text { burden on the } \\
\text { copyright } \\
\text { holder, } \\
\text { particularly in } \\
\text { case the } \\
\text { infringer is } \\
\text { located and } \\
\text { operated in a } \\
\text { copyright } \\
\text { haven. }\end{array}$ & \\
\hline $\begin{array}{l}\text { Balance of } \\
\text { broader interests } \\
\text { involved }\end{array}$ & $\begin{array}{l}\text { Yes } \\
\text { On the one hand, } \\
\text { the 'focal point' } \\
\text { approach will } \\
\text { provide } \\
\text { predictability to } \\
\text { providers of } \\
\text { information and } \\
\text { traders as regards } \\
\text { where they may get } \\
\text { sued. Hence, this } \\
\text { approach will not } \\
\text { impede the cross- } \\
\text { border trade and } \\
\text { flow of } \\
\text { information. } \\
\text { On the other hand, } \\
\text { the 'focal point' } \\
\text { and knowledge } \\
\text { criteria will } \\
\text { enhance copyright } \\
\text { protection, } \\
\text { particularly against } \\
\text { malicious } \\
\text { infringers. } \\
\text { However, the } \\
\text { 'subjective' } \\
\text { knowledge } \\
\text { criterion may be } \\
\text { difficult to prove. }\end{array}$ & $\begin{array}{l}\text { Yes } \\
\text { On the one hand, } \\
\text { the combination } \\
\text { of the knowledge } \\
\text { criterion and the } \\
\text { 'victim's centre } \\
\text { of interests' } \\
\text { approach will } \\
\text { enhance } \\
\text { copyright } \\
\text { protection, } \\
\text { particularly } \\
\text { against malicious } \\
\text { infringers. } \\
\text { On the other } \\
\text { hand, this } \\
\text { combined } \\
\text { approach will } \\
\text { likely not impede } \\
\text { the cross-border } \\
\text { trade and flow of } \\
\text { information as } \\
\text { the knowledge } \\
\text { criterion will } \\
\text { generally enable } \\
\text { potential } \\
\text { copyright } \\
\text { infringers to } \\
\text { predict that they } \\
\text { may get sued in } \\
\text { the state where } \\
\text { the copyright }\end{array}$ & $\begin{array}{l}\text { No } \\
\text { On the one } \\
\text { hand, the } \\
\text { Zippo } \\
\text { approach will } \\
\text { entail } \\
\text { inefficient } \\
\text { copyright } \\
\text { protection at } \\
\text { procedural } \\
\text { level as } \\
\text { infringers who } \\
\text { operate via } \\
\text { passive } \\
\text { websites can } \\
\text { only be sued } \\
\text { in the forum } \\
\text { rei. On the } \\
\text { other hand, } \\
\text { due to the } \\
\text { vague Zippo } \\
\text { test, providers } \\
\text { of information } \\
\text { may block } \\
\text { their } \\
\text { interactive } \\
\text { websites and } \\
\text { traders will be } \\
\text { discouraged to } \\
\text { sell their } \\
\text { products and } \\
\text { services via }\end{array}$ & $\begin{array}{l}\text { Yes } \\
\text { On the one hand, } \\
\text { the targeting } \\
\text { approach will } \\
\text { generally enhance } \\
\text { copyright } \\
\text { protection. On the } \\
\text { other hand, it will } \\
\text { provide } \\
\text { predictability to } \\
\text { traders and } \\
\text { providers of } \\
\text { information as } \\
\text { regards where they } \\
\text { may get sued. } \\
\text { However, in view } \\
\text { of multistate or } \\
\text { ubiquitous } \\
\text { copyright } \\
\text { infringements, the } \\
\text { targeting and } \\
\text { mosaic approach } \\
\text { do not provide } \\
\text { efficient copyright } \\
\text { protection, } \\
\text { particularly in case } \\
\text { of online piracy } \\
\text { and copyright } \\
\text { havens. In } \\
\text { addition, }\end{array}$ \\
\hline
\end{tabular}




\begin{tabular}{|c|c|c|c|c|}
\hline & & $\begin{array}{l}\text { holder's centre of } \\
\text { interests is } \\
\text { located. }\end{array}$ & $\begin{array}{l}\text { (inter)active } \\
\text { websites. } \\
\text { Hence, the } \\
\text { cross-border } \\
\text { flow of } \\
\text { information } \\
\text { and trade will } \\
\text { likely be } \\
\text { impeded. }\end{array}$ & $\begin{array}{l}\text { the cross-border } \\
\text { flow of } \\
\text { information and } \\
\text { trade may be } \\
\text { impeded due to the } \\
\text { fear to get sued in } \\
\text { multiple states. }\end{array}$ \\
\hline $\begin{array}{l}\text { Geo-blocking } \\
\text { Regulation }\end{array}$ & $\begin{array}{l}\text { If the alleged } \\
\text { copyright infringer } \\
\text { has been a trader } \\
\text { who provides } \\
\text { goods and services } \\
\text { that are not } \\
\text { excluded under this } \\
\text { Regulation, the } \\
\text { court seised has to } \\
\text { examine the } \\
\text { trader's activities } \\
\text { more thoroughly to } \\
\text { assess whether the } \\
\text { alleged infringer's } \\
\text { activities have } \\
\text { directed the forum } \\
\text { state. Due to the } \\
\text { prohibitions in the } \\
\text { Geo-blocking } \\
\text { Regulation, the } \\
\text { trader's tools to } \\
\text { prevent directing } \\
\text { activities to } \\
\text { particular European } \\
\text { Union Member } \\
\text { States will be } \\
\text { reduced. } \\
\text {. }\end{array}$ & No effect & $\begin{array}{l}\text { If the alleged } \\
\text { copyright } \\
\text { infringer has } \\
\text { been a trader } \\
\text { who provides } \\
\text { goods and } \\
\text { services that } \\
\text { are not } \\
\text { excluded } \\
\text { under this } \\
\text { Regulation, he } \\
\text { will not be } \\
\text { allowed to } \\
\text { block or limit } \\
\text { the access to } \\
\text { his website. }\end{array}$ & $\begin{array}{l}\text { If the alleged } \\
\text { copyright infringer } \\
\text { has been a trader } \\
\text { who provides } \\
\text { goods and services } \\
\text { that are not } \\
\text { excluded under } \\
\text { this Regulation, } \\
\text { the court seised } \\
\text { has to examine the } \\
\text { trader's activities } \\
\text { more thoroughly } \\
\text { to assess whether } \\
\text { the alleged } \\
\text { infringer's } \\
\text { activities targeted } \\
\text { the forum state. } \\
\text { Due to the } \\
\text { prohibitions under } \\
\text { the Geo-blocking } \\
\text { Regulation, the } \\
\text { trader's tools to } \\
\text { prevent targeting } \\
\text { activities to } \\
\text { particular } \\
\text { European Union } \\
\text { Member States } \\
\text { will be reduced. }\end{array}$ \\
\hline
\end{tabular}




\subsection{The United States Supreme Court rejects a third party-based approach to specific personal jurisdiction}

As demonstrated in chapter five, the CJEU established a third party-based approach to jurisdiction in cross-border copyright infringement cases. ${ }^{2526}$ It has been argued that the CJEU's third party-based approach to jurisdiction does not entail predictability or guarantee a close connection between the dispute and the court as required under Article 7(2) Brussels Ibis. ${ }^{2527}$ The United States Supreme Court's case law appears to reject a third party-based approach to specific personal jurisdiction. ${ }^{2528}$ With respect to the 'minimum contacts' requirement, the United States Supreme Court has repeatedly held that "the unilateral activity of another party or a third person is not an appropriate consideration when determining whether a defendant has sufficient contacts with a forum State to justify an assertion of jurisdiction". ${ }^{2529}$ In the case of Walden v. Fiore, the United States Supreme Court emphasised that "the relationship must arise out of contacts that the "defendant himself creates with the forum State". ${ }^{2530}$ The primary focus of specific personal jurisdiction lies on "the relationship among the defendant, the forum, and the litigation". 2531

The United States Supreme Court's rejection of jurisdiction based on contacts between the plaintiff or third parties and the forum state denotes the pro-defendant approach to jurisdiction in view of due process. The United States Supreme Court argued that "due process limits on the State's adjudicative authority principally protect the liberty of the nonresident defendant not the convenience of plaintiffs or third parties". ${ }^{2532}$ Hence, "due process requires that a defendant be haled into court in a forum State based on his own affiliation with the State, not based on 'random, fortuitous, attenuated' contacts he makes by interacting with other persons affiliated with the State". ${ }^{2533}$ "The defendant's suit-related conduct must create a substantial connection with the forum state". 2534

The foregoing indicates that the United States Supreme Court rejects jurisdiction merely based on activities by third parties in the forum state. In the cases Pinckney and Hi Hotel involving damage caused by third parties in the forum state, ${ }^{2535}$ the United States Supreme

\footnotetext{
${ }^{2526}$ See paragraphs 5.2.3 up to and including 5.2.3.1.4.

${ }^{2527}$ See paragraphs 5.2.3 up to and including 5.2.3.1.4.

${ }^{2528}$ See Walden v. Fiore, 571 U.S. 277, 134 S. Ct. 1115 (2014); Bristol-Myers Squibb Co. v. Superior Court of California, San Francisco County, et Al., 582 U.S. 137 S. Ct. 1773 (2017). See also Hanson v. Denckla, 357 U.S. 235 at 253 (1958); Kulko v. California Superior Court, 436 U.S. 84 at 93 (1978); Helicopteros Nationales de Columbia S.S. v. Hall, 466 U.S. 408 at 417 (1984); World-Wide Volkswagen Corp v. Woodson, 444 U.S. 286 at 298 (1980).

${ }^{2529}$ Helicopteros Nationales de Columbia S.S. v Hall, 466 U.S. 408 at 417 (1984). See also Burger King Corp. v. Rudzewicz, 471 U.S. 462 at 475 (1985); Walden v. Fiore, 571 U.S. 277, 134 S. Ct. 1115 (2014).

${ }^{2530}$ Walden v. Fiore, 571 U.S. 277, 134 S. Ct. 1115 (2014).

${ }^{2531}$ Walden v. Fiore, 571 U.S. 277, 134 S. Ct. 1115 (2014). See also Shaffer v. Heitner, 433 U.S. 186 at 204 (1977); Keeton v. Hustler Magazine, 465 U.S. 770 at 775 (1984).

${ }^{2532}$ Walden v. Fiore, 571 U.S. 277, 134 S. Ct. 1115 (2014). The United States Supreme Court refers to Burger King Corp. v. Rudzewicz, 471 U.S. 462 at 475 (1985). See also Hanson v. Deckla, 357 U.S. 235 at 253-254 (1958).

${ }^{2533}$ In the case of Walden v. Fiore, 571 U.S. 277, 134 S. Ct. 1115 (2014), the United States Supreme Court referred to the case of Burger King Corp. v. Rudzewicz, 471 U.S. 462 at 475 (1985).

${ }^{2534}$ Walden v. Fiore, 571 U.S. 277, 134 S. Ct. 1115 (2014). See also Kulko v. California Superior Court, 436 U.S. 84 at 94 (1978).

2535 See paragraph 5.2.3.
} 
Court would likely have rejected jurisdiction. The case of Walden v. Fiore seems to indicate that the United States Supreme Court also rejects jurisdiction merely based on the plaintiff's residence or activities in the forum state such as the 'victim's centre of interests' or forum actoris approach. ${ }^{2536}$ The earlier discussed 'individualized targeting' approach to jurisdiction ${ }^{2537}$ therefore seems to be called into question. ${ }^{2538}$

\subsection{Concluding remarks}

The United States Supreme Court's aim of the 'minimum contacts' requirement that "the defendant's conduct and connections with the forum must be such that he should reasonably anticipate being haled into the court there" ${ }^{2539}$ appears to resemble one of the main objectives underlying Article 7(2) Brussels Ibis to establish a close connection between the dispute and the court that provides predictability as regards which court will be competent ${ }^{2540}$. Unlike the CJEU, the United States Supreme Court rejected the third party-based approach to jurisdiction as the due process principles require that the defendant himself created activities related to the forum state.

In view of the case law in this chapter, lower courts of states of the United States of America have developed various interpretations regarding the 'minimum contacts' requirement that do not all yield adequate predictability to potential copyright infringers as regards where they may get sued. Most courts require 'something more' than mere effects in the forum state to establish jurisdiction in tort related cases. ${ }^{2541}$ This 'something more' has generally been found in the 'express aiming' prong of the Calder effects test. According to the case law in this chapter, courts have adopted various interpretations of the Calder effects test such as the 'focal point' approach and the 'individualized targeting' approach. It is noteworthy that the latter two approaches are technology neutral. They appear to confer full jurisdiction regardless whether the alleged copyright infringements have been disseminated by ubiquitous media such as the Internet. In view of changing technologies, it has been argued that a technology neutral approach to jurisdiction will provide legal certainty and predictability ${ }^{2542}$.

The decision of the New York Court of Appeals in the case of Penguin v. American Buddha supports the adoption of the 'victim's centre of interest' approach under Article 7(2) Brussels Ibis in online copyright infringement disputes ${ }^{2543}$. As argued in paragraph 6.2.4.2, the 'victim's centre of interests' approach will nonetheless lack predictability to potential copyright infringers as regards where they may get sued. The combination of 'victim's centre of interests'

\footnotetext{
${ }^{2536}$ In the case of Walden v. Fiore, 571 U.S. 277, 134 S. Ct. 1115 (2014), the United States Supreme Court illustrates that the mere place of residence of the plaintiff in the forum state is not sufficient to establish jurisdiction by referring to the case of Calder v. Jones, 465 U.S. 783 (1984).

${ }^{2537}$ See paragraph 7.5.1.3.

${ }^{2538}$ See Chan, Chud \& Weiss 2018.

${ }^{2539}$ See the United States Supreme Court in the case of World-Wide Volkswagen Corp v. Woodson, 444 U.S. 286 at 297 (1980). See also Burger King Corp. v. Rudzewicz, 471 U.S. 462 at 474 (1985).

${ }^{2540}$ See paragraph 4.2.4.2.

${ }^{2541}$ See the case law referred to by the Supreme Court of Minnesota Court in the case of Griffis v. Luban, 646 N.W. 2d 527 at 533 (Minn. 2002).

${ }^{2542}$ See paragraph 6.6.

${ }^{2543}$ See paragraph 6.2.
} 
approach and the knowledge criterion, referred to as the 'individualized targeting' approach, ${ }^{2544}$ could increase predictability for potential copyright infringers. This knowledge criterion will aim to guarantee that the alleged infringer can only be sued in state of the copyright holder's centre of interests if he was aware of the fact that the copyright holder has been located in that state. However, it may require an extensive assessment to determine the 'subjective' knowledge of the alleged copyright infringer which does not fit at the jurisdictional stage under Article 7(2) Brussels Ibis.

Since the combination of the 'victim's centre of interests' approach and the knowledge criterion cannot guarantee a close connection between the copyright infringement dispute and the court, there seems to be a lack of justification to confer full jurisdiction under Article 7(2) Brussels Ibis. ${ }^{2545}$ Considering the 'focal point' approach, the combination of the 'focal point of the harm' and the 'focal point of the purposive efforts' will entail a strong territorial link between the court and the dispute. ${ }^{2546}$ These latter connecting factors are reminiscent of the effects-based approach under Article 2:203(2) CLIP that has been assessed in paragraph 6.4.5.2.

The targeting approach appears to resemble the 'directed activities' approach as demonstrated in paragraph 6.1. Despite the similarities between the targeting and 'directed activities' approach, the latter more objective approach will be preferred under Article 7(2) Brussels Ibis for reasons of legal certainty and predictability.

\footnotetext{
2544 See paragraph 7.5.1.3.1.

${ }^{2545}$ See paragraph 7.5.1.3.1.2.

${ }^{2546}$ See paragraph 5.3.4.1.
} 



\section{Chapter 8}

Conclusion 



\subsection{The necessity to rethink the CJEU's approach to jurisdiction in cross-border copyright infringement cases}

\subsubsection{Legitimate interpretation of Article 7(2) Brussels Ibis in cross-border copyright infringement cases}

First of all, this dissertation aimed to demonstrate the necessity to rethink the CJEU's approach to jurisdiction under Article 7(2) Brussels Ibis in cross-border copyright infringement cases, the so-called Pinckney doctrine. In the context of the issue of judicial activism, ${ }^{2547}$ this dissertation examined whether the CJEU's interpretation could be regarded as legitimate. In view of the textual and historical method of interpretation, the connecting factor 'place where the harmful event occurred or may occur' in Article 7(2) Brussels Ibis seems to provide quite a broad leeway to interpret. From a legitimate perspective, this dissertation nonetheless addressed limitations with respect to the interpretation of Article 7(2) Brussels Ibis in cross-border copyright infringement cases by employing common methods of interpretation namely the teleological and contextual method. ${ }^{2548}$

On the basis of these methods of interpretation, an assessment framework has been set up to examine the CJEU's approach to jurisdiction under Article 7(2) Brussels Ibis in cross-border copyright infringement cases. ${ }^{2549}$ This assessment framework has also been used to examine alternative approaches to jurisdiction in cross-border copyright infringement cases adopted by scholars and courts of European Union Member States and states of the United States of America. ${ }^{2550}$ By studying case law of these courts, this dissertation also employed the comparative method of law. Although the predominantly civil law-based Member States prefer clear abstract rules that yield certainty instead of 'flexible' common law-based methods that seek fairness in litigation, both legal systems favour an approach to jurisdiction that provides predictability as regards where a defendant may get sued. ${ }^{2551}$ In view of the general desire to unify the approach to jurisdiction in cross-border copyright infringement cases at worldwide level, it is also useful to compare the different approaches adopted by both legal systems. ${ }^{2552}$

Considering the teleological method of interpretation, the approach to jurisdiction under Article 7(2) Brussels Ibis in cross-border copyright infringement cases should provide predictability; entail a close connection between the dispute and the court; enhance sound administration of justice; and strike a fair procedural balance between the copyright holder and the alleged infringer. From a legitimate perspective, this dissertation also provided arguments to include the principle of balancing the broader interests of copyright holders, on the one hand,

\footnotetext{
${ }^{2547}$ See paragraph 4.1 .3 on the concept of judicial activism.

2548 See chapter four on the various common methods of interpretation employed to set up the assessment framework of this dissertation.

${ }^{2549}$ See paragraph 4.6.

${ }^{2550}$ See chapters six and seven.

${ }^{2551}$ See paragraph 7.1.

${ }^{2552}$ See paragraph 8.5.2 on the adoption of the desirable approach to jurisdiction as will be demonstrated in this chapter at international level.
} 
and users of information and traders, on the other hand. ${ }^{2553}$ In light of the contextual method of interpretation, the impact of the Geo-blocking Regulation on the approach to jurisdiction in cross-border copyright infringement cases has also been included in the assessment framework. Based on the precedent-based method of interpretation, the effects of several rulings of the CJEU have been considered. ${ }^{2554}$ In view of the principle of international comity, this dissertation has argued to adopt the 'strong territorial connection' requirement to justify that the court of the Erfolgsort obtains jurisdiction regarding the entire copyright infringement dispute. ${ }^{2555}$ Furthermore, it has also been demonstrated that the principle of international comity may influence the actual scope of full jurisdiction of the latter court. ${ }^{2556}$

Although the territorial principle related to copyrights has not been an explicit part of the assessment framework, the influence of this principle on the approach to jurisdiction in crossborder copyright infringement cases has been addressed in this dissertation. First, this dissertation focused on the issue whether the locus protectionis criterion should be a prerequisite to establish jurisdiction in cross-border copyright infringement cases. Several scholars argued that this criterion should not be adopted at the jurisdictional level and will only be relevant when assessing the merits of the case. ${ }^{2557}$ In view of the principles of non-formality and national treatment under the Berne Convention 1979, this dissertation argued that the locus protection criterion can be an implicit criterion at the jurisdictional level. ${ }^{2558}$

Second, this dissertation discussed the influence of the territorial protection of copyrights on the scope of the court's jurisdiction based on the Erfolgsort under Article 7(2) Brussels Ibis in cross-border copyright infringement cases. The territorially limited approach to jurisdiction adopted by the CJEU in the Pinckney doctrine suits the territorial protection of copyrights. Due to globalization and the Internet, scholars ${ }^{2559}$ and courts ${ }^{2560}$ have nonetheless argued that under certain conditions full jurisdiction in cross-border copyright infringement cases could be legitimate for reasons of sound administration of justice and in view of the moral rights-based

\footnotetext{
${ }^{2553}$ See chapter four on the following arguments in favour of the principle of balancing the broader interests related to copyrights: balancing as common "interpretative technique" (paragraph 4.4.2.1); "Interessenjurisprudenz" established by Kegel (paragraph 4.4.2.1.1); indirect horizontal effect of fundamental rights (paragraph 4.4.2.2); consequentialist reasoning (paragraph 4.2.3); fundamental rights as primary source of European Union law (paragraph 4.4.2.4); the principle of interest balancing in substantive copyright law (paragraph 4.4.2.5).

${ }^{2554}$ See the precedent-based method of interpretation in the table of paragraph 4.6.2 on the several rulings that have been employed in this dissertation to rethink the CJEU's approach to jurisdiction in cross-border copyright infringement cases.

${ }^{2555}$ See paragraph 5.3.4.1.

2556 See paragraph 5.3.3.1.

2557 See paragraph 5.1.3.

2558 See paragraph 5.1.3.

${ }^{2559}$ See Kono and Jurcys (paragraph 6.2.3), Dreyfuss and Ginsburg (paragraph 6.4.3), the CLIP Group (paragraph 6.4.5). See also Torremans 2014, p. 388.

${ }^{2560}$ See the Swedish Supreme Court in the case of Micael Engström v. Tylden \& Co AS (Norway), NJA $2012 \mathrm{~s}$ 483 decided on 4 July 2012 (paragraph 6.2.2.2). The New York Court of Appeals in the case of Penguin Group (USA) Inc. v. American Buddha, 16 N.Y. 3d 295 (2011) (Am. Buddha III), see paragraph 7.3.2.1. See courts of states of the United States of America that adopted the 'focal point' approach in paragraph 7.5.1.2 or the 'individualized targeting' approach in paragraph 7.5.1.
} 
approach to jurisdiction, ${ }^{2561}$ the digital economy ${ }^{2562}$ and to address online copyright piracy and copyright havens. ${ }^{2563}$ This dissertation also pointed out that the risk of getting unexpectedly sued in multiple states may negatively affect the cross-border flow of information and trade ${ }^{2564}$.

\subsubsection{The CJEU's approach to jurisdiction in cross-border copyright infringement cases undermines the principles underlying the special jurisdiction rule of Article 7(2) Brussels Ibis}

The CJEU's approach to jurisdiction under Article 7(2) Brussels Ibis in cross-border copyright infringement cases, the so-called Pinckney doctrine, consists of three layers: the locus protectionis criterion, the 'likelihood of damage' criterion, and the territorially limited approach to jurisdiction. ${ }^{2565}$ First, the CJEU has based its approach to jurisdiction on the European Union's policy aim that copyrights should be automatically protected in all Member States by virtue of the Information Society Directive. ${ }^{2566}$ Although the CJEU's concept of locus protectionis does not resemble the prevailing concept of locus protectionis, the CJEU is allowed to provide an autonomous interpretation. ${ }^{2567}$ The CJEU's approach to protect copyrights suits the general accepted trend of instrumentalisation of private international law for policy purposes and the so-called new public-private law pillar of private international law. ${ }^{2568}$

Yet, it is important to uphold the main principles of private international law to achieve a legitimate interpretation of Article 7(2) Brussels Ibis. ${ }^{2569}$ Chapter five demonstrated that the CJEU's approach to jurisdiction in cross-border copyright infringement cases undermines the principles underlying the special jurisdiction rule of Article 7(2) Brussels Ibis. ${ }^{2570}$ The following paragraphs will briefly set out this undermining and highlight the need to rethink the Pinckney doctrine in view of the assessment framework in paragraph 4.6.

\subsubsection{The principle of predictability}

The 'locus protectionis' and 'likelihood of damage' criterion will not guarantee predictability for potential copyright infringers as regards where they may get sued. ${ }^{2571}$ Due to the mere accessibility of the website involving copyright infringing content, the alleged infringer can easily be sued in any Member State of the European Union. The CJEU's approach

\footnotetext{
${ }^{2561}$ See the Swedish Supreme Court in the case of Micael Engström v. Tylden \& Co AS (Norway), NJA $2012 \mathrm{~s}$ 483 in paragraph 6.2.2.2. See also the New York Court of Appeals in the case of Penguin Group (USA) Inc. v. American Buddha in paragraph 7.3.2.1.1. See also Lundstedt 2018, pp. 1035-1037, 1045.

2562 See Kono \& Jurcys 2015, p. 32. See also see case of the Dutch Supreme Court (Hoge Raad) 24 November 1989 Interlas $v$. Lincoln, para. 4.2.4 see paragraph 5.3.1.

${ }^{2563}$ See also Kur 2013(b), p. 88, 2:203.C09.

${ }^{2564}$ See paragraph 5.2.4.3.

${ }^{2565}$ See paragraph 3.5 .

${ }^{2566}$ See rulings Pinckney, Hi Hotel, Pez Hejduk in chapter 3.

2567 See paragraph 5.1.2.

${ }^{2568}$ See paragraphs 2.1.2.1 up to and including 2.1.2.2.1 and 2.1.2.1.4.

${ }^{2569}$ See scholars in paragraph 1.2.

${ }^{2570}$ See paragraphs 5.1.4 and 5.2.4.

${ }^{2571}$ See paragraph 5.2.4.1.
} 
to confer jurisdiction based on damage caused by a third party in the forum state will even increase the unpredictability. ${ }^{2572}$ As demonstrated in paragraph 4.2.4.2, the principle of predictability is of paramount importance as it is considered to be the main overarching principle of the jurisdictional rules under the Brussels Ibis Regulation.

\subsubsection{A close connection between dispute and court/ sound administration of justice}

The 'locus protectionis' and 'likelihood of damage' criterion will not guarantee a close connection between the dispute and the court. ${ }^{2573}$ There will often be a lack of a close connection between an internet-related copyright infringing dispute and the court since the mere accessibility of the website involved in the forum state will be sufficient. The risk of the lack of a close connection will be increased by the fact that jurisdiction can be obtained by the court of the state where the defendant did not cause damage but a third party. ${ }^{2574}$ Hence, the Pinckney doctrine may lead to so-called empty jurisdiction in case there has been no actual damage in the forum state or the substantive law of the forum state lacks a liability rule with respect to joint tort-feasorship ${ }^{2575}$.

It is this 'close connection' requirement that constitutes the core rationale of the special jurisdiction rule of Article 7(2) Brussels Ibis. ${ }^{2576}$ Effects-based jurisdiction in tort cases has generally been accepted provided that there exists a substantial connection between the dispute and the forum state. ${ }^{2577}$ This 'close connection' requirement will allow the defendant to reasonably predict in which state he may get sued. ${ }^{2578}$ Furthermore, the competent court will be in a good position to assess the facts of the case and have easily access to the evidence. ${ }^{2579}$

From a perspective of sound administration of justice, the Pinckney doctrine will often not enhance the sound administration of justice that has been required by jurisdiction based on Article 7(2) Brussels Ibis. Due to the possible lack of a close connection, the court will not always be in a good position to assess the facts of the case. In multistate or ubiquitous copyright infringement cases, courts in multiple states may be competent which increases the risk of forum shopping, irreconcilable decisions and high litigation costs..$^{2580}$

\subsubsection{The principle of balancing the interests involved}

The so-called Pinckney doctrine will frequently not entail a procedural balance between the copyright holder and the alleged infringer. ${ }^{2581}$ On the one hand, the alleged infringer may not

\footnotetext{
2572 See also Müller 2014, p. 434.

${ }^{2573}$ See paragraph 5.2.4.2.

${ }^{2574}$ See also Advocate General Jääskinen in the case C-360/12 Coty, para. 62.

2575 See Huvosec 2014, p. 372 in paragraph 5.2.4.2.

${ }^{2576}$ See recital 16 in the preamble to the Brussels Ibis Regulation. See also paragraph 2.1.2.2.2.

${ }^{2577}$ See paragraph 2.1.2.2.2.

${ }^{2578}$ Recital 16 in the preamble to the Brussels Ibis Regulation.

2579 See Case C-21/76 Handelskwekerij G.J. Bier v. Mines de Potasse d'Alsace SA as demonstrated in the paragraphs 2.1.2.2.2 and 4.3.1.

${ }^{2580}$ See also paragraph 5.3.1.

${ }^{2581}$ See paragraph 5.2.4.3.
} 
predict in which state he can be sued. In case of alleged online copyright infringing activities, the infringer can even get sued in multiple Member States. On the other hand, it may be an unreasonable heavy burden for the copyright holder to obtain full redress in case of online piracy or if the infringer is located and operated in a copyright haven. Despite the European Union's aim to harmonize the copyright laws of the Member States, copyright havens can still exist since not all aspects related to copyrights have been harmonized (yet) such as moral rights. $^{2582}$

From a broad perspective, the Pinckney doctrine does not appear to balance the interests between copyright holders, on the one hand, and users of information and traders, on the other hand. ${ }^{2583}$ The territorially limited approach to jurisdiction may not entail efficient copyright protection at jurisdictional level, particularly in view of online copyright piracy and copyright havens. Due to the risk of getting unexpectedly sued in multiple Member States, internet users may hesitate to exchange information. Hence, the Pinckney doctrine may impede the flow of information via the Internet.

Considering the risk to get unexpectedly sued in many states, traders may hesitate to offer goods and services to customers in the Member States of the European Union. The Geoblocking Regulation will often force traders who operate within the European Union to keep their websites open for customers of all Member States. ${ }^{2584}$ Due to the accessibility approach to jurisdiction, these traders can therefore not prevent to get sued in certain Member States for copyright infringing activities. Hence, particularly small trading companies established outside the European Union may not be willing to sell their products and services to customers within the European Union. As audiovisual services and electronically supplied services that contain copyrighted content are for now excluded from the prohibitions under the Geo-blocking Regulation, ${ }^{2585}$ traders who provide these excluded services may block their online interfaces for customers of certain Member States. The latter will not enhance the proper functioning of the internal market.

It is remarkable that a trader who provides goods and services to customers within the European Union cannot get sued on the basis of the mere accessibility of a website involved in case of an internet-related consumer dispute. ${ }^{2586}$ Unlike copyright holders, consumers are considered as 'weak' parties who need special procedural protection under the Brussels Ibis Regulation. ${ }^{2587}$ Yet, European Union legislators and the CJEU did not adopt the accessibility approach but the 'directed activities' approach to jurisdiction in cross-border consumer disputes because the latter approach balances the interests of traders to employ the Internet as a

\footnotetext{
2582 See paragraph 5.1.2.

${ }^{2583}$ See paragraph 5.2.4.3.

${ }^{2584}$ See paragraph 4.5.1 on the scope of the Geo-blocking Regulation and paragraph 4.5.2.3 on services that are excluded from the prohibitions in the Geo-blocking Regulation.

${ }^{2585}$ See paragraphs 4.5.2.3 and 5.2.3.1.1.1. The first evaluation of the Geo-blocking Regulation in May 2020 will review whether these excluded services should fall under the scope of this Regulation. See paragraph 4.5.2.3.

${ }^{2586}$ See paragraph 6.1.2.1 on the contextual interpretation of the rulings Pinckney, Hi Hotel and Pez Hejduk in view of the Pammer and Alpenhof ruling.

${ }^{2587}$ See paragraphs 5.1.4 and 6.1.2.1.
} 
customary means of engaging in trade, on the one hand, and the interests of consumers to sue traders in their home state, on the other hand. ${ }^{2588}$

\subsection{The 'directed activities' approach to jurisdiction under Article 7(2) Brussels Ibis in cross-border copyright infringement cases}

From a legitimate perspective, the foregoing paragraphs demonstrated that the CJEU's approach to jurisdiction under Article 7(2) Brussels Ibis in cross-border copyright infringement cases is not in accordance with the principles underlying this special jurisdiction rule. Chapter five has argued that the CJEU's interpretation could therefore be regarded as illegitimate judicial activism. ${ }^{2589}$ Considering the role of the CJEU as law-finder, ${ }^{2590}$ it is important that the interpretation of Article 7(2) Brussels Ibis is in accordance with the principles underlying this provision. Hence, this dissertation aimed to focus on alternative approaches to jurisdiction that could provide a legitimate approach under Article 7(2) Brussels Ibis in cross-border copyright infringement cases. In the chapters six and seven, several alternative approaches to jurisdiction adopted by scholars and courts of European Union Member States and states of the United States of America have been assessed in light of the assessment framework of paragraph 4.6. This framework consists of principles underlying Article 7(2) Brussels Ibis, the principle of balancing the broader interests related to copyrights, and the impact of the Geo-blocking Regulation. In view of the assessments of the various alternative approaches, the 'directed activities' approach seems to satisfy the principles underlying Article 7(2) Brussels Ibis most. ${ }^{2591}$ The targeting approach as demonstrated in chapter seven could be regarded as a similar approach but more flexible and therefore providing lesser certainty and preditability.

Compared to the 'likelihood of damage' criterion under the Pinckney doctrine, the 'directed activities' approach can be more a suitable response to the trend of "competing claims for jurisdiction" 2592 . Furthermore, the 'directed activities' approach will likely prevent generalization of the forum actoris that is important to maintain the forum rei as general basis for jurisdiction. The following paragraphs will demonstrate the suitability of the 'directed activities' approach under Article 7(2) Brussels Ibis in cross-border copyright infringement cases.

\subsubsection{The principle of predictability}

The 'directed activities' approach to jurisdiction will generally provide predictability as regards which court will be competent under Article 7(2) Brussels Ibis based on the effects

\footnotetext{
${ }^{2588}$ See joined Cases C-585/08 and C-144/09 Pammer and Alpenhof, para. 70-74 and Opinion of Advocate General Trstenjak in the joined cases C-585/08 and C-144/09 Pammer and Alpenhof, para. 64. See also paragraph 6.1.2.1. ${ }^{2589}$ See paragraph 5.4 .

2590 See paragraph 4.1.3.

${ }^{2591}$ See the tables in paragraphs $6.3,6.5,7.6$.

${ }^{2592}$ See Wautelet 2004, p. 60. See also Kohl 2010, pp. 4-5, 19, 22; Ryngaert \& Vagias 2019; Svantesson 2019(a), p. 51 .
} 
caused by a cross-border copyright infringement. ${ }^{2593}$ Whenever a potential copyright infringer directs his activities to a certain Member State, he may predict to get sued there. By focusing on the 'objective' intention of the copyright infringer, the 'directed activities' approach will also yield predictability for the copyright holder as regards where he may sue an infringer. For instance, if the alleged infringer has advertised the alleged copyright infringing products by newspaper or broadcast in a particular state, it indicates that he directed his activities to the latter state. With respect to copyright infringing activities committed via the Internet, the nonexhaustive factors as enumerated by the CJEU in the Pammer and Alpenhof ruling can be employed such as the language used, a country code top-level domain, and delivery possibilities ${ }^{2594}$. The factors in Article 3 of the Joint Recommendation Concerning Provisions on the Protection of Marks, and Other Industrial Property Rights in Signs drafted by the World Intellectual Property Organization in 2001 can also be employed to assess whether the alleged activities have been directed to the forum state. ${ }^{2595}$

The lack of unpredictability as regards where potential copyright infringers may get sued based on alleged damage caused by a third party ${ }^{2596}$ appears to be solved by the 'directed activities' approach. A court may only obtain jurisdiction based on alleged damage caused by a third party in the forum state if the defendant objectively intended to direct copyright infringing activities to that state. The latter may be the case when there exist an agreement or collaboration between the alleged copyright infringer and the third party that aims to disseminate the alleged copyright infringing content or products. The court seised then has to examine whether the alleged infringer directed the alleged copyright infringing activities to the forum state. ${ }^{2597}$

The adoption of a technology neutral 'directed activities' approach to jurisdiction will yield legal certainty and predictability in view of changing technologies. ${ }^{2598}$ Copyright infringing content can easily be placed from an offline medium, such as newspaper or book, onto the Internet. ${ }^{2599}$ The European Union legislators have also adopted a technology neutral 'directed activities' approach to jurisdiction under Article 17(1)(c) Brussels Ibis Regulation ${ }^{2600}$. According to the rulings Pinckney, Hi Hotel and Pez Hejduk, the CJEU also seemed to have adopted a technology neutral approach to jurisdiction in cross-border copyright infringement cases by employing the 'likelihood of damage' criterion. ${ }^{2601}$

\footnotetext{
${ }^{2593}$ See paragraph 6.1.4.1.

${ }^{2594}$ See joined Cases C-585/08 and C-144/09 Pammer and Alpenhof, para. 83. See also paragraph 6.1.2.

${ }^{2595}$ See paragraphs 6.1 and 6.1.3.2.

2596 See paragraphs 5.2.3 and 5.2.4.1.

2597 See paragraph 8.5.1.

${ }^{2598}$ See Hestermeyer 2006, p. 286; Kuipers 2012(a), pp. 393, 395. See also the Opinion of Advocate General Cruz Villalón delivered on 29 March 2011 in the joined cases C-509/09 and C-161/10 eDate Advertising GmbH v. X and Martinez v. MGN Limited, para. 53.

${ }^{2599}$ See also Cruz Villalón who advocated a technology neutral approach to jurisdiction under Article 7(2) Brussels Ibis since infringing content "is fungible and its formats are interchangeable". See the Opinion of AG Cruz Villalón in the joined cases C-509/09 and C-161/10 eDate and Martinez, para. 53. See also Kuipers 2012(a), p. 393.

${ }^{2600}$ See Kuipers 2012(a), p. 395.

${ }^{2601}$ See paragraph 3.5.
} 


\subsubsection{A close connection between dispute and court/ sound administration of justice}

The 'directed activities' approach will generally entail a close connection between the dispute and the court as required under Article 7(2) Brussels Ibis. ${ }^{2602}$ The court of the state where the alleged copyright infringing activities have been directed to will likely be in a good position to assess the damage caused within the forum state. In view of this "factor of proximity", the CJEU militated in the AMS Neve ruling in favour of the 'directed activities' approach to establish jurisdiction in a European Union trade mark infringement case. ${ }^{2603}$

The risk of the lack of a close connection between the dispute and the court as a result of third party-based approach to jurisdiction in cross-border copyright infringements ${ }^{2604}$ appears to be solved by the 'directed activities' approach. A court may only obtain jurisdiction based on alleged damage caused by a third party if the defendant objectively intended to direct copyright infringing activities to the forum state. As mentioned in the previous paragraph, the latter may be the case when there exists a collaboration or agreement between the alleged copyright infringer and the third party that aims to disseminate the alleged copyright infringing content or products. The court seised then has to examine whether the alleged infringer intended to direct the alleged copyright infringing activities to the forum state. ${ }^{2605}$ Since the court can only obtain jurisdiction if the defendant objectively intended to direct alleged copyright infringing activities to the forum state, there will likely be a close connection between that dispute and the court. In view of principles of due process, the United States Supreme Court did not adopt a third party-based approach to jurisdiction by reasoning that "the defendant's suit-related conduct must create a substantial connection with the forum state" 2606 .

From a perspective of sound administration of justice, the 'directed activities' approach will generally facilitate efficient adjudication as the risk of jurisdiction based on overspills or so-called empty jurisdiction will be prevented. ${ }^{2607}$ Compared to the 'likelihood of damage' criterion under the Pinckney doctrine, the risk of forum shopping and irreconcilable decisions will likely be reduced. ${ }^{2608}$ Yet, in case of multistate or ubiquitous copyright infringement cases, the 'directed activities' approach may often not enhance the sound administration of justice. ${ }^{2609}$ Due to the Internet and globalization, copyright infringing content or products can easily be directed to many states and yield multiple competent courts. As will be demonstrated in the next paragraph, multistate litigation can be burdensome for both litigants.

Providing full jurisdiction to the court of the state to which alleged infringing copyright activities have been directed does not seem to guarantee a strong enough connection that could

\footnotetext{
${ }^{2602}$ See paragraph 6.1.4.2.

${ }^{2603}$ See Case C-172/18 AMS Neve Ltd and Others v. Heritage Audio SL, Pedro Rodriguez Arribas, para. 57. See also paragraph 3.6.1.

${ }^{2604}$ See paragraph 5.2.4.2.

2605 See paragraph 8.5.1.

${ }^{2606}$ Walden v. Fiore, 571 U.S. 277, 134 S. Ct. 1115 (2014). See also Kulko v. California Superior Court, 436 U.S. 84 at 94 (1978). See paragraph 7.7.

${ }^{2607}$ See paragraph 6.1.4.2.

${ }^{2608}$ See Matulionyte 2015, p. 136.

${ }^{2609}$ See paragraph 6.1.4.2.
} 
justify full jurisdiction. ${ }^{2610}$ The court of the state to which alleged activities are directed to will not always be in the best position to assess the entire copyright infringement case; substantial damage may be caused in another state. While the 'directed activities' approach will generally satisfy the 'close connection' requirement with respect to territorially limited jurisdiction, a stronger connection seems to be desired to justify full jurisdiction. Paragraph 8.3.2 will examine the two main approaches to jurisdiction that confer full jurisdiction in cross-border copyright infringement disputes.

\subsubsection{The principle of balancing the interests}

The 'directed activities' approach will generally provide a procedural balance between the interests of the copyright holder and the alleged infringer. ${ }^{2611}$ On the one hand, the copyright holder may sue the infringer in all states to which the activities are directed to. On the other hand, the alleged infringer can reasonably predict to get sued in these states. Yet, in case of a multistate or ubiquitous copyright infringement dispute, there may often be an imbalance between the procedural interests of these litigants. In order to receive full redress, the copyright holder will likely have to sue the infringer in multiple states which may be considered as an unreasonable burden in case of online piracy or infringers who are located or operated in copyright havens. ${ }^{2612}$ Furthermore, the alleged copyright infringer may get sued before courts in multiple states which will entail high litigation costs and inconvenience. This burden can be considered particularly unreasonable in case of litigational harassment by an economically sound copyright holder.

From a broad perspective, the 'directed activities' approach appears to balance the interests of copyright holders, on the one hand, and the interests of users of information and traders, on the other hand. ${ }^{2613}$ In view of multistate or ubiquitous copyright infringements, the 'directed activities' approach may, however, not enhance efficient copyright protection at procedural level, particularly in case of online piracy and copyright havens as mentioned above. The risk of getting sued in multiple states can negatively affect the cross-border flow of information and trade. ${ }^{2614}$ If providers of information run the risk to get sued in multiple states, the cross-border flow of information may hamper which can decrease knowledge and innovation. ${ }^{2615}$ Due to the Geo-blocking Regulation, the traders' tools to prevent getting sued in a particular European Union Member State will often be reduced since they are frequently not allowed anymore to block or limit their online interfaces or employ other forms of discrimination based on customers' nationality, place of residence or place of establishment. ${ }^{2616}$ Particularly small trading companies may therefore not be willing to sell their products and services via the Internet to customers within the European Union. The following paragraphs will focus on the

${ }^{2610}$ See paragraph 5.3.4.1.

2611 See paragraph 6.1.4.3.

${ }^{2612}$ See paragraphs 5.3.1 and 6.1.4.3. See paragraph 2.2.2.2 on the concept of copyright havens.

${ }^{2613}$ See paragraph 6.1.4.3.

${ }^{2614}$ See paragraph 6.1.4.3.

2615 See paragraph 4.4.1.

${ }^{2616}$ See paragraph 4.5.3 and 6.1.4.4. 
possibilities to confer 'full' jurisdiction under Article 7(2) Brussels Ibis in case of alleged multistate or ubiquitous cross-border copyright infringements.

\section{3 'Full' jurisdiction of the court of the Erfolgsort in ubiquitous copyright infringement cases}

As argued in the previous paragraphs, the 'directed activities' approach may not be a suitable approach in case of multistate or ubiquitous copyright infringement cases. Due to the Internet and globalization, copyright infringing content or products can easily be directed to many states and yield multiple competent courts. From a perspective of sound administration of justice, the risk of forum shopping, parallel proceedings and irreconcilable decisions should be reduced. Multistate litigation will generally be burdensome for both litigants. As demonstrated in the previous paragraph, the territorially limited 'directed activities' approach to jurisdiction in cross-border copyright infringements can cause an imbalance between the procedural interests of these litigants and the broader interests related to copyrights. When infringing activities are directed to many states, the foregoing indicates that the mosaic approach will likely undermine the principles underlying Article 7(2) Brussels Ibis. As argued in paragraph 8.2.1, the mere 'directed activities' criterion will not guarantee a strong close connection between the dispute and the court to justify full jurisdiction.

The abovementioned disadvantages related to the territorially limited approach to jurisdiction can appear in multistate or ubiquitous copyright infringement cases. The concept of a multistate copyright infringement dispute seems to be quite broad and it is difficult to quantify the number of states that would entail a multistate copyright infringement dispute. The concept of ubiquitous copyright infringements has been defined as "concurrent multi-territorial infringements evoked by a single act of operation". ${ }^{2617}$ Hence, the term ubiquitous is more accurate defined than the term multistate. The term ubiquitous is broader than internet-related since it involves alleged copyright infringing activities that are instantaneous disseminated via any random technology. For instance, broadcasting copyright infringing content via radio or television are also infringements carried out through ubiquitous media. ${ }^{2618}$ While a technology neutral approach has often been favored in view of legal certainty and predictability, ${ }^{2619}$ the concept of ubiquitous will be open for new technologies as it is future-proof.

This dissertation has provided the following arguments to adopt an approach to full jurisdiction in ubiquitous copyright infringement cases. ${ }^{2620}$ In the Shevill ruling the CJEU preferred the territorially limited approach to jurisdiction because the courts of each Member State will be in the best position to assess damage within forum state. ${ }^{2621}$ In the eDate and Martinez ruling, the CJEU nonetheless pointed out the technical difficulty to localise and

\footnotetext{
${ }^{2617}$ See Chaen, Kono \& Yokomizo 2010, p. 98.

2618 See paragraph 6.4.5.

2619 See paragraph 8.2.1.

${ }^{2620}$ See also paragraph 5.3.1. Chapter six demonstrated that the majority of the suggested connecting factors to establish full jurisdiction in cross-border copyright infringement cases are only applicable to ubiquitous or internetrelated infringements. See paragraph 6.6.

${ }^{2621}$ See Case C-68/93 Shevill and Others v. Presse Alliance, para. 30-31.
} 
quantify the instantaneous worldwide dissemination of infringements of personality rights via the Internet as one of the factors to justify the conferral of full jurisdiction under Article 7(2) Brussels Ibis to the court of the victim's centre of interests. ${ }^{2622}$ In a similar way, the New York Court of Appeals employed the latter argument to confer full jurisdiction to the court of the copyright holder's principal place of business in an online copyright infringement case. ${ }^{2623}$ In the Pez Hejduk ruling, Advocate General Cruz Villalón also emphasised the difficulty to localise damage caused by online copyright infringing activities. ${ }^{2624}$ Furthermore, a territorially limited injunction related to online copyright infringing content will likely not be effective and satisfactory since the content will generally still be accessible in other states. ${ }^{2625}$ In addition, territorially limited injunctions will increase the risk of irreconcilable decisions. ${ }^{2626}$

A territorially limited approach to jurisdiction in ubiquitous copyright infringement disputes will likely also negatively affect broader interests. Due to the increasingly international contacts, it has been argued that fragmentation of litigation does not "fit the needs of the digital economy". ${ }^{2627}$ The risk of getting sued in multiple states can especially affect small companies that trade via the Internet. As a result of the Geo-blocking Regulation, the traders' tools to prevent getting sued in certain Member States of the European Union have often been reduced because they are frequently not allowed anymore to block or limit their online interfaces based on the customers' nationality, place of residence or establishment. The fear of getting sued in multiple states may also hamper the online flow of information. The Geo-blocking Regulation does not prohibit providers of information to block or limited the access to their online interfaces. For the cross-border exchange of knowledge, it is particularly relevant that the Internet remains 'open'.

The mosaic approach also jeopardizes efficient copyright protection at procedural level. To address the problem of online piracy and copyright havens, it is important that copyright holders have the opportunity to sue these malicious infringer for the entire ubiquitous copyright infringement before another court than the forum rei ${ }^{2628}$ Adopting an approach to jurisdiction in ubiquitous copyright infringement cases that considers the abovementioned broader interests will fit the desire to employ private international law as an instrument to serve common goods in the context of global governance ${ }^{2629}$.

From a perspective of private international law and public international law, this dissertation adopted the common stance that the court of the Erfolgsort can only obtain full

${ }^{2622}$ See joined Cases C-509/09 and C-161/10 eDate and Martinez, para 46-47. See also Kur 2013(b), p. 91, 2:203.N02.

${ }^{2623}$ Penguin Group (USA) Inc. v. American Buddha, 16 N.Y. 3d 295 (2011) (Am. Buddha III). See paragraph 7.3.2.1.

${ }^{2624}$ See Opinion of Advocate General Cruz Villalón delivered on 11 September 2014 in the case C-441/13 Pez Hejduk v. EnergieAgentur. $N R W G m b H$, para. 2, 16-17. See also paragraph 5.3.1.

${ }^{2625}$ See paragraph 5.3.3.1.

${ }^{2626}$ See paragraph 5.3.3.1.

${ }^{2627}$ Kono \& Jurcys 2015, p. 32. See also see case of the Dutch Supreme Court (Hoge Raad) 24 November 1989 Interlas v. Lincoln, para. 4.2.4 see paragraph 5.3.1.

${ }^{2628}$ Kur 2013(b), p. 88, 2:203.C09. See also Metzger 2009, p. 261.

${ }^{2629}$ See paragraph 2.1.2.1.5. Svantesson argued that "cross-border internet-related legal issues are central matters in society today, and this must be reflected in public and private international discussions." See Svantesson 2019(a), p. 47. 
jurisdiction if the close connection between the dispute and the court is particularly strong. ${ }^{2630}$ In view of sound administration of justice, the latter court will likely be in the best position to assess the entire case. In the light of the assessment framework of paragraph 4.6, the next paragraphs will examine which approach to full jurisdiction would fit best under Article 7(2) Brussels Ibis in ubiquitous copyright infringement cases. But first the concept of 'full' jurisdiction under Article 7(2) Brussels Ibis in cross-border copyright infringement cases will be discussed.

\subsubsection{The concept of 'full' jurisdiction}

Considering the principle of international comity, this dissertation argued that the court of the Erfolgort that obtains full jurisdiction under 7(2) Brussels Ibis will in practice only be allowed to assess the damage caused within the territories of the European Union Member States and to issue a cross-border injunction regarding infringing activities within these territories as long as there is a lack at worldwide level of uniform copyright law or a uniform conflict-of-laws rule related to cross-border copyright infringement cases. ${ }^{2631}$ Due to the European Union lex loci protectionis rule in Article 8 Rome II, the latter court can obtain jurisdiction to assess the damage within the European Union Member States and to issue a cross-border injunction to cease or prevent infringing activities within these territories.

\subsubsection{Approaches that confer 'full' jurisdiction in cross-border copyright infringement disputes}

The chapters six and seven demonstrated various approaches that confer 'full' jurisdiction to another court than the forum rei in case of a cross-border copyright infringement dispute. ${ }^{2632}$ Based on the various approaches, the following two main approaches can be identified: the 'copyright holder's centre of interests', or forum actoris, approach and the substantial effectsbased approach.

\footnotetext{
${ }^{2630}$ See paragraph 5.3.4.1.

${ }^{2631}$ See paragraph 5.3.3.1.

${ }^{2632}$ See the 'copyright holder's centre of interests' approach related to the infringement of moral rights (paragraph 6.2.2.2); the 'case-specific copyright holder's centre of interests' approach (paragraph 6.2.3); the combined forum actoris approach under Article 10(1)(b) and (4) Draft Hague Convention of 1999 (paragraph 6.4.2); the combined forum actoris approach under Article 6(1)(b) and Article 6(2) Dreyfuss and Ginsburg Convention (paragraph 6.4.3); the effects-based connecting factors under Article 2:202 CLIP and Article 2:203(2) CLIP (paragraph 6.4.5); the 'focal point' approach (paragraph 7.5.1.2) and the 'individualized targeting' approach (7.5.1.3) established by courts of states of the United States of America.
} 


\subsubsection{The 'copyright holder's centre of interests', or forum actoris, approach}

This dissertation demonstrated that several scholars, ${ }^{2633}$ a court of a European Union Member State and courts of states of the United States of America ${ }^{2634}$ adopted the 'copyright holder's centre of interests', or forum actoris, approach to jurisdiction in ubiquitous copyright infringements cases. While the forum actoris concerns the court of the state in which the copyright holder has been domiciled or established, the copyright holder's centre of interests' will generally be in the state of his habitual residence but other factors may also constitute the existence of a particularly close link with a state such as the pursuit of a professional activity. ${ }^{2635}$ Hence, there may exist more centre of interests.

The 'copyright holder's centre of interests', or forum actoris, approach has frequently been advocated from the perspective of the moral right-based approach to copyrights. ${ }^{2636}$ Similar to personality rights, the inalienable character of moral rights of copyright holders resembles human rights. ${ }^{2637}$ As demonstrated by the Penguin ruling, ${ }^{2638}$ the same reasoning the CJEU has provided to adopt the 'victim's centre of interests' approach under Article 7(2) Brussels Ibis in case of online infringements of personality rights can be applied to online infringements of the moral sides of copyrights. First, the dissemination of infringing content via ubiquitous media such as the internet will be instantaneous and worldwide "irrespective of any intention on the part of the person who placed it" and it will be technically difficult to quantify and assess the damage that occurred within a particular state. ${ }^{2639}$ Second, due to this instantaneous and worldwide dissemination, the victim will suffer serious damage that justifies full redress before the court of the state of the victim's centre of interests. ${ }^{2640}$

Despite the abovementioned two factors, the adoption of the 'copyright holder's centre of interests', or forum actoris, approach under Article 7(2) Brussels Ibis will not satisfy the principles underlying this special jurisdiction rule. First, it will often be unpredictable for potential copyright infringers as regards where the copyright holder has been domiciled, established or has his centre of interests, they may even not be aware of the copyright itself. To

\footnotetext{
${ }^{2633}$ Dreyfuss \& Ginsburg 2002, pp. $1065-1153$ (paragraph 6.4.3); Kono \& Jurcys 2015, p. 29. The Draft Hague Convention 1999 also employs the forum actoris approach in tort cases according to Article 10(4) (see paragraph 6.4.2). The following scholars particularly advocate the 'copyright holder's centre of interests' approach with respect to infringements of moral sides of copyrights: Lundstedt 2018, pp. 1035-1037, 1045; Maunsbach 2012, pp. 58-59.

${ }^{2634}$ See the Swedish Supreme Court in the case of Micael Engström v. Tylden \& Co AS (Norway), NJA $2012 \mathrm{~s}$ 483 (paragraph 6.2.2.2). See the New York Court of Appeals in the case of Penguin Group (USA) Inc. v. American Buddha (paragraph 7.3.2.1). The 'individualized targeting' approach adopted by several courts of states of the United States of America also reflects the copyright holder's centre of interests' approach (see paragraph 7.5.1.3). ${ }^{2635}$ See joined Cases C-509/09 and C-161/10 eDate and Martinez, para. 49.

${ }^{2636}$ See the Swedish Supreme Court in the case of Micael Engström v. Tylden \& Co AS (Norway), NJA $2012 \mathrm{~s}$ 483 in paragraph 6.2.2.2. See also the New York Court of Appeals in the case of Penguin Group (USA) Inc. $v$. American Buddha in paragraph 7.3.2.1.1. See also Lundstedt 2018, pp. 1035-1037, 1045; Maunsbach 2012, pp. 58-59.

${ }^{2637}$ See paragraph 2.2.1.2 on the issue of copyrights as private rights or human rights.

${ }^{2638}$ See paragraph 7.3.2.1.

2639 Joined Cases C-509/09 and C-161/10 eDate Advertising GmbH v. X and Olivier Martinez and Robert Martinez v. MGN Limited, para. 45. See also the Penguin ruling in paragraph 7.3.2.1.

${ }^{2640}$ See paragraph 6.2.1.1.2. See also the Penguin ruling in paragraph 7.3.2.1.
} 
alleviate this unpredictability, De Boer ${ }^{2641}$ and several courts of states of the United States of America employ the so-called 'intentional tort' or knowledge criterion. ${ }^{2642}$ Based on the latter criterion, the court can only obtain jurisdiction provided that the alleged infringer had been aware of the copyright and the place of the copyright holder's domicile or centre of interests. As argued in this dissertation, the knowledge criterion is a vague 'subjective' criterion that may require quite an extensive assessment of the merits of the case that does not suit the jurisdictional phase and will not yield ex ante predictability as regards which court will be competent. $^{2643}$

Second, the 'copyright holder's centre of interests', or forum actoris, approach will not guarantee a close connection between the dispute and the court. As argued in this dissertation, the conferral of full jurisdiction under Article 7(2) Brussels Ibis will require a strong enough connection between the dispute and the forum state. ${ }^{2644}$ While the 'copyright holder's centre of interests', or forum actoris, approach will guarantee a close connection between the infringement of moral rights and the court, this close connection may not exist between the infringement of economic rights and the court. The infringement of economic rights, such as the right of distribution, reproduction and making available to the public, will not always occur in the state where the copyright holder has been domiciled, established, or has his centre of interest. ${ }^{2645}$ While moral rights remain at the copyright holder, economic rights can be transferred. ${ }^{2646}$ The court of the state where the 'copyright holder's centre of interests' is located and the forum actoris may therefore not be in the best position to assess the entire copyright infringement dispute.

Third, in view of the principle of balancing the interests involved, the 'copyright holder's centre of interests' and the forum actoris approach will frequently tip the balance in favor of the copyright holder as the infringer may often not know in which state the copyright holder has been domiciled or has his centre of interests. Copyright holders are not considered as weaker parties under the Brussels Ibis Regulation who require special protection. ${ }^{2647}$ From a broad perspective, the lack of predictability as regards where potential copyright infringers may get sued can negatively affect the online trade and flow of information within the European Union. ${ }^{2648}$

Adding the 'directed activities' approach to the 'copyright holder's centre of interests', or forum actoris, approach will yield more predictability and entail a closer connection. ${ }^{2649}$ Yet, the issue remains whether the connection will be strong enough to obtain full jurisdiction in ubiquitous copyright infringement cases. Even if alleged infringing activities have been

\footnotetext{
${ }^{2641}$ See paragraph 6.2.4.1.

${ }^{2642}$ See paragraph 7.5.1.2 on the 'focal point' approach and paragraph 7.5.1.3 on the 'individualized targeting' approach.

${ }^{2643}$ See paragraphs 7.5.1.2.1 and 7.5.1.3.1.

${ }^{2644}$ See paragraph 5.3.4.1.

${ }^{2645}$ See paragraphs 2.2.1.1 and 6.2.2.1; 6.2.2.2 on the difference between economic and moral rights related to copyrights.

${ }^{2646}$ See paragraph 2.2.1.1.

${ }^{2647}$ See paragraphs 2.1.2.1.3 and 6.2.4.4.

2648 See paragraph 6.2.4.4.

${ }^{2649}$ See also the combination of the 'intentionally directed' criterion and the forum actoris approach under Article 6(1)(b) and Article 6(2) of the Dreyfuss and Ginsburg-Convention of 2002 (paragraph 6.4.3).
} 
directed to the state in which the copyright holder has been domiciled or has his centre of interests, the court of that state will not always be in best position to assess the entire damage because the infringement of economic rights may occur in other states and cause substantial damage there.

\subsubsection{The substantial effects-based approach}

This dissertation demonstrated several scholarly proposals that confer jurisdiction to the court of the state where substantial effects occurred. ${ }^{2650}$ While not all of these proposals confer full jurisdiction, ${ }^{2651}$ all proposals additionally comprise a 'directed activities'-based criterion. ${ }^{2652}$ Potential copyright infringers will not always reasonably foresee in which state the infringement will cause substantial effects. A 'malicious' copyright infringer will generally be able to reasonably expect in which state(s) his activities cause substantial effects. It will, however, be difficult to provide a definition which distinguishes potential infringers who acted in 'good faith' or in 'bad faith'2653. The so-called intentional tort or knowledge criterion will not yield ex ante predictability. ${ }^{2654}$ Adding the 'directed activities' criterion to the substantial effects-based approach will yield predictability for potential copyright infringers to get sued in the state where their activities have been directed to.

The CLIP Principles combines effects-based connecting factors in Article 2:203(2) CLIP 2655 and the 'directed activities'-based escape clause in Article 2:202 CLIP to confer full jurisdiction in ubiquitous copyright infringement cases. This combination will likely entail a strong territorial connection between the dispute and the court that could justify full jurisdiction. ${ }^{2656}$ Yet, the effects-based connecting factors in Article 2:203(2) CLIP may force the court seised to assess the facts of the case quite extensive: the effects in the forum rei have to be quantified ${ }^{2657}$ as well as the damage that occurred in the forum state in relation to the entire damage caused by the infringement ${ }^{2658}$. An extensive assessment of the facts of the case will not suit at the jurisdictional level; it will not enhance sound administration of justice or entail ex ante predictability as regards which court will be competent. ${ }^{2659}$

Reducing the threshold of the effects-based connecting factors to 'substantial damages' caused in the forum state will require a lesser extensive assessment of the facts of the case. In view of the application of the single publication rule to copyright infringement disputes, the

\footnotetext{
${ }^{2650}$ See Article 2:202 and 2:203(2) CLIP; Article 12a Paragraph 6(1)(a) MPI Proposal of 2001; Article 5(b) Draft Guidelines ILA of 2018. The 'focal point' approach adopted by several courts in the United States of America also reflects the substantial effects-based approach (see paragraph 7.5.1.2).

${ }^{2651}$ See Article 12a Paragraph 6(1)(a) MPI Proposal of 2001; Article 5(b) Draft Guidelines ILA of 2018.

${ }^{2652}$ See Article 2:202 CLIP; Article 12a Paragraph 6(1)(a) MPI Proposal of 2001; Article 5(b) Draft Guidelines ILA of 2018. The third prong of the 'focal point' approach adopted by several courts of states of the United States of America is reminiscent of the 'directed activities' approach (see paragraph 7.5.1.2.1).

${ }^{2653}$ See also paragraph 6.2.4.2.

${ }^{2654}$ See paragraph 7.5.1.2.1 on the assessment of the 'focal point' approach and paragraph 7.5.1.3.1 on the assessment of the 'individualized targeting' approach.

${ }^{2655}$ See Article 2:203(2) CLIP and Article 2:203(2)(b) CLIP.

${ }^{2656}$ See paragraph 6.4.5.2.2.

2657 Article 2:203(2) CLIP.

2658 Article 2:203(2)(b) CLIP.

${ }^{2659}$ See paragraph 4.2.4.2.
} 
United States Supreme Court's case law seems to indicate that a court can obtain full jurisdiction if the alleged damage has been foreseeable and substantial in the forum state..$^{2660}$ As indicated above, the combination of the 'substantial damages' criterion and the 'directed activities' criterion will yield predictability as regards where potential copyright infringers may get sued. The scholarly proposals as laid down in Article 12a Paragraph 6(1)(a) and (2) MPI Proposal of 2001 and Article 5(b) Draft Guidelines ILA of 2018 also employ the combination of the 'substantial effects' criterion and the 'directed activities'-based escape clause ${ }^{2661}$ or 'unforeseeability of substantial damages' escape clause ${ }^{2662}$. Yet, the latter proposals only confer territorially limited jurisdiction. ${ }^{2663}$ The question arises whether the 'substantial damages' criterion combined with the 'directed activities'-based criterion will entail a strong enough close connection to justify full jurisdiction.

As argued in the previous paragraph, the infringement of moral rights can only occur in the states where the copyright holder has been domiciled, established, or has his of centre of interests; the damage caused by the infringement of moral rights will always be substantial in these states. Based on the 'substantial damages' criterion, the courts of the latter states can thus obtain jurisdiction with respect to infringements of moral rights without an extensive assessment of the facts of the case. When the alleged infringement of moral rights has been directed to the forum actoris or the state where the copyright holder's centre of interests is located, there seems to be a strong enough connection between the dispute and the court to assess the entire damage caused by the alleged infringements of moral rights. Based on the 'substantial damage' and 'directed activities 'criterion, the court of the state where the copyright holder's centre of interests is located or the forum actoris will generally be in a good position to assess the entire damage with respect to infringements of moral rights.

Nonetheless, a ubiquitous copyright infringement dispute will often also involve the alleged infringement of the economic side(s) of the copyright. ${ }^{2664}$ Unlike infringements of moral rights, infringements of economic rights will not always cause substantial damage in the state where the copyright holder has been domiciled or established. ${ }^{2665}$ Alleged infringements of economic rights may be directed to multiple states and cause substantial damage there. Due to the possible distinction between the location of substantial effects caused by the infringement of moral rights and substantial effects caused by the infringement of economic rights, the abovementioned combination of the 'substantial damages' and 'directed activities 'criterion does not seem to guarantee a particular strong connection between the ubiquitous copyright infringement dispute and the forum that could justify the conferral of full jurisdiction. In view of sound administration of justice, it is not desirable that there will be separate proceedings involving the infringement of economic rights, on the one hand, and the infringement of moral rights, on the

\footnotetext{
${ }^{2660}$ See paragraph 5.3.4.1.

${ }^{2661}$ See the combination of the substantial impact' criterion and the 'directed activities'-based escape clause under Article 12a Paragraph 6(1)(a) and (2) MPI Proposal of 2001 in paragraph 6.4.4.1.

${ }^{2662}$ See the combination of the 'substantial damages' criterion and the 'unforeseeability of substantial damages' escape clause under Article 5(b) Draft Guidelines ILA of 2018 in paragraph 6.4.6.1.

2663 See Article 12a Paragraph 6(2) MPI Proposal of 2001 and Article 5(b) Draft Guidelines ILA of 2018.

${ }^{2664}$ See also Sterling \& Cook 2015, p. 680. See paragraph 2.2.1.1 on economic rights related to copyright.

${ }^{2665}$ See paragraph 8.3.2.1.
} 
other hand, with respect to one cross-border copyright infringement dispute. ${ }^{2666}$ Furthermore, although European Union Member States generally acknowledge moral rights, there are differences regarding the content of the protected moral rights and the exercise of these rights after the death of the copyright holder. ${ }^{2667}$

\subsection{The combination of the 'directed activities' criterion and the 'flagrant substantial damages in relation to the entire damage' criterion}

From a perspective of sound administration of justice and to guarantee a strong territorial connection between the entire dispute and the court, the focus should lie on whether the damage caused in the state of the court seised has been substantial in relation to the entire damage caused by the ubiquitous copyright infringement dispute. This 'substantial damages in relation to the entire damage' criterion resembles the effects-based connecting factor as laid down in Article 2:203(2)(b) CLIP. Considering the principles of sound administration of justice and predictability, the court seised should, however, not be required to thoroughly assess the facts of the case at the jurisdictional level. ${ }^{2668}$ It will therefore be desirable to define the 'substantial damages' criterion as flagrant substantial damages caused in the forum state in relation to the entire damage caused by the ubiquitous copyright infringement dispute. The 'flagrant substantial damages in relation to the entire damage' criterion denotes that the alleged damages are obviously substantial within the forum state in relation to the entire damage caused by the cross-border copyright infringement dispute. Unlike the effects-based connecting factors under Article 2:203(2)(b) CLIP, the latter criterion will therefore not require the court to assess the facts extensively. In light of sound administration of justice and predictability, a "prima facie" assessment whether the alleged damage caused by the ubiquitous copyright infringement dispute has been substantial in relation to the entire damage will suit at jurisdictional level. ${ }^{2669}$

In view of the CJEU's settled case law regarding the Erfolgsort under Article 7(2) Brussels Ibis, the concept of damage refers to the initial damage, not the consequential damage. ${ }^{2670}$ Here the distinction between moral rights and economic rights again comes in. With respect to the infringement of moral rights, the initial damage will consist of immaterial damage. As mentioned in the previous paragraph, the infringement of moral rights will occur in the state(s) where the copyright holder has been domiciled, established, or has his of centre of interests. The initial damage of the infringement of economic rights will consist of material damage. With respect to material damage, it is important to consider the distinction between the initial damage and the consequential financial damage as established by settled case law of the CJEU. ${ }^{2671}$ While the loss of sales that resulted in loss of profits can be regarded as initial damage, ${ }^{2672}$ the

\footnotetext{
${ }^{2666}$ See paragraph 6.2.4.3.

${ }^{2667}$ See paragraph 6.2.2.1.

${ }^{2668}$ See paragraph 4.2.4.2.

${ }^{2669}$ See paragraph 4.2.4.2.

${ }^{2670}$ For the rationale of this settled case law, see paragraph 5.2.2.

${ }^{2671}$ See the settled case law in paragraph 5.2.2.

${ }^{2672}$ See Case C-618/15 Concurrence SARL v. Samsung Electronics France SAS and Amazon Services Europe Sarl, para. 33, 35. This case concerned an internet-related alleged infringement of the prohibition on resale outside a selective distribution network, see paragraph 5.1.1. See also Case C-27/17 AB flyLAL-Lithuanian Airlines v.
} 
mere loss of income will often be consequential financial damage ${ }^{2673}$. To locate the place of loss of sales that resulted in loss of income, the place where the market is affected has been considered as an indicator. ${ }^{2674}$

In the context of the assessment framework of this dissertation, ${ }^{2675}$ the combination of the 'directed activities' and 'flagrant substantial damages in relation to the entire damage' criterion will guarantee a strong territorial connection between the dispute and the court that could justify full jurisdiction in ubiquitous copyright infringement cases. Furthermore, this combined approach to full jurisdiction will decrease the possibility of a lack of balance between the procedural interests of the litigants in case of a ubiquitous copyright infringement dispute as demonstrated in paragraph 8.2.3. The copyright holder will receive efficient and full redress before the court of the state where the alleged ubiquitous copyright infringing activities have been directed to and the alleged damage has been clearly substantial in relation to the entire damage caused by the infringing activities. This combined approach to full jurisdiction increases the chance the copyright holder can receive efficient redress in case the infringer is established and operated in a copyright haven. The alleged infringer can generally predict to get sued in the state to which his activities have been directed.

From a broad perspective, the suggested combined approach will likely balance the interests between copyright holders, on the one hand, and users of information and traders, on the other hand. This combined approach will increase efficient copyright protection at procedural level. It also addresses the global issues of online piracy and copyright havens. Reducing the risk of getting sued in multiple states will be favorable to providers of information and traders; the online flow of information and trade will therefore not be impeded. Unlike the accessibility approach under the Pinckney doctrine, the 'directed activities' approach will enable traders to prevent getting sued in a particular Member State of the European Union despite of the Geo-blocking Regulation ${ }^{2676}$.

This combined approach is in accordance with the rationale underlying Article 7(2) Brussels Ibis as the court of the state to which the infringing activities have been directed to and where flagrant substantial damage has been caused in relation to the entire damage will have easily access to the facts of the case and will therefore be in a good position to assess the

Starptautiskä lidosta Riga VAS and Air Baltic Corporation AS, para 36. The latter case concerned a claim for compensation for damage allegedly caused by cross-border anticompetitive conduct.

2673 Case C-12/15 Universal Music Holding BV v. Michael Tétreault Schilling, Irwin Schwartz, Josef Broz, para. 30-40. See also the settled case law in paragraph 5.2.2. Saarloos argued that the CJEU did not follow its settled case law on the distinction between the initial damage and consequential damage in the case C-27/17 $A B$ flyLALLithuanian Airlines v. Starptautiskä lidosta Riga VAS and Air Baltic Corporation AS. See Saarlos 2019, pp. 391392.

${ }^{2674}$ Case C-27/17 AB flyLAL-Lithuanian Airlines v. Starptautiskä lidosta Riga VAS and Air Baltic Corporation $A S$, para 37-43. With respect to the concentration of litigation involving cross-border patent infringements, Pertegás Sender argued that "selecting the appropriate forum may require an examination of the economic repercussions of the alleged infringement in the several national markets involved". See Pertegás Sender 2002, p. 276. See also paragraph 5.3.4.1. See also Nuyts 2008, p. 126.

${ }^{2675}$ See the assessment framework in paragraph 4.6 and see paragraph 5.3.4.1 on the requirement of a strong (territorial) connection between the dispute and the court to justify 'full' jurisdiction.

${ }^{2676}$ See paragraphs 5.2.4.3 and 6.1.4.4. 
entire ubiquitous copyright infringement case. ${ }^{2677}$ In view of the principle of international comity related to the principle of sovereign equality in public international law, ${ }^{2678}$ the conferral of full jurisdiction based on the combination of the 'directed activities' criterion and 'flagrant substantial damages in relation to the entire damage' criterion can also be defended since this combination will ensure a strong territorial connection between the ubiquitous copyright infringement dispute and the court.

Furthermore, the abovementioned combined approach to jurisdiction will suit the development related to tort law to focus on the compensation of the damage. ${ }^{2679}$ Strikwerda argued that the absolute authority of the lex loci delict rule has been decreased due to the changing aim of tort law from the prevention of torts to the compensation of the damage caused by torts. ${ }^{2680} \mathrm{He}$ has also pointed out that the lex loci delict rule need to be revised in view of technological developments and the globalization. ${ }^{2681}$ Due to the difficulty to identify and localise damage in ubiquitous copyright infringement cases, it particularly "became necessary to artificially invent a concept of damage for the purpose" of the jurisdiction rule in Article 7(2) Brussels Ibis ${ }^{2682}$. The table in the next paragraph will demonstrate the desirable approach to jurisdiction in cross-border copyright infringement cases as argued in this dissertation.

2677 See Case C-21/76 Handelskwekerij G.J. Bier v. Mines de Potasse d'Alsace SA as demonstrated in the paragraphs 2.1.2.2.2 and 4.3.1.

${ }^{2678}$ See paragraph 5.3.4.1. See also paragraph 5.3.3.1 on the principle of comity.

${ }^{2679}$ See paragraph 6.2.4.1.

2680 See Strikwerda 2015, p. 189.

${ }^{2681}$ See Strikwerda 2015, p. 190. Kuipers pointed out that the advent of Internet requires a revision of the basic principles underlying private international law. See Kuipers 2012(a), p. 390.

${ }^{2682}$ See Fawcett \& Torremans 2011, p. 163 in paragraph 5.2.2. 
8.4 Table on the desirable approach to effects-based jurisdiction under Article 7(2) Brussels Ibis in cross-border copyright infringement cases

\begin{tabular}{|l|l|l|}
\cline { 2 - 3 } \multicolumn{1}{l|}{} & Connecting factors & $\begin{array}{l}\text { Scope of the court's } \\
\text { jurisdiction }\end{array}$ \\
\hline $\begin{array}{l}\text { Alleged cross-border } \\
\text { activities }\end{array}$ & $\begin{array}{l}\text { Alleged copyright infringing } \\
\text { activities have to be directed to } \\
\text { the forum state, the 'directed } \\
\text { activities' criterion (see } \\
\text { paragraph 8.2.1 on the objective } \\
\text { intention of the defendant and } \\
\text { non-exhaustive factors). }\end{array}$ & $\begin{array}{l}\text { Territorially limited to the } \\
\text { infringing activities and } \\
\text { damage caused within the } \\
\text { forum state (the so-called } \\
\text { mosaic approach, see } \\
\text { alleged ubiquitous }\end{array}$ \\
paragraph 1.1.4).
\end{tabular}

8.4.1 Applying the desirable approach to jurisdiction to cases Pinckney, Hi Hotel and Pez Hejduk

The next paragraphs will apply the desirable approach to jurisdiction as set out in the previous paragraph to the three cases referred to as Pinckney, Hi Hotel and Pez Hejduk to examine whether the court seised could have obtained jurisdiction. The facts of these cases have been demonstrated in chapter three.

\subsubsection{The Pinckney case}

Mr Pinckney sued Mediatech, established in Austria, before a French court for reproducing compact discs involving songs which he composed. The question arose whether the French court could obtain jurisdiction based on the accessibility of the website that offered the copyright infringing songs for sale. Mediatech argued that they could not be sued before the

${ }^{2683}$ See paragraphs 2.3 .4 .1 and 8.3 on the definition of ubiquitous. 
French court since the compact discs had been pressed in Austria at the request of companies established in the United Kingdom that marketed these through an internet site. ${ }^{2684}$ The Cour d'appel de Toulouse (Court of Appeal, Toulouse) noted that there had been no allegation of a collaboration between Mediatech and the United Kingdom companies. ${ }^{2685}$ The latter court therefore held that the French court lacked jurisdiction. ${ }^{2686}$ Advocate General Jääskinen argued that the request for a preliminary ruling in the Pinckney case was inadmissible due to the lack of information regarding the triangular relationship involved. ${ }^{2687}$

Applying the 'directed activities' approach, the defendant Mediatech does not seem to have objectively directed its activities to the forum state France. The alleged damage had been caused in the forum state by copyright infringing activities committed by marketing companies established in the United Kingdom as third parties. If there had been a collaboration or agreement between Mediatech and the United Kingdom-based companies to disseminate the copyright infringing compact discs, the French court could have obtained jurisdiction if Mediatech objectively intented to direct copyright infringing to France. For instance, if there had been an agreement to sell the compacts discs via Internet to residents in France. The possibility to deliver the compacts discs in France or the use of the French language would then have been indicators that the alleged infringing activities had been directed to the forum state France.

\subsubsection{The Hi Hotel case}

Mr Spoering sued Hi Hotel, established in France, before a German court for copyright infringing activities. Hi Hotel asserted that the German court lacked jurisdiction since they handed the alleged copyright infringing photos to a publishing company in France without knowing that this company would provide the photos to its subsidiary company in Germany that published these photos in books for sale in German bookshops.

Based on the 'directed activities' approach, it is important whether the defendant Hi Hotel objectively had the intention to direct the alleged copyright infringing activities to the forum state Germany. With respect to the relationship between Hi Hotel and the French publisher, this case does not provide any facts on a collaboration or agreement that could indicate the intention to disseminate the copyright infringing photos. Hence, Hi Hotel does not appear to have objectively directed the alleged copyright infringing activities to Germany. The German court could therefore not obtain jurisdiction.

\subsubsection{The Pez Hejduk case}

Ms. Hejduk sued the company EnergieAgentur, established in Germany, before an Austrian court for making available copyright infringing photos via their website. EnergieAgentur

\footnotetext{
${ }^{2684}$ Case C-170/12 Pinckney, para. 12, 22.

${ }^{2685}$ Case C-170/12 Pinckney, para 13.

${ }^{2686}$ Case C-170/12 Pinckney, para 13.

${ }^{2687}$ Opinion of Advocate General Jääskinen in the case C-170/12 Peter Pinckney v. KGD Mediatech AG, para. 19.
} 
argued that the Austrian court lacked jurisdiction because the website was not directed at Austria as EnergieAgentur used the country code top-level domain for Germany 'de'.

To assess whether alleged copyright infringing activities had been directed to Austria, it is relevant to examine the objective intention of the defendant EnergieAgentur. The country code top-level domain for Germany has been an indication that the activities were directed to Germany. Yet, other factors should be examined such as the language that has been employed on the website involved or the content that relates to the infringing photos on this website.

\subsection{A codified uniform approach to jurisdiction in cross-border copyright infringement cases?}

\subsubsection{At European Union level}

From a perspective of legal certainty, it is preferable to codify the desirable approach to jurisdiction in cross-border copyright infringement cases as demonstrated in paragraph 8.4. This approach could be codified in a separate provision in the future recast of the Brussels Ibis Regulation under the section of special jurisdiction rules that deviate from the general forum rei rule. ${ }^{2688}$ The proposed connecting factors could also be employed in the future European Union Copyright Regulation. As indicated in paragraph 3.6, there are several European Union intellectual property rights that are governed by European Union Regulations that contain special jurisdiction rules such as the EU trade marks Regulation, ${ }^{2689}$ the Community design rights Regulation, ${ }^{2690}$ the Community plant variety rights Regulation ${ }^{2691}$. These special jurisdiction rules have to be applied by specialized courts of the European Union Member States in infringement cases. In the future a European Union copyright may come into existence. ${ }^{2692}$ The connecting factors that have been proposed in the table of paragraph 8.4 could be employed in the future European Union Copyright Regulation in infringement cases.

As demonstrated in this thesis, it has generally been argued that due to the territorial protection of copyrights the dichotomy Handlungsort and Erfolgsort established in the Bier ruling should not be applied with respect to cross-border copyright infringements; the place of the infringement has been preferred as connecting factor to establish jurisdiction in cross-border copyright infringements cases. ${ }^{2693}$ The 'place of infringement' will include both the

\footnotetext{
${ }^{2688}$ Torremans (2017, p. 240) argues that there are limits regarding the 'one size fits all' approach of the Brussels Ibis Regulation; the time has come to consider more detailed and specialized private international law rules for difficult issues such as intellectual property. However, he points out that it remains an open question whether there will be a political will. See Ten Wolde (2020, pp. 251-275) on the classification of the CJEU's interpretations of the Erfolgsort under Article 7(2) Brussels Ibis based on the type of the particular right that has allegedly been infringed.

${ }^{2689}$ Regulation (EU) No. 2017/1001 of the European Parliament and of the Council of 14 June 2017 on the European Union trade mark (OJ L 154, 16.6.2017, pp. 1-99).

${ }^{2690}$ Council Regulation (EC) No. 6/2002 of 12 December 2001 on Community designs (OJ L 3, 5.1.2002, pp. 124).

${ }^{2691}$ Council Regulation (EC) No. 2100/94 of 27 July 1994 on Community plant variety rights (OJ L 227, 1.09.1994, pp. 1-30).

${ }^{2692}$ See paragraphs 2.2.2.2 and 5.3.5.

${ }^{2693}$ See paragraph 2.3.2.
} 
Handlungsort and the Erfolgsort. The abovementioned European Union Regulations also employ the place of infringement as connecting factor to establish jurisdiction regarding crossborder infringements of the intellectual property rights involved. ${ }^{2694}$ Paragraph 6.1.3.2 demonstrates that while Article 2:202 CLIP employs the 'place of infringement' as connecting factor to establish jurisdiction in cross-border copyright infringement cases, the 'directed activities'-based escape clause in this provision relates to the Erfolgsort. If the 'place of infringement' will be employed in cross-border copyright infringement cases, the suggested 'directed activities' approach and desired combined approach for ubiquitous copyright infringements in paragraph 8.4 will also relate to the Erfolgsort. The Handlungsort will be the place where the infringer has initiated the copyright infringer activities that will generally be the place where the infringer is domiciled or established. ${ }^{2695}$

\subsubsection{At international level}

The desirable approach to effects-based jurisdiction in cross-border copyright infringement cases as set out in paragraph 8.4 could be employed at international level. First of all, the approach satisfies the main principle of jurisdiction rules related to private international law namely predictability as regards which court will be competent in cross-border copyright infringements. ${ }^{2696}$ Second, the desirable approach is in accordance with the general accepted core principle of effects-based jurisdiction namely the principle of a close connection between the dispute and the court. ${ }^{2697}$

On the one hand, the territorially limited 'directed activities' approach to jurisdiction suits the territorial principle related to sovereignty of states and the prevailing territorial protection of copyrights. On the other hand, an approach to 'full' jurisdiction in case of ubiquitous copyright infringement cases has regularly been advocated by courts and scholars for reasons of sound administration of justice and to balance the interests of the litigants and broader interests related to copyrights. ${ }^{2698}$ The suggested combination of the 'directed activities' criterion and the 'flagrant substantial damages in relation to the entire damage' criterion seems to entail a strong territorial connection that could justify the conferral of full jurisdiction in view of the principle of international comity and comparative law ${ }^{2699}$. In light of the principle of international comity, it will nonetheless be desirable to limit the territorial scope of the 'full' jurisdiction to the states that adhere to a similar conflict-of-laws rule ${ }^{2700}$ with respect to copyright infringements as long as there exist no uniform copyright.

\footnotetext{
${ }^{2694}$ See paragraph 3.6. See Article 125 of the Regulation (EU) No. 2017/1001 of the European Parliament and of the Council of 14 June 2017 on the European Union trade mark; Article 82 Council Regulation (EC) No. 6/2002 of 12 December 2001 on Community designs.

2695 See paragraphs 2.1.2.2.2 and 3.5.

${ }^{2696}$ See paragraphs 4.2.4.2 and 7.1.

${ }^{2697}$ See paragraphs $2.1 .2 .2 .2,4.2 .4 .2$ and 5.3.4.1.

${ }^{2698}$ See paragraph 8.3 .

${ }^{2699}$ See paragraph 5.3.4.1.

${ }^{2700}$ Article 8(1) Rome II comprises a uniform conflict-of-laws rule related to infringements of intellectual property rights that has to be applied by the courts in the Member States of the European Union. There exist, however, various views on the issue whether the Berne Convention of 1979 consists of a uniform conflict-of-laws rule that could be applied in copyright infringement cases. See paragraph 2.3.2.
} 
The desirable approach in this dissertation has taken global interests and problems into consideration such as copyright protection, online piracy, copyright havens, cross-border trade, digital economy, cross-border flow of information. Hence, adopting this desirable approach to jurisdiction at international level will serve the trend of instrumentalization of private international law for global interests and does not seem to undermine the main principles of private international law.

As mentioned in paragraph 1.1.2, between 1992 and 2001, the Hague Conference on Private International Law did not succeed to unify the private international law rules on jurisdiction in civil and commercial matters. The differences between civil law and common law systems, particularly regarding intellectual property litigation, played a major role. ${ }^{2701}$ Yet, globalization and the Internet have increased the need to an adequate approach to jurisdiction in cross-border copyright infringement cases at international level. The proper functioning of the 'worldwide' internet environment particularly requires cooperation and a uniform approach to jurisdiction in cross-border copyright infringement cases. ${ }^{2702} \mathrm{~A}$ uniform approach would enhance the possibility of enforcement. Chapter seven has compared the approaches to jurisdiction in crossborder copyright infringement cases in the European Union and states of the United States of America. The desirable approach to jurisdiction in this chapter appears to suit both civil law and common law and could therefore be laid down in a future Hague Convention on jurisdiction.

Despite the differences between common law-based and civil law-based states, the Berne Convention of 1979 has laid down certain uniform rules with respect to copyrights that are applicable to both legal systems. ${ }^{2703}$ Although most common law-based states do not adhere to the moral rights approach, Article 6bis Berne Convention 1979 stipulates that copyrights consist of economic and certain moral rights. ${ }^{2704}$ Unlike other intellectual property rights, copyrights generally come into existence without any formality due to Article 5(2) of the Berne Convention 1979. ${ }^{2705}$ The desirable approach to effects-based jurisdiction under Article 7(2) Brussels Ibis in cross-border copyright infringement cases as set out in paragraph 8.4 could be incorporated into the Berne Convention of 1979 by drafting a private international law chapter, or incorporated into a new Convention under the auspices of the World Intellectual Property Organization. It would also be advisable to incorporate a uniform conflict-of-laws rule for cross-border copyright infringement cases that would make it possible for the court that obtains full jurisdiction to issue an injunction to cease or prevent copyright infringing activities in all territories of the Contracting States and to assess the entire damage in these states.

\footnotetext{
${ }^{2701}$ See also paragraphs 1.1.2 and 6.4.2.

${ }^{2702}$ See also Svantesson 2019(a), p. 46.

2703 For a list of the Contracting States of the Berne Convention of 1979 see http://www.wipo.int/treaties/en/ShowResults.jsp?treaty $\mathrm{id}=15$.

${ }^{2704}$ See paragraph 2.2.1.1.

2705 See paragraph 2.2.1.
} 
Bibliography 



\section{Literature}

\section{Adams, De Waele, Meeusen, \& Straetmans 2015}

M. Adams, H. de Waele, J. Meeusen and G. Straetmans, "Introduction: Judging Europe's Judges", in: M. Adams, H. de Waele, J. Meeusen and G. Straetmans (eds.), Judging Europe's Judges. The Legitimacy of the Case Law of the European Court of Justice, Oxford: Hart Publishing 2015, pp. 1-12.

\section{Adeney 2006}

E. Adeney, The moral rights of authors and performers. An International and Comparative Analysis, Oxford: Oxford University Press 2006.

\section{Alexy 1983}

R. Alexy, Theorie der juristischen Argumentation. A Theory of Legal Argumentation, Frankfurt: Suhrkamp 1983.

\section{Alkema 1988}

E.A. Alkema, "The Third-Party Applicability or 'Drittwirkung' of the European Convention on Human Rights", in: F. Matscher and H. Petzold (eds.), Protecting Human Rights: The European Dimension. Studies in Honour of G.J. Wiarda, Köln: Carl Heymans Verlag KG 1988, pp. 3345.

\section{Allen 2012}

J. Allen, "The Three 'RS' of Recent Australian Judicial Activism: Roach, Rowe and (No)' Riginalism”, Melbourne University Law Review 2012, 36, pp. 743-782.

\section{American Law Institute 2015}

American Law Institute, "Capturing the Voice of the American Law Institute: A Handbook for ALI Reporters and Those Who Review Their Work", Philadelphia: The Executive Office The American Law Institute, First edition published 2005 Revised 2015.

Available at https://www.ali.org/media/filer_public/08/f2/08f2f7c7-29c7-4de1-8c02d66f5b05a6bb/ali-style-manual.pdf

\section{Annan 2000}

K. Annan, "We The Peoples. The Role of the United Nations in the 21st Century (Millenium Report of the Secretary-General)", Report Millenium Summit, New York: United Nations 2000. See http://www.un.org/en/events/pastevents/we the peoples.shtml

\section{Anonymous 2010}

Anonymous, "The Single Publication Rule and Online Copyright: Tensions Between Broadcast, Licensing, and Defamation Law", Harvard Law Review, 2010, 23 (5), pp. 13151338.

\section{Arnull 2013}

A. Arnull, "Judicial activism and the European Court of Justice: how should academics respond?", in: B. de Witte, E. Muir and M. Dawson, Judicial Activism at the European Court of Justice, Cheltenham: Edward Elgar Publishing 2013, pp. 211-232.

\section{Austin 1997}

G. W. Austin, "The infringement of foreign intellectual property rights”, Law Quarterly Review 1997, pp. 321-340. 


\section{Axhamn 2010}

J. Axhamn, "The Nordic countries", in: G. Davies and K. Garnett, Moral rights, London: Sweet \& Maxwell 2010, pp. 505-535.

\section{Baarsma 2011}

N. A. Baarsma, The European of International Family Law, The Hague: T.M.C. Asser Press 2011.

\section{Babayev 2012}

R. Babayev, "Equal Treatment On The Grounds Of Movement And Union Choice-Of-Law Rules under Article 81 TFEU", Maastricht Journal of Europe and Comparative Law 2012, 19, pp. 63-82.

\section{Barak 2006}

A. Barak, The Judge in a Democracy, Woodstock: Princeton University Press 2006.

\section{Barbosa 2007}

R. G. Barbosa, "International Copyright Law and Litigation: A Mechanism for Improvement”, Marquette Intellectual Property Law Review 2007, 11(1), pp. 77-149.

\section{Barbosa 2008}

R. G. Barbosa, International Copyright Law and Litigation, A Mechanism for Improvement, Saarbrücken: VDM Verlag Dr. Müller 2008.

\section{Basedow 2010}

J. Basedow, "Foundations of Private International Law in Intellectual Property", in: J. Basedow, T. Kono and A. Metzger (eds.), Intellectual Property in the Global Arena. Jurisdiction, Applicable Law, and the Recognition of Judgments in Europe, Japan and the US, Tübingen: Mohr Siebeck 2010, pp. 3-29.

\section{Baudenbacher 2005}

C. Baudenbacher, "The Implementation of Decisions of the ECJ and of the EFTA Court in Member States' Domestic Legal Order”, Texas International Law Journal 2005, 40(3), pp. 383416.

\section{Beale 1935}

J. H. Beale, A Treatise on the Conflict of Laws, New York: Baker, Voorhis \& Co 1935.

\section{Beck 2012}

G. Beck, The Legal Reasoning of the Court of Justice of the EU, Oxford: Hart Publishing 2012.

\section{Beldner 2011}

J. Beldner, "How Technologically Savvy Do You Have to be to Apply Zippo? An Approach to Internet Personal Jurisdiction after Fancaster and Edvisors", Boston University Journal of Science \& Technology Law 2011, 17(2), pp. 318-332.

\section{Bellamy 2006}

R. Bellamy, "Still in Deficit: Rights, Regulation, and Democracy in the EU", European Law Journal 2006, 12(6), pp. 725-742.

\section{Bengoetxea 1993}

J. Bengoetxea, The Legal Reasoning of the European Court of Justice: Towards a European Jurisprudence, Oxford: Clarendon Press 1993. 


\section{Bengtsson 2016}

H. Bengtsson, "EU harmonisation of the copyright originality criterion", in: J. Rosén (ed.), European Intellectual Property Law, Cheltenham: Edward Elgar Publishing 2016, pp. 486-493.

\section{Bennett \& Granata 2019}

A. Bennett and S. Granata, When Private International Law Meets Intellectual Property Law. A Guide for Judges, The Hague: Hague Conference on Private International Law 2019; Geneva: World Intellectual Property Organization 2019.

Available at https://www.wipo.int/edocs/pubdocs/en/wipo_pub_1053.pdf

\section{Berman 2002}

P. S. Berman, "The Globalization of Jurisdiction", University of Pennsylvania Law Review 2002, 151(2), pp. 311-545.

\section{Berman 2007}

P. S. Berman, "Global Legal Pluralism”, Southern California Law Review 2007, pp. 1155-1238.

\section{Berman 2015}

P. S. Berman, "Non-State Lawmaking through the Lens of Global Legal Pluralism", in: A. Hefland (ed.), Negotiating State and Non-State law: The Challenge of Global and Local Legal Pluralism, New York: Cambridge University Press 2015, pp.15-40.

\section{Bianchi 1997}

A. Bianchi, "Globalization of Human Rights: The Role of Non-state Actors", in: G. Teubner (ed.), Global Law Without a State, Aldershot: Dartmouth Publishing Company 1997, pp. 179214.

\section{Biering 2010}

P. Biering 2010, "Have the Court of Justice ever taken integration too far?", in: H. Koch, K. Hagel-Sorensen, U. Haltern and J. H. H. Weiler (eds.), Europe The New Legal Realism. Essays in Honour of Hjalte Rasmussen, Djof Publishing 2010, pp. 57-80.

\section{Bobek 2013}

M. Bobek, "Of Feasibility and Silent Elephants: The Legitimacy of the Court of Justice through the Eyes of National Courts", in: M Adams, H. de Waele, J. Meeusen and G. Straetmans (eds.), Judging Europe's Judges. The Legitimacy of the Case Law of the European Court of Justice, Oxford: Hart Publishing 2013, pp. 197-234.

\section{Boele-Woelki, Joustra \& Steenhoff 1998}

K. Boele-Woelki, C. Joustra and G. Steenhoff, "Dutch private international law at the end of the $20^{\text {th }}$ century: pluralism of methods", in: E.H. Hondius (ed.), Netherlands Reports to the Fifteenth International Congress of Comparative Law in Bristol, Antwerpen/Groningen: Intersentia Rechtswetenschappen 1998, pp. 203-228.

\section{Boer \& Werner 2019}

L. J. M. Boer \& W. G. Werner, "Concepties van territorialiteit in het internationaal recht", in: Preadviezen van K. Arts, L. Boer, M. Scheltema, T. Strik, A. Terlouw, W. Werner, De Grenzen voorbij. De actualiteit van territorialiteit en jurisdictie. Handelingen Nederlandse JuristenVereniging jaargang 149/2019, Alphen aan den Rijn: Wolters Kluwer 2019, pp. 15-58. 


\section{Boone 2006}

B. D. Boone, "Bullseye!: Why a "Targeting" approach to Personal Jurisdiction in the ECommerce Context Makes Sense Internationally", Emory International Law Review 2006, 20(1), pp. 241-289.

\section{Borchers 1992}

P. J. Borchers, "Comparing Personal Jurisdiction in the United States and the European Community: Lessons for American Reform”, American Journal of Comparative Law 1992, 40, pp. 121-157.

\section{Borchers 2017}

P. J. Borchers, "Extending Federal Rule of Civil Procedure 4(K)(2): A Way to (Partially) Clean Up the Personal Jurisdiction Mess", American University Law Review 2017, 67(2), pp. 413456.

\section{Brachotte \& Nuyts 2014}

S. Brachotte and A. Nuyts, "Jurisdiction over Cyber Torts in the Brussels I Regulation", in: A. Savin and J. Trzakowski (eds.), Research Handbook on EU Internet Law, Cheltenham: Edward Elgar Publishing 2014, pp. 231-253.

\section{Brand 1998}

R. A. Brand, "Tort Jurisdiction in a Multilateral Convention: The Lessons of the Due Process Clause and the Brussels Convention", Brooklyn Journal of International Law 1998, pp. 125156.

\section{Brand 2002}

R. A. Brand, "Comparative Forum Non Conveniens and the Hague Convention on Jurisdiction and Judgments", Texas International Law Journal 2002, 37(3), pp. 467-498.

\section{Bredimas 1978}

A. Bredimas, Methods of Interpretation and Community Law, Amsterdam: North-Holland Publishing Company 1978.

\section{Briggs 2012}

A. Briggs, "The Principle of Comity in Private International Law", Recueil des Cours Volume 354, Collected Courses of the Hague Academy of International Law, 2012, pp. 77-182.

\section{Brilmayer, Haverkamp, Logan, Lynch, Neuwirth \& O'Brien 1988}

L. Brilmayer, J. Haverkamp, B. Logan, L. Lynch, S. Neuwirth and J. O’Brien, “A General Look at General Jurisdiction”, Yale Law School Faculty Scholarship Series 1988, pp. 721-784.

\section{Busch 2011(a)}

C. Busch, "Fundamental Rights and Private Law in the EU Member States", in: C. Busch and H. Schulte-Nölke (eds.), EU Compendium Fundamental Rights and Private Law, Munich: Sellier European Law Publishers 2011, pp. 1-23.

\section{Busch 2011(b)}

C. Busch, "The Impact of Fundamental Rights and Key Areas of Private Law", in: C. Busch and H. Schulte-Nölke (eds.), EU Compendium Fundamental Rights and Private Law, Munich: Sellier European Law Publishers 2011, pp. 26-65. 


\section{Campo Comba 2018}

M. Campo Comba, "The new Geo-blocking Regulation: general overview and private international law aspects", Nederlands Internationaal Privaatrecht 2018, 3, pp. 512-525.

\section{Cases Vallés 2009}

R. Cases Vallés, “The requirement of originality”, in: E. Derclaye, Research Handbook on the Future of EU Copyright, Cheltenham: Edward Elgar Publishing, 2009, pp. 102-132.

\section{Cassese, Clapham \& Weiler 1991}

A. Cassese, A. Chapham and J. Weiler, Human Rights and the European Community: Methods of Protection, Baden-Baden: Nomos Verlagsgeschellschaft 1999.

\section{Carballo Pineiro \& Kramer 2014}

L. Carballo Pineiro and X. Kramer, "The Role of Private International Law in Contemporary Society: Global Governance as a Challenge", Erasmus Law Review 2014, 3, pp. 109-112.

Available at http://www.erasmuslawreview.nl/tijdschrift/ELR/2014/3/ELR 22102671_2014_007_003_0011

\section{Carruthers 2016}

J. Carruthers, "Commercial Agency and the Conflict of Laws-What Place for Party Autonomy?", in: D. Busch, L. Macgregor and P. Watts, Agency Law in Commercial Practice, New York: Oxford University Press 2016, pp. 247-268.

\section{Chaen, Kono \& Yokomizo 2010}

S. Chaen, T. Kono and D. Yokomizo, "Jurisdiction in Intellectual Property Cases: The Transparency Proposal", in: Basedow, T. Kono and A. Metzger (eds.), Intellectual Property in the Global Arena. Jurisdiction, Applicable Law, and the Recognition of Judgments in Europe, Japan and the US, Tübingen: Mohr Siebeck 2010, pp. 78-145.

\section{Chan, Chud \& Weiss 2018}

Y. W. Chan, A. Chud and J. D. Weiss, Business Litigation Courts: Regional Case Summeries 26 March 2018.

Avaiable at https://www.goodwinlaw.com/publications/2018/03/03_26_2018-businesslitigation-reporter/regional-case-summaries

\section{Chapman 2001}

A. R. Chapman, “Approaching Intellectual Property as a Human Right”, Copyright Bulletin, xxxv no. 3, Paris: Unesco Publishing 2001, pp. 4-36.

\section{Chiou 2014}

T. Chiou, "Case Note on 'Trésor-Armani-Mania' Intellectual Property Code, Sec L. 112-1SNC Lancôme Parfums et Beauté and co., GA Modefine prestige et collection international v. M. X., International Review of Intellectual Property and Competition Law 2014, 45(7), pp. 852-854.

\section{Christie 2017}

A. F. Christie, "Private international law principles for ubiquitous intellectual property infringement-a solution in search of a problem?", Journal of Private International Law 2017, 13(1), pp. 152-183.

\section{Clark 2002}

D. S. Clark, "The Sources of Law", in: D. S. Clark and T. Ansay, Introduction to the Law of the United States, second edition, The Hague: Kluwer Law International 2002, pp. 35-52. 


\section{Cohen 1993}

A. B. Cohen, "Arising under Jurisdiction and the Copyright Laws", Hasting Laws Journal 1993, 44(2), pp. 337-398.

\section{Cohen Jehoram 2006}

H. Cohen Jehoram, "The Dutch Supreme Court Recognises Copyright in the Scent of a Parfume. The Flying Dutchman: All Sails, no Anchor (Lancome v. Kecofa)", European Intellectual Property Review 2006, 28(12), pp. 629-631.

\section{Condlin 2004}

R. J. Condlin, “'Defendant veto' or 'Totality of the Circumstances' It's Time for the Supreme Court to Straighten out the Personal Jurisdiction Standard Once Again”, Catholic University Law Review 2004, 54(1), pp. 53-149.

\section{Constantinesco 2000}

V. Constantinesco, “The ECJ as a Law-Maker: Praeter aut Contra Legem?”, in: D. O'Keeffe and A. Bavasso (eds.), Judicial Review in European Union Law. Liber Amicorum in Honour of Lord Slynn of Hadley Volume I, The Hague: Kluwer Law International 2000, pp. 73-80.

\section{Conway 2013}

G. Conway, The Limits of Legal Reasoning and the European Court of Justice, New York: Cambridge University Press 2013 (paperback edition).

\section{Cook 1924}

W.W. Cook, "The Logical and Legal Bases of the Conflict of Laws", Yale Law Journal 1924, pp. $457-488$.

\section{Coutinho 2015}

L. P. Coutinho, "The Passive Sovereignty of the Constitutional Judge a State Theory Approach", in: L. P. Coutinho, M. La Torre, S. D. Smith (eds.), Judicial Activism. An Interdisciplinary Approach to the American and European Experiences, Cham: Springer, 2015, pp. 137-160.

\section{Currie 1963}

B. Currie, Selected Essays on the Conflict of Laws, Durham: Duke University Press 1963.

\section{Cutler 2003}

A. C. Cutler, Private Power and global authority; transnational merchant law in the global political economy, New York: Cambridge University Press 2003.

\section{Dahl 2006}

R. A. Dahl, On Political Equality, New Haven: Yale Press University 2006.

Davis 2012(a)

J. Davis, Intellectual Property Law Core Text, fourth edition, Oxford: Oxford University Press 2012.

\section{Davis 2012(b)}

G. Davis, "Moral Rights in the Borderless Online Environment", in: J. Axhamn (ed.), Copyright in a Borderless Online Environment, Stockholm: Norstedts Juridik 2012, pp. 37-46. 


\section{De Almeida Ribeiro 2015}

G. de Almeida Ribeiro, "Judicial Activism and Fidelity to Law", in: L. P. Coutinho, M. La Torre and S. D. Smith (eds.), Judicial Activism. An Interdisciplinary Approach to the American and European Experiences, Cham: Springer, 2015, pp. 31-46.

\section{De Beer 1989}

A. C. G. de Beer, “Auteursrecht van universitaire auteurs”, in: D. Kokkini-Iatridou and F. W. Grosheide, Eenvormig en Vergelijkend Privaatrecht, Lelystad: Koninklijke Vermande BV 1989, pp. 385-428.

\section{De Boer 1980}

Th. M. de Boer, "De vermaatschappelijking van het internationaal privaatrecht", Nederlands Juristenblad 1980, 55, pp. 785-796.

\section{De Boer 1982}

Th. M. de Boer, Alternatieven voor de lex loci delicti, Deventer: Kluwer 1982.

\section{De Boer 1987}

Th. M. de Boer, Beyond lex loci delicti. Conflicts methodology and multistate torts in American case law, Deventer: Kluwer Law and Taxation Publishers 1987.

\section{De Boer 1990}

Th. M. de Boer, "Forty Years On: The Evolution of Postwar Private International Law in Europe", in: Th. M. de Boer (ed.), Forty Years On: The Evolution of Postwar Private International Law in Europe, Deventer: Kluwer 1990, pp. 1-14.

\section{De Boer 1993}

Th. M. de Boer, De wisselwerking tussen materieel recht en conflictenrecht. Preadvies uitgebracht voor de Nederlandse Vereniging voor de Rechtsvergelijking, Deventer: Kluwer 1993.

\section{De Boer 1998}

Th. M. de Boer, "Bescherming en begunstiging op het terrein van de internationale onrechtmatige daad", in: Th. M. de Boer (ed.), Vijftig jaar lex loci delicti. Van Dubbinks proefschrift tot een Wet conflictenrecht onrechtmatige daad, Deventer: Kluwer 1998, pp. 3546.

\section{De Boer 2012}

Th. M. de Boer, "And the winner is ...? Hoe het afliep met de grondslagenstrijd in het IPR", in: A. A. H. van Hoek, R. J. Q. Klomp, M. B. M. Loos, A. E. Oderkerk, J. A. Pontier and J. W. Rutgers (eds), Offerhauskring vijftig jaar: jubileumbundel ter gelegenheid van het vijftigjarig bestaan van de Studiekring 'Prof. Mr. J. Offerhaus' (1962-2012), Den Haag: Boom Juridische Uitgevers 2012, pp. 35-44.

\section{De Búrca 2001}

G. de Búrca, "Introduction”, in: G. de Búrca and J. H. H. Weiler (eds.), The European Court of Justice, New York: Oxford University Press 2001, pp. 1-8.

\section{Deelen 1966}

J. E. J. Th. Deelen, De blinddoek van von Savigny, Amsterdam: Scheltema \& Holkema 1966. 


\section{De Cock Buning 2010}

M. De Cock Buning, "Expension and covergence in copyright law", in: F. W. Grosheide (ed.), Intellectual Property and Human Rights. A Paradox, Cheltenham: Edward Elgar Publishing Limited 2010, pp. 47-71.

\section{De Groote 2004}

B. de Groote, Onrechtmatige Daad en Internet: Analyse van Artikel 5.3. EEX-Verordening, Brussels: Larcier 2004.

\section{De Groote 2009}

B. de Groote, "Jurisdiction problems regarding Internet torts: Critical remarks", Computer Law $\&$ Security Review: The International Journal of Technology and Practice 2009, 25(5), pp. 447454.

\section{De Ly 1989}

F. De Ly, De Lex Mercatoria. Inleiding op de studie van het transnationaal handelsrecht, Antwerpen/Apeldoorn: Maklu 1989.

\section{De Miguel Asensio 2009}

P. A. De Miguel Asensio, "The Private International Law of Intellectual Property and of Unfair Commercial Practices: Convergence or Divergence?”, in: S. Leible and A. Ohly (eds.), Intellectual Property and Private International Law, Tübingen: Mohr Siebeck 2009, pp. 137190.

\section{De Miguel Asensio 2010}

P. A. De Miguel Asensio, The Networked Information Society: Territoriality and Beyond, Conference Paper, Annual Kyushu University Law Conference-Fukuoka, 2010.

Available at

\section{http://www.law.kyushu-u.ac.jp/programsinenglish/conference2010/draft12.pdf}

\section{De Miguel Asensio 2017}

P. A. De Miguel Asensio, "Internet, jurisdiction", in: J. Basedow, G. Rühl, F. Ferrari and P. De Miguel Asensio (eds.), Encyclopedia of Private International Law, Cheltenham: Edward Elgar Publishing 2017, pp. 989-998.

\section{De Vries, Groussot, Petursson 2012}

S. de Vries, X. Groussot, G. T. Petursson, Balancing Fundamental Rights with the EU Treaty Freedoms: The European Court of Justice as 'tightrope' walker, The Hague: Eleven International Publishing 2012.

\section{De Waele 2009}

H. de Waele, Rechterlijke Activisme en het Europese Hof van Justitie, Den Haag: Boom Juridische Uitgevers 2009.

\section{De Waele 2012}

H. de Waele, "Traditioneel tekstueel of typisch teleologisch?" Rechtsvindingen bij het Europese Hof van Justitie", in: L. E. de Groot-van Leeuwen and J. D. A den Tonkelaar (eds.), Rechtsvinding op veertien terreinen, Deventer: Kluwer 2012, pp. 53-66.

\section{De Werra 2016}

J. De Werra, "A closer look at specialized intellectual property courts", WIPO Magazine, November 2016, pp. 28-31. 


\section{De Winter 1947}

L. I. De Winter, "De sociale functies der rechtsnormen als grondslag voor de oplossing van internationaal privaatrechtelijke wetsconflicten", Rechtsgeleerd Magazijn Themis 1947, pp. 101-166.

\section{De Witte, Muir, Dawson 2013}

B. de Witte, E. Muir and M. Dawson, Judicial Activism at the European Court of Justice, Cheltenham: Edward Elgar Publishing 2013.

\section{Dehousse 1998}

R. Dehousse, The European Court of Justice: The Politics of Judicial Integration, London: Macmillan 1998.

\section{Depreeuw \& Hubin 2014}

S. Depreeuw and J.-B. Hubin, "Of availability, targeting and accessibility: online copyright infringements and jurisdiction in the EU", Journal of Intellectual Property Law \& Practice 2014, 9(9), pp. 750-764.

\section{Derclaye 2014}

E. Derclaye, "Assessing the impact and reception of the Court of Justice of the European Union case law on UK copyright law: what does the future hold?", Revue Internationale du Droit d'auteur 2014, pp. 5-117.

\section{Dicey 1896}

A. V. Dicey, A Digest of the Law of England with Reference to the Conflict of Laws, London: Stevens and Sons 1896.

\section{Dinwoodie 2003}

G. B. Dinwoodie, "Commitments to Territoriality in International Copyright Scholarship", in: Paul Brügger (ed.), ALAI Copyright-Internet World: Report on the Neuchatel Study Session 16/17 September 2002, Lausanne/Bern: Groupe Swiss de 1' ALAI, 2003.

\section{Dinwoodie 2005}

G. B. Dinwoodie, "Conflict and International Copyright Litigation: The Role of International Norms", in: J. Basedow, J. Drexl, A. Kur \& A. Metzger (eds.), Intellectual Property in the Conflict of Laws, Tübingen: Mohr Siebeck 2005, pp. 195-210.

\section{Dinwoodie 2009(a)}

G. B. Dinwoodie, "Developing a Private International Intellectual Property Law: The Demise of Territoriality?", William and Mary Law Review 2009, 51, pp. 711-800. Available at http://papers.ssrn.com/sol3/papers.cfm?abstract_id=1502228

\section{Dinwoodie 2009(b)}

G. B. Dinwoodie, "Extra-Territorial Application of IP Law: A View from America", in: S. Leible and A. Ohly (eds.), Intellectual Property and Private International Law, Tübingen: Mohr Siebeck 2009, pp. 123-136.

\section{Dorsaneo 2015}

W. Dorsaneo, "Pennoyer strikes back: Personal Jurisdiction in a Global Age", Texas A\&M Law Review 2015, 3(1); SMU Dedman School of Law Legal Studies Research Paper No. 185. Available at https://papers.ssrn.com/sol3/papers.cfm?abstract id=2703963 


\section{Douglas-Scott 2002}

S. Douglas-Scott, Constitutional Law of the European Union, Harlow: Pearson Education Limited 2002.

\section{Douglas 2018}

M. Douglas, "Extraterritorial injunctions affecting the internet", Journal of Equity 2018, pp. 34-57.

\section{Drexl \& Kur 2005}

J. Drexl and A. Kur, "Annex II MPI-Proposal", in: J. Drexl and A. Kur (eds.) Intellectual Property and Private International Law Heading for the Future, Oregon: Hart Publishing 2005, pp. 309-347.

\section{Drexl 2007}

J. Drexl, "Constitutional Protection of Authors' Moral Rights in the European Union-Between Privacy, Property and the Regulation of the Economy", in: K. S Ziegler (ed.) Human Rights as Private Law: Privacy and Autonomy, Oxford: Hart Publishing 2007, pp. 159-176.

\section{Dreyfuss \& Ginsburg 2002}

R. C. Dreyfuss and J. Ginsburg, "Draft Convention on Jurisdiction and Recognition of Judgments in Intellectual Property Matters”, Chicago-Kent Law Review 2002, 77(3), pp. 10651153.

\section{Dreyfuss 2005}

R. C. Dreyfuss, "The ALI Principles on Transnational Intellectual Property Disputes: Why Invite Conflicts?”, Brooklyn Journal of International Law 2005, pp. 819-848.

\section{Dubbink 1947}

C. W. Dubbink, De onrechtmatige daad in het Nederlandse internationaal privaatrecht, 'sGravenhage: Martinus Nijhoff 1947.

\section{Dubbink 1973}

C. W. Dubbink, "Het rechtvaardigheidsgehalte van het internationaal privaatrecht", in: Speculum Langemeijer: 31 Rechtsgeleerde opstellen, W.E.J. Tjeenk Willink Zwolle 1973, pp. 63-72.

\section{Dubbink 1998}

C. W. Dubbink, "Vijftig jaren”, in: Th. M. de Boer, Vijtfig jaar lex loci delicti. Van Dubbinks proefschrift tot een Wet conflictenrecht onrechtmatige daad, Deventer: Kluwer 1998, pp. 7-16.

\section{Dworkin 2013}

R. Dworkin, Taking Rights Seriously, London/New York: Bloomsbury Academy 2013.

\section{Edward 1996}

D. Edward, "Judicial Activism-Myth or Reality?", in: A. Campbell and M. Voyatzi (eds.), Legal Reasoning and Judicial Interpretation of European Law: Essays in Honour of Lord Mackenzie, London: Trenton Publishing 1996, pp. 29-67.

\section{Ehrenzweig 1956}

A. A. Ehrenzweig, "The transient rule of personal jurisdiction: The "power" and the forum non conveniens", Yale Law Journal 1956, 65(3), pp. 289-314. 


\section{Everling 1984}

U. Everling, "The Court of Justice as Decisionmaking Authority", Michigan Law Review 1984, pp. 1294-1310.

\section{Everling 2000}

U. Everling, "On the Judge-Made Law of the European Community's Courts”, in: D. O'Keeffe and A. Bavasso (eds.), Judicial Review in European Union Law. Liber Amicorum in Honour of Lord Slynn of Hadley Volume I, The Hague: Kluwer Law International 2000, pp. 29-44.

\section{Fawcett \& Torremans 2011}

J. J. Fawcett and P. L. C. Torremans, Intellectual Property and Private International Law, second edition, Oxford: Oxford University Press 2011.

\section{Favale, Kretschmer \& Torremans 2016}

M. Favale, M. Kretschmer, and P. L. C. Torremans, "Is There a EU Copyright Jurisprudence? An Empirical Analysis of the Workings of the European Court of Justice", The Modern Law Review 2016, 79(1), pp. 31-75.

\section{Fennelly 1996}

N. Fennelly, "Legal Interpretation at the European Court of Justice", Fordham International Law Journal 1996, 20(3), pp. 656-679.

\section{Fentiman 2005}

R. Fentiman, "Choice of Law and Intellectual Property", in: J. Drexl and A. Kur (eds.), Intellectual Property and Private International Law Heading for the Future, Oregon: Hart Publishing 2005, pp. 129-148.

\section{Ferrari 2017}

F. Ferrari, "Forum-(and law) shopping”, in: J. Basedow, G. Rühl, F. Ferrari and P. De Miguel Asensio (eds.), Encyclopedia of Private International Law, Cheltenham: Edward Elgar Publishing 2017, pp. 789-797.

\section{Ferster 2002}

L. S. Ferster, "Griffis v. Luban: A Red Herring in the High Seas of Personal Jurisdiction", William Mitchell Law Review 2002, 29(2), pp. 343-373.

\section{Flessner 1990}

A. Flessner, Interessenjurisprudenz im internationalen Privatrecht, Tübingen: Mohr Siebeck 1990.

\section{Floyd \& Baradaran-Robinson 2006}

C. D. Floyd and S. Baradaran-Robinson, "Toward a Unified Test of Personal Jurisdiction in an Are of Widely Diffused Wrongs: The Relevance of Purpose and Effects", Indiana Law Journal 2006, 81(2), pp. 602-665.

\section{Fockema Andreae 1904}

J. P. Fockema Andreae, Tien jaren rechtspraak van den Hoogen Raad: bijdrage tot de leer der wetsuitlegging, Leiden: S. C. van Doesburgh 1904.

\section{Foelix 1843}

M. Foelix, Traité du Droit International Privé ou Du Conflict des Lois De Differentes Nations en Matière de Droit Privé, Paris: Joubert, Libraire De La Cour De Cassation 1843. 


\section{Franq 2017}

S. Franq, "Unilateralism”, in: J. Basedow, G. Rühl, F. Ferrari and P. De Miguel Asensio (eds.), Encyclopedia of Private International Law, Cheltenham: Edward Elgar Publishing 2017, pp. 1779-1791.

\section{García-Castrillón 2014}

C. O. Garcia-Castrillon, "Choice of Law in IP: Rounding Off Territoriality", in: P. L. C. Torremans (ed.), Research Handbook on Cross-Border Enforcement of Intellectual Property, Cheltenham: Edward Elgar Publishing 2014, pp. 421-468.

\section{Garcimartín Alférez 2013}

F. J. Garcimartín Alférez, "Hermeneutic Dialogue between Rome I and Rome II: General Principles and Argumentative rules," in: Permanent Bureau of the Hague Conference on Private International Law (ed.), A Commitment to Private International Law: Essays in honour of Hans van Loon, Cambridge: Intersentia 2013, pp. 169-179.

\section{Gebauer 2000}

M. Gebauer, "Uniform Law, General Principles and Autonomous Interpretation", Uniform Law Review 2000, 5(4), pp. 683-704.

\section{Gedid 1999}

J. L. Gedid, "Minimum Contact Analyses in Cyberspace- Sales of Goods and Services DraftWork in Progress", Jurisdiction: Building Confidence in a Borderless Medium July 26-27 1999 Montreal Canada.

\section{Geiger 2006}

C. Geiger, "Copyright and free access to information: for a fair balance between interests in a globalised world”, European Intellectual Property Review 2006, 28(7), pp. 366-373.

\section{Geiger 2009}

C. Geiger, "Copyright's fundamental rights dimension at EU level", in: E. Derclaye, Research Handbook on the Future of EU Copyright, Cheltenham: Edward Elgar Publishing 2009, pp. 2748.

\section{Geiger \& Schönherr 2014}

C. Geiger and F. Schönherr, "The Information Society Directive", in: I. A. Stamatoudi and P.

L. C. Torremans (eds.), EU Copyright Law: A Commentary, Cheltenham: Edward Elgar Publishing 2014, pp. 395-527.

\section{Geiger 2015}

C. Geiger, "Reconceptualizing the Constitutional Dimension of Intellectual Property", in: P. L.

C. Torremans (ed.), Intellectual Property and Human Rights. Enhanced Edition of Copyright and Human Rights, Alphen aan den Rijn: Kluwer Law International third edition, 2015, pp. 115-161.

\section{Geiger 2016}

C. Geiger, "The Role of the Court of Justice of the European Union: Harmonizing, Creating and sometimes Disrupting Copyright Law in the European Union", in: A. Stamatoudi (ed.), New Developments in EU and International Copyright Law, Alphen aan den Rijn: Kluwer Law International 2016, pp. 435-446. 


\section{Geist 2001}

M. A. Geist, "Is There a There There?-Toward Greater Certainty for Internet Jurisdiction", Berkeley Technological Law Journal 2001, 16 (3), pp. 1345-1406.

\section{Georgescu, Marin, Vasile \& Florecsu 2016}

G. G. Georgescu, P. M. Marin, D. Vasile, G. Florescu, "Jurisdiction over cyber torts under Brussels I Bis Regulation", Themis Competition 2016, Semi-Final C, International Judicial Cooperation in Civil Matters-European Civil procedure, pp. 1-20. Available at http://www.ejtn.eu/PageFiles/14777/Written paper_Romania.pdf.

\section{Gerards 2012}

J. H. Gerards, "Oordelen over grondrechtenzaken. Rechtsvinding door drie hoogste rechters in Nederland", in: L. E. de Groot-van Leeuwen and J. D. A den Tonkelaar (eds.), Rechtsvinding op veertien terreinen, Deventer: Kluwer 2012, pp. 9-52.

\section{Gervais 2015}

D. J. Gervais, "Intellectual Property and Human Rights: Learning to Live Together", in: P. L.C. Torremans (ed.), Intellectual Property and Human Rights. Enhanced Edition of Copyright and Human Rights, Alphen aan den Rijn: Kluwer Law International third edition, 2015, pp. 3-26.

Gibson \& Caldeira 1993

J. L. Gibson and G. A. Caldeira, "The European Court of Justice: A question of legitimacy", Zeitschrift für Rechtssoziologie 1993, pp. 204-222.

\section{Gielen 2017}

C. Gielen, "Intellectuele eigendomsrecht", in: C. Gielen (ed.), Kort begrip van het intellectuele eigendomsrecht, Deventer: Wolters Kluwer, 2017, pp. 1-12.

\section{Ginsburg 1990}

J. C. Ginsburg, "A Tale of Two Copyrights: Literary Property in Revolutionary France and America”, Tulane Law Review 1990, 64(5), pp. 991-1031.

\section{Ginsburg 1995}

J. C. Ginsburg, "Putting Cars on the 'Information Superhighway': Authors, Exploiters, and Copyright in Cyberspace”, Columbia Law Review 1995, 95, pp. 1466-1499.

\section{Ginsburg 1998}

J. C. Ginsburg, "The Private International Law of Copyright in an Era of Technological Change", in: Recueil Des Cours. Collected Courses of the Hague Academy of International Law, Volume 273, The Hague: Martinus Nijhoff Publishers 1998, pp. 239-405.

\section{Ginsburg \& Treppoz 2015}

J. C. Ginsburg and E. Treppoz, International Copyright Law: U.S. and E.U. Perspectives. Text and Cases, Cheltenham: Edward Elgar Publishing 2015.

\section{Goldstein \& Hugenholtz 2013}

P. Goldstein and B. Hugenholtz, International Copyright. Principle, Law, and Practice, Oxford: Oxford University Press 2013.

\section{Gottschalk 2007}

E. Gottschalk, "The Law Applicable to Intellectual Property Rights. Is the Lex Loci Protectionis a Pertinent Choice-of-Law Approach?”, in: E. Gottschalk, R. Michaels, G. Rühl and J. von Hein 
(eds.), Conflict of Laws in a Globalized World, Cambridge: Cambridge University Press 2007, pp. 184-219.

\section{Granger 2013}

M-P, F. Granger, "The Court of Justice and the transformation of Europe: looking to the future, dealing with the present but living in the past?" 2013. Available at https:/www.ceu.edu/sites/default/files/attachment/event/8922/mpgrangereuropean-courtjustice15nov2013.pdf

\section{Green 2009}

C. Green, “An Intellectual History of Judicial Activism”, Emory Law Journal, 5, 2009, pp. 1195-1264.

\section{Greig 1976}

D. W. Greig, International Law, London: Butterworths 1976.

\section{Grenig 2014}

J. E. Grenig, "After the Arbitration Award: Not Always Final and Binding" Marquette Sports Law Review 2014, 25, pp. 65-99.

\section{Griffiths 2013(a)}

J. Griffiths, "Dematerialization, Pragmatism and the European Copyright Revolution", Oxford Journal of Legal Studies 2013, 33(4), pp. 767-790.

\section{Griffiths 2013(b)}

J. Griffiths, "Constitutionalising or Harmonising? The Court of Justice, the Right to Property and European Copyright Law”, European Law Review 2013, 38, pp. 65-78.

\section{Griffiths 2014}

J. Griffiths, "The Role of the Court of Justice in the Development of European Union Law", in: I. A. Stamatoudi and P. L. C. Torremans (eds.), EU Copyright Law: A Commentary, Cheltenham: Edward Elgar Publishing 2014, pp. 1098-1126.

\section{Griffiths 2015}

J. Griffiths, "Moral right of a copyright perspective", in: F. Brison, S. Dusollier, M.-C. Janssens and $\mathrm{H}$. Vanhees (eds.), Moral Rights in the $21^{\text {st }}$ Century. The changing role of the moral rights in an era of information overload, Brussels: Lancier 2015, pp. 83-89.

\section{Groenewegen 2006}

F. T. Groenewegen, Wetsinterpretatie en rechtsvorming. Een rechtstheoretisch onderzoek naar rechtsvorming door de rechter in het bestuursrecht en het privaatrecht, Den Haag: Boom Juridische Uitgevers 2006.

\section{Grosheide 1986}

F. W. Grosheide, Auteursrecht op maat, Deventer: Kluwer 1986.

\section{Grosheide 1998}

F. W. Grosheide, "Experiences in the Field of Intellectual Property", in: K. Boele-Woelki and C. Kessedjian (eds.), Internet Which Court Decides? Which Law Applies? Quel tribunal decide? Quel droit s'applique?, The Hague/London/Boston: Kluwer Law International 1998, pp. 35-46. 


\section{Grosheide 2009}

F. W. Grosheide, "Moral Rights", in: E. Derclaye, Research Handbook on the Future of EU Copyright, Cheltenham Edward Elgar 2009, pp. 242-266.

\section{Grosheide 2010}

F. W. Grosheide, “General Introduction”, in: F. W. Grosheide (ed.), Intellectual Property and Human Rights. A Paradox, Cheltenham: Edward Elgar Publishing Limited 2010, pp. 3-36.

\section{Grossi 2016}

S. Grossi, The U.S. Supreme Court and the Modern Common Law Approach, paperback edition, New York: Cambridge University Press 2016.

\section{Grünberger 2015}

M. Grünberger, "Zuständigkeitsbegründender Erfolgsort bei Urheberrechtsverletzungen. (zu EuGH, 3.10.2013-Rs. C-170/12- Pinckney/ KDG Mediatech AG, unten S. 87, Nr. 2, und Cour de Cassation, 22.1.2014-10-15.890)", Praxis des Internationalen Privat- und Verfahrensrecht 2015, pp. 56-65.

\section{Grusic 2015}

U. Grusic, The European Private International Law of Employment, Cambridge: Cambridge University Press 2015.

\section{Grusic, Heinze, Merrett, Mills, Carcia-Castrillón, Tang, Trimmings, Walker 2017}

U. Grusic, C. Heinze, L. Merrett, A. Mills, C. O. Carcia-Castrillón, Z. S. Tang, K. Trimmings, L. Walker, in: P. L. C. Torremans \& Fawcett (eds.), Cheshire, North \& Fawcett Private International Law, fifteenth edition, Oxford: Oxford University Press 2017.

\section{Halpern, Port \& Seymore 2015}

S. W. Halpern, K. L. Port and S. B. Seymore, Fundamentals of United States Intellectual Property Law. Copyright, Patent and Trademark, fifth edition, Alphen aan den Rijn: Kluwer Law International 2015.

\section{Hart 2012}

H. L. A. Hart, The Concept of Law, third edition, With an introduction by Leslie Green, Oxford: Oxford University Press 2012.

\section{Hartley 1999}

T. C. Hartley, Constitutional Problems of the European Union, Oregon: Hart Publishing 1999.

\section{Hartley 2014}

T. C. Hartley, The Foundations of European Union Law. An Introduction to the Constitutional and Administrative Law of the European Union, eight edition, Oxford: Oxford University Press 2014.

\section{Hartley 2015}

T. C. Hartley, International Commercial Litigation. Text, Cases and Materials in Private International Law, second edition, Cambridge: Cambridge University Press 2015.

\section{Haugen 2007}

H. M. Haugen, "General Comment No. 17 on "Authors' Rights", The World of Intellectual Property 2007, pp. 53-69. 


\section{Hay, Borchers \& Symeonides 2010}

P. Hay, P. Borchers, S. C. Symeonides, Conflict of Laws, fifth edition, Eagan: West Publishers 2010.

\section{Hay 1991}

P. Hay, "Book Reviews: Interessenjurisprudenz im Internationalen Privatrecht by Alex Flessner, Tübingen: Mohr (Paul Siebeck) 1990”, American Journal of Comparative Law 1991, 39, pp. 437-444.

\section{Hay 2018}

P. Hay, Advanced introduction to Private International Law and Procedure, Cheltenham: Edward Elgar Publishing 2018.

\section{Heck 1932}

P. Heck, Begriffsbildung und Interessenjurisprudenz, Tübingen: Mohr Siebeck 1932.

\section{Hefland 2015}

M. A. Hefland, "Introduction", in: M. A. Hefland (ed.), Negotiating state and non-state law: The challenge of global and local legal pluralism, New York: Cambridge University Press 2015, pp. 1-14.

\section{Heinze 2010}

C. Heinze, "A Framework for International Enforcement of Territorial Rights: The CLIP Principles on Jurisdiction", in: J. Basedow, T. Kono and A. Metzger (eds.), Intellectual Property in the Global Arena. Jurisdiction, Applicable Law, and the Recognition of Judgments in Europe, Japan and the US, Tübingen: Mohr Siebeck 2010, pp. 53-76.

\section{Heinze 2013}

C. Heinze, “Article 2:101 General Jurisdiction”, in: J. Basedow \& J. Drexl (eds.), Conflict of Laws in Intellectual Property. The CLIP Principles and Commentary. European Max Planck Group on Conflict of Laws in Intellectual Property, Oxford: Oxford University Press 2013, pp. 56-60.

\section{Held \& McGrew 2002}

D. Held and A. McGrew, "Introduction". in: D. Held and A. McGrew, Governing Globalization: Power, Authority, and Global Governance, Cambridge: Polity Press 2002, pp. $1-24$.

\section{Heldrich 1969}

A. Heldrich, Internationale Zuständigkeit und Anwendbares Recht, Tübingen: Mohr Siebeck 1969.

\section{Helfer 2003}

L. R. Helfer, "Human Rights and Intellectual Property: Conflict or Coexistence?", Minnesota Intellectual Property Review 2003, 5(1), pp. 47-61.

\section{Helfer 2015}

L. R. Helfer, "The New Innovation Frontier? Intellectual Property and the European Court of Human Rights", in: P. L. C. Torremans (ed.), Intellectual Property and Human Rights, third edition, Alphen aan den Rijn: Kluwer Law International 2015, pp. 27-85. 


\section{Hertz 1998}

K. Hertz, Jurisdiction in Contract and Tort under the Brussels Convention, Copenhagen: Djof Publishing 1998.

\section{Herzog \& Gerken 2008}

R. Herzog and L. Gerken, "Stop the European Court of Justice", euobserver 10 September 2008. Available at https://euobserver.com/opinion/26714.

\section{Hess, Pfeiffer \& Schlosser 2007}

B. Hess, T. Pfeiffer and P. Schlosser, Report on the Application of Regulation Brussels I in the Member States (Study JLS/C4/2005/03), Final Version September 2007, Ruprecht-KarlsUniversität Heidelberg.

\section{Hesselink 2002}

M. Hesselink, The New European Private Law: Essays on the Future of Private Law in Europe, The Hague: Kluwer Law International 2002.

\section{Hestermeyer 2006}

H. Hestermeyer, "Personal Jurisdiction for Internet Torts: Towards an International Solution?", Northwestern Journal of International Law \& Business 2006, 26(2), pp. 267-288.

\section{Hijmans 1910}

I. H. Hijmans, Het Recht der Werkelijkheid, Haarlem: De Erven F. Bohn, 1910.

\section{Hill 2001}

J. Hill, "Jurisdiction in civil and commercial matters: is there a third way?", Current Legal Problems 2001, 54, pp. 439-476.

\section{Hill 2003}

J. Hill, "The Exercise of Jurisdiction in Private International Law", in: P. Capps, M. Evans and S. Konstadinidis, Asserting Jurisdiction. International and European Legal Approaches, Oregon: Hart Publishing 2003, pp. 39-62.

\section{Holland 1991(a)}

K. M. Holland, "Preface", in: K. M. Holland (ed.), Judicial Activism in Comparative Perspective, London: Macmillan 1991, pp. vii-viii.

\section{Holland 1991(b)}

K. M. Holland, "Introduction", in: K. M. Holland (ed.), Judicial Activism in Comparative Perspective, London: Macmillan 1991, pp. 1-11.

\section{Hörnle 2009}

J. Hörnle, "The Jurisdictional Challenge of the Internet", in: L. Edwards and C. Waelde (eds.), Law and the Internet, Portland: Hart Publishing 2009, pp. 121-158.

\section{Horsley 2013}

T. Horsley, "Reflections on the role of the Court of Justice as the 'motor' of European Integration: Legal limits to judicial lawmaking”, Common Market Law Review 2013, 4, pp. 931-964.

\section{Horspool, Humpreys \& Wells-Greco 2016}

M. Horspool, M. Humpreys \& W. Wells-Greco, European Union Law, Oxford: Oxford University Press 2016. 


\section{Hua 2014(a)}

J. J. Hua, "Introduction", in: J.J. Hua (eds.), Toward a More Balanced Approach: Rethinking and Readjusting Copyright systems in the Digital Network Era, Berlin/Heidelberg: Springer 2014, pp. xiii-xxiii.

\section{Hua 2014(b)}

J. J. Hua, "Balance of Interest in Copyright Systems and Imbalances Under Digital Network Environments". J.J. Hua (eds.), Toward a More Balanced Approach: Rethinking and Readjusting Copyright systems in the Digital Network Era, Berlin/Heidelberg: Springer 2014, pp. 39-68.

\section{Hudson 1998}

A. Hudson, "Beyond the borders: Globalisation, sovereignty and extra-territoriality", Geopolitics 1998, 3(1), pp. 89-105.

\section{Hugenholtz 2001}

P. B. Hugenholtz, "Copyright and Freedom of Expression in Europe", in: R. C. Dreyfuss, D.

L. Zimmerman, H. First (eds.), Expanding the Boundaries of Intellectual Property. Innovation Policy for the Knowledge Society, Oxford: Oxford University Press 2001, pp. 343-364.

\section{Hugenholtz 2009}

P. B. Hugenholtz, "Copyright without frontiers: the problem of territoriality in European copyright law", in: E. Derclaye, Research Handbook on the Future of EU Copyright, Cheltenham: Edward Elgar 2009, pp. 12-26.

\section{Hugenholtz 2012(a)}

P. B. Hugenholtz, “The Wittem Group's European Copyright Code”, in: T.E. Synodinou (ed.), Codification of European Copyright Law: challenges and perspectives, Alphen aan den Rijn: Kluwer International Law 2012, pp. 339-354.

\section{Hugenholtz 2012(b)}

P. B. Hugenholtz, "Harmonisation or Unification of European Union Copyright Law", Monash University Law Review 2012, 38(1), pp. 4-16.

\section{Hugenholtz 2013}

P. B. Hugenholtz, "The dynamics of harmonization of copyright at the European level", in: C. Geiger (ed.), Constructing European Intellectual Property. Achievements and New Perspectives, Cheltenham: Edward Elgar Publishing 2013, pp. 273-291.

\section{Hugenholtz 2016}

P. B. Hugenholtz, "Flexible Copyright: Can EU Author's Right Accommodate Fair Use?", in: A. Stamatoudi (ed.), New Developments in EU and International Copyright Law, Alphen aan den Rijn: Kluwer Law International 2016, pp. 417-433.

\section{Hughes 1988}

J. Hughes, "The Philosophy of Intellectual Property", Georgetown Law Journal 1988, $77(2)$, pp. 287-366.

\section{Huvosec 2013}

M. Huvosec, "Is Pinckney Dangerous Law?", Hutko's Technology Law Blog, 23 November 2013. Available at http://www.husovec.eu/2013/11/is-pinckney-dangerous-law.html 


\section{Huvosec 2014}

M. Husovec, “Comment on 'Pinckney': Council Regulation (EC) No. 44/2001 of 22 December 2000 on Jurisdiction and the Enforcement of Judgments in Civil and Commercial Matters, Art 5(3)-Peter Pinckney v. KDG Mediatech AG”, International Review of Intellectual Property and Competition Law 2014, 45(3), pp. 370-374.

\section{Illar 2010}

D. J. Illar, "Unraveling International Jurisdictional Issues on the World Wide Web", University of Detroit Mercy Law Review 2010, 88(1), pp. 1-16.

\section{Isola-Miettinen 2010}

H. Isola-Miettinen, "Balancing and Legitimacy, Reflections on the Balancing of Legal Principles", in: J. Sieckmann (ed.), Legal Reasoning: The Methods of Balancing. Proceedings of the Special Workshop "Legal Reasoning: The Methods of Balancing" held at the $24^{\text {th }}$ World Congress of the International Association for Philosophy of Law and Social Philosophy (IVR), Stuttgart: Franz-Steiner Verlag 2010, pp. 169-187.

\section{Itzovich 2014}

G. Itzovich, "The interpretation of Community Law by the European Court of Justice", German Law Journal 2009, pp. 537-560.

\section{Jacob 2014}

M. Jacob, Precedents and Case-Based Reasoning in the European Court of Justice. Unfinished Business, New York: Cambridge University Press 2012.

\section{Jaspers 1980}

T. Jaspers, Rechtspreken in de Maatschappij. Een onderzoek naar opvattingen over plaats en funktie van de rechtspraak in het Nederlands ekonomische, sociale en politieke bestel van het einde van de achttiende tot begin van de twintigste eeuw, Den Haag: Universitaire Pers Leiden; Zwolle: W.E.J. Tjeenk Willink 1980.

\section{Jayme 1990}

E. Jayme, "The American Conflicts Revolution and its Impact on European Private International Law", in: Th. M. de Boer (ed.), Forty Years On: The Evolution of Postwar Private International Law in Europe, Deventer: Kluwer 1990, pp. 15-28.

\section{Jessurun D'Oliveira 1976}

H. U. Jessurun D’Oliveira, De ruïne van een paradigma: de konfliktregel, Deventer: Kluwer 1976.

\section{Jessurun D'Oliveira 1988}

H. U. Jessurun D'Oliveira, "Hijmans, het RdW en het IPR", in: Th. M. de Boer, J. Wiarda. J. van Schellen, A. J. Hoekema, H. U. Jesserum d' Oliveira, R. Kotting, J. A. Ankum, J. W. Westenberg, De Werkelijkheid van I. Henri Hijmans. Symposion gehouden op 23 oktober 1987. Centrum voor Buitenlands recht en International Privaatrecht Universiteit van Amsterdam, Deventer: Kluwer 1988, pp. 83-106.

\section{Jessurun D'Oliveira 2002}

H. U. Jessurun D'Oliveira, “The EU and a Metamorphosis of Private International Law”, in: J. J. Fawcett (ed.), Reform and Development of Private International Law, Oxford: Oxford University Press 2002, pp. 111-136. 


\section{Johnston \& Powles 2004}

A. Johnston and E. Powles, "The King of the world and their dukes' dilemma: Globalisation, jurisdiction and the Rule of Law", in: P. Slot and M. Bulterman (eds.), Globalisation and Jurisdiction, Leiden: Kluwer Law International 2004, pp. 13-54.

\section{Jooris 1996}

E. Jooris, "Infringement of Foreign Copyright and the Jurisdiction of English Courts", European Intellectual Property Review 1996, 18(3), pp. 127-140.

\section{Josephs 2013}

S. Josephs, "Determining the Location of Injury for New York's Long Arm Statute in an Infringement Claim", Touro Law Review 2013, 29 (4), pp. 1025-1061.

\section{Juenger 1984}

F. Juenger, "Judicial Jurisdiction in the United States and in the European Communities: A Comparison," Michigan Law Review 1984, 82, pp. 1195-1212.

\section{Juenger 1989}

F. Juenger, "Forum Shopping, Domestic and International", Tulane Law Review 1989, 63, pp. 553-574.

\section{Juenger 1993}

F. Juenger, Choice of Law and Multistate Justice, Dordrecht: Martinus Nijhoff Publishers 1993. Juenger 1996

F. Juenger, "An Addendum on the United States Approach", in: C. McLachlan and P. Nygh (eds.), Transnational Tort Litigation: Jurisdictional Principles, Oxford: Clarendon Press 1996, pp. 37-40.

\section{Jurcys 2012}

P. Jurcys, "International Jurisdiction in Intellectual Property Disputes: CLIP, ALI Principles and other Legislative Proposals in Comparative Perspective", Journal of Intellectual Property, Information Technology and E-Commerce Law 2012, 3, pp. 174-226.

\section{Jütte 2017(a)}

B. J. Jütte, Reconstructing European Copyright Law for the Digital Single Market. Between Old Paradigms and Digital Challenges, Baden-Baden: Nomos 2017.

\section{Jütte 2017(b)}

B. J. Jütte, “AG Bobek suggests limiting jurisdiction for online defamation of legal and natural persons (C-194/16, Bolagsupplysningen and Ilsjan)”, European Law Blog, 1 August 2017.

Available at http://europeanlawblog.eu/2017/08/01/ag-bobek-suggests-limiting-jurisdictionfor-online-defamation-of-legal-and-natural-persons-c-19416-bolagsupplysningen-and-ilsjan/

\section{Kakouris 1994}

C. N. Kakouris, "Use of the Comparative Method by the Court of Justice of the European Communities", Pace International Law Review 1994, 6(2), pp. 267-283.

\section{Kang 2003}

Y. Kang, "Is Copyright Haven A True Haven?: Legal and Economic Analyses of Copyright Haven”, Korean Journal of International and Comparative Law 2003, Vol. 31, pp. 95-151. 


\section{Kegel 1953}

G. Kegel, "Begriffs- und Interessenjurisprudenz Im Internationalen Privatrecht", in: Festschrift Hans Lewald, Basel: Verlag Helbing \& Lichtenhahn 1953, pp. 259-288.

\section{Kegel 1979}

G. Kegel, "Paternal Home and Dream Home: Traditional Conflict of Laws and the American Reformers", The American Law Journal of Comparative Law 1979, pp. 615-633.

\section{Kegel 1987}

G. Kegel, Internationales Privatrecht. Ein Studienbuch, München: Beck 1987.

\section{Kegel 1989}

G. Kegel, "Story and Savigny”, American Journal of Comparative Law 1989, 37, pp. 39-66.

\section{Kessedjian 1996}

C. Kessedjian, "Competition", in: C. McLachlan and P. Nygh (eds.), Transnational Tort Litigation: Jurisdictional Principles, Oxford: Clarendon Press 1996, pp. 171-188.

\section{Kessedjian 1997}

C. Kessedjian, International Jurisdiction and Foreign Judgments in civil and commercial matters, Report drawn up by Catherine Kessedjian, Preliminary Document No 7 of April 1997 for the attention of the Special Commission of June 1997 on the question of jurisdiction, and recognition and enforcement of foreign judgments in civil and commercial matters.

Available at https://www.hcch.net/en/projects/legislative-projects/judgments/preparation-of-apreliminary-draft-convention-1997-1999-

\section{Kiestra 2014}

L. R. Kiestra, The Impact of the European Convention on Human Rights on Private International Law, The Hague: T.M.C. Asser Press 2014.

\section{Kiikeri 2001}

M. Kiikeri, Comparative Legal Reasoning and European Law, Dordrecht: Kluwer Academic Publishers 2001.

\section{Kleven 2018}

A. R. Kleven, "Minimum Virtual Contacts: A Framework for Specific Jurisdiction in Cyberspace", Michigan Law Review 2018, 5, pp. 785-810.

\section{Kohl 2010}

U. Kohl, Jurisdiction and the Internet: Regulatory Competence over Online Activity, Cambridge: Cambridge University Press 2010.

\section{Kokkini-Iatridou \& Frohn 1989}

D. Kokkini-Iatridou and E. N. Frohn, "De Exceptieclausules in het Verdragenrecht, Een Verkenning", in: D. Kokkini-Iatridou and F. W. Grosheide, Eenvormig en Vergelijkend Privaatrecht, Lelystad: Koninklijke Vermande BV 1989.

\section{Kono \& Jurcys 2012}

T. Kono and P. Jurcys, "General Report", in: T. Kono (ed.), Intellectual Property and Private International Law: Comparative Perspectives, Oxford: Hart Publishing 2012, pp. 1-216.

\section{Kono \& Jurcys 2015}

T. Kono and P. Jurcys, "Jurisdiction over Ubiquitous Copyright Infringements: Should RightHolders be Allowed to Sue at Home?", Kyushu University Legal Research Bulletin 2015, 5, 
pp. 1-33. Available at http://papers.ssrn.com/sol3/Papers.cfm?abstract_id=2181671.

\section{Kono 2017}

T. Kono, “Territoriality”, in: J. Basedow, G. Rühl, F. Ferrari and P. De Miguel Asensio (eds.), Encyclopedia of Private International Law, Cheltenham: Edward Elgar Publishing 2017, pp. 1702-1709.

\section{Koopmans 1986}

T. Koopmans, "The Role of Law in the Next Stage of European Integration", The International and Comparative Law Quarterly 1986, 35(4), pp. 925-931.

\section{Koopmans 1991}

T. Koopmans, "The Birth of European Law in the Crossroads of Legal Traditions", American Journal of Comparative Law 1991, 39, pp. 493-508.

\section{Koopmans 2000}

T. Koopmans, "The Theory of Interpretation and the Court of Justice", in: D. O'Keeffe and A. Bavasso (eds.), Judicial Review in European Union Law. Liber Amicorum in Honour of Lord Slynn of Hadley Volume I, The Hague: Kluwer Law International 2000, pp. 45-58.

\section{Kosters \& Dubbink 1962}

J. Kosters and C. W. Dubbink, Algemeen Deel van het Nederlands Internationaal Privaatrecht, Haarlem: De Erven F. Bohn 1962.

\section{Koumantos 1998}

G. Koumantos, "Reflections on the Concept of Intellectual Property", in: J. J.C. Kabel and G. J.H.M. Mom (eds.), Intellectual Property and Information Law, Essays in Honour of Herman Cohen Jehoram, The Hague: Kluwer Law International, pp. 39-58.

\section{Kramer 2010}

X. E. Kramer "The interaction between Rome I and mandatory EU private rules- EPIL and EPL: communicating vessels?", conference paper 2010,

Available at https://papers.ssrn.com/sol3/papers.cfm?abstract id $=1666740$

\section{Kuipers 2011}

J.-J. Kuipers, EU Law and Private International Law, Leiden: Brill/Martinus Nijhoff Publishers 2011.

\section{Kuipers 2012(a)}

J.-J. Kuipers, "Het internet en de Brussels I Verordening: een kwestie van Luxemburgse wispelturigheid?", Nederlands Internationaal Privaatrecht 2012, 3, pp. 390-395.

\section{Kuipers 2012(b)}

J.-J. Kuipers, "Joined Cases C-509/09 \& 161/10, eDate Advertising v. X and Olivier Martinez and Robert Martinez v. MGN Limited, Judgment of the Court of Justice (Grand Chamber) of 25 October 2011”, Common Market Law Review 2012, 3, pp. 1211-1231.

\section{Kuipers 2018}

J.-J. Kuipers, "Nieuwe ronde, nieuwe kansen? Een nieuw arrest van het HvJEU over het internet, vrijheid van meningsuiting en bescherming van de persoonlijke levenssfeer. HvJEU 17 oktober 2017, zaak C-194/16 (Bolagsupplysiningen)", Nederlands Internationaal Privaatrecht 2018, 3, pp. 541-548. 


\section{Kur 2002}

A. Kur, "International Hague Convention on Jurisdiction and Foreign Judgments: a way forward for I.P.?”, European Intellectual Property Review 2002, 24(4), pp. 175-183.

\section{Kur 2005}

A Kur, "Jurisdiction and Enforcement of Foreign Judgements-The General Structure of the MPI Proposal", in: T. Drexl and A. Kur (eds.), Intellectual Property and Private International Law Heading for the Future, Oregon: Hart Publishing 2005, pp. 21-34.

Kur 2009

A. Kur, Are there any Common European Principles of Private International Law with regard to Intellectual Property, in: S. Leible and A. Ohly (eds.), Intellectual property and Private International Law, Tübingen: Mohr Siebeck 2009, pp. 1-14.

\section{Kur 2013(a)}

A. Kur, "Article 2:202: Infringement", in: J. Basedow and J. Drexl (eds.), Conflict of Laws in Intellectual Property. The CLIP Principles and Commentary. European Max Planck Group on Conflict of Laws in Intellectual Property, Oxford: Oxford University Press 2013, pp. 69-84.

\section{Kur 2013(b)}

A. Kur, "Article 2:203: Extent of jurisdiction over infringement claims", in: J. Basedow and J. Drexl (eds.), Conflict of Laws in Intellectual Property. The CLIP Principles and Commentary. European Max Planck Group on Conflict of Laws in Intellectual Property, Oxford: Oxford University Press 2013, pp. 85-95.

\section{Kur 2013(c)}

A. Kur, "Article 3:602: De minimis rule", in: J. Basedow and J. Drexl (eds.), Conflict of Laws in Intellectual Property. The CLIP Principles and Commentary. European Max Planck Group on Conflict of Laws in Intellectual Property, Oxford: Oxford University Press 2013, pp. 308313.

\section{Kur \& Dreier 2013}

A. Kur and T. Dreier, European Intellectual Property Law. Text, Cases \& Materials, Cheltenham: Edward Elgar Publishing 2013.

\section{Kutscher 1976}

H. Kutscher, "Methods of Interpretation as Seen by a Judge at the Court of Justice", Judicial and Academic Conference Luxembourg 1976.

\section{Kwak 2003}

A. J. Kwak, "De moderne rechter in spagaat", in: A. F. M. Brenninkmeijer (ed.), De taakopvatting van de rechter, Den Haag: Boom Juridische Uitgevers 2003, pp. 63-73.

\section{Larsen 2018(a)}

T. B. Larsen, "Wintersteiger v. Coty Prestige: The place of infringement under the forum delicti”, Journal of Intellectual Property Law \& Practice 2018, 13(3), pp. 179-185.

\section{Larsen 2018(b)}

T. B. Larsen, "The extent of jurisdiction under the forum delicti rule in European trademark litigation”, Journal of Private International Law 2018, pp. 549-561. 


\section{La Torre 2015}

M. La Torre, "Between Nightmare and Noble Dreams: Judicial Activism and Legal Theory", in: L. P. Coutinho, M. La Torre, S. D. Smith (eds.), Judicial Activism. An Interdisciplinary Approach to the American and European Experiences, Cham: Springer 2015, pp. 3-14.

\section{Latty 1966}

E. R. Latty, "Brainerd Currie-Five Tributes”, Duke of Law Journal 1966, pp. 2-22.

\section{Lau 2000}

E. C. Y. Lau, "Update on the Hague Convention on the Recognition \& Enforcement of Foreign Judgments”, Annual Survey of International \& Comparative Law 2000, Vol. 6(3), pp. 13-25.

\section{Laurent 2012}

P. Laurent, "Belgian Supreme Court: against the tide of the CJEU's case law on “originality"?", Kluwer Copyright Blog, March 6, 2012.

Available at http://kluwercopyrightblog.com/2012/03/06/belgian-supreme-court-against-thetide-of-the-cjeus-case-law-on-originality/.

\section{Leaffer 2014}

M. Leaffer, "Cross-border enforcement of intellectual property rights in U.S. law", in: P. L. C. Torremans (ed.), Research Handbook on Cross-Border Enforcement of Intellectual Property, Cheltenham: Edward Edgar Publishing 2014, pp. 3-45.

\section{Leflar 1966}

R. A. Leflar, "Choice-Influencing Considerations in Conflicts Law", New York University Law Review 1966, 41(2), pp. 267-327.

\section{Lehmann 2011}

M. Lehmann, "Where Does Economic Loss Occur", Journal of Private International Law 2011, 7(3), pp. 527-550.

\section{Leistner 2014}

M. Leistner, "Europe's Copyright Law Decade: Recent Case Law of the European Court of Justice and Policy Perspectives", Common Market Law Review 2014, 51(2), pp. 559-600.

\section{Lenaerts 2013}

K. Lenaerts, "How the ECJ Thinks: A Study on Judicial Legitimacy", Fordham International Law Journal 2013, 36, pp. 1302-1371.

\section{Lenaerts \& Gutiérrez-Fons 2013}

K. Lenaerts and J. A. Gutiérrez-Fons, "To Say What the Law of the EU Is: Methods of Interpretation and the European Court of Justice, European University Institute Working Papers 2013, 9, pp. 3-48. Available at

http://cadmus.eui.eu/bitstream/handle/1814/28339/AEL_2013_09_DL.pdf?sequence=1\&isAll owed $=\mathrm{y}$

\section{Lenaerts \& Gutman 2016}

K. Lenaerts and K. Gutman, "The Comparative Law Method and the European Court: Echoes Across the Atlantic", The American Journal of Comparative Law 2016, 64, pp. 841-864.

\section{Lenaerts, Van Nuffel, Bray \& Cambien 2011}

K. Lenaerts, P. Van Nuffel, R. Bray and N. Cambien (eds.) European Union Law, third edition, London: Thomson Reuters 2011. 


\section{Llorens 2000}

A. A. Llorens, "The European Court of Justice, More Than a Teleological Court", in: A. Dashwood and A. Ward (eds.), The Cambridge Yearbook of European Legal Studies Volume 2 1999, Oregon: Hart Publishing 2000, pp. 373-398.

\section{Locke 1689}

J. Locke, Second Treatise of Government, London: Awnsham Churchill 1689.

\section{Logue 1997}

D. V. Logue, "If the International Shoe Fits, Wear It: Applying Traditional Personal Jurisdiction Analysis to Cyberspace in Compuserve, Inc. b. Patterson, Villanova Law Review 1997, Vol. 42, pp. 1213-1254.

\section{Lopez-Tarruella 2012}

A. Lopez-Tarruella, "The International Dimension of Google Activities: Private International Law and the Need of Legal Certainty", in: A. Lopez-Tarruella (ed.), Google and the Law: Empirical Approaches to Legal Aspects of Knowledge-Economy Business Models, The Hague: T.M.C. Asser Press 2012, pp. 329-355.

\section{Lorenzen 1919}

E. G. Lorenzen, “Huber's De Conflcity Legum”, Yale Law School 1919, pp. 199-242.

\section{Lorenzen 1924}

E. G. Lorenzen, "Territoriality, Public Policy and the Conflict of Laws", Yale Law Journal 1924, pp. 736-751.

\section{Lundstedt 2001}

L. Lundstedt, "Jurisdiction and the principle of territoriality in intellectual property law: Has the pendulum swung too far in the other direction?", International Review of Intellectual Property and Competition Law 2001, 32(2), pp. 124-141.

\section{Lundstedt 2018}

L. Lundstedt, "Putting Right Holders in the Centre: Bolagsupplysningen and Ilsjan (C-194/16): What does It Mean for International Jurisdiction over Transborder Intellectual Property Infringement Disputes?", International Review of Intellectual Property and Competition Law 2018, 49(9), pp. 1022-1047.

\section{Lundstedt 2019}

L. Lundstedt, "The Newly Adopted Hague Judgments Convention: A Missed Opportunity for Intellectuel Property”, International Review of Intellectual Property and Competition Law, pp. 933-936.

\section{Maas, Shannon, De Boer 2013}

W. J. G. Maas, C. Shannon, C. de Boer, De handhavingsrichtlijn. Handhaving van IE-rechten in Nederland, Den Haag: Boom Juridische Uitgevers 2013.

\section{MacCormick \& Summers 1991}

P. N. MacCormick and R. S. Summers, Interpreting Statutes. A Comparative Study, Aldershot: Dartmouth 1991. 


\section{MacCormick \& Bankowski 1989}

N. MacCormick and Z. Bankowski, "Some Principles of Statutory Interpretation”, in: J. Van Dunné (ed.), Legal Reasoning and Statutory Interpretation. Rotterdam Lectures in Jurisprudence. 1986-1988, Arnhem: Gouda Quint BV 1989, pp. 41-53.

\section{MacCormick 1994}

N. MacCormick, Legal Reasoning and Legal Theory, Oxford: Oxford University Press 1994.

\section{Madiega 2015}

T. Madiega, "EU Copyright reform: Revisiting the principle of territoriality", European Parliamentary Research Service Briefing, September $2015 . \quad$ See http://www.europarl.europa.eu/RegData/etudes/BRIE/2015/568348/EPRS_BRI(2015)568348 EN.pdf

\section{Maerowitz 1981}

K. Maerowitz, "World-Wide Volkswagen Corp v. Woodson: A Limit to the Expansion of Long-Arm Jurisdiction", California Law Review 1981, 69(2), pp. 611-632.

\section{Magnus \& Mankowski 2016}

U. Magnus and P. Mankowski (eds.), European Commentaries on Private International Law: Brussels Ibis Regulation, Köln: Dr. Otto Schmidt KG 2016.

\section{Maier 1982}

H. G. Maier, "Extraterritorial Jurisdiction at a Crossroads: An Intersection between Public and Private International Law", The American Journal of International Law, 1982, 2, pp. 280-320.

\section{Maier \& Mccoy 1991}

H. G. Maier and T. R. Mccoy, "A Unifying Theory for Judicial Jurisdiction and Choice of Law”, The American Journal of Comparative Law 1991, 39(2), pp. 249-292.

\section{Mancini 1989}

G. F. Mancini, "The Making of A Constitution for Europe”, Common Market Law Review 1989, 4, pp. 595-614.

\section{Mancini \& Keeling 1994}

G. F. Mancini and D. T. Keeling, "Democracy and the European Court of Justice", The Modern Law Review 1994, pp. 175-190.

\section{Manko 2013}

R. Manko, "The notion of 'consumer' in EU law", Library Briefing-Library of the European Parliament 60/05/2013.

Available http://www.europarl.europa.eu/RegData/bibliotheque/briefing/2013/130477/LDM_BRI(2013) 130477_REV1_EN.pdf

\section{Mann 1964}

F. A. Mann, "The Doctrine of Jurisdiction in International Law", in: Recueil Des Cours. Collected Courses of the Hague Academy of International Law, Volume III, Leiden: Sijthoff 1964, pp. 9-162. 


\section{Mann 1984}

F. A. Mann, "The Doctrine of International Jurisdiction Revisited After Twenty Years", in: Recueil Des Cours. Collected Courses of the Hague Academy of International Law, Volume 186, Leiden: Sijthoff 1984, pp. 9-115.

\section{Martinek 2001}

M. Martinek, "The Seven Pillars of Wisdom in Private International Law- The German and the Swiss Experience with the Codification of Conflicts Law Rules", in; H. Jin (ed.), Chinese Yearbook of Private International Law 2001, Beijing: Law Press China, pp. 15-54.

\section{Martiny 1998}

D. Martiny, "Die Anknüpfung an den Markt", in: J. Basedow, K. J. Hopt, H. Kötz, Festschrift für Ulrich Drobnig zum siebzigsten Geburtstag, Tübingen: Mohr Siebeck 1998, pp. 389-408.

\section{Matulionyte 2015}

R. Matulionyte, "Enforcing Copyright Infringements Online: In Search of Balanced International Private Law Rules", Journal of Intellectual Property, Information, Technology and E-Commerce Law 2015, 6.

Available at https://www.jipitec.eu/issues/jipitec-6-2-2015/4274

\section{Maunsbach 2010-2012}

U. Maunsbach, "Jurisdiction in Relation to Online Cross-border Infringements: The Code and the Law”, in: D. J. B. Svantesson and S. Greenstein (eds.), Internationalisation of Law in the Digital Information Society, Nordic Yearbook of Law and Informatics 2010-2012, Copenhagen: Ex Tuto Publishing, pp.173-193.

\section{Maunsbach 2012}

U. Maunsbach, "Copyright in a Borderless Online Environment-Comments from a Swedish Horizon", in: J. Axhamn (ed.), Copyright in a Borderless Online Environment, Stockholm: Norstedts Juridik 2012, pp. 47-61.

\section{Maunsbach 2014}

U. Maunsbach, "Information society perspectives on choice of law and jurisdiction-party autonomy in transition, in: A. Savin and J. Trzakowski (eds.), Research Handbook on EU Internet Law, Cheltenham: Edward Elgar Publishing 2014, pp. 211-230.

\section{Mazziotti 2015}

G. Mazziotti, "Is geo-blocking a real cause for concern in Europe?", Euopean University Institute Working Paper Law 2015/43.

Available at http://cadmus.eui.eu/handle/1814/38084

\section{McGrew 2017}

A. McGrew, "Globalization and global politics", in: J. Baylis, S. Smith and P. Owens, The Globalization of World Politics. An Introduction to International Relations, seventh edition, Oxford: Oxford University Press 2017, pp. 15-32.

\section{Meehan 2008}

K. A. Meehan, "The Continuing Conundrum of International Internet Jurisdiction", Boston College International and Comparative Law Review 2008, 32(2), pp. 345-369. 


\section{Meeusen 2004}

J. Meeusen, "European private international law and the challenges of globalisation", in: P. J. Slot and M. Bulterman (eds.), Globalisation and Jurisdiction, Leiden: Kluwer Law International 2004, pp. 79-90.

\section{Meeusen 2007}

J. Meeusen, "Instrumentalisation of Private International Law in the European Union: Towards a European Conflicts Revolution?", European Journal of Migration and Law 2007, 9, pp. 287 305.

\section{Mendis 2011}

S. Mendis, Copyright, the Freedom of Expression and the Right to Information. Exploring a Potential Public Interest Exception to Copyright in Europe, Baden-Baden: Nomos 2011.

\section{Metzger 2009}

A. Metzger, "Jurisdiction in Cases Concerning Intellectual Property Infringements on the Internet, Brussels-I-Regulation, ALI-Principles and Max-Planck Proposals”, in: S. Leible and A. Ohly (eds.), Intellectual Property and Private International Law, Tübingen: Mohr Siebeck 2009, pp. 251-267.

\section{Michaels 2004}

R. Michaels, "Territorial jurisdiction after territoriality”, in: P. J. Slot and M. Bulterman (eds.), Globalisation and Jurisdiction, Leiden: Kluwer Law International 2004, pp. 105-130.

\section{Michaels 2005}

R. Michaels, "Globalizing Savigny? The State in Savigny's Private International Law and the Challenge of Europeanization and Globalization", Duke Law School Legal Studies Paper No. 74, 2005, pp. 1-28.

Available at https://papers.ssrn.com/sol3/papers.cfm?abstract id $=796228$

\section{Michaels 2006}

R. Michaels, "EU Law as Private International Law? Re-conceptualising the Country-of-Origin Principle as Vested Rights Theory", ZERP-Diskussionspapier 5/2006.

Available at https://scholarship.law.duke.edu/faculty_scholarship/1573/.

\section{Michaels 2008}

R. Michaels, "The New European Choice-of-Law Revolution", Tulane Law Review 2008, 82(5), pp. 1607-1644.

\section{Michaels 2017(a)}

R. Michaels, "Story, Joseph", in: J. Basedow, G. Rühl, F. Ferrari and P. De Miguel Asensio (eds.), Encyclopedia of Private International Law, Cheltenham: Edward Elgar Publishing 2017, pp. 1659-1667.

\section{Michaels 2017(b)}

R. Michaels, "Jurisdiction, Foundations", in: J. Basedow, G. Rühl, F. Ferrari and P. De Miguel Asensio (eds.), Encyclopedia of Private International Law, Cheltenham: Edward Elgar Publishing 2017, pp. 1042-1051.

\section{Mills 2013}

A. Mills, "The Identities of Private International Law: Lessons from the U.S. and EU Revolutions, Duke Journal of Comparative and International Law 2013, pp. 445-475. 


\section{Mills 2014}

A. Mills, "Rethinking Jurisdiction in International Law", The British Yearbook of International Law, Oxford: Oxford University Press 2014, pp. 187-239.

\section{Mills 2018}

A. Mills, "Connecting Public and Private International Law", in: V. R. Abou-Nigm, K. McCallSmith and D. French (eds.), Linkages and Boundaries in Private and Public International Law, Portland: Hart Publishing 2018, pp. 13-32.

\section{Monti 2010}

M. Monti, "A new strategy for the single market at the service of Europe's Economy and Society. Report to the President of the European Commission José Manuel Barroso", 9 May 2010.

\section{Monticello 1999}

S. A. Monticello, "Subafilms Revisited: The Case for Imposing Liability on Domestic Authorizers of Extraterritorial Copyright Infringements", The Journal of Intellectual Property 1999, 1(1), pp. 101-136.

\section{Montesquieu 1748}

C. Montesquieu, De l'esprit des lois, Bordeaux: Ville de Bordeaux 1748

\section{Muir, Dawson \& de Witte 2013}

E. Muir, M. Dawson and B. de Witte, "Introduction: the European Court of Justice as a political actor”, in: B. de Witte, E. Muir and M. Dawson, Judicial Activism at the European Court of Justice, Cheltenham: Edward Elgar Publishing 2013, pp. 1-11.

\section{Muir 2013}

E. Muir, "The Court of Justice: a fundamental rights institution among others", in: B. de Witte,

E. Muir and M. Dawson, Judicial Activism at the European Court of Justice, Cheltenham: Edward Elgar Publishing 2013, pp. 76-101.

\section{Muir-Watt 2011}

H. Muir-Watt, "Private International Law Beyond the Schism", Transnational Legal Theory 2011, 2(3), pp. 347-428.

\section{Muir-Watt 2016}

H. Muir-Watt, "Theorizing Private International Law", in: A. Oxford and F. Hoffmann, The Oxford Handbook of the Theory of International Law, Oxford: Oxford University Press 2016, pp. 862-881.

\section{Müller-Erzbach 1929}

R. Müller-Erzbach, "Rechsgericht und Interessenjurisprudenz", Reichsgerichtpraxis im deutschen Rechtsleben 1929, pp. 161-177.

\section{Müller 2014}

M. Müller, "EuGVVO: Deliktsgerichtsstand bei Teilnahmehandlung in anderem MitgliedstaatHi Hotel”, Europäische Zeitschrift für Wirtschafsrecht 2014, pp. 432-435.

\section{Neuhaus 1949}

P.H. Neuhaus, "Savigny und die Rechtsfindung aus der Natur der Sache", RabelsZ 1949-1950, pp. 346-381. 


\section{Neumann 2011}

S. Neumann, "Intellectual Property Rights Infringements in European Private International Law: Meeting the Requirements of Territoriality and Private International Law", Journal of Private International Law 2011, 7(3), pp. 583-600.

\section{Neumann 2014}

S. Neumann, "Ubiquitous and multistate cases", in: P. L. C. Torremans (ed.), Research Handbook on Cross-Border Enforcement of Intellectual Property, Cheltenham: Edward Elgar Publishing 2014, pp. 497-525.

\section{Nieuwenhuis, Heijer \& Hins 2017}

A. J. Nieuwenhuis, W. den Heijer and A. W. Hins, Hoofdstukken Grondrechten, fourth edition, Nijmegen: Ars Aequi Libri 2017.

\section{Nonet \& Selznick 2001}

P. Nonet and P. Selznick, Toward Responsive Law \& Society in Transition. With a new introduction by Robert A. Kagan, New Brunswick: Transaction Publishers 2001.

\section{Nuyts 2008}

A. Nuyts, "Suing at the Place of Infringement: The Application of Article 5(3) of Regulation 44/2001 to IP Matters and Internet Disputes", in: A. Nuyts (ed.), International Litigation in Intellectual Property and Information Technology, Alphen aan den Rijn: Kluwer Law International 2008, pp. 121-127.

\section{Nuyts, Szychowska \& Hatzimihail 2008}

A. Nuyts, K. Szychowska and N. Hatzimihail, "Cross-border litigation in IP/IT Matters in the European Union: The Transformation of Jurisdictional Landscape", in: A. Nuyts (ed.), International Litigation in Intellectual Property and Information Technology, Alphen aan den Rijn: Kluwer Law International 2008, pp. 1-47.

\section{Nygh \& Pocar 2000}

P. Nygh and F. Pocar, Report on the Preliminary Draft Convention on Jurisdiction and Foreign Judgments in Civil and Commercial Matters adopted by the Special Commission on 30 October 1999, Preliminary Document No. 11 of August 2000 for the attention of the Nineteenth Session of June 2001.

Available at https://www.hcch.net/en/publications-and-studies/details4/?pid=3494\&dtid=35.

\section{Nyman-Metcalf \& Papageorgiou 2005}

K. Nyman-Metcalf and I. Papageorgiou, Regional Integration and Courts of Justice, Antwerpen/Oxford: Intersentia 2005.

\section{Ohly 2009}

A. Ohly, "Economic rights", in: E. Derclaye, Research Handbook on the Future of EU Copyright, Cheltenham: Edward Elgar Publishing, 2009, pp. 212-241.

\section{Ohly 2012}

A. Ohly, "Introduction: The Quest for Common Principles of European Intellectual Property Law-Useful, Futile, Dangerous?", A. Ohly (ed.), Common Principles of European Intellectual Property Law, Tübingen: Mohr Siebeck 2012, pp. 3-14. 


\section{Olson 2009}

K. C. Olson, Principles of Legal Research. Successor to How to Find the Law, ninth edition, St. Paul: Thomson Reuters 2009.

\section{O’Neill 1994}

A. O'Neill, Decisions of the European Court of Justice and their Constitutional Implications, London: Butterworths 1994.

\section{Oster 2012}

J. Oster, "Rethinking Shevill, Conceptualising the EU private international law of Internet torts against personality rights", International Review of Law Computers \& Technology 2012, pp. 113-128.

\section{Palombella 2009}

G. Palombella, "The Rule of Law and its Core", in: G. Palombella and N. Walker (eds.), Relocating the Rule of Law, Oregon: Hart Publishing 2009, pp. 17-42.

\section{Pansch 2000}

R. Pansch, "The Proper Forum for Illicit Acts in Cases of Cross-Border Infringement of Proprietary Commercial Rights. Proposed Interpretations of Article 5, No. 3 of the Brussels Convention", The European Legal Forum. Forum iuris communis Europae, 2000, pp. 353-362.

\section{Parra-Aranguren 1988}

G. Parra-Aranguren, "General course of private international law: Selected problems", in: D. Vignes (ed.), Reueil des Cours 1988-III, Collected Courses of the Hague Academy of International Law, Dordrecht/Boston/London: Nijhoff Publishers 1988, pp. 9-224.

\section{Patry 1994}

W. F. Patry, Copyright Law and Practice, Washington: BNA Books 1994.

\section{Patry 2011}

W. F. Patry, How to Fix Copyright, New York: Oxford University Press 2011.

\section{Paul 2008}

J. R. Paul, "The Transformation of International Comity", Law and Contemporary Problems 2008, pp. 19-38.

\section{Pavelka 2011}

T. Pavelka, "The Concept of 'Directed Website'- A Jurisdictional Phenomenon Clarified? Cross-Border Consumer and Tort Victim Protection in the Light of Recent ECJ Jurisprudence", ELSA Malta Law Review 2011, 1(1).

Available at http://papers.ssrn.com/sol3/papers.cfm?abstract-idz2007031.

\section{Pejovic 2001}

C. Pejovic, "Civil Law and Common Law: Two Different Paths Leading to the Same Goal", Victoria University Wellington Law Review 2001, 32, pp. 817-842.

\section{Pertegás Sender 2002}

M. Pertegás Sender, Cross-border Enforcement of Patent Rights. An Analysis of the Interface between Intellectual Property and Private International Law, Oxford: Oxford University Press 2002. 


\section{Pertegás Sender 2017}

M. Pertegás Sender, "Hague Conference on Private International law", in: J. Basedow, G. Rühl,

F. Ferrari and P. De Miguel Asensio (eds.), Encyclopedia of Private International Law, Cheltenham: Edward Elgar Publishing 2017, pp. 870-875.

\section{Peters 2016}

N. Peters, IPR, Proces \& Arbitrage. Over grondslagen en rechtspraktijk, Apeldoorn/Antwerpen: Maklu 2016.

\section{Petersen, Riis \& Schovsbo 2015}

C. S. Petersen, T. Riis and J. Schovsbo, "How will the Design of the UPC Affect Patent Law?", in: R. M. Ballerdini, M. Norrgård, N. Bruun, Transitions in European Patent Law: Influences of the Unitary Patent Package, Alphen aan den Rijn: Kluwer Law International 2015, pp. 3758.

\section{Peukert 2012}

A. Peukert, "Territoriality and Extraterritoriality in Intellectual Property Law", in: G. Handl, J. Zekoll and P Zumbansen (eds.), Beyond territoriality: Transnational Legal Authority in an Age of Globalization, Leiden: Brill/Martinus Nijhoff Publishers 2012, pp. 189-229.

\section{Peukert 2013}

A. Peukert, "Preamble", in: J. Basedow and J. Drexl (eds.), Conflict of Laws in Intellectual Property. The CLIP Principles and Commentary. European Max Planck Group on Conflict of Laws in Intellectual Property, Oxford: Oxford University Press 2013, pp. 25-46.

\section{Picht \& Kopp 2016}

P. Peter and C. Kopp, "Die internationale Zuständigkeit für Immaterialgüterrechtsverletzungen im Internet nach den EuGH-Entscheidungen Hejduk und Pinckney", Gewerblicher Rechtsschutz und Urheberrecht Internationaler Teil, 2016, pp. 232-236.

Pitlo 1972

A. Pitlo, Evolutie in het privaatrecht, second edition, Groningen: Tjeenk Willink 1972.

\section{Pitlo 1975}

A. Pitlo, Figuratief-Nonfiguratief. Legalism-Vrije Rechtsvinding. Mededelingen van de Koninklijke Academie voor Wetenschappen, Letteren en Schone Kunsten van België, Klasse der Letteren-Jaargang XXXVII-1971-nr 2, Brussel: Paleis der Academiën 1975.

\section{Polak 1953}

M. Polak, Theorie en Rechtsvinding, Zwolle: Tjeenk Willink 1953.

\section{Polak 2012}

M. Polak, "Noot onder arrest Hof van Justitie van de Europese Unie 19 april 2012, nr. C-523/10, Wintersteiger/Products 4 U Sondermaschinenbau”, Nederlands Juristenblad 2012, 403.

\section{Poiares Maduro 1998}

M. Poiares Maduro, We the Court. The European Court of Justice and the European Economic Constitution. A Critical Reading of Article 30 of the EC Treaty, Oxford: Hart Publishing 1998.

\section{Poiares Maduro 2007}

M. Poiares Maduro, "Interpreting European Law: Judicial Adjudication in a Context of Constitutional Pluralism”, European Journal of Legal Studies 2007, 1(2), pp. 137-152. 


\section{Poiares Maduro 2010}

M. Poiares Maduro, "Interpreting European law- On why and how law and policy meet at the European Court of Justice", in: H. Koch, K. Hagel-Sorensen, U. Haltern and J. H. H. Weiler (eds.), Europe The New Legal Realism. Essays in Honour of Hjalte Rasmussen, Djof Publishing 2010, pp. 457-478.

\section{Pontier 1997}

J. A. Pontier, Conflictenrecht: grondslagen, methoden, beginselen en belangen. Een politiek liberaal perspectief, Nijmegen: Ars Aequi Libri 1997.

\section{Pontier 1998}

J. A. Pontier, Rechtsvinding, Nijmegen: Ars Aequi Libri 1998.

\section{Pontier \& Burg 2004}

J. A. Pontier and E. Burg, EU Principles on Jurisdiction and Recognition and Enforcement of Judgments in Civil and Commercial Matters according to the case law of the European Court of Justice, The Hague: T.M.C. Asser Press 2004.

\section{Pontier 2005}

J. A. Pontier, Europees conflictenrecht: een complete geschiedenis in vogelvlucht, Amsterdam Vossiuspers 2005.

\section{Pontier 2006}

J. A. Pontier, "Ideal rules on international jurisdiction under the Brussels I Regulation? Concurrent jurisdiction, separate and parallel procedures, fragmentation of proceedings, antisuit injunctions, forum non conveniens and related procedural issues: is there a need to reform?", in: A. F. Salamons and G. J. P. de Vries, Pro forma? Opstellen over de rol van formele regels en vormvoorschriften in het privaatrecht. Essays on the role of Formal Rules and Formal Requirements in Private Law, Den Haag: Boom Juridische Uitgevers 2006, pp. 69104.

\section{Pontier 2015}

J.A. Pontier, Onrechtmatige daad en andere niet-contractuele verbintenissen, third edition, Apeldoorn/Antwerpen: Maklu 2015.

\section{Raitio 2013}

J. Raitio, "Legal Certainty as an Element of Objectivity in Law", in: J. Husa and M. Van Hoecke, Objectivity in Law and Legal Reasoning, Oregon: Hart Publishing 2013, pp. 85-108.

\section{Ramalho 2016}

A. Ramalho, The Competence of the European Union in Copyright Lawmaking. A Normative Perspective of EU Powers for Copyright Harmonization, Switzerland: Springer 2016.

\section{Ramsey 1997-1998}

M. D. Ramsey, “Escaping 'International Comity’, Iowa Law Review 893 1997-1998, pp. 893952.

\section{Ras 2011}

P. Ras, Auteursrechtrevolutie. De gevolgen van het Infopaq-arrest van het Europese Hof voor het auteursrechtelijke beschermingscriterium van Nederland, Engeland en Duitsland, Tilburg: Celsius juridische uitgeverij 2011. 


\section{Rasmussen 1986}

H. Rasmussen, On Law and Policy in the European Court of Justice: A Comparative Study in Policy Making, Dordrecht: Martinus Nijhoff Publishers 1986.

\section{Rasmussen 1988}

H. Rasmussen, "Between self-restraint and activism: a judicial policy for the European Court", European Law Review 1998, pp. 28-38.

\section{Rasmussen 1992}

H. Rasmussen, "Towards a Normative Theory of Interpretation of Community law, University of Chicago Legal Forum 1992, pp. 135-178.

\section{Reding 2011}

V. Reding, "Foreword", in: Busch and Schulte-Nölke (eds.), EU Compendium Fundamental Rights and Private Law, Munich: Sellier European Law Publishers 2011.

\section{Reich 2014}

N. Reich, General Principles of EU Civil Law, Cambridge: Intersentia 2014

\section{Reimann 2017}

M. W. Reimann, "Better law approach”, in: J. Basedow, G. Rühl, F. Ferrari and P. De Miguel Asensio (eds.), Encyclopedia of Private International Law, Cheltenham: Edward Elgar Publishing 2017, pp. 179-187.

\section{Reimann 2019}

M. W. Reimann, "Comparative Law and Private International Law", in: M. W. Reimann and R. Zimmermann (eds.), The Oxford Handbook of Comparative Law, Oxford: Oxford University Press, 2019, pp. 1339-1369.

\section{Retchless 2011}

Heather N. Retchless, "Tamburo v. Dworkin: Extending Calder v. Jones to Establish Personal Jurisdiction in a World of Internet Contacts", American Journal of Trail Advocacy 2011, 35, pp. 411-428.

\section{Reymond 2013}

M. Reymond, "Jurisdiction in case of Personality Torts Committed over the Internet: A Proposal for a Targeting Test", in: A. Bonomi and G. P. Romano (eds.), Yearbook of Private International Law. Volume XIV (2012/2013), Munich: Sellier European Law Publishers 2013, pp. 205-246.

\section{Rice \& Gladstone 2003}

D. T. Rice and J. Gladstone, "An Assessment of the Effects Test in Determining Personal Jurisdiction in Cyberspace", The Business Lawyer 2003, 58(2), pp. 601-654.

\section{Ricketson \& Ginsburg 2006}

S. Ricketson and J. C. Ginsburg, International Copyright and Neighbouring Rights. The Berne Convention and Beyond. Volume II, second edition, New York: Oxford University Press 2006.

\section{Richman \& Riley 1997}

W. M. Richman and D. Riley, "The First Restatement of Conflict of Laws on the Twenty-Fifth Anniversary of Its Successor: Contemporary Practice in Traditional Courts", Maryland Law Review 1997, pp. 1196-1231. 


\section{Rigamonti 2006}

C. P. Rigamonti, "Deconstructing Moral Rights", Harvard International Law Journal 2006, 47(2), pp. 355-367.

\section{Roelvink 1998}

H. L. J. Roelvink, “De meervoudige locus delicti”, in: Th. M. de Boer (ed.), Vijftig jaar lex loci delicti. Van Dubbinks proefschrift tot een Wet conflictenrecht onrechtmatige daad, Deventer: Kluwer 1998, pp. 29-34.

\section{Roosevelt \& Jones 2016}

K. Roosevelt and B. Jones, "Symposium on the Third Restatement of Conflict of Laws", American Journal of International Law 2016, 11, pp. 139-143.

\section{Rosati 2013}

E. Rosati, Originality in EU Copyright: Full Harmonization through Case Law, Cheltenham: Edward Elgar Publishing 2013.

\section{Rosati 2014(a)}

E. Rosati, "Brussels I Regulation and online copyright infringement: 'intention to target' approach rejected", Journal of Intellectual Property Law and Practice 2014, 9(1), pp. 18-19.

\section{Rosati 2014(b)}

E. Rosati, "Luxembourg, we have a problem: where have the Advocates General gone?", Journal of Intellectual Property Law \& Practice 2014, 9(8), p. 619.

\section{Rose 1994}

F. Rose, "Related Contacts and Personal Jurisdiction: The But for Test", California Law Review 1994, 82, pp. 1545-1549.

\section{Rösler 2017}

H. Rösler, "Interpretation, autonomous", in: J. Basedow, G. Rühl, F. Ferrari and P. De Miguel Asensio (eds.), Encyclopedia of Private International Law, Cheltenham: Edward Elgar Publishing 2017, pp. 1006-1015.

\section{Ruggie 1993}

J. G. Ruggie, "Territoriality and Beyond: Problematizing Modernity in International Relations", International Organization 1993, 47 (1), pp. 139-174.

\section{Rushton 1998}

M. Rusthon, “The Moral Rights of Artists: Droit Moral ou Droit Pécuniaire?", Journal of Cultural Economics 1998, pp. 15-32.

\section{Russell 1995}

J. W. Russell, "A Map out of the Personal Jurisdiction Labyrint, A Symposium: Fifty Years of International Shoe: The Past and Future of Personal Jurisdiction", University of California Davis Law Review 1995, 28(3), pp. 531-560.

\section{Ryngaert 2015(a)}

C. Ryngaert, Jurisdiction in International Law, second edition, Oxford: Oxford University Press 2015. 


\section{Ryngaert 2015(b)}

C. Ryngaert, "The Concept of Jurisdiction in International Law", in: A. Orakhelashvili (ed.), Research Handbook on Jurisdiction and Immunities in International Law, Cheltenham: Edward Elgar Publishing 2015, pp. 50-75.

\section{Ryngaert 2015(c)}

C. Ryngaert, Unilateral Jurisdiction and Global Values, 2015, Den Haag: Eleven International Publishing.

\section{Ryngaert \& Vagias 2019}

C. Ryngaert and M. Vagias, "Jurisdictional Reasonableness", Questions of International Law (QIL), under the section "Zoom in", 31 October 2019.

Available at http://www.qil-qdi.org/jurisdictional-reasonableness/

\section{Ryngaert \& Zoetekouw 2017}

C. Ryngaert and M. Zoetekouw, "The End of Territory? The Re-Emergence of Community as a Principle of Jurisdictional Order in the Internet Era", in: U. Kohl (ed.), The Net and the Nation State: Multidisciplinary Perspectives in Internet Governance, Cambridge: Cambridge University Press 2017, pp. 185-201.

\section{Saarloos 2019}

K. Saarloos, Annotatie "De plaats van het schadebrengende feit bij inbreuken op het mededingingsrecht, HvJEU 5 juli 2018, zaak C-27/17, ECLI:EU:C:2018:533 (flyLAL II)", Nederlands Internationaal Privaatrecht 2019, 2, pp. 387-397.

\section{Sadl 2015}

U. Sadl, "The role of effet utile in preserving the continuity and authority of European Union Law: Evidence from the citation web of the pre-accession case law of the Court of Justice of the EU", European Journal of Legal Studies 2015, 8(1), pp. 18-45.

\section{Sassen 2015}

S. Sassen, Losing Control? Sovereignty in an Age of Globalization, New York: Columbia University Press 2015.

\section{Saurugger \& Terpan 2017}

S. Saurugger and F. Terpan, The Court of Justice of the European Union and the Politics of Law, London: Palgrave 2017.

\section{Savvides \& Ibbetson 2016}

T. Savvides and S. Ibbetson, "Brexit and copyright law: will the English courts revert to the 'old' test for originality?”, Kluwer Copyright Blog, 5 December 2016.

See http://copyrightblog.kluweriplaw.com/2016/12/05/brexit-copyright-law-will-englishcourts-revert-old-test-originality/

\section{Schaafsma 2009}

S. J. Schaafsma, Intellectuele eigendom in het conflictenrecht: de verborgen conflictregel in het beginsel van nationale behandeling, Deventer: Kluwer 2009.

\section{Schaafsma 2014}

S. J. Schaafsma, IPR en EPR. Over wisselwerking, eenheid en verscheidenheid, oratie uitgesproken door prof. Mr. S. J. Schaafsma bij de aanvaarding van het ambt van buitengewoon hoogleraar in het internationaal privaatrecht aan de Universiteit Leiden 11 April 2014. 
Available at https://openaccess.leidenuniv.nl/handle/1887/29744.

\section{Schaafsma 2016}

S. J. Schaafsma, "Internationale bevoegdheid en de grensoverschrijdende inbreuk", Intellectuele Eigendom en Reclamerecht 2016, 60, pp. 398-407.

\section{Schaafsma 2018}

S. J. Schaafsma, "Bijzondere bevoegdheidsgronden; verbintenissen uit overeenkomst; verbintenissen uit onrechtmatige daad; schadevergoeding of teruggave naar aanleiding van strafbaar feit; teruggave cultuurgoed; geschillen betreffende de exploitatie van een filiaal, agentschap of andere vestiging; trusts; geschillen betreffende betaling van hulp-of bergingsloon", in: A. I. M. van Mierlo and C. J. J. C. van Nispen, Tekst en Commentaar Burgerlijke Rechtsvordering, Deventer: Wolters Kluwer 2018, pp. 1-21.

\section{Schaeffner 1841}

W. Schaeffner, Entwickelung des Internationalen Privatrechts, Frankfurt: J. D. Sauerländer 1841 .

\section{Schack 1983}

H. Schack, Jurisdictional Minimum Contacts Scrutinized. Interstaatliche und Internationale Zuständigkeit US-amerikanischer Gerichte, Heidelberg: C. F. Müller Juristischer Verlag 1983.

\section{Schack 2009}

H. Schack, "The Law Applicable to (unregistered) IP Rights After Rome II", in: S. Leible and A. Ohly (eds.), Intellectual Property and Private International Law, Tübingen: Mohr Siebeck 2009, pp. 79-96.

\section{Schack 2013}

H. Schack, "Internationale Zuständigkeit bei Verletzung von Urhebervermögensrechten über Internet", Neue juristische Wochenschrift 2013, pp. 3629-3630.

\section{Schack 2017}

H. Schack, Urheber- und Urheberverstragsrecht, Tübingen: Mohr Siebeck 2017.

\section{Schepel \& Blankenburg 2001}

H. Schepel and E. Blankenburg, "Mobilizing the European Court of Justice", in: G. de Búrca and J. H. H. Weiler (eds.), The European Court of Justice, New York: Oxford University Press 2001, pp. 9-42.

\section{Schermers 1974}

H. G. Schermers, "The European Court of Justice: Promoter of European Integration", American Journal of Comparative Law 1974, 22, pp. 444-464.

\section{Schmidt 1995}

V. A. Schmidt, "The New World Order, Incorporated: The Rise of Business and the Decline of Nation-State", Political Economy Research Group, Papers in Political Economy 1995, No. 63 London, pp. 1-46.

\section{Scholten 1974}

P. Scholten, Mr. C. Asser's handleiding tot de beoefening van het Nederlandsch Burgerlijk Recht: Algemeen deel, third edition, Zwolle: Tjeenk Willink 1974. 


\section{Schultz \& Ridi 2018}

T. Schultz and N. Ridi, "Comity: the American Development of a Transnational Concept, in: A. Bonomi \& G. P. Romano (eds.), Yearbook of Private International Law, Volume 18, 2016/2017, Köln: Verlag Dr Ottto Schmidt KG, pp. 211-244.

\section{Sever 2014}

S. Sever, "The horizontal effect of the European Union's Charter of Fundamental Rights: from market integration towards the social justice?”, e-Pública 2014, pp. 174-193.

\section{Shapiro 1993}

M. Shapiro, “The Globalization of Law”, Indiana Journal of Global Legal Studies 1993, pp. 37-64.

\section{Shapiro \& Stone-Sweet 2002}

M. M. Shapiro and A. Stone-Sweet, On Law, Politics, and Judicialization, Oxford: Oxford University Press 2002.

\section{Shi 2008}

W. Shi, Intellectual property in global trading system: EU-China Perspective, Berlin/London: Springer 2008.

\section{Shuibhne 2013}

N. N. Shuinhne, The Coherence of EU Free Movement Law: Constitutional Responsibility and the Court of Justice, Oxford: Oxford University Press 2013.

\section{Sieckmann 2010}

J. Sieckman, "Balancing, Optimisation, and Alexy's 'Weight Formula”, in: J. Sieckmann (ed.), Legal Reasoning: The Methods of Balancing. Proceedings of the Special Workshop "Legal Reasoning: The Methods of Balancing” held at the $24^{\text {th }}$ World Congress of the International Association for Philosophy of Law and Social Philosophy (IVR), Stuttgart: Franz-Steiner Verlag 2010, pp. 101-118.

\section{Silberman 1978}

L. J. Silberman, "Shaffer v. Heitner: The End of an Era", New York University Law Review 1978, 33, pp. 33-101.

\section{Silberman 2002}

L. J. Silberman, "Comparative Jurisdiction in the International Context: Will the Proposed Hague Judgments Convention be Installed? (Symposium: Export/Import; American Civil Justice in a Global Context, DePaul Law Review 2002, 52(2), pp. 319-349.

\section{Silberman 2017}

L. J. Silberman, "USA”, in: J. Basedow, G. Rühl, F. Ferrari and P. De Miguel Asensio (eds.), Encyclopedia of Private International Law, Cheltenham: Edward Elgar Publishing 2017, pp. 2637-2647.

\section{Silberman, Stein \& Wolff 2017}

L. J. Silberman, A. R. Stein and T. B. Wolff, Civil Procedure: Theory and Practice 2017, New York: Wolters Kluwer.

\section{Sirvinskaite 2010}

I. Sirvinskaite, “Toward copyright ‘Europeanification': European Union moral rights”, Journal of International Media \& Entertainment Law 2010, 3(2), pp. 263-288. 


\section{Smith 2013}

G. Smith, "Pinckney-the CJEU wields a broad brush", Graham Smith's blog on law, IT, the Internet and dew media, Cyberleagle.com.

See https://www.cyberleagle.com/2013/10/pinckney-cjeu-wields-broad-brush.html

\section{Smith \& Newton 2015}

J. Smith \& H. Newton, "Accessibility (not targeting) is the key to jurisdiction for online copyright infringement”, European Intellectual Property Review 2015, 37(7), pp. 459-460.

\section{Smits 2006}

J. M. Smits, "Belangenafweging door de rechter in het vermogensrecht: een kritische beschouwing", Rechtsgeleerd Magazijn Themis, 2006, 4, pp. 134-140.

\section{Solley 2008}

T. Solley, "The Problem and the Solution: Using the Internet to resolve Internet Copyright Disputes", Georgia State University Law Review 2008, 24(3), pp. 813-842.

\section{Spaak 2009}

T. Spaak, "Karl Olivecrona on Judicial Law-Making”, Ration Juris 2009, pp. 483-498.

\section{Spoor, Verkade \& Visser 2019}

J. H. Spoor, D.W.F. Verkade and D. J. G. Visser, Auteursrecht. Auteursrecht, naburige rechten en databankenrecht, fourth edition, Deventer: Kluwer 2019.

\section{Staker 2014}

C. Staker, "Jurisdiction", in: M. D. Evans (ed.), International Law, fourth edition Oxford: Oxford University Press 2014, pp. 309-335.

\section{Stamatoudi 2016}

A. Stamatoudi (ed.), New Developments in EU and International Copyright Law, Alphen aan den Rijn: Kluwer Law International 2016, preface.

\section{Stein 1981}

E. Stein, "Lawyers, Judges and the Making of a Transnational Constitution", American Journal of International Law 1981, pp. 1-27.

\section{Stein 2004}

A. R. Stein, "Personal Jurisdiction and the Internet: Seeing Due Process Through the Lens of Regulatory Precision", Northwestern University Law Review 2004, 98(2) pp. 411-454.

\section{Steiner, Alston \& Goodman 2008}

H. J. Steiner, P. Alston and R. Goodman, International Human Rights in Context. Law, Politics, Morals. Text and Materials, third edition, Oxford: Oxford University Press 2008.

\section{Sterling \& Cook 2015}

J. A. L. Sterling and T. M. Cook (ed.), Sterling on world copyright law, fourth edition, London: Sweet and Maxwell 2015.

\section{Stoll 1931}

H. Stoll, "Begriff und Konstruktion in der Lehre der Interessenjurisprudenz", M. Rümelin and A. B. Schmidt (eds.), Festschrift für Heck, Tübingen: Mohr Siebeck1931, pp. 60-117.

\section{Stoll 1979}

H. Stoll, "Internationalprivatrechtliche Probleme bei Verwendung Allgemeiner Geschäftsbedingungen. Ein Diskussionsbeitrag", in: O. Sandrock, Festschrift für Günther 
Beitzke zum 70. Geburtstag am 26. April 1979, Berlin, New York: Walter de Gruyter 1979, pp. 759-785.

\section{Story 1834}

J. Story, Commentaries on the Conflict of Laws, Foreign and Domestic, in regard to Contracts, Rights and Remedies and especially in regard to Marriages, Divorces, Wills, Successions and Judgments, Boston: Hilliard, Gray and, Company 1834.

\section{Stone-Sweet 2000}

A. Stone-Sweet, Governing with judges: constitutional politics in Europe, Oxford/New York: Oxford University Press 2000.

\section{Stone-Sweet 2004}

A. Stone-Sweet, The Judicial Construction of Europe, New York: Oxford University Press 2004.

\section{Stone 2014}

P. Stone, EU Private International Law, third edition, Cheltenham: Edward Elgar Publishing 2014.

\section{Strange 1996}

S. Strange, The Retreat of the State. The Diffusion of Power in the World Economy, Cambridge: Cambridge University Press 1996.

\section{Strikwerda 1978}

L. Strikwerda, Semipubliekrecht in het conflictenrecht. Verkenningen op een kruispunt in het conflictenrecht, Alphen aan den Rijn: H.D. Tjeenk Willink 1978.

\section{Strikwerda 2013}

L. Strikwerda, "Noot onder arrest Hoge Raad 07 december 2012, H\&M/G-Star (ECLI:NL:HR:2012:BX9018)”, Nederlands Juristenblad 2013, 199.

\section{Strikwerda 2014}

L. Strikwerda, "Noot onder arrest Hof van Justitie van de Europese Unie 3 oktober 2014 Peter Pinckney/ KGD Mediatech", Nederlands Juristenblad 2014, 166.

\section{Strikwerda 2015}

L. Strikwerda, Inleiding tot het Nederlandse Internationaal Privaatrecht, eleventh edition, Deventer: Kluwer 2015.

\section{Strikwerda \& Schaafsma 2019}

L. Strikwerda and S. J. Schaafsma, Inleiding tot het Nederlandse Internationaal Privaatrecht, twelfth edition, Deventer: Kluwer 2019.

\section{Strowel 2014}

A. Strowel, "Towards a European Copyright Law: Four issues to consider", in: I. A. Stamatoudi and P. L. C. Torremans (eds.), EU Copyright Law: A Commentary, Cheltenham: Edward Elgar Publishing 2014, pp. 1127-1154.

\section{Sujecki 2013}

B. Sujecki, "EuGVVO: Zuständigkeit bei Verletzung von Urhebervermögensrechten über Internet”, Europäische Zeitschrift für Wirtschafstrecht 2013, pp. 866-867. 


\section{Sundara Rajan 2011}

M. T. Sundara Rajan, Moral Rights: Principles, Practice and New Technology, New York: Oxford University Press 2011.

\section{Svantesson 2016(a)}

D. J. B. Svantesson, Private International Law and the Internet, third edition, Alphen aan den Rijn: Kluwer Law International 2016.

\section{Svantesson 2016(b)}

D. J. B. Svantesson, "Nostradamus Lite-Selected Speculations as to the Future of Internet Jurisdiction", Masaryk University Journal of Law and Technology 2016, pp. 47-72.

\section{Svantesson 2017}

D. J. B. Svantesson, Solving the Internet Jurisdiction Puzzle, Oxford: Oxford University Press 2017.

\section{Svantesson 2018}

D. J. B. Svantesson, "European Union Claims of Jurisdiction over the Internet- an Analysis of Three Recent Key Development”, Journal of Intellectual Property, Information Technology and E-Commerce Law 2018, 10(2), pp. 113-125.

\section{Svantesson 2019(a)}

D. J. B. Svantesson, Internet \& Jurisdiction Global Status Report 2019, Paris: Secretariat of the Internet \& Jurisdiction Policy Network, 2019.

\section{Svantesson 2019(b)}

D. J. B. Svantesson, "Bad news for the Internet as Europe's top court opens the door for global content blocking orders", 3 October 2019.

See https://www.linkedin.com/pulse/bad-news-internet-europes-top-court-opens-door-globalsvantesson/

\section{Swedlow 1997}

L. Swedlow, "Three Paradigms of Presence: A Solution for Personal Jurisdiction on the Internet", Oklahoma City University Law Review 1997, 22(1), pp. 337-396.

\section{Symeonides 1997}

S. C. Symeonides, "The Judicial Acceptance of the Second Conflicts Restatement: A Mixed Blessing”, Mary Land Review 1997, 56, pp. 1248-1283.

\section{Symeonides 2001}

S. C. Symeonides, "Material Justice and Conflicts Justice in Choice of Law", in: P. Borchers and J. Zekoll (eds.), International Conflict of Laws for the Third Millennium, New York: Transnational Publishers Inc. 2001, pp. 125-140.

\section{Symeonides 2006}

S. C. Symeonides, The American Choice-of-Law Revolution: Past, Present and Future, Leiden: Koninklijke Brill NV 2006.

\section{Symeonides 2008}

S. C. Symeonides, American Private International Law, Alphen aan den Rijn: Kluwer Law International BV 2008. 


\section{Symeonides 2015}

S. C. Symeonides, "The Choice-Of-Law Revolution Fifty Years After Currie: An End and a Beginning”, University of Illinois Law Review, pp. 1847-1922.

\section{Symeonides 2016}

S. C. Symeonides, "The 'Private' in Private International Law", in: Recueil Des Cours Collected Courses of the Hague Academy of International Law, Leiden/Bosten: Brill/Nijhoff 2016, 384, pp. 100-130.

\section{Symeonides 2017(a)}

S. C. Symeonides, Codifying Choice of Law Around the World, an International Comparative Analysis, paperback edition, New York: Oxford University Press 2014.

\section{Symeonides 2017(b)}

S. C. Symeonides, "The Third Conflicts Restatement's First Draft on Tort Conflicts", Tulane Law Review 2017, Vol. 92, pp. 1-52.

\section{Tavakoli \& Yohannan 2011}

Y. R. Tavakoli and D. R. Yohannan, "Personal Jurisdiction in Cyberspace: Where Does it Begin and Where Does It End?", Intellectual Property and Intellectual Law Journal 2011, 23(1).

\section{Ten Wolde 2020}

M. H. ten Wolde, "De plaats van het Erfolgsort in het forum delicti van het EEX. Is de puzzel gelegd?”, Nederlands Internationaal Privaatrecht, 2020, 2, pp. 251-275.

\section{Teubner 1997(a)}

G. Teubner, "Foreword: Legal Regimes of Global Non-state Actors", in: G. Teubner (ed.), Global Law Without a State, Aldershot: Dartmouth Publishing Company 1997, pp. xiii-xvii.

\section{Teubner 1997(b)}

G. Teubner, “'Global Bukowina': Legal Pluralism in the World Society”, in: G. Teubner (ed.), Global Law Without a State, Aldershot: Dartmouth Publishing Company, 1997, pp. 3-30.

\section{Torremans 2012}

P. L. C. Torremans, "Copyright Territoriality in a Borderless Online Environment", in: Johan Axhamn (ed.), Copyright Territoriality in a Borderless Online Environment, Stockholm: Norstedts Juridik 2012, pp. 23-35.

\section{Torremans 2014}

P. L. C. Torremans, "Jurisdiction in intellectual property cases", in: P. Torremans (ed.), Research Handbook on Cross-Border Enforcement of Intellectual Property, Cheltenham: Edward Elgar Publishing 2014, pp. 381-420.

\section{Torremans 2015}

P. L. C. Torremans, "Copyright (and Other Intellectual Property Rights) as a Human Right", in: P. Torremans (ed.), Intellectual Property and Human Rights. Enhanced Edition of Copyright and Human Rights, Alphen aan den Rijn: Kluwer Law International third edition, 2015, pp. 221-254.

\section{Torremans 2016}

P. L. C. Torremans, "Private International Law Issues on the Internet", in: A. Stamatoudi (ed.), New Developments in EU and International Copyright Law, Wolters Kluwer 2016, pp. 379396. 


\section{Torremans 2017}

P. L. C. Torremans, "Noot onder het arrest van het Hof van Justitie in de zaak C-441/13, Pez Hejduk tegen EnergieAgentur.NRW GmbH.", Tijdschrift voor het Belgisch Handelsrecht Revue de Droit Commercial Belge (TBH-RDC) 2., pp. 236-240.

\section{Tridimas 1996}

T. Tridimas, "The Court of Justice and judicial activism", European Law Review 2996, 21(3), pp. 199-210.

\section{Tridimas 2006}

T. Tridimas, The General Principles of EU law, second edition, Oxford: Oxford University Press 2006.

\section{Trimble 2012}

M. Trimble, "The Future of Cybertravel: Legal Implications of the Evasion of Geolocation", Scholarly Works, Paper, at University of Nevada, Las Vegas, William S. Boyd Scholl of Law, 2012, pp. 567-657.

\section{Trimble \& Lionel 2016}

M. Trimble and S. Lionel, "Geolocation, Geoblocking and Private International Law", William S. Boyd School of Law 2016. See https://scholars.law.unlv.edu/cgi/viewcontent.cgi?article=1174\&context=rscholars

\section{Trimble 2018}

M. Trimble, "Geoblocking and 'Legitimate Trade", in: C. Heath, A. Kamperman Sanders \& A. Moerland (eds.), Intellectual Property Rights as Obstacles to International Trade?, Alphen aan den Rijn: Kluwer Law International 2018.

\section{Trimble 2019(a)}

M. Trimble, "Conflict of Laws (Private International Law) and Remedies", in: Y. Gendreau (ed.), Le Droit d'auteur en action: Perspectives internationales sur les recours: Copyright in action: International perspectives on remedies; El derecho de autor in accion: Perspectivas internationals sobre los médios de proteccion, Montréal: Editions Thémis 2019.

Available at https://papers.ssrn.com/sol3/papers.cfm?abstract id=3404598.

\section{Trimble 2019(b)}

M. Trimble, "The Territorial Discrepancy between Intellectual Property Rights Infringement Claims and Remedies", Lewis Clark Law Review 2019, 23, pp. 501-552.

\section{Troller 1983}

A. Troller, Immaterialgüterrecht (band I), Basel: Helbing \& Lichtenhahn 1983.

\section{Urbano 2015}

M. B. Urbano, "Politics and the Judiciary: A Naïve Step Towards the End of Judicial PolicyMaking", in: L. P. Coutinho, M. La Torre, S. D. Smith (eds.), Judicial Activism. An Interdisciplinary Approach to the American and European Experiences, Cham: Springer, 2015, pp. 161-172.

\section{Van Bochove \& Kramer 2010}

L. M. van Bochove and X. E. Kramer, "Opgelegde bescherming in het Europees internationaal privaatrecht: Van waardeneutraal verwijzingssysteem tot communautair beschermingsmechanisme", in: F. G. M. Smeele and M. A. Verbrugh (eds.), Opgelegde 
bescherming in het bedrijfsrecht. Ratio, methodiek en dymaniek van dwingendrechtelijke bescherming van kwetsbare belangen in het bedrijfsrecht, Den Haag: Boom Juridische Uitgevers 2010, pp. 5-32.

\section{Van Calster 2016}

G. Van Calster, European Private International Law, second edition, Oxford: Hart Publishing 2016.

\section{Van Den Eeckhout 2002}

V. Van Den Eeckhout, "De vermaatschappelijking van het internationaal privaatrecht. Ontwikkelingen aan het begin van de 21e eeuw”, Migrantenrecht 2002, pp. 144-158.

\section{Van Den Eeckhout 2010}

V. Van Den Eeckhout, "Internationale milieuverontreinging en enkele andere ipr-aspecten van Maatschappelijk Verantwoord Ondernemen. Een Case-Study Naar de vermaatschappelijking van het internationaal privaatrecht anno 2010: ontwikkelingen aan het begin van een nieuw decennium. (International Environment Pollution and some other PIL-Issues of Transnational Corporate Social Responsibility. A case-study of the Instrumentalisation of Private International Law in the year 2010: developments at the beginning of a new decade)".

Available at https://papers.ssrn.com/sol3/papers.cfm?abstract id=1550760

\section{Van Den Eeckhout 2013(a)}

V. Van Den Eeckhout, "Private International Law questions that arise in the relation between migration law (in the broad sense of the word) and family law: subjection of PIL to policies of migration law?", PILAGG-Presentation 2013.

Available at https://papers.ssrn.com/sol3/papers.cfm?abstract id=2203729

\section{Van Den Eeckhout 2013(b)}

V. Van Den Eeckhout, "The Instrumentalisation of Private International Law: Quo Vadis? Rethinking the 'Neutrality' of Private International Law in an Era of Globalisation and Europeanisation of Private International Law" 2013.

Available at https://papers.ssrn.com/sol3/papers.cfm?abstract id=2338375

\section{Van Den Eeckhout 2015}

V. Van Den Eeckhout, "The 'Right' Way to Go in International Labour Law-And Beyond. (Some considerations further to the paper of Houwerzijl and Van Hoek)" 2015.

Available at https://papers.ssrn.com/sol3/papers.cfm?abstract_id=2626598

\section{Van Den Eeckhout 2017}

V. Van Den Eeckhout, "Private International Law in an Era of Globalisation. "Neutral" Private International Law!?” 2017, pp. 1-17.

Available at https://papers.ssrn.com/sol3/papers.cfm?abstract_id=2919080

\section{Van Eechoud 2003}

M. M. M. van Eechoud, Choice of Law in Copyright and Related Rights: Alternatives to the Lex Loci Protectionis, The Hague: Kluwer International Law 2003.

\section{Van Eechoud 2005}

M. M. M. van Eechoud, “Overleefde Territorialiteit: grensoverschrijdende auteursrechtinbreuken onder de 'Rome II' ontwerpverordening", Tijdschrift voor auteurs-, media-\& informatierecht 2005, 2, pp. 45-56. 


\section{Van Eechoud 2012}

M. M. M. van Eechoud, "Along the Road to Uniformity: Diverse Readings of the Court of Justice Judgments on Copyright Work", Journal of Intellectual Property, Information Technology and E-Commerce Law 2012, 3, pp. 60-80.

\section{Van Eechoud \& Kur 2012}

M. M. M. van Eechoud and A. Kur, "Internationaal privaatrecht in intellectuele eigendomszaken - de 'CLIP' Principles”, Nederlands Internationaal Privaatrecht 2012, 2, pp. 185-192.

\section{Van Eechoud 2013}

M. M. M. van Eechoud, "De grensoverschrijdende inbreuk. Daad, plaats en norm na Football Dataco \& Pinckney", Tijdschrift voor Auteurs-, media- \& informatierecht 2013, 6, pp. 169178.

\section{Van Eechoud 2014}

M. M. M. van Eechoud, “Annotation of C-387/12 Hi Hotel/Spoering”, Tijdschrift voor Auteurs, Media-, en Informatierecht 2014, 4, pp. 117-120.

\section{Van Engelen 2007}

Th. C. J. A. van Engelen, Intellectuele eigendom en internationaal privaatrecht, Den Haag: Boom Juridische uitgevers 2007.

\section{Van Eechoud 2016}

M. M. M. van Eechoud, "Bridging the gap: Private international law principles for intellectual property law”, Nederlands Internationaal Privaatrecht 2016, 4, pp. 716-723.

\section{Van Eechoud 2016}

M. M. M. van Eechoud, "Bridging the gap: Private international law principles for intellectual property law", Nederlands Internationaal Privaatrecht 2016, 4, pp. 716-723.

\section{Van der Plas 2018}

C. G. van der Plas, “Annotatie, HvJ EU, 17-10-2017, C-194/16”, Jurisprudentie Onderneming en Recht 2018, 3.

\section{Van der Hof 2002}

S. van der Hof, Internationale on-line overeenkomsten. Internationale privaatrechtelijke aspecten van on-line business-to-business en business-to consumer overeenkomsten in Europa en de Verenigde Staten, Den Haag: Sdu Uitgevers 2002.

\section{Van Gerven \& Lierman 2010}

W. Van Gerven and S. Lierman, Beginselen van Belgisch Privaatrecht. Algemeen Deel. Veertig Jaar Later. Privaat-en Publiekrecht in een Meergelaagd Kader van Regelgeving, Rechtsvorming en Regeltoepassing, Mechelen: Kluwer 2010.

\section{Van Hoecke 2002}

M. Van Hoecke, Law as Communication, Oxford and Portland, Oregon: Hart Publising 2002.

\section{Van Loon 2008}

H. van Loon, "Remarks on the needs and methods for governance in the field of private international law-at the global and regional levels", in: F. Cafaggi and H. Muir-Watt (eds.), Making European Private Law. Governance Design, Cheltenham: Edward Elgar Publishing 2008, pp. 197-208. 


\section{Van Loon 2015}

H. van Loon, "The Global Horizon of Private International Law", in: Recueil Des Cours Collected Courses of the Hague Academy of International Law, Leiden/Bosten: Brill/Nijhoff 2015, 380, pp. 9-108.

\section{Vaver 2001}

D. Vaver, "The Copyright Mixture in a Mixed Legal System: Fit for Human Consumption", Electronic Journal of Comparative Law 2001, 5(2), part III. Available at http://www.ejcl.org/52/abs52-3.html.

\section{Verhagen 2002}

H. L. E. Verhagen, "The Tension Between Party Autonomy and European Union Law: Some Observations on Ingmar GB Ltd V Eaton Leonard Technologies Inc", International \& Comparative Law Quarterly, 2002, pp. 135-154.

\section{Vicente 2016}

D. M. Vicente, "The territoriality principle in intellectual property revisited", Nederlands Internationaal Privaatrecht 2016, 4, pp. 724-729.

\section{Vlas 2011}

P. Vlas, Hoofdlijnen Boek 10 BW (internationaal privaatrecht), Den Haag: Sdu Uitgevers 2011.

\section{Von Hein 2014-2015}

J. von Hein, "Protecting Victims of Cross-border Torts Under Article 7 No. 2 Brussels Ibis: Towards a More Differentiated and Balanced Approach", Yearbook of Private International Law, Vol. 16, 2014-2015, pp. 241-274.

\section{Von Lewinski 2008}

S. von Lewinski, International Copyright Law and Policy, New York: Oxford University Press 2008.

\section{Von Mehren 2007}

A. T. von Mehren, Adjudicatory Authority in Private International Law A Comparative Study, The Hague Academy of International Law Monographs, Leiden/Boston: Martinus Nijhoff Publishers 2007.

\section{Von Mehren \& Trautman 1996}

A. T. von Mehren and D. T. Trautman, "Jurisdiction to Adjudicate: A Suggested Analysis", Harvard Law Review 1996, 6, pp. 1121-1179.

\section{Von Savigny 1849}

F. C. von Savigny, System des heutigen Römischen Rechts, Bd VIII, Berlin: Beit und Comp 1849.

\section{Vonken 2018}

A. P. M. J. Vonken, Mr. C. Assers Handleiding tot de beoefening van het Nederlands Burgerlijk recht, Internationaal privaatrecht, Algemeen deel IPR, Deel 10-I, Deventer: Kluwer 2018.

\section{Vranken 1995}

J. B. M. Vranken, Mr. C. Assers Handleiding tot de beoefening van het Nederlands Burgerlijk recht: Algemeen Deel (2), Zwolle: Deventer: Kluwer 1995.

\section{Vranken 2005}

J. B. M. Vranken, Mr. C. Assers Handleiding tot de beoefening van het Nederlands Burgerlijk recht: Algemeen Deel (3), Zwolle: Deventer: Kluwer 2005. 


\section{Wadlow 1998}

C. Wadlow, Enforcement of Intellectual Property in European and International Law. The New Private International Law of Intellectual Property in the United Kingdom and the European Community, Londen: Sweet \& Maxwell 1998.

\section{Wadlow 2009}

C. Wadlow, "The new private international law of unfair competition and the Rome II Regulation", Journal of Intellectual Property Law \& Practice 2009, 4(11), pp. 789-797.

\section{Wai 2002}

R. Wai, "Transnational Litoff and Juridical Touchdown: The Regulatory Function of Private International Law in an Era of Globalisation", Columbia Journal of Transnational Law 2002, 40(2), pp. 209-274.

\section{Wanat 2008}

D. E. Wanat, "Copyright Infringement Litigation and the Exercise of Personal Jurisdiction within Due Process Limits: Judicial Application of Purposeful Availment, Purposeful Direction or Purposeful Effects Requirements to Finding that a Plaintiff Has Established a Defendant's Minimum Contacts within the Forum State", Mercer Law Review 2008, 59(2), pp. 553-595.

\section{Wardhaugh 1989}

B. Wardhaugh, "From Natural Law to Legal Realism: Legal Philosophy, Legal Theory, and the Development of American Conflict Laws Since 1830", Maine Law Review 1989, 41, pp. $307-$ 360.

\section{Watson 1993}

A. Watson, Legal Transplants: An Approach to Comparative Law, second edition, Georgia: The University of Georgia Press 1993.

\section{Wautelet 2004}

P. Wautelet, "What has international private law achieved in meeting the challenges posed by globalisation?", in: P. Slot and M. Bulterman (eds.), Globalisation and Jurisdiction, Leiden: Kluwer Law International 2004, pp. 55-77.

\section{Weinberg 2005}

L. Weinberg, "Theory Wars in the Conflict of Laws", Michigan Law Review 2005, pp. 16311670.

\section{Weiler 1990}

J. H. H. Weiler, “The Transformation of Europe”, Yale Law Journal 1990, pp. 2403-2484.

\section{Wefers Bettink 2011}

H. W. Wefers Bettink, "De gerichtheid van een website bij een inbreuk op IE-rechten en ongeoorloofde reclame: rechterlijke bevoegdheid na Pammer en Alpenhof', Intellectuele Eigendom en Reclamerecht 2011, 3, pp. 157-163.

\section{Wiarda 1999}

G. J. Wiarda, Drie typen van rechtsvinding, vierde druk bewerkt door T. Koopmans, Deventer: W. E. J. Tjeenk Willink 1999.

\section{Winch 1967}

P. Winch, The Idea of Social Science, London: Routledge \& Kegan Paul 1967. 


\section{Woodfield 2010}

A. Woodfield, Teleology, Cambridge: Cambridge University Press 2010.

\section{Xalabarder 2002}

R. Xalabarder, "Copyright: Choice of Law and Jurisdiction in the Digital Age", Annual Survey of International \& Comparative Law 2002, 8(1), pp. 79-96.

\section{Yokoyama 2005}

D. T. Yokoyama, "You Can't Always Use the Zippo Code: The Fallacy of a Uniform Theory of Internet Personal Jurisdiction", DePaul Law Review 2005, 54(4), pp. 1147-1196.

\section{Zoll 2011}

A. Zoll, "Foreword by Professor A. Zoll", in: C. Busch and H. Schulte-Nölke (eds.), EU Compendium Fundamental Rights and Private Law, Munich: Sellier European Law Publishers 2011, pp. XI-XXIII. 


\section{Case law}

\section{International or regional:}

\section{European Union}

C-1/54 France Republic v. High Authority of the European Coal and Steel Community, ECLI:EU:C:1954:7

C-30/59 Steenkolenmijnen in Limburg v. High Authority of the European Coal and Steel Community, ECLI:EU:C:1960:6

Opinion of Advocate General Lagrange delivered on 4 June 1962 in the case C-14/61 Koninklijke Nederlandsche Hoogovens en Staalfabrieken NV v. High Authority of the European Coal and Steel Community, ECLI:EU:C:1962:19

C-26/62 Van Gend \& Loos v. Nederlandse Administratie der Belastingen, ECLI:EU:C:1963:1

C-28/62 to 30/62 Costa en Schaake NV and Others v. Administratie der Belastingen, ECLI:EU:C:1963/6

C-6/64 Flaminio Costa v. E.N.E.L., ECLI:EU:C:1964:66

C-29/69 Erich Stauder v. City of Ulm-Socialamt, ECLI:EU:C:1969:57

C-11/70 Internationale Handelsgesellschaft $m b H$ v. Einfuhr- und Vorratsstelle für Getreide und Futtermittel, ECLI:EU:C:1970:114

C-4/73 Nold v. Commission of the European Communities, ECLI:EU:C:1974:51

C-43/75 Gabrielle Defrenne v. Société anonyme belge de navigation aérienne Sabena, ECLI:EU:C:1976:56

C-12/76 Industrie Tessili Italiana Como v. Dunlop AG, ECLI:EU:C:1976:133

C-14/76 De Bloos v. Société en commandite par actions Bouyer ECLI:EU:C:1976:134

C-21/76 Handelskwekerij G.J. Bier v. Mines de Potasse d'Alsace SA, ECLI:EU:C:1976:166

Opinion of Advocate General Capotorti delivered on 10 November 1976 in the case C-21/76 Handelskwekerij G.J. Bier v. Mines de Potasse d'Alsace SA, ECLI:EU:C:1976:147. 
C-106/77 Amministrazione delle Finanze dello Stato v. Simmenthal SpA, ECLI:EU:C:1978:49

C-44/79 Liselotte Hauer v. Land Rheinland-Pfalz, ECLI:EU:C:1979:290

C-62/79 Coditel v. Ciné Vog Films and Others, ECLI:EU:C:1980:84

C-38/81 Effer SpA v. Hans-Joachim Kantner, ECLI:EU:C:1982:79

C-283/81 CLIFIT and Lanificio di Gavardo SPA v. Ministry of Health, ECLI:EU:C:1982:335

C-34/82 Martin Peters Bauunternehmung GmbH v. Zuid Nederlandse Aannemers Vereniging, ECLI:EU:C:1983:87

C-241/83 Erich Rösler v. Horst Rottwinkel, ECLI:EU:C:1985:6

C-294/83 Les Verts v. European Parliament, ECLI:EU:C:1986:166

C-189/87 Kalfelis v. Schröder, ECLI:EU:C:1988:459

C-265/87 Hermann Schräder HS Kraftfutter GmbH \& Co KG v. Hauptzollamt Gronau, ECLI:EU:C:1989:303

C-220/88 Dumez France and Tracoba v. Hessische Landesbank and Others, ECLI:EU:C:1990:8

C-305/88 Isabelle Lancray v Peters und Sickert KG, ECLI:EU:C:1990:275

C-260/89 Elliniki Radiophonia Tiléorassi AE and Panellinia v. Dimotiki and Others, ECLI:EU:C:1991:254

C-6/90 and 9/90 Andrea Francovich and Danila Bonifaci and Others v. Italian Republic, ECLI:EU:C:1991:428

C-261/90 Reichert Kockler v. Dresdner Bank, ECLI:EU:C:1992:149

C-26/91 Jakob Handte \& Co. GmbH v. Traitment Mécano-chimiques des Surfaces SA, ECLI:EU:C:1992:268

C-89/91 Shearson Lehmann Hutton Inc $v$ TVB Treuhandgeschellschaft für Vermögensverwaltung und Beteiligung mbH, ECLI:EU:C:1993:15 
C-46/93 and C-48/93 Brasserie du Pêcheur SA and Federal Republic of Germany and The Queen v. Secretary of State for Transport, ECLI:EU:C:1996:79

C-68/93 Shevill and Others v. Presse Alliance, ECLI:EU:C:1995:61

Opinion of Advocate General Darmon delivered on 14 July 1994 in the case C-68/93 Shevill v. Press Alliance SA ECLI:EU:C:1994:303

C-280/93 Federal Republic of Germany v. Council of the European Union, ECLI:EU:C:1994:367

C-364/93 Antonio Marinari v. Loyds Bank plc and Zubaidi Trading Company, ECLI:EU:C:1995:289

Opinion of Advocate General Léger delivered on 12 March 1996 in the case C-84/94 United Kingdom of Great Britain and Northern Ireland v. Council of the European Union, ECLI:EU:C:1996:93

C-269/95 Francesco Benincasa v. Dentalkit, ECLI:EU:C:1997:337

Opinion of Advocate General Tesauro delivered on 6 April 1995 in the case C-450/93 Eckhard Kalanke v. Freie Hansestadt Bremen, ECLI:EU:C:1995:105

C-51/97 Réunion Européenne SA and Others v. Spliethoff's Bevrachtingskantoor BV and the Master of the vessel Alblasgracht V002, ECLI:EU:C:1998:509.

C-126/97 Eco Swiss China Time Ltd v. Benetton International NV, ECLI:EU:C:1999:269

C-381/98 Ingmar GB Ltd. v. Eaton Leonard Technologies Inc., ECLI:EU:C:2000:605

C-412/98 Group Josi Reinsurance Company SA v. Universal General Insurance Company (UGIC), ECLI:EU:C:2000:399

C-167/00 Verein für Konsumenteninformation v. Karl Hein, ECLI:EU:C:2002:555

C-208/00 Überseering BV v. Nordic Construction Company Baumanagment GmbH (NNC), ECLI:EU:C:2002:632

C-256/00 Besix SA v. Wasserreinigungsbau Alfred GmbH \& Co. KG and Planungs-und Forschungsgesellschaft Dipl. Ing. W. Kretzschmar GmbH \& KG, ECLI:EU:C:2002:99

C-271/00 Gemeente Steenbergen v. Luc Baten, ECLI:EU:C:2002:656 
C-334/00 Fonderie Officine Meccaniche Taconi Spa v. Heinrich Wagner Sinto Maschinenfabrik GmbH, ECLI:EU:C:2002:499

C-167/01 Kamer van Koophandel en Fabrieken voor Amsterdam v. Inspire Art Ltd., ECLI:EU:C:2003:512

C-18/02 DFDS Torline v. LO Landesorganisationen, ECLI:EU:C:2004:74

C-148/02 Garcia Avello v. Belgium, ECLI:EU:C:2003:539

C-168/02 Rudolf Kronhofer v Marianne Maier and Others, ECLI:EU:C:2004:364

C-281/02 Andrew Owusu v. N.B. Jackson, ECLI:EU:C:2005:120

C-105/03 Maria Pupino, ECLI:EU:C:2005:386

C-347/03 Regione autonoma Friuli Venezia Giulia and Agenzia regionale v. Ministero delle Politiche Agricole e Forestali, ECLI:EU:C:2005:285

C-144/04 Werner Mangold v. Rüdiger Helm, ECLI:EU:C:2005:709

C-192/04 Lagardère Active Broadcast v. SPRE and Others, ECLI:EU:C:2005:475

C-479/04 Laderdisken ApS v. Kulturministeriet, ECLI:EU:C:2006:549

C-305/05 Ordre des barreaux francophones et Germanophone and Others v. Conseil des Ministres, ECLI:EU:C:2007:383

C-402/05 and C-415/05 Yassin Abdullah Kadi v. Al Brakaat International Foundation, ECLI:EU:C:2008:461

C-275/06 Productores de Música de Espana (Promusicae) v. Telefónica de Espana SAU, ECLI:EU:C:2008:54

C-353/06 Grunkin and Paul, ECLI:EU:C:2008:559

C-33/07 Seagon v. Deko Marty Belgium, ECLI:EU:C:2009:83.

C-5/08 Infopaq International A/S v. Danske Dagblades Forening, ECLI:EU:C:2009:465 
C-101/08 Audiolux SA and Others v. Groupe Bruxelles Lambert SA (GBL) and Others, Bretelsmann AG and Others, ECLI:EU:C:2009:626

C-174/08 NCC Construction Danmark A/S v. Skatteministeriet, ECLI:EU:C:2009:669

C-189/08 Zuid-Chemie BVv. Philippo's Mineralenfabriek NV/SA, ECLI:EU:C:2009:475

C-403/08 and C-429/08 Football Association Premier League Ltd. and Others and Karen Murphyv. Media Protection Services Ltd., ECLI:EU:C:2011:631

C-578/08 Rhimou Chakroun v. Minister van Buitenlandse Zaken, ECLI:EU:C:2010:117

C-585/08 and C-144/09 Peter Pammer v. Reederei Karl Schlütter GmbH \& Co. KG and Hotel Alpenhof GesmbH v. Oliver Heller, ECLI:EU:C:2010:273

Opinion of Advocate General Trstenjak delivered on 18 May 2010 in the joined cases C-585/08 and C-144/09 Peter Pammer v. Reederei Karl Schlütter GmbH \& Co. KG and Hotel Alpenhof GesmbH v. Oliver Heller, ECLI:EU:C:2010:273.

C-324/09 L'Oréal and Others v. eBay, ECLI:EU:C:2011:474

C-393/09 Bezpecnostni softwarová asociace - Svaz softwaeové ochrany v. Ministerstvo kultury, ECLI:EU:C:2010:816

C-462/09 Stichting de Thuiskopie v. Opus Supplies Deutschland GmbH and Others, ECLI:EU:C:2011:397

C-509/09 and C-161/10 eDate Advertising GmbH v. $X$ and Olivier Martinez and Robert Martinez v. MGN Limited, ECLI:EU:C:2011:685

Opinion of Advocate General Cruz Villalón delivered on 29 March 2011 in the joined cases C509/09 and C-161/10 eDate Advertising GmbH v. $X$ and Martinez v. MGN Limited, ECLI:EU:C:2011:192

C-70/10 Scarlet Extended SA v. Société beige des auteur, compositeurs et éditeurs SCRL (SABAM), ECLI:EU:C:2011:771

C-145/10 Eva-Maria Painer v. Standard VerlagsGmbH and Others, ECLI:EU:C:2011:631

C-277/10 Martin Luksan v. Petrus van der Let, ECLI:EU:C:2012:65

C-406/10 SAS Institute Inc v. World Programming Ltd., ECLI:EU:C:2012:259 
C-523/10 Wintersteiger $A G \quad v$. Products $4 U$ Sondermaschinenbau GmbH, ECLI:EU:C:2012:220

Opinion of Advocate General Cruz Villalón delivered on 16 February 2012 in the case C523/10 Wintersteiger AG v. Products $4 U$ Sondermaschinenbau GmbH, ECLI:EU:C:2012:90

C-604/10 Football Dataco Ltd and Others v. Yahoo! UK Ltd and Others, ECLI:EU:C:2012:115

C-5/11 Donner, ECLI:EU:C:2012:370

C-128/11 UsedSoft GmbH v. Oracle International Corp, ECLI:EU:C:2012:407

C-133/11 Folien Fischer and Fofitec AG v. Ritrama SpA, ECLI:EU:C:2012:664

C-173/11 Football Dataco and Others v. Sportrader, ECLI:C:2012:624

C-228/11 Melzer v. MF Global UK Ltd., ECLI:EU:C:2013:305

Opinion of Advocate General Jääskinen delivered on 29 November 2012 in the case C-228/11 Melzer v. MF Global UK Ltd, ECLI:EU:C:2012:766

C-335/11 and C-337/11 HK Denmark v. Dansk, ECLI:EU:C:2013:222

C-131/12 Google Spain SL and Google Inc v. Agencia Espanola de Protección de Datos (AEPD) and Mario Costeja Conzález, ECLI:EU:C:2014:317

C-170/12 Peter Pinckney v. KGD Mediatech AG, ECLI:EU:C:2013:635

Opinion of Advocate General Jääskinen delivered on 13 June 2013 in the case C-170/12 Peter Pinckney v. KGD Mediatech AG, ECLI:EU:C:2013:400

C-360/12 Coty Germany GmbH v. First Note Perfumes NV, ECLI:EU:C:2014:1318

Opinion of Advocate General Jääskinen delivered on 21 November 2013 in the case C-360/12 Coty Germany GmbH v First Note Perfumes NV, ECLI:C:2013:764

C-387/12 Hi Hotel HCF SARL v. Uwe Spoering, ECLI:C:2014:215

C-201/13 Johan Deckmyn, Vrijheidsfonds VZW v. Helena Vandersteen and Others, ECLI:C:2014:2132 
C-375/13 Harald Kolassa v. Barclays Bank plc, ECLI:C:2015:37

C-441/13 Pez Hejduk v. EnergieAgentur NWR GmbH, ECLI:EU:C:2015:28

Opinion of Advocate General Cruz Villalón delivered on 11 September 2014 in the case C441/13 Pez Hejduk v. EnergieAgentur. NRW GmbH, ECLI:EU:C:2014:2212

C-12/15 Universal Music Holding BV v. Michael Tétreault Schilling, Irwin Schwartz, Josef Broz, ECLI:EU:C:2016:449

C-617/15 Hummel Holding A/S v. Nike Inc., ECLI:EU:C:2017:390

C-618/15 Concurrence SARL v. Samsung Electronics France SAS and Amazon Services Europe Sarl, ECLI:EU:C:2016:976

Opinion of Advocate General Wathelet in the case C-618/15 Concurrence SARL v. Samsung Electronics France SAS and Amazon Services Europe Sarl, ECLI:EU:C:2016:843

C-194/16 Bolagsupplysningen Ö̈ and Ingrid Ilsjan v. Svensk Handel AB, ECLI:EU:C:2017:766.

Opinion of Advocate General Bobek delivered on 13 July 2017 in the case C-194/16 Bolagsupplysningen Oü and Ingrid Ilsjan v. Svensk Handel AB, ECLI:C:2017:554

C-340/16 Landeskrankenanstalten-Betriebsgeschellschaft-KABEG, ECLI:C:2017:576

C-27/17 AB flyLAL-Lithuanian Airlines v. Starptautiskä lidosta Riga VAS and Air Baltic Corporation AS, ECLI:EU:C:2018:533

C-106/17 Pawel Hofsoe v. LVM Landwirtschaftlicher Versicherungsverein Münster AG, ECLI:C:2018:50

C-304/17 Helga Löber v. Barclays Bank plc., ECLI:C:2018:701

C-310/17 Levola Hengelo BV v. Smilde Foods BV, ECLI:C:2018:899

C-507/17 Google LLC v. Commission nationale de l'informatique et des libertés (CNIL), ECLI:EU:C:2019:772

Opinion of Advocate General Szpunar delivered on 10 January 2019 in the case C-507/17 Google LLC v. Commission nationale de l'informatique et des libertés (CNIL), ECLI:EU:C:2019:15 
Opinion of Advocate-General Szpunar delivered on 2 May 2019 in the case C-683/17 CofemelSociedade de Vestuário SA v. G-Star Raw CV, ECLI:EU:C:2019:363

C-18/18 Eva Glawischnig-Piesczek v. Facebook Ireland Limited, ECLI:EU:C:2019:

Opinion of Advocate General Szpunar delivered on 4 June 2019 in the case C-18/18 Eva Glawischnig-Piesczek v. Facebook Ireland Limited, ECLI:EU:C:2019:458

C-172/18 AMS Neve Ltd and Others v. Heritage Audio SL, Pedro Rodriguez Arribas, ECLI:EU:C:2019:674

Opinion of Advocate General Szpunar delivered on 28 March 2019 in the case of C-172/18 AMS Neve Ltd, Barnett Waddingham Trustees, Mark Crabtree v. Heritage Audio SL, Pedro Rodriguez Arribas, ECLI:EU:C:2019:276

C-263/18 Nederlandse Uitgeversverbond v. Tom Kabinet, ECLI:EU:C:2019:1111

C-803/18 AAS 'Balta' v. UAB 'Grifs $A G$ ', ECLI:EU:C:2020:123

C-343/19 Verein für Konstumenteninformation v. Volkswagen AG, ECLI:EU:2020:534

\section{European Court of Human Rights}

ECtHR 26 May 2005, Dima v. Romania, App. No. 58472/00

ECtHR 19 June 2006, Hutten-Czapska v. Poland, App. No. 35014/97

ECtHR 28 June 2007, Wagner and J.M.W.L. v. Luxembourg, App. No. 76240/01

ECtHR 29 January 2008, Balan v. Moldova, App. No. 19247/03

ECtHR 4 October 2012, Harroudj v. France, App. No. 43631/09

\section{Permanent Court of International Justice}

S. S. Lotus, France v. Turkey, Permanent Court of International Justice 7 September 1927, No. 10

\section{National:}

\section{Australia}

High Court of Australia, Dow Jones \& Co Inc. v. Gutnick (2002) 210 CLR 575

\section{Canada}

Supreme Court of Canada, Google LLC. v. Equustek Solutions Inc., 2017 S.C.C. 34 


\section{France}

Cour de Cassation 13 June 2006, Bsiri-Barbir v. Haarmann \& Reimer, no. 02-44.718

Cour de Cassation, civile, Chambre commerciale 13 July 2010, no. 06-20.230 (Google v. Louis Vuitton).

Cour de Cassation, civile, Chambre commerciale, 23 November 2010, no. 07-19.543 (Axav. Google).

Cour de Cassation, civile, Chambre commerciale 29 March 2011, no. 10-12.272 (eBay Europe v. Maceo).

Cour de Cassation 10 December 2013, SNC Lancôme Parfums et Beauté and co., GA Modefine prestige et collection international v. M. X., no. 11-19.872.

\section{Germany}

Oberlandesgericht Köln (OGL), 30 October 2007, 6 W 161/07 (Internet-Fotos)

Bundesgerichtshof(BGH), 13 October 2004, I ZR 163/02 (Hotel Maritime)

Bundesgerichtshof(BGH), 27 May 2008, VI ZR 69/07

\section{Netherlands}

Rechtbank Den Haag 30 January 2013 Apkan and Vereniging Mileudefensie v. Royal Dutch Shell PLC and Shell Petroleum Development Company of Nigeria LTD., ECLI:NL:RBDHA:2013:BY9854.

Rechtbank Den Haag 30 January 2013 Dooh and Vereniging Mileudefensie v. Royal Dutch Shell PLC and Shell Petroleum NV, ECLI:NL:RBDHA:2013:BY9845.

Rechtbank Den Haag 30 January 2013 Orugu and Efanga and Vereniging Mileudefensie v. Shell Petroleum NV, ECLI:NL:RBDHA:2013:BY9850.

Gerechtshof Den Haag 18 December 2015 Apkan and Vereniging Mileudefensie v. Royal Dutch Shell PLC and Shell Petroleum Development Company of Nigeria LTD., ECLI:NL:GHDHA:2015:3587.

Gerechtshof Den Haag 18 December 2015 Dooh and Vereniging Milieudefensie. v. Royal Dutch Shell PLC and Shell Petroleum NV, ECLI:NL:GHDHA:2015:3586.

Gerechtshof Den Haag 18 December 2015 Orugu and Efanga and Vereniging Mileudefensie v. Shell Petroleum NV, ECLI:NL:GHDHA:2015:3588.

Hoge Raad 13 May 1966 Alnati (Goudrian en Co's Stoomvaart NV Maatschappij v. Hollandsche Assurantie Societeit), ECLI:NL:HR:1966:AB4654 
Hoge Raad 24 November 1989 Interlas v. Lincoln, ECLI:NL:PHR:1989:AD0964

Hoge Raad 21 February 1992 MB International BV v. Mattel, ECLI:NL:HR:1992:ZC0513

Hoge Raad 7 December 2001, ECLI:NL:HR:2001:AD3965

Conclusion of Advocate General L. Strikwerda, 21 September 2001, ECLI:NL:PHR:2001:AD3965

Hoge Raad 19 March 2004 Koninklijke Philips Electronics N. V. v. Postech Corporation and Others, ECLI:NL:HR:2004:AO0903.

Conclusion of Advocate General L. Strikwerda, 19 December 2003, ECLI:NL: PHR:2004:AO0903.

Hoge Raad 16 June 2006, Kecofa v. Lancôme, ECLI:NL:HR:2006:AU8940

Conclusion of Advocate-General L. Strikwerda, 1 February 2008 Zuid-Chemie B.V. v. Philippo's Mineralenfabriek N.V./S.A., ECLI:NL:PHR:2008:BC3305

Hoge Raad 7 December 2012 H\&M v. G-Star, ECLI:NL:HR:2012:BX9018

For the full text of the abovementioned Dutch case law, see https://www.rechtspraak.nl/.

\section{States of the United States of America}

Pennoyer v. Neff, 95 U.S. 714 (1878)

Strassheim v. Daily, 221 U.S. 280 (1911)

Erie Railroad Co v. Tompkins, 304 U.S. 64 (1938)

Swift \& Co. v. Bankers Trust Co., 280 N. Y. 135 (N. Y. 1939)

Milliken v. Meyer, 311 U.S. 457 (1940)

International Shoe Co. v. Washington, 326 U.S. 310 (1945)

W. H. Barber Co. v. Hughes, 63 N.E.2d 417 (Ind. 1945)

United States v. Aluminium Co of America, 148 F. 2d 416 ( $2^{\text {nd }}$ Cir. 1945)

Auten v. Auten, 124 N.E.2d 99 (N.Y. 1954)

Hanson v. Denckla, 357 U.S. 235 (1958)

Kilberg of Northeas Airlines, 9 N.Y.2d 34 (N. Y. 1961)

Babcock v. Jackson, 12 N.Y.2d 473 (1963)

American Eutectic Welding Alloys Sales Co., Inc. v. Dytron Alloys Corp., 439 F. 2d 428 (2d Cir. 1971)

Shaffer v. Heitner, 433 U.S. 186 (1977)

Kulko v. California Superior Court, 436 U.S. 84 (1978)

Fantis Foods, Inc. v. Standard Importing Co., Inc., 49 N.Y.2d 317 (1980) 
World-Wide Volkswagen Corp v. Woodson, 444 U.S. 286 (1980)

Helicopteros Nationales de Columbia S.S. v. Hall, 466 U.S. 408 (1984)

London Film Productions, Ltd. v. Intercontinental Communications, Inc. 580 F. Supp. 47 (S.D.N.Y. 1984)

Keeton v. Hustler Magazine, 465 U.S. 770 (1984)

Calder v. Jones, 465 U.S. 783 (1984)

Burger King Corp. v. Rudzewicz, 471 U.S. 462 (1985)

Thomas Jackson Pub. Inc. v. Buckner, 625 F. Supp. 1044 (D. Neb. 1985)

Peter Starr Production Co. v. Twin Continental Films, Inc., 783 F.2d 1440 (9 $9^{\text {th }}$ Cir. 1986)

Asahi Metal Industry Co. v. Superior Court, 480 U.S. 102 (1987)

IMO Indus, Inc. v. Kiekert AG, 155 F. 3d 254 ( $3^{\text {rd }}$ Cir. 1998)

Update Art v. Modiin Publishing, Ltd., 843 F.2d 67 (2d Cir. 1988)

Burnham v. Superior Court of California, 495 U.S. 604 (1990)

Subafilms, Ltd v. MGM-Pathe Communications Co., 24 F.3d 1088 (9 ${ }^{\text {th }}$ Cir. 1994)

Indianapolis Colts, Inc. v. Metropolitan Baltimore Football Club Ltd. Partnership, 34 F.3d 410 ( $7^{\text {th }}$ Cir. 1994)

Far West Capital, Inc. v. Towne, 46 F.3d 1071 (10 ${ }^{\text {th }}$ Cir. 1995)

Inset Systems, Inc v. Instruction Set Inc., 937 F. Supp 161 (D. Conn.1996)

Maritz, Inc v. Cybergold Inc., 947 F. Supp. 1328 (E.D. Mo 1996)

CompuServe, Inc. v. Patterson, 89 F.3d 1257 (6 $6^{\text {th }}$ Cir. 1996)

Boosey \& Hawkes Music Publishers Ltd. v. Walt Disney Company, 934 F. Supp. 119 (S.D.N.Y. 1996)

Bensusan Restaurant v. Corp. v. King, 937 F. Supp. 295 (S.D.N.Y. 1996) aff'd 126 F. 3d 25 (2d Cir. 1997)

Weber v. Jolly Hotels, 977 F. Supp. 327 (D.N.J. 1997)

Columbia Pictures Television v Krypton BC, 106 F.3d 284 ( $9^{\text {th }}$ Cir. 1997)

Zippo Manufacturing Co. v. Zippo Dot Com, Inc., 952 F. Supp. 1119 (W.D. Pa. 1997)

Cybersell, Inc. v. Cybersel, Inc., 130 F. 3d. 414 (9 $9^{\text {th }}$ Cir. 1997)

Janmark Inc. v. Reidy, 132 F. 3d 1200 ( $7^{\text {th }}$ Cir. 1997)

Itar-Tass Russian News Agency v. Russian Kurier, Inc., 153 F.3d 82 (2d Cir. 1998)

Boosey \& Hawkes Music Publishers Ltd. v. Walt Disney Company, 145 F. 3d 481 (2d Cir. 1998)

International Star Registry v. Bowman-Haight Ventures Inc., 1999 WL 300285 (N.D. 111. 1999)

Mink v. AAAA Development LLC, 190 F. 3d. 333 (5 th $^{\text {Cir. } 1999)}$

Millenium Entreprises, Inc. v. Millenium Music LP., 33 F. Supp. 2d. 907 (D.Or. 1999)

Bancroft Masters, Inc. v. Augusta Nat'l. Inc., 223 F. 3d 1082 (9 $9^{\text {th }}$ Cir. 2000)

Stewart v. Vista Point Verlag, 56 U.S.P.Q. 2d 1842 (S.D.N.Y. 2000)

Dole Food Co. Inc. v. Watts, 303 F.3d 1104 (2002)

Griffis v. Luban, 646 N.W. 2d 527 (Minn. 2002)

ALS Scan, Inc. v. Digital Service Consultants Inc. 293 F.3d 707 (4 ${ }^{\text {th }}$ Cir. 2002)

Arclightz \& Films Pvt. Ltd v. Video Palace Inc., 303 F. Supp. 2d 356 (S.D.N.Y. 2003)

Schwarzenegger v. Fred Martin Motor Co., 374 F. $3 d 797$ (9 $9^{\text {th }}$ Cir. 2004) 
Images of the World, Inc. v. Continental American Industries Inc., No. 04C 7002, 2005 WL 2171193 (N.D. III. Aug. 30, 2005)

eBay Inc. v. MercExchange L.L.C., 547 U.S. 388 (2006)

Yahoo v. La Ligue Contre Le Racisme, 433 F.3d 1199 (9 $9^{\text {th }}$ Cir. 2006)

Pebble Beach Co. v. Caddy, 453 F.3d 1151 (9 $9^{\text {th }}$ Cir. 2006)

Columbia Pictures Industries Inc. v. Fysh, No. 5:06-CV-37, 2007 WL541988 (W.D. Mich. Feb. 16, 2007)

Dudnikov v. Chalk \& Vermillion Fine Arts Inc., 514 F.3d 1063 (10 ${ }^{\text {th }}$ Cir. 2008)

Penguin Group (USA) Inc. v. American Buddha, No. 09-cv-528, 2009 WL 1069158, 2009 U.S.

Dist. LEXIS 34032 (S.D.N.Y. April 21, 2009) (Am. Buddha I)

Salinger v. Colting, 607 F. 3d 68 (2d Cir. 2009)

Penguin Group (USA) Inc. v. American Buddha, 609 F.3d 30 (2d Cir. 2010) (Am. Buddha II)

Brayton Purcell LLP v. Recordon \& Recordon, 606 F.3d 1124 (9 $9^{\text {th }}$ Cir. 2010)

New Engeland Ltd. P'Ship v. Fancaster Inc., No 09cv 11884-NG 2010 WL 3895177 dt •5 (D.

Mass Oct 1, 2010)

Jagex Limited v. Impulse Software, 750 F. Supp. 2d 228 (D. Mass. 2010)

Sportchannel New Engeland Ltd. P'Ship v. Fancaster Inc., No. 09cv 11884-NG 2010 WL 3895177 (D. Mass Oct 1, 2010)

Mavrix Photo v. Inc. Brand Technologies, 647 F.3d 1218 (9 $9^{\text {th }}$ Cir. 2011)

Goodyear Dunlop Tires Operations S.A. v. Brown, 564 U.S. 915 (2011)

Penguin Group (USA) Inc. v. American Buddha, 16 N.Y. 3d 295 (2011) (Am. Buddha III)

Washington Shoe Company v. A-Z Sporting Goods Inc., No. 11-35166 and 11-35206 (9 (th $^{\text {Cir. }}$ 2012)

Philips Med. Sys. Int'l B.V. v. Bruetman, 8 F.3d 600 (7th Cir.1993)

Penguin Group (USA) Inc. v. American Buddha, No. 09 Civ. 528 (RA), 2013 WL 865486, *7 (S.D.N.Y. March 9, 2013)

Walden v. Fiore, 571 U.S. 277, 134 S. Ct. 1115 (2014)

Bristol-Myers Squibb Co. v. Superior Court of California, San Francisco County, et Al., 582 U.S. 137 S. Ct. 1773 (2017)

Google LLC v. Equustek Solutions, Inc., 2017 WL 5000834 (N.D. Ca. 2017)

\section{Sweden}

Swedish Supreme Court, Micael Engström v. Tylden \& Co AS 4 July 2012, NJA 2012 s 483

\section{United Kingdom}

House of Lords of the United Kingdom 8 September 1983, British South Africa Co. v. Companhia de Moçambique [1893] A. C. 602

Court of Appeal (Civil Division) of England and Wales 21 January 1999, Pearce v. Ove Arup Partnership Ltd. and Others [2000] 3 W.L.R. 332 [2000] Ch. 403 
Court of Appeal (Civil Division) of England and Wales 14 February 2002, Henderson v. Jacquen \& Anor, [2002] EWCA Civ 75

Court of Appeal of England and Wales 27 July 2011, The Newspaper Licensing Agency Ltd and others v. Meltwater Holding BV and Others, [2011] EWCA Civ 890

United Kingdom Supreme Court 27 July 2011, Lucasfilm Ltd. and Others v. Andrew Ainsworth and Another [2011] UKSC 39 [2012] 1 AC 208

New South Wales Supreme Court Xv. Twitter [2017] N.S.W.S.C. 1300 


\section{Treaties/Agreements}

Anti-Counterfeiting Trade Agreement signed on 1 October 2011, not in force yet.

Agreement on a Unified Patent Court (OJ C 175, 20.6.2013, pp. 1-40).

Agreement on Trade Related Aspects of Intellectual Property Rights 1994 (TRIPS-Agreement 1994)

Agreement on Trade Related Aspects of Intellectual Property Rights, Annex 1C of the Marrakesh Agreement Establishing the World Trade Organisation, signed in Marrakesh, Morocco on 15 April 1994, entered into force 1 January 1995, 1869 UNTS 299.

Berne Convention of 1979

Berne Convention for the Protection of Literary and Artistic Works signed at Berne on 9 September 1886, entered into force 5 December 1887, lastly revised at Paris on 24 July 1971, and amended on 28 September 1979, 828 UNTS 221.

Brussels Convention of 1968

Brussels Convention on Jurisdiction and the Enforcement of Judgments in Civil and Commercial Matters 1968 (OJ L 299, 31.12.1972, pp. 34-42).

Charter of Fundamental Rights of the European Union of 2000

Charter of Fundamental Rights of the European Union proclaimed on 7 December 2000 by the European Parliament, the Council of Ministers and the European Commission, entered into force on 1 December 2009 (OJ C 364, 18.12. 2000, pp. 1-22).

Convention for the European Patent for the common market

Convention for the European Patent for the common market (OJ L 71, 26.1.1976, pp. 1-28).

European Convention on Human Rights of 1950

European Convention for the Protection of Human Rights and Fundamental Freedoms adopted in Rome on 4 November 1950, entered into force 3 September 1953, ETS No. 005.

\section{European Coal and Steel Community Treaty}

European Coal and Steel Community Treaty (ECSC) signed on 18 April 1951, also known as the Treaty of Paris, came into force 23 July 1952 and expired 23 July 2002.

Treaty establishing the European Economic Community

Treaty establishing the European Economic Community (EEC Treaty), also referred to as Treaty of Rome, signed on 25 March 1957 came into force 1 January 1958 (not published in an official journal). 


\section{European Atomic Energy Community Treaty}

European Atomic Energy Community Treaty (EURATOM Treaty) signed on 25 March 1957 came into force 1 January 1958 (not published in an official journal).

\section{Lugano Convention of 1988/2007}

Lugano Convention on Jurisdiction and the Enforcement of Judgments in Civil and Commercial Matters of 1988 (OJ L 319, 25.11.1988, pp. 9-48), revised in 2007 (OJ L 339, 21.12.2007, pp. $3-41)$.

United Nations Convention on the Recognition and Enforcement of Foreign Arbitral Awards of 1958

United Nations Convention on the Recognition and Enforcement of Foreign Arbitral Awards adopted in New York by the United Nations on 10 June 1958, entered into force 7 June 1957 UNTS 330 .

Protocol No. 1 to the European Convention for the Protection of Human Rights of 1952

Protocol No. 1 to the European Convention for the Protection of Human Rights and Fundamental Freedoms adopted in Paris on 20 March 1952, entered into force on 18 May 1954, ETS No. 009.

Protocol on the settlement of litigation concerning the infringement and validity of community patents (Protocol on litigation) (OJ L 401, 30.12.89, pp. 34-44) annexed to the Convention for the European Patent for the common market (OJ L 71, 26.1.1976, pp. 1-28).

Protocol No. 3 on the Statute of the Court of Justice of the European Union Protocol No. 3 on the Statute of the Court of Justice of the European Union (OJ C 310, 16.12.2004, pp. 210-224).

Rome Convention of 1980

Convention 80/934/EEC on the Law Applicable to Contractual Obligations adopted at Rome on 19 June 1980 (OJ L 266, 9.10.1980, pp. 1-19).

Treaty establishing the European Community

Treaty establishing the European Community (EC Treaty) (OJ 1997 C340, 10.11.1997, pp. 173306).

Treaty of Lisbon of 2007

Treaty of Lisbon amending the Treaty on European Union and the Treaty establishing the European Community, signed at Lisbon, 13 December 2007, entered into force 1 December 2009 (OJ C 306, 17.12.2007, pp. 1-271). 
Treaty on European Union (TEU)

Treaty on European Union established by the Treaty of Maastricht, signed on 7 February 1992, entered into force 1 November 1993, and alternated by the Treaty of Lisbon signed on 13 December 2007, entered into force 1 December 2009 (OJ C 326, 26.10.2012, pp. 13-46).

Treaty on the Functioning of the European Union (TFEU)

Treaty on the Functioning of the European Union (OJ C 326, 26.10.2012, pp. 47-390).

Universal Copyright Convention of 1952

Universal Copyright Convention adopted at Geneva on 6 September 1952, entered into force 16 September 1955, 216 UNTS 132.

Universal Declaration of Human Rights of 1948 (UDHR)

Universal Declaration of Human Rights adopted by the United Nations General Assembly in Paris on 10 December 1948.

United Nations International Covenant on Economic, Social and Cultural Rights of 1966 (ICESCR)

United Nations International Covenant on Economic, Social and Cultural Rights adopted at New York 16 December 1966, entered into force 3 January 1976, 993 UNTS 3.

World Intellectual Property Organization Copyright Treaty of 1996 (WIPO Copyright Treaty) World Intellectual Property Organization Copyright Treaty signed at Geneva on 20 December 1996, entered into force on 6 March 2002, 2186 UNTS 152.

World Intellectual Property Organization Performances and Phonograms Treaty of 1996 World Intellectual Property Organization Performances and Phonograms Treaty signed at Geneva on 20 December 1996, entered into force on 20 May 2002, 2186 UNTS 250.

\section{Hague Conventions:}

Hague Convention on the Law Applicable to Traffic Accidents concluded 4 May 1971, entered into force 3 June 1975.

Hague Convention on the Recognition and Enforcement of Decisions Relating to Maintenance Obligations concluded 2 October 1973, entered into force 1 August 1976.

Hague Convention on the Law Applicable to Products Liability concluded 2 October 1973, entered into force 1 October 1977.

Hague Convention on the Law Applicable to Maintenance Obligations concluded 2 October 1973, entered into force 1 October 1977. 
Hague Convention on the Civil Aspects of International Child Abduction concluded 25 October 1980, entered into force 1 December 1983.

Hague Convention on Jurisdiction, Applicable Law, Recognition, Enforcement and Cooperation in Respect of Parental Responsibility and Measures for the Protection of Children concluded 19 October 1996, entered into force 1 January 2020.

Hague Draft Convention on Jurisdiction and Foreign Judgments in Civil and Commercial Matters adopted by the Special Commission on 30 October 1999, did not enter into force (See Nygh \& Pocar 2000).

Hague Convention on Choice of Court Agreements of 30 June 2005, entered into force 1 October 2015.

Hague Protocol on the Law Applicable to Maintenance Obligations concluded 23 November 2007, entered into force 1 August 2013.

Hague Convention of 2 July 2019 on the Recognition and Enforcement of Foreign Judgments in Civil or Commercial Matters, did not enter into force.

For the text of the Hague Conventions see https://www.hcch.net/en/instruments/conventions 


\section{European Union Directives and Regulations}

Brussels I Regulation

Council Regulation (EC) No. 44/2001 of 22 December 2000 on jurisdiction and the recognition and enforcement of judgments in civil and commercial matters (OJ L 12, 16.01.2001, pp. 1-23)

Brussels Ibis Regulation

Council Regulation (EU) No. 1215/2012 of the European Parliament and the Council of 12 December 2012 on jurisdiction and the recognition and enforcement of judgements in civil and commercial matters (OJ L 351, 20.12.2012, pp. 1-32)

Collective Rights Management Directive

Directive 2014/26/EU of the European Parliament and of the Council of 26 February 2014 on collective management of copyright and related rights and multi-territorial licensing of rights in musical works for online use in the internal market (OJ L 84, 20.3.2014, pp. 72-98)

Commercial Agents Directive

Council Directive 86/653/EEC of 18 December 1986 on the coordination of the laws of the Member States relating to self-employed commercial agents (OJ L 382, 31.12.1986, pp. 17-21)

Community designs Regulation

Council Regulation (EC) No. 6/2002 of 12 December 2001 on Community designs (OJ L 3, 5.1.2002, pp. 1-24)

Community plant variety rights

Council Regulation (EC) No. 2100/94 of 27 July 1994 on Community plant variety rights, OJ L 227, 1.09.1994, pp. 1-30)

Community trade mark Regulation

Council Regulation No. 40/94 of 20 December 1993 on the Community trade mark (OJ L 11, 14.01.1994, pp. 1-66)

Council Decision of 5 October 2006 on the accession of the Community to the Hague Conference on Private International Law (OJ L 297, 26.10.2006, pp. 1-14).

Council Decision of 26 February 2009 on the signing on behalf of the European Community of the Convention on Choice of Court Agreements (OJ L 133, 29.5.2009, pp. 1-13)

Council Decision 2014/887/EU of 4 December 2014 on the approval, on behalf of the European Union, of the Hague Convention of 30 June 2005 of Choice of Court Agreements (OJ L 353, 10.12.2014, pp. 5-8) 


\section{Database Directive}

Directive 96/6/EC of the European Parliament and of the Council of 11 March 1996 on the legal protection of databases (OJ 1996 L 77, pp. 20-28)

Directive (EU) 2017/1564 of the European Parliament and of the Council of 13 September 2017 on certain permitted uses of certain works and other subject matter protected by copyright and related rights for the benefit of persons who are blind, visually impaired or otherwise printdisabled and amending Directive 2001/29/EC on the harmonization of certain aspects of copyright and related rights in the information society (OJ L 242, 20.9.2017, pp. 6-13)

Directive on Copyright in the Digital Single Market

Directive (EU) 2019/790 of the European Parliament and of the Council of 17 April 2019 on copyright and related rights in the Digital Single Market and amending Directives 96/9/EC and 2001/29/EC (OJ L 130, 17.05.2019, pp. 92-125)

Directive on Electronic Commerce

Directive 2000/31/EC of the European Parliament and of the Council of 8 June 2000 on certain legal aspects of information society services, in particular electronic commerce, in the Internal Market (OJ L 178, 17.7.2000, pp. 1-16)

Directive on the Enforcement of Intellectual Property Rights

Directive 2004/48/EC of the European Parliament and of the Council of 29 April 2004 on the enforcement of intellectual property rights (OJ 2004 L195 pp. 16-25)

EU trade mark Regulation

Council Regulation (EC) No. 207/2009 of 26 February 2009 on the European Union trade mark (OJ L 78, 24.3.2009, p. 1) replaced by the Regulation (EU) No 2017/1001 of the European Parliament and of the Council of 14 June 2017 on the European Union trade mark (OJ L 154, 16.6.2017, pp. 1-99)

General Data Protection Regulation

Regulation (EU) 2016/679 of the European Parliament and of the Council of 27 April 2016 on the protection of natural persons with regard to the processing of personal data on the free movement of such data, and repealing Directive 95/46/EC (OJ L 119, 4.5.2016, pp. 1-88)

Geo-blocking Regulation

Regulation (EU) 2018/302 of the European Parliament and of the Council of 28 February 2018 on addressing unjustified geo-blocking and other forms of discrimination based on customers' nationality, place of residence or place of establishment within the internal market and amending Regulations (EC) No 2006/2004 and (EU) 2017/2394 and Directive 2009/22/EC (OJ L 60I, 2.3.2018, pp. 1-15) 
Information Society Directive

Directive 2001/29/EU of the European Parliament and of the Council of 22 May 2001 on the harmonisation of certain aspects of copyrights and related rights in the information society (OJ L167, 22.06.2001, pp. 10-19)

Orphan Works Directive

Directive 2012/28/EU of the European Parliament and of the Council of 25 October 2012 on certain permitted uses of orphan works (OJ 2012 L 299, pp. 5-12)

Portability Regulation

Regulation (EU) 2017/1128 of the European Parliament and of the Council of 14 June 2017 on cross-border portability of online content services in the internal market (OJ L 168, 30.6.2017, pp. 1-11)

Regulation (EU) No 1257/2012 of the European Parliament and of the Council of 17 December 2012 implementing enhanced cooperation in the area of the creation of unitary patent protection (OJ L 361, 31.12.2012, pp. 1-8)

Regulation (EU) No 1260/2012 of 17 December 2012 implementing enhanced cooperation in the area of the creation of unitary patent protection with regard to the applicable translation arrangements (OJ L 361, 31.12.2012, pp. 89-92)

Rental and Lending Rights Directive

Directive 92/100/EEC of 19 November 1992 on rental right and lending right and on certain rights related to copyright in the field of intellectual property (OJ 1992 L 346, pp. 61-66) replaced by

Directive 2006/115/EC of the European Parliament and of the Council of 12 December 2006 on rental right and lending rights and on certain rights related to copyright in the field of intellectual property (OJ 2006 L 376, pp. 28-35)

Resale Right Directive

Directive 2001/84/EC 27 of the European Parliament and of the Council of 27 September 2001 on the resale right for the benefit of the author of an original work of art (OJ $2001 \mathrm{~L} 272$, pp. 32-36)

\section{Rome I Regulation}

Council Regulation (EC) No. 593/2008 of the European Parliament and of the Council of 17 June 2008 on the Law Applicable to Contractual Obligations (OJ L177, 4.7.2008, pp. 6-16)

\section{Rome II Regulation}

Council Regulation (EC) No. 864/2006 of the European Parliament and the Council of 11 July 2007 on the applicable law to non-contractual obligations (OJ L199, 31.07.2007, pp. 40-49) 
Satellite and Cable Directive

Council Directive 93/83/EEC of 27 September 1993 on the coordination of certain rules concerning copyright and related rights to copyright applicable to satellite broadcasting and cable transmission (OJ 1993 L 248, pp. 15-21) amended by Directive (EU) 2019/789 of the European Parliament and of the Council of 17 April 2019 laying down rules on the exercise of copyright and related rights applicable to online transmissions of broadcasting organisations and retransmissions of television and radio programmes (OJ L 130, 17.5.2019, pp. 82-91)

Service Directive

Directive 2006/123/EC of the European Parliament and of the Council of 12 December 2006 on services in the internal market (OJ L 376, 27.12.2006, pp. 36-68)

\section{Software Directive}

Council Directive 91/250/EEC of 14 May 1991 on the legal protection of computer programs (OJ 1991 L122 pp. 9-13) replaced by

Directive 2009/24/EC of the European Parliament and of the Council of 23 April 2009 on the legal protection of computer programs (OJ 2009 L111 pp.16-22).

\section{Term Directive}

Council Directive 93/98/EEC of 29 October 1993 harmonizing the term of protection and certain related rights (OJ 1993 L 290, pp. 9-13) replaced by Directive 2006/116/EC of the European Parliament and of the Council of 12 December 2006 on the term of protection of copyright and certain related rights (OJ 2006 L 372, pp. 12-18) and Directive 2011/77/EU of the European Parliament and of the Council of 27 September 2011 amending Directive 2006/116/EC on the term of protection of copyright and certain related rights (OJ 2011 L 265, pp. 1-5) 


\section{Soft law}

ALI Principles

Principles on Intellectual Property: Principles Governing Jurisdiction, Choice of Law and Judgments in Transnational Disputes, published 2008 under the auspices of the American Law Institute

\section{CLIP Principles}

Principles on Conflict of Laws related to Intellectual Property, the so-called CLIP Principles. In this dissertation CLIP refers to the final text of the Principles on Conflict of Laws in Intellectual Property of 1 December 2011, available at https://www.ip.mpg.de/en/research/research-news/principles-on-conflict-of-laws-inintellectual-property-clip.html

Draft Convention on Jurisdiction and Recognition of judgments in Intellectual Property Matters presented by R. C. Dreyfuss and J. C. Ginsburg at World Intellectual Property Organization, WIPO Forum on Private International Law and Intellectual Property, Geneva, January 30 and 31, 2001

Avalaible at http://www.wipo.int/meetings/en/doc_details.jsp?doc_id=12386.

See also the Draft Convention on Jurisdiction and Recognition of Judgments in Intellectual Property Matters established by R. C. Dreyfuss and J. Ginsburg in 2002 and referred to as the Dreyfuss and Ginsburg-Convention of 2002 in paragraph 6.4.3. See R. C. Dreyfuss and J. Ginsburg, "Draft Convention on Jurisdiction and Recognition of Judgments in Intellectual Property Matters", Chicago-Kent Law Review 2002, 77(3), pp. 1065-1153. (see also Dreyfuss \& Ginsburg 2002)

\section{HCCH-WIPO Guide}

In 2019, the Hague Conference on Private International Law and the World Intellectual Property Organisation jointly drafted a guide titled "When Private International Law meets Intellectual Property Law. A Guide for Judges".

Available at https://www.wipo.int/edocs/pubdocs/en/wipo_pub_1053.pdf

(See also Bennett \& Granata 2019, pp. 1-88)

Joint Japanese-Korean Proposal of October 2010 (also referred to as Waseda Principles) Joint Japanese-Korean Proposal Drafted by Members of the Private International Law Association of Korea and Japan, Waseda University Global COE Project, 14 October 2010 Available at http://www.win-cls.sakura.ne.jp/pdf/28/08.pdf.

\section{Joint Recommendation WIPO}

Joint Recommendation Concerning Provisions of Marks, and Other Industrial Property Rights in Signs on the Internet adopted by the WIPO at the Thirty-Sixth Series of Meetings of the Assemblies of the Member States of WIPO 24 September to 3 October, 2001 
Available at http://www.wipo.int/edocs/pubdocs/en/marks/845/pub845.pdf

Principles on International Intellectual Property Litigation (KOPLIA Principles)

Principles on International Intellectual Property Litigation have been drafted by the Korean Private International Law Association on 26 March 2010

(See García-Castrillón 2014, p. 423)

Transparency Proposal on Jurisdiction, Choice of Law, Recognition and Enforcement of Foreign Judgments in Intellectual Property

Transparency Proposal on Jurisdiction, Choice of Law, Recognition and Enforcement of Foreign Judgments in Intellectual Property; the Principles on International Intellectual Property Litigation of October 2009

(See Kono \& Jurcys 2012, p. 12)

United Nations Guiding Principles on Business and Human Rights

United Nations Guiding Principles on Business and Human Rights endorsed by the United Nations Human Rights Council in June 2011, also referred to as the Ruggie Principles, are implementing the United Nations 'Project, Respect and Remedy' Framework of 2011 


\section{Reports and miscellaneous}

Article 13 Open letter- Monitoring and Filtering of Internet Content is Unacceptable by the Civil Liberties Union for Europe (Liberties), 16 October 2017.

Available at https://www.liberties.eu/en/news/delete-article-thirteen-open-letter/13194

Blogs of law firms:

-"The taste of cheese cannot be protected by copyright! What about fragrances of perfume?", see https://www.lexgo.be/nl/artikels/ip-it-telecom/intellectueel-eigendomsrecht/the-taste-ofcheese-cannot-be-protected-by-copyright-what-about-fragrances-of-perfume, 124051.html -"Levola/Smilde: copyright on taste or scent? Not according to Advocate General", see https://www.boelszanders.nl/en/publication/levola-smilde-copyright-on-taste-or-scent-notaccording-to-advocate-general/

Brief of the European Commission on Behalf of the European Union as Amicus Curiae in Support of Neither Party in the case of United States of America v. Mircosoft Corporation, 253 F. $3 d 34$ (D. C. Cir. 2001).

Available at

https://www.supremecourt.gov/DocketPDF/17/172/23655/20171213123137791_17-

2\%20ac\%20European $\% 20$ Commission $\% 20$ for $\% 20$ filing.pdf

Council Decision of 26 February 2009 on the signing on behalf of the European Community of the Convention on Choice of Court Agreements (OJ L 133, 29.5.2009, pp. 1-13).

Council Decision 2014/887/EU of 4 December 2014 on the approval, on behalf of the European Union, of the Hague Convention of 30 June 2005 of Choice of Court Agreements (OJ L 353, 10.12.2014, pp. 5-8).

Council Resolution of 16 March 2009 on the EU customs Action combat IPR infringements for the years 2009 to 2012 [2009] OJ C71/1.

Commentary on Principles of Private International Law on Intellectual Property Rights (Joint Proposal Drafted by Members of the Private International Law Association of Korea and Japan)", Waseda University Global COE Project, 14 October 2010. Available at http://www.win-cls.sakura.ne.jp/pdf/28/08.pdf

Commission of European Communities, Follow-up to the Green Paper on Copyright and Related Rights in the Information Society, COM (1996) 586 final, Brussels 20.11.1996, pp. 130. 
Communication from the Commission to the European Parliament, the Council, the European Economic and Social Committee and the Committee of the Regions. A Digital Single Market Strategy for Europe, COM (2015) 192 final, Brussels, 6 May 2015, pp. 1-20.

Communication from the Commission to the Council, the European Parliament, the Economic and Social Committee and the Committee of the Regions. Principles and guidelines for the Community's audiovisual policy in the digital age, Brussels, 14.12.1999 COM (1999) 657 final.

Communication from the Commission to the European Parliament, the Council, the European Economic, and Social Committee and the Committee of the Regions, Promoting a fair, efficient and competitive European copyright-based economy in the Digital Single Market, COM (2016) 592 final, Brussels 14 September 2016, pp. 1-10.

European Commission, "A single Market for Intellectual Property Rights-Boosting creativity and innovation to provide economic growth, high quality jobs and first class products and services in Europe”, COM (2011) 287 final, Brussels 24 May 2011, pp. 3-25.

European Commission, Proposal for a Regulation of the European Parliament and of the Council on addressing geo-blocking and other forms of discrimination based on customers' nationality, place of residence or place of establishment within the internal market and amending Regulation (EC) No 2006/2004 and Directive 2009/22/EC, Brussels, 25.5.2016, COM (2016) 289 final, pp. 1-21.

Explanations Relating to the Charter of Fundamental Rights 2007

Explanations Relating to the Charter of Fundamental Rights OJ C303, 14.12.2007, pp. 17-35.

Global Online Piracy Study of the Institute for Information Law of University of Amsterdam 2018.

See https://www.ivir.nl/publicaties/download/Global-Online-Piracy-Study.pdf

Green Paper of 15 October 1998 Combating Counterfeiting and Piracy in the Single Digital Market, COM (98) 569 final.

Intellectual Property and Private international Law Working Session 10 August 2016 report Johannesburg Conference 2016, pp. 1-8.

See documents of the Intellectual Property and Private International Law Committee at http://www.ila-hq.org/index.php/committees

Jenard Report on the Brussels Convention of 1968 
Jenard Report on the Convention on Jurisdiction and the Enforcement of Judgments in Civil and Commercial Matters signed at Brussels, 27 September 1968, by Mr. P. Jenard, Official Journal of the European Communities 5. 03. 1979, No C 59/1-59/65.

Report International Law Association, Sofia Conference (2012) Intellectual Property and Private International Law, T. Kono, P. A. de Miguel Asensio \& A. M. Metzger (eds.), pp. 117.

See documents of the Intellectual Property and Private International Law Committee at http://www.ila-hq.org/index.php/committees

Report International Law Association Johannesburg Conference (2016) Intellectual Property and Private International Law, T. Kono, P. A. de Miguel Asensio \& A. Metzger (eds.), pp. 118.

See documents of the Intellectual Property and Private International Law Committee at http://www.ila-hq.org/index.php/committees

Report International Law Association Sydney Conference (2018) Intellectual Property and Private International Law, T. Kono, P. A. de Miguel Asensio \& A. Metzger (eds.), pp. 1-18. See documents of the Intellectual Property and Private International Law Committee at http://www.ila-hq.org/index.php/committees

Unified Patent Court Project: https://www.unified-patent-court.org/news; 


\section{Samenvatting}



Door de toenemende globalisatie en het gebruik van internet worden rechtbanken steeds vaker geconfronteerd met geschillen over grensoverschrijdende inbreuken op auteursrechten. De eerste vraag die bij dit soort geschillen moet worden beantwoord is of de aangezochte rechter bevoegd is. Daarvoor moet het aangezochte gerecht van een lidstaat in de Europese Unie de "Verordening van 12 december 2012 betreffende de rechterlijke bevoegdheid, de erkenning en de tenuitvoerlegging van beslissingen in burgerlijke en handelszaken" (hierna Brussel Ibis-Verordening) raadplegen. ${ }^{2706}$

Volgens artikel 4(1) Brussel Ibis-Verordening kan de beweerde inbreukmaker die een woonplaats heeft in een lidstaat van de Europese Unie, ongeacht zijn nationaliteit, altijd worden opgeroepen voor de gerechten van die lidstaat. Daarnaast bepaalt artikel 7(2) Brussel IbisVerordening dat de inbreukmaker kan worden opgeroepen in een andere lidstaat voor "het gerecht van de plaats waar het schadebrengende feit zich heeft voorgedaan of zich kan voordoen". Volgens vaste rechtspraak van het Hof van Justitie van de Europese Unie (hierna Hof) verwijst deze bijzondere bevoegdheidsregel naar zowel het gerecht van de plaats waar het schadebrengende feit is gepleegd (Handlungsort) als het gerecht van de plaats waar de schade is ingetreden of kan intreden (Erfolgsort). ${ }^{2707}$

Het Hof heeft het laatstgenoemde aanknopingspunt 'de plaats waar de schade is ingetreden of kan intreden' geïnterpreteerd in drie zaken betreffende grensoverschrijdende inbreuken op auteursrechten genaamd Pinckney, Hi Hotel en Pez Hejduk. ${ }^{2708}$ Hoofdstuk drie van het proefschrift beschrijft de interpretatie door het Hof in deze drie zaken. Deze interpretatie bestaat uit de volgende drie stellingen door het Hof. Ten eerste, ondanks de territoriale bescherming van auteursrechten, moeten auteursrechten in alle lidstaten automatisch worden beschermd krachtens de "Richtlijn van 22 mei 2001 betreffende de harmonisatie van bepaalde aspecten van het auteursrecht en de naburige rechten in de informatiemaatschappij". ${ }^{2709}$ Deze eerste stelling wordt aangeduid als het locus protectionis criterium. Ten tweede, een gerecht van een lidstaat is bevoegd als de beweerde schade kan intreden in die lidstaat. Deze tweede stelling wordt in het proefschrift aangeduid als het 'waarschijnlijkheid van de schade' criterium. Ten derde, de bevoegdheid van het gerecht is beperkt tot het beoordelen van de schade die intreedt in de lidstaat van het aangezochte gerecht vanwege de territoriale bescherming van auteursrechten.

Dit proefschrift duidt de noodzaak aan om de bovenstaande interpretatie van het Hof te heroverwegen. Hoofdstuk vier beschrijft dat de rol van het Hof als motor van de Europese integratie algemeen wordt erkend maar benadrukt dat het Hof binnen de grenzen van het recht dient te blijven. Door het bovengenoemde ruime locus protectionis criterium lijkt het Hof artikel 7(2) Brussel Ibis-Verordening te gebruiken als een instrument ter bevordering van de

\footnotetext{
${ }^{2706}$ Verordening (EU) nr. 1215/2012 van het Europees Parlement en de Raad van 12 december 2012 betreffende de rechterlijke bevoegdheid, de erkenning en de tenuitvoerlegging van beslissingen in burgerlijke en handelszaken.

${ }^{2707}$ Zie de zaak C-21/76 Handelskwekerij G.J. Bier tegen Mines de Potasse d'Alsace SA.

${ }^{2708}$ C-170/12 Peter Pinckney tegen KGD Mediatech AG; C-387/12 Hi Hotel HCF SARL tegen Uwe Spoering; C441/13 Pez Hejduk tegen EnergieAgentur NWR GmbH.

${ }^{2709}$ Richtlijn 2001/29/EG van het Europees Parlement en de Raad van 22 mei 2001 betreffende de harmonisatie van bepaalde aspecten van het auteursrecht en de naburige rechten in de informatiemaatschappij.
} 
harmonisatie van auteursrechtbescherming in de Europese Unie. Zoals reeds betoogd door diverse academici is het echter belangrijk dat de instrumentalisatie, ook wel genoemd vermaatschappelijking, ${ }^{2710}$ van het rechtsgebied internationaal privaatrecht niet ten koste gaat van de beginselen die aan dit rechtsgebied ten grondslag liggen. De vier beginselen die ten grondslag liggen aan artikel 7(2) Brussel Ibis-Verordening zijn: de voorspelbaarheid van het bevoegde gerecht; het bestaan van een nauwe band tussen het bevoegde gerecht en het geschil; het vergemakkelijken van goede rechtsbedeling; en het bestaan van een procedurele balans tussen de partijen. In hoofdstuk vier wordt verdedigd dat ook gestreefd moet worden naar een balans tussen enerzijds de belangen van auteursrechthebbenden, anderzijds de belangen van gebruikers van informatie en handelaren. Hoewel dit laatste beginsel zijn oorsprong vindt in het auteursrecht, kan het ook vanuit het rechtsgebied internationaal privaatrecht worden verdedigd.

De interpretatie van de bijzondere bevoegdheidsregel in artikel 7(2) Brussel IbisVerordening in het licht van voornoemde vier beginselen van internationaal privaatrecht betreft de teleologische methode van interpretatie. Daarnaast gaat het proefschrift in op de mogelijke invloeden van andere rechtsgebieden zoals het auteursrecht, internationaal publiekrecht en het recht van de Europese Unie. De invloed van deze rechtsgebieden op de interpretatie van artikel 7(2) Brussel Ibis-Verordening kan worden aangeduid als de contextuele methode van interpretatie.

Hoofdstuk vijf betoogt dat de bovengenoemde beginselen van internationaal privaatrecht en auteursrecht worden ondermijnd door de benadering van het Hof betreffende de rechterlijke bevoegdheid in zaken aangaande grensoverschrijdende inbreuken op auteursrechten. Door de 'waarschijnlijkheid van de schade' als aanknopingscriterium voor de rechterlijke bevoegdheid is het voor de potentiële inbreukmaker vaak zeer onvoorspelbaar in welke lidstaat hij kan worden gedaagd. Uit de zaak Pinckney blijkt dat de beweerde inbreukmaker al kan worden gedaagd in een lidstaat op basis van de enkele toegankelijkheid van de website waar auteursrechtelijk beschermde liedjes via compact discs te koop worden aangeboden. In de zaak Pez Hejduk achtte het Hof het voldoende dat de auteursrechtelijk beschermde foto's werden getoond door de website die toegankelijk was in de lidstaat van het aangezochte gerecht. In de zaken Pinckney en Hi Hotel is het Hof zelfs voorbijgegaan aan de omstandigheid dat de auteursrechtelijk inbreukmakende producten te koop werden aangeboden door een derde partij zonder medewerking van de beweerde inbreukmaker.

Potentiële inbreukmakers kunnen dus vaak niet voorspellen in welke lidstaten zij kunnen worden gedaagd. Dit kan ook de volgende maatschappelijke gevolgen hebben. Informatieverstrekkers kunnen besluiten om de toegang tot hun informatie alleen beschikbaar te stellen voor gebruikers van bepaalde lidstaten. Hierdoor wordt de uitwisseling van informatie belemmerd hetgeen nadelige gevolgen heeft voor innovatie en onderwijs. Daarnaast kunnen handelaren besluiten het aanbieden van goederen en diensten aan consumenten tot bepaalde lidstaten te beperken.

2710 Th. M. de Boer duidt deze trend aan met de term "De vermaatschappelijking van het internationaal privaatrecht" zie Nederlands Juristenblad 1980, 55, pp. 785-796. Hoofdstuk twee van het proefschrift gaat nader in op de ontwikkeling omtrent de 'instrumentalisatie' van het internationaal privaatrecht. 
Sinds 2018 mogen handelaren in beginsel echter niet meer de toegang tot hun websites voor consumenten van lidstaten belemmeren vanwege de "Verordening inzake de aanpak van ongerechtvaardigde geoblocking en andere vormen van discriminatie van klanten op grond van nationaliteit, verblijfplaats of plaats van vestiging in de interne markt" (hierna Geoblocking Verordening). ${ }^{2711}$ Uit vrees om onvoorzienbaar en in meerdere lidstaten te worden gedaagd, kunnen voornamelijk kleine handelsondernemingen ervan afzien om hun producten en diensten online aan te bieden aan consumenten in de Europese Unie. Handelaren kunnen echter wel websites blokkeren aangaande audiovisuele diensten dan wel elektronische diensten die hoofdzakelijk toegang geven tot het gebruik van auteursrechtelijk beschermde werken. Deze laatste diensten zijn namelijk uitgezonderd van de verboden in de Geoblocking Verordening. ${ }^{2712}$

De hoofdstukken zes en zeven onderzoeken alternatieve benaderingen van academici en gerechten van lidstaten van de Europese Unie en staten van de Verenigde Staten inzake de rechterlijke bevoegdheid aangaande grensoverschrijdende inbreuken op auteursrechten. In hoofdstuk acht wordt geconcludeerd dat het zogenaamde 'gerichte activiteiten' criterium het meest voldoet aan de beginselen die ten grondslag liggen aan artikel 7(2) Brussel IbisVerordening. Volgens deze benadering is het aangezochte gerecht bevoegd als de gedaagde zijn inbreukmakende activiteiten objectief heeft gericht op de staat van het aangezochte gerecht. Ten aanzien van online inbreuken op auteursrechten zijn mogelijke indicatoren: de inhoud van de betrokken website, de gebezigde taal, de internetdomein naam van de website en de mogelijkheid tot levering van de inbreukmakende goederen in de staat van de aangezochte rechter.

Door de 'gerichte activiteiten' benadering zal de potentiële inbreukmaker redelijkerwijs voorzien in welke lidstaat hij kan worden gedaagd. Daarnaast zorgt deze benadering ook voor een nauwe band tussen het bevoegde gerecht en de beweerde schending van het auteursrecht in de lidstaat van het aangezochte gerecht. De bevoegdheid van het gerecht op basis van het 'gerichte activiteiten' criterium zal beperkt zijn tot de beoordeling van de schade die is geleden in de lidstaat van het aangezochte gerecht. Het bevoegde gerecht van een lidstaat zal gewoonlijk goed in staat zijn om de schade in die lidstaat te beoordelen. Als de inbreukmaker zijn handelingen op meerdere lidstaten heeft gericht, zullen echter gerechten in meerdere lidstaten tegelijk bevoegd zijn. Parallelle procedures zijn belastend voor zowel de inbreukmaker als de auteursrechthebbende. Zeker als de inbreukmaker heeft gehandeld vanuit een copyright haven kan de balans te zeer ten nadele van de auteursrechthebbende uitvallen. ${ }^{2713}$

\footnotetext{
${ }^{2711}$ Verordening (EU) 2018/302 van het Europees Parlement en de Raad van 28 februari 2018 inzake aanpak van geoblocking en andere vormen van discriminatie van klanten op grond van nationaliteit, verblijfplaats of plaats van vestiging in de interne markt, en tot wijziging van Verordeningen (EG) nr. 2006/2004 en (EU) 2017/2394 en Richtlijn 2009/22/EG.

${ }^{2712}$ Hoofdstuk vier van het proefschrift beschrijft bepaalde diensten die uitgesloten zijn van de verboden van de Geoblocking Verordening. Volgens de herzieningsclause in artikel 9(2) Geoblocking Verordening zal het een van de speerpunten zijn of de Verordening ook op deze diensten betrekking moet gaan hebben.

${ }^{2713}$ De term 'copyright havens' verwijst naar staten die geen of weinig auteursrechtelijke bescherming bieden of laks zijn in het afdwingen van bescherming van auteursrechten. In paragraaf 2.2.2.2 wordt betoogd dat, ondanks de Europese richtlijnen voor het harmoniseren van auteursrechten, er nog zogenaamde copyright havens aanwezig zijn in de Europese Unie. Morele auteursrechten zijn bijvoorbeeld niet geharmoniseerd en de Berner Conventie
} 
Hoofdstuk vijf onderzoekt dan ook de mogelijkheid dat een gerecht op grond van artikel 7(2) Brussel Ibis-Verordening bevoegd is om te oordelen over de gehele schade die ontstaan is door een geschil omtrent grensoverschrijdende inbreuken op auteursrechten. In het bijzonder wordt aandacht besteedt aan de invloed van de territoriale bescherming van auteursrechten en het beginsel van internationale comity. ${ }^{2714}$ In hoofdstuk vijf wordt beargumenteerd dat het niet wenselijk is dat het bevoegde gerecht oordeelt over inbreuken op auteursrechten wereldwijd vanwege het beginsel van internationale comity dat duidt op het respect voor de soevereiniteit van staten. Er bestaat namelijk geen gemeenschappelijk auteursrecht dan wel een uniforme conflictregel betreffende schendingen van auteursrechten. De gerechten van lidstaten van de Europese Unie zijn echter verplicht om de gemeenschappelijke conflictregel voor schendingen van auteursrechten toe te passen zoals neergelegd in artikel 8(1) van de Verordening betreffende het recht dat van toepassing is op niet-contractuele verbintenissen. ${ }^{2715}$ In hoofdstuk vijf wordt daarom betoogt dat het gerecht van een lidstaat waar de schade is ingetreden, of kan intreden, dat over 'volledige' rechtsmacht beschikt dus alleen zal mogen oordelen over schendingen van auteursrechten die schade veroorzaken in de lidstaten van de Europese Unie. Daarnaast kan het bevoegde gerecht een verbodsactie uitvaardigen omtrent inbreukmakende handelingen die zijn gepleegd in de lidstaten.

In hoofdstuk acht wordt beargumenteerd dat het gerecht dat bevoegd is op grond van het 'gerichte activiteiten' criterium onder bepaalde voorwaarden kan oordelen over de gehele schade die is ingetreden in de lidstaten. De hoofdstukken zes en zeven beschrijven diverse criteria die volledige rechtsmacht verlenen volgens academici en gerechten van lidstaten en staten van de Verenigde Staten. Deze criteria betreffen voornamelijk geschillen omtrent internet-gerelateerde dan wel zogenaamde ubiquitous schendingen van auteursrechten. De term ubiquitous verwijst naar schendingen van auteursrechten die alomtegenwoordig aanwezig zijn door verspreiding via het internet of andere media zoals radio en televisie. Het concept ubiquitous betreft ook toekomstige technieken die zorgen voor een alomtegenwoordige verspreiding van schendingen van auteursrechten.

Hoofdstuk acht onderscheidt twee hoofdbenaderingen die volledige rechtsmacht verlenen aan het gerecht van de plaats waar de schade is ingetreden of kan intreden. De eerste hoofdbenadering heeft als aanknopingspunt de woonplaats dan wel de plaats van het centrum van belangen van de auteursrechthebbende. Deze benadering biedt potentiële inbreukmakers echter geen voorspelbaarheid welk gerecht bevoegd is. In hoofdstuk vijf is beargumenteerd dat volledige rechtsmacht een bijzonder nauw verband vereist tussen het geschil en het bevoegde gerecht. De inbreukmakende handelingen kunnen echter zijn gericht op andere lidstaten dan de

voor de bescherming van werken van letterkunde en kunst van 1979 slechts bescherming biedt aan bepaalde morele rechten.

${ }^{2714}$ De Engelse term comity betekent letterlijk hoffelijkheid. De Latijnse term 'comitas gentium' wordt gebezigd om de hoffelijkheid tussen volkeren aan te duiden. In het internationale recht wordt de term comitas gebruikt om aan te duiden dat staten elkaars belangen dienen te respecteren.

${ }^{2715}$ Verordening (EG) nr. 864/2007 van het Europees Parlement en de Raad van 11 juli 2007 betreffende het recht dat van toepassing is op niet-contractuele verbintenissen, verkort aangeduid als de Rome II-Verordening. Artikel 8(1) Rome II-Verordening bepaalt dat "de niet-contractuele verbintenis die voortvloeit uit een inbreuk op een intellectuele-eigendomsrecht, wordt beheerst door het recht van het land waarvoor de bescherming wordt gevorderd". Deze conflictregel wordt ook wel de lex loci protectionis regel genoemd. 
lidstaat waar de auteursrechthebbende zijn woonplaats of centrum van belangen heeft. Daarnaast kunnen de schendingen van auteursrechten in andere lidstaten substantiële schade veroorzaken. De hoofdstukken zes en acht besteden in dit kader aandacht aan het onderscheid tussen morele en economische rechten.

Morele rechten, zoals het recht op integriteit, zijn auteursrechten die verbonden zijn aan de persoon van de auteursrechthebbende en dus niet kunnen worden overgedragen. Morele rechten kunnen daardoor alleen geschonden worden in de staat waar de auteursrechthebbende woonachtig is dan wel zijn centrum van belangen heeft. Economische rechten, zoals het recht op productie, distributie en openbaarmaking aan het publiek, zijn overdraagbaar en kunnen daarom in een andere staat dan waar de (oorspronkelijke) auteursrechthebbende woonachtig is, dan wel zijn centrum van belangen heeft, worden geschonden en daar schade veroorzaken.

De tweede hoofdbenadering betreffende volledige rechtsmacht hanteert als aanknopingspunt de plaats waar substantiële schade is ingetreden of kan intreden. Zoals beschreven in de hoofdstukken zes en zeven wordt deze benadering vaak gecombineerd met het 'gerichte activiteiten' criterium zodat het voor de inbreukmaker voorspelbaar is in welke staat hij kan worden gedaagd. Hoofdstuk acht betoogt dat een gerecht op grond van artikel 7(2) Brussel Ibis-Verordening bevoegd zou moeten zijn te oordelen over het gehele geschil inzake ubiquitous schendingen van auteursrechten op basis van de volgende twee voorwaarden. Ten eerste, volgens het 'gerichte activiteiten' criterium moet de beweerde inbreukmaker zijn activiteiten objectief gericht hebben op de staat van het aangezochte gerecht. Ten tweede, de inbreukmakende activiteiten veroorzaken in de staat van het aangezochte gerecht flagrante substantiële schade in verhouding tot de geleden schade in andere staten. Deze twee criteria garanderen een sterke territoriale band tussen het geschil en de bevoegde rechter.

Ter bevordering van rechtszekerheid is het wenselijk om de in hoofdstuk acht voorgestelde criteria voor het vestigen van rechterlijke bevoegdheid op grond van schade ingetreden door grensoverschrijdende inbreuken op auteursrechten in Europese Unie wetgeving neer te leggen. Deze codificatie kan plaatsvinden in de toekomstige herschikte Brussels Ibis-Verordening dan wel in de toekomstige Europese Unie auteursrecht Verordening indien er sprake is van een uniform auteursrecht in de Europese Unie. Door de toegenomen globalisering en het gebruik van internet is het ook belangrijk om op internationaal niveau een gemeenschappelijke benadering te codificeren inzake rechterlijke bevoegdheid op grond van schade ingetreden door grensoverschrijdende inbreuken op auteursrechten. De Haagse Conferentie voor Internationaal Privaatrecht dan wel de Wereldorganisatie voor de Intellectuele Eigendom zouden hierin een leidende rol kunnen spelen. De voorgestelde criteria in hoofdstuk acht voldoen aan de beginselen die in het algemeen gelden in het internationaal privaatrecht voor het verlenen van bevoegdheid aan het gerecht van de plaats waar de schade intreedt of kan intreden. Daarnaast streeft de voorgestelde benadering globale belangen na zoals het bevorderen van efficiënte auteursrechtelijke bescherming; het aanpakken van online piraterij van auteursrechten en copyright havens; en het faciliteren van de grensoverschrijdende 'flow' van informatie en handel. 

Valorisation addendum 

The addendum on valorisation to the dissertation, is in accordance with Article 22 of the "Regulation Governing the Attainment of Doctoral Degrees at Maastricht University", decreed by resolution of the Board of Deans, dated 24 January 2018.

\section{1) Relevance: What is the social and/ or economic relevance of the research results?}

The reasons of states to protect copyrights concern individual authors as well as the public since copyright protection enhances, inter alia, creativity, innovation, cultural heritage, legal certainty and economic growth. ${ }^{2716}$ The attribution of jurisdiction in cross-border copyright infringement cases involves various social and economic interests. Efficient copyright protection at procedural level is particularly relevant to increase creativity which yields knowledge and innovation. An efficient approach to jurisdiction will therefore be beneficial for public sectors such as education and healthcare. While the CJEU's approach to jurisdiction seems to favour copyright holders, a copyright holder may not be able to receive efficient redress in multistate copyright infringement cases. In ubiquitous copyright infringement cases, this dissertation argued to adopt the combination of the 'directed activities' criterion and the 'flagrant substantial damages in relation to the entire damage' criterion that will increase the opportunities for copyright holders to receive efficient and full redress before a suitable court. This combined approach to jurisdiction will frequently address the societal problems of online piracy and copyright havens. From an economic perspective, consolidation of litigation will be lesser costly for both litigants. It will also put a lower financial burden on the judicial system of the Member States of the European Union if the court in the Member State that has a strong territorial connection to the copyright infringement case can adjudicate the entire case.

This dissertation demonstrated that the lack of predictability due to the CJEU's approach to jurisdiction in cross-border copyright infringement cases can be detrimental to the crossborder flow of information. If providers of information cannot reasonably predict in which state(s) they can get sued, the cross-border flow of information may be impeded which will negatively affect the increase of knowledge, education, innovation and healthcare. The Geoblocking Regulation does not prevent providers of information to block or limit the access of online interfaces. For the cross-border flow of information, it is relevant that the Internet stays 'open'.

In the context of the proper functioning of trade, it is important that traders will be able to predict in which state they may get sued. Since the Geo-blocking Regulation, traders will frequently not be allowed to block or limit their websites for customers in the European Union. In view of the CJEU's accessibility approach to jurisdiction in cross-border copyright infringement cases, traders can thus often not prevent getting sued in certain Member States by blocking their websites. Particularly small trading companies may therefore not want to sell their products and services via the Internet to customers in the European Union. Audiovisual services or electronically provided services that contain copyrighted content are for now excluded from the prohibitions under the Geo-blocking Regulation. ${ }^{2717}$ In view of the mere

${ }^{2716}$ Hua 2014(a), xiii. See also paragraph 2.2.1.1.

${ }^{2717}$ See paragraph 4.5.2.3. 
accessibility approach, traders who provide these excluded services may thus block or limit their online interfaces to customers of certain Member States which will not enhance the proper functioning of the internal market.

When rethinking the CJEU's approach to jurisdiction in cross-border copyright infringement cases and searching an alternative approach, the social and economic relevance of this dissertation has been reflected by the aim to balance the interests between copyright holders, on the one hand, and users of information and traders, on the other hand. The proposed 'directed activities' approach provides traders and users of information predictability as regards where they can get sued. In ubiquitous copyright infringement cases, the suggested combination of the 'directed activities' criterion and the 'flagrant substantial damages in relation to the entire damage' criterion will entail predictability as regards which court can be competent and enhance efficient copyright protection at procedural level as mentioned above. Taking into consideration the global interests of copyright holders, traders, and users of information suits the contemporary way of policy-making referred to as global governance. Various academics advocate that private international law should play an important role in addressing global issues. $^{2718}$

\section{2) Target Groups: To who, in addition to the academic community, are the research results of interest and why?}

The Court of Justice of the European Union can learn from the research results that their interpretation of European Union law related to private international law should not undermine the principles underlying the latter field in view of legitimacy. In addition, the Court has to seek to balance the broader interests involved. The latter suits the increasing demand for global governance. Considering the criticism of the European Union's legitimacy and democratic deficit, it is also particularly relevant that the CJEU interprets European Union law in light of fundamental rights. ${ }^{2719}$

To achieve legal certainty and predictability, the European Union legislature should consider to codify the approach to jurisdiction in cross-border copyright infringements as proposed in this dissertation. This approach can be incorporated in a separate provision in the future recast of the Brussels Ibis Regulation. If a European Union copyright law comes into existence, the suggested approach to jurisdiction can be laid down in the future European Union Copyright Regulation.

By 23 March 2020, the European Union Commission has to review the Geo-blocking Regulation by taking "into account the overall impact of the Regulation on the internal market and cross-border e-commerce". ${ }^{2720}$ The research results of this dissertation will be relevant for the latter review. Although the Geo-blocking Regulation claims not to affect the 'directed activities' approach to jurisdiction in consumer disputes under Article 17(1)(c) Brussels Ibis

\footnotetext{
${ }^{2718}$ See, for instance, Carballo Pineiro \& Kramer 2014, pp. 109-112; Muir-Watt 2011, pp. 347-428; Muir-Watt 2016, pp. 862-881; Waj 2002, pp. 209-274; Van Den Eeckhout 2017; Van Loon 2008, pp. 197-208.

${ }^{2719}$ See paragraph 4.4.2.4.1.

${ }^{2720}$ Article 9(1) Geo-blocking Regulation.
} 
Regulation, this dissertation demonstrated that the traders' tools to prevent jurisdiction are frequently reduced since they are often not allowed anymore to block or limit access to their websites or use other forms of discrimination based on customers' nationality, place of residence or place of establishment within the European Union. Due to this prohibition to block or limit access to online interfaces, traders can easily get sued in multiple Member States for copyright infringing activities as the CJEU adopted the mere accessibility approach to jurisdiction in cross-border copyright infringement cases. The latter side effects of the Geoblocking Regulation can impact the internal market and cross-border e-commerce. Due to fear of getting sued in multiple Member States, particularly small trading companies may decline to offer their goods and services via the Internet to customers within the European Union. As audiovisual services and electronically supplied services that provide copyright protected content are, for now, excluded from the Geo-blocking Regulation, traders can still block websites involving these services which will not enhance the proper functioning of the internal market and cross-border e-commerce. The review of the Geo-blocking Regulation will focus on whether the latter services should also be covered by the prohibitions. ${ }^{2721}$

At international level, the research results in this dissertation can be employed by interest groups that aim to enhance copyright protection, protect the right to information, or serve the interests of traders. Due to globalization and the Internet, the issue of jurisdiction in crossborder copyright infringement cases has become more pressing for the latter groups. Online piracy and copyright havens are global issues that need to be addressed at international level. The abovementioned interest groups can lobby with states to adopt the approach to jurisdiction as proposed in this dissertation into a convention such as the Berne Convention for the Protection of Literary and Artistic Works of 1979 or a new convention under the auspices of the Hague Conference of Private International Law or the World Intellectual Property Organization.

\section{3) Activities/Products: Into which concrete products, services, processes, activities or commercial activities will the research activities be translated or shaped?}

As mentioned at point two above, the approach to jurisdiction in cross-border copyright infringement cases as proposed in this dissertation can be incorporated in European Union law such as the future recast of the Brussels Ibis Regulation or the future European Union Copyright Regulation. At international level, the suggested approach to jurisdiction could be laid down in a Convention on jurisdiction of the Hague Conference on Private International Law or a Convention related to copyrights, or intellectual property rights, such as the Berne Convention for the Protection of Literary and Artistic Works of 1979.

The proposed approach to jurisdiction in cross-border copyright infringement cases in this dissertation can also serve as a model for scholarly groups that deal with jurisdiction rules in cross-border copyright infringement cases. Point five below will mention scholarly groups that could benefit from this research results.

${ }^{2721}$ See Article 9 Geo-blocking Regulation. 


\section{4) Innovation: To which extent can the research results be considered as innovative compared to existing proposals}

Although several scholars have discussed the instrumentalisation of private international law with respect to certain policy areas of the European Union, ${ }^{2722}$ the area of copyright law has not been scrutinised in this setting yet. As demonstrated in this dissertation, various scholars have proposed connecting factors to establish jurisdiction in cross-border copyright infringement cases. Unlike these proposals, the desirable approach in this dissertation has been the result of an extensive assessment that includes principles of private international law, public international law, copyright law, the principle of balancing the broader interests, and the impact of the Geo-blocking Regulation.

While various scholars have suggested connecting factors that confer full jurisdiction in cross-border copyright infringement cases, this dissertation has examined the concept of full jurisdiction in view of the principle of international comity. Due to the lack at worldwide level of a uniform copyright law or conflict-of-laws rule related to cross-border copyright infringements, this dissertation argued that the exercise of full jurisdiction of the court of the Erfolgsort under Article 7(2) Brussels Ibis in practice should be limited to alleged infringing activities and damage caused within the Member States of the European Union.

This dissertation can also be considered as innovative as it compares the approaches to jurisdiction in cross-border copyright infringement cases in the European Union and states of the United States of America. Despite the differences between civil law and common law, this dissertation demonstrates that a common approach with respect to effects-based jurisdiction in cross-border copyright infringement cases could be possible. The proposed connecting factors in the conclusion appear to suit both legal systems and could therefore be laid down in a convention at international level.

\section{5) Planning and implementation: how will this valorization plan be shaped?}

The research results will be brought to the attention of scholarly groups that deal with jurisdiction rules related to cross-border copyright infringements. This dissertation has demonstrated proposals of various scholarly groups such as the European Max Planck Group for Conflict-of-Laws in Intellectual Property (the CLIP group) at the Max Planck Institute. While the CLIP group has drafted the final text of the Principles on Conflict of laws in Intellectual Property of 1 December 2011, ${ }^{2723}$ revisions may come. As mentioned in this dissertation, the Committee on Intellectual Property and Private International Law under the auspices of the International Law Association (the ILA Committee) has drafted their final

\footnotetext{
${ }^{2722}$ Van Den Eeckhout refers to the instrumentalisation of private international law with respect to, inter alia, migration law, labour law, social security law, nationality law, human rights and environmental law. See Van Den Eeckhout 2002, pp. 144-158; Van Den Eeckhout 2010(b); Van Den Eeckhout 2013(a). See Meeusen (2007, p. 288) on the instrumental function of private international law for the achievement of the internal market of the European Union.

${ }^{2723}$ See https://www.ip.mpg.de/en/research/research-news/principles-on-conflict-of-laws-in-intellectualproperty-clip.html.
} 
guidelines on 'Intellectual Property and Private International Law' in 2018. ${ }^{2724}$ The work of the ALI Committee "builds upon the earlier projects conducted by the Hague Conference of Private International Law as well as several academic initiatives that followed it". ${ }^{2725}$ The ALI Committee appears to be an ongoing group that will have meetings in future. While this Committee acknowledged that in complex multistate IP disputes, there may be situations where there is a need to consolidate objectively related claims, they pointed out that "at the heart of the discussion is the question about the minimum connection that has to be met in order to consolidate objectively related claims" ${ }^{2726}$. In the latter context, the combined approach to jurisdiction in ubiquitous copyright infringement cases as proposed in this dissertation can be considered in the next meeting of the ALI Committee.

The research results can also contribute to the current discussion on the scope of the jurisdiction of courts in cross-border infringement cases. The recent report on Internet and Jurisdiction Global Status points out that it is relevant to critically examine the trend of too broad jurisdictional claims by states that yields several issues such as enforcement difficulties. ${ }^{2727}$ It is also important to keep assessing the CJEU's interpretations of private international law in light of the underlying principles to prevent that this important field of law will be undermined.

${ }^{2724}$ See International Law Association Committee on Intellectual Property and Private International Law (hereinafter the ILA Committee) http://www.ila-hq.org/index.php/committees. See Report International Law Association Sydney Conference (2018) Intellectual Property and Private International Law.

2725 See Report International Law Association Washington Conference (2014) Intellectual Property and Private International Law, p. 2. See Report International Law Association, Sofia Conference (2012) Intellectual Property and Private International Law, p. 3.

${ }^{2726}$ See Report International Law Association Washington Conference (2014) Intellectual Property and Private International, p. 4.

${ }^{2727}$ See Svantesson 2019(a), pp. 50-51. 



\section{Curriculum Vitae}

Birgit van Houtert was born on 26 May in 1980 in Weert, the Netherlands. Between 1998 and 2005, she studied Dutch law at the Faculty of Law of Maastricht University. She achieved both Bachelor of Laws (cum laude) and Master of Laws (cum laude) at Maastricht University. From 2005 till 2009, Birgit had been living in India. From July 2009 till now, she has been providing legal advice on issues related to private law to 'Aurelia Beheer BV' and thereafter to 'Colosseum Accountants BV'. From April 2014 till January 2015, Birgit provided legal assistance in complex issues related to private (international) law to the law firm 'Hoeberechts Advocaten' in Weert. As a PhD candidate at the Faculty of Law at Maastricht University, Birgit drafted this doctoral dissertation between June 2017 until July 2020 under the supervision of Prof. Dr. René de Groot and Dr. Stephan Rammeloo. 
